UNIVERSIDADE DE SÃO PAULO

escola de comunicacóes e artes

JORGE MTANIOS ISKANDAR ARBACH

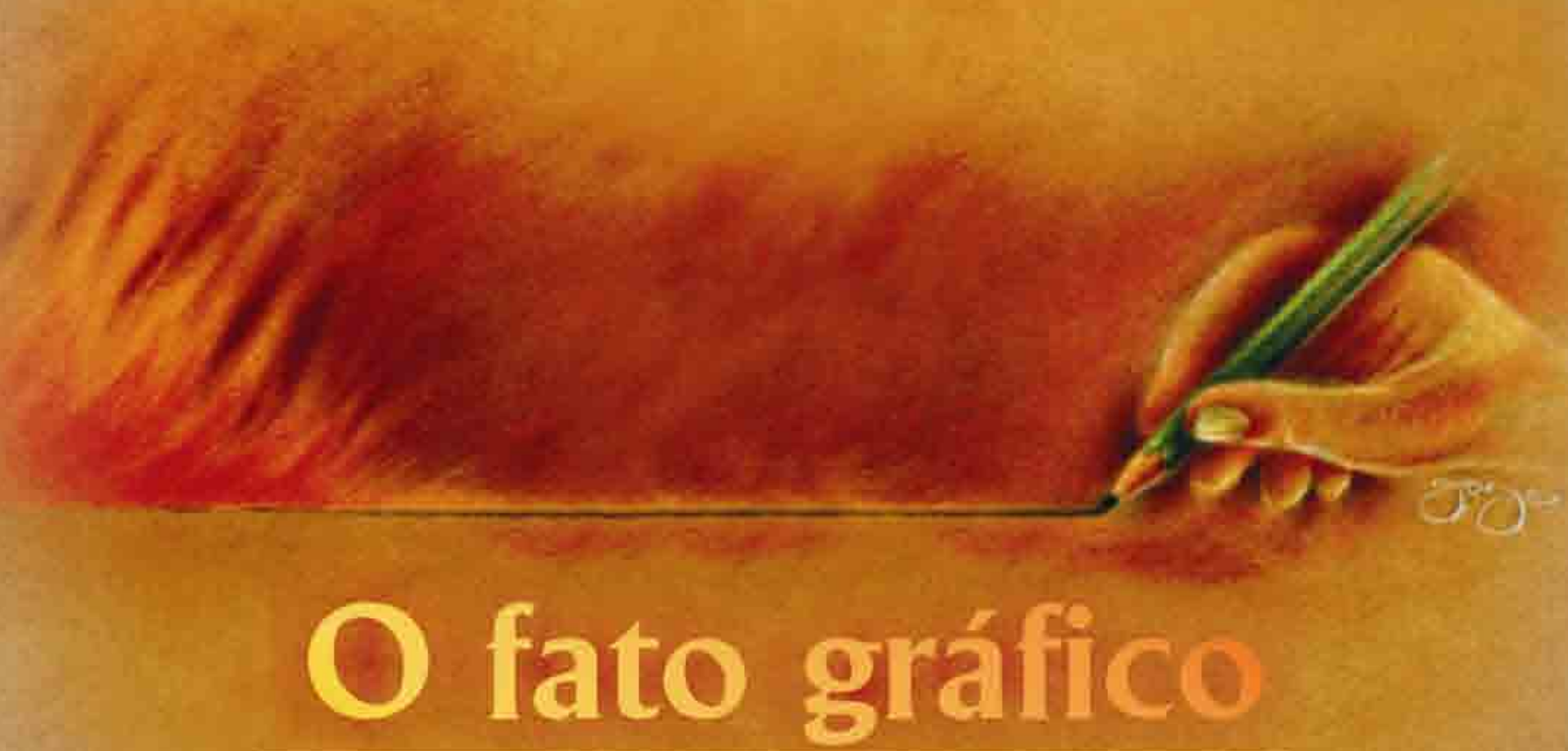

o humor gráfico como gênero jornalístico 


\section{O fato gráfico}

o humor gráfico como gênero jornalístico

Tese apresentada à

Escola de Comunicações e Artes da

Universidade de São Paulo

para obtenção do título de Doutor

em Ciências da Comunicação

PROGRAMA DE CIÊNCIAS DA COMUNICAÇÃO

Área de Concentração

$$
\text { JORNALISMO }
$$

Linha de Pesquisa

JORNALISMO E LINGUAGEM

$$
\text { Orientador }
$$

MANUEL CARLOS DA CONCEIÇÃO CHAPARRO 
Ficha catalográfica elaborada pelo Centro de Difusão do Conhecimento Universidade Federal de Juiz de Fora - UFJF

Arbach, Jorge Mtanios Iskandar

O fato gráfico : o humor gráfico como gênero jornalístico / Jorge Arbach ; orientador : prof. Dr. Manuel Carlos da Conceição Chaparro. 2007.

246 f. il.

Tese (Doutorado em Ciências da Comunicação. Jornalismo e Linguagem) Escola de Comunicações e Artes, Universidade de São Paulo, 2007.

1. Jornalismo humorístico. 2. Gênero jornalístico. 3. Caricaturas.

4. Humor. I. Chaparro, Manuel Carlos da Conceição, orientador. II. Titulo. 
ARBACH, Jorge M. Iskandar. O fato gráfico: o humor gráfico como gênero jornalístico. Tese (Doutorado em Ciências da Comunicação) Escola de Comunicações e Artes Universidade de São Paulo
São Paulo - 2007

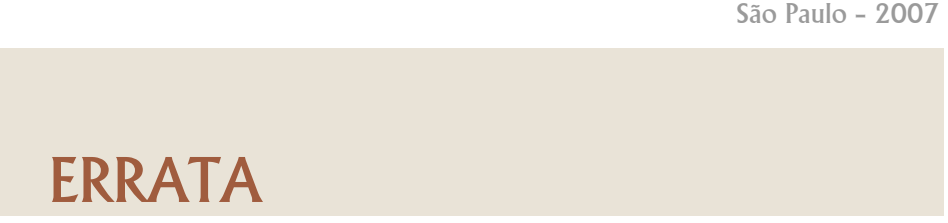

Por motivos técnicos ocorreu alteração

na numeração das páginas abaixo relacionadas.

Saliento que este fato em nenhum momento

acarretou alteração de qualquer natureza nos

conteúdos deste trabalho.

Ao iniciar o sub-título 3.2 inexiste o número da pg. 70

Ao iniciar o sub-título 4.2 inexiste o número da pg. 88

Ao iniciar o sub-título 5.2 há duplicidade do número da pg. 113

Ao iniciar o sub-título 5.3 inexiste o número da pg. 121 


\section{AVALIACÃO}

BANCA EXAMINADORA

Jorge Mtanios Iskandar Arbach

fato gráfico

o humor gráfico como gênero jornalístico

Tese apresentada à

Escola de Comunicaçōes e Artes da Universidade de São Paulo para obtenção do título de Doutor em Ciências da Comunicação

PROGRAMA DE CIÊNCIAS DA COMUINICAÇÃO

Área de Concentração JORNALISMO

Linha de Pesquisa JORNAUSMO E LNGUAGEM

\section{Orientador}

MANUEL CARLOS DA CONCEIÇÃO CHAPARRO
1

Prof. Dr.
Assinatura

2 Prof. Dr. Instituição

Assinatur

Assinatura

3

Instituição

Prof. Dr.
Prof. Dr.

4

Instituição

Assinatura

5 Prof. Dr. 


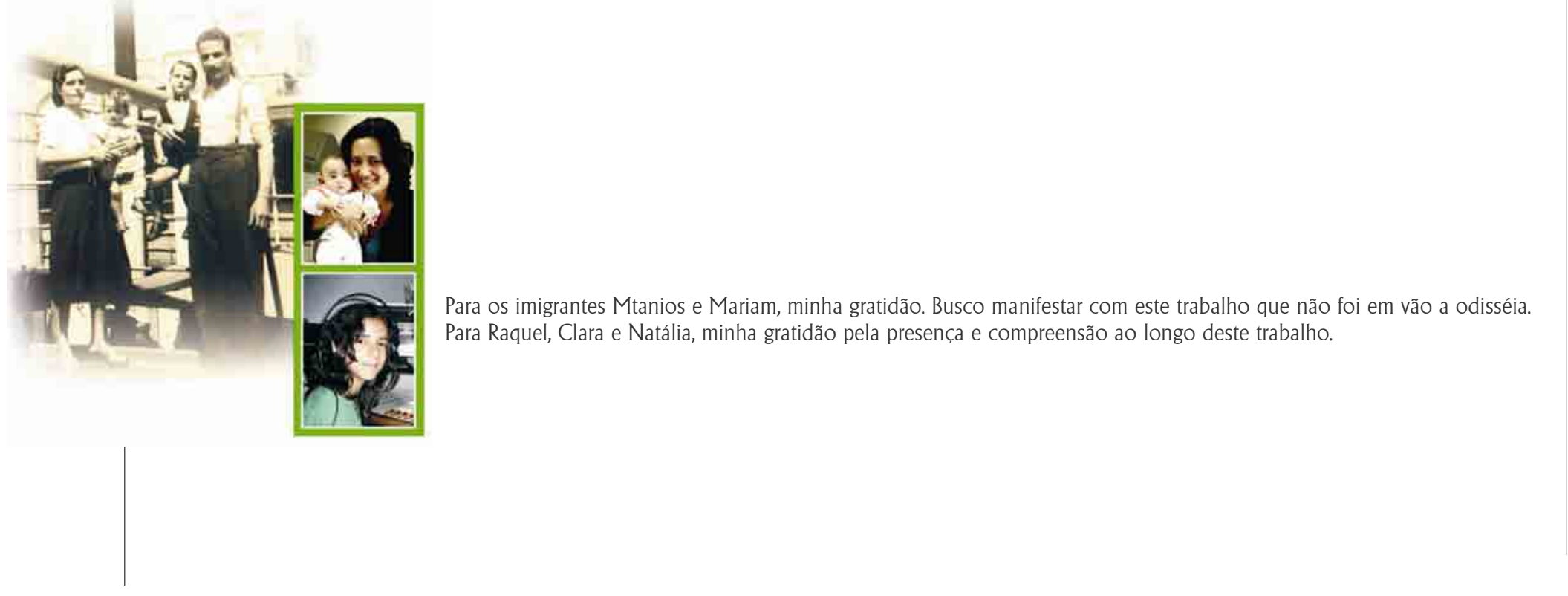


Ao Prof. Dr. Manuel C. Chaparro por acreditar continuamente nos objetivos deste trabalho;

À UFJF pela oportunidade oferecida em poder realizar o doutoramento;

A CAPES pela concessão da bolsa de doutorado para elaboração desta pesquisa;

Aos colegas do DEPRO e DAUR por estimularem e permitirem minha capacitação docente;

À Margarida Salomão, Ronaldo Bastos e Neusa Salim pelo empenho em buscar condições ideais para a capacitação dos docentes da UFJF:

À Gisele Corni Ribeiro e Aline de Oliveira e Lima pela sempre valiosa colaboração;

A Sandra, Valéria e Norma por me ajudarem

Ao Marcos Borges e Regina Kopke, companheiros de UFJF, meu agradecimento pelas dicas e principalmente pela solidária amizade;

À Wanilda de Oliveira e Miriam Cotta do PRORH e Márcia Pereira da PROPP pela presteza e gentileza no atendimento junto à UFJF;

Ao Sérgio de Souza, Mariana Duccini, Luiz Egipto, Marcos Kopschitz e Mauro Bastos que possibilitaram a veiculação da seção Desenhos Falados junto aos meios de comunicação;

Ao Antônio Carlos Weiss e irmãos, minha admiração por darem continuidade à arte da tipografia;

Aos professores das disciplinas do Doutorado do Programa de Pós-Graduação da ECA, meus especiais agradecimentos pela transmissão dos conhecimentos;

Ao Fábio Sales e ao Valter Pereira pelo estímulo e pela cessão das imagens para este trabalho

Para os amigos da Editora UFJF, da Caligrama, do NJL, do COSEAS, do CRUSP, à Vânia Pinheiro de Sousa, ao Rodrigo Pinheiro, à Sidneia Ramos de Oiveira e ao Joílson, que, de alguma maneira ou de outra, contribuíram na realização deste trabalho. 


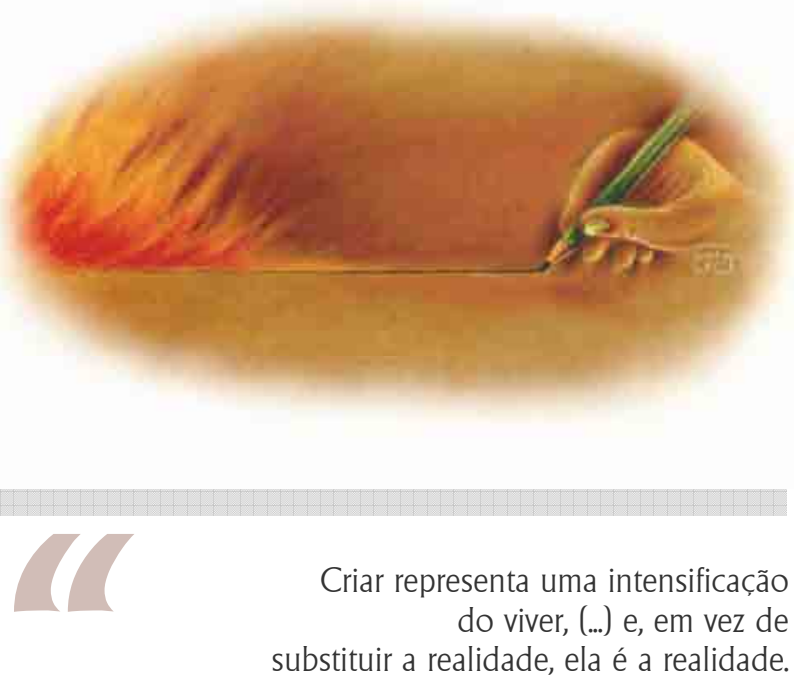

O indivíduo configura o seu caminhar criando formas, dentro de si e em redor de si.

Ele se procura nas formas da imagem criada, nas formas do seu fazer, nas formas do seu viver.

Certamente, chegará ao seu destino. Encontrando, saberá o que buscou. 


\section{RESUMO}

ARBACH, Jorge Mtanios Iskandar. O fato gráfico: o humor gráfico como gênero jornalístico. Tese (Doutorado) - Escola de Comunicaçōes e Artes, Universidade de São Paulo, São Paulo, 2007.

Esta pesquisa busca referências que especifiquem o Humor Gráfico como uma das formas com que se constrói o discurso jornalístico. Desenvolve a questão a partir do uso da imagem pelo homem desde a pré-história, ao definir os sinais e elaborar suas significaçōes $\mathrm{O}$ fio condutor do trabalho sustenta que a imagem é detentora de linguagem própria e que cada ser humano possui mecanismos inatos para assimilar seu discurso não-verbal. $O$ trabalho trata em sua parte final da configuração da imagem no mundo contemporâneo como uma linguagem já inserida no meio informativo, porém não reconhecida.

\section{PALAVRAS-CHAVE}

Humor gráfico; Gênero jornalístico; llustração; Desenho de humor; Cartum. 


\section{ABSTRACT}

ARBACH, Jorge Mtanios Iskandar. The graphic fact: the graphic humour as journalistic genre. Thesis (Doctoral) - Escola de Comunicações e Artes, Universidade de São Paulo, São Paulo, 2007.

This research looks for references that specify the Graphic Humour as one of the ways with which the journalistic discourse is built. The issue is developed from the study of the use of the image since prehistory, when the man making forms into signs and elaborating their significances. The common thread of this work comes when sustaining that the image has its own language and that every human being possesses innate mechanisms to assimilate the no-verbal discourse of the images. At the final part, the work treats of the configuration of the image in the contemporary world as language already inserted in the informative discourse, but not yet recognized.

\section{KEYWORDS}

Graphic humour; Journalistic genre; Illustration; Caricature; Cartoon. 


\section{LISTA DE ILUSTRAÇÕES}

CAPITULO 2

Página 42 - Embaixo Carlos Estevão: As aparências enganamp Página 43 - Acervo Jorge Arbach; Página 44 - Embaixo à esquerda: Magritte História da Arte Milênio, 1986 ; Página 45 - Acervo Jorge Arbach; Página 46 - Embaixo à esquerda : Retratos de Fayun: História da arte Milênio 1983. Embaixo à direita: Ícones Bizantinos: História da arte, Milênio.1983; Página 47 - HERKENHOFF, Paulo. Biblioteca Nacional, p. 29; Página 48 - História da arte, Milênio.1983; Página 49 - Villard de Honnecourt; Página 51 Magritte: História da arte, Milênio.1983; Página 54 - Seqüência: LAGO, Pedro Corrêa. Caricaturistas Brasileiros (1836-1999), p. 68; Página 55 - No alto à esquerda : DORÉ: História da Arte, Milênio. 1996;

CAPITULO 3

Página 63 - À esquerda : A Compendium, Haet Pictures Archive p. 111: Embaixo à esquerda: GONTIIO, Silvana, O Mundo em Comunicação, p. 17: À direita: BARRY, Sir Gerald. Os meios de expressão, p. 47; Página 64 - No alto à esquerda - Primeira: BRUCE-MITFORD, Miranda. O Livro Ilustrado dos Simbolos, p. 51 ; Segunda: DOVER, Compendium, p. 132; No centro à esquerda: DOVER, Compendium, p. 135; No alto à direita: GOMES, Luiz Vidal N. Desenhando um panorama dos sistemas gráficos, Embaixo: Seqüência- Leonardo da Vinci. p. 32-56; Página 65 - Da esquerda para direita:OLIVEIRA, Jô e Lucília Garcez. Explicando a Arte: (uma iniciação para entender e apreciar as Artes Visuais). p. 35-38; Embaixo à esquerda: A Compendium, Haet Pictures Archive, p. 284; Página 66 - No alto à esquerda : A Compendium Haet Pictures Archive. p. 55; Embaixo da esquerda para direita - História da Arte - Hart collection. Herculano e Pompéia. p. 35; Página 67 -Sequêência da página: História da Arte - Hart collection. p. 23-45-88; Página 68 - No alto à esquerda: História da Arte - Hart collection.- Renascimento, p. 79; Embaixo à direita: A Compendium, Haet Pictures Archive p. 134: Página 71 - À esquerda: Acervo Jorge Arbach; Página 72 - À esquerda: Acervo Jorge Arbach; Página 73 - À esquerda: Acervo Jorge Arbach. Página 76 - A linouar Técnica, p. 95.

CAPÍTULO 4

Página 83 - Embaixo à esquerda : BARRY, Sir Gerald. Os meios de expressão, p. 129; Página 84 - À esquerda : MARTINS, Itajahy. Desenho, Arte e Técnica, p. 36; À direita: MARTINS, Itajahy. Desenho, Arte e Técnica, p. 32; Embaixo à direita: MARTINS, Itajahy. Desenho, Arte e Técnica, p. 32; Página 85 - No alto à esquerda : MARTINS, Itajahy. Desenho, Arte e Técnica, p. 32; Embaixo à esquerda: BARRY, Sir Gerald. Os meios de expressão. p. 53; No alto à direita: DOCZl, Gyorgy. O poder dos limites Harmonias e Proporçoes na natureza, arte e arquitetura, p. 29; Embaixo à direita: MARTINS, Itajahy. Desenho, Arte e Técnica, p. 29; Página 86 - À esquerda : GOMES, Luiz Vidal N. Desenhando um panorama dos sistemas gráficos, A direita: BERWANGER, Ana Regina, LEAL, João Eurípedes K. Noções de Paleografia e Diplomática, p. 26; Página 87 - Acervo Jorge Arbach; Página 89 - À esquerda : Sinais e símbolos - Desenho, projeto e significado, À direita: BARRY, Sir Gerald. Os meios de expressão; Embaixo à

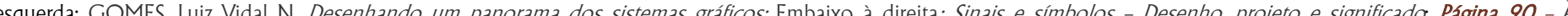

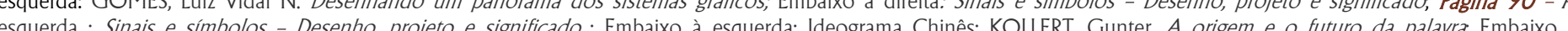
esquerda : Shers, esquerda: BRUCE-MIT p. 101, Embaixo à squerda. Teorla da Imagem, p. 65, No alto à direlta. Desenho, Aree da escrita, junho de 1995, p.43; No centro: GOMES, Luiz Vidal N. Desenhando um panorama dos sistemas gráficos, p. 55; Embaixo à esquerda: RIBEIRO, Milton. Planejamento Visual Grafico, p. 26; A direita: Sinais e simbolos - Desenho, projeto e significado, p.92; Página 95 - A esquerda: RIBEIRO, Milton. Planejamento Visual Gráfico, p. 178; À direita: GONTIJO, Silvana, O Mundo em Comunicação, p. 55; Página 96 - No alto à esquerda: GONTIJO, Silvana, O Mundo em Comunicação, p. 58; Embaixo a esquerda: RIBEIRO, Milton. Planejamento Visual Gráfico, p. 27; À direita: RIBEIRO, Milton. Planejamento Visual Gráfico, p. 27; Página 97 - No alto à direita: RIBEIRO, Milton. Planejamento Visual Gráfico, p. 175; À esquerda: RIBEIRO, Milton. Planejamento Visual Gráfico, p. 33 Embaixo à direita: RIBEIRO, Milton. Planejamento Visual Gráfico, p. 44 Página 98 - No alto à esqueda: RIBEIRO, Milton. Planejamento Visual Gráfico, p. 29; Embaixo à esquerda: O Correio, $A$ arte de imprimir, setembro de 1998, p. 44; A direita: GOMES, Luiz Vidal N. Desenhando um panorama dos sistemas gráficos, p. 56; Página 99 - RIBEIRO, Milton. Planejamento Visual Gráfico, p. 49; Página 100 - No alto à esquerda: A Compendium, Haet Pictures Archive, p. 111; Embaixo à esquerda: HERKENHOFF, Paulo. Biblioteca Nacional, p. 29; A direita: BRUCE-MITFORD, Miranda. $O$ Livro Ilustrado dos Símbolos, p. 19; Embaixo à direita: RIBEIRO, Milton. Planejamento Visual Gráfico, p. 46; Página 101 - No alto à direita: RIBEIRO, Milton. Planejamento

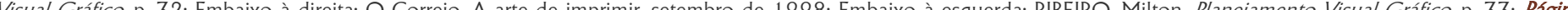
Planejamento Visual Gráfico, p. 60; Página 103 - À esquerda: KOLLERT, Günter. A origem e o futuro da palavra: a teoria da linguagem segundo Goethe, p. 33 À Planejamento Visual Gráfico, p. 60; Página 103 - A esquerda:

CAPÍTULO5 Página 105 - A seqüência - O Correio, A arte de imprimir, setembro de 1998; Página 106 - No alto à direita: Arte e Indústria no Brasil - 180 anos de história, EDUSC, p. 20; Embaixo à esquerda: RIBEIRO, Milton. Planejamento Visual Gráfico, p. 274; Página 107 - A esquerda : RIBEIRO, Milton. Planejamento Visual Gráfico, p. 32; À direita: GONTIJO, Silvana, O Mundo em Comunicação, p. 158; Embaixo à direita: RIBEIRO, Milton. Planejamento Visual Gráfico, p. 32; Página 108 - A esquerda : DOVER Compendiumr, p. 67; À direita: RIBEIRO, Milton. Planejamento Visual Gráfico, p. 32; Embaixo à direita: HERKENHOFF, Paulo. Biblioteca Nacional, p. 51 e 73; Página 109 No alto à direita: DOVER, Compendium, p. 99; Sequência embaixo: DOVER, Compendium, p. 67-89; Página 111 - HERKENHOFF, Paulo. Biblioteca Nacional, p. 36; 
CAPÍTULO 6 Página 127 - No alto à esquerda: DOVER, Compendium, p. 176; Embaixo à esquerda: A Compendium - Hart Pictures Archive, vol 1, p. 269; À direita: : BARRY, Sir Gerald. Os meios de expressão, p. 118 ; Página 128 - A Compendium - Heat Pictures Archive, vol 1, p. 249; Página 129 - À esquerda : RIBEIRO, Milton. Planejamento Visual Grafíco, p. 45 A direita: GONTIJO, Silvana, O Mundo em Comunicacão, p. 114: Página 131 - No alto à esquerda: A Compendium - Heat Píctures Archive, vol 1, p. 269: Página, 132 - No alto à direita: A Compendium - Heat Pictures Archive, vol 1, p. 270; Embaixo à esquerda: DOVER, Compendium, p. 198; Página 133 - No alto à esquerda Página 132 - No alto à direita: A Compendium - Heat Pictures Archive, vol 1, p. 270; Embaixo à esquerda: DOVER, Compendium, p. 198; Página I33 - No alto à esquerda
: Acervo Jorge Arbach; Embaixo à esquerda: HERKENHOFF, Paulo. Biblioteca Nacional, p. 73; Embaixo à direita: HERKENHOFF, Paulo. Biblioteca Nacional, p. 166; Página 134 - HERKENHOFF, Paulo. Biblioteca Nacional, p. 16; Página 135 - Acervo Jorge Arbach; Página 136 - Acervo Jorge Arbach; Página 137 - À esquerda www.mathew brady.com; Página 138 - Acervo Jorge Arbach; Página 139-Acervo Jorge Arbach; Página 142- No alto: Eadward Muybridge: photographe, p. 47; Embaixo à esquerda: Diabo Coxo, EDUSP. Jornal Domingueiro, série II, nº, p. 4 e 5; Embaixo à direita: LAGO, Pedro Corrêa. Caricaturistas Brasileiros (1836-1999), p. 68; Página 143 - No alto à esquerda: HERKENHOFF, Paulo. Biblioteca Nacional, p. 244; Embaixo à direita: Ilusōes 2, p. 142 e LANNERS, E. Ilusōes, p. 143; Página 144 - No alto à esquerda: VEJA. no. 1912 - set/2005, p. 47; Embaixo à direita: VEJA. no. 1912 - set/2005, p. 47; Página 145 - Sequuência embaixo: Diabo Coxo, EDUSP. Jornal Domingueiro, série II, nº, p. 1; Página 146 - Embaixo à esquerda: ANDRADE, Joaquim Marçal Ferreira de. História da fotorreportagem no Brasil. p. 190; Página 147 - Embaixo à esquerda: ANDRADE, Joaquim Marçal Ferreira de. História da fotorreportagem no Brasil. p. 89 e 70; Página 148 - Embaixo à esquerda: ANDRADE, Joaquim Marçal Ferreira de. História da fotorreportagem no Brasil. p. 147; No centro: História da Fotorreportagem no Brasil, p. 69; À direita: História da Fotorreportagem no Brasil, p. 70; Página 149 - No centro: ANDRADE, Joaquim Marçal Ferreira de. História da fotorreportagem no Brasil. , p. 192; A direita: ANDRADE, Joaquim Marçal Ferreira de. História da fotorreportagem no Brasil, p. 190. Embaixo à esquerda: ANDRADE, Joaquim Marçal Ferreira de. História da fotorreportagem no Brasil, , p. 167; Ao lado da anterior: ANDRADE, Joaquim Marçal Ferreira de. História da fotorreportagem no Brasil, p. 169.

CAPÍTULO 7 Página 152 - Sequência embaixo: A Compendium - Hart Pictures Archive, vol 1, p. 234; Página 153 - Acervo Jorge Arbach; Página 154 - No alto à esquerda: Acervo Jorge Arbach; Embaixo à esquerda: LESSA, Washington Dias. Dois Estudos de Comunicaçäo Visual, Primeiro Caderno, 12 de novembro de 1956, p. 1; À direita: LESSA, Washington Dias. Dois Estudos de Comunicação Visual, Primeiro Caderno, 9 de outubro de 1959, p. 3; Página 156 - A Compendium - Hart Pictures Archive, vol 1, p. 1 39; Página 157 - História das civilizaçôes, Milênio, p. 78; Página 158 - HERKENHOFF, Paulo. Biblioteca Nacional, p. 143; Página 159 - GONTJU, Silvana, O Mundo em Comunicação p. 170; Página 160 - No alto à esquerda : HERKENHOFF, Paulo. Biblioteca Nacional, p. 78; Embaixo à esquerda: HERKENHOFF, Paulo. Biblioteca Nacional, p. 88 ; Página 164 - DOVER, Compendium, p. 121; Página 165-Conjunto à esquerda: Gráfica - Arte e Indústria no Brasil - 180 anos de história - EDUSC, p. 28; Página 166 Embaixo à esquerda: GONTIJO, Silvana, O Mundo em Comunicação, p. 204; Página 168 - Conjunto à esquerda: Gráfica - Arte e Indústria no Brasil - 180 anos de história - EDUSC, p. 49; Página 170 - CAVALCANTI, Laílson de Holanda. História do humor gráfico no Brasil. p.32 ; Página 171 - À direita: FONSECA, Joaquim. Caricatura - A imagem gráfica do humor. p. 87; A esquerda: www.artistasbrasileiros.org; Página 172 - No alto à esquerda: Gráfica - Arte e Indústria no Brasil - 180 anos de história - EDUSC, p. 27; Embaixo: Diabo Coxo, EDUSP. Jornal Domingueiro, Ano I, n 12, p. 1; Página 173 - No alto à esquerda: Diabo Coxo, EDUSP. Jornal Domingueiro, série II, nº 6, p. 1; Embaixo à esquerda: História da Fotorreportagem no Brasil, p. 70; Página 174 - História da Fotorreportagem no Brasil, p. 90; Página LAGO, Pedro Corrêa. Caricaturistas Brasileiros (1836-1999), p. 36; Página 176 - No alto à esquerda: Gráfica - Arte e Indústria no Brasil - 180 anos de históriaEDUSC, p.48; Embaixo à esquerda: www.omalho.com.br, Embaixo à direita: Gráfica - Arte e Indústria no Brasil - 180 anos de história - EDUSC, p. 51; Página 177 HERKENHOFF, Paulo. Biblioteca Nacional, p. 104; Página 178 - No alto à esquerda: Gráfica - Arte e Indústria no Brasil - 180 anos de história - EDUSC, p. 43; Embaixo à esquerda: Nosso Século, Abril, V. 3; p. 56; Embaixo à direita: Nosso Século, Abril, V. 3; p. 59; Página 179 - No alto à esquerda: Nosso Século, Abril, V. 3; p. 76; Embaixo à esquerda: Gráfica - Arte e Indústria no Brasil - 180 anos de história - EDUSC, p. 51; Página 180 - No alto à esquerda: Nosso Século, Abril, V. 3; p. 68; Embaixo à esquerda: HERKENHOFF, Paulo. Biblioteca Nacional, p. 104; Embaixo à direita: Gráfica - Arte e Indústria no Brasil - 180 anos de história - EDUSC, p. 41; Página 181 Sequência: www.nossoseculocom.br; Página 183 - ANDRADE, Joaquim Marçal Ferreira de. História da fotorreportagem no Brasil, p. 154; Página 184 HERKENHOFF, Paulo. Biblioteca Nacional, p. 96; Página 185 -www.cartumvirtual.com.br; Página 186- No alto à esquerda: Uma Histórí do Brasil através da Caricatura, p. 27; Embaixo à direita: Uma História do Brasil através da Caricatura, p. 25; Página 187 - GONTIJO, Silvana, O Mundo em Comunicąãão, p. 192; Página 188 - LAGO, Pedro Corrêa. Caricaturistas Brasileiros (1836-1999), p. 46; Página 189 -Caricaturistas portugueses, Milênio, 1989, p. 34; Página 190 - Embaixo à esquerda: LAGO, Pedro Corrêa. Caricaturistas Brasileiros (1836-1999), p. 42; Página 191 - Sequêencia de quatro imagens no alto à esquerda: A Aurora; Sequêencia de três imagens no 

202; Sequência de quatro imagens embaixo à direita - Primeira: HERKENHOFF, Paulo. Biblioteca Nacional, p. 75; Terceira: LAGO, Pedro Corrêa. Caricaturistas Brasileiros (1836-1999), p. 76; Quarta: História da Fotoreportagem no Brasil, p. 169.

Página 193 - À esquerda: HERKENHOFF, Paulo. Biblioteca Nacional, p. 74; Embaixo à direita: Gráfica - Arte e Indústria no Brasil - 180 anos de história - EDUSC, p. 53;

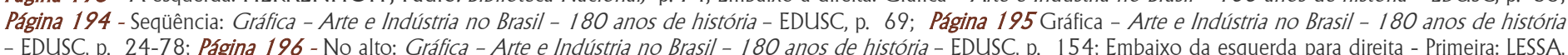
- EDUSC, p. 24-78; Página 196 - No alto: Gráfica - Arte e Indústria no Brasil - 180 anos de história - EDUSC, p. 154; Embaixo da esquerda para direita - Primeira: LESSA,
Washington Dias. Dois Estudos de Comunicação Visual, 12 de novembro de 1956, p. 1; Segunda: LESSA, Washington Dias. Dois Estudos de Comunicação Visual, 11 de março de 1957, p. 1; Terceira: LESSA, Washington Dias. Dois Estudos de Comunicação Visual, 18 de abril de 1959, p. 1; Quarta: LESSA, Washington Dias. Dois Estudos de Comunicação Visual, 9 de maio de 1960, p. 1; Página 197 - À esquerda : MARTINS, Sérgio. A invenção do humor no espaço gráfico, p. 96 ; À direita: MARTINS, Sérgio. A invenção do humor no espaço gráfico, p. 97; Página 198 - Embaixo da esquerda para direita - Primeira;: MORAES, Ary. Revista Imprensa. ano 14, n. 161, jun.2001 Segunda: MORAES, Ary, Revista Imprensa ano 14, n. 161, jun./2001. Terceira: MORAES, Ary. Revista Imprensa, ano 15, n. 197, jun./2003. Quarta: MORAES, Ary. Revista Imprensa. ano 15, n. 199, jun./2003; Quinta: Acervo Fábio Sales; Página 200 - BRUCE-MITFORD, Miranda. O Livro Ilustrado dos Símbolos, p. 102; Página 201 - À esquerda : LAGO, Pedro Corrêa. Caricaturistas Brasileiros (1836-1999), p. 65 À direita: LAGO, Pedro Corrêa. Caricaturistas Brasileiros (1836-1999), p. 98; Página 202 - No alto à esquerda : Caulos; No alto à direita: Quino; No centro à esquerda: Quino; No centro à direita: Quino; Embaixo à esquerda: Quino; Embaixo à direita: Escher; Página 204 - LIMA, Herman. História da caricatura no Brasil. p. 76; Página 205 - No alto à esquerda: ANDRADE, Joaquim Marçal Ferreira de. História da fotorreportagem no Brasil, p. 193 Embaixo à esquerda: ANDRADE, Joaquim Marçal Ferreira de. História da fotorreportagem no Brasil, p. 197. Página 206 - No alto à esquerda: Diabo Coxo, EDUSP. Jornal Domingueiro, série II, nº 9, p. 8; Embaixo à direita: LAGO, Pedro Corrêa. Caricaturistas Brasileiros (1836-1999), p. 36; Página 207 - À esquerda: LAGO, Pedro Corrêa. Caricaturistas Brasileiros (1836-1999), p. 26; À direita: LAGO, Pedro Corrêa. Caricaturistas Brasileiros (1836-1999), p. 54; Página 208 - Acervo Jorge Arbach; Página 209 - No alto à esquerda: LAGO, Pedro Corrêa. Caricaturistas Brasileiros (1836-1999), p. 124; Embaixo à esquerda:Vazques de Sola. Caricatures. 1975; Página 210 - No alto à direita: FONSECA, Joaquim.. Caricatura - $A$ imagem gráfica do humor.p. 78; Embaixo à esquerda: LAGO, Pedro Corrêa. Caricaturistas Brasileiros (1836-1999), p. 205; Página 211 - No alto à esquerda: LAGO, Pedro Corrêa. Caricaturistas Brasileiros (1836-1999), p. 124; Embaixo à esquerda: FONSECA, Joaquim.. Caricatura - A imagem gráfica do humor. p. 67; Página 212 - No alto à esquerda: $O$ Pasquim, nº 53, p. 19; Embaixo à esquerda - Primeira: $O$ Pasquim, $n^{\circ} 55$, p. 29; - Segunda: $O$ Pasquim, $n^{\circ} 71$, p. 28; - Terceira: 0 Pasquim, $n^{\circ} 51$, p. 35 ; Página 213 - Embaixo da esquerda para direita - Primeira: TOPOR, 1985, p. 88 - Segunda: Magritte, Milenio ; Terceira: Acervo Jorge Arbach; - Quarta: Millôr Fernandes; Página 214 - No alto à esquerda: LAGO, Pedro Corrêa. Caricaturistas Brasileiros (1836-1999), p. 28; Embaixo à esquerda: Frank Miller; Embaixo à direita: IANNONE. Leila Rentroia e IANNONE. Antonio Roberto. O mundo das histórias em quadrinhos. p.63.

Estudo de Caso Página 216 - LAGO, Pedro Corrêa. Caricaturistas Brasileiros (1836-1999), p. 34; Página 217 - No alto à esquerda : Belmonte in LAGO, Pedro Corrêa. Caricaturistas Brasileiros (1836-1999), p. 43; Seqüência: LEMOS, Renato. (org.). Uma história do Brasil através da caricatura.(1840-2001); Página 219 - No alto à direita: O Pasquim, no 42 p. 6; Embaixo à esquerda: Pif-paf no. 4; Embaixo no centro: Pif-paf no. 6. Embaixo à direita: Pif-paf no. 3; Página 220 -Pifpaf no. 1 ; Página 221 à direita: O Pasquim, n ${ }^{\circ}$ 42, p. 6; Embaixo à esquerda: Pif-paf no. 4; Embaixo no centro: Pif-paf no. 6; Embaixo à direita: Pif-paf no. 3; Página 220 -Pifpaf no. 1; Página 221 -
No alto à esquerda: Pif-paf no. 3; Embaixo à esquerda:Ziraldo. Marcas nada patentes, 1985; Embaixo à direita: Ziraldo. Marcas nada patentes, 1985; Página 223 - A esquerda : O Pasquim, no. 76 ; Página 224 - Embaixo da esquerda para direita - Primeira: O Pasquim, n 44, p. 6; Segunda: O Pasquim, $n^{\circ}$ 90, p. 31 ; Terceira: 0 Pasquim, n 85, p. 6; Quarta: $\mathrm{O}$ Pasquim, n⿳ 77, p. 1 1; Página 225 - O Pasquim, n 52, p. 32; Página 226 - Da esquerda para direita - Primeira: $\mathrm{O}$ Pasquim, $\mathrm{n}^{\circ} 85$, p. 6; Segunda: $\mathrm{O}$ Pasquim, $n^{\circ}$ 34, p. 23; Terceira: $O$ Pasquim, n 33, p. 18; Quarta: $O$ Pasquim, $n^{\circ}$ 58, p. 19; Página 227 - $O$ Pasquim, n 53, p. 21 ; Página 228 - Embaixo da esquerda para

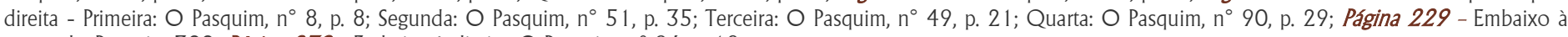
esquerda: Pasquim 300; Página 230 - Embaixo à direita: $O$ Pasquim, n ${ }^{\circ}$ 96, p. 18 ;

Conclusão $\quad$ Página 232 - Acervo Jorge Arbach; Página 246 - DOVER, Compendium, p. 213.

Num trabalho desta natureza, em que necessitamos recorrer de ilustraçōes reproduzidas em diversas fontes, é freqüentemente difícil, e algumas vezes impossível, averiguar as informacões para os devidos créditos. Se não foram mencionados em quaisquer das imagens aqui reproduzidas o mesmo ocorreu involuntariamente, o autor apresenta suas desculpas e se declara pronto a registrar de alguma forma as devidas informações. 
SUMÁRIO

INTRODUCÃO

12

\section{CAPITULO 1}

OS GÊNEROS JORNALÍSTICOS

1.1 - O JORNAL E OS GÊNEROS

1.2 - NOVAS FORMAS DISCURSIVAS

\section{CAPITULO 2}

ILUSTRAC̄ÃO EDITORIAL

2.1 - O DISCURSO DA ILUSTRAÇÃO

2.2 - A SINTAXE DA ILUSTRAÇÃO

2.3 - A SEMÂNTICA DA ILUSTRAC̄ÃO

\section{CAPITULO 3}

O DESENHO

3.1 - REPRESENTAÇĀO DA IMAGEM

3.2 - SIGNIFICADOS DO DESENHO

\section{CAPÍTULO 4}

A PALAVRA

4.1 - A COMUNICAC̄ĀO VERBAL

83

4.2 - O DESENHO DA PALAVRA

4.3 - A PALAVRA ILUMINADA 


\section{CAPÍTULO 5 \\ A IMPRENSA}

5.1 - MEIOS DE PRODUÇÃO E REPRODUÇÃO

105

5.2 - A PRESENÇA DA FOTOGRAFIA 113

5.3 - INFLUÊNCIAS E REPERCUSSÕES

\section{CAPITULO 6 \\ A INFORMAC̄ÃO}

6.1 - A CIRCULAÇÃO DA INFORMAÇÃO

127

6.2 - A VERSÃO DOS FATOS 135

6.3 - A VERSÃO DAS FOTOS

\section{CAPITULO 7}

O JORNAL

7.1 - ASPECTOS HISTÓRICOS

7.2 - O JORNAL NO BRASIL

7.3 - A EMPRESA JORNALÍSTICA

\section{CAPITULO 8}

\section{HUMOR GRÁFICO}

8.1 - OS MEIOS E OS MOVIMENTOS

8.2 - ASPECTOS CONCEITUAIS 


\section{ESTUDO DE CASO}

1 - CÓDIGOS DO HUMOR GRÁFICO

216

2 - O PASQUIM

CONCLUSÕES

O FATO GRÁFICO

232

BIBLIOGRAFIA 


\section{INTRODUÇÃO}

\section{CONSIDERAÇÕES INICIAIS}

Há anos trabalho profissionalmente ilustrando textos para o jornalismo impresso, sempre considerando essas ilustrações detentoras de conceitos próprios, permitindo que o leitor encontrasse novas e variadas leituras. A possibilidade de trabalhar com a imagem permeada de interpretações permitiu expressar-me mesmo onde a palavra não estivesse presente. Busco cada vez mais abrir espaços dentro do jornalismo para que o discurso não-verbal consolide seu lugar, pois acredito que a ilustração nas páginas do jornal tem a capacidade de estar no mesmo nível comunicativo que um texto ou uma foto. Assim, não a considero somente capaz de ornar visualmente a mancha gráfica do texto, ou considerá-la um atrativo para o leitor se apropriar da matéria. Nem a considero limitada a revestir de redundâncias narrativas paralelas ao conteúdo do texto.

Hoje o ilustrador tem a possibilidade de ser opinativo e reflexivo sobre qualquer tema abordado, não podendo considerar seu trabalho dentro do espaço do jornal somente elemento complementar ao texto, mas possuidor das mesmas possibilidades de discurso que o texto e a foto possuem. Nem deve considerar-se um sobrevivente graças à existência do texto. O ilustrador atento à sua função dentro do jornal enfoca sua atividade não só como possibilidade de expressão artística, mas como possibilidade real de expressão opinativa junto ao público. Caso contrário, por melhor que seja o conteúdo do texto a ser ilustrado, a imagem que o acompanha não estará preenchida de todas as potencialidades discursivas.

Para exercitar com veracidade esse modelo discursivo tenho publicado regularmente em diversos órgãos de imprensa a seção denominada Desenhos Falados. E é nessa oportunidade em que vários órgãos de comunicação oferecem-me espaço para publicar essa seção, é que me permitiu aprofundar essa análise na prática.

Nos jornais diários, habitualmente, o leitor encontra abaixo da manchete um texto que o conduz (e muitas vezes o induz) aos conceitos emitidos, reforçando o perfil do leitor/espectador. Na seção Desenhos Falados proponho modificar essa configuração onde, abaixo da manchete o leitor encontrará um discurso não-verbal, com possibilidades de leituras e interpretações, sempre associadas às suas vivências pessoais, ampliando a interação com o leitor. Assim, ele passa a ser um espectador/leitor. 
Naquelas páginas dedico-me profundamente em praticar tal enfoque, fazendo a imagem cumprir seu papel como linguagem onde, através de associações, adquirem conceitos, extrapolando o fato isolado.

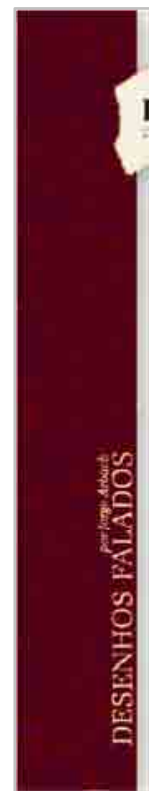

PFL acusa tucano de espionagem

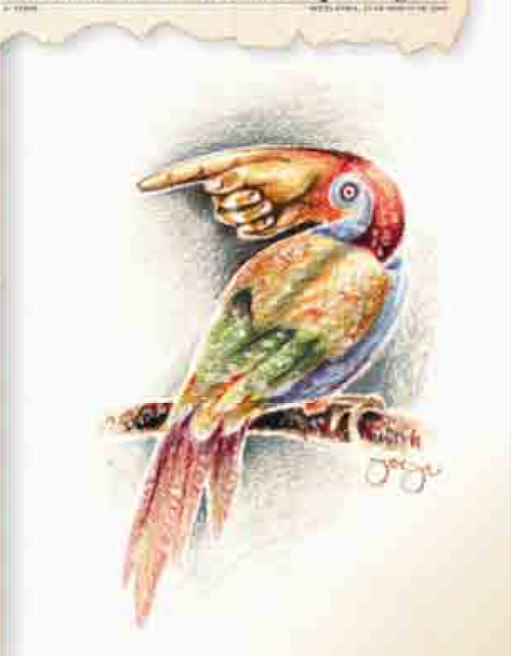

Seção Desenhos Falados Revista Caros Amigos
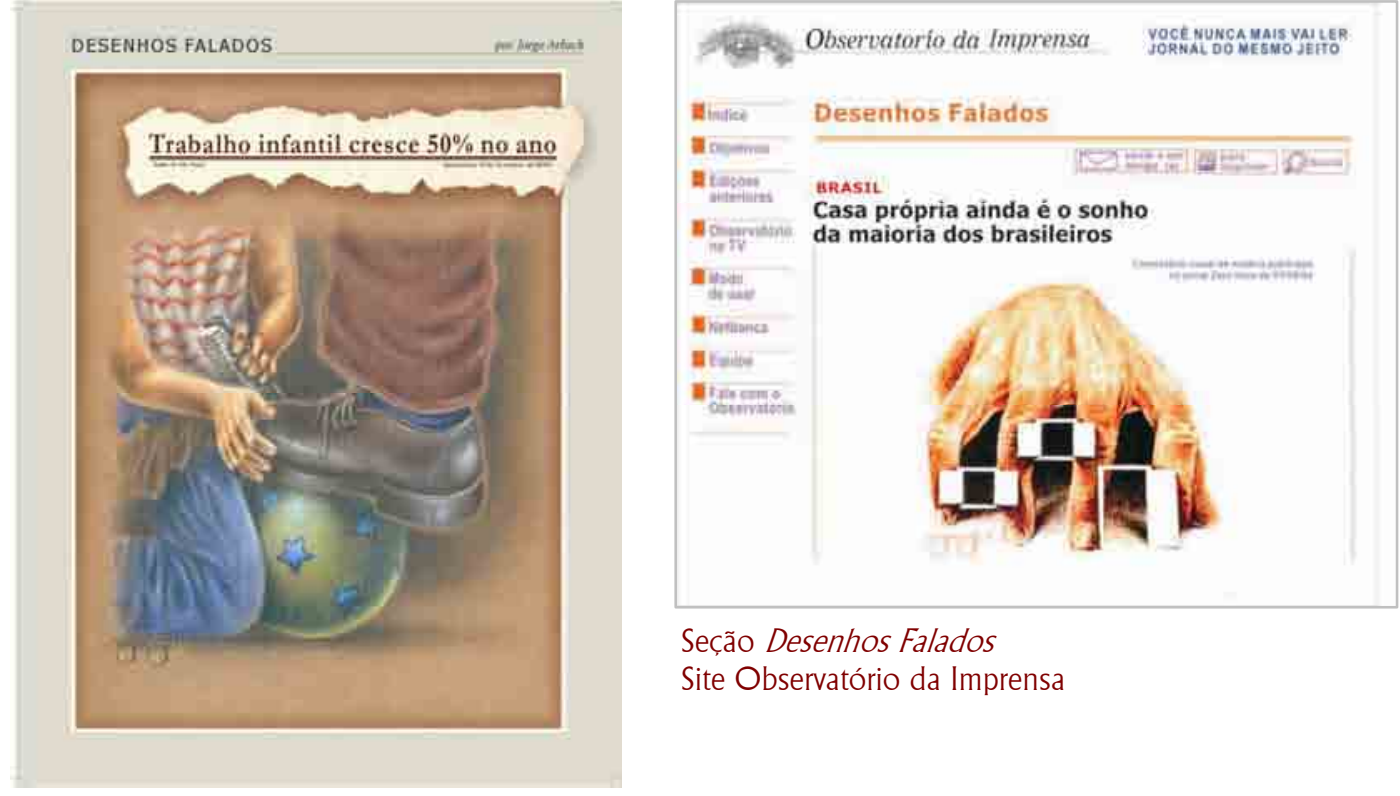

Seção Desenhos Falados

Site Observatório da Imprensa

\section{Seção Desenhos Falados}

Revista Imprensa

Empenhado em refletir conceitualmente sobre esse papel da ilustração é que venho apresentar este trabalho e conduzir minhas reflexões junto ao meio acadêmico.

\section{OBJETIVOS}

O objetivo do presente estudo é demonstrar a possibilidade que a imagem tem de participar do discurso jornalístico por meio da ilustração que esclarece e informa. Pretendo analisar o espaço real em que elas se inserem no jornalismo como fonte de informação e de opinião. Interessa-me, de modo particular, estudar formas e circunstâncias da produção e utilização do humor gráfico como recurso discursivo, para que seja reconhecido academicamente como gênero jornalístico e continue ocupando espaços significativos dentro da comunicação. 
Com essa perspectiva proponho refletir sobre o tema ao configurá-lo em seus aspectos essenciais, indicando pontuações que ampliem essa discussão. Ao final das argumentações, pretendo reivindicar um espaço definitivo para que as variadas modalidades de ilustrações de humor sejam consideradas formas com que se constroem o jornalismo.

\section{A QUESTÃO}

Atualmente as formas de manifestação do humor gráfico não são consideradas nas classificações dos gêneros como componentes do discurso jornalístico. A questão se agrava pela não aceitação do desenho como veículo de opinião e informação. Participa, mas não é reconhecido como tal. Essa situação se aprofunda quando se sobrepõe o aspecto erudito determinado pela palavra, como universo exclusivo de letrados, enquanto que a comunicação com imagens seria propriedade para os não letrados, ou seja, crianças e analfabetos.

\section{A TESE}

A ilustração é possuidora de linguagem capaz de gerar discurso visual próprio, e consequentemente inserir-se no espaço do jornal. Considero a ilustração como uma forma de gênero capaz de informar e opinar, tanto quanto é o texto jornalístico.

A ilustração só não é reconhecida como parte do discurso jornalístico por haver predominância da palavra como articuladora do pensamento. Não é considerada plenamente como gênero nos dias de hoje por permanecer ainda refratária ao espaço ocupado pela palavra como meio preponderante de reflexão e comunicação das idéias.

Esse aspecto se agrava dentro do jornalismo devido à presença da fotografia como testemunha e narradora visual dos fatos, ficando a ilustração exaurida de seus aspectos narrativos e argumentativos.

\section{A HIPÓTESE}

A retenção da ilustração como mecanismo articulador do pensamento foi marcado historicamente por dois momentos críticos:

Quando do surgimento da tipografia.

Quando do surgimento da fotografia 


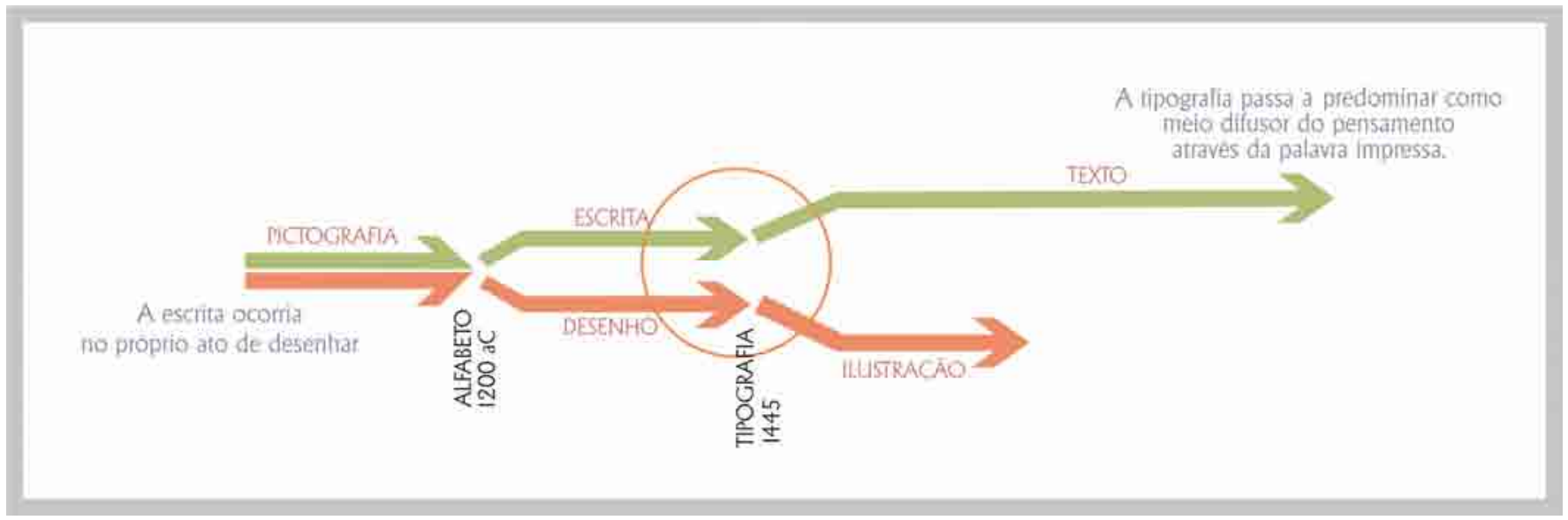

O primeiro momento crítico pode ser situado a partir dos primórdios da comunicação humana quando a escrita e o desenho encontravam-se interligados nos pictogramas.

A partir da invenção do alfabeto, em 1200 aC, a escrita e o desenho se separam, tornando-se independentes como mecanismos artesanais de comunicação.

Com o advento da tipografia, em 1445, a difusão do pensamento passa a se dar mais aceleradamente com a palavra, provocando retenção na fluência das idéias pelo desenho. Por ser mais ágil, a técnica tipográfica passa a ser multiplicadora do discurso, popularizando sua linguagem.

Assim, com a técnica da tipografia, a palavra impressa adquiriu agilidade na comunicação do pensamento. Enquanto que a imagem desenhada, comparativamente, estagnou em seu processo de reprodução, pois a lenta e laboriosa confecção artesanal de matrizes para impressão, e a incompatibilidade técnica de reproduzir a imagem em conjunto com a técnica tipográfica, privou o desenho, consequentemente, na desenvoltura da propagação do pensamento.

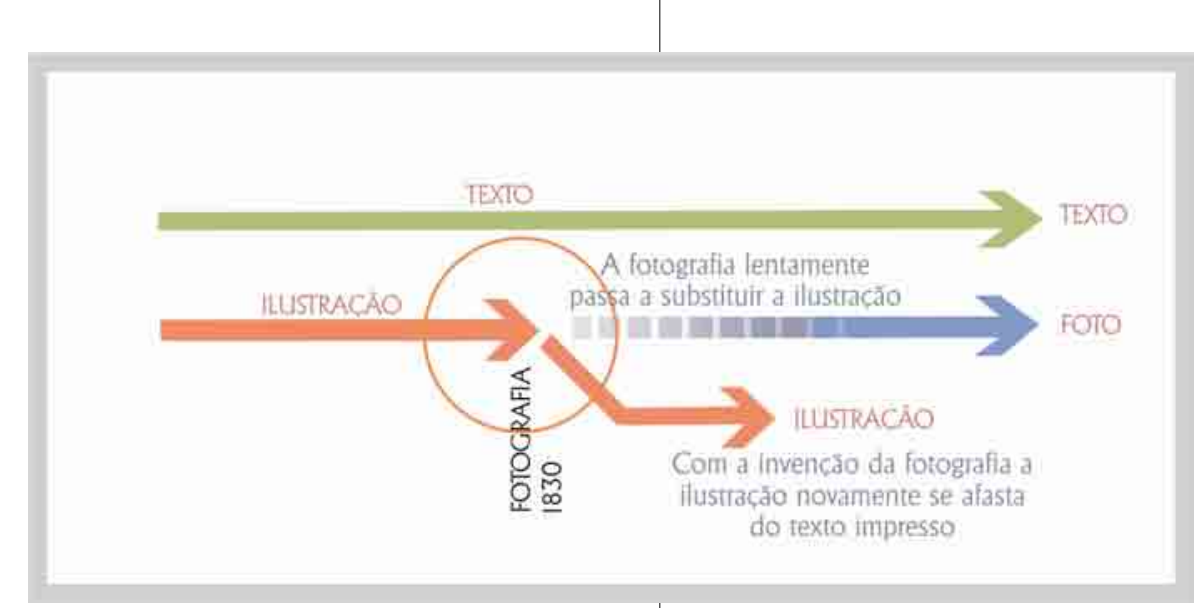

2ำ momento crítico
O segundo momento crítico que agravou mais ainda a retenção da imagem como meio de comunicação foi diante da invenção da fotografia, em 1830. Naquele momento a fotografia retirou da ilustração a veracidade da informação. A foto assumiu a condição de narradora visual dos fatos. A partir de então o desenho foi deslocado das páginas dos jornais para o campo das artes plásticas. Comportamento que reverbera até os dias atuais.

A valorização da palavra impressa perdurou por cerca de 4 séculos, ou seja, de 1445 com a invenção da tipografia, até os experimentos com a fotogravura, em 1882. Nesse período a imagem não conseguiu acompanhar esse processo, por não existir tecnologia capaz de substituir a matriz artesanal, confeccionada em madeira e metal, capaz de gerar compatibilidade de impressão conjunta com a impressão tipográfica das palavras. 
Dentro desse período de quase 4 séculos esboçou-se uma reação com o surgimento da litografia em 1798. Porém, a técnica da litografia não foi suficiente para consolidar a presença da ilustração dentro do jornalismo nascente, pois logo em seguida, em 1830, foi novamente abalada com o advento da fotografia.

Durante esse longo período histórico os processos de impressão tipográficos evoluíram a ponto de difundir livros, folhas avulsas e jornais. Como uma das características do jornal é a sua atualidade, a tipografia concorreu para que as idéias fossem rapidamente transmitidas pela palavra impressa. $O$ mesmo não ocorreu com a ilustração, que deixou de conviver regularmente nas páginas dos jornais durante esse período. O que só veio a ocorrer favoravelmente a partir de 1882 quando começaram os experimentos com matrizes de impressão gravadas por processos luminosos, e não mais por processos artesanais.

\section{O MÉTODO}

Para aprofundar o tema da pesquisa estruturei de início os campos de conhecimento relacionados ao objeto pesquisado, estudando na bibliografia específica seus aspectos históricos, culturais e conceituais, assim, os campos pesquisados foram:

\begin{tabular}{l}
\hline Gêneros Jornalísticos \\
Ilustração Editorial \\
Desenho \\
Palavra \\
Imprensa \\
Informação \\
Jornal \\
Humor Gráfico \\
\hline
\end{tabular}

Montei a seleção e o ordenamento expositivo de cada tópico através de uma articulação ampla, onde cada tema pudesse contribuir para afirmar os demais. Ou seja, por se encontrarem interligados e por haver uma interdependência teórica entre eles, foi possível montá-los como capítulos em um roteiro circular, como veremos a seguir.

Devo frisar também que em cada tópico os enfoques estarão interligados. Por exemplo, no Capítulo 4 ( $A$ Palavra), ao apresentar o subtítulo dos Manuscritos, foi necessário falar brevemente sobre advento da prensa, com Gutemberg. Esse tema aprofundar-se-á em seguida, no Capítulo 5 ( $A$ Imprensa)

É preciso ressaltar que foi necessário retomar uma cronologia histórica em cada capítulo para o perfeito aprofundamento analítico de cada campo temático.

O referido roteiro circular que norteou meus estudos apresenta-se da seguinte forma, com seus respectivos conteúdos: 


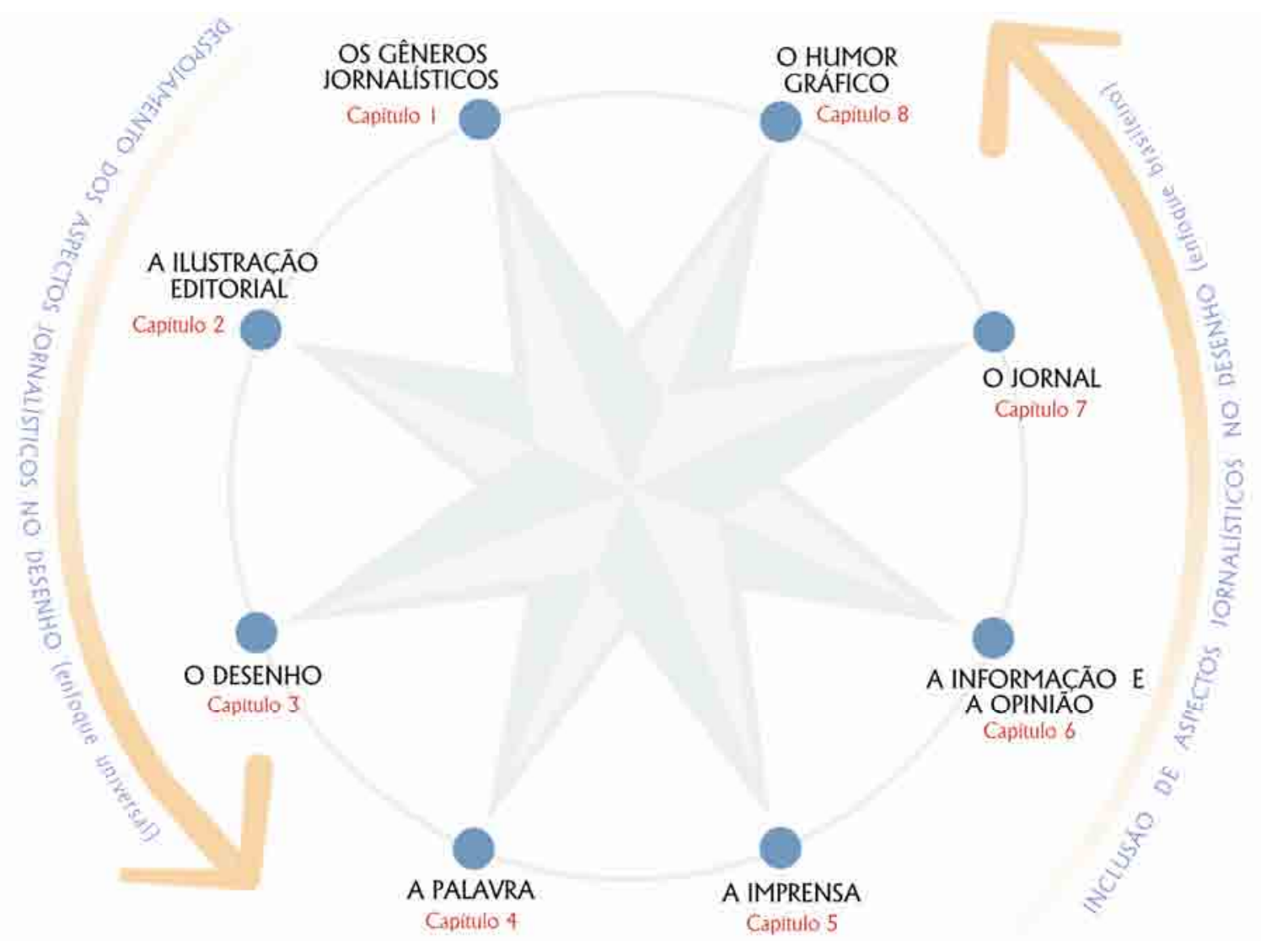

Cap. 1 - Os Gêneros Jornalísticos - Enfoca a classificação das formas com que se constrói o discurso jornalístico Cap. 2 - A Ilustração Editorial - Aborda as características do desenho vinculadas ao texto

Cap. 3 - O Desenho - Analisa o instrumento da linguagem icônica

Cap. 4 - A Palavra - Analisa o instrumento da linguagem escrita

Cap. 5 - A Imprensa - Trata dos mecanismos de reprodução do desenho e da palavra

Cap. 6 - A Informação - Enfoca o conteúdo do discurso impresso

Cap. 7 - O Jornal - Aborda o veículo de difusão do discurso impresso

Cap. 8 - O Humor Gráfico - Trata de apresentar as formas do discurso desenhado 
Por focarmos nossa defesa na inserção do humor gráfico como gênero, tomamos o tópico Gêneros Jornalísticos como início de nossa exposição elegendo-o como Capítulo 1. Seguindo a seqüência enumerada, procurei nos 4 capítulos iniciais despojá-los dos aspectos jornalísticos e revesti-los de características universais, enquanto que para os 4 últimos capítulos procurei inserir aspectos relacionados ao jornalismo brasileiro.

Por fim, após a exposição argumentativa no corpo do trabalho e da pesquisa histórica, apresentarei um Estudo de Caso onde o humor gráfico é apresentado em um periódico referencial brasileiro. Selecionei desenhos que ali foram publicados e que pudessem confirmar minha explanação.

Para fundamentar conceitualmente minha pesquisa pautar-me-ei nos estudos de dois teóricos. O primeiro é o Prof. Dr. Manuel Carlos da C. Chaparro, com suas análises conceituais e históricas a respeito dos gêneros jornalísticos. A segunda é a Profa. Fayga Ostrower com suas reflexões sobre os processos de criação. $O$ fio condutor para minha argumentação se dará ao sustentar que a imagem é detentora de linguagem própria, e que cada ser humano possui mecanismos inatos para assimilar o discurso não-verbal das imagens.

\section{A FORMATAÇÃO}

Além das argumentações teóricas lançadas, parte significativa desta explanação irá ancorar-se na apresentação de imagens, pois parte dos conceitos emitidos será sustentada com as próprias imagens, por considerá-las possuidoras de discurso próprio utilizo-as com o nítido propósito de se tornarem elementos comprobatórios da veracidade das argumentações emitidas.

Considero também que as divisões dos capítulos, com seus respectivos subtítulos conduzem e esclarecem as propostas lançadas. Ali, encontram-se argumentações que orientam na certeza de alcançar a substância necessária que uma pesquisa científica exige.

Necessário se faz mencionar que a formatação desse volume foi aprimorada conjuntamente com o texto, levando em conta questões editoriais, como: encadernação, tratamento de imagens, diagramação, paginação, etc. por considerá-los também objeto de análise e de aplicação prática do que se pretende argumentar.

Mesmo se diferenciando das habituais apresentações de teses, neste trabalho implementei adequações às normas técnicas vigentes, como: identificações autorais, crédito de imagens, referências editoriais, etc. Pautei-me na normatização 
vigente para apresentação de trabalhos científicos, mantendo uma apresentação esteticamente elaborada intelectualmente compreensível.

Defendendo ainda a formatação desta apresentação, esclareço que tenho plenamente configurado os objetivos a serem alcançados com a presente pesquisa. Quaisquer lacunas que por ventura aqui transpareçam e que sejam identificadas pelos membros desta banca de doutorado, estarei receptivo para as necessárias intervenções visando alcançar os objetivos pretendidos.

Espero também que este trabalho estimule outros interessados no tema a debaterem e a complementarem as idéias aqui lançadas. 


\section{CAPÍTULO 1 \\ OS GÊNEROS JORNALÍSTICOS}

1.1 - O JORNAL E OS GÊNEROS

1.2 - NOVAS FORMAS DISCURSIVAS 


\section{1 - O JORNAL E OS GÊNEROS}

\section{Conceituação Sobre os Gêneros}

Define-se gênero como qualquer agrupamento que possua certo número de características comuns convencionalmente estabelecidas. São as semelhanças que existem nas diferentes espécies. As regras para seu estabelecimento surgiram, em princípio, no âmbito das ciências naturais para classificação da fauna e da flora. Posteriormente, passaram a servir na classificação dos estudos em filosofia e daí servindo para definir as formas literárias. Foi através da literatura que passou a ser utilizado na classificação dos textos jornalísticos europeus e americanos.

Os textos jornalísticos se delinearam como gêneros a partir do século XIX, quando a notícia e a reportagem dos acontecimentos mais importantes se consolidaram como material jornalístico. Fato evidenciado na época através dos extensos relatos sobre as guerras e as viagens dos exploradores.

Ao normatizar as características estruturais comuns nos textos jornalísticos, os gêneros passaram a atuar como unificadores e uniformizadores da informação, permitindo que os produtores estruturassem suas matérias numa produção coletiva.

Numa breve avaliação da evolução da eficácia comunicativa dos gêneros jornalísticos, percebe-se um vínculo com a evolução dos recursos de construção da informação., isto é, confirma-se a influência entre o surgimento de novas tecnologias com a evolução das formas discursivas na imprensa.

(1) LIMA, Alceu Amoroso. O jornalismo como gênero literário. São Paulo: Edusp/Com-Arte. 1990
Para o escritor Alceu Amoroso Lima (1), o gênero é "compreendido não como uma imposição ou um modelo, de fora para dentro, mas como uma livre disciplina, de dentro para fora, como princípio ordenador, determinado pela própria arte em sua função criadora" (LIMA, 1990, p. 29). Amoroso Lima esclarece que o gênero realiza-se como uma realidade dinâmica, pois, na medida em que o diálogo avança, as formas de apresentação vão mudando. E, por conter caráter mutável, o gênero passa a ser instrumento de diálogo entre produtor e receptor.

O gênero tem atuação estratégica na produção e na leitura de si mesmo, permitindo que seja lido e compreendido, e que, diferentemente do funcionamento da obra culta, constitui-se objeto de análise da cultura de massas Em resumo, fica assinalado que, ao permitir relacionar forma e conteúdo, os gêneros ajudam o escritor a escrever e o leitor a ler. 
Não há texto sem intenção, nem leitura sem atribuição de sentidos. E, nessa interação entre intenções de autoria e intenções de leitura, talvez até os principais intérpretes sejam os que lêem, não os que escrevem. Umberto Eco sugere que, entre a intenção do autor que ele considera "freqüentemente irrelevante para a interpretação de um texto e a intenção do intérprete (leitor), existe a intenção do texto".

(..)

As fontes também inserem, nessa macrointerlocução, pontos de vista e elementos interpretativos, que a mediação crítica organiza para a difusão social. E tudo isso interage, na construção de um fenômeno a que poderíamos chamar polissemia de conteúdos, do qual nem as notícias nem os artigos podem ser excluídos. (CHAPARRO,1998, p. 104).

Assim, cabe também ao leitor uma parcela de participação no processo jornalístico. Para que a informação veiculada não seja interpretada unilateralmente é necessário que durante a leitura haja espaço para a participação analítica do leitor. Isto só é possível através de um processo interpretativo, considerando-o como um processo de atribuição de significados que vai além do autor. Assim, cabe aos leitores dar sentido aos textos.

Os gêneros jornalísticos, portanto, são "formas que o jornalista busca para se expressar". Seu traço definido está portanto no "estilo", no manejo da língua: são "formas jornalístico-literárias" porque seu objetivo é o "relato da informação e não necessariamente o prazer estético".

Ou seja, a essência do estilo jornalístico estaria na tentativa de fazer o relato do cotidiano utilizando uma linguagem capaz de estar sintonizada com a "linguagem da vida" e que pressupõe o uso de "todos recursos expressivos e vitais, próprios e adequados para expressar a variadíssima gama do acontecer diário".

Os gêneros se diferenciam a partir da articulação existente entre:

Os acontecimentos (a realidade),

Sua expressão jornalística (o relato)

A apreensão pela coletividade (a leitura).

Se gêneros são determinados pelo estilo e se este depende da relação de diálogo que o jornalista deve manter com seu público, apreendendo seus modos de expressão (linguagem) e suas expectativas (temáticas), é evidente que a sua classificação restrinja-se a universos culturais distintos.

A formulação de gêneros jornalísticos no Brasil está ligada em agrupamentos no espaço dos jornais obedecendo comumente às categorias informativas e opinativas. Essas categorias não se assemelham aos gêneros, pois, os princípios que regem o jornalismo informativo não são os mesmos que regem o jornalismo opinativo. 
Uma categoria jornalística é um universo de mensagens estruturadas, a partir de modalidades narrativas. Isto é, estruturadas a partir dos gêneros jornalísticos. Portanto informar, opinar, interpretar, faz parte de um conjunto de regras que servem para distinguir procedimentos técnico-lingüísticos. "Enquanto as categorias delimitam fronteiras, através das técnicas de coleta de informações e construção dos fatos, os gêneros jornalísticos são responsáveis pelo equilíbrio do universo da linguagem jornalística, embora se configurem como unidades narrativas autônomas”. (PEREIRA, 1994, p. 116)

\section{Trajetória histórica}

Como diz o pesquisador italiano Domenico de Gregório os limites cronológicos do jornalismo não estão no aparecimento das "primeiras e mais rudimentares formas da informação e da propaganda", e sim na "aparição das primeiras folhas periódicas impressas a partir dos começos do século XVI e se desenvolve gradualmente em épocas sucessivas até alcançar no século XIX as dimensões que hoje conhecemos e que o tornam uma das formas mais representativas da civilização contemporânea".

Fica evidente a natureza eminentemente política que o jornalismo assume desde o seu nascimento como processo
social. Suas formas embrionárias - que Domenico de Gregorio rotula como "pré-história do jornalismo" - situam-se em
dois níveis. Ou são publicações clandestinas manuscritas ou até mesmo impressas, que circulam à margem do aparelho
censório, desafiando o poder absolutista(...) Ou são publicações oficiais (...), mas que, "submetida à censura prévia e
licença", (trazia) escasso expediente oficial e elogios à corte e aos poderosos, assuntos de nulo interesse público". Não
passavam de propaganda governamental.
O autêntico jornalismo - processos regulares, contínuos e livres de informação sobre a atualidade e de opinião sobre a
conjuntura - só emerge com a ascensão da burguesia ao poder e a abolição da censura prévia. (MELO, 2003, p. 28)

De qualquer maneira, o fim da censura prévia em fins do séc. XVIII constituiu um fator preponderante para que o jornalismo assumisse fisionomia de uma atividade comprometida com o exercício do poder político, difundindo idéias, combatendo princípios e defendendo pontos de vista. Nesses primeiros momentos da sua afirmação, o jornalismo caracteriza-se pela expressão de opiniões, na medida em que a liberdade de imprensa beneficiava as diferentes correntes de pensamento ou distintos grupos sociais que se confrontavam através das páginas dos jornais. Pois, o exercício da atividade jornalística não requeria grandes capitais. Bastava adquirir apetrechos básicos: como uma prensa manual, tipos móveis, tinta e papel.

Durante o século XVIII o jornalismo francês e o jornalismo inglês suscitaram diferentes padrões de expressão simbólica. Enquanto o jornalismo francês apresentava-se com todo o vigor opinativo, promovendo debates, levantando problemas e participando ativamente do cenário político, o jornalismo inglês assumia uma tendência informativa, retraindo-se do combate, preferindo distanciar-se ideologicamente do confronto direto com o centro do poder. 
O que se esboçou a partir de então no jornalismo britânico acabou impondo-se como uma bipolarização do material jornalístico no espaço do jornal. Ficou estabelecida em suas próprias páginas a distinção entre as categorias informações (news) das opiniões (comments).

A diferenciação entre as categorias jornalismo informativo e jornalismo opinativo emergiu da necessidade sócio-política de distinguir os fatos (news) das suas versões (comments), ou seja, delimitar os textos que continham opiniões explícitas. O equilíbrio entre ambas as categorias (informação e opinião) com a predominância de uma sobre a outra permaneceu até hoje como uma peculiaridade de cada processo jornalístico.

Mas sem dúvida o jornalismo informativo afigura-se como categoria hegemônica, no século XIX, quando a imprensa norte-americana acelera seu ritmo produtivo, assumindo feição industrial e convertendo a informação da atualidade em mercadoria. A edição de jornais e revistas que, nos seus primórdios, possui o caráter de participação política, de influência na vida pública, transforma-se em negócio, em empreendimento rentável. O rádio e a televisão já nascem e se afirmam nesse contexto mercantil.

Evidentemente o jornalismo opinativo não desaparece. Na prática, ele tem seu espaço reduzido. Sua presença na superfície impressa (fica) circunscrita às páginas chamadas "editoriais". (MELO, 2003, p. 97)

O jornalismo mundial por não ser uma entidade unificada, existe aspectos formais que distinguem os diversos jornalismos. "A imprensa estadunidense somente utiliza dois gêneros, enquanto entre os latinos são normais outras divisões em mais de dois gêneros".

O jornalismo articula-se, portanto em função de dois núcleos de interesse: a informação (saber o que passa) e a opinião (saber o que se pensa sobre o que se passa). Daí o relato jornalístico haver assumido duas modalidades: a descrição dos fatos e a versão dos fatos. Esse relato só adquire sentido no confronto com o destinatário: e é aí que reside a autonomia do processo jornalístico - que na liberdade que tem um receptor de escolher o que quer saber e através de que meios vai concretizá-lo. Completa-se então o fluxo da determinação ideológica: o leitor/receptor também dispõe de mecanismos para captar o sentido que orienta a ordenação das mensagens jornalísticas.

(..)

Reside aí a bifurcação que identificamos no bojo do relato jornalístico e que chamaremos, para utilizar as expressões correntes, de jornalismo informativo e jornalismo opinativo. Essa categorização exclui naturalmente as tendências rotuladas como jornalismo interpretativo e jornalismo diversiona/ por não encontrarem ancoragem na práxis jornalística observada no Brasil. Entendemos que a interpretação (enquanto procedimento explicativo, para ser um fiel ao sentido que the atribuem os norte-americanos) cumpre-se perfeitamente através do jornalismo informativo. $\bigcirc$ mesmo ocorre com a diversão, mero recurso narrativo que busca estreitar os laços entre a instituição jornalística e o seu público e não transcende a descrição da realidade, apesar das formas que sugerem sua dimensão imaginária. (MELO, 2003, p. 101) 


\section{Características dos Gêneros}

Abaixo relacionamos os gêneros informativos e opinativos com suas respectivas características, pautando-nos pela conceituação adotada na bibliografia de José Marques de Melo e comumente difundida nas Redações e nas Escolas de Comunicação:

\section{Nota}

Corresponde ao relato de acontecimentos que estão em processo de configuração.

\section{Notícia}

É o relato integral de um fato que já eclodiu no organismo social.

\section{Resenha}

Descrição pormenorizada de uma obra ou evento.

\section{Reportagem}

É o relato ampliado de um acontecimento que já repercutiu no organismo social.

\section{Entrevista}

É um relato que privilegia um ou mais protagonistas do acontecimento, possibilitando-Ihes um contato direto com a coletividade.

\section{Fotografia}

Apresenta a realidade através de dois olhares: da objetiva (da lente) e o subjetivo (do olhar) do fotógrafo. Assim, este gênero flui entre as categorias informativa e opinativa.

\section{Artigo}

Representa geralmente a opinião de personalidades representativas da sociedade.

O tema é determinado pelo critério e competência do autor. Possui autoria definida e explicitada.

\section{Editorial}

É o gênero jornalístico que expressa a opinião oficial da

empresa diante dos fatos de maior repercussão no momento. 


\section{Comentário}

O comentário possui uma angulagem a critério do autor.

Exige continuidade e imediatismo. Possui sempre autor definido e explicitado.

\section{Coluna}

É uma opinião temporalmente contínua, sincronizada com o

emergir e o repercutir dos acontecimentos. Possui autoria explicitada.

\section{Carta}

É a presença e a opinião do leitor no espaço do jornal. Estrutura-se de modo

temporalmente mais defasado. Não coincide obrigatoriamente com a eclosão dos fatos.

\section{Crônica}

A crônica possui a feição do relato do real, situando-se na fronteira entre a informação da atualidade e a narração literária. O relato da crônica quanto mais perto estiver do noticiário, mais claramente se configurará como Comentário.

\section{Caricatura}

Tem por objetivo a crítica e a sátira social e política manifestada através de 2 formas não verbais distintas: a caricatura (personalizada) e a charge (situação).

A seguir é apresentado um estudo esquemático onde é possível visualizar as manifestações de diversos gêneros jornalísticos verbais e não-verbais relacionando-os com o momento em que o fato se revela. Nele é possível perceber, entre outros detalhes, que os gêneros informativos verbais (Nota, Notícia e Reportagem) encontram-se no mesmo alinhamento evolutivo, diferenciando-se apenas na temporalidade diante da eclosão dos fatos, conforme afirma José Marques de Melo. Como objeto de estudo, procurei ensaiar nesse quadro a manifestação de outras formas gráficas, como o cartum, o story-board, gráficos, etc..., É possível perceber também que o gênero Comentário evolui para o gênero Crônica na medida em se distancia temporalmente do fato. É de se notar também que a incidência do Desenho de Humor (de caráter reflexivo) e do Cartum (a piada gráfica), ocorrem no mesmo espaço temporal que a Crônica, isto é, distante da eclosão do fato. 


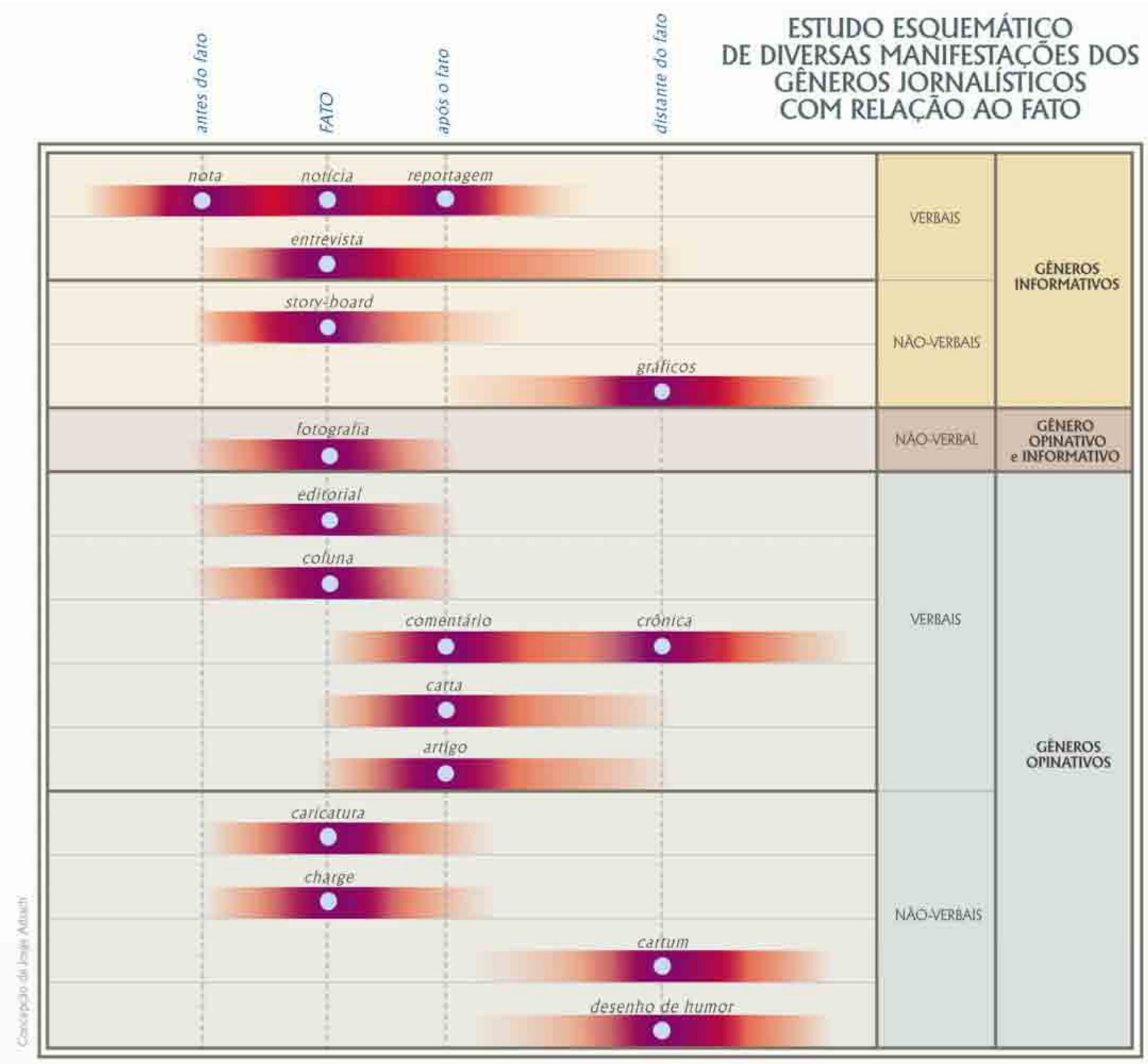




\section{Classificação de Gêneros no Brasil}

Na escassa literatura sobre o tema dos gêneros brasileiros encontramos os estudos do Prof. Luiz Beltrão. Preocupado com a sistematização e classificação do texto jornalístico, Beltrão tem o mérito de ter sido pioneiro em estudar os gêneros jornalísticos no Brasil. Produziu as primeiras obras de natureza acadêmica voltadas para a consolidação do ensino e da aplicação metodológica no jornalismo brasileiro. Nas obras, em que aprofundou os conceitos sobre as categorias jornalísticas, vários outros pesquisadores se pautaram para formularem seus estudos. Esse autor frisa, em $A$ Imprensa Informativa (2), que "a primeira das funções sociais experimentadas pelo jornal moderno é a da informação, ou seja, o relato puro do que ocorre de significativo em todos os domínios do pensamento e da atividade humana" (BELTRÃO,1969, p. 81). Num sentido mais comum, o autor afirma que a informação é uma função que consiste em perceber o real para satisfazer as condições da vida e do progresso da humanidade. Antes de entrar em ação, o homem procura conhecer seu meio exterior para adaptar convenientemente as suas reações. Essas reações não são apenas instintivas, pois recorre a uma característica própria da sua espécie - o raciocínio. Assim, por esse meio, reúne às percepções elementares de sobrevivência não somente reflexos orgânicos, mas idéias sobre o próprio destino, modificando o curso da sua existência em um sentido que Ihe seja mais favorável. Ao Interpretar os fatos atuais, relacionando-os aos acontecimentos futuros, estuda as causas e suas possíveis conseqüências. E valendo-se de experiências anteriores, chega a uma conclusão pela qual se conduz.

Quanto ao jornalista, este deve levar em conta um dos primeiros deveres da imprensa, que é obter a mais breve e correta apuração dos acontecimentos, publicando-o imediatamente, para torná-los como propriedade coletiva. Assim, organiza o material informativo adequando-o ao objetivo da informação, suprimindo e selecionando o que for apropriado.

Já Alceu Amoroso Lima reforça suas reflexões pessoais sobre o jornalismo demonstrando que a função do jornal é ser intermediária entre a informação e o leitor, devendo estabelecer o melhor critério na seleção dos acontecimentos para sua publicação. Afirma que não existe nenhuma função informativa que não inclua algum tipo de apreciação subjetiva ou impregnada de juízo de valor. Atenta para a distinção entre os fatos que são informados e as opiniões de quem informa. E apesar da distinção, acentua:

(...) o jornalismo informativo é aquele que tem predominantemente por objeto a informação da atualidade; seu fim principal é dar conta do que acontece () O jornalismo interpretativo é um modo de aprofundar a informação seu fim principal é o de relacionar a informação da atualidade com seu contexto temporal e espacial; tem, pois, um sentido conjuntural e não se limita a dar conta do que acontece (...). No jornalismo de opinião, a recopilação de dados informativos é subsidiária, o principal é que o jornalista toma posição a partir desses dados e trata de convencer o leitor de que, esta tomada de partido é a mais adequada ou correta. (LIMA, 1960, p. 8). 
José Marques de Melo, dando continuidade aos estudos iniciados por Luiz Beltrão, e revendo a bibliografia internacional, aprofundou a questão dos gêneros jornalísticos praticados no Brasil. Ex-aluno de Beltrão e seu grande admirador, Melo discordou dos critérios que o mestre utilizou para classificar os tipos de textos, e adotou uma nova proposta classificatória.

Pautado no trabalho de Beltrão, a sua análise sobre o jornalismo de opinião ganha força quando faz um estudo específico para sua classificação. Nesta análise, afirma que Beltrão adota critérios funcionais e que "não se ateve à natureza de cada um dos gêneros (estilo, estrutura narrativa, e técnica de codificação), mas obedeceu ao senso comum que rege a própria atividade profissional” (MELO,1994, p. 60). O professor Melo considera dois critérios para sua proposta: a primeira advinda do exercício jornalístico, definindo os gêneros relacionados aos propósitos do relato; e o segundo busca identificar a natureza que organiza os relatos.

Após analisar os gêneros norte-americanos, europeus e hispano-americanos, o professor Marques de Melo centrou sua atenção nos periódicos nacionais e propôs classificar o conteúdo jornalístico brasileiro em duas categorias: jornalismo informativo e jornalismo opinativo.

Melo justifica a classificação do discurso jornalístico em informativo e opinativo através da evolução histórica ocorrida dentro do próprio jornalismo, da qual resultou a "necessidade sociopolítica de distinguir os fatos (news) das suas versões (comments), ou seja, delimitar os textos que continham opiniões explícitas”. (MELO, 1985, p. 38)

Na mesma obra em que reúne seus estudos, o autor reafirma o paradigma anglo-saxônico dividindo os textos jornalísticos em categorias de News e de Comments, isto é, de Informação e de Opinião. Para organizar sua classificação, Melo fundamenta que as duas categorias em que agrupa os gêneros jornalísticos "correspondem à intencionalidade determinante dos relatos". Identifica, assim, duas vertentes:

Vertente da "reprodução do real", determinada pela informação

Vertente da "leitura do real", determinada pela opinião.

"Reproduzir o real significa descrevê-lo jornalisticamente a partir de dois parâmetros: o atual e o novo. Ler o real significa identificar o valor do atual e o valor do novo na conjuntura que nutre e transforma os processos jornalísticos". (MELO, 1985, p. 62) 
Os gêneros que correspondem ao universo da informação estruturam-se a partir de um referencial exterior à instituição jornalística: a sua expressão depende diretamente da eclosão e evolucão dos acontecimentos e da relação que os mediadores profissionais (jornalistas) estabelecem em relação aos protagonistas (personalidades e organizações). Já no caso dos gêneros que se agrupam na área da opinião, a estrutura da mensagem é codeterminada por variáveis controladas pela instituição jornalística e que assumem duas feições: a autoria (quem emite a opinião) e a angulagem (perspectiva temporal ou espacial que dá sentido à opinião)." (MELO,1985, p. 64)

Assim, é possível distinguir os gêneros entre os informativos e os opinativos. $\bigcirc$ primeiro estaria determinado pela evolução temporal dos fatos, enquanto que o outro teria a estrutura da mensagem co-determinada por variáveis controladas pela instituição jornalística, que assumem duas feições: a autoria e a angulagem.

Para fins de estudo sobre as formas dos gêneros, apresentamos a seguir os 12 gêneros jornalísticos estabelecidos pelo professor José M. Melo para Jornalismo Informativo e Jornalismo Opinativo:

\begin{tabular}{l}
\hline JORNALISMO INFORMATIVO - nota notícia, reportagem e entrevista. \\
Esses gêneros são estruturados a partir: \\
1- da evolução temporal do evento \\
2- da relação dos profissionais com os protagonistas do fato; \\
JORNALISMO OPINATIVO - editorial, comentário, artigo, resenha, coluna, crônica, caricatura e carta \\
\hline Esses gêneros são estruturados a partir: \\
1- da autoria (quem emite a opinião) \\
2 - da angulagem (perspectiva temporal e espacial, que dá sentido à opinião) \\
\hline
\end{tabular}

A seguir apresentamos uma visualização desta classificação: 
Gêneros e formatos na comunicacão massiva periodística- um estudo do jornal "Folha de São Paulo" e da revista "Veja".

Coord. Prof. Dr. José M. de Melo.

São Paulo: Universidade Metodista de São Paulo, s/d.

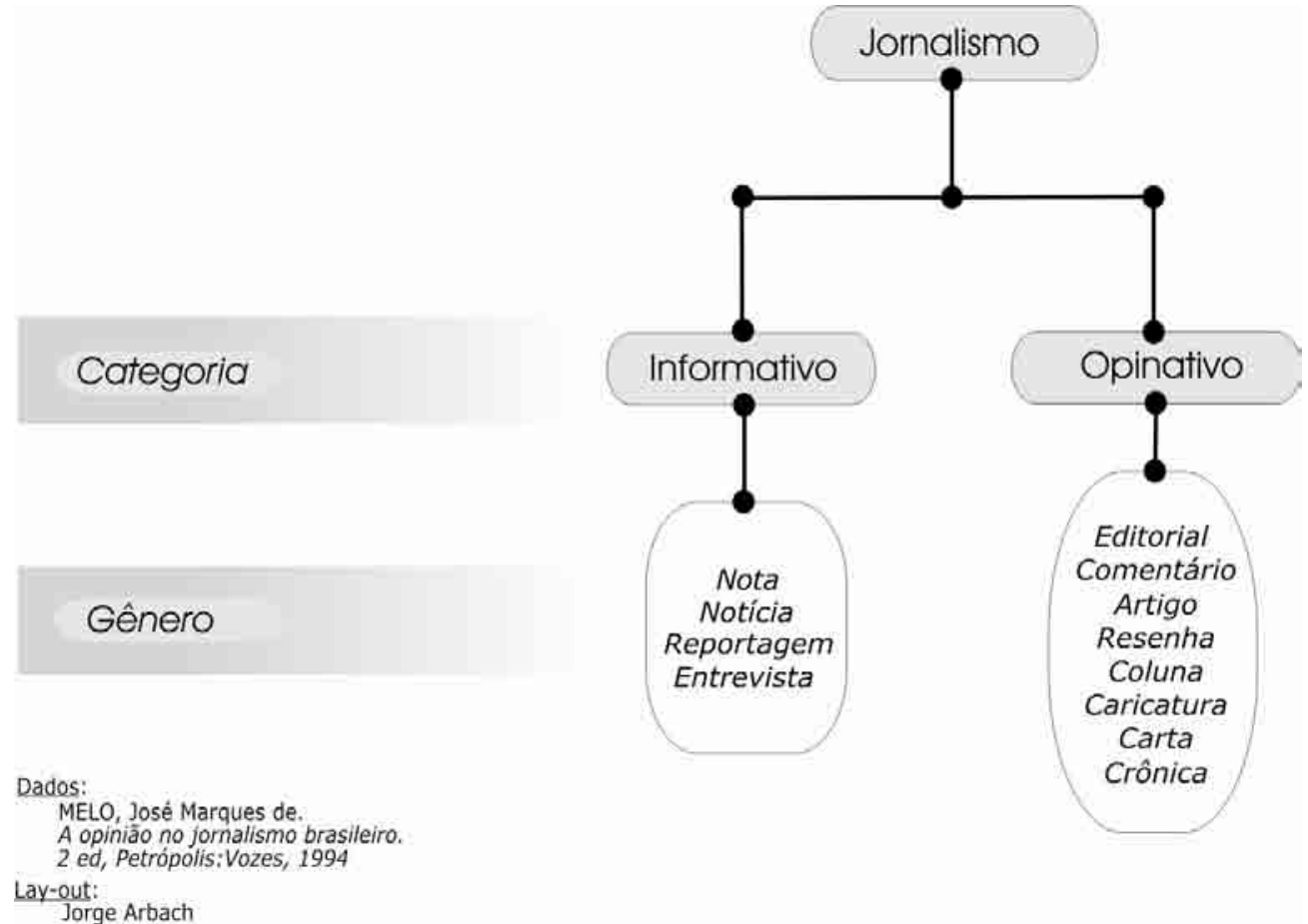

Em uma outra proposta acadêmica de classificação dos gêneros jornalísticos (3), encontramos o resultado de uma pesquisa realizada na Universidade Metodista de São Paulo, sob a orientação do Professor Dr. José Marques de Melo. Nela os pesquisadores procuraram reunir em uma mesma grade classificatória, os gêneros jornalísticos definidos por outros que propuseram a refletirem sobre os gêneros jornalísticos, ou seja, Luiz Beltrão, Alceu Amoroso Lima, Mário Erbolato e José Marques de Melo. Além de reunirem conceitos destes intelectuais e pesquisadores afirmam que em cada gênero há um esquema para se tratar o acontecimento de forma que sua compreensão seja clara e rápida, dando unidade à informação.

Esta grade classificatória é apresentada da seguinte forma: 


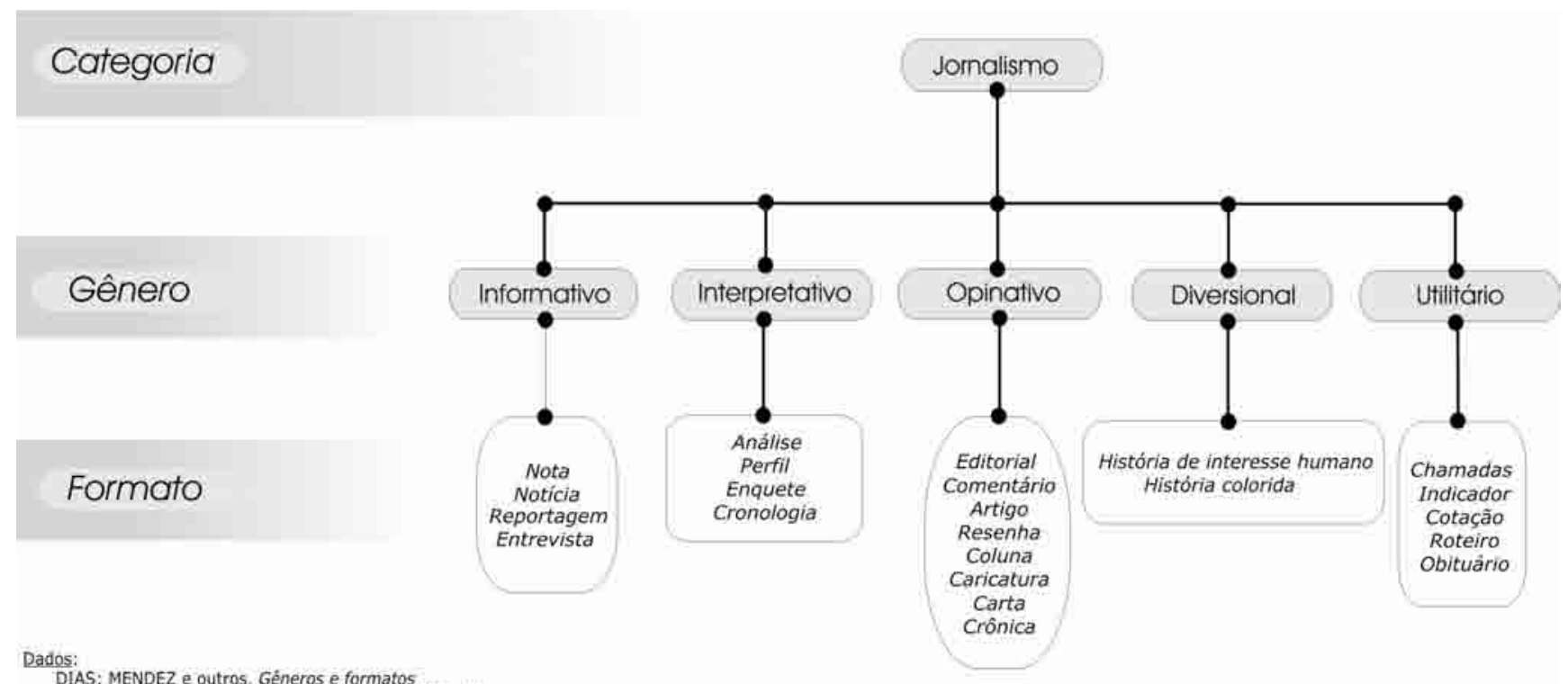

na comunicaçào massiva (...). Săo Paulo: UMESP, s/d.

Lay-out: Jorge Arbach

Por estarmos nesta presente pesquisa focando a imagem dentro do espaço do jornal, é de se notar que nas duas classificações demonstradas anteriormente não há a inclusão da fotografia em nenhuma das formas apresentadas. Certamente por considerá-la mecanismo contribuinte aos demais gêneros, tanto informativos quanto opinativos.

Quanto aos gêneros desenhados, José Marques de Melo salienta que:

(...) a Caricatura como um gênero jornalístico opinativo, em toda sua essência, surge apenas em forma de Charge nas publicações, junto com o Editorial (...) ficando as demais manifestações a traço incluídas como subgêneros da própria Caricatura, pois essas, apesar de possuírem a forma caricatural e apresentarem juízos de valor, trazem no traço maior carga de informação simbólica, mas buscando no senso estético e na plasticidade da forma a sua sustentação ideológica através da abstração. (MELO, 2003, p. 97)

É necessário expressar aqui que José Marques de Melo ergue uma delimitação de participação do Cartoon (cartum) e dos Comics (quadrinhos) no discurso jornalístico. Frisa que, das quatro formas em que o gênero Caricatura se 
manifesta (Caricatura, Charge, Cartoon e Comic), apenas duas dessas quatro espécies de Caricaturas não pertencem ao universo jornalístico. São exatamente aquelas que ultrapassam a fronteira do real e se fundam no imaginário, "(...) por mais que estejam sintonizadas com o momento vivido, com fatos e personagens da atualidade, seu referencial não é vivido. $O$ Cartoon e o Comic não possuem limites de tempo e espaço. São criações da livre imaginação do desenhista", conclui.

A presente pesquisa visa também romper este represamento classificatório das formas de manifestações gráfico-artísticas, sugerido pelo Prof. Marques de Melo, considerando que as mesmas não só possuem uma linguagem fundada na imaginação, como também possuidoras de linguagem autônoma, que as permite participar intensamente do discurso jornalístico. 


\section{2 - NOVAS FORMAS DISCURSIVAS}

\section{Sotaques Jornalísticos}

Analisamos também os estudos do professor e jornalista Manuel Carlos da Conceição Chaparro, trazendo novas observações norteadoras na discussão dos gêneros jornalísticos brasileiros. Em sua obra Sotaques d'aquém e d'além mar (4) o pesquisador conceitua e consolida uma nova proposta classificatória para os gêneros jornalísticos, entendidos como formas discursivas de conceitos práticos. Refuta a clássica herança anglo-saxônica da divisão do discurso jornalístico em informação e opinião. Sustenta sua argumentação ao comparar as formas discursivas no jornalismo diário do Brasil e de Portugal durante os anos de 1945 a 1995.

Chaparro observa que há quase três séculos que os estudos que organizam e explicam academicamente o discurso jornalístico foram pautados no tradicional conceito de origem anglo-saxônica, que divide o jornalismo em gêneros de informação e gêneros de opinião. Ao se estudar a questão dos gêneros jornalísticos, o pesquisador demonstra que o jornalismo não é dividido em informação e opinião, mas construído com informação e opinião. Em sua análise questiona os fundamentos teóricos que pautaram esses conceitos, e ao percorrer as classificações de autores nacionais e internacionais, conclui que não é pertinente explicar e entender a ação discursiva do jornalismo baseado nessa classificação tradicional. Entende que o limiar que distingue opinião e informação fica destruído já na avaliação do material jornalístico a ser editado, sendo influenciado pela intervenção dos vários sujeitos envolvidos no processo de difusão, tanto no relato quanto no comentário da informação.

Inspirado nos estudos de Teun Van Dijk sobre esquemas, Chaparro enquadra os gêneros jornalísticos em dois esquemas:

\begin{tabular}{ll}
\hline Esquema Narrativo & construído com o relato dos acontecimentos \\
\hline \hline Esquema Argumentativo & construído com o comentário dos acontecimentos \\
\hline
\end{tabular}

No seu entender, esta divisão entre as classes de textos não se equivale à comparação "informação versus opinião", pois informações e opiniões estão sempre presentes em todos os gêneros jornalísticos. Acrescenta que normalmente é colocado pelo jornalista o aspecto de que até a notícia dita objetiva, ao ser construído com informações diretas, resulta de seleções e exclusões influenciadas pela opinião do jornalista ou do editor. 
As análises e interpretações contidas no estudo do prof. Chaparro redirecionam a antiga discussão dos gêneros jornalísticos para novas formas de expressão que estão constantemente surgindo ou em mudança e que fogem ao controle rígido do jornalista e da própria atividade jornalística.

Assim, os gêneros devem ser encarados como formas de discurso, deslocando a discussão para o campo das Ciências da Linguagem. Essa proposição teórica foi comprovada, na prática, na investigação empreendida por Chaparro, que resultou numa classificação que identifica os textos jornalísticos em dois únicos gêneros:

$$
\begin{array}{|l}
\hline \text { Formas de Relato } \\
\hline \text { Formas de Comentário }
\end{array}
$$

Chaparro ao argumentar seus estudos frisa que na classificação elaborada por José M. Melo (comumente adotada pelas Escolas de Comunicação) são definidos quatro gêneros informativos (nota, notícia, reportagem e entrevista). E que estes possuem uma característica em comum:

"A nota corresponde ao relato de acontecimentos que estão em processo de configuração. A notícia é o relato integral
de um fato que já eclodiu no organismo social. A reportagem é o relato ampliado de um acontecimento que já
repercutiu no organismo social e produziu alterações que são percebidas pela instituição jornalística. A entrevista é o
relato que privilegia um ou mais protagonistas do acontecer, possibilitando-lhes um contato direto com a coletividade".
(MELO,1994, p 65) (grifo nosso)

Apresentados desta maneira, Chaparro demonstra que, como gênero é a semelhança que permanece nas espécies, temos aí configurada então a possibilidade de aplicação da definição segundo a qual "gênero é a parte da essência comum entre espécies diferentes". Como os quatro gêneros apresentados por Melo(nota, notícia, reportagem e entrevista) têm o relato como essência comum, então é o relato a semelhança que agrupa as quatro espécies. Ou seja: relato é o gênero.

Desta análise, Chaparro propõe em sua grade classificatória apenas dois gêneros por onde se constrói o discurso jornalístico: Relato e Comentário. Mais adiante será apresentada uma grade classificatória, para visualizar a proposta lançada pelo Prof. Chaparro, 


\section{Paradigmas Históricos}

Para argumentar sobre as atuais referências que separam os textos jornalísticos em informação e opinião, Chaparro remonta aos primórdios do empreendimento jornalístico, ainda no início do século XVIII:

Em 11 de Maio de 1702, o jornal inglês The Daily Courant veio ao mundo para ser o primeiro diário de natureza política, na Europa. A importância do Courant, porém, vai além das datas: ganhou fama e lugar na história da imprensa por causa de uma inovação criada por Samuel Buckley, seu diretor.

(...)

Face à crise financeira que ameaçou o Courant logo nos seus primeiros tempos de existência, Elizabeth Mallet, fundadora do diário, chamou Buckley e confiou-lhe a missão de salvar o jornal. (...) O novo diretor criou uma estratégia e um estilo que influenciaram todo o jornalismo mundial: separou as notícias dos artigos (...) para não "contaminar" as informações, porque "os leitores são capazes de refletir por eles próprios". (CHAPARRO, 1998, p. 97)

A linha jornalística implantada pelo Daily Courant foi culturalmente revolucionária, ao privilegiar a informação sem juízos de valor opinativo (news), separando-as dos artigos imbuídos de valores opinativos (comments). Estava criado o mito anglo-saxônico da objetividade jornalística.

Desaparecido em 1735, o modelo criado pelo Daily Courant resistiu ao tempo. A experiência editorial de Buckley criou o paradigma que sobrevive até os dias atuais de que o jornalismo é dividido em Opinião e Informação. Estando consolidado o paradigma, este permaneceu como valor definitivo, gerando conceitos ilusórios.

O paradigma opinião/informação tem condicionado e balizado há décadas a discussão sobre gêneros jornalísticos, impondo-se como critério classificatório e modelo de análise para a maioria dos autores que tratam do assunto. (...)

Trata-se de um falso paradigma, porque o jornalismo não se divide, mas constrói-se com informações e opiniões. Além de falso, está enrugado pela velhice de três séculos. (CHAPARRO, 1998, p. 100).

A opinião enfática de Chaparro é determinante por considerar que o discurso jornalístico modificou-se ao longo dos últimos 3 séculos, e consequentemente a forma de se apresentar ao público.

Depois da experiência inovadora do Daily Courant, no início do século XVIII, as interações humanas e as várias revoluções (cultural, política e tecnológica) mudaram a sociedade, impondo adequações no fazer jornalístico. Ao mesmo tempo, o jornalismo no mundo se expandiu e entrou no ciclo da informação (telefone, telégrafo, rádio, fotografia, cinema, TV ...) 
Dois fatores foram decisivos para definir os rumos da difusão do jornalismo no mundo ocidental:

1 - Os avanços das tecnologias de comunicação à distância, consolidando as agências noticiosas.

2- O revolucionário desenvolvimento da indústria gráfica.

Influenciado por essa evolução, o jornalismo deixou de se expressar apenas por notícias e comentários.

Nos últimos cem anos, a reportagem, por exemplo, tornou-se a forma discursiva predominante em jornais e revistas. 'A maioria do que se publica num jornal é reportagem' (...). Além disso, surgiram e desenvolveram-se a entrevista e o fotojornalismo, técnicas de relato cuja eficácia, tal como acontece na reportagem, está na aptidão de associar os fatos às idéias, os dados às emoções, os acontecimentos à reflexão, os sintomas ao diagnóstico, a observação à explicação, o pressuposto à observação.

O próprio desenvolvimento da diagramação e da infografia, com a utilização dos modernos recursos eletrônicos de edição gráfica, cria e amplia campos de relação interativa, dialética, entre a informação e a opinião. E disso resultam ganhos significativos para a apreensão e/ou a atribuição de significados na realidade, entendida, na sua totalidade, como sinônimo de mundo, espaço do que existe e acontece e do que falta e não acontece. (CHAPARRO, 1998, p. 100)

Evidencia-se ainda nas formas discursivas do jornalismo o aspecto da batalha da conquista do leitor, enriquecidas cada vez mais pelas tecnologias eletrônicas de edição gráfica.

Em sua argumentação, Chaparro expressa que "não há como ajustar as formas discursivas do jornalismo ao critério que divide os textos em informativos e opinativos". Considera ele que esta análise pertence a universos diferentes, isto é: a divisão dos textos em artigo, notícia, reportagem, entrevista, crônica, etc... é resultado da diversidade das estruturas externas, identificadas somente como formas, e não como gêneros. As propriedades informativas e opinativas das mensagens são como substâncias pertencentes à ação jornalística, quer se relate ou se comente o fato. Enquanto que os gêneros são as estruturas externas; isto é, as formas discursivas da informação.

Chaparro rebate os conceitos de José M. Melo quando este menciona que, na categoria dos que reproduzem o real (próprio dos gêneros informativos) a diferença entre Nota, Notícia e Reportagem está na progressão dos acontecimentos. Se assim for considerado, passa a ser introduzido no elenco das razões um novo critério, o da temporalidade.

A quantidade de gêneros da grade classificatória (utilizada por José Marques de Melo) torna inevitável a similaridade entre vários deles. Em alguns casos, as semelhanças são bem mais bem acentuadas do que as diferenças, o que, no mínimo, não se harmoniza com o entendimento predominante (...) da questão dos gêneros: eles definem-se pelas diferenças formais entre si. Talvez por isso, quando caracteriza os gêneros incluídos na sua proposta, o autor recorre a critérios que nada têm a ver com a forma dos textos. (CHAPARRO,1998, p. 108). 
Acrescentamos outros critérios que não têm nada a ver com a forma dos textos, e que são recorrentes: temporalidade, autoria, e angulagem. Assim, as investigações realizadas por Chaparro sobre a evolução dos gêneros jornalísticos na imprensa produziram....

(...) a evidência de que os conceitos opinião e informação perderam eficácia (se é que alguma vez a tiveram) como critérios para categorizar gêneros jornalísticos. (A pesquisa de Chaparro) demonstrou que o relato jornalístico acolhe cada vez mais a elucidação opinativa, e que o comentário da atualidade exige cada vez mais a sustentação de informações qualificadas. Surgiu daí a convicção de que seriam necessárias novas buscas, teóricas e de observação, para um novo entendimento da questão dos gêneros jornalísticos.

()

A leitura sistemática de textos narrativos e argumentativos indica que o jornalismo não se divide em "Opinião" e "Informação". É preciso, portanto, pensar a questão dos gêneros jornalísticos por outra perspectiva. (CHAPARRO, 2000, p. 94 e 110)

\section{Espécies Gráfico-Artísticas}

Quando Samuel Buckley, no Daily Courant, decidiu separar as notícias (news) dos comentários (comments) não pretendeu criar qualquer limite divisório entre informação e opinião. O que pretendeu foi separar dois tipos de textos, um com estrutura formal narrativa e outro com estrutura formal argumentativa. Porém, nas intenções e nos conteúdos, lá estavam contempladas a informação e a opinião, substâncias que permanecem interagindo, conservando-se como linguagem asseveradora.

No "policiamento" da opinião, que os crentes da objetividade fazem, é claramente identificável um viés moralista, como se a opinião, só por si, tornasse suspeita a informação. E a questão não é moral nem ética, mas técnica: para o relato dos acontecimentos, a narração é mais eficaz. Ao relatar-se, conta-se uma história, com suas complicacões e seus sucessos, mas os juízos de valor estão lá, implícitos, nas intencionalidades das estratégias autorais, e explícitos, nas falas (escolhidas) dos personagens, às vezes até nos títulos.

Há que dar início a uma nova discussão sobre a teoria dos gêneros jornalísticos, ancorando-a nas ciências da linguagem. Porque gêneros são formas de discurso. Na visão pragmática, formas de dizer, para fazer - o que explica, no jornalismo, a importância da eficácia. (CHAPARRO, 1998, p. 113-114)

Conclui-se então que o relato jornalístico ao fazer parte dos acontecimentos, é capaz de alterar o estado das coisas, potencializando efeitos transformadores na sociedade. 
Como vimos, o professor Chaparro ao inspirar-se nas referências esquemáticas de Teun A. Van Dijk propõe dois tipos de esquemas para o discurso jornalístico:

\section{Esquemas da Narração, para o relato dos acontecimentos;}

Esquemas da Argumentação, para o comentário dos acontecimentos.

Em menor volume de participação na edição jornalística, Chaparro propõe um terceiro e um quarto esquema, além dos esquemas narrativo e argumentativo. . Identifica formas que se adequam ao Esquema Prático, como por exemplo, a previsão do tempo, os índices financeiros, os horários de transportes, as programações de espetáculos, etc... E aprofunda sua classificação esquemática ao inserir uma quarta categoria denominada Esquema Gráfico-Artístico. A inserção desse quarto esquema traz novos critérios para reconhecer e contemplar modalidades não-verbais que já participam intensamente do discurso jornalístico sem, no entanto, serem reconhecidas como pertencentes ao universo dos gêneros jornalísticos, como as fotos e as ilustrações.

Assim, essa nova proposta classificatória abre a possibilidade da inserção das 5 manifestações de Humor Gráfico como formas já participantes do discurso jornalístico. Nesse campo estarão incluídas as Caricaturas, as Charges, os Cartuns, os Quadrinhos e uma modalidade que vem se distinguindo junto com as demais: o Desenho de Humor.

Resumindo e visualizando a classificação do Prof. Chaparro, temos:

Para o gênero RELATO correspondem

\section{Espécies Narrativas}

Espécies Práticas.

\section{Para o gênero COMENTÁRIO correspondem}

Espécies Argumentativas

Espécies Gráfico-Artísticas.

Por fim, a proposta lançada por Chaparro gera a seguinte grade classificatória: 
$\left(^{*}\right)$ Em conversa com o autor, este me identificou dois formatos com vocação híbrida: a Coluna e a Foto, que servem com igual aptidão ao Relato e ao Comentário

A forma Coluna já se encontra incluída no atual quadro e a forma Foto deverá ser incluída em uma próxima edição classificatória.

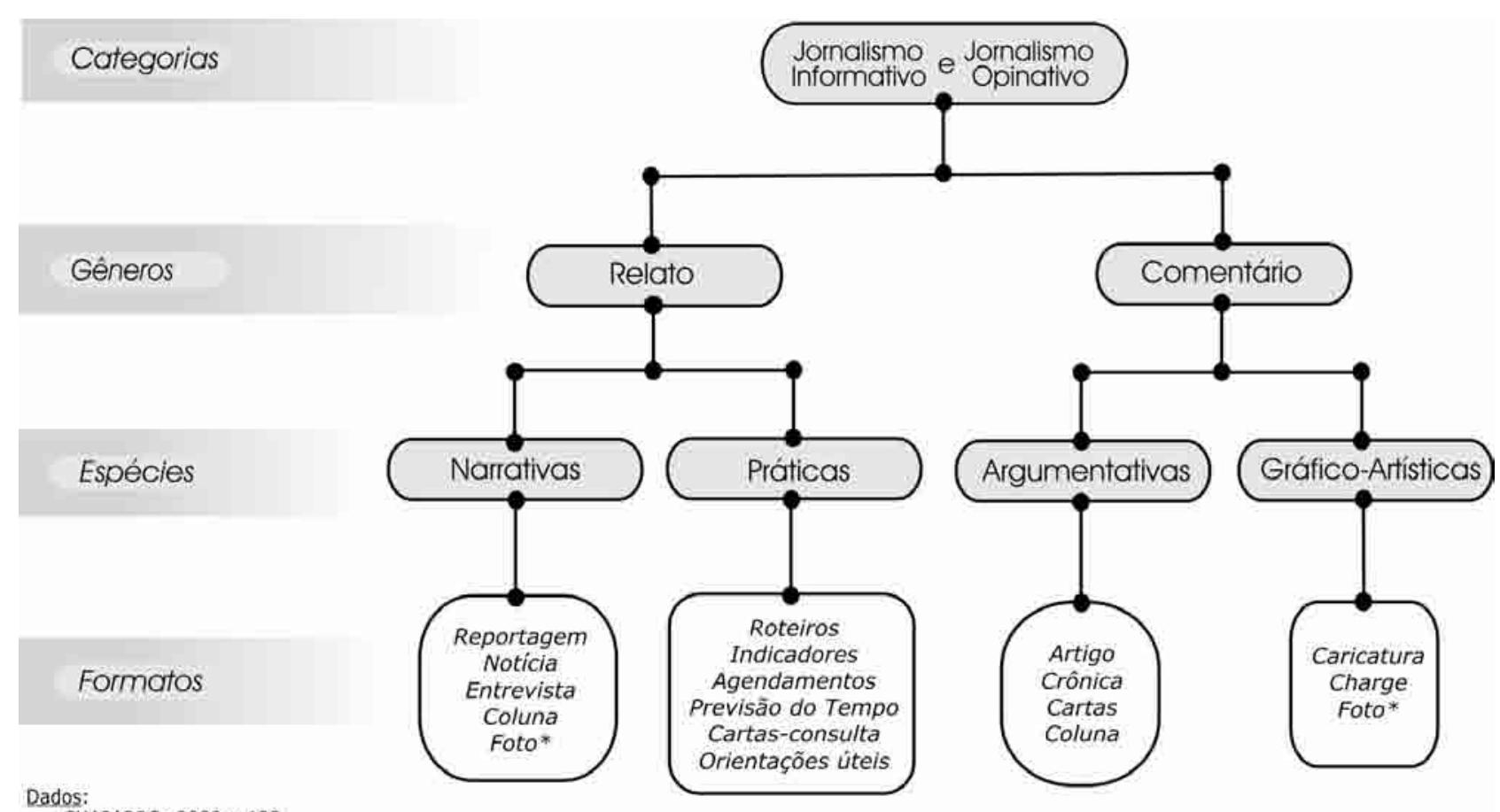

CHAPARRO; 2000:p 122

Lay-out:

Jorge Arbach 


\section{CAPÍTULO 2}

ILUSTRAÇÃO EDITORIAL

2.1 - O DISCURSO DA ILUSTRAÇÃO

2.2 - A SINTAXE DA ILUSTRAÇÃO

2.3 - A SEMÂNTICA DA ILUSTRAÇÃO 


\section{1 - O DISCURSO DA ILUSTRAÇÃO}

A palavra ilustração é, ainda hoje, categorizada como complemento visual do texto. O relacionamento do texto com a ilustração é mais que um diálogo complementar entre duas linguagens. Com o passar dos anos a ilustração evoluiu e ganhou autonomia, até tornar-se informação visual com consciência crítica e atuação editorial no contexto dos periódicos. Como o texto, a ilustração por si só é possuidora de linguagem com discurso próprio.

Numa abordagem semântica do termo ilustrar, encontramos nas enciclopédias definições correlatas:

\begin{tabular}{l} 
tornar ilustre \\
iluminar, clarear \\
elucidar; esclarecer \\
transmitir conhecimento \\
adquirir conhecimento \\
comentar; explicar \\
instruir; instruir-se \\
\hline
\end{tabular}

Ilustrar é iluminar o texto - e isso acontece sempre de um certo ângulo ou ponto de vista, assim a parte iluminada ou destacada produz também uma sombra. De modo que toda ilustração deveria ressaltar algo do texto que ao mesmo tempo mostra qual é a visão/posição do ilustrador. Ele ilumina e se ilumina, se faz presente pela maneira com que ilustra o texto, pela originalidade da sua abordagem.. (SPACCA. mar/2001: p 1)

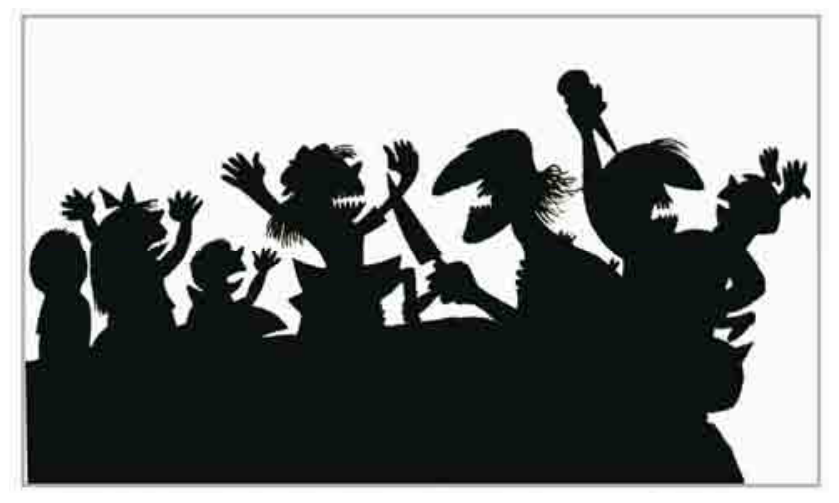

Assim, o ato de ilustrar um texto pressupõe lançar luz sobre o conteúdo do texto. É iluminar o conhecimento acrescentando informações e significados sobre o texto. É como considerar que a imagem que ilustra carrega consigo uma elucidação.

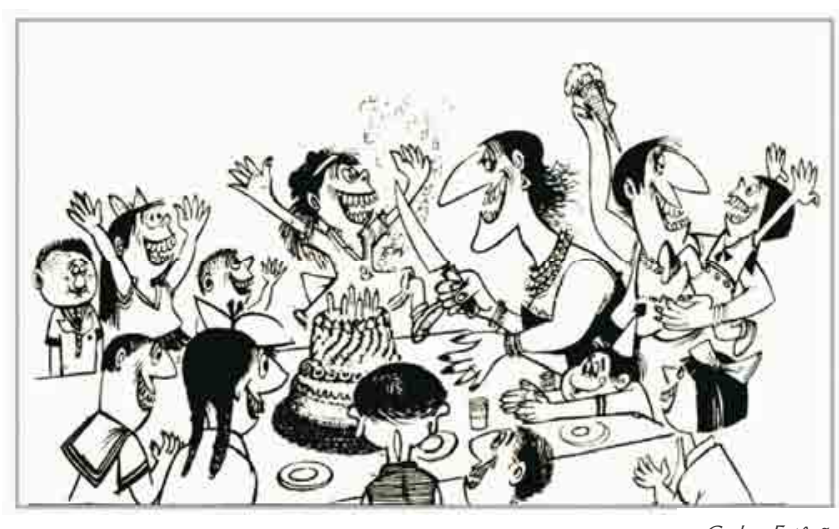

Carlos Estêvão 


\section{O Ato de llustrar}

Sendo a ilustração um dos elementos mais utilizados na comunicação impressa, sua utilização pode atender a variados objetivos. Pode ser veiculada para tornar o texto visualmente mais atraente ou servir para melhor esclarecer uma informação textual ou, até mesmo, contrapor-se a ele.

Nas páginas de jornal a ilustração não busca competir com o texto nem tampouco com a fotografia. Entre as três distintas linguagens há, na verdade, uma relação de complementação. Ainda que no jornalismo prevaleça a presença do texto, o jornal impresso é construído pela união dessas três diferentes maneiras de expressar o mundo. Conseqüentemente, capazes de apresentar relatos e comentários sobre o mundo.

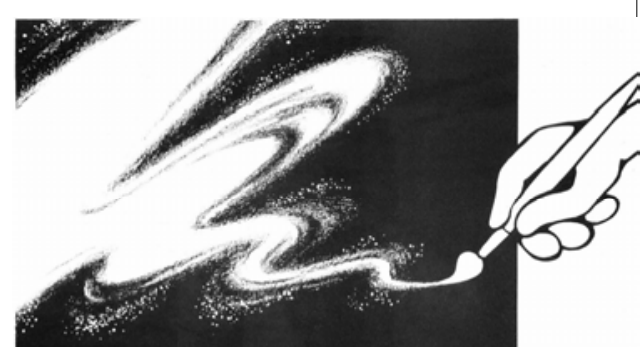

Comumente o conceito que se tem de ilustração é de qualquer desenho que esteja acompanhando um texto. E o que se espera das ilustrações é que não ocupe apenas espaço no jornal, decorando ou descrevendo exatamente o conteúdo do texto. Numa melhor concepção, a ilustração dialoga com o texto. A ilustração tem a possibilidade de sustentar uma autonomia ou se subordinar plenamente à uma descrição gráfica do texto.

"Assim como existem os códigos ou as convenções de uma língua que permitem a comunicação do pensamento, a linguagem não verbal também possui seus códigos. Isto é, ela possui elementos em sua estruturação "interna" e "externa" que são perfeitamente analisáveis. "A forma é uma configuração visível do conteúdo", como bem disse o pintor e desenhista americano Bem Shahn”. (OLIVEIRA, 2004, p. 11)

Quando realizada em sua plenitude artística, a ilustração deixa de ser um utilitário circunstancial para tornar-se obra autônoma, detentora de vida própria. Similar fenômeno ocorre no universo musical, com as trilhas sonoras de filmes. As músicas que participam do roteiro possuem vida própria, independente de estarem ou não acompanhadas da produção cinematográfica.

Assim como a ilustração, devemos considerar o texto também como uma forma, isto é, uma forma definida de linguagem, materializada pela palavra escrita. E o impulso que leva ao ato de ilustrar esse texto nasce de uma idéia, uma idéia ainda sem materialização. Uma idéia que só irá se materializar através do desenho. 
O ilustrador Spacca esclarece este aspecto:

(1) FERDINAND DE SAUSSURE (1857-1913)

Lingüista suíço, cujas elaborações teóricas propriciaram o desenvolvimento da lingüística.
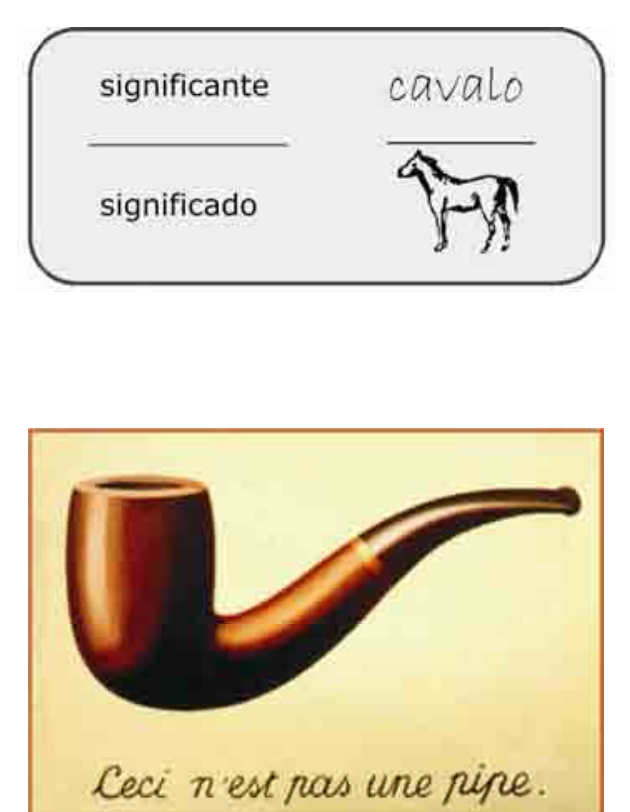

A traição das imagens. René Magritte - 1928
Só se entra em contato com idéias quando elas são manifestadas através de alguma materialidade. São idéias faladas, idéias escritas, idéias desenhadas, cantadas, representadas, pintadas, encenadas, etc.

Um texto não é uma idéia, é a expressão de uma idéia (um conceito) por meio de um texto. Texto e imagem estão num mesmo plano, ambos são veículos, ou melhor dizendo, "encarnações" de uma idéia.

Sendo (que) o conceito de idéia (ê) a organização mental de uma vontade ou sentimento. (SPACCA, ago/2001, p. 1)

Diferentemente da imagem, que possui uma analogia visual com a realidade, a palavra escrita atua como um signo. E conforme prenunciou Saussure (1) o signo é composto de um significante e de um significado. Isto é, o plano dos significantes constitui o plano da forma em que se revela o signo (no caso ao lado, a palavra cavalo), enquanto que o plano dos significados constitui o plano de conteúdo (no caso, a imagem mental que temos de um cavalo ). Assim, Saussure define significado como a imagem mental que temos de algo, representado por meio de um significante. No caso, o significante é a palavra cavalo, e o significado é o cavalo que está em nossa mente, e não o cavalo real em si.

Para situarmo-nos no universo da presente pesquisa sobre o discurso da ilustração, exemplificamos este raciocínio com a famosa pintura $A$ traição das imagens de René Magritte: Ceci n'est pas une pipe.

De fato a imagem pintada na tela não é um cachimbo real. Portanto, nem a representação pictórica do objeto é o cachimbo real, nem a palavra cachimbo (pipe) escrita abaixo ainda é o cachimbo real. Ali está a idéia mental que fazemos dele.

Com isso, é possível perceber que o valor das imagens pintadas, ou desenhadas, extrapola as divisões ordenadoras e classificatórias. É perceptível que o valor discursivo da imagem leva em conta o repertório mental que cada indivíduo adquiriu ao longo de sua vida. Essa aquisição mental das diversas imagens ao longo da vida do indivíduo é que vai nutrir o universo de sua própria imaginação, e consequentemente construir seu próprio repertório de imagens, ou seja, seu próprio imaginário.

O filósofo alemão Walter Benjamim (1994, p. 169) observou o impacto da percepção da imagem no cotidiano social ao considerar que "(...) a forma de percepção das coletividades humanas se transforma ao mesmo tempo em que (transforma) seu modo de existência". Ou seja, a maneira de como um grupo social percebe a realidade está relacionada 
com os recursos técnicos disponíveis na época para sua veiculação. Assim, a imagem participa não como um recurso disponível, mas como algo que altera significativamente nossa história no mundo. A partir de qualquer contexto social, a obra de arte não representa tão somente uma expressão individual transmitida por um artista, mas como um objeto concreto pertencente ao acervo cultural de seu ambiente social.

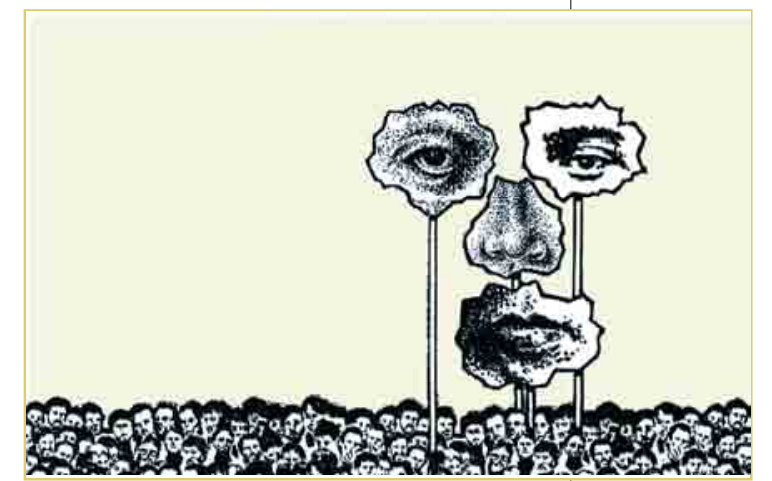

Assim, os conhecimentos culturalmente organizados por uma comunidade são assimilados por meio das linguagens, constituindo-se em condição primordial para o desenvolvimento simbólico da consciência. Segundo Jacques Aumont, toda imagem é portadora de representação e esta, por sua vez, "só tem dimensão simbólica tão importante porque é capaz de significar". (AUMONT, 1995, p. 250). Portanto qualquer enunciação produzida pelas pessoas só poderá ser compreendida se entendermos sua relação com outras enunciações.

Bakhtin afirma que toda enunciação é um diálogo, que faz parte de um processo ininterrupto da comunicacăo humana.

Um enunciado jamais pode ser entendido como fato isolado, pois ele pressupõe uma conexão com todos aqueles que

o antecederam e com aqueles que o sucederão; um enunciado configura-se como o elo de uma cadeia e só é possível

a sua compreensão dentro desta cadeia". (MIANI, 2000, p. 68)

Sendo detentora de um caráter simbólico, a linguagem não-verbal manifestada pela imagem é transformada em instrumento de pensamento do artista, muitas vezes em alegorias ou metáforas visuais.

O desenvolvimento da ilustração jornalística sempre esteve associado ao desenvolvimento das tecnologias de reprodução gráfica. Cada avanço permitiu uma melhor reprodução das imagens, tanto em nível de quantidade como de qualidade, contribuindo para a fluência da linguagem icônica.

Para fins deste estudo, vale ressaltar as três dimensões semióticas lançadas por Peirce (2), através da Semiologia, para análise das imagens, e que serão aprofundadas na seqüência deste capítulo:

(2) (CHARLES PEIRCE (1839-1894) Fundador do Pragmatismo e da ciência dos signos. a Semiótica.

\section{SINTÁTICA - Manifesta-se através da forma. Diz respeito aos elementos estruturais e técnicos de composição}

SEMÂNTICA - Manifesta-se através do conteúdo. Diz respeito àquilo que se pretende expressar

PRAGMÁTICA - Manifesta-se através da função . Diz respeito à finalidade comunicativa da imagem

Numa escala de valores, até meados do século XIX a mensagem através dos desenhos ocorria predominantemente pelo valor da sintaxe da ilustração, isto é, pelo valor das formas Por conseguinte a visibilidade da forma estava acima da mensagem semântica da ilustração, isto é, acima dos conteúdos interpretativos da imagem. Portanto, até o século XIX as ilustrações possuíam caráter narrativo ao acompanhar os textos, onde a forma prevalecia sobre o conteúdo interpretativo. 


\section{RETRATOS DE FAYUM}

nome dado às pinturas funerárias egípcias, realizadas entre os século

e o século III. Eram pinturas encáusticas, feitas com cera quente pigmentos, sobre painéis de madeira.
Assim como existe uma sintaxe para a linguagem verbal ordenando o universo das palavras, existe também uma sintaxe para a linguagem não verbal, ordenando o universo das imagens. Além dos fatores estruturais contidas nas imagens, outros fatores participam para a sua correta assimilação. Para o professor e ilustrador Rui de Oliveira (2004, p. 8), todo fenômeno artístico é um fenômeno de comunicação. E para o ilustrador um dos objetivos fundamentais da arte de ilustrar é a construção de um processo flexível para a leitura das imagens, não simplesmente relacionando-as com o texto. "Sua leitura possui uma iniciação metodológica, e que, acima de tudo, ela é aptidão adquirida. Uma capacidade adestrada e cultivada." (OLIVEIRA. 2004: p 8)

Ao considerar que as imagens criam uma memória visual, a assimilação participativa da imagem com a palavra amplia o alcance do seu conteúdo simbólico., pois "(...) nenhum gênero artístico sobrevive sem influência de seus antecessores. A arte primitiva cristã utilizou velhas formas da mitologia pagã (...) como os laicos retratos de Fayum do Egito, no inicio da era cristã, que deram origem aos crédulos ícones bizantinos, símbolos da cristandade." (OLIVEIRA, 2004, p. 22)
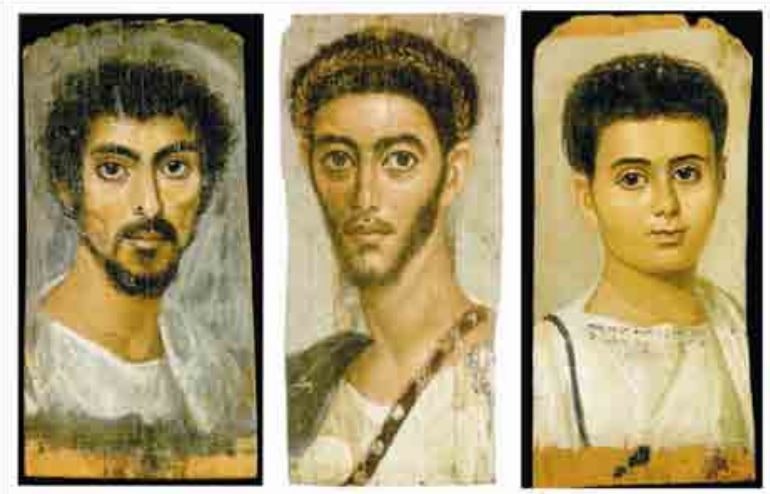

Retratos de Fayun - aprox. séc. Il
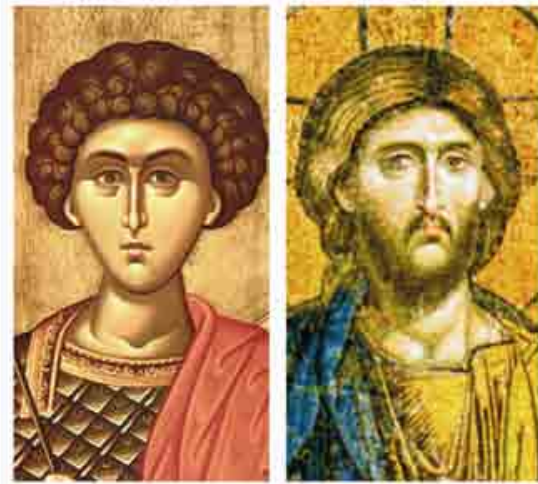

Icones Bizantinos - aprox. séc. IX

Assim como podemos vislumbrar o panorâmico histórico da evolução da leitura da imagem como cultura adquirida, o mesmo ocorre com o aprendizado de uma criança.

A palavra é o espírito e a imagem (é) o seu corpo. Portanto, palavra (espírito) e imagem (corpo) são indissociáveis. A imagem de um livro no psiquismo de uma criança pode se estender por toda a vida adulta. Um indissipável vestígio em nossa memória. Ela, a imagem, é muito mais pregnante do que qualquer palavra. Portanto, diante desse quadro, os ilustradores e os projetistas gráficos têm uma grande responsabilidade: estarem criando não apenas a memória e o passado visual de seus leitores, mas acima de tudo de estarem formando e educando o olhar. (OLIVEIRA, 2004, p. 20) 


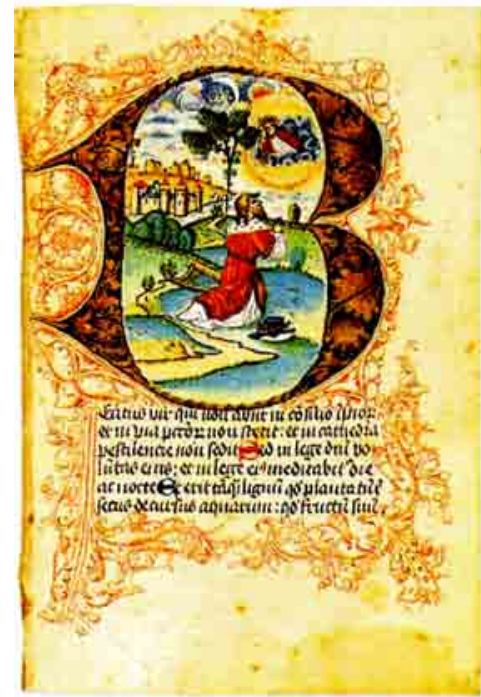

Manuscrito iluminado sobre pergaminho Século XV

\section{A Palavra e a Imagem}

A palavra, como fenômeno do universo verbal, nos remete com intensidade à abstração. Não encontramos outra linguagem tão esclarecedora como permite a ilustração, como fenômeno do universo não verbal. É a linguagem apropriada para esclarecer a abstração. Aqui sentimos o quanto é apropriado o termo ilustração, ou primitivamente iluminura, para esclarecer e iluminar um texto, trazendo para a luz aquilo que se encontrava oculto.

“Nem tudo pode ser ilustrado figurativamente. (...) O material a ser utilizado pelo ilustrador não está diretamente nas palavras, mas no espaço entre elas. É nesse espaço vazio, indefinido, nesta área crepuscular entre uma palavra e outra que se localiza a ilustração." (OLIVEIRA, 2004, p. 25)

O fenômeno da alternância de valores estéticos da imagem fica mais evidente nos primórdios da ilustração, quando a imagem artesanal acompanhava as páginas dos livros religiosos. A desvalorização da iluminura, como esclarecimento da palavra manuscrita ocorreu com o advento da tipografia e a adoção do tipo móvel e da impressão em série. Se antes a palavra manuscrita e a imagem artesanal possuíam o mesmo processo de produção, com o surgimento da tipografia a palavra passou a ser o veículo predominante na elaboração do pensamento. A partir de então, o pensamento ganhou amplitude, tendo a palavra impressa como meio difusor. Ganhando em velocidade, propagou com mais rapidez novos conceitos e idéias. Desse modo, a produção artesanal da ilustração não foi capaz de acompanhar a agilidade da produção da palavra impressa. A dissociação da palavra e da imagem na difusão do pensamento remeteu cada uma delas a campos distintos. Ocorre, a partir de então, um grande florescimento artístico para ambos. Por um lado nas técnicas tipográficas e, por outro lado, no campo da pintura.

É necessário para o ilustrador possuir domínio técnico dos materiais para que a ilustração se torne inteligível. Saber desenhar não preenche os requisitos para uma boa ilustração. Rui de Oliveira (2004, p. 49) reforça que "o domínio da representação figurativa é necessário. (...) Mas essa qualidade, mesmo que virtuosa enquanto ilustração, não é um fim em si mesmo, ou pré-requisito, muito menos salvo-conduto para uma boa imagem narrativa. (...) O desenho é como se fosse uma caligrafia (e todos nós temos a nossa). A ilustração é uma forma de literatura; onde o desenho é o seu alfabeto, e as formas são as suas sentenças. (...) é a fala visual do artista".

É necessária uma atividade continuada para um bom domínio na arte de ilustrar. É um somatório de vocabulários, como o aprendizado de um novo idioma. 
É difícil admitir que, após o esplendor da arte grega, a extraordinária arquitetura romana e a sua expressiva estatuária e magnífica pintura, como a Vila dos Mistérios em Pompéia, tenha ocorrido nos séculos subseqüentes um retrocesso no ato de pintar e desenhar. É como se os artistas tivessem desaprendido a arte da representação figurativa. (OLIVEIRA, 2004, p. 58 a 62$)$

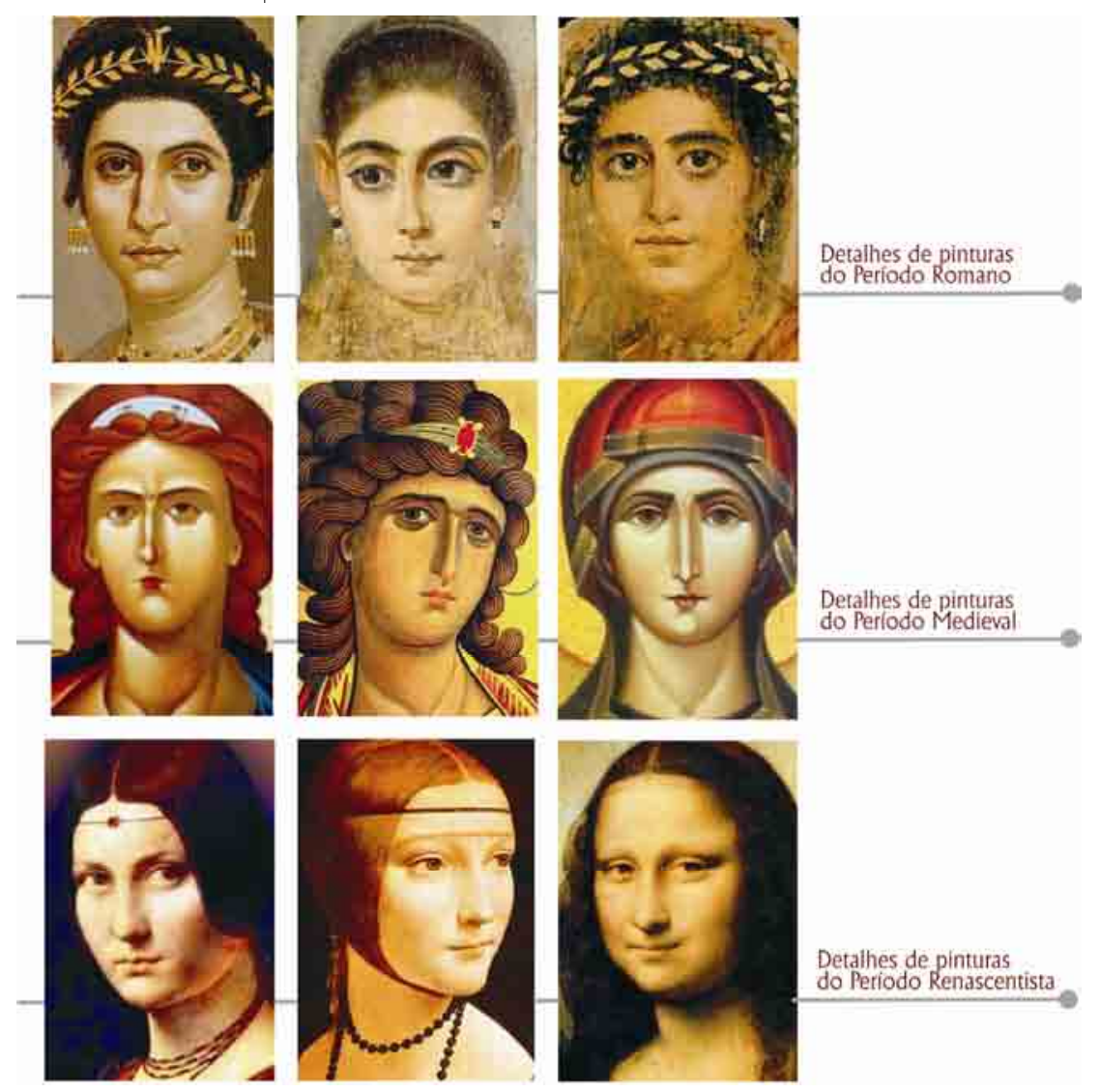

"Retornando ainda mais às sombras esclarecedoras do passado, veremos que o desenho dos artistas bizantinos, apesar de sua esquematização planimétrica, já possuía seus esquemas de construção da figura, com nítida referência à estrutura orgânica do corpo." (OLIVEIRA, 2004, p. 66)

Encontramos nos ícones bizantinos, e posteriormente na arte medieval, o conceito estético que, por princípio se opunha ao naturalismo.

Na nossa visão de mundo ocidental, preocupamo-nos com a leitura detalhada do mundo visível, enquanto que a visão de mundo do artista oriental é oposta. "Nós, ocidentais, representamos; os orientais, interpretam".

Rui de Oliveira entende que ilustrar, não se limita à arte de descrever, é a arte de sugerir narrativas. Dentro deste conceito, vê que a arte da idade média com seus claros objetivos teológicos, visava conduzir o homem de suas trevas à verdade divina. Ao incorporarem estes princípios, os artistas medievais procuravam se afastar da imagem realista, e da herança pagã da arte grega, que certamente conheciam, e possivelmente até admiravam.

Tomando como exemplo o desenho praticado nos séculos XII e XIII e ainda acrescentando a esta análise às transformações sociais, culturais, filosóficas e artísticas ocorridas àquela época que anunciaram a gênese do Renascimento, veremos que a construção da figura humana através de cânones era fato perfeitamente conhecido, basta citar os estudos do arquiteto francês Villard de Honnecourt (OLIVEIRA, 2004, p. 63) 
MASSACCIO (1401-1428)

Pintor renascentista italiano

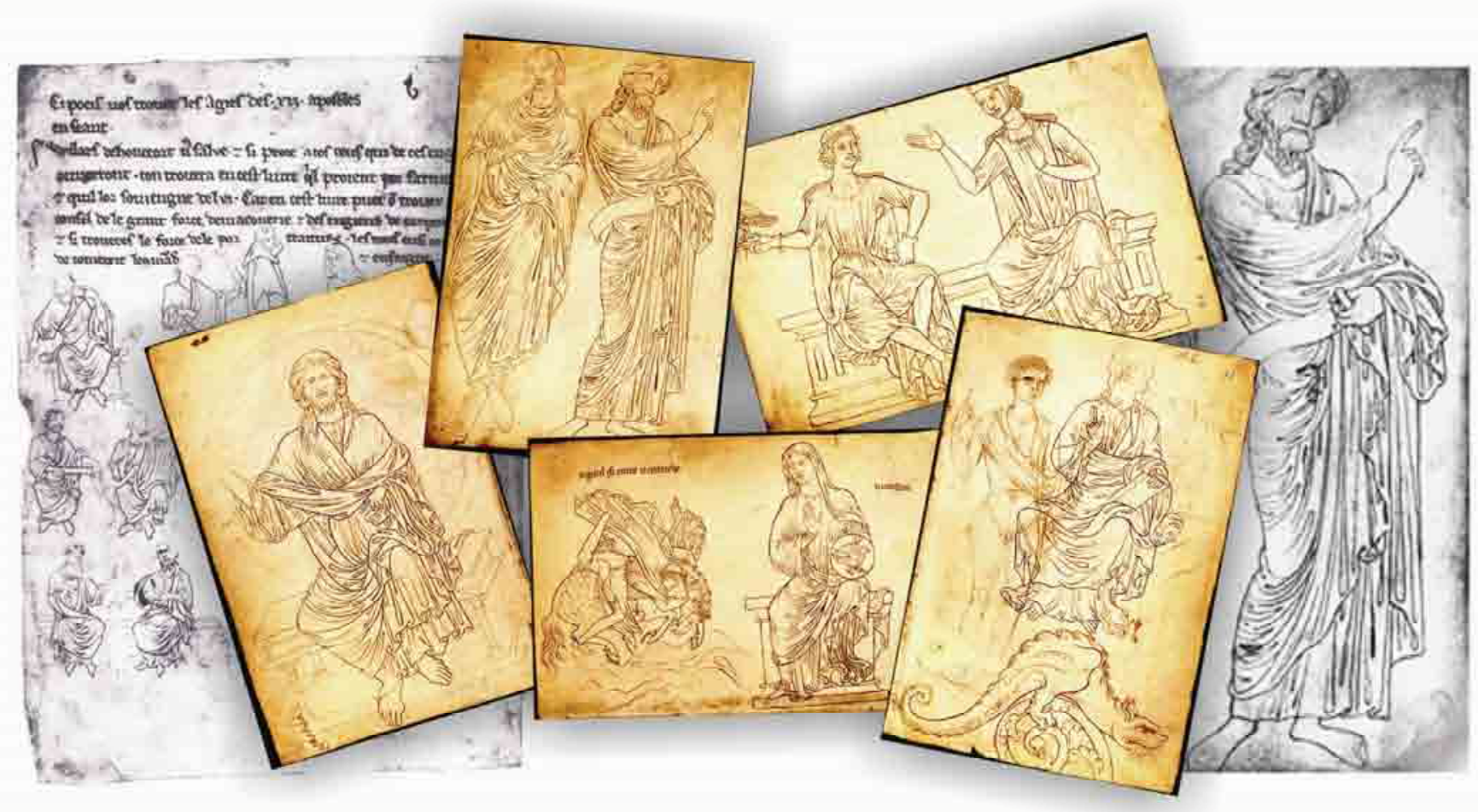

Desenhos de Villard de Honnecourt Século XIII

A alusão à arte medieval e à arte bizantina nos séculos citados foi justamente por encerrarem em suas imagens uma proposta espiritual, metafísica e teológica, plena de convenções e dogmatismos na concepção da figura humana, mas que sem dúvida explicam que a origem de suas imagens (pág.67) não adivinham da incapacidade de representar o mundo, desenhar, ou materializar em seus trabalhos uma réplica do real. Havia, portanto, um escopo filosófico e científico que sedimentava seu imaginário. (OLIVEIRA. 2004: p 67)

Um bom exemplo é a obra artística de Massaccio (3). "Podemos dizer que Masaccio desenhava muito bem e que seus afrescos na S. Maria Novella, a sua extraordinária descoberta da tridimensionalidade expressiva, os ajudaram a contar visualmente de forma convincente suas narrativas". 


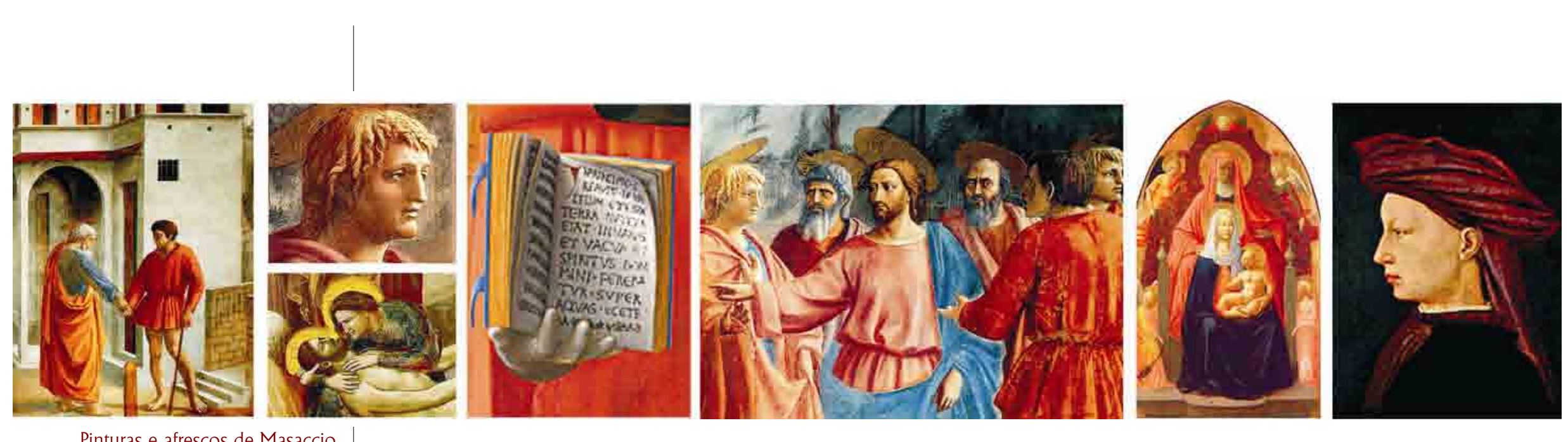

Pinturas e afrescos de Masaccio

Século XV

Porém, é necessário definir o que corresponde descrever, narrar e interpretar. Ou seja, há uma grande diferença entre ilustração narrativa e ilustração interpretativa.

Uma ilustração adequada jamais é a história do texto. A sua perenidade (...) será melhor obtida quando o ilustrador materializa em sua imagem aquilo que é inexprimível pela palavra, e até mesmo pelo universo conhecido (...). llustramos não o que vemos, mas aquilo que temos expectativa de ver. As imagens da suposição são mais perenes por serem mais interrogativas. No entanto, nem tudo pode ser explicado. (...) Talvez mais importante seja contemplar do que decifrar. (OLIVEIRA. 2004: p 86) 


\section{2 - A SINTAXE DA ILUSTRAC̄ÃO}

Como vimos, as dimensões semióticas da imagem são estabelecidas em:

SINTÁTICA - Manifesta-se através da forma. Diz respeito aos elementos estruturais e técnicos de composição

SEMÂNTICA - Manifesta-se através do conteúdo. Diz respeito àquilo que se pretende expressar

PRAGMÁTICA - Manifesta-se através da função. Diz respeito à finalidade comunicativa da imagem

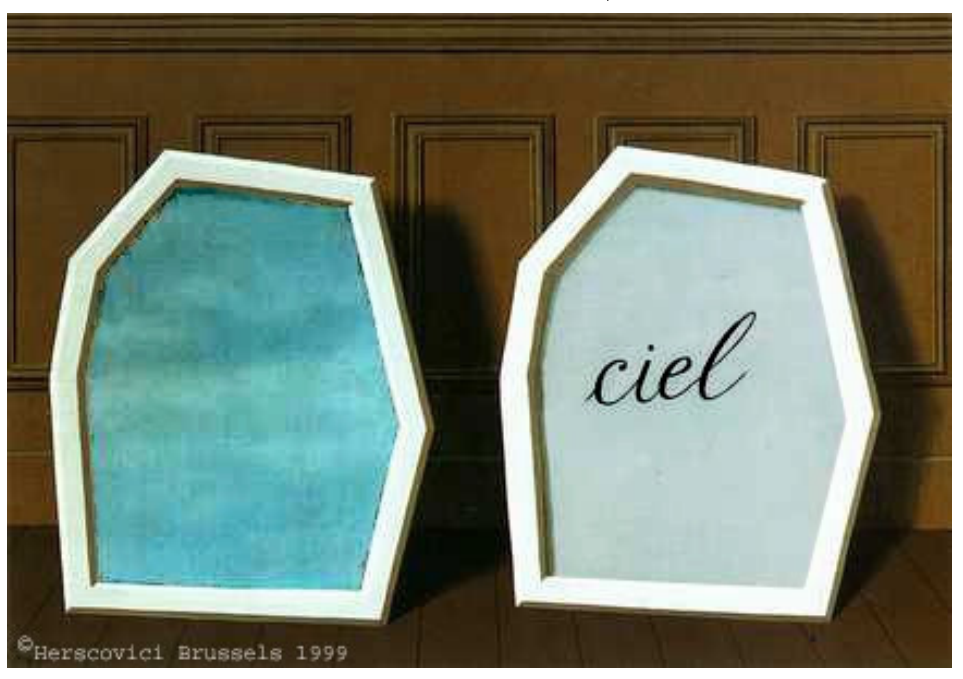

René Magritte - The Palace of Curtains - 1929

As imagens não-figurativas, como são as letras, possuem significados inalterados. Sua interpretação é fixa e absoluta. As letras são imagens totalmente abstratas, ou seja, não têm semelhança alguma com as figuras. Sua forma não altera seu significado porque representa uma idéia não visível.

As letras $L-C-i-E$ separadamente não possuem nenhum significado além de valores fonéticos. Porém, no exemplo ao lado, convencionalmente a reunião delas em uma determinada ordem irá designar a abóbada celeste.

Já nas figuras o nível de abstração é variável. O significado é fluido e variável. Por passarem a ter significados, elas passam a ter níveis de interpretação de acordo com o nível de detalhamento de sua aparência. Determinados desenhos são tão precisos e detalhados que são muito parecidos com seus correspondentes reais. São consideradas imagens analógicas. Outras são menos detalhadas, porém mantendo uma estrutura elementar que permita identificar o modelo desenhado. Começam a se tornar mais abstrata. São consideradas imagens simbólicas.

Assim, percebe-se que através do nível do detalhamento de um desenho podemos amplificar o alcance do tempo e do espaço de uma ilustração.

(3) McClOUD Scott Desvendando os quadrinhos. São Paulo: Makron Books. 1995

O desenhista americano Scott McCloud em seu livro Desvendando os Quadrinhos (3), frisa que ao abstrairmos uma imagem através de sua representação gráfica, não estamos só eliminando detalhes, mas nos concentrando em detalhes específicos. $\mathrm{O}$ artista ao reduzir uma imagem ao seu significado essencial amplia esse significado. É a universalidade que o desenho é capaz de transmitir. 
Por exemplo, quanto mais simplificado for o desenho de um cavalo, mais cavalos ele poderá descrever. Ao trocar a aparência do mundo físico pela idéia da forma, o desenho passa a ser cada vez mais simbólico deslocando-se lentamente para o mundo dos conceitos. grego antigo Eikhon, que significa imagem.

Designa, geralmente, uma imagem sagrada.

ICONOGRAFIA

Arte da representação através das imagens
As imagens mais realisticamente detalhadas têm um caminho mais entrecortado para alcançar maiores campos de significação. Sua existência é uma construção prioritariamente visual, por isso não flui livremente pelo mundo das idéias. Deduz-se que, é através do desenho realístico tradicional que 0 ilustrador representa o mundo externo, porém é através das abstrações gráficas que ele representa o mundo interno. Paradoxalmente, o ilustrador ao deixar de representar com o desenho algo específico, passa a representar o mundo interno, universalizando o conhecimento do mundo.
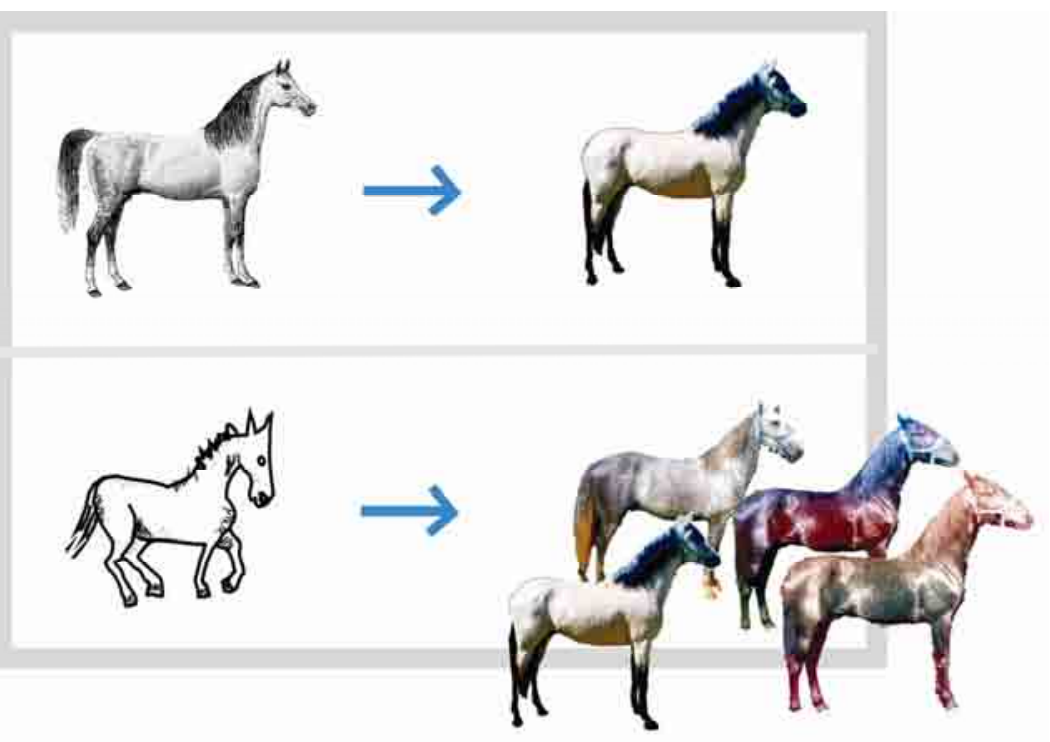

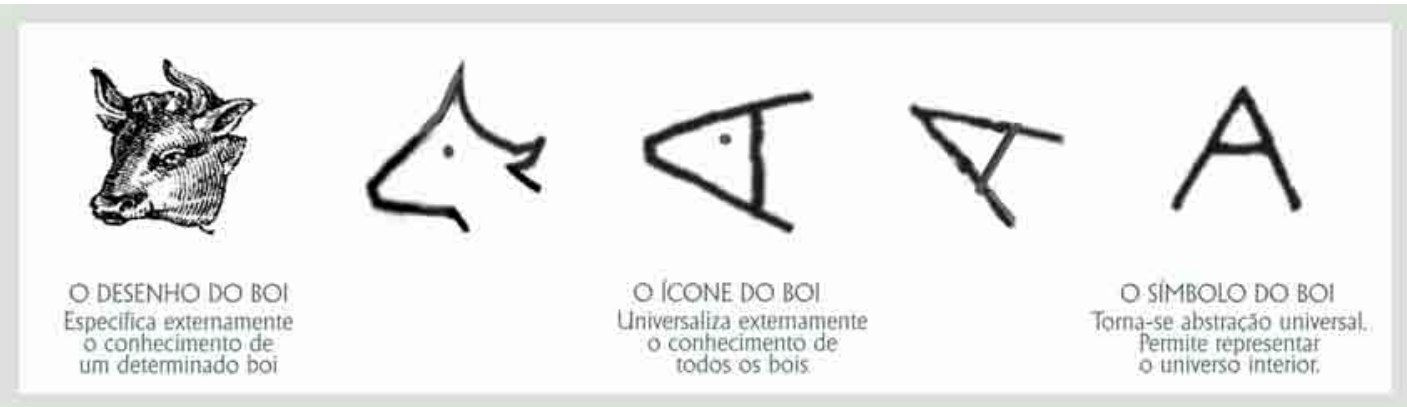

O desenho mais simplificado, ou seja, mais icônico, vai se transformando e exigindo maior participação individual do observador para que funcione plenamente. Assim, o sentido do ícone será sempre dado através da leitura que cada um fizer. Portanto, o desenho icônico não possui uma limitação de significados como no desenho realístico. Essa amplitude de significados é dado por cada um que o vê. E a universalização de significados evolui para transforma-se em código de uma coletividade.

Nossa percepção da realidade através do desenho é um ato individual sustentado em fragmentos, vivenciados pela história de cada indivíduo. Isto é: as imagens só podem ser recebidas através das experiências vividas anteriormente por cada um, e que se encontram gravadas intransferivelmente na alma de cada pessoa. É a imaginação entrando em cena. 
(4)

IMAGEM

IMAGINACÃO

IMAGINÁRIO

São palavras que possuem a mesma raiz semântica IMAGO. A palavra imago tem origem latina significando "embrança (..) formada na infância e que se conserva sem modificação na

$$
\text { vida adulta". }
$$

Portanto, essas palavras não se limitam somente ao repertório de imagens visuais adquiridas, mas a todas as lembranças absorvidas pelos órgãos sensoriais que o ser humano possui: visão, audição, olfato, paladar e tato.

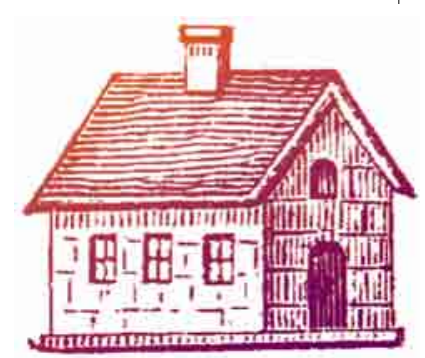

\section{As imagens são informações recebidas.}

Não há necessidade de uma educação formal para entender sua mensagem. Sua recepção é instantânea.

\section{CASA HOUSE MAISON}

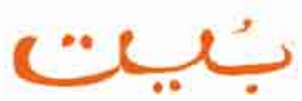

E necessário ter conhecimento especializado do código para compreender os símbolos abstratos da linguagem.
O que podemos ressaltar na relação entre os dois universos discursivos, o icônico e o textual, é a variação da fluência na decodificação da mensagem contida em ambas. A imagem impressa possui acesso mais imediato e universal que o texto por possuir analogia visual com o objeto real representado. Já, para a palavra escrita não há a mesma fluência, pois o entendimento de seu conteúdo é mais complexo devido ao caráter simbólico que a escrita possui. Pois, a palavra que designa o objeto não possui nenhuma semelhança com ele.

Devemos ter em conta que os dois universos discursivos, isto é, o verbal e o não verbal, não são excludentes. Interagem, dialogando entre si. 
Esse diálogo foi-se aperfeiçoando com o passar do tempo. Inicialmente, a aplicação da imagem junto à palavra impressa funcionou como elemento ornamental. Em um segundo momento sua presença adquiriu caráter de comentário para, atualmente ser fluente a ponto de travar diálogo com o próprio texto.

A frase, que no século XVII era longa, passa a ser dividida em frases menores no século XVIII. Essas frases curtas seriam as bases da frase atual. Já no século XX o texto ocupa apenas o lugar de complemento da imagem, onde algumas linhas são suficientes para o entendimento.

\section{Expressão da Linguagem Gráfica}

A linha no desenho é muito mais que um simples contorno do pensamento narrativo do ilustrador. A linha é para o ilustrador o alfabeto e a caligrafia, vitais para expressar sua imaginação. "A análise da função da linha na ilustração é na verdade um motivo para desenvolver reflexões sobre a arte de ilustrar, no sentido de desenhar. (Cito abaixo três artistas brasileiros) da primeira metade do século XX para exemplificar que, muito além do universo por vezes cômico, macabro, lascivo, bizarro de suas obras, existe uma profunda diferença na maneira de compreender o significado da linha de cada um deles. Essencialmente ela representa a individualidade e a caligrafia pessoal do ilustrador, a sua maneira intransferível de expressar sua literatura visual. A linha é a escrita do ilustrador". (OLIVEIRA, 2004, p. 93)

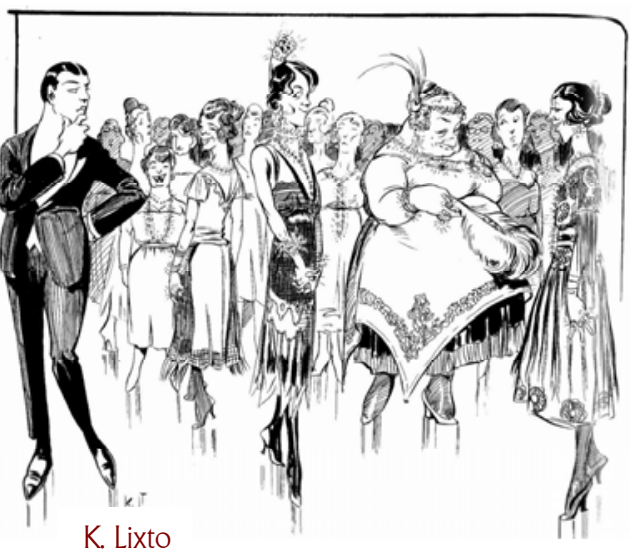

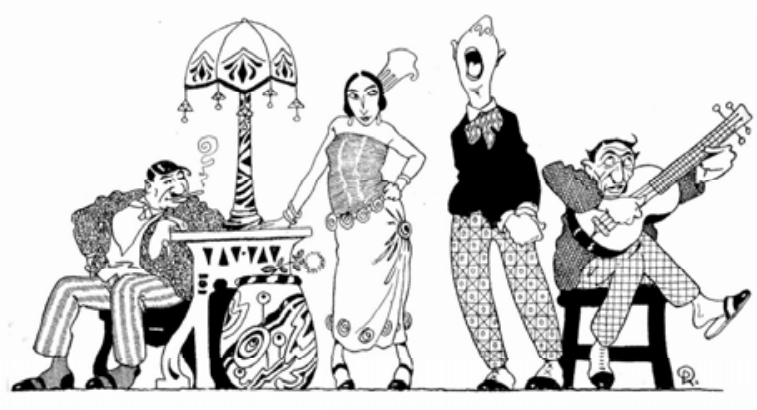

Raul Pederneiras

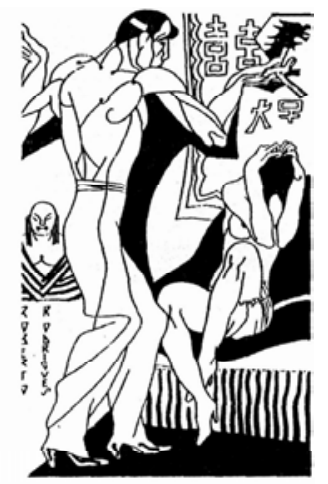

Roberto Rodrigues 


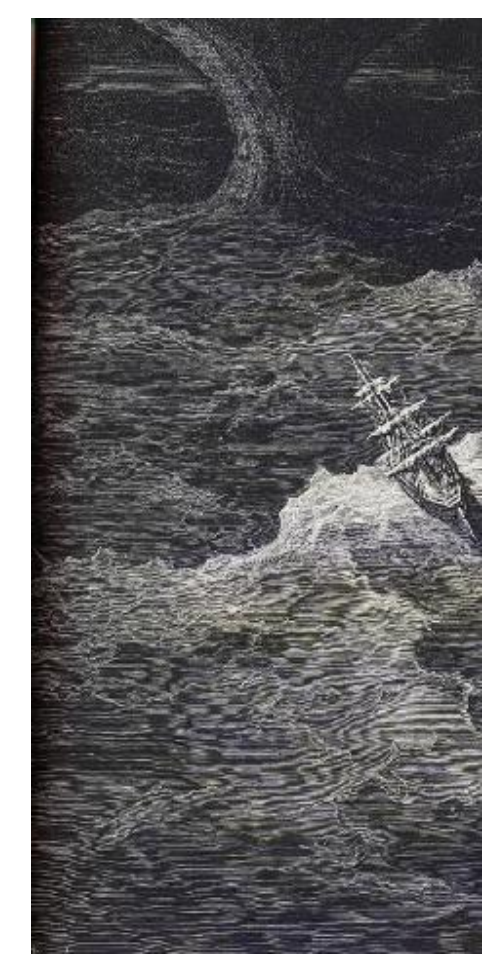

Gustave Doré (detalhe)
Dentro destes espaços não revelados, onde a crença está assentada na ficção e no irreal, outro mestre da ilustração deve ser citado. Cito as ilustrações para um texto de Samuel Coleridge realizadas por Gustave Doré: um pequeno navio está prestes a se precipitar em um abismo de vagas escuras (detalhe ao lado). Este apavorante espaço do insondável ocupa mais da metade da área útil da ilustração, colocando-nos não como mero espectadores, mas cúmplices e coparticipantes da imagem. (...) É nestes espaços entre o real e o imaginário, criados pelo engenho do ilustrador, que o (...) leitor imerge seu olhar imaginário - a que eu chamaria de silêncio das imagens. (OLIVEIRA. 2004: P 113)

O conceito de silêncio das imagens, onde habita o insondável e o não revelado pela visão, está exemplificado abaixo em outras ilustrações de Doré. O que está velado possui mais presença imaginativa do que aquilo que está revelado.
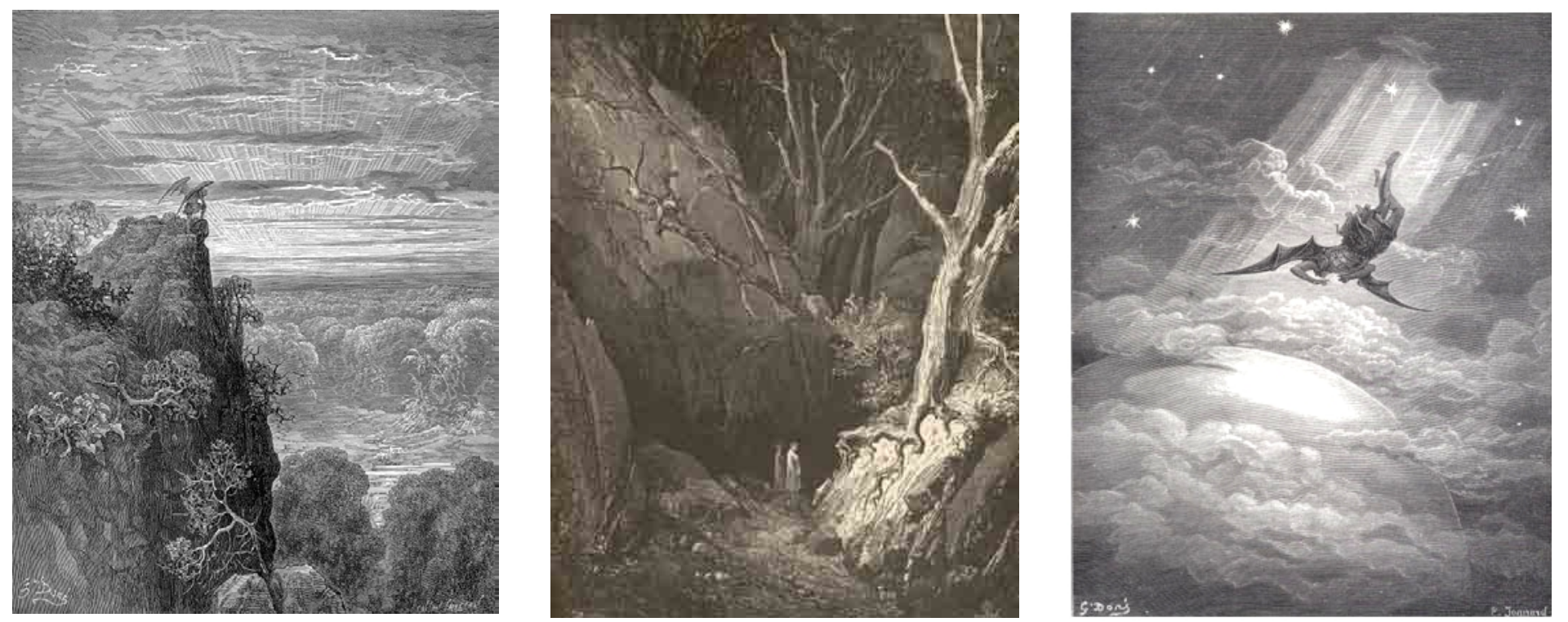


\section{3 - A SEMÂNTICA DA ILUSTRAÇÃO}

No final do ano de 2000 o ilustrador Henrique Kipper, junto com demais ilustradores, coordenou pela internet o site FrontBraza, como experiência de um grupo de discussão sobre as questões relativas às atividades do ilustrador editorial. Neste site, alem da circulação de imagens, artigos e pesquisas técnicas, o espaço serviu também para a discussão conceitual da atividade. Juntamente com Henrique Kipper, o site FrontBraza, contava com a ativa participação de Flávio de Almeida e de Spacca (João Spacca de Oliveira). Ambos também experientes ilustradores na imprensa brasileira.

Em um dos depoimentos Kipper frisava seu ponto de vista sobre a atividade de ilustrar

(...) não se ilustra sem carregar (o conteúdo do) ilustrado consigo (...). São duas formas que atualmente têm neutralizado
o poder da imagem desenhada na imprensa:
1 - Por um lado a total submissão ao texto, na qual a imagem usa dos cacoetes sintáticos do texto linear jornalístico,
pois se considera que apenas a razão pura e a objetividade transmitem conhecimentos e informações.
2 - Por outro lado a imagem levanta vôo e cai no auto-engano de uma total liberdade narcísea em que o ilustrador é
considerado um artista no pior sentido do termo, sendo seu trabalho pura subjetividade. Novamente não há diálogo
com o texto e a imagem está ali apenas como decoração servil ao texto, considerado o verdadeiro e único meio de
transmitir informação e de comunicar.
Em ambos os casos a imagem não ousa abrir as caixas dos signos e recriar. Num caso é escrava total e no outro
narciso embevecido com a sua imagem refletida. (KIPPER, 2001, p. 3)

Hoje, a linguagem jornalística, tanto a verbal como a não verbal, tecem discursos de construção da realidade cuja preocupação não é a de ser exclusivamente uma versão precisa do fato real, mas sim a de preencher o imaginário do leitor de acordo com o que ele quer ler e ver.

Kipper conclui sua reflexão apontando:

A alma do artista (então) impregnaria o objeto-arte com uma aura. (...) Ecos do conceito de artista dotado de um dom que lhe é dado de forma divina.

Assim, os artistas gráficos se resumiriam em dois grupos: (...) os pragmáticos que introjetaram o discurso do texto e sua sintaxe; e os artísticos, que aceitaram um nome bonito para se absterem de tocar o mundo. Ambos os grupos se consideram superior ao outro, mas ambos, à sua forma, reificam, o real.

Aqui podemos entender porque a cisão entre estes extremos tem sido aprofundada nos últimos tempos: cada dia a individualidade é menos interessante para uma sociedade de comunicação de massas em processo de padronização crescente.

Neste cenário, fica evidente como os extremos são vendidos como simulacros de liberdade, seja como objetividade pura, seja como expressão pura. Vivemos o ocaso do indivíduo criativo. (KIPPER, 2001, p. 3) 
Mesmo com a preponderante presença das imagens descritivas nas páginas dos jornais, não se pode conceber o jornalismo atual sem levar em conta a ilustração interpretativa como elemento participante. A presença do espaço ilustrado permite que o texto saia do relato visual e amplie seu campo de significação. A imagem não tem a pretensão de substituir o texto, mas é possuidora da capacidade de comentá-lo.

No início dos anos 80, o chargista Ronaldo Cunha Brito já manifestava no jornal Opinião uma visão que se agravou nos anos subseqüentes. Em determinado trecho escrevia.

A questão do desenho (...) na imprensa brasileira hoje é um ponto importante a discutir. Ela é sintomática, esclarece
particularidades dos códigos jornalísticos vigentes, mesmo entre veículos com posições políticas radicalmente diversas
entre si. E demonstra, em última análise, uma crença ingênua e autoritária na palavra como forma mágica e exclusiva do
real se exprimir (...) sobretudo por se considerar a linguagem verbal como o próprio modo de apreensão do real, como
que esquecendo a sua condição de linguagem, atribuindo à imagem uma função meramente decorativa e privá-la de
todo e qualquer significado específico. (BRITO, 1981, p. 4)

Portanto, é necessário que a imagem ilustrativa transporte um significante ou vários significantes icônicos para que coloque o receptor de frente com o significado.

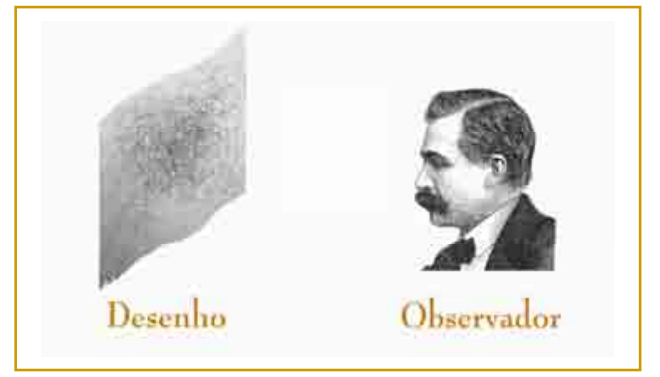

Para fazer uma classificação dos tipos de ilustrações, assinalamos 3 características abrangentes:

\begin{tabular}{l}
\hline ilustração descritiva \\
ilustração narrativa \\
ilustração interpretativa \\
\hline
\end{tabular}

A seguir é apresentado quadro ilustrativo descrevendo os processos de interacão comunicativa nas ilustraç̃es. Na descrição de cada tipo aparecem os quatro elementos que compõe a ação: o tema, o artista, o desenho e o observador. 


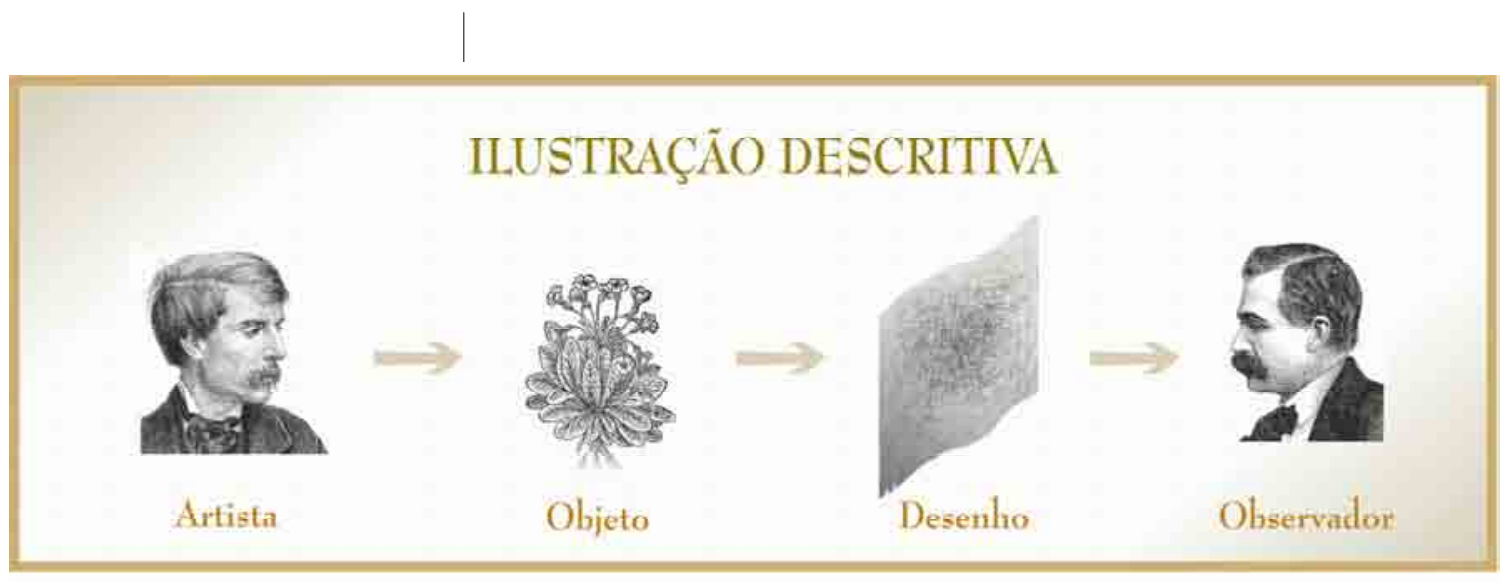

\section{ILUSTRAÇÃO DESCRITIVA}

O artista reproduz no

desenho os pormenores do

objeto para a perfeita leitura

do observador.

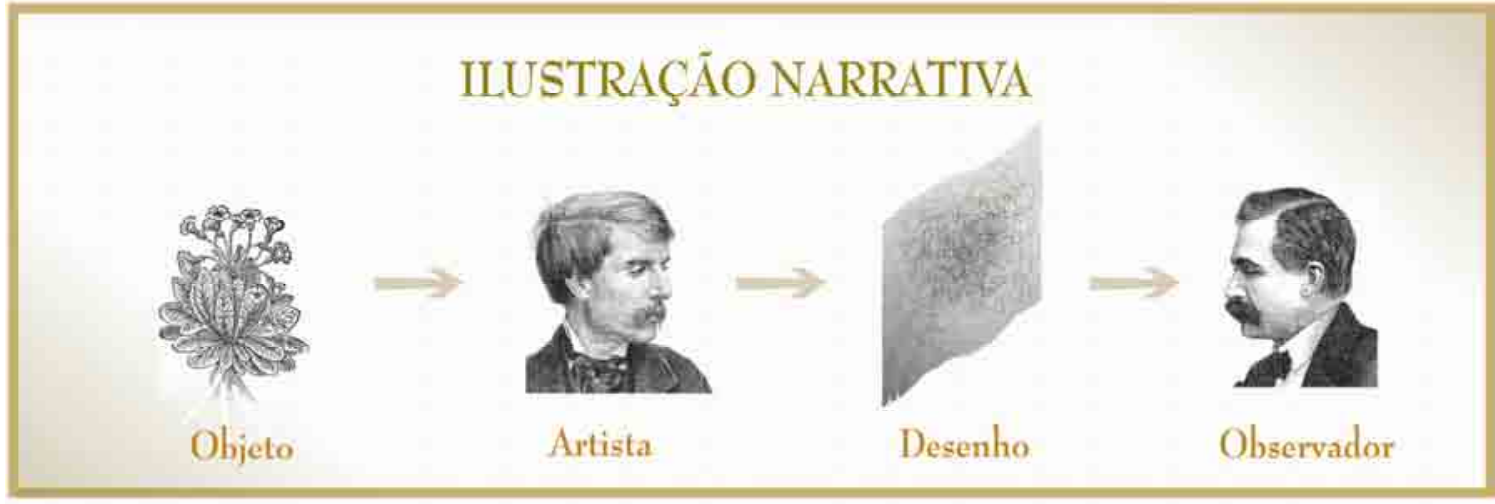

\section{ILUSTRAÇÃO NARRATIVA}

Através do desenho o

artista manifesta para 0

observador suas impressões

sobre o objeto.

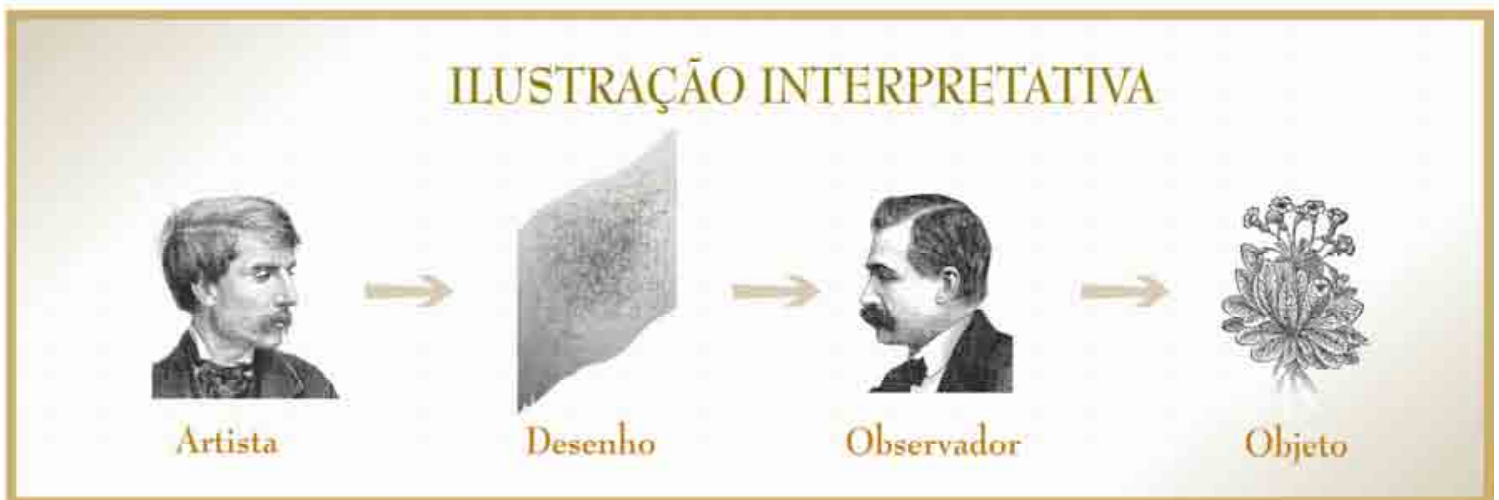

\section{ILUSTRAÇÃO INTERPRETATIVA}

O observador constrói

mentalmente um objeto,

estimulado pela criação

do artista.

concepcāo de Jorge Arbach 
É aquela em que possui características informativas. Manifesta-se valendo de estruturas descritivas racionais, através das quais propõem uma representação objetiva de um fenômeno ou de um objeto real do mundo exterior. Os signos na I/ustração Descritiva possuem elementos compreensíveis em nível universal. Sua estrutura descritiva prevalece sobre suas estruturas interpretativas, isto é: a sintaxe da forma prevalece sobre a semântica do conteúdo. Nessa funcão a imagem é monossêmica, ou seja, não aceita qualquer outra significação associada a outros signos. A ilustração é figurativa, e o processo de dedução ocorre a partir de analogias, ransmitidas em pormenores, não havendo intervenção de caracteres subjetivos. Aqui, a interpretação da imagem já estará pré-determinada. Por possuir objetivos específicos, destina-se a informar com clareza, não permitindo ambigüidade de interpretações.

\section{ILUSTRAÇÃO NARRATIVA}

Nesse tipo de ilustração a função da imagem é ser um meio de tradução das impressões que o ilustrador tem sobre o tema abordado. Nessa função são aceitos aspectos subjetivos do ilustrador. Possui ao mesmo tempo caráter informativo e interpretativo. Aqui o ilustrador trabalha mais com a impressão do real do que com o realismo. $\mathrm{O}$ propósito deste tipo de ilustração é transmitir sensação do que racionalização. Com a Ilustração Narrativa o desenho torna perceptível o objeto. $O$ que caracteriza principalmente este gênero é que a narrativa não é uma tradução visual do tema, mas impressões através de imagens. Aqui a imagem preenche aspectos que a descrição verbal não alcança. Essa ilustração deixa espaços para ser complementado pela imaginação do observador. Essa participação imaginária significa explorar a expectativa do ver, e não necessariamente explicar a realidade com as formas.

\section{ILUSTRAÇÃO INTERPRETATIVA}

Nesse tipo de ilustração a imaginaç̃o do espectador investiga universos subjetivos, abolindo tempo e espaço. Recria vivências pessoais onde, através da imagem é motivado a remontar a lógica do mundo. O processo de transmissão da mensagem na Ilustração Interpretativa vincula-se aos aspectos mais sensíveis da imagem. Daí podemos determinar que ela se destine mais ao inconsciente do que à razão. Neste processo, a mensagem contida na ilustração visa dissociar a ordem icônica inicial para, em seguida, propor um novo reagrupamento das idéias. Na função dessa imagem ocorre a transcendência da representação objetiva, ampliando o universo de significações. A monossemia é substituída pela polissemia, o denotativo dá lugar ao conotativo. A comunicação ocorre indiretamente com ajuda de simulacros ou metáforas visuais. O tema focado iá não será mais aquilo que representa, mas um signo de uma nova realidade. 


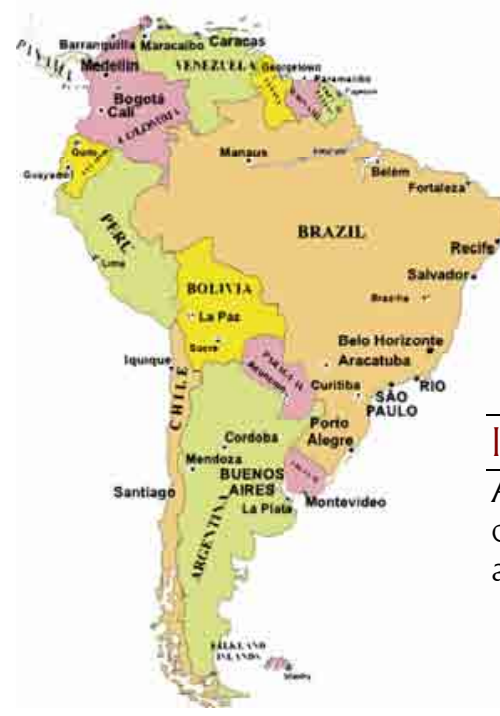

\section{DEMONSTRAÇÃO DOS 3 TIPOS DE ILUSTRAÇÕES}

\section{LUSTRACC̃̃O DESCRITIVA}

A ilustração é figurativa, com extrema objetividade, onde

o processo de dedução ocorre a partir de analogias. Aqui,

a interpretação da imagem já estará pré-determinada. ilustrador tem sobre o tema. Nessa função são aceitos aspectos subietivos do ilustrador. Possui ao mesmo tempo caráter descritivo e interpretativo.

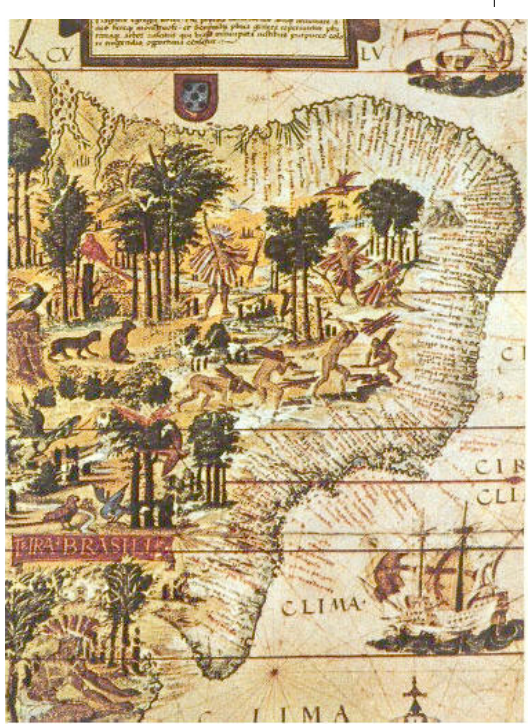

ILUSTRAÇÃO INTERPRETATIVA

A comunicação ocorre indiretamente com ajuda de simulacros ou metáforas visuais. $O$ objeto já não será mais aquilo que representa, mas um signo da realidade que ela se propõe a representar.

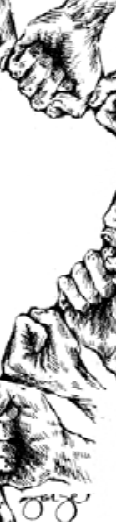


Como vimos, as ilustrações possuem 3 formas de serem abordadas: descritiva, narrativa e interpretativa. Pretendemos neste trabalho aprofundarmos somente nos aspectos da llustração Interpretativa por possuírem possibilidades de manifestação opinativa e capacidade de efetuar comentários por meio de uma linguagem não-verbal.

Potencialmente, a llustração Interpretativa possui mais diversidade de interpretações, tanto em nível de emissor quanto de receptor. Suas mensagens não se baseiam em códigos determinados de elaboração e interpretação. Aqui, o inconsciente se superpõe à razão, o sensorial toma o lugar do inteligível. E nesse tipo de comunicação não verbal a linguagem expressiva torna-se mutável, e as análises interpretativas passam a ser feitas mais em nível qualitativo do que estrutural. $\bigcirc$ estímulo visa o inconsciente do receptor, apoiando-se em arquétipos universais. Assim, mostrando-se polissêmica amplia a interação com o leitor, possibilitando maior fluência discursiva.

Assim, a Ilustração Interpretativa será mais expressiva quanto mais abrangente for o caráter de identificação e transferência de valores. Todo o processo será articulado por intermédio do repertório do próprio espectador. E será a circulação dessas imagens interpretativas que irá desvelar e abastecer gradualmente ao longo do tempo o imaginário coletivo. 


\section{CAPÍTULO 3 \\ O DESENHO}

3.1 - REPRESENTAÇĀO DA IMAGEM

3.2 - SIGNIFICADOS DO DESENHO 


\section{1 - REPRESENTAÇÃO DA IMAGEM}

\section{Panorama Histórico}

O homem está cercado maciçamente pelas imagens que são produzidas pela cultura do seu ambiente. Aonde quer que vá a comunicação visual é o meio por excelência. Mesmo utilizando vários sentidos para absorver o mundo ao seu redor a visão atua como órgão preponderante como veículo sensorial para sua percepção. A imagem é mais facilmente assimilada intelectualmente por esse meio que qualquer outro recurso. Tanto é que para melhor nos comunicarmos e sermos mais bem compreendidos utilizamos cotidianamente expressões vinculadas ao universo visual.

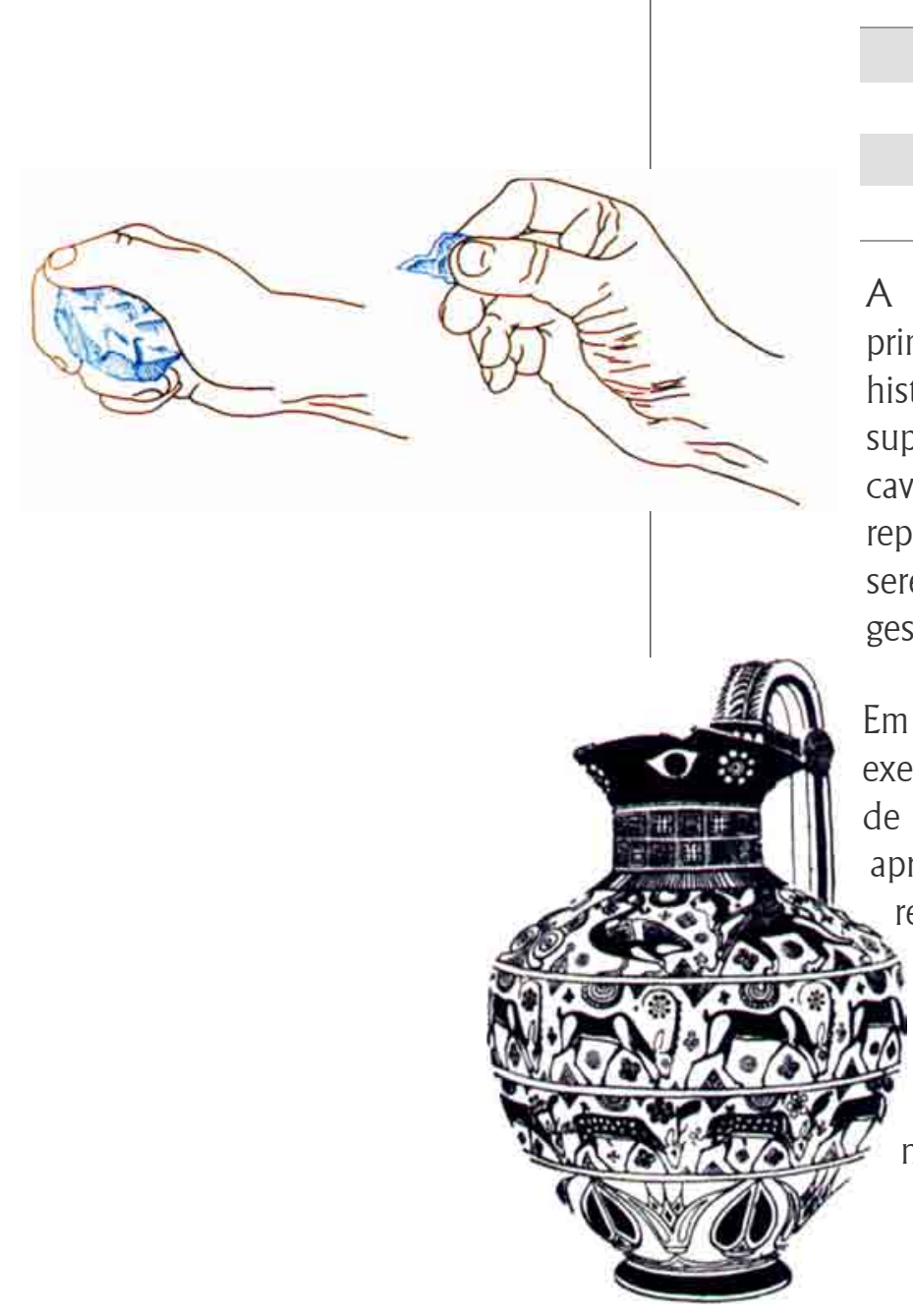

$\begin{array}{ll}\text { Olha como é bom esse perfume! } & \text { (substituindo o olfato) } \\ \text { Vou ver como ficou o tempero. } & \text { (substituindo o paladar) } \\ \text { Não consigo enxergar a mensagem do discurso. } & \text { (substituindo a compreensão) } \\ \text { Fechei os olhos para o que ele me falava. } & \text { (substituindo a audição) }\end{array}$

A imagem produzida pelo desenho pode ser entendida como uma das primeiras formas de comunicação e de expressão do homem. Já na préhistória registros eram feitos usando-se as rochas como instrumento e como suporte para representações gráficas. Ao desenhar os animais nas paredes das cavernas os homens da pré-história já os faziam considerando que a representação gráfica sugeria a infusão de poderes e domínio sobre esses seres, como se o gesto de gravá-los já Ihes infundisse sua captura. Com aquele gesto dissipavam-se todos os temores que os ameaçavam.

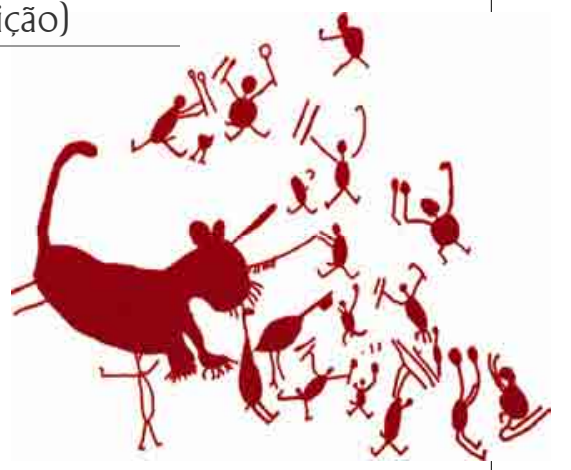

Em diferentes épocas os recursos e os temas utilizados têm sido os mais variados. Na Mesopotâmia, por exemplo, os desenhos de mapas e plantas das cidades eram traçados em placas de argila. Na Grécia, modelo de civilização, restaram poucas peças em que o desenho estivesse presente. No início o desenho se apresentava com temas simples, ligados ao povo, e posteriormente passaram a representar temas ligados à religião. As referências marcantes do desenho grego são encontradas nos vasos, ornamentos e esculturas. "É nos séculos V e IV a.C. que a Grécia revela seu ideal de realismo e beleza, que se expressa no emprego da perspectiva científica, na precisão do desenho e do uso do claro-escuro, no requinte técnico e na preocupação matemática com o estudo da composição e da forma” (MARTINS. 1992: p 45). Ao conquistar a Grécia os romanos foram fortemente influenciados pelos gregos, cujas características do desenho foram muito empregadas na arquitetura e decoração. 

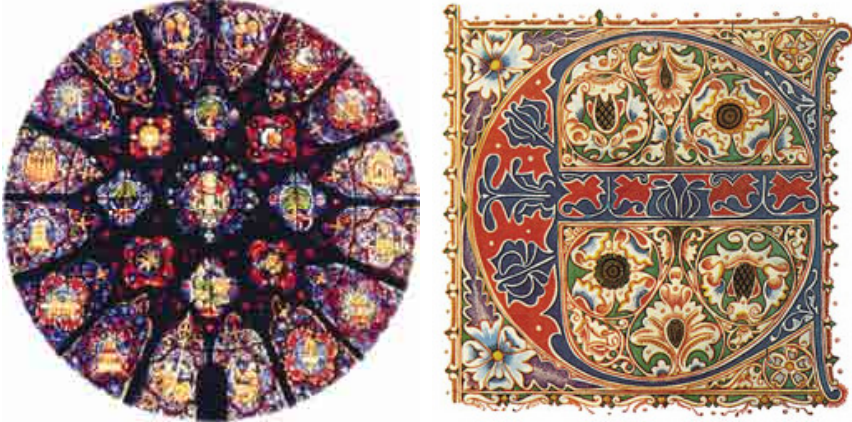

Cem anos antes de Cristo traçava-se em pergaminhos com auxílio de bastões de chumbo. No início da Idade Média, com o advento do Cristianismo, predominou um intenso sentimento religioso, em oposição à concepção naturalista e racionalista dos gregos e romanos. Estes princípios desembocariam na Arte Bizantina e Românica.

Nessa época os artistas e artesãos desenvolveram seus temas pautados no simbolismo cristão. Resultando obras-primas nas igrejas, como os vitrais e os mosaicos executados com fragmentos de pedras coloridas.

Já no período que antecede a Renascença é intenso o trabalho artesanal, revelados em sua maioria nos mosaicos, nos livros manuscritos, nas iluminuras, nos ícones e nos trabalhos dos miniaturistas.
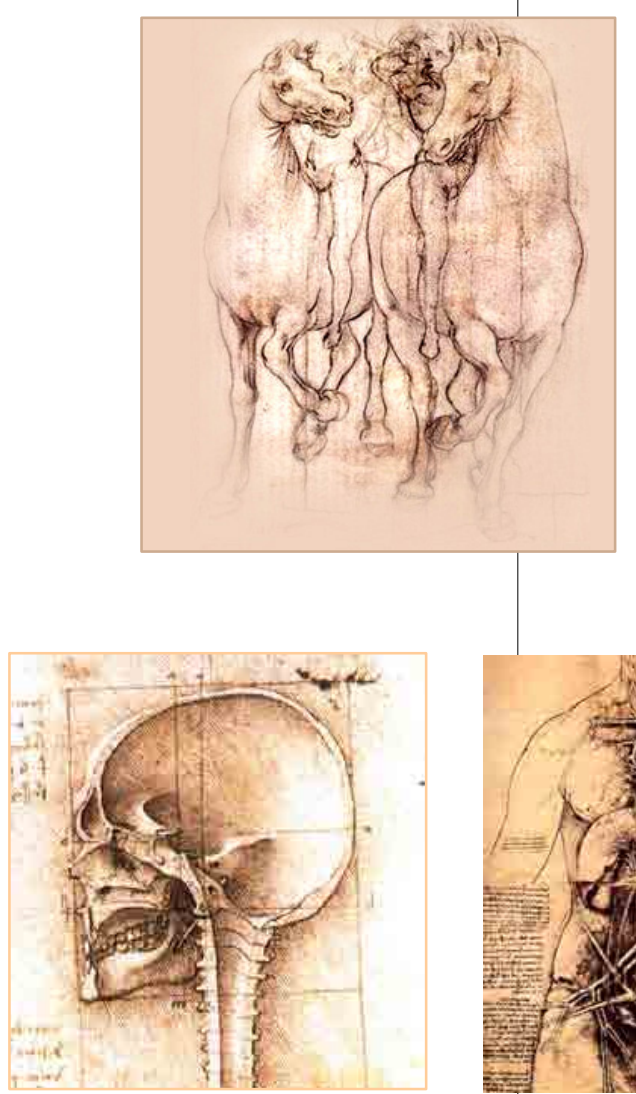

Por volta do século XVI, após a utilização do chumbo junto ao estanho e à prata, chegou-se ao grafite. Na Alemanha, no século XVII, foi desenvolvida a idéia de colar tiras de grafite em madeira, proporcionando maior firmeza para o traçado, fazendo surgir o lápis. E em 1795 o francês Conté aperfeiçoou o uso do grafite por meio de uma mistura de grafite moído com argila e posteriormente submetida a um processo de estiramento por pressão. Dependendo da proporção de grafite e argila eram obtidos diferentes graus de dureza.

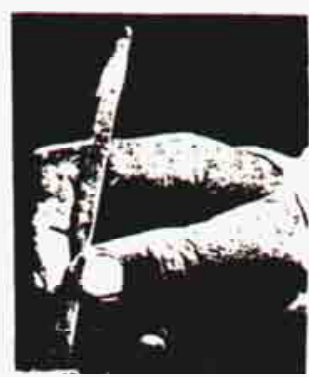

Durante alguns séculos o desenho foi um conhecimento e um processo gráfico de representação de acesso restrito, e por isso mesmo descomprometido com regras e normas de execução. Um dos maiores complicadores residia na dificuldade de se demonstrar a volumetria das formas em superfícies planas, problema que foi minimizado no século XV quando Leonardo da Vinci desenvolveu um estudo relativo à teoria do desenho e pôde representar graficamente inúmeras pesquisas e inventos.
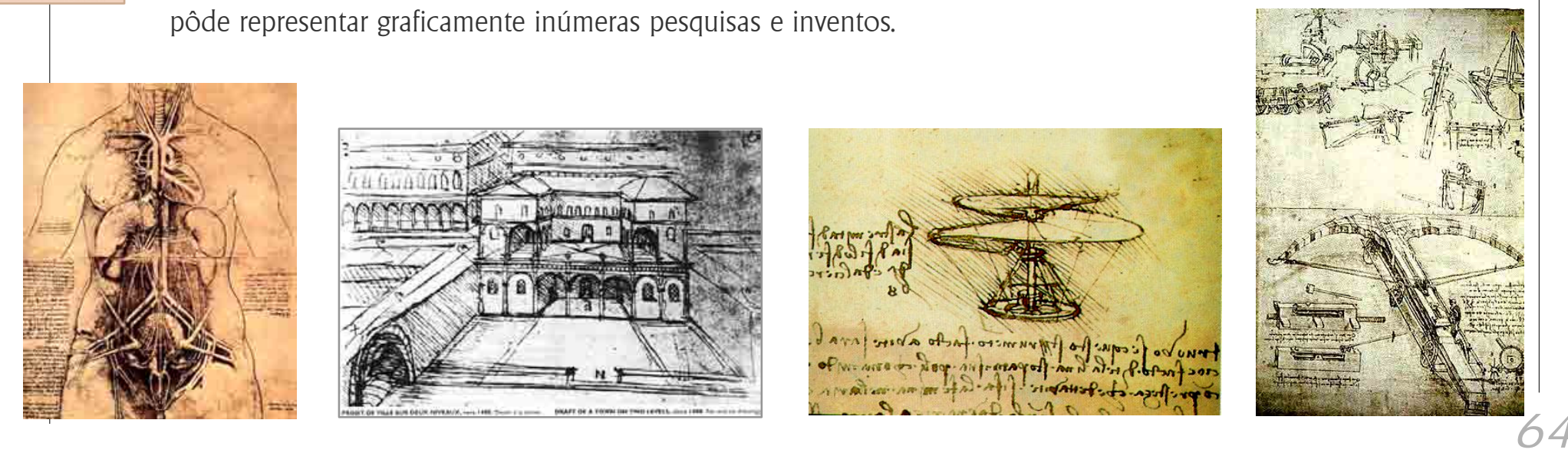


\section{Valores Históricos}

Os estilos ao longo dos séculos corresponderam a visões de vida. Nelas confluíram os conhecimentos e as técnicas disponíveis de uma sociedade em um dado momento. Confluíram os costumes, os ideais, as necessidades e certas possibilidades de satisfazê-las material e espiritualmente.

Assim, o homem veio desdobrando o seu ser social em formas culturais. Com o estilo o artista conseguiu expressar sua maneira de pensar, de imaginar, e de sentir. Expressou sua maneira de agir e reagir. $O$ estilo de uma época é a forma de cultura daquela época.
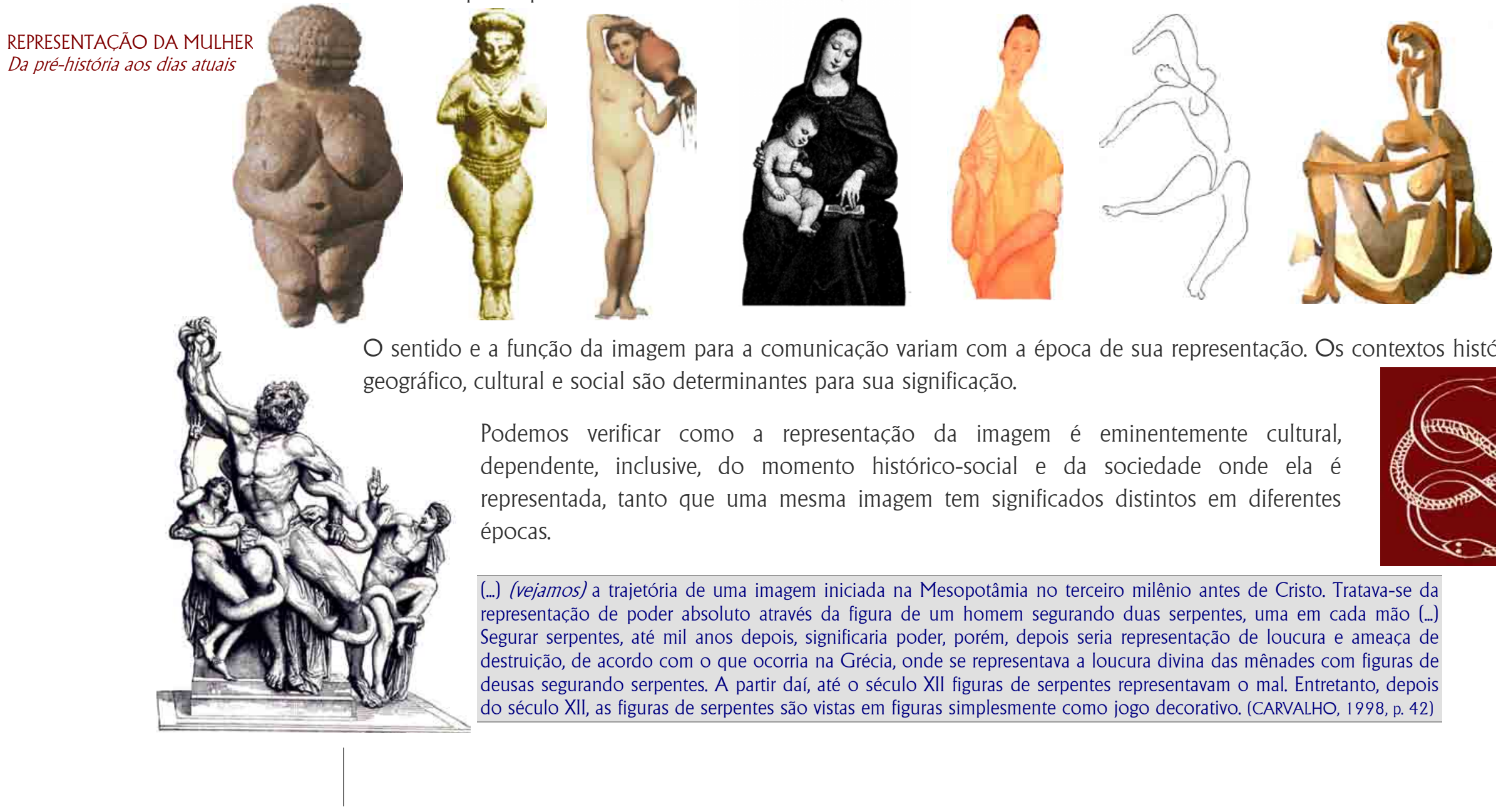

O sentido e a função da imagem para a comunicação variam com a época de sua representação. Os contextos histórico, eográfico, cultural e social são determinantes para sua significação.

Podemos verificar como a representação da imagem é eminentemente cultural, dependente, inclusive, do momento histórico-social e da sociedade onde ela é representada, tanto que uma mesma imagem tem significados distintos em diferentes épocas.

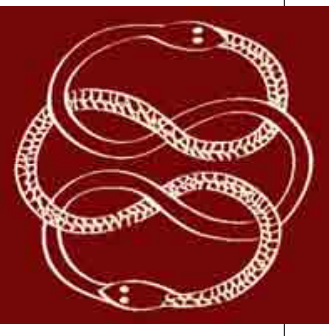

(...) (vejamos) a trajetória de uma imagem iniciada na Mesopotâmia no terceiro milênio antes de Cristo. Tratava-se da representação de poder absoluto através da figura de um homem segurando duas serpentes, uma em cada mão (...) Segurar serpentes, até mil anos depois, significaria poder, porém, depois seria representação de loucura e ameaça de destruição, de acordo com o que ocorria na Grécia, onde se representava a loucura divina das mênades com figuras de deusas segurando serpentes. A partir daí, até o século XII figuras de serpentes representavam o mal. Entretanto, depois do século XII, as figuras de serpentes são vistas em figuras simplesmente como jogo decorativo. (CARVALHO, 1998, p. 42) 


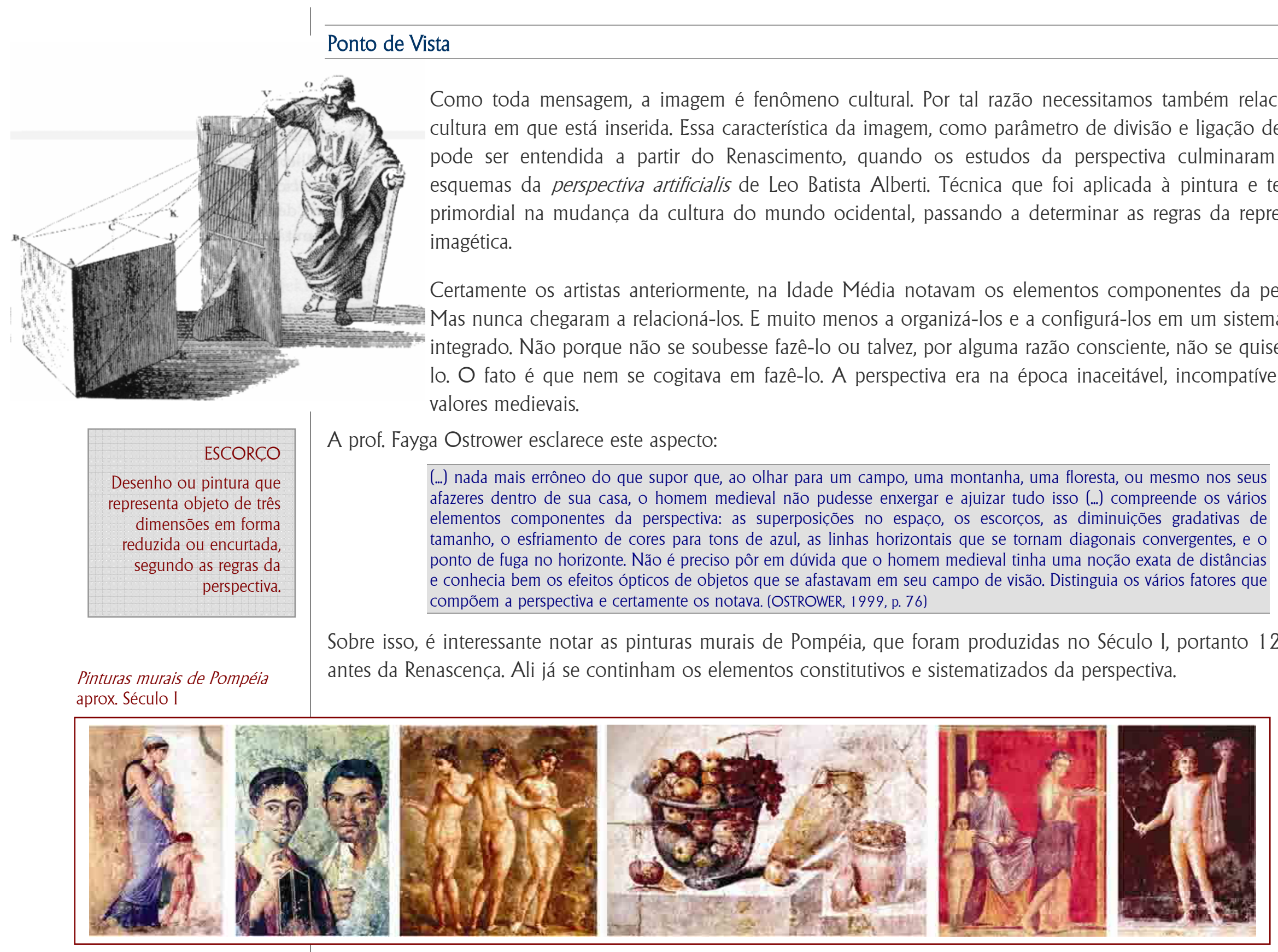

Como toda mensagem, a imagem é fenômeno cultural. Por tal razão necessitamos também relacioná-la à cultura em que está inserida. Essa característica da imagem, como parâmetro de divisão e ligação de culturas pode ser entendida a partir do Renascimento, quando os estudos da perspectiva culminaram com os esquemas da perspectiva artificialis de Leo Batista Alberti. Técnica que foi aplicada à pintura e teve papel primordial na mudança da cultura do mundo ocidental, passando a determinar as regras da representação imagética.

Certamente os artistas anteriormente, na Idade Média notavam os elementos componentes da perspectiva. lo. O fato é que nem se cogitava em fazê-lo. A perspectiva era na época inaceitável, incompatível com os valores medievais.

(.) nada mais errôneo do que supor que, ao olhar para um campo, uma montanha, uma floresta, ou mesmo nos seus afazeres dentro de sua casa, o homem medieval não pudesse enxergar e ajuizar tudo isso () compreende os vários elementos componentes da perspectiva: as superposiçōes no espaço, os escorços, as diminuiçōes gradativas de (O) conhecia bem os efeitos ópticos de objetos que se afastavam em seu campo de visão. Distinguia os vários fatores que compõem a perspectiva e certamente os notava. (OSTROWER, 1999, p. 76)

Pinturas murais de Pompéia prox. Século I 


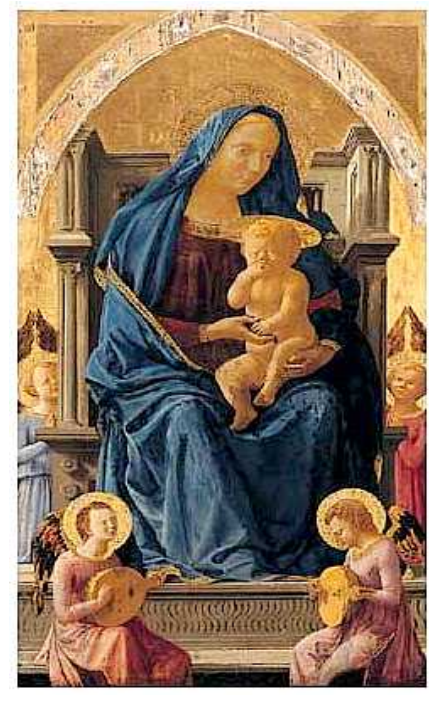

Posteriormente, a configuração espacial na Idade Média passou a ter outra característica. Todo tempo e espaço era dado como simultâneo. Todos os detalhes, inclusive os vários episódios que pela narrativa se sucedem em lugares e épocas diversas, são dados no mesmo plano, como idênticos no tempo e acontecendo no mesmo momento. Não existe um vir-a-ser, um passado ligando a um futuro. Tudo é. Tudo continua sendo inteiramente presente e próximo.
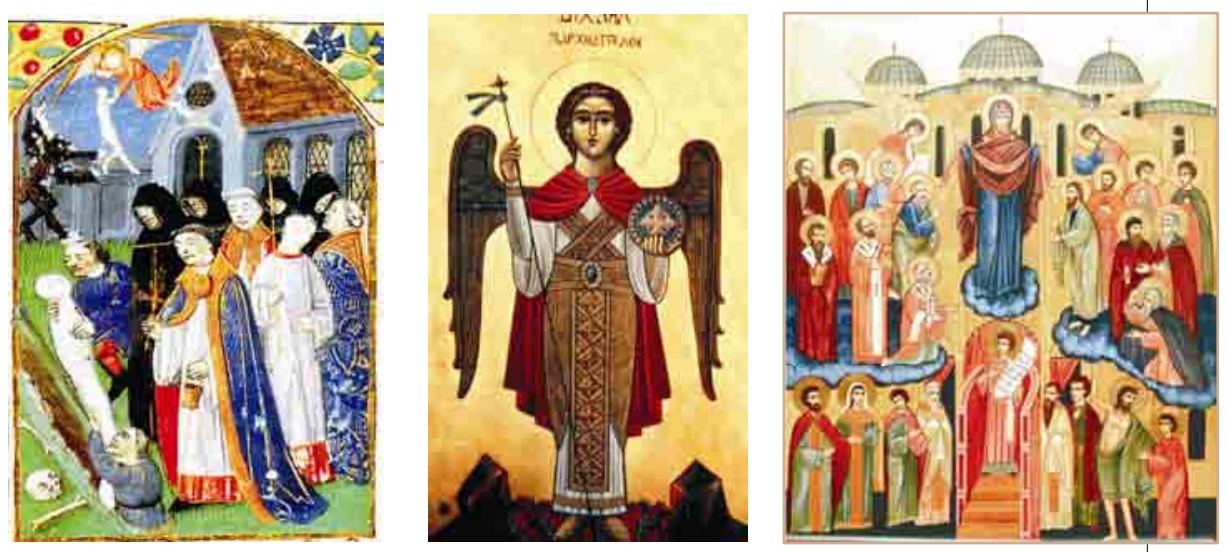

As aparências visuais das figuras solenes, ou dos seres divinos ou dos humanos, vêm salientadas por gestos rituais e definindo seu caráter de simbólico e de seu valor ético. Assim como quase todas as cores têm sentido simbólico: o manto da virgem: azul, grupos de anjos divididos em serafins: rosa, e querubins: azul, o paraíso: ouro, assim também as magnitudes se reportam a uma escala hierárquica: os santos são sempre maiores do que os mortais, os anjos sempre maiores do que os santos, a Madona e Cristo maiores do que todos.

Ao analisarmos esse modelo de representação devemos levar em conta o seu aspecto religioso. Naquele momento era necessário cuidar do espírito, que é eterno enquanto que o corpo terreno é secundário e passageiro.. Portanto sua representação visual também é secundária. Sua expressão artística se concentra num testemunho de fé enfatizando padrões de uma vida espiritual. Era essa a realidade válida. Não só dispensava qualquer visão de espaço em termos de perspectiva, menos ainda permitia ser abordada em termos de análise ou métodos racionalistas. Não é possível colocar em perspectiva algo que seja imaterial, que não tenha propriedades físicas.
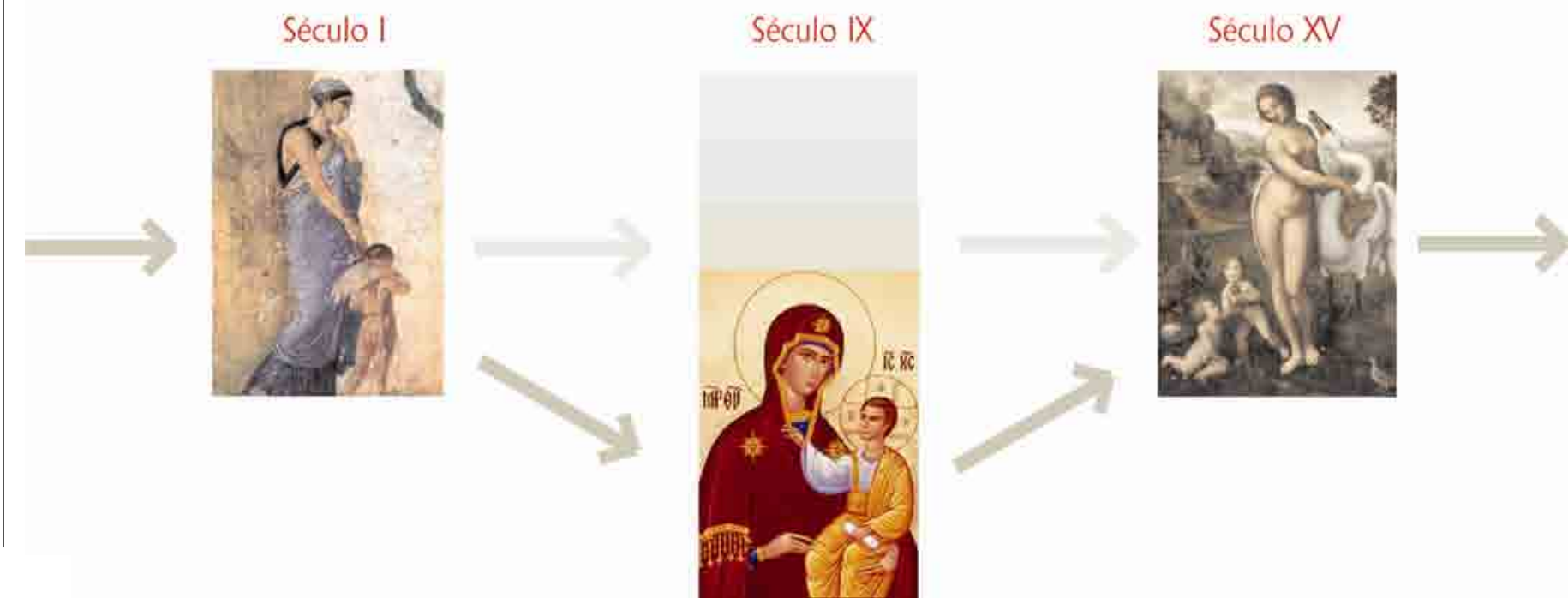


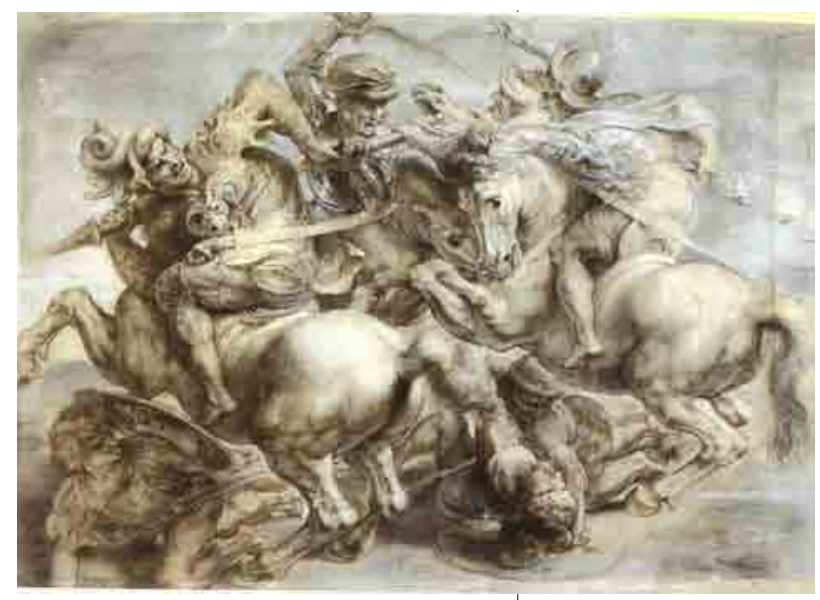

Com as mudanças econômicas e sociais ocorridas na Europa, a partir do século XVI o desenho se liberta da influência religiosa. Seus temas fixam-se na realidade da natureza, porém fundamentada na Antigüidade clássica greco-romana. A Renascença se inicia sob o impacto do racionalismo científico, e isso se percebe no desenho, transparece nos estudos de volumes, na predominância do claroescuro, na harmonia das composições e no emprego da perspectiva. A temática ainda sofre influência religiosa, porém com forte expressão realista.

Foi no Renascimento que o desenho começou a ser valorizado. Por ser tão despojado e tão imediato, o desenho representou o meio de expressão mais fácil do ponto de vista técnico, porém o mais difícil do ponto de vista artístico. Tornou-se uma forma de expressão em si completa, quando antes servia como fase preparatória para murais e pinturas.

Quando o Renascimento descobre a Antiguidade, redescobre além das formas clássicas, redescobre também idéias e valores aparentemente 'esquecidos' durante a Idade Média. Os valores da Antiguidade, ressuscitados, ressurgem como valores inteiramente novos e originais, sustentando outras relações sociais e outras possibilidades de realização para o indivíduo. O indivíduo pôde descobrir no real novas realidades, cujos novos horizontes encerravam propostas de requalificação dos valores culturais.

No Renascimento, na afirmação da existência física material como algo positivo e digno, surge um novo valor. Cabe dar-lhe uma relevância, pois a "afirmação da matéria" deve ser compreendida como "imprescindível". Assim, essa premissa deve ser incorporada ao sistema da perspectiva.

Conseqüentemente, em virtude da nova visão de mundo, admitindo a materialidade dos fenômenos, é que se pôde elaborar a proposta da perspectiva. A perspectiva pôde tornarse a expressão gráfica para dar forma e volume à matéria recém-descoberta. Desenvolveram-se as idéias de observação, de medição e de análise racional

"Nessa visão coerente, todas as massas e todos os intervalos fluem num contraponto rítmico e sem interrupção, em gradações proporcionais e consistentemente interligadas, para convergirem no ponto do infinito: o ponto de fuga. (...) Na polaridade entre o homem e o ponto de fuga - ponto onde o finito se condensa e toca no infinito - estende-se uma linha imaginária atravessando o espaço. Em torno dessa linha gira o universo". (OSTROWER, 1999, p. 102)

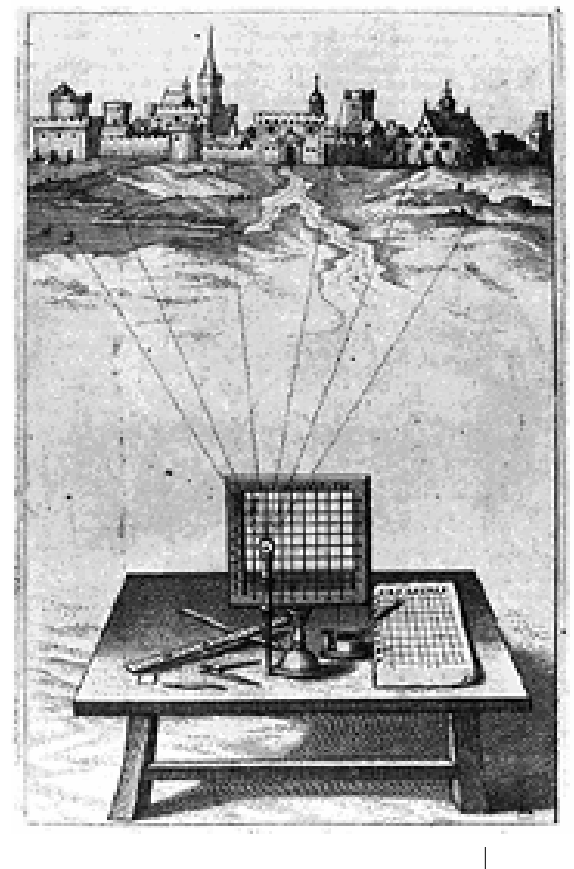


É necessário frisar que a leitura da presente tese faz referência ao contexto cultural do mundo ocidental, no qual estamos inseridos. À margem de nosso raciocínio, exemplificamos as diferentes visões de perspectiva que outras culturas adotaram como representação gráfica da relação do homem com a sua compreensão do universo.
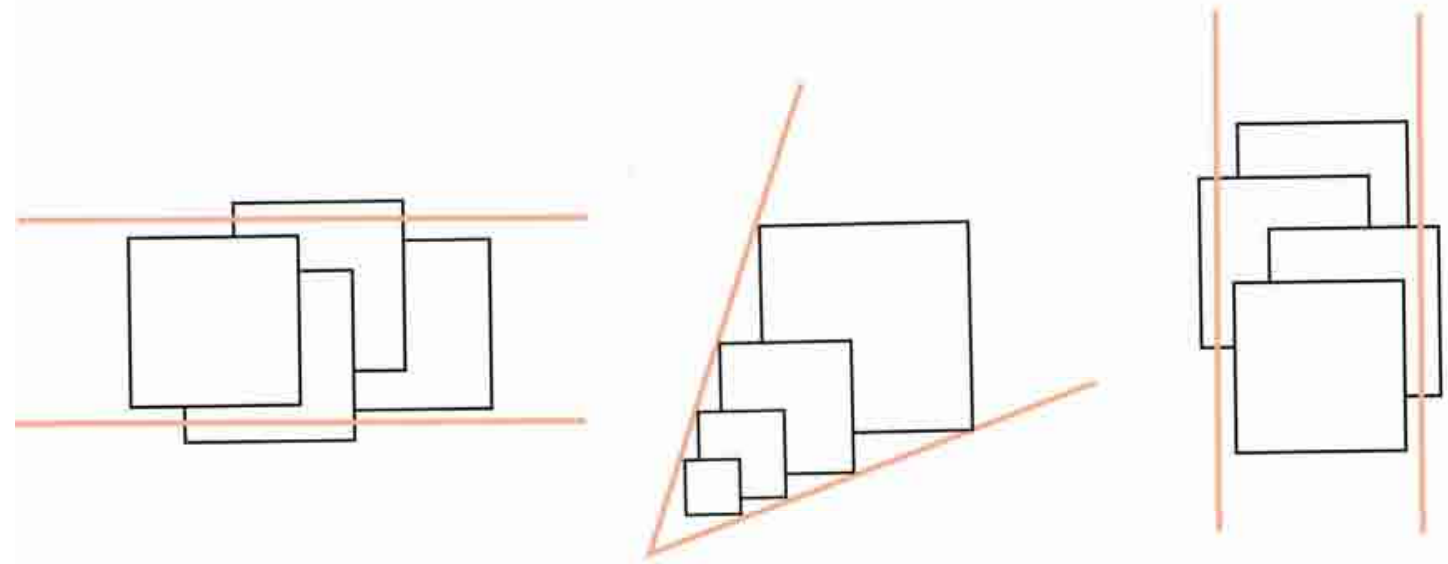

Segundo a perspectiva egípcia antiga, a representação gráfica não se referencia a um centro de perspectiva. Não há volumes e os planos seguem uma seqüência linear, paralela à linha do horizonte. Não há concepção do infinito.
Segundo antigas teorias chinesas, a linha do horizonte está situada atrás do espectador. Para ela convergem os centros de perspectiva, que se projetam sobre o quadro, divergindo à medida que se afastam $A$ pintura chinesa amplia o horizonte ao infinito.

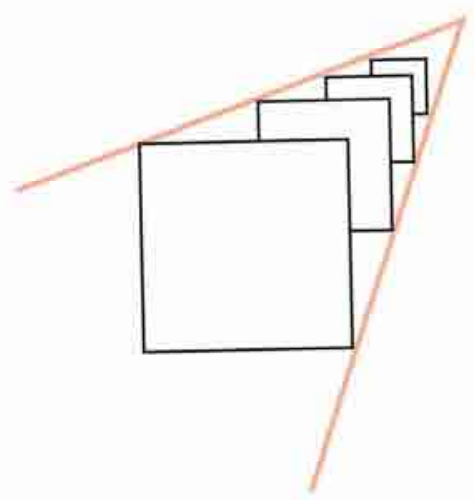

Segundo a concepção ocidental de perspectiva, a linha do horizonte está situada ao nível do olho. Todas as linhas que partem do primeiro plano

convergem para o horizonte,

que se acha sempre ao fundo da paisagem. A perspectiva linear cria a ilusão da realidade.

difícil para o homem renunciar a uma visão tal como a que prevalece no Renascimento, visão egocêntrica $e$ também afirmativa para a humanidade. Essa visão encerra entre outras, na idéia do humanismo, a proposição de potencialidades do indivíduo a determinarem o seu destino. (...) essas idéias representam, contudo, legítimas aspirações da época e, durante o período em que se articulam e adquirem peso, possuem uma vitalidade extraordinária. Com efeito, das primeiras gerações renascentistas até (...) nos dois séculos XIV e XV, sentimos em todas as obras um espírito de aventura e de descoberta do desconhecido, de curiosidade e mobilidade espiritual, uma visão positiva da vida. Apesar de guerras, misérias e pestes, o clima renascentista é um clima lúcido e ativo, nunca cético.

Outros fatos sociais existem hoje, outras interpretações, outras possibilidades, outros relacionamentos. Nossos destinos mudaram.

Na arte moderna, não se encontra a perspectiva como configuração do espaço. Seria impossível atribuir esse fato a qualquer tipo de ignorância. A perspectiva é conhecida por nós. (é) ensinada nas escolas e é profissionalmente praticada(...). Mas hoje a perspectiva representa apenas uma técnica de projeção, um método. Deixou de ser forma expressiva.

A causa principal deve ser reconhecida no fato de a perspectiva não corresponder, (...) às experiências em nosso contexto cultural e aos conteúdos valorativos. De certo modo o significado da perspectiva se tornou tão alheio à nossa realidade, às nossas vivências do espaço e da própria vida, quanto por outras razões o era à mentalidade da Idade Média.

Naturalmente, para os renascentistas, a perspectiva não constituía apenas uma conceituação, (...) Simbolizava, como forma configurada, uma visão de mundo transfundido por valores vivos, visão do sensual da vida, da solidez densidade da matéria, da permanência terrena. (OSTROWER. 1999: p 96) 


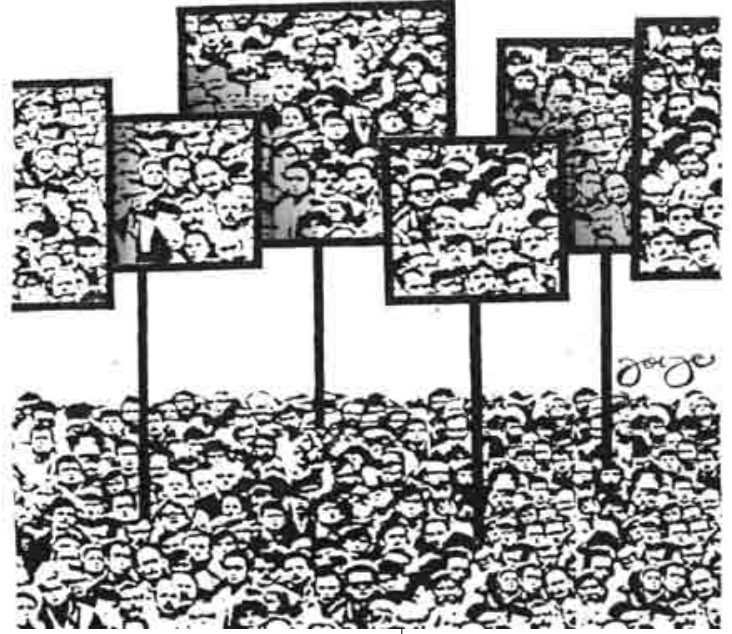

Independente do contexto cultural, no cerne do ato criativo essencialmente estará a capacidade de nos comunicarmos por meio de ordenações, isto é, através de formas. Em tudo que o homem faz, imagina, compreende, ele o faz ordenando. Todo o conhecimento lhe é dado através das disposições nas quais as coisas se estruturam. Se o falar representa um modo de ordenar, também o comportamento é ordenação. A pintura é ordenação, a arquitetura, a música, a dança, ou qualquer outra prática significante. Todas são ordenações, todas são linguagens capazes de gerar formas. Não são formas verbais, nem suas ordenações poderiam ser verbalizadas. Elas se determinam dentro de outras materialidades. (2)

As culturas se transformam com rapidez, bem mais rápidas do que as eventuais modificações no homem. As cultus acumulam-se, diversificam-se e se enriquecem. Desenvolvem-se e, por vários motivos, são extintas. Fica claro que as culturas não são herdadas, mas transmitidas.

Segundo os conhecimentos sobre o passado da humanidade o homem surge na história como um ser apoiado e inserido em uma cultura. Os valores culturais constituem ambiente propício para o seu agir. Criam referências para novas propostas, mesmo que os objetivos sejam de caráter pessoal. Mesmo assim, estarão elaboradas possibilidades culturais. Sua subjetividade representará sua cultura e assim estará representando a cultura da sua coletividade.

O ato criativo de cada indivíduo, no contexto de cada cultura resulta de associações mentais de seus valores, contribuindo na construção de experiências do que seria possível e provável. O que ampliará a imaginação do indivíduo será a capacidade de perfazer uma série de ações, associandoas e manipulando-as mentalmente.
(2) Cabe notar aqui que a palavra materialidade é originária da palavra matéria, que por conseguinte possui origem no prefixo latino MATER. (mãe).

Isto é, aquela que faz nascer, a que

materializa. Aquela que encarna o que ainda não existe.

\section{2 - SIGNIFICADOS DO DESENHO}

Para aprofundarmos a análise sobre a expressão e a representação gráfica, nos pautamos nas reflexões de Fayga ostrower, em seu livro Criatividade e Processos de Criação(1).

criador será um ser consciente e sensível em qualquer cultura, e em qualquer época. Isto é, a consciência e a Também é inerente a cada pessoa o ambiente social em que vive, sendo que a cultura representa o desenvolvimento social, configurando a convivência de cada coletividade. Na história da humanidade as culturas revelam-se como caminhos de humanização. 


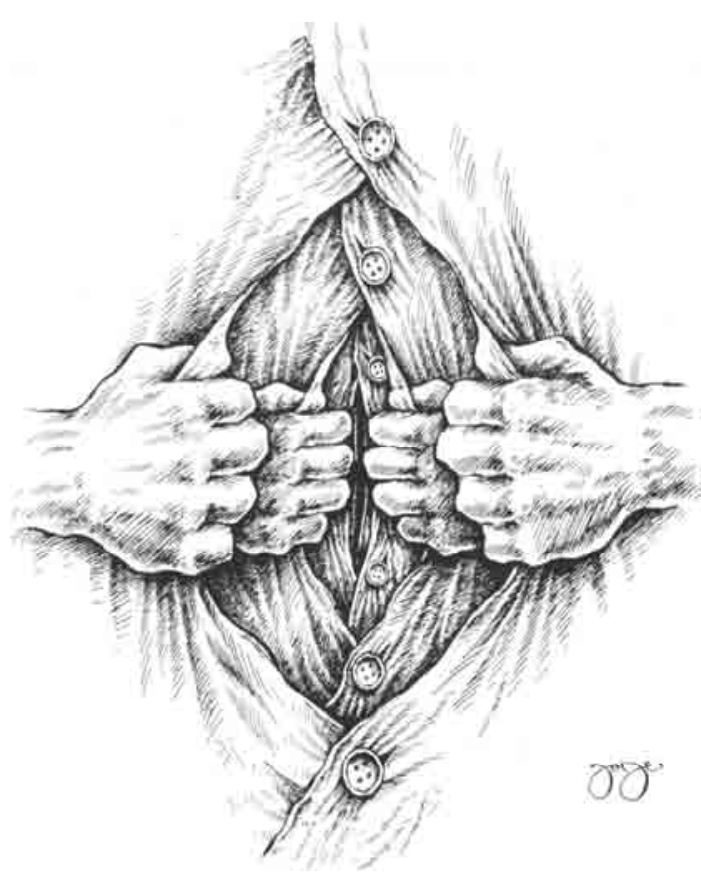

Usamos o termo materialidade, em vez de matéria, para abranger não somente alguma substância, e sim tudo o que está sendo formado e transformado pelo homem. O pedreiro trabalha com pedras, o filósofo lida com pensamentos, o matemático com conceitos, o músico com sons (...), o psicólogo com estados afetivos, e assim por diante.

Cada materialidade abrange, de início, certas possibilidades de ação e outras tantas impossibilidades. Se as vemos como limitadoras para o curso criador, devem ser reconhecidas também como orientadoras, pois dentro das delimitações, através delas, é que surgem sugestões para se prosseguir um trabalho (...) ampliá-lo em direções novas.

De fato, só na medida em que o homem admita e respeite os determinantes da matéria com que lida como essência de um ser, poderá seu espírito criar asas e levantar vôo, e indagar o desconhecido. (OSTROWER, 1999, p. 92)

O aspecto relevante a ser considerado é que, por meio de ordenações, se objetiva um conteúdo expressivo, pois "a forma converte a expressão subjetiva em comunicação objetiva". O criar é sempre um ordenar para se comunicar. "Pode-se falar, por exemplo, (...) sobre os vários tons de azul que entraram em uma pintura; mas a própria criação da pintura, ou seja, a ordenação só poderia ser feita com os vários tons de azul, e não com palavras.

O que quer que se crie e se comunique, corresponderá a um modo particular que não existia antes, nem existirá outro idêntico. Uma realidade configurada exclui outras realidades. É nesse sentido, que, no formar, todo construir é um destruir. Cada decisão que se toma representa um ponto de partida, num processo de transformação que está sempre recriando o impulso criativo.

\section{Potencialidade Criadora}

Mais fundamental para o indivíduo que está criando, é o sentimento concomitante de reestruturação e enriquecimento da própria produtividade. No processo criativo será oferecida ao ser maior amplitude que se manifesta no ato de criar. Não advindo da energia descarregada, mas da energia renovada. Como um renascer.

Criar não representa um esvaziamento de energia pessoal, nem uma substituição imaginativa da realidade. Criar representa uma intensificação do viver, um vivenciar-se no fazer e, em vez de substituir a realidade, ela é a realidade. É uma realidade nova que adquire dimensões novas pelo fato de nos articularmos, perante nós mesmos, em níveis de consciência mais elevados e mais complexos. Somos nós a realidade nova. Daí o sentimento do essencial e necessário no criar. O sentimento de um crescimento interior, que nos amplia na abertura para a vida. 
O homem elabora seu potencial criador através do trabalho. E o trabalho é uma experiência vital. Nela o homem encontra sua humanidade ao realizar tarefas essencialmente humanas. A criação se desdobra no trabalho enquanto trouxer a necessidade de gerar possíveis soluções criativas.

Nem na arte existiria criatividade se não pudéssemos encarar o fazer artístico como trabalho. Se retirarmos da arte o caráter de trabalho, ela será reduzida ao supérfluo, dispensável à existência humana. Assim, durante o processo criativo, a imaginação levanta hipóteses sobre certas configurações viáveis em determinadas materialidades. "O imaginar passa a ser um pensar específico sobre um fazer concreto. Um carpinteiro, ao lidar com madeira pensa em termos de trabalhos a serem executados em madeira. As possibilidades que ele elabora, não seriam, por exemplo, possibilidades para um trabalho em alumínio, com elasticidades, espessuras e moldes possíveis em alumínio. Portanto, o pensar só poderá tornar-se imaginativo através da concretização de uma matéria. Sem o que não passaria de um divagar descompromissado". (OSTROWER, 1999, p. 122)

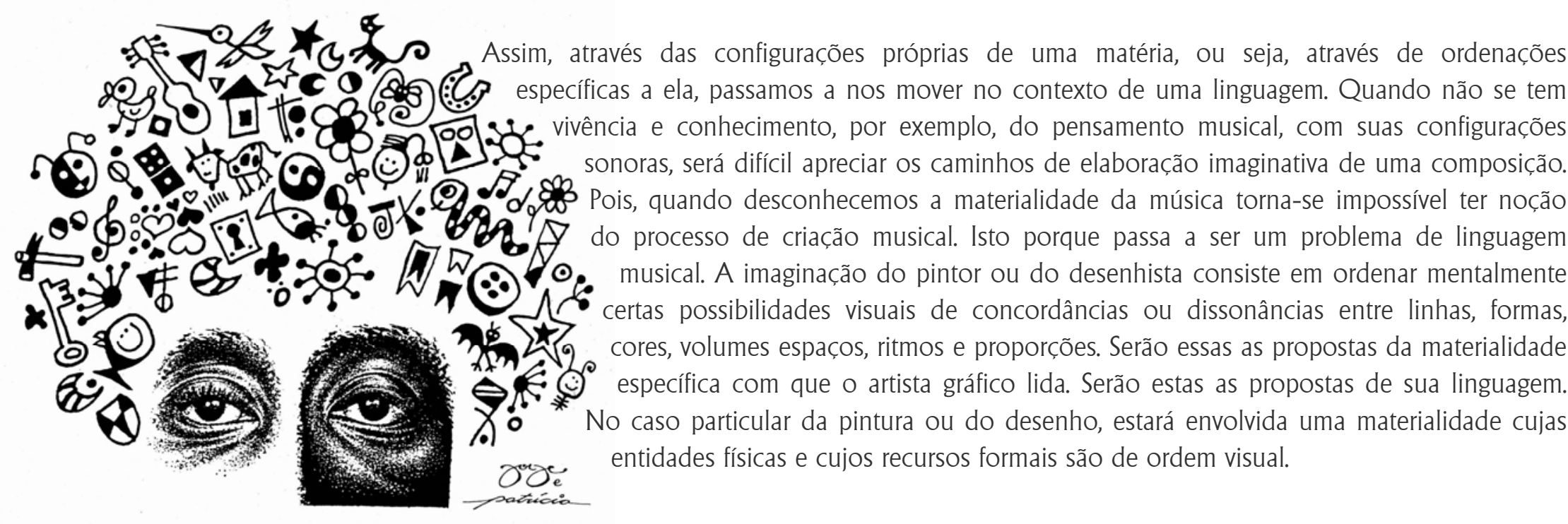

(3) COMPREENDER Inata ou inerente ao aprendizado, a sensibilidade não é somente patrimônio de artistas ou de privilegiados. Ela é com + aprender patrimônio de todos. Ainda que em graus distintos, todo ser humano nasce com um potencial de sensibilidade. "Aprender com o tempo, é compreender o seu tempo" (3) 
É possível reconhecer uma sensibilidade diferente em cada artista, uma atitude seletiva diante das propostas do contexto cultural, não tanto na temática do desenho ou na interpretação iconográfica. Mas na maneira de desenhar, nas ordenações, nas harmonias colorísticas, nas ênfases, ou seja, no enfoque manifesto na própria linguagem. Sem isso, seria de fato impossível atribuir a obra a determinadas personalidades. Na sensibilidade variável de cada um a imaginação e a linguagem adquirem formas subjetivas, como uma caligrafia. Sem ter a materialidade presente, as contribuições subjetivas da criação se desvalorizam, ou seja, não se concretizam como linguagem.

\section{Formar e transformar}

"Criar é basicamente, formar. Isto é: poder dar forma a algo novo. Em qualquer campo de atividade, trata-se de dar (...) novas coerências que se estabelecerão na mente humana. Serão fenômenos relacionados de modo novo e compreendidos em termos novos. Portanto o ato criador abrangerá a capacidade de compreender. E esta compreensão, por sua vez, abrangerá a capacidade de configurar (...) de significar”.(OSTROWER, 1999, p. 71 )

Formar importa em transformar(4). Todo o processo de elaboração abrange um processo dinâmico de transformação, em que a matéria orienta a ação criativa.

(...) isto é, ao seguir certos rumos a fim de configurar uma matéria, o próprio homem com isso se configura. Estruturando a matéria, também dentro de si ele se estruturou. Criando, ele se recriou.

É isso que cala tão profundamente em nós. Compreendemos que todos os processos de criação representam, na origem, tentativas de estruturação, de experimentação e controle, processos produtivos onde o homem se descobre, onde ele próprio se articula à medida que passa a identificar-se com a matéria. São transferências simbólicas do homem à materialidade das coisas, e que novamente são transferidas para si.

Formando a matéria, ordenando-a, configurando-a, dominando-a, também o homem vem a se ordenar interiormente e a dominar-se. (OSTROWER, 1999, p. 89)

Formar é criar formas. E para criar formas é necessário experimentar a materialidade. E ao experimentá-la vai-se configurando. Sem a configuração não se realiza o conteúdo significativo.

Para aquele que deseja criar algo, é necessário conhecer a especificidade do material. Procurará também nas configurações possíveis, alguma forma que ele sinta como mais significativa em determinada ordenação, de acordo com seu próprio senso de ordenação interior. 
Ciência Exata
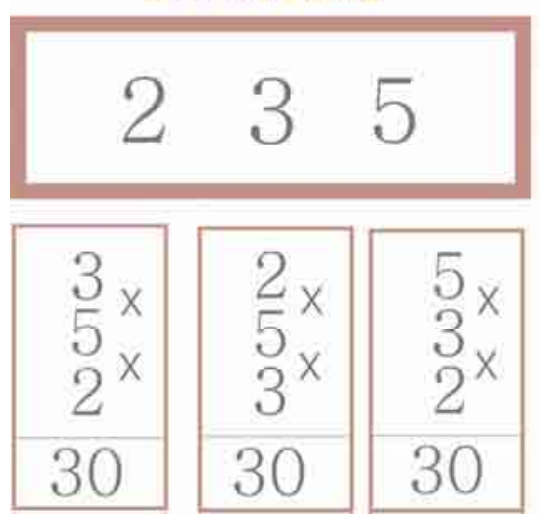

Linguagem Visual
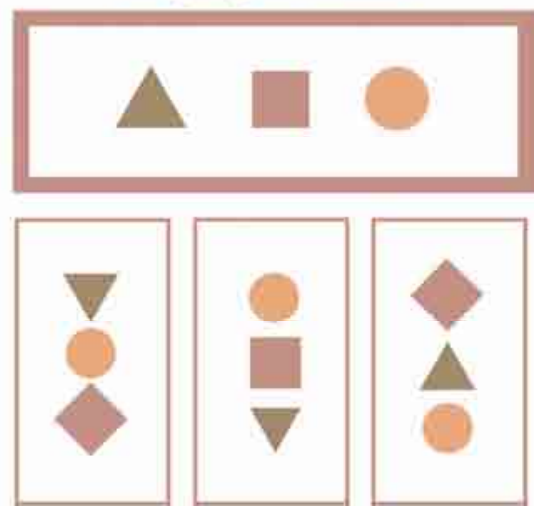

Ao criar formas com os materiais o ser humano também cria formas dentro de si e em redor de si, configurando o seu caminho. E assim, como na arte, o artista se procura nas formas da criação. Cada indivíduo se procura nas formas do seu fazer, e consequentemente nas formas do seu viver.

A proposição matemática "a ordem dos fatores não altera o produto" nunca se aplica a configurações plásticas. Nas configurações plásticas sempre a ordem há de alterar o produto, pois ela própria é o produto. Pela ordenação dada, forma e conteúdo passam a se interpenetrar e a corresponder-se.

Na linguagem visual os componentes formais a serem configurados são poucos:

\section{LINHA SUPERFÍCIE VOLUME LUZ COR}

Eles se apresentam inicialmente numa indeterminação. Em si são indefinidos, porém permitem inúmeros relacionamentos que podem ser combinados entre si e ordenados em várias direções espaciais.

\section{Linguagem Universal}
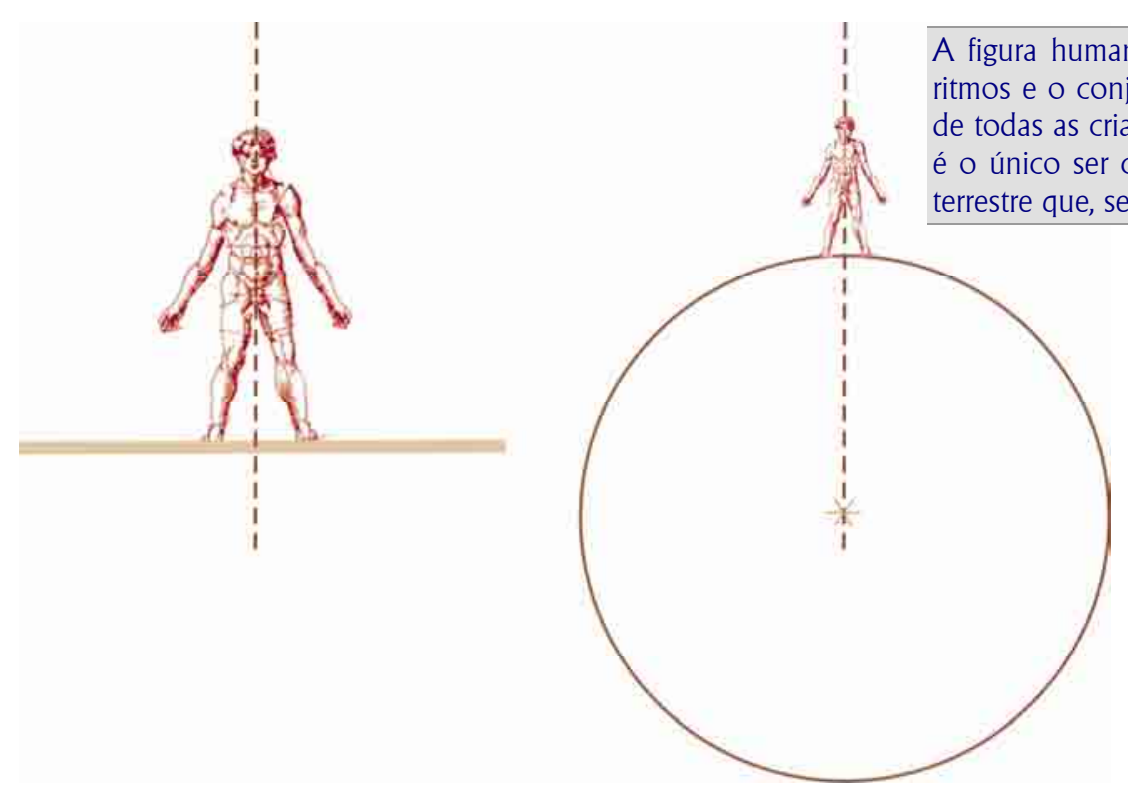

Em contextos culturais mais primitivos, o homem sempre esteve vinculado à vida através de um enfoque predominantemente sensorial. Orientava suas ações pelos sentidos. Sem conceituar, imaginava e concebia múltiplas ligações entre os fenômenos. Abordava e compreendia a realidade pela via dos sentidos. E por esse meio tentava influenciar e dominar seu entorno.

Na história da humanidade a abstração e a racionalização representaram uma conquista mais atual. Sem dúvida, uma ampliação e enriquecimento de conhecimentos. 
A criatividade é um potencial próprio do ser humano, e sua realização é uma de suas necessidades.

Porém, vale observar que as alterações na linguagem gráfica das crianças, até próximo à idade da puberdade, são similares em todas as crianças. As alterações estilísticas pouco variam de cultura para cultura. Poder-se-ia chamar a esse desenvolvimento quase que de estilo 'biológico'.

\section{A LINGUAGEM GRÁFICA DA CRIANCA NO II: SETẼNIO}

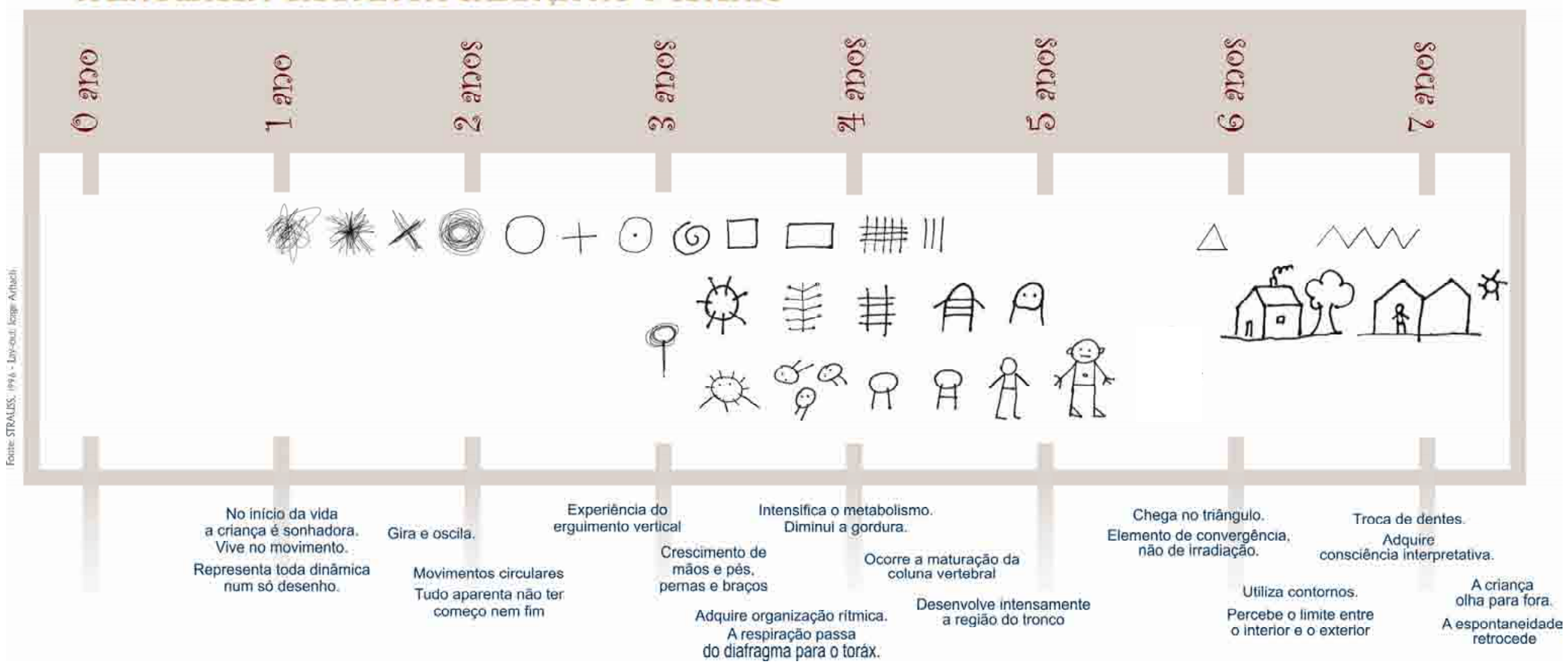

Mesmo existindo nos primeiro anos de vida um processo de orientação cultural por parte dos adultos, como ter contato com papéis, lápis de cor, tintas, pincéis, etc., as crianças possuem impulsos similares no momento das representações gráficas. Se uma criança, por exemplo, nunca teve contato com uma caneta, certamente não irá saber manuseá-la e 
certamente não saberá elaborar desenhos com esse instrumento. Porém, com qualquer pedra ou pedaço de pau ela desenhará as formas idênticas às de uma outra criança que usa a caneta.

Surgem, inicialmente, experiências sensório-motoras, pontos, traços, círculos, espirais, onde a criança procura estabelecer para si mesma o domínio sobre certos movimentos físicos junto com uma medida de domínio sobre o meio ambiente. Quando a criança se aproxima da puberdade, suas formas expressivas mudam visivelmente. O modo da representação se torna mais analítica, mais descritiva, entrando numa linha mais 'realista'. Esse desenvolvimento é comum às várias sociedades e culturas. Aos poucos começam a inserir-se em sua própria coletividade.

Assim, as alterações que ocorrem na expressividade infantil correspondem às fases do crescimento físico e psíquico da criança. Ao mudar a realidade para a criança, concomitantemente mudará o caráter de convivência dessa realidade, portanto modificará suas formas de comunicação. A criança amadurecendo progressivamente se diferencia dentro de si e, se orienta.

\section{Referências Corporais}

No mundo, as imagens são cada vez mais numerosas, diversificadas e intercambiáveis. Sua percepção é uma atividade que não pode se separar das funções psíquicas, intelectuais, da memória e do desejo. O conjunto de imagens internas que habitam em cada um não tem uma relação única com a realidade. Realiza-se em contextos multiplamente determinados: contexto social, cultural, regional e temporal.

As imagens estão alicerçadas em práticas significantes, ou seja, práticas de produção de sentido simbólico, como fenômeno cultural da sociedade onde ela se implanta. Por ser uma linguagem criada pelo homem sempre trará consigo signos carregados de ideologia que a fazem ser entendida. Em outras palavras: por ser produto de uma determinada sociedade, a imagem é também um objeto ideológico impregnado de signos.

Em épocas passadas, quando não havia grande número de imagens, o imaginário tinha mais liberdade de ação, sendo a imaginação o grande articulador do imaginário. Diferentemente da atualidade onde o imaginário é criado a partir de imagens fabricadas. Anteriormente acontecia justamente o contrário: as imagens surgiam a partir do imaginário, motivadas ou provocadas pela crença religiosa, mitos e lendas, de acordo com o pensamento vigente.

O desenhista pré-histórico, ao figurar animais e caçadas nas paredes de pedras de sua caverna fazia referências àquilo que era sua grande preocupação, a sobrevivência. Assim, o desenho da caça, objeto de seu desejo, era a manifestação de seu imaginário através da representação visual. Justamente o contrário do imaginário estimulado por uma imagem já representada. Pois, ali já se encontram todas as características da imagem delineada pelo imaginário do autor, prescindindo do imaginário do observador. 


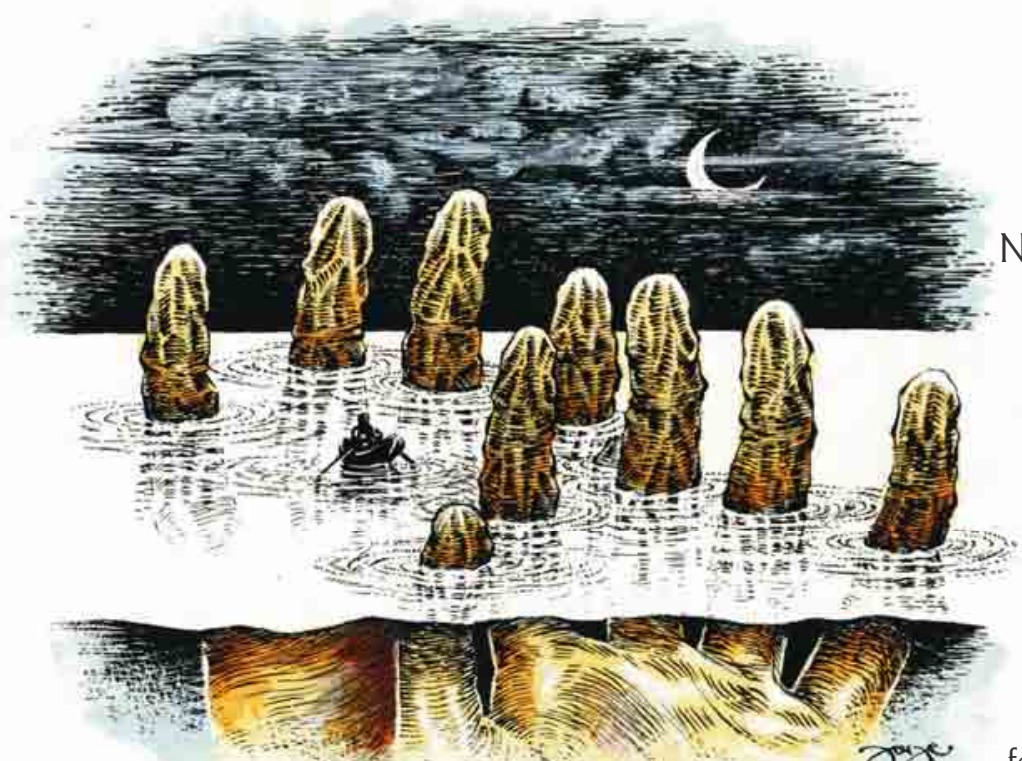

Nas sociedades pré-históricas, antes do surgimento da escrita, quando ainda haviam poucas imagens representadas, o poder era o do sobrenatural. $O$ homem temia, sobretudo, aquilo que não era visível, cuja explicação ficava por conta do imaginário. Daí o respeito e o temor por deuses que manifestavam-se através de animais, trovões, chuvas, florestas etc. e pelos sacerdotes e curandeiros que sabiam invocar deuses e espíritos, pessoas que sempre gozavam de grande prestígio e poder nas suas comunidades.

Apesar das imagens estarem representadas na escrita, as civilizações antigas foram mais orais que imagéticas. Campos vastos para a imaginação humana eram provocados mais pela audição do que pela visão. Porém, toda nossa cultura ocidental alicerçou-se no conhecimento Jay fornecido pelos meios de comunicação a partir da invenção dos tipos móveis, permitindo a produção em série.

ANÍMICO
Pertencente ou
relativo à alma; psíquico.

Por ser um ato involuntário, o impulso criador do ser humano é um processo estruturado a partir de seu inconsciente e condição prévia da mente como dinâmica inata, em que atuam a razão e o pensamento lógico. A análise de qualquer criação artística revela que o artista não é o único intérprete de sua obra, ele é o agente que a configura, determinado culturalmente pelo contexto histórico vivido no momento da criação. E a ação sensível do indivíduo durante o ato criativo envolve toda a humanidade, satisfazendo necessidades anímicas (5) de uma coletividade.

“(...) toda representação icônica é antes de tudo um signo de uma ausência. Ausência daquilo que está sendo representado". (SOUZA, 1992, p. 15). Alguns autores defendem que quanto maior o grau de síntese representando uma imagem mais ela será icônica. Nesta escala, destacam-se alguns tipos de imagem que têm maior grau de realismo ou iconicidade e que demonstram maior veracidade perante o espectador. Nessa ordem, citamos:

o próprio objeto a reprodução fotográfica o desenho do objeto a interpretação gráfica a descrição por palavras a descrição por fórmulas 
A percepção de qualquer imagem representada graficamente utiliza os mesmos processos de percepção visual de uma imagem real visualizada, isto é, desenvolve-se com a idade e com a experiência. Assim, como exemplo, a imagem de uma esfera representada graficamente no papel é a transposição de um meio espacial para um meio planimétrico, isto é, são elementos visuais em duas dimensões, transcrevendo dados obtidos por uma projeção da realidade tridimensional.

A interpretação gráfica do objeto desenhado é dada pela mais provável de ser reconhecida e identificada, seguindo os mesmos procedimentos que na imagem real. Assim, a imagem é percebida de modo automático por uma interpretação espacial e tridimensional. A assimilação é facilitada quando os elementos percebidos são invariáveis em sua aparência, mantendo constância na sua identificação em tamanho, forma, localização, orientações e propriedades. Automaticamente é colocado em ação um saber sobre a realidade. E esse saber vai se aperfeiçoando com o crescimento corporal do indivíduo de modo intuitivo, tanto com referência à sua própria posição no espaço bem como em relação com os outros seres. A percepção do mundo estará vinculada ao corpo e ao seu deslocamento no espaço real.

Nosso corpo é totalmente material e habitante de um mundo material. A partir do reconhecimento material de si passamos a reconhecer o mundo material externo. Porém, nada percebemos e nada transformamos no mundo real a não ser por meio de nossa percepção sensorial através do corpo. Nada nos atinge como realidade, e tampouco atingimos a realidade sem a constante mediação dos processos sensoriais corpóreos. Assim, a corporeidade do nosso ser é a instância referencial de critérios para a ética, para a educação, para a política, para a economia, para a religião e para os afetos. Nenhum ideal se encaminha e se cumpre se não estiver ligado à mediação da corporeidade com o entorno do mundo. É vivendo e experimentando a espacialidade por intermédio do corpo que se percebe o fenômeno de estar no mundo com o restante do mundo. Uma observação ou um movimento só será aprendido quando o corpo o compreender, passando a incorporá-lo no seu próprio mundo.

Primeiramente é feito o reconhecimento sensorial das três dimensões espaciais: o comprimento, a altura e a profundidade; estas representadas no papel respectivamente pelas linhas horizontal, vertical, e diagonal. Essa percepção dá referências materiais ao corpo, orientando-o com o mundo que o cerca, atraindo para si todos os pontos do universo, como se o centro do mundo se encontrasse nele próprio. Sua posição também o projeta em direção a todos os pontos do horizonte permitindo situar-se no mundo, percebendo todo o universo residente em si enquanto habitante também de todo o universo. Ele se reconhece como criador e criatura do próprio mundo. 
Para que possamos mover nosso corpo no espaço em direção a um outro ser no espaço, primeiramente é preciso que este ser exista para o nosso corpo. Isto ocorre quando do aprendizado natural que a criança faz ao engatinhar. É o primeiro reconhecimento consciente da espacialidade. Na busca do objeto desejado há uma tomada de consciência da espacialidade como elemento expressivo da vontade, sendo reconhecido inicialmente pelos três eixos espaciais norteadores: o da horizontalidade ao reconhecer a linha do horizonte, o da verticalidade ao erguer-se, e o da profundidade ao deslocar-se ao objeto desejado.
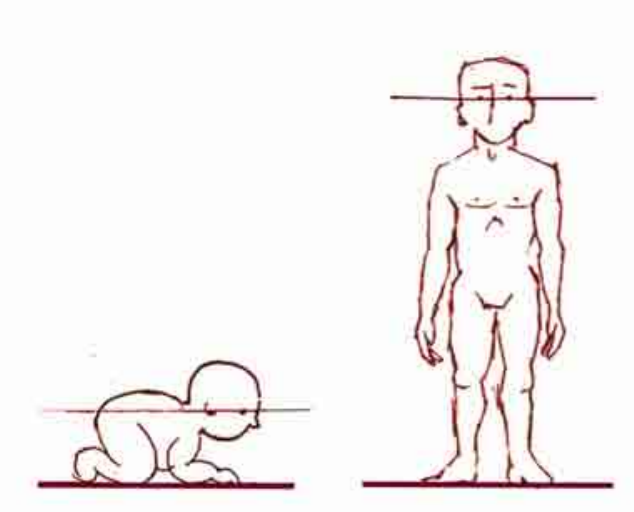

Linha Horizontal

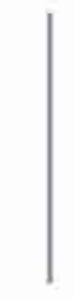

Linha vertical
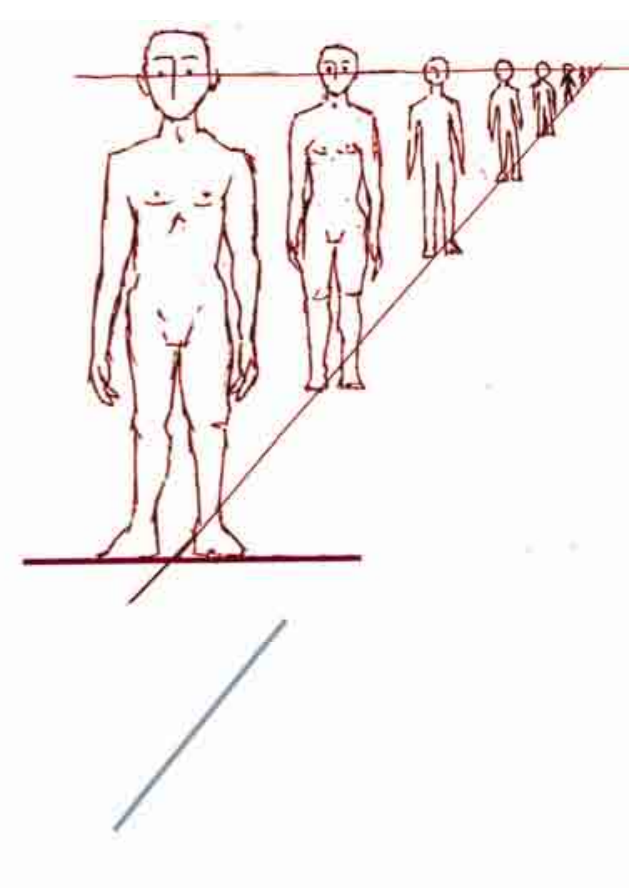

Linha Diagonal

\section{A Linha Horizontal}

No princípio, ao sair do útero materno, o bebê rasteja como um réptil recémsaído do mar. Ele reconhece a linha horizontal, que estará sempre à altura de seus olhos. Vivenciando o aqui e agora, a linha do horizonte encontra-se nele mesmo. A integração é total com o mundo externo que o cerca.

\section{A Linha Vertical}

Ao erguer-se para aprender a andar, o ser humano reconhece a linha vertical. Seu horizonte se amplia. A linha do horizonte, que estará sempre na altura de seus olhos, se desloca para cima e para longe. Neste estágio ele pensa, imagina e sonha. Com o pensar busca o objeto do desejo. Vê o além.

\section{A Linha Diagonal}

Ao descortinar o amplo horizonte à sua frente, pode escolher caminhos para ir ao encontro do objeto desejado. Reconhece a profundidade e a incorpora como caminho a seguir. Nesse estágio ele dialoga, troca, convive e sente. Interage com o mundo através de valores simbólicos (linguagens, objetos, normas ...). Vai buscar do mundo o que desejou. 


\section{Significados na Representação Gráfica}

A imagem gráfica é um sinal visível numa superfície que tem uma finalidade comunicativa. A linha é o mais elementar dos componentes da linguagem visual. Pode se apresentar de diversas maneiras, variando na direção, intensidade, espessura, etc. dependendo do instrumento, das intenções do artista e das funções comunicativas que vai assumir.

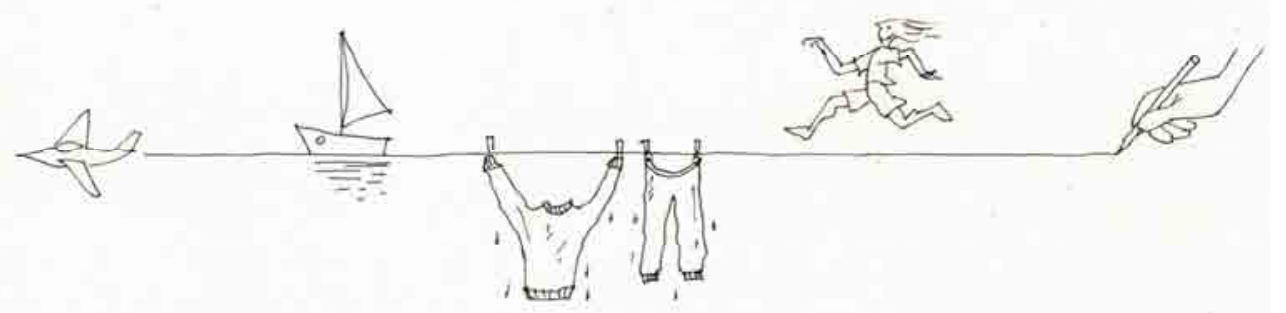

É o meio indispensável para visualizar o que não pode ser visto, o que não existe, a não ser na imaginação. A linha como contorno, como recurso de configuração ou captura de forma, é uma criação do homem. Na natureza existem limites entre figura e fundo, ou entre elementos, como a linha do horizonte observada da praia, limitando céu e mar, por exemplo, que tem sua a distinção baseada no contraste ou de cor ou de valor. A distância pode converter determinados elementos em linhas, como rios, vistos e um avião em grande altitude, ou um fio de cabelo, mas na função de contorno ela não é observável na natureza.

Quando uma linha muda sua trajetória e retorna ao ponto de partida, encerrando uma área e diferenciando-a do espaço restante, configura-se uma superfície. Assim obtém-se o $2^{\circ}$ elemento da linguagem gráfica: a superfície.

Cada vez que se representa um desenho buscando a verossimilhança ao objeto real, mais se tornam complexos os componentes da linguagem visual. Como vimos, esses componentes sequencialmente são, em grau de complexidade: Linha / Superfície / Volume / Luz / Cor.

Para efeitos de apresentação desta tese, será suficiente nos determos apenas nos dois primeiros componentes.

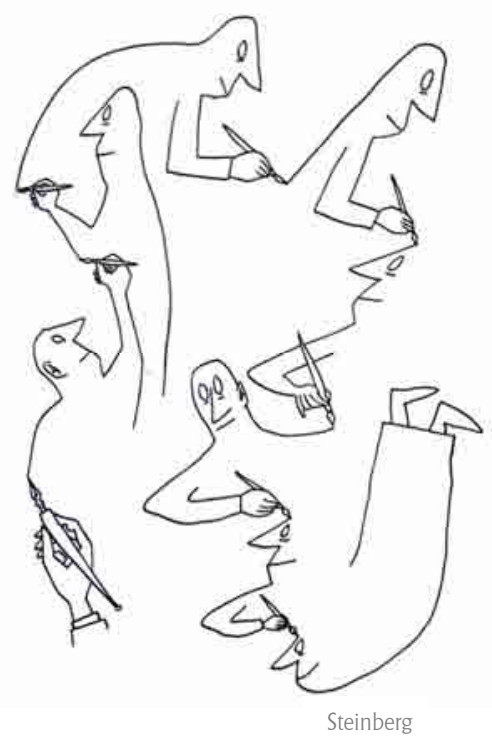




\section{CAPÍTULO 4}

A PALAVRA

4.1 - A COMUNICAÇÃO VERBAL

4.2 - O DESENHO DA PALAVRA

4.3 - A PALAVRA ILUMINADA 


\section{1 - COMUNICAÇÃO VERBAL}

A linguagem verbal é sempre simbólica, por ser construída através de palavras. E palavras são signos abstratos, não tendo nenhuma analogia com o objeto verbalizado. Esses signos abstratos são aceitos socialmente por convenção, em que cada palavra simboliza algo. A operação mental através da qual o homem consegue representar algo que está em sua mente é o que se chama de abstração ou raciocínio. Por isso a linguagem verbal é tão importante na história do homem, pois foi através dela que o ser humano pôde evoluir culturalmente.

A base da linguagem verbal é a criatividade, é a imaginação. Através do simbólico ela dá diversos sentidos às palavras. Porém, ainda hoje existem comunidades que se utilizam das escritas pictográficas como meio de comunicação, resistindo às mudanças ocorridas com a maioria das culturas. Determinados grupos tribais e comunidades regionais guardam ainda vestígios desse processo proto-alfabético.

A conquista da manifestação e da representação do alfabeto fonético pode ser considerada como uma tecnologia ímpar: letras sem significação figurada associando-se a sons também sem significado com as letras escritas. Assim, a expressão da palavra escrita decretou o fim do universo da percepção sensorial, representados anteriormente pela escrita figurativa, como nos hieróglifos.

\section{Escrita Figurativa}

Uma conta feita por pedreiro analfabèto inglês, cerca de 1830 . Eis o seu significado:

Três quartos de dia de trabalho de dois homens e um rapaz: Dois cochos de argamassa? Dez shillings e dez moedas" $O$ desenho do enforcado quer dizer: "conta saldada"

\section{Escrita Alfabética}

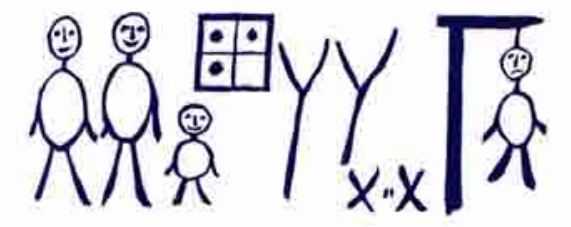

Em nosso idioma a palavra verbal é originária do latim verbu, significando palavra. A comunicação entre os humanos não ocorre somente com palavras, mesmo sendo a que mais utilizamos. Semelhante ao simbolismo das palavras, outros sentidos também inserem o ser humano no meio social. Imagens, gestos e sons fazem parte desses recursos. 


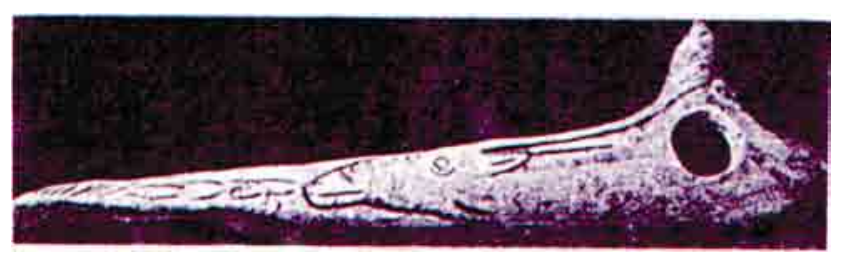

Os homens primitivos, depois de abaterem os animais, utilizavam seus ossos para empregá-los na confecção de armas, e enfeites. Sobre esse material empregavam pontas ou sílex para gravarem desenhos onde fixavam idéias sobre a vida e os costumes.

Na antiguidade, aproximadamente 3.000 a.C., já se empregava o mármore na fabricação de vasilhas redondas, passando-se em seguida ao uso do torno do oleiro no qual se riscavam desenhos pintados. Cenas de caça, grande quantidade de animais como bisões, renas, cavalos, serpentes e mamutes aparecem desenhados e gravados em pedra, osso, marfim, dando um quadro da vida reinante.

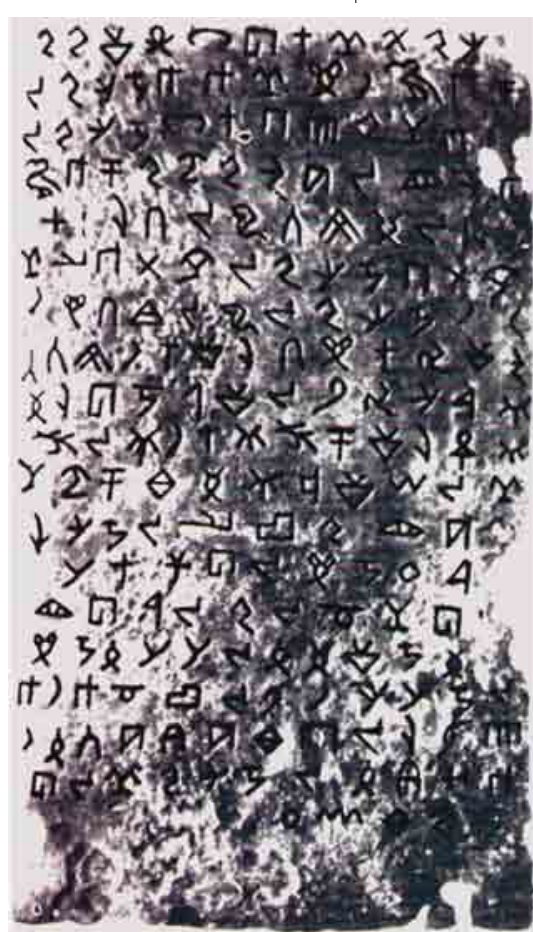

A arte rupestre constitui a mais antiga forma de projeção gráfica utilizada pelo homem e se acha disseminada por todos os continentes, configurando patrimônio comum da humanidade (...) como os famosos bisontes de Altamira e como os numerosos painéis pintados nas cavernas espanholas e francesas, bem como os exemplares do norte da África, e dos desenhos da Austrália (...)

Essas ocorrências constituem, em outras palavras, os fundamentos mais antigos das artes plásticas, das artes gráficas e da própria escrita. (MARTINS, 1992, p.45)

Desde os tempos mais remotos o homem lançou mão de diversos materiais para expressar suas idéias. Para essa finalidade, certamente o barro deve ter sido o primeiro material a ser empregado.

Nesse primórdio da comunicação, o homem ainda se expressava por gestos, imagens e sons. Nessa primeira etapa estávamos no domínio do concreto, do sensorial. Expressávamos através dos sentidos e das sensações. O mesmo como se dá com a expressão das crianças na préinfância. Só muito mais tarde é que o homem aprendeu a usar os sinais gráficos para se referir aos objetos que conhecia pelos sentidos e comunicava por gestos. Nessa passagem para a palavra a humanidade evoluiu em termos de

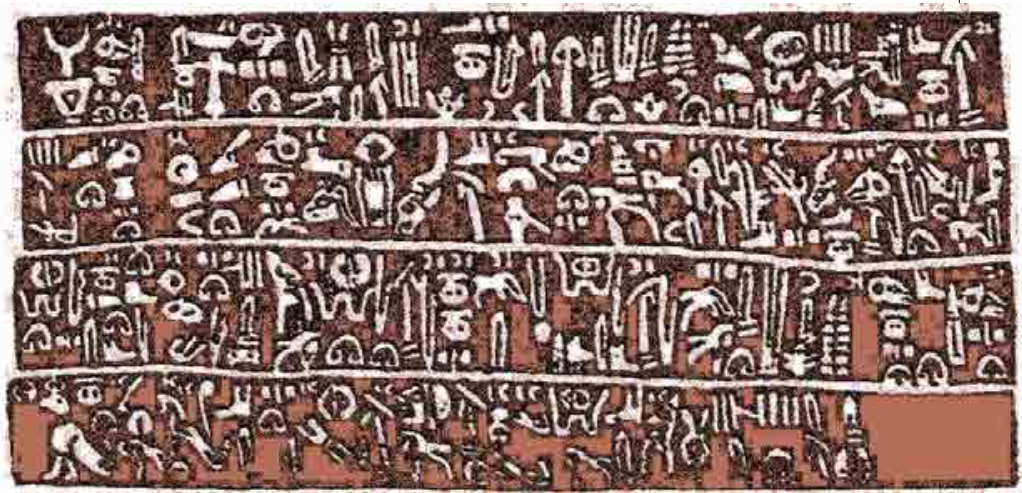
pensamento.

As palavras passaram a reter a idéia daquilo que já não está mais ao alcance dos nossos sentidos, e sempre que as pronunciamos nossos interlocutores sabem o que estamos dizendo. Essa passagem do objeto à idéia do objeto se dá graças à capacidade de abstração, própria do homem. As coisas que ele sempre representara com gestos, desenhos e imagens, atingem com a palavra o ponto mais alto da representação simbólica. 
Com a conquista da fala, as possibilidades de comunicação entre os homens aumentaram muito. Criando palavras (...) e submetendoas a regras e códigos, os homens conheceram a lógica da comunicação verbal. A possibilidade garantida pela linguagem verbal, de memorizar mensagens, gravá-las, vencendo as barreiras do tempo e do espaço, liquidou o nomadismo em que vivia o homem primitivo. Com os registros escritos, inaugura-se a História e, com ela, a construção das civilizações. (ALCUNE; FERRAZ; CARNEIRO, 1996, p. 44)

Os primeiros registros humanos pertencem muito mais ao domínio da expressão que da comunicação. São pinturas e incisões encontradas em cavernas, algumas delas conservadas até os nossos dias. Ao fazermos essas observações estamos mergulhando
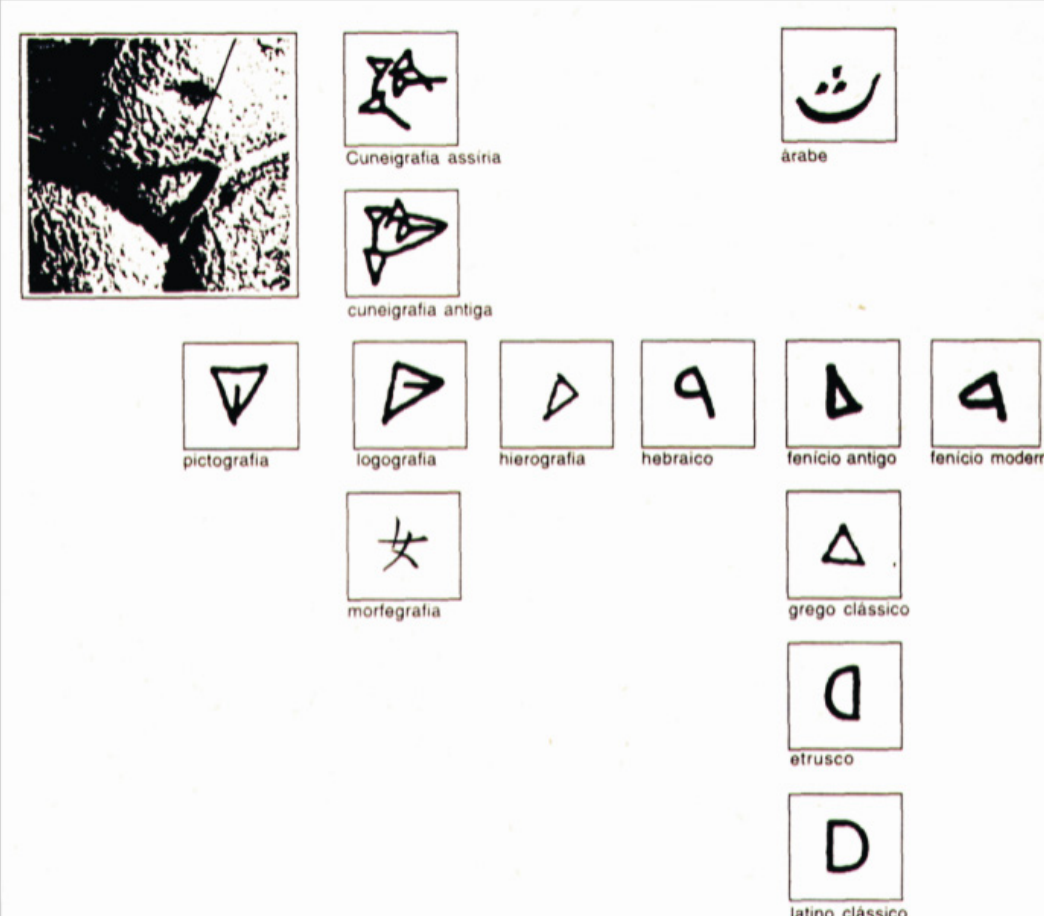
na história da escrita.

A escrita é a representação em sinais gráficos dos sons articulados na fala, uma transformação da língua natural em um código. Surgiu milhares de anos depois da fala.

De acordo com a Lingüística, a escrita é considerada um sistema segundo, uma aquisição secundária no processo da linguagem. Isto é, a palavra falada são os sinais escritos que substituíram os signos vocais expressos nas palavras. Sendo considerada a comunicação oral como o sistema primeiro .

A comunicação verbal se faz de forma oral ou escrita. Não há notícia de povo que não tenha alcançado a comunicação oral. No entanto existem culturas que subsistem mesmo sem terem conhecido qualquer tipo de código escrito, como algumas tribos indígenas. Mas, se sob certo ponto de vista podemos encarar a escrita como secundária, é a linguagem escrita que favorece o domínio do

\section{thisiot to

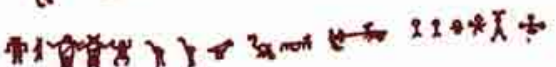

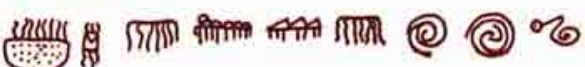

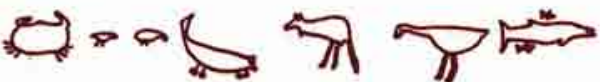 (1) II) (1) 01000

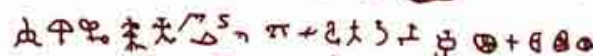

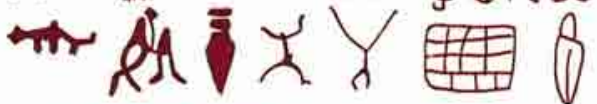

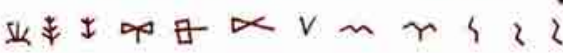




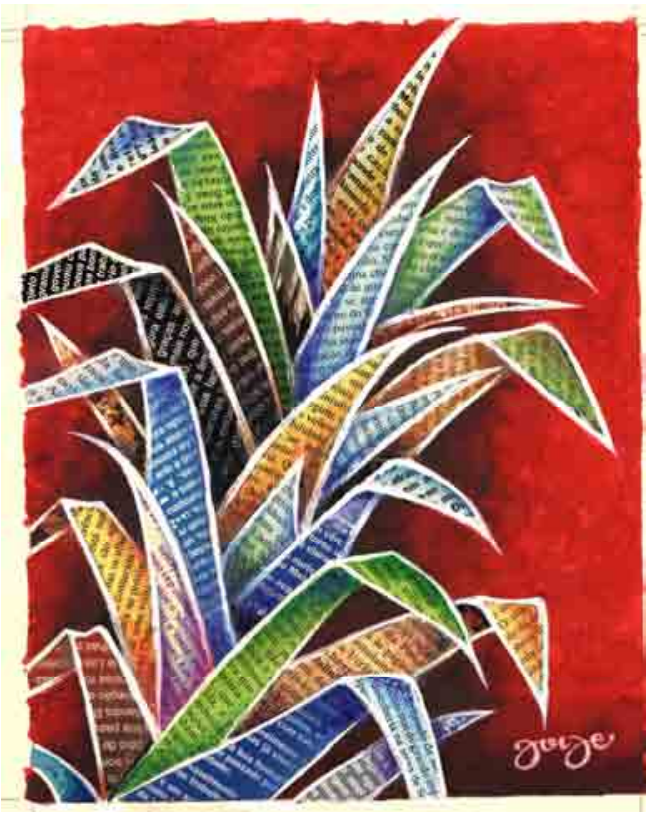

Com a conquista da palavra falada o homem deixou o domínio do concreto, do sensorial, quando (ainda) se referia às coisas através de sons e gestos, e passou para o domínio do simbólico, graças à sua capacidade de abstração. (...) Representando o mundo (..) verbalmente, o homem aumentou em muito as suas possibilidades de comunicação, já que ele ultrapassou os limites da inteligência concreta (animal), e avançou até o pensamento lógico. (ALCUNE; FERRAZ; CARNEIRO, 1996, p. 67)

\section{A Palavra Hoje}

A palavra livro origina-se do grego biblos, que significa casca, ou seja, os primeiros livros eram produzidos nas folhas ou cascas de certos vegetais. $O$ conceito de livro, lingüisticamente, pelo menos, refere-se às folhas individualmente e não ao volume em si. Se compararmos um livro de 100 anos atrás com um livro atual, verificaríamos que a mudança é apenas decorrente das mudanças da linguagem. O objeto livro continua com a mesma técnica de produção e manuseio.

As palavras atuam como mediadoras entre nosso consciente e o mundo. Quando ditas, as coisas se tornam presentes para nós. Não os próprios fenômenos físicos que continuam, naturalmente, pertencendo ao domínio físico. Torna-se presente a noção dos fenômenos. Na língua, como em todos os processos de imaginação, dá-se um deslocamento do real físico do objeto para o real da idéia do objeto. A palavra evoca o objeto por intermédio de sua noção. Entretanto, qualquer noção já surge em nossa consciência carregada de conteúdos valorativos. Orientado por um propósito seletivo e qualificador, o falar torna-se mais do que um assinalar, torna-se um representar as coisas com seus conteúdos, torna-se um significar.

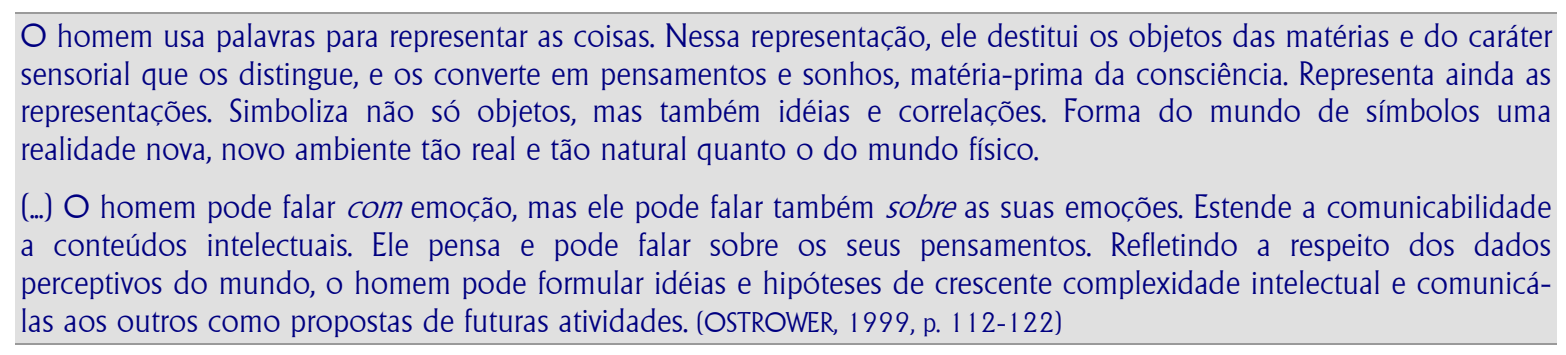

No entender de Fayga (1999, p. 118) "a realidade física recua na medida em que a atividade simbólica avança”.

As novas tecnologias que se utilizam da palavra e da imagem, isto é, os meios audiovisuais (fotografia, cinema vídeo e TV) acabaram por influenciar a construção e a apresentação da linguagem verbal, tornando-a mais coloquial e mais acessível, como são as imagens. Jornais, revistas e livros sofreram bastante essa influência tornando a linguagem mais ágil e instantânea. 


\section{2 - O DESENHO DA PALAVRA}

\section{Primeiros Escritos}

A língua falada ou escrita é um mecanismo peculiar e predominante na expressão do pensamento humano. Constantemente em uso, sofreu múltiplas evoluções desde seus primórdios. Para cada povo, região ou época existiu um idioma correspondente, com diferenças e variações em sua representação. Os pensamentos tiveram na expressão da

Desenvolvimento da escrita latina

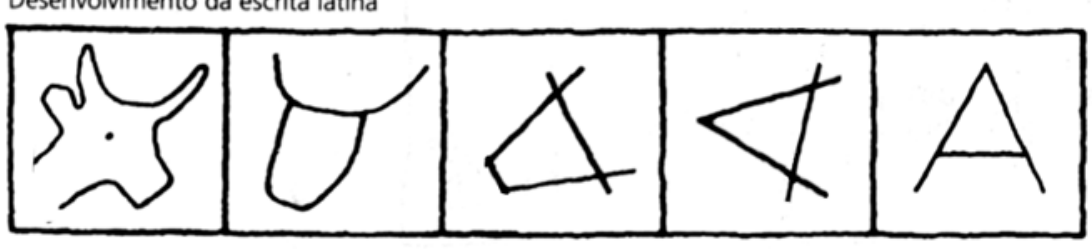

Do hieróglifo ao atual fonema "A" escrita seu principal veículo de comunicação. A evolução da escrita artesanal foi sendo sempre reformada com o objetivo de se conseguir maior legibilidade e facilidade para a execução e compreensão. Desde o primeiro sinal gravado pelo homem primitivo nas cavernas a escrita transportou aspectos próprios e dinâmicos em sua configuração, independente da técnica de sua produção, seja com o buril, pincel, pena de ave, ou com as tecnologias atuais. A representação da escrita através do alfabeto constituiu num veículo básico nas relações humanas.

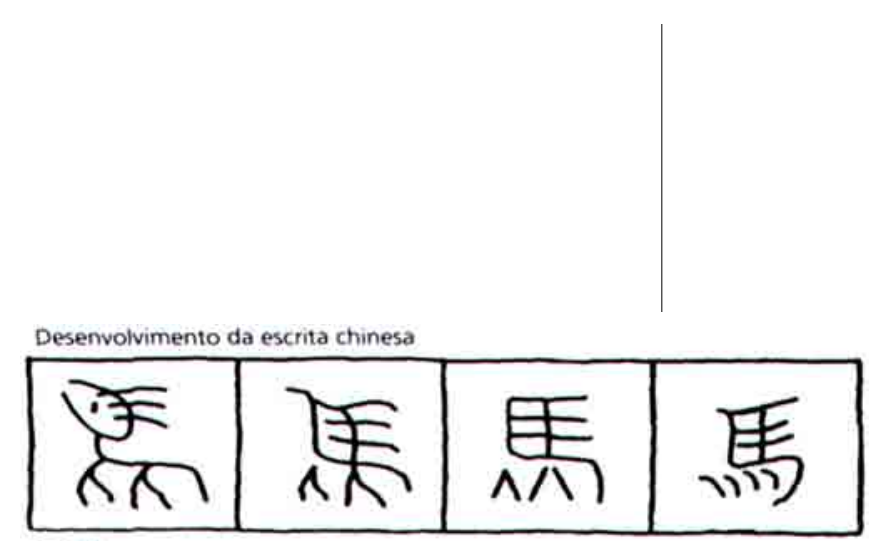

( $A$ representação gráfica), principalmente no mundo ocidental, foi feita por meio do alfabeto de origem fenícia, que passou à Grécia e a Roma, e pela sua simplicidade se constituiu no principal veículo de transmissão do conhecimento humano. Anteriormente, essa comunicação era feita por meio do desenho, às vezes bem rudimentar, do homem primitivo. Ou por meio de hieróglifos como no Egito ou no México, gravados ou esculpidos nos monumentos, ou por meio dos caracteres ideográficos sino-japoneses. Algumas tribos primitivas se serviram de paus, pedras, fios tecidos, colares, e com eles faziam palavras, compondo frases e expressando idéias. (RIBEIRO, s/d, p. 25)

A origem da escrita perde-se nos tempos. Se comparada ao desenvolvimento intelectual da humanidade, ela data de um passado recente, pois não há qualquer sistema completo de escrita antes de 4.000 e 3.000 a.C. Entre as mais antigas estão as escritas sumeriana, egípcia e chinesa. De qualquer forma era considerada tão importante pelos antigos povos que estes atribuíam sua invenção aos deuses e heróis. (MARTINS, 1992, p. 32)

\section{Pinturas Rupestres}

São figuras de animais, cenas de caça, modelos geométricos, várias espécies de objetos, sem qualquer relacionamento com a escrita sistemática, limitando-se a fixar idéias de forma estática. Esta fase rudimentar da escrita remonta a 20.000 a.C. ou seja, ao Homem do Paleolítico.

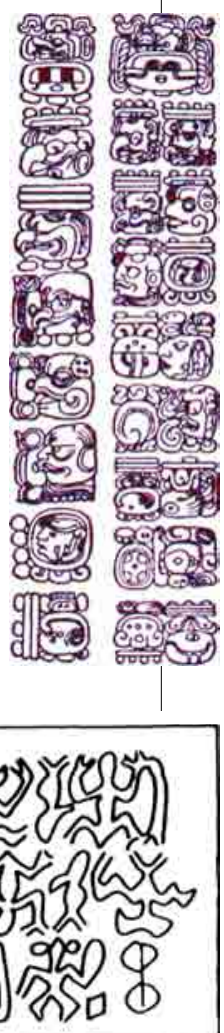




\section{Pictogramas}

Escrita através de desenhos do latim pictus (pintura) e do grego graphe (escrita).

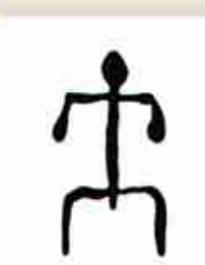

pictograma
pré-histórico

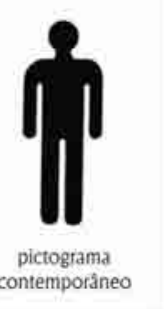

IDEOGRAFIA

Fixação das idéias através de símbolos

A evolução da escrita teve início por meio da pictografia, caracterizada como registro figurado, gravado pelo homem primitivo nas paredes das cavernas. Através dos pictogramas registravam suas principais realizações, cenas, utensílios, animais, etc. Esse mecanismo inicial de escrita restringia a linguagem gráfica ao registro de fatos ou coisas materiais. Para expressar a palavra touro, desenhava-se o touro, se desejasse

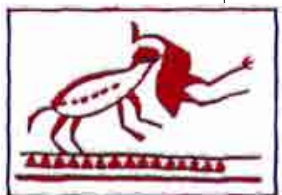
expressar a palavra montanha, desenhava-se a montanha. Termos mais complexos, como caça, desenhava-se um contexto com homens, armas e animais. A contínua evolução expressiva dos pictogramas conduziu a escrita ao terreno da abstração, avançando na transmissão de pensamentos.

Com a pictografia só foi possível referir-se a uma seqüência de planos ou idéias de uma narrativa. Pois, a partir daí já se pressupõe um processo de análise e abstração que estará presente adiante na escrita sistemática.

\section{Ideogramas}

A utilização contínua dos pictogramas fez com que a linguagem evoluísse também em sua forma, transformando o registro gráfico figurativo em idéias. Os registros passaram a ser feitos por meio de signos correspondentes a determinadas expressões, sugerindo idéias. Signos que, em sua maioria, não significavam acontecimentos vividos. Cada desenho possuía separadamente um significado, no qual uma idéia poderia ser representada. Por exemplo, o mês era simbolizado pela lua; a vigilância tinha como representação o olho; o sol já não

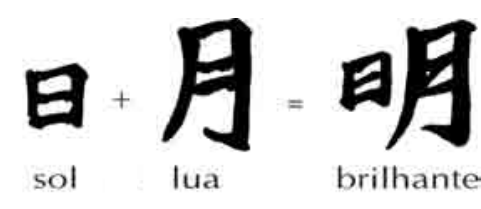

tão luminoso como o sol e a lua juntos designava o astro, mas o dia.

\section{Os sinais de trânsito}

\section{IX, VIII, XVI Os algarismos romanos \\ $+\div \pi$ Os sinais aritméticos}

分時 浮須
A escrita chinesa
É uma linguagem simbólica em que cada palavra ou grupo de palavras essenciais da frase têm simbologia individual ou fixo, representando uma idéia abstrata, uma qualidade ou uma ação. É o caso da figura do sol conotando calor, dia, luz. 


\section{Escrita Cuneiforme}

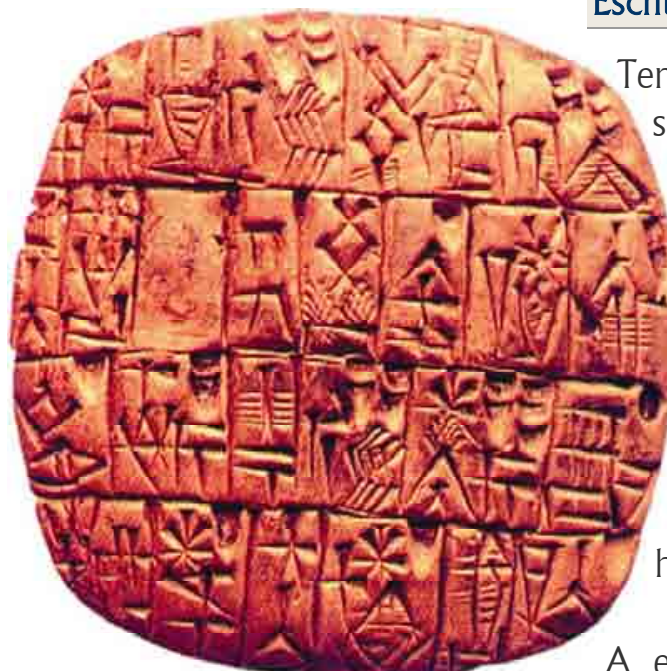

Tendo origem na Mesopotâmia, a escrita cuneiforme é o mais antigo sistema silábico conhecido. Era executado em pequenas placas de argila, por meio de um caniço talhado obliquamente com seção triangular. Utilizava-se para escrever ou estilete de cana, osso, madeira ou metal de ponta triangular, o sty/us.

O nome cuneiforme deriva do fato do início de cada traço de seus caracteres assemelharem-se à forma de uma cunha. Esse mecanismo de registro não permitia aplicação livre de linhas curvas, obrigando à utilização de um só elemento gráfico - o traço reto - nas posições horizontal, vertical ou inclinada.

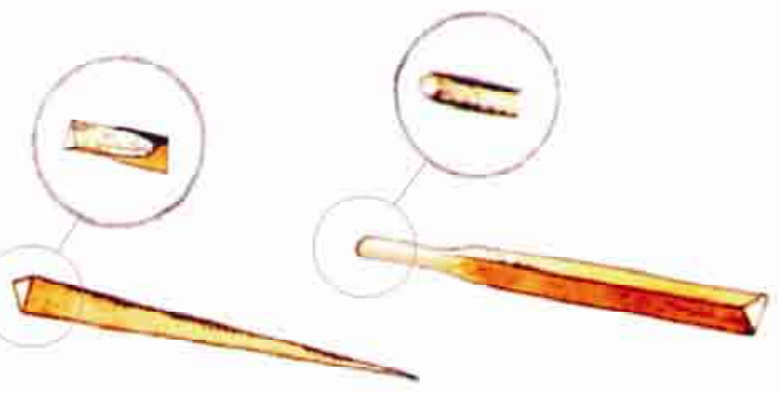

Placa de argila com escrita cuneiforme

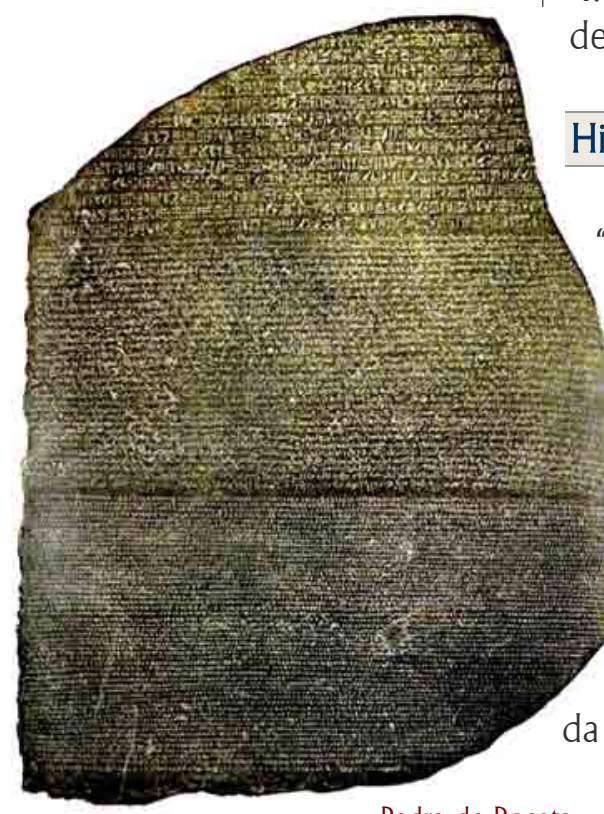

A escrita em forma de cunha foi usada por vários povos do Oriente Médio. Era uma combinação de incisões triangulares gravadas com regularidade em tabuinhas de argila, predominando desenhos de animais, plantas e utensílios. É considerada a primeira tentativa de escrita do homem. A invenção foi dos sumérios, povo que viveu entre 5.000 e 4.000 anos a.C. no Oriente Médio. Nesses desenhos havia também sinais abstratos, talvez números. A maioria dos desenhos e sinais representava objetos concretos.

Hieróglifos

"Alguns imprevistos surgem (...) para reativar no ser humano uma centelha. Foi o que ocorreu com as tropas do general Bouchard, ao se defender das tropas inglesas, pouco antes de Napoleão empreender a retirada de suas tropas do Egito, em 1799. Eis que um soldado, ao remover as terras da trincheira, resvala com uma pedra de basalto negro. Tratava-se da Pedra de Roseta”. (MARTINS, 1992, p. 23). Ao ser estudada por vários pesquisadores, destacou-se Jean-François Champollion que, em 1821, conseguiu decifrá-la e elucidar enigmas da história do Egito perdidos havia 1500 anos, como prova da existência dos faraós no segundo milênio a.C. e a convicção de que, além dos ideogramas, usavam-se também sinais alfabéticos como parte fundamental do sistema de escrita.

A Pedra de Roseta, encontrada pelas tropas francesas em 1799 apresentava uma inscrição em hieróglifo, demótico e grego, tratando-se de um decreto do faraó Ptolomeu V Epifano (196 a.C.). Champollion a partir da decifração da Pedra da Roseta lançou os fundamentos da moderna egiptologia. 
HIERÓGLIFO

Ideograma figurativo

do grego:

hiero - sagrado glifo - escrita (gravada)
Os tempos revelaram que quanto mais a escrita se integrava às necessidades da vida cotidiana, mais ela precisou abandonar a linha de imagens, pois as figuras se tornaram insuficientes para a troca de idéias e caminhava para a padronização dos sinais - o que, em termos práticos, corresponde à mudança da imagem para a letra, estágio final da escrita figurativa.

Um pouco depois do aparecimento da escrita os egípcios desenvolveram uma nova escrita, misturando ideogramas e sinais fonéticos. Mas, mesmo representando os sons, esses sinais nunca chegaram a se desvincular da imagem, do signo icônico. Daí o nome que lhes deram os gregos e que chegou até nós: hieróglifos, que quer dizer imagens sagradas. Essa escrita era muito utilizada em livros sagrados e nas tumbas dos faraós.

Nos próprios hieróglifos encontramos vestígios da evolução da forma cursiva, simplificando a forma das figuras, Nessa fase desapareceram as imagens dos objetos, passando o seu correspondente fonético ao sinal da escrita.

Esse importante aspecto ensejou um grande passo no sentido do que os estudiosos chamam de fonetização da escrita, que permitiu que um mesmo sinal pudesse ser usado para diversas palavras. Entre o desenho do ícone para o desenho da letra como símbolo, existiu um processo de transformação, partindo de uma relação imediata para uma relação mediata na percepção do objeto. $\bigcirc$ que quer dizer que os símbolos passaram a ser uma norma, ou uma regra de interpretação.

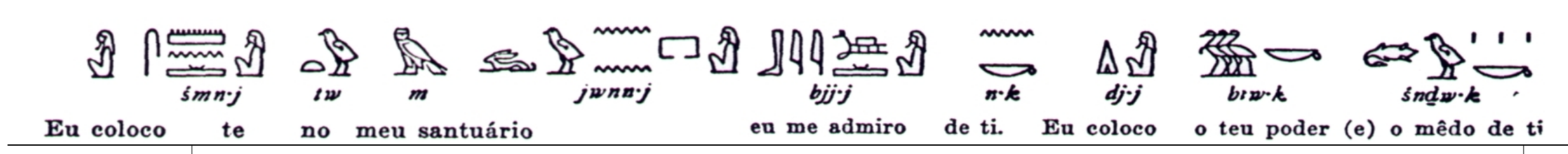

As linhas dos ideogramas foram se modificando e se tornaram sinais, que começaram a representar as sílabas das palavras. Esses foram os primeiros escritos fonéticos correspondentes à fala. 


\section{Sistema Fonético e Silábico}

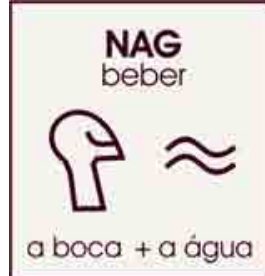

BAIXA MESOPOTÂMIA $4000 \mathrm{AC}$

Algumas linguagens escritas sobrevivem até hoje mantendo traços de sua herança pictórica. Só que, com o tempo, a maior parte da escrita moderna passou a representar apenas o som e a perder qualquer semelhança com o visível.

Diante da dificuldade em comunicar idéias mais complexas, o registro pictórico/ideográfico encontrou uma representação para cada uma destas novas palavras, separando-as em sílabas, tendo um desenho para cada uma. No campo fonético também transformou a decomposição das palavras em sílabas, ou seja, num conjunto de sons que se agrupam para criar novos significados.

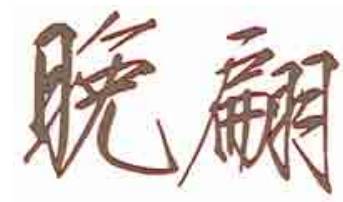

Trata-se de um sistema em que cada sílaba tem sua representação própria como na escrita japonesa.

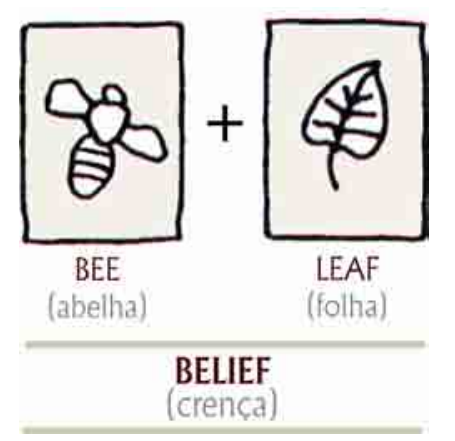

Alfabeto

\section{LX⿻尸月IY $\triangle \triangle 144$

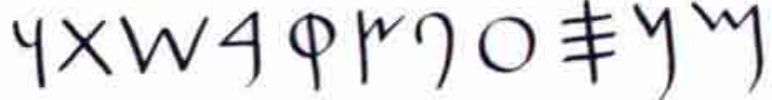

ALFABETO FENÍCIO escrita da direita para a esquerda
O alfabeto é um sistema baseado em um conjunto de 20 a 30 letras indicativas dos sons mais simples nos quais se pode decompor uma língua. Nesse sistema cada som tem seu símbolo individual, chamado letra. É adotado em todas as línguas ocidentais e por algumas línguas orientais. A escrita alfabética desenvolveu-se quase dois mil anos depois dos primeiros pictogramas sumérios. 
Em todas as línguas, o alfabeto representa um conjunto de letras convencionalmente organizadas. O mais importante sistema alfabético apareceu na antiga Fenícia, atual Líbano, por volta de 1200 a.C. Simplificaram os complexos signos gráficos que existiam à época. Inspirados nos caracteres egípcios ordenaram um total de 22 letras, que correspondiam às articulações fundamentais de sua língua, dando origem às letras. Ao dispô-las convencionalmente, deram origem ao alfabeto, possibilitando realizar a partir daí quaisquer combinações sonoras. A iniciativa dos fenícios foi imaginar uma simplificação gráfica e sonora onde o mesmo símbolo representasse sempre o mesmo som, em qualquer palavra.

\section{Os Fenícios}

Foram grandes navegadores, construíram frotas numerosas, tinham intensa atividade comercial e fundaram colônias em várias regiões. Com o desenvolvimento do comércio passaram a utilizar um veículo importante: a escrita. Criaram seu alfabeto com o objetivo de ampliar e conservar o comércio. Simplificaram a escrita mediante o emprego de poucos sinais com valor de consoantes.

O alfabeto foi o maior legado dos Fenícios. A forma das letras foram trazidas para o Ocidente em torno do séc. X. Deu origem a outros alfabetos no Oriente: árabe, hebreu e siríaco.

O alfabeto é considerado um dos grandes acontecimentos do progresso humano, pois permitiu a universalização do pensamento através da escrita. Como qualquer código verbal, o alfabeto fenício acabou sofrendo inevitáveis modificações ao longo do tempo. Com as constantes invasões sofridas em seu território a Fenícia perdeu aos poucos o que possuía. Sua cultura foi sendo destruída e acabou desaparecendo da região, perdendo o grande prestígio comercial de que desfrutava. Inevitavelmente desapareceu também a prática de seu alfabeto, que se tornaria a base do alfabeto grego. Por sua vez o alfabeto grego foi adotado pelos Romanos, com algumas alterações, e assim através do Latim chegou até nós. Consequentemente o latim foi adotado como base de todos os alfabetos dos povos ocidentais. 
Tipos de serifas

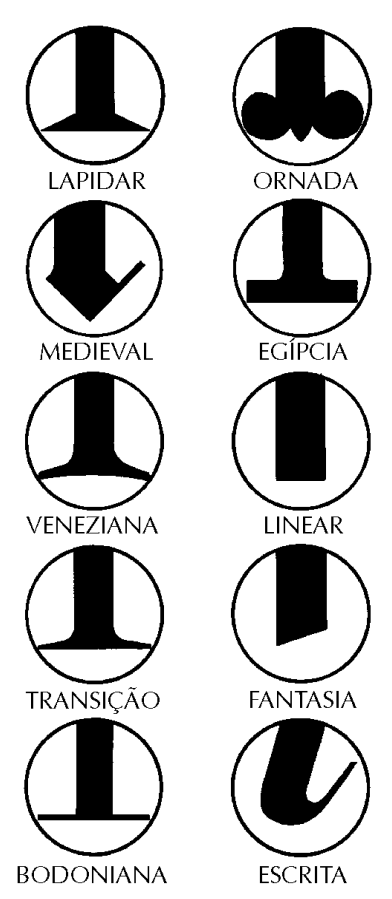

\section{A Difusão do Alfabeto}

Os gregos, ao empregaram os sinais fenícios, adaptaram-no conforme as circunstâncias locais. As alterações foram decorrentes dos meios de difusão, da situação geográfica, de comunicação e pelo fato de que a escrita entre os gregos não se restringir a uma só classe privilegiada, mas estendia-se a todos, adaptando-se segundo as características e necessidades de cada classe.

Os primeiros símbolos gradualmente foram se afastando de qualquer semelhança com seu traço original, assumindo as formas abstratas das linguagens modernas, até chegar ao nosso sistema totalmente abstrato baseado em som.

Quanto mais tempo de existência tem uma forma de comunicação, mais símbolos ela acumula. Dentro de uma determinada cultura, esses símbolos logo se tornam conhecidos por todos. As palavras, mais do que qualquer símbolo visual, têm o poder de descrever completamente o reino invisível dos sentidos e emoções. Elas podem capturar imagens aparentemente neutras e vincular nelas uma infinidade de sensações e experiências.

Assim, o alfabeto ao ser introduzido na Grécia pelos navegadores fenícios, utilizou inicialmente dezesseis letras rudimentares. Posteriormente, os gregos transformaram outras para conseguir representações sonoras da língua, compondo ao final seu próprio alfabeto. Daí passou rapidamente para o domínio público.

Poetas e filósofos em sua disciplina e organização, não cessaram de aprimorar o conjunto das letras existentes. Acrescentaram novas letras, adotaram caracteres minúsculos e introduziram vários novos sinais, compondo, ao final, um conjunto organizado de vinte e quatro letras.
ETEINTHNENAAS NTOY ËQEYYEHN OTEE TITTPONOIAK YAIRNOS AYQITEN TEPONADAIPE QET: INNATIAISNOEAY 5 NOMENO IN NR Th ATOATOKATELTH KTONOMIASKAIEA

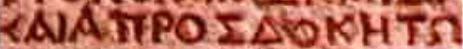
EI TTRNIIPO EPOI AAHTIANTA $\triangle E$ AOR VNEAPOISKAITR $\triangle H$ NTONEPOET $\Omega \Delta I T$.

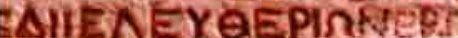
otoyato rots: TATPIOIS

Respeitadores da ordem e do equilíbrio, os gregos deram qualidade arquitetônica à escrita. Um reforço retangular (serifa), necessário ao bom alinhamento dos textos, aparece nas extremidades das letras. Devido ao trabalho do cinzelador na pedra, tornou-se ela triangular, de aparência nobre, menos dura, e assim passou para o latim, sendo adotada em suas inscrições monumentais.

(...)

Quinhentos anos depois da fundação de Roma o alfabeto começou a se transformar e evoluir. As palavras passaram a ser separadas, inicialmente, com um ponto e as letras comecaram a apresentar forma acentuadamente quadrada. Com a natural evolução da própria escrita e as necessidades impostas pelo progresso em geral, surgiram novas letras, como J, $\mathrm{U}, \mathrm{Y}$ e o $\mathrm{Z}$, que foram colocadas no fim, completando-se assim o alfabeto latino, o mais usado em todo mundo até hoje. (RIBEIRO, s/d, p. 27) 


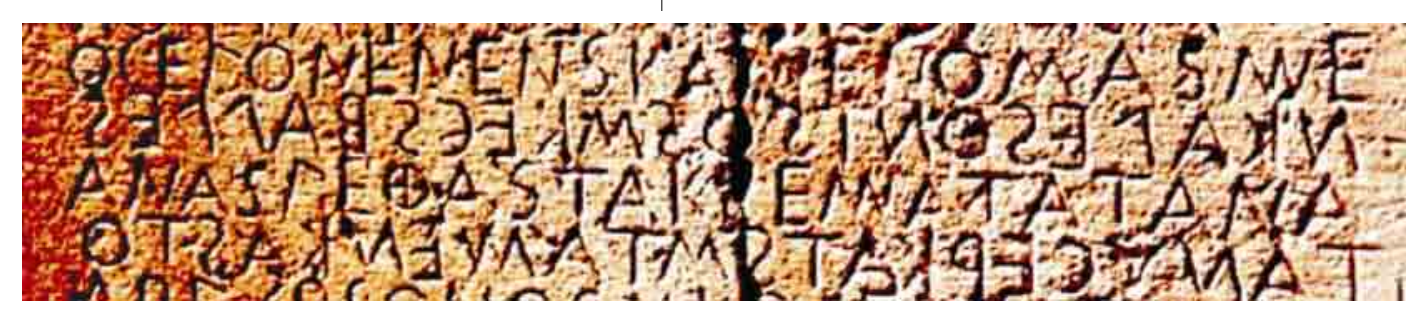

ESCRITA BOUSTROPHEDON

Alternava-se da direita para a esquerda e na linha seguinte da esquerda para a direita
Os documentos oficiais eram gravados em pedra por meio da escrita chamada monumental ou lapidária. No momento em que começam a aparecer materiais de escrita mais acessíveis (pergaminho e papiro), passa a se escrever mais rapidamente e as letras diminuem de tamanho, surgindo as minúsculas.

A escrita teve maior desenvolvimento com o governo de Constantino I no séc. IV, em Roma, com a aceitação do Cristianismo, permitindo a divulgação da escrita em todas as camadas sociais e com a propagação dos Evangelhos, promovida com a ajuda dos catequistas.
Inicialmente a escrita grega seguia da direita para a esquerda (grega primitiva). Depois adotou no sistema Boustrophedon (séc. VI a.C.) escrevendo-se em linhas alternadas da esquerda para a direita e da direita para a esquerda. $O$ nome deriva da palavra grega bous (boi) e strophé (virar; cf. estrofe), pois este tipo de escrita recorda os trilhos abertos por um boi atrelado a um arado a trabalhar nas terras agrícolas, que ao chegar ao fim de um campo dá meia-volta e regressa para trás.

\section{Alfabeto Latino}

$$
\begin{aligned}
& \text { Jesus = Inoous } \\
& \text { Cristo }=\text { Xpiotos } \\
& \text { de Deus }=\text { Oєov } \\
& \text { Filho }=\text { 'Yios } \\
& \text { Salvador }=\Sigma \omega T \eta p
\end{aligned}
$$

\section{Escrita Latina \\ A $B \Gamma \triangle E Z H \Theta$ $\mathrm{I} K \wedge M \mathrm{~N} \equiv \mathrm{O} \Pi$ $P \Sigma T Y \phi X \Psi \Omega$}

Agora as palavras faladas ou escritas já são signos de natureza simbólica, não tendo nenhuma relação necessária com o representado.

Com a queda do Império Romano, em 395, começava a Idade Média, e o cristianismo continuava a se expandir e mantinha o interesse pela expansão da escrita.

No ano 1000 já quase toda a Europa era cristã, e nos mosteiros e conventos os monges se dedicavam pacientemente à cópia de preciosos documentos antigos e à elaboração de novos textos. A exigência sempre maior de textos aumentou o número de copistas, que, contudo, eram obrigados a executar as escritas, sempre com maior rapidez, abandonando certos princípios clássicos, dando novo caráter e formas mais variadas às letras. (RIBEIRO, s/d, p. 28) 
(1) Daí a origem da palavra estilo como identificação personalizada das características gráficas de um artista.
O Cristianismo difundiu o alfabeto latino no Ocidente e através da Bíblia fixou o latim. Dessa forma a religião foi elemento fundamental para a fixação das línguas. Durante muito tempo o latim foi a língua literária universal, permanecendo como língua oficial da Igreja Católica até o séc. XVII. Nesse período todas as obras científicas e filosóficas foram escritas em latim.
Até cerca do século XII a maiúscula romana foi utilizada em inscrições monumentais, quando sua forma atingiu o máximo equilíbrio em proporção e elegância. A partir daí, o alfabeto ganhou em legibilidade. Agora a preocupação passou a ser de caráter estético. Algumas letras * aumentaram ou diminuíram de tamanho em benefício da proporcionalidade do conjunto. Outras passaram a apresentar contrastes e detalhes, como as cerifas triangulares.
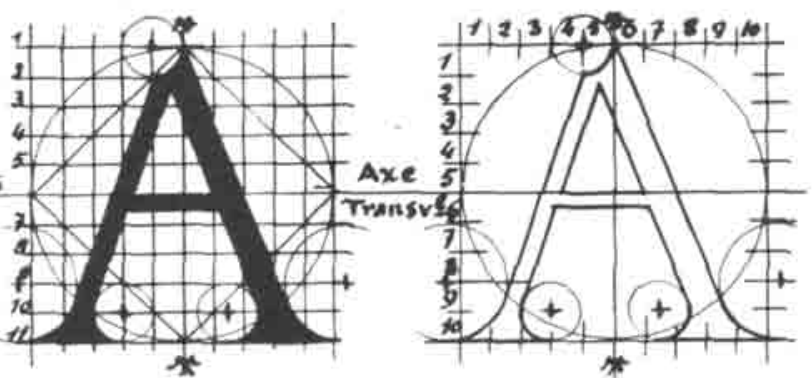

O cinzel era o instrumento apropriado para gravar sobre suportes duros, como pedra e metal. Para gravar sobre superfícies macias como argila, madeira ou cascas, utilizava-se uma ponteira de osso ou bronze, conhecido como estilete (ou estilo). (1)

\section{Quadrata (100 a.C.) \\ ETPICTVMCRO}

No início da era cristã, ocorreu a primeira variação da quadrada, resultado evolutivo na execução acelerada e tosca, de onde advém o nome rústica. A configuração de seus caracteres é mais alta e era escrita com transversais ligeiramente oblíquas.

Nessa primeira transformação, a escrita foi chamada (...) quadrada, por suas letras apresentarem a largura igual à altura. Era de construção severa, guardando muita relação com a arquitetura, possuindo partes vazias que apresentavam harmoniosamente as proporçōes entre os claros e os cheios. Era um alfabeto de rara beleza, que soube encarnar a expressão do pensamento aristocrático e imperial de Roma. Quando escrito sobre papiro ou pergaminho era traçado com o bico do bambu ou canico carregado de tinta com algumas inflexões devidas aos movimentos da mão. Teve seu começo aproximadamente a 100 a.C. e seguiu tendo grandes transformacões na sua forma e designaç̃es. (RIBEIRO, s/d, p. 28)

Abandonando o rigor clássico, a escrita rústica demonstrava e permitia a independência do escritor em sua elaboração. Era a letra de utilização vulgar do povo romano para anotações de uso comum. Também utilizada na transcrição dos livros manuscritos (os códices). Uma escrita traçada principalmente em suportes macios e maleáveis, como o papiro e o pergaminho, diferentemente das utilizadas em inscrições sobre suportes duros, como pedra e metal. Devido à rapidez de seu traçado chegava a apresentar deformacões de tal forma que, às vezes, sua leitura tornava-se de extrema dificuldade.

\section{Rústica (começo da era cristã) SOLESVVB:ARDENI}




\section{Escrita Romana}

\section{Uncial (século IV d.C.)}

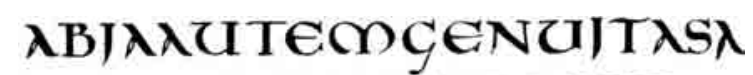
ASAגUTEOGENUIT josxphat

\section{jos $\lambda$ phat גutem}

Deriva desta época a mistura de letra de escrita ereta dos romanos (capital maiúscula) com a escrita cursiva inclinada, de uso mais corrente, com predominância das minúsculas

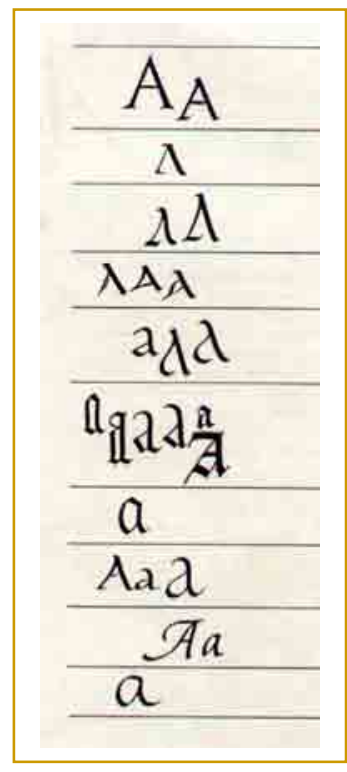

Variações gráficasdo fonema $A$ ao longo dos séculos
Até então, as letras romanas não haviam sofrido alteração fundamental em sua forma. A letra Uncial foi a primeira transformação real da grafia do alfabeto. Sua designação nominal é atribuída à palavra uncia (unha), por possuir forma arredondada semelhante à unha. Devido à sua utilização fácil, tanto na escrita quanto na leitura, essas letras mantiveram-se em uso por um longo tempo. Nos primórdios era composta essencialmente em formato maiúsculo. Gradativamente, em torno do século IV, no período de decadência do Império Romano, passou a apresentar formas peculiares, bem diversas das escritas anteriores. Era apropriada para uma escrita manual. Foi o primeiro conjunto de letras manuscritas de traçado contínuo, rápido e fácil, por possuir fatores essenciais para uma escrita confortável. Era largamente utilizada na execução dos textos manuscritos dos livros e empregada freqüentemente em documentos e contabilidade cotidiana. Assim, com poucas transformações, permaneceu em uso por aproximadamente 900 anos, até o século XIII.

Devido à rapidez com que as unciais eram traçadas e com o uso corrente do papiro e do pergaminho, progressivamente foram diferenciando-se das maiúsculas utilizadas em inscrições lapidárias, cujo interesse na aplicação era a perenidade, clareza, estética e perfeição. Por não terem sido concebidos originalmente, os caracteres minúsculos resultaram de transformações e adaptações sofridas pela maior rapidez com que eram traçadas as capitais (maiúsculas).

"No século VIII a escrita manual passou a ser mais ordenada, principalmente empregando as minúsculas. Com a decadência de Roma sua escrita sofreu grande influência dos caracteres de outras regiões que cresciam e se desenvolviam” (RIBEIRO, s/d, p. 28).

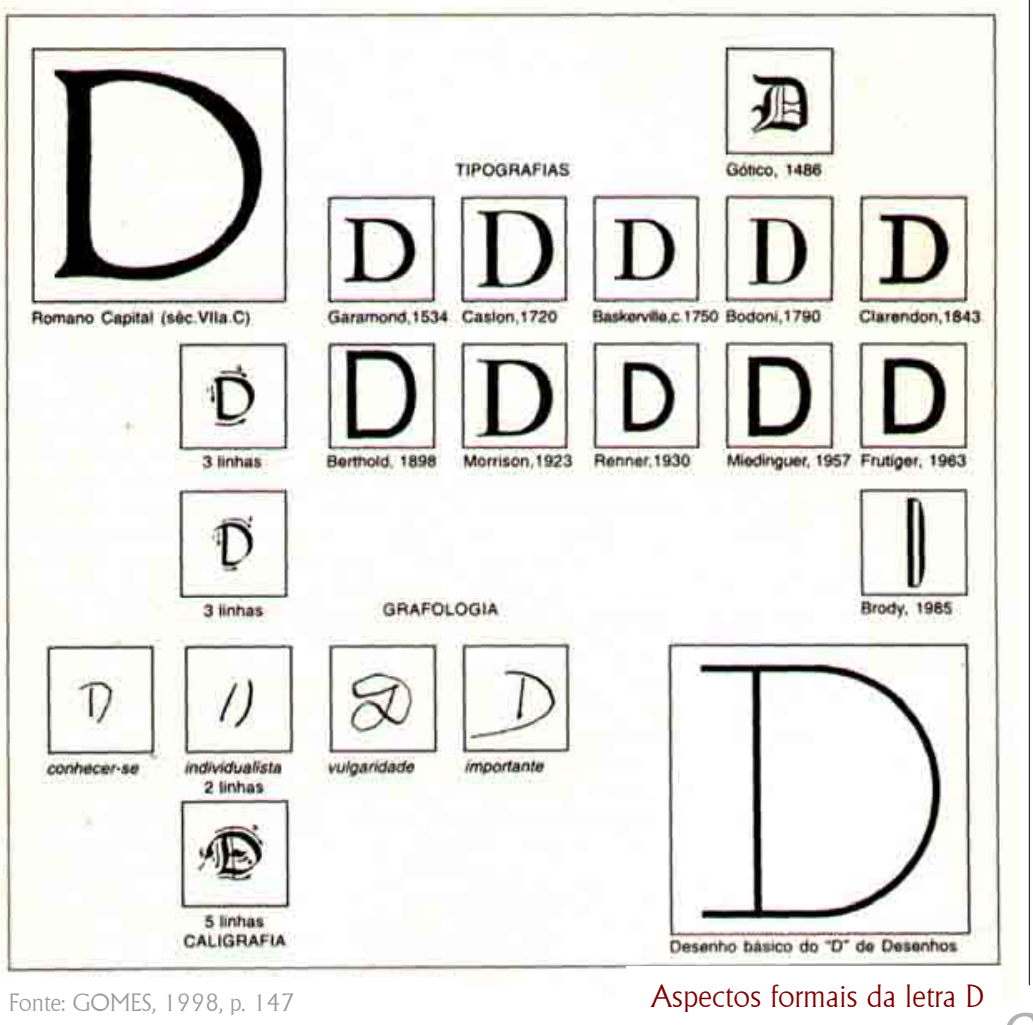




\section{Escrita Gótica}

Já se observa no século XII a formação do caractere de estilo gótico. Com base nos caracteres de origem latina, os franceses, ingleses, teutões e visigodos criaram suas próprias escritas que, em pouco tempo, logo se fundiram no gótico. Devido à abundância de textos e pela escassez de materiais para a reprodução manuscrita dos livros, os copistas foram obrigados a adaptar suas escritas aos espaços disponíveis:

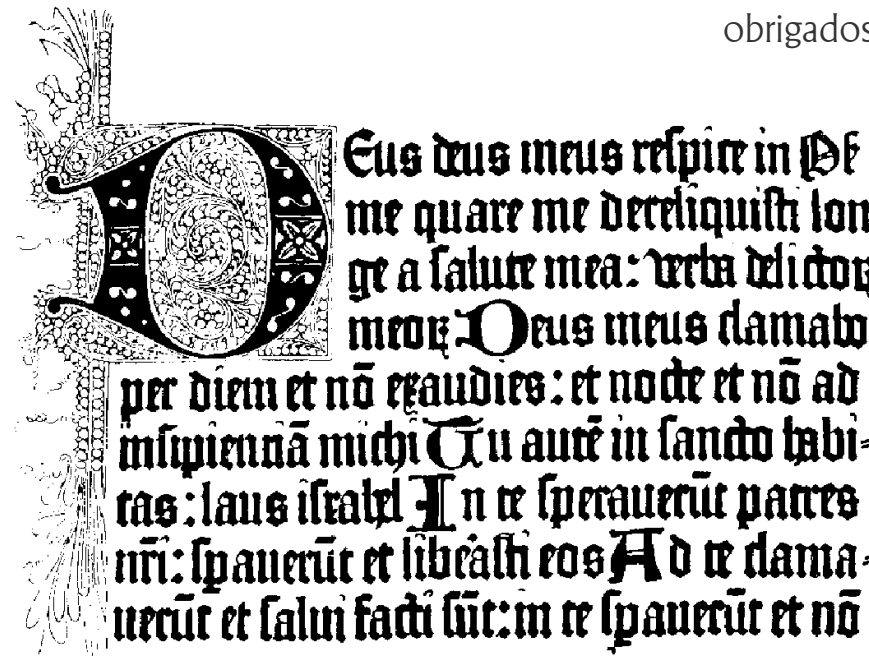
utrüt et Calun facti tuit:in te fpaumît et nō
(..) começam a apertar cada vez mais seus escritos, a fim de aproveitarem ao máximo os espaços disponíveis. Mantendo a caneta perpendicular ao manuscrito, inovaram um grafismo apertado, anguloso, cujas conseqüências se fizeram senti até na ornamentação dos textos. As iniciais, conservadas redondas, passam a se adornar de pontas e espirais até então desconhecidas.

No fim do século XV, (a escrita gótica) estava tão cheia de ornamentos que dificilmente era legível.

Nas minúsculas do gótico, os traços retos, uniformemente perpendiculares, nos dão uma letra muito mais negra e muito mais maciça e angulosa que as romanas. Sua maior difusão se fez na Germânia, e o caractere mais genuinamente gótico é o da letra alemã. (...) e por terem o temperamento de gravadores e escultores sobre madeira, fizeram-na de uso nacional.

A versão gótica alemã é a mais vigorosa e autêntica (...). Seu nome provavelmente advém do grafismo empregado ou atribuído aos godos. Há quem atribua a sua origem ao verticalismo e paralelismo característica da arquitetura, da escultura e da pintura da época.

(...) A escrita gótica predominou durante quase três séculos nos países do ocidente europeu. Aos poucos foi sendo abandonada, desaparecendo quase que totalmente no fim do século XVI". (RIBEIRO, s/d, p. 30)

Com a criação do tipo móvel e a utilização da prensa para reprodução da palavra, a letra impressa inicia uma nova era. 

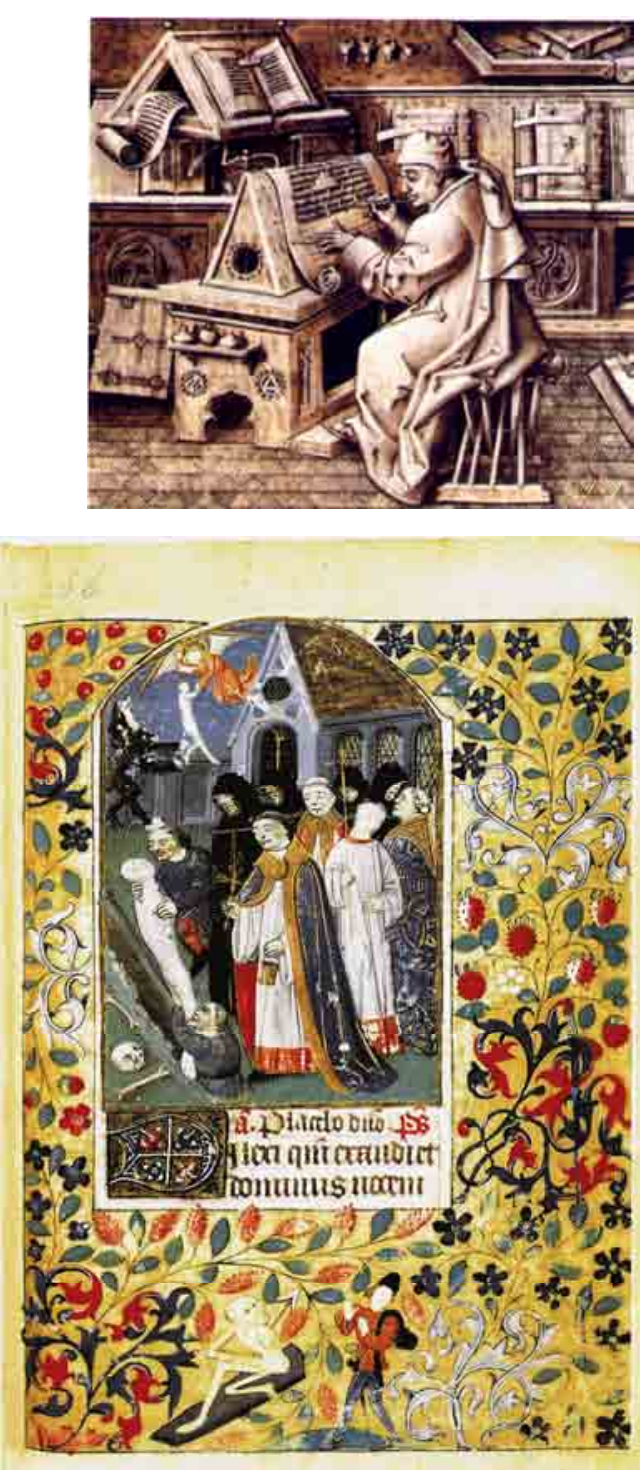

Tornou-se indispensável produzir livros em grande quantidade para atender a quem tivesse condições de encomendá-los. Novos mecanismos de produção passaram a ser necessários e o primeiro processo adotado foi o da xilogravura.

É da Holanda, no princípio do século XIV, que se tem notícia das primeiras impressões em xilografia. No princípio, eram ilustrações com legendas explicativas. Só mais tarde é que os livros passaram a ser reproduzidos por este mecanismo. Eram livros impressos de um só lado, devido à grande pressão empregada durante o processo de reprodução.

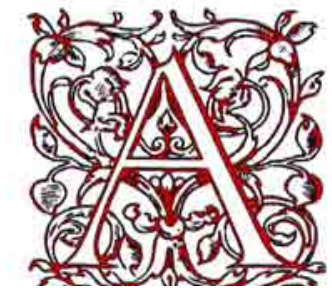

capitular ornamental 
XILOGRAFIA

técnica de reprodução através de prancha de madeira com letras ou

desenhos entalhados em relevo

\section{(2) PUNÇÃO TIPOGRÁFICO}

Haste de aço que em uma das extremidades tem gravado em relevo uma letra ou sinal tipográfico. Esta haste

posteriormente servirá para pressionar um bloco de cobre

e obter uma matriz oca, gerando os sulcos das letras criando, assim, as matrizes em que serão fundidos os tipos.
Texto de Pi-Cheng - séc. XI

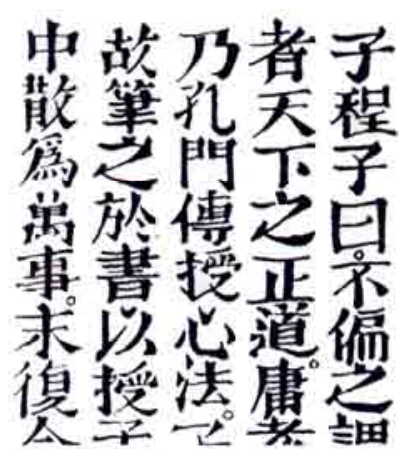

Quando foi iniciada a reprodução de livros pelo processo xilográfico, copistas, calígrafos e miniaturistas se opuseram, sentindo que sua atividade artesanal encontrava-se ameaçada. Mais tarde, compreendendo o valor do novo mecanismo de reproduzir livros, passaram a ser colaboradores, desenhando letras capitulares, ilustrando para os impressores ou desenhando novos tipos.

Nos manuscritos iluminados as palavras e figuras ainda coexistiam nessa fase, contudo isso foi se tornando a exceção, não mais a regra.

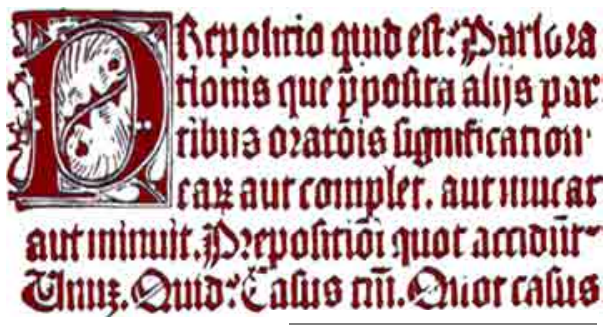

Obra do século XIV impressa em xilografia

\section{Tipografia}

Na mesma época em que a xilografia de letras e imagens na mesma matriz se expandia nas oficinas de impressão, surgiram algumas tentativas de impressão com letras móveis talhadas em madeira. A idéia era que estas mesmas letras móveis servissem para a composição de outros textos. Porém, os caracteres móveis não seriam considerados uma inovação. Tem-se conhecimento de que os chineses, já em 1041, conheciam e empregavam tal processo de impressão para reproduções. Portanto, quatro séculos antes dos europeus os chineses já reproduziam seus ideogramas pelo processo tipográfico.

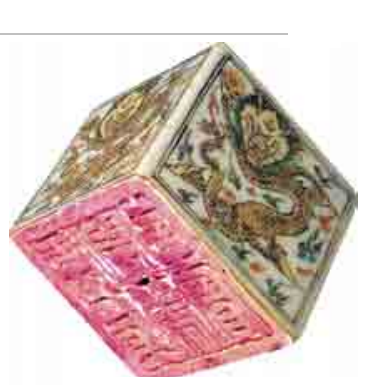

caractere móvel chinês

Pi-Cheng utilizou a porcelana moldada em formas de ferro. Posteriormente, os chineses, para esse mesmo fim valeram-se da madeira, enquanto na Coréia, por volta de 1043, o rei Tsai-Tung mandou fundir tipos em bronze com punções (2) gravados em madeira de bambu e com as matrizes feitas em areia. (RIBEIRO, s/d, p. 33)

A solicitação maciça para a reprodução de livros reduzia a resistência dos tipos xilogravados. Os caracteres de madeira, sob constante pressão deformavam-se, não resistindo às necessárias tiragens. $\mathrm{O}$ cobre passou a substituir a madeira. $\mathrm{O}$ resultado foi satisfatório, mas a necessidade de gravar cada uma das letras tornava exaustiva e dispendiosa a operação. A produção da quantidade de tipos necessária à composição das obras, procurando superar as limitações de resistência dos materiais levou o tipógrafo Johann Gutemberg a aperfeiçoar os mecanismos de reprodução de textos. E em 1450, Gutemberg associou-se a Johann Fust e os dois, em 1452, se uniram a Pieter Schoeffer e com esta associação o empreendimento tipográfico conseguiu produzir tipos mais fortes e com mais qualidade. Schoeffer passou a cunhar os tipos a partir de um punção de aço em relevo, gerando as matrizes para fundir os tipos necessários ao atelier tipográfico. 


\section{Tentes !)}

rt libre: [rò omnia z in ommibus In Duite voe rago frout dinti ori fanth it Dilntu vifma mifrecorois: tenignttamu- tumiluram mriam. mubifmēo quis luque babst querd quis adurters a Donauit nobie itar pos Buptro muiaz du

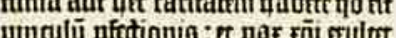
uintuir piftionia: $\pi$ pax xpi ruittr ctioi

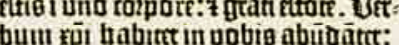

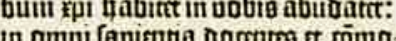
in omini fapitutia oortire ft toma

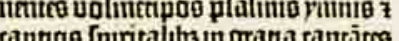

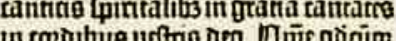

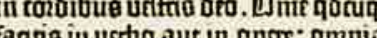
fantis in yotbo aut in oper: ommi in noir ominoftri thefiu xpi : gratias agraumo dra it patta p ipm. Afuliem

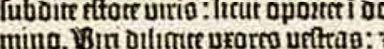
mino. Bin otligure uxores urftas: nolite amant tle ad nillao. filin obco if partutbuto per oumuia: bot mum placitim rit in dina. PBrre nolite a ratuontamprouscare filiog urftros: ut non pulilla anumo fiant. Sorni abcuire g onima dima rarnalibua:

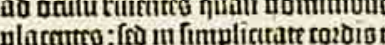
placatro: iñ inf immplictuate ro:oist

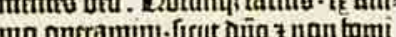
mo optamim- fitut anio z non tomi

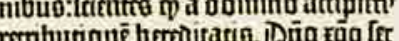
urr Dumuninunam fartor

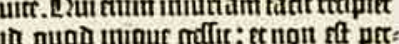

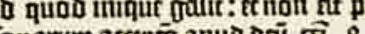
6 Drmini quod mitum eft rt tquî. (a) Din habrtis in

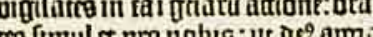

O objetivo inicial da criação da tipografia era para fins comerciais. Ao trabalhar mais depressa e mais barato, a tipografia concorria com a produção manual dos copistas. Os caracteres empregados por Gutenberg em estilo gótico, em 1450, tinham o intuito de fazer crer aos compradores que os livros impressos eram manuscritos. Era comum na atividade tipográfica imitar a escrita da época. Ao longo do tempo os variados tipos gráficos sofreram variações em seus detalhes, que deram características individuais a cada uma.

A tendência agora passou a ser a busca de fatores práticos de legibilidade, culminando com as obras dos grandes criadores de tipos da Renascença e nos séculos seguintes, como Bodoni, Garamond e Palatino. A técnica tipográfica, inventada por Gutenberg, Ihes ofereceu a possibilidade de desenvolver aspectos gráficos das letras em total independência do ato de escrever e respectivamente de imprimir.

Assim, a escrita tornou-se definitivamente um mundo de formas que representa a si mesma admitindo apenas a influência de fatores práticos. Hoje os caracteres da tipografia moderna mantêm apenas relações gráficas com os contextos de linha e página.

A expressividade figurativa atual se tornou redundante, não estando mais presente na comunicação escrita. Hoje as palavras faladas ou escritas são sinais convencionais que simbolizam sons, não tendo mais nenhuma relação necessária com o representado. Por conhecermos pela convenção o significado dos sons e caracteres, não necessitamos da possibilidade de vivenciá-los como o homem primitivo, que podia dispensar o conhecimento, por viver a união entre o signo e o conceito.
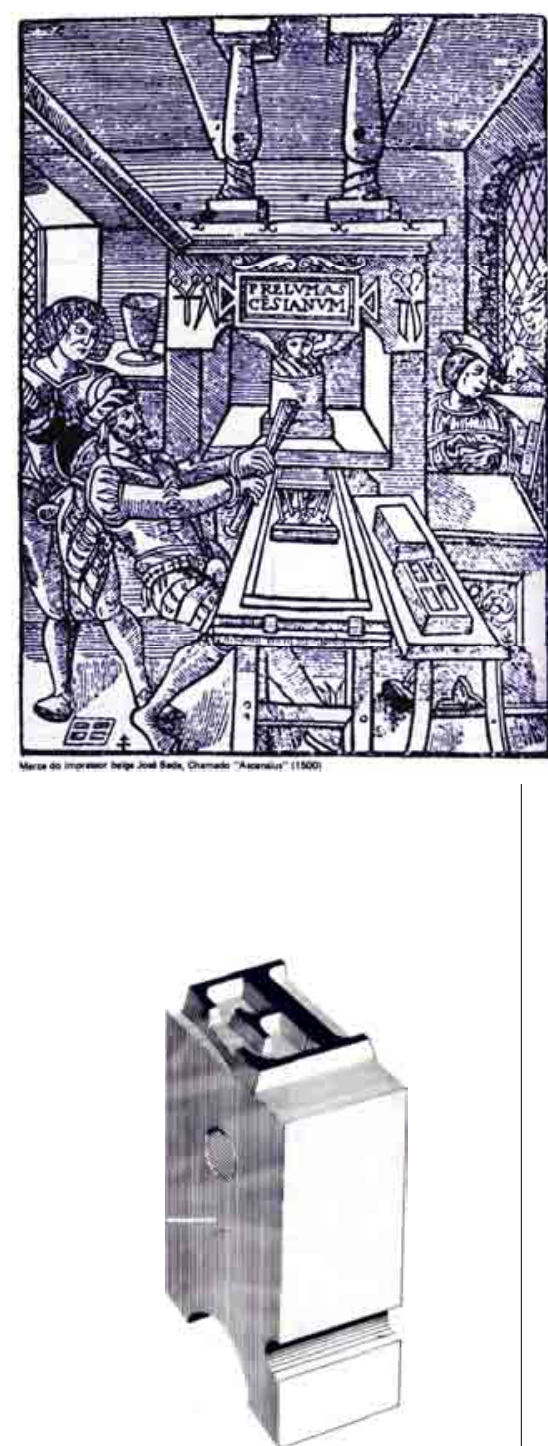

Tipo metálico ocidental 


\begin{tabular}{|c|c|c|c|c|c|}
\hline mateb & pictagr & forma & 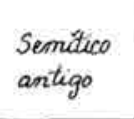 & Grego & Remarn \\
\hline Egua & $\approx \approx$ & $m$ & $\eta$ & $M_{m u}$ & $M$ \\
\hline touro & $\mathcal{F}$ & $\Delta$ & $\nless$ & $A_{\text {apse }}$ & A \\
\hline notitarsa & M․ & $M$ & $M$ & $\sum_{\text {signe }}$ & $S$ \\
\hline cotra & Sمـ & $\sim$ & $\sim$ & $N_{m}$ & $\mathrm{~N}$ \\
\hline marco & $\frac{n}{0}$ & + & + & $T_{\text {tauk }}$ & $\mathrm{T}$ \\
\hline omemen & W & $\Psi$ & 4 & $E_{\text {sosion }}$ & $E$ \\
\hline locea & $\Leftrightarrow$ & $\simeq$ & $\nexists$ & $\prod_{p^{i}}$ & $P$ \\
\hline otho & $\infty$ & (2) & $\odot$ & $\bigcirc_{\text {omirm }}$ & $\mathrm{O}$ \\
\hline $\operatorname{mär}$ & $\Omega_{3}$ & $k$ & $\kappa$ & $K_{k a p}$ & $\mathrm{~K}$ \\
\hline
\end{tabular}

Para liquidar com a evolução da expressão da palavra escrita surgiram melhores recursos de reprodução de imagens ilustrativas facilitando maior absorção da informação. Por essa via só é transmitido pela palavra o que o desenho absolutamente não consegue representar. $\mathrm{O}$ conteúdo visual e intelectual suplantou as qualidades sonoras da linguagem. Os elementos ilustrativos, que atingem de modo direto a mente do leitor, tornaram-se cada vez mais presentes e atraentes. Com a substituição do texto pelas imagens a era da palavra começou a ser enterrada com o surgimento das tecnologias de reprodução das imagens, como a fotografia e o cinema, culminando com o advento da TV e a internet. O clímax dessa tendência de independência da escrita foi alcançado com os recursos digitais, tornando viável a criação, gravação e transmissão binária da tipografia através dos computadores.
Garamond Caslon Bodoni Futura $1100 \mathrm{~S} \begin{aligned} & \text { Criado em } 1929 \\ & \text { por Victor Lardent } \\ & \text { Stanley Morison }\end{aligned}$ Univers Projetado em 1957 por Adrian Frutigeri Helvética

Desenhado em 1957 por Max Miedinger 


\section{CAPITTLLO 5}

A IMPRENSA

5.1 - MEIOS DE PRODUÇĀO E REPRODUÇĀO

5.2 - A PRESENÇA DA FOTOGRAFIA

5.3 - INFLUÊNCIAS E REPERCUSSÕES 


\section{1 - MEIOS DE PRODUÇÃO E REPRODUÇÃO}

\section{Gravura}

Gravura é a arte de transformar a superfície plana de um material resistente num condutor de imagem, isto é, na matriz de uma forma criada para ser reproduzida certo número de vezes. A placa deve para isso ser trabalhada de modo a somente transmitir ao papel zonas que estruturem a forma desejada, por meio da tinta, numa operação de transferência efetuada mediante pressão. O branco do papel realizará ativamente a sua contraparte na ordenação e surgimento da imagem integral da estampa.

A arte da gravura é composta por dois estágios: inicialmente a produção da matriz e em seguida a cópia. Embora ambos os estágios mereçam maiores cuidados, de nada adianta uma boa matriz se a impressão deixa a desejar. E é exatamente nessa última etapa que muitas vezes houve dificuldade ou mesmo inviabilizou historicamente a utilização da gravura em larga escala na imprensa, visto que nem sempre era possível conciliar a produção da matriz com a técnica da impressão.

XILOGRAFIA gravura sobre madeira

CALCOGRAFIA gravura sobre metal

LITOGRAFIA gravura sobre pedra

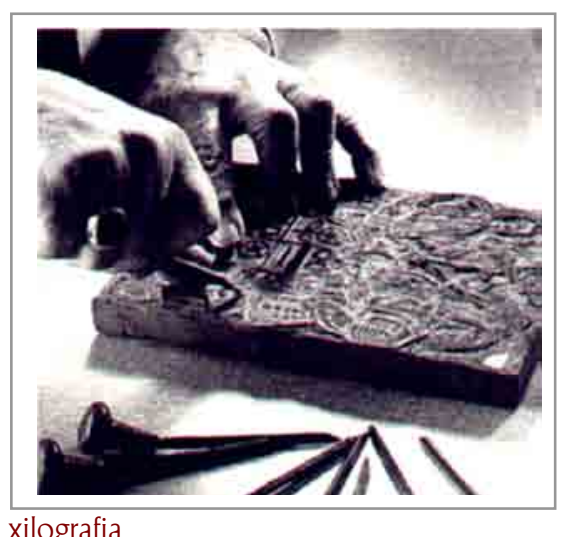

xilografia

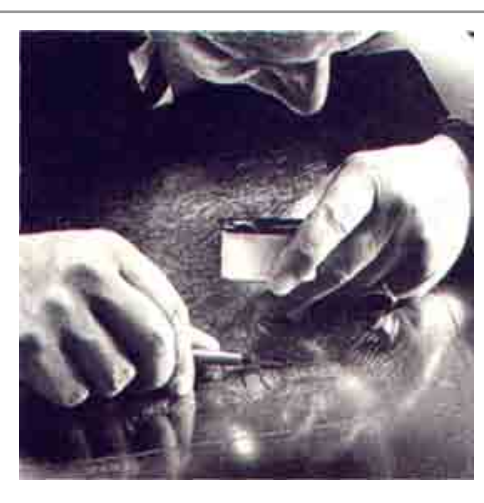

calcografia

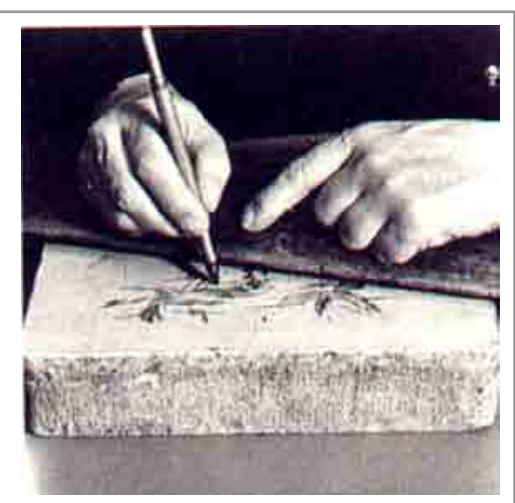

litografia

As primeiras ilustrações impressas em papel surgiram na China, em torno do século IX. Na Europa, o fenômeno surge a partir do século XIV. (...) Tudo começa com cartas de baralho, depois imagens devotas - os santinhos - e, mais à frente, os livrinhos populares. Devidamente autorizados pelo Papa, os monges vendiam bulas e gravuras religiosas nas festas da igreja. Surgem aí as gravuras em folha solta.

(...)

Neste processo, a gravura de folha solta transforma-se em arte popular, vendida em feiras e negociada na rua, não só pelos comerciantes de arte, mas também pelos próprios artistas. Havia a estampa de crítica social, a religiosa, a de feitos heróicos, as de comemorações, os retratos, as edições especiais referentes às festas etc. (ANDRADE, 2004, p. 72) 
Mais tarde algumas iluminuras também passaram a ser reproduzidas por meio de xilogravuras. As iluminuras, executadas manualmente pelos monges medievais, tinham como finalidade ilustrar os livros religiosos (1).

Em fins do séc. $X V$, apesar de ser ainda predominante a recopilação manual dos textos, as figuras produzidas em matrizes xilográficas começaram também a ser reproduzidas pela prensa de parafuso de Gutenberg. A xilografia continuou sendo usada regularmente, principalmente por seu custo ser inferior ao dos gravados em metal. Com a xilografia a gravura teve à sua disposição os elementos imprescindíveis à impressão tipográfica: a prensa, o papel de linho, e a tinta a óleo recém-inventada (séc. XIV). Faltasse um desses três elementos, não teria existido a tipografia. No entanto, durante o período entre a segunda metade dos séculos XVI e o século XVII, os métodos de reprodução de imagens experimentaram sucessivos aperfeiçoamentos, proporcionando a produção de figuras de melhor qualidade.

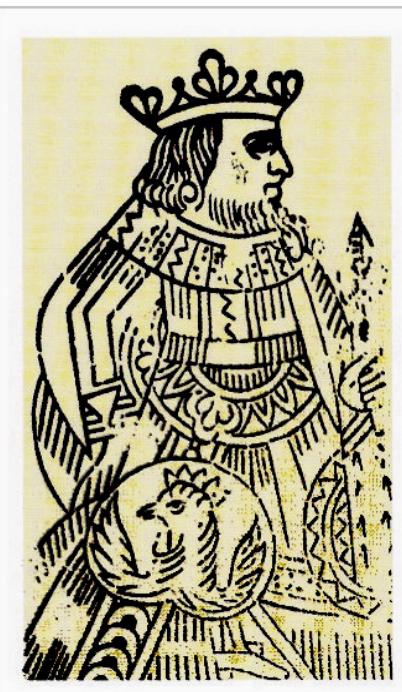

cartas de baralho xilogravadas

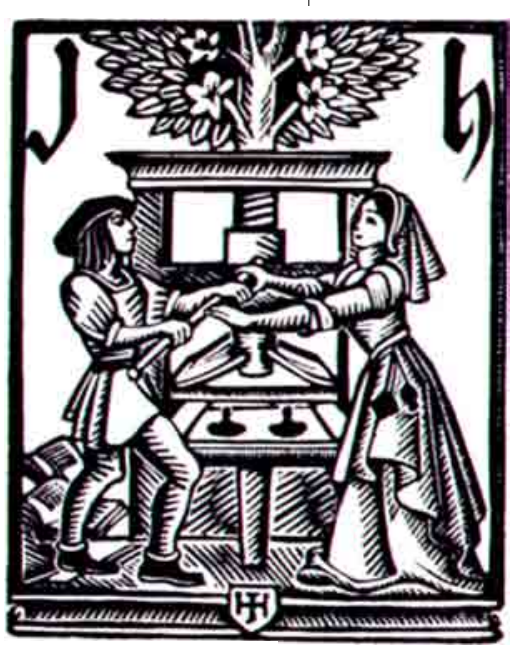

Ex-Libris xilogravado

As impressões ocorriam em folhas soltas e limitava-se quase que exclusivamente às figuras de santos de igreja pelas quais os fiéis se interessavam para dedicar suas orações. Paralelamente havia outras aplicações, como na confecção de cartas de baralho e em alguns livros manuscritos, onde utilizavam folhas soltas para ilustrar as obras, encadernando-as posteriormente junto às demais que continham somente textos.

Ressalte-se aqui a importância da tinta, pois imprimir tipograficamente é transferir letras ou figuras de uma a outra superfície por meio de tinta. Os antigos, contando com a prensa e com a madeira ou o bronze gravados, teriam certamente chegado à impressão tipográfica se também contassem com a tinta apropriada a óleo, porém isso não aconteceu. A tinta da Antiguidade, até a Idade Média, era composta de negro de fumo, carvão e goma, uma mistura aquosa, inconsistente, imprópria à impressão. A tinta oleosa, própria para impressão, surgiria somente no séc. XIV, com o químico e pintor Van Eyck. Sobressai a certeza de não ter havido nem na Antiguidade nem na Idade Média a impressão de letras ou figuras à tinta. 


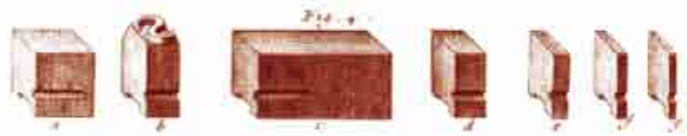

Yis

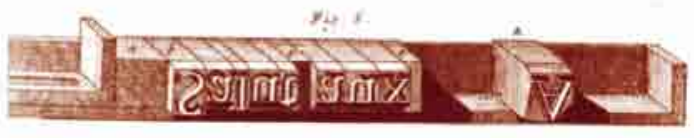

In.

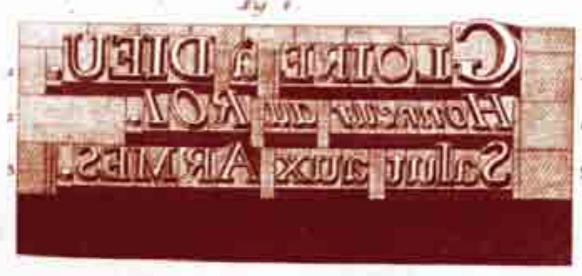

A tipografia atual é, em seus princípios técnicos, um aperfeiçoamento da arte de imprimir. Praticava-se inicialmente com letras esculpidas em tábuas inteiriças, com palavras e desenhos. Depois as letras passaram a ser esculpidas em madeira, letra por letra separadamente, sendo posteriormente compostas palavras com todas as letras individuais e reunidas com os desenhos entalhados, compondo ao final a página a ser impressa.

Depois surgiu com Gutenberg as letras soltas fundidas em metal. A invenção consistiu essencialmente em modelar, moldar e fundir letras de metal, menos perecíveis, mais baratas e em profusão.

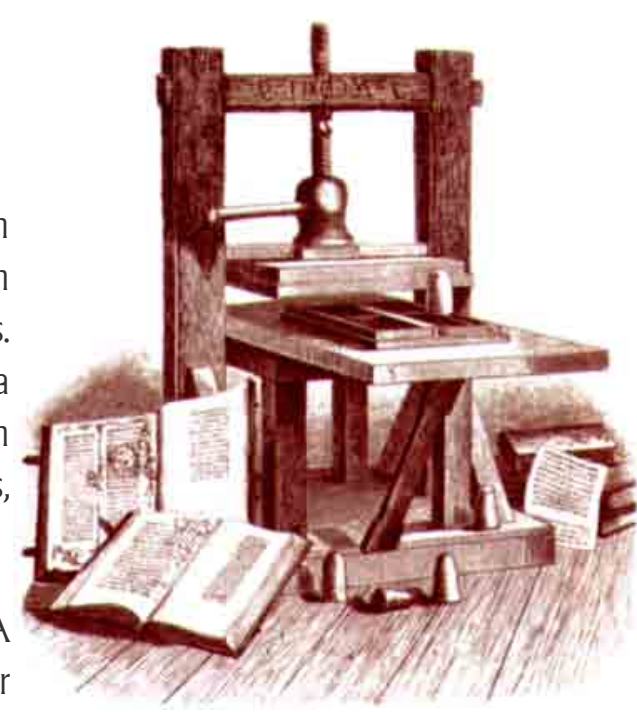

Prensa manual ou prelo
MONTAGEM TIPOGRÁFICA

Letras

Palavras

Frases

\section{A Impressão Tabulária}

A tábua entalhada com figuras e palavras, era uma arte de origem monástica, que começou a ser aplicada na estampagem de motivos sacros, em panos e tapetes de igreja. Atraída pelo comércio profano, logo se expandiu na impressão de imagens de santos, cuja procura aumentara com o incremento dado às peregrinações. Os romeiros compravam-nas e traziam-nas para suas casas como lembrança e atestado de presença e como objeto de culto. Rezando diante delas ganhavam as indulgências necessárias.

Inicialmente a impressão tabulária de textos decorreu da impressão de figuras. No início eram gravados os textos e as imagens em chapas inteiriças. Depois passaram a ser compostos com as pranchas dos textos separadas das pranchas de imagens. Às vezes as mesmas imagens serviam a textos diferentes.

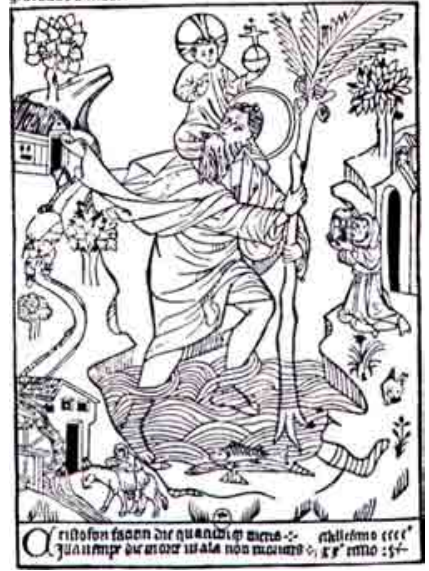

São Cristóvão levando o Menino Jesus Xilogravura com textos gravados à mão Autor anônimo - 1423 


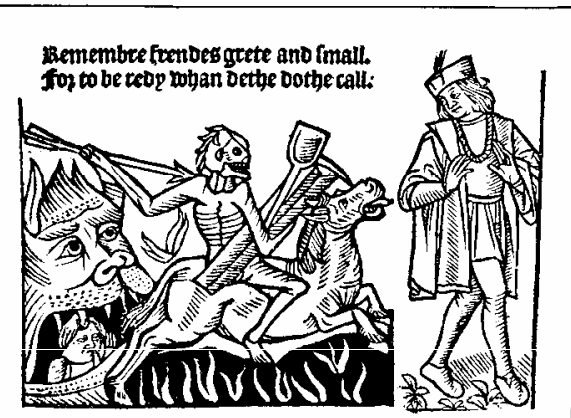

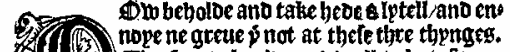

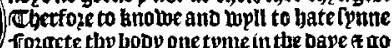
13. S Sorgcte thp bodp one tpme intye dape zigo

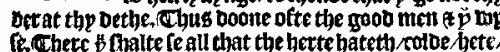

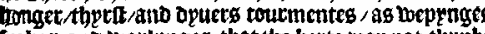

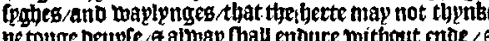

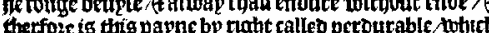
is alwape Dethe in lpuynge/and lyfe in openge/ hoban is

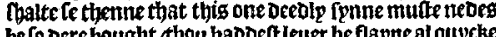
befo betecos * is.t:

Impressão tabulária

Texto e imagem xilogravados séc. XV
As pranchas inteiriças de madeira eram altamente perecíveis e a quase impossibilidade de corrigi-las induziram os impressores a uma operação natural e conseqüente: soltar as letras e, mantê-las avulsas, reunindo-as em palavras para compor os textos.

Daí em diante, a impressão (...) (tipográfica estava) pronta a despontar (...). Bastava substituir os caracteres de madeira de rápido desgaste e de manufatura lenta e individual, por caracteres resistentes e de fácil multiplicação. Para alcançar esse objetivo, aparentemente simples, ofereciam-se (...) os demais e imprescindíveis elementos (para a tipografia). Já havia papel à farta, quinze vezes mais barato do que pergaminho. A tinta surgira homogênea e indelével das felizes experiências de Van Eyck que, adicionando ao óleo de linhaça e de nozes umas tantas substâncias resinosas, conseguiu evitar-lhe a deterioração e emprestar aos seus matizes perene frescura e transparência. A prensa de rosca, adequada ao esmagamento de uvas e azeitonas, (...) vinha sendo já comumente utilizada pelos xilógrafos na tiragem de estampas e opúsculos. A impressão avulsa das letras do alfabeto, (...) praticavam-na normalmente os encadernadores nas capas dos livros por processo ainda hoje seguido na douração das lombadas. Por fim incluía-se entre as atividades de ourives e medalhistas a fundição de pequenos objetos, em moldes de barro, medular ao fabrico dos tipos. (RIZZINI, 1977, p. 79)

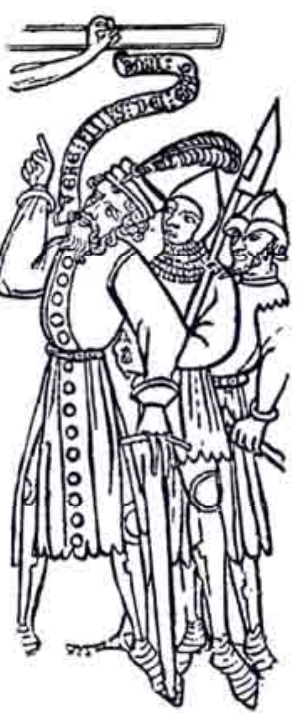

A mais antiga xilogravura conhecida. Autor anônimo

Assim, com a tipografia, os livros passaram a custar naturalmente muito menos do que os manuscritos. E com a presença do prelo difundiu-se a palavra impressa, popularizando a leitura.

Frontispício de Frontispício de Os Lusíadas Arte de Gramática

$$
1584 \quad 1595
$$

Pelos séculos as matrizes xilográficas alcançaram um alto grau de qualidade e definição gráfica. Este fato explica o uso em profusão da xilogravura em periódicos no século XIX, época em que foi alcançado o aperfeiçoamento dos papéis e das técnicas de entintamento por meios mecânicos, com o emprego de rolos de borracha. Com o aperfeiçoamento também da qualidade das técnicas de gravação em metal, foi possível a confecção de figuras impressas com melhor qualidade, tanto em folhas soltas como nos livros. Fato que estimulou maior produção de publicações e ilustrações.

A R T B D B GRAM4

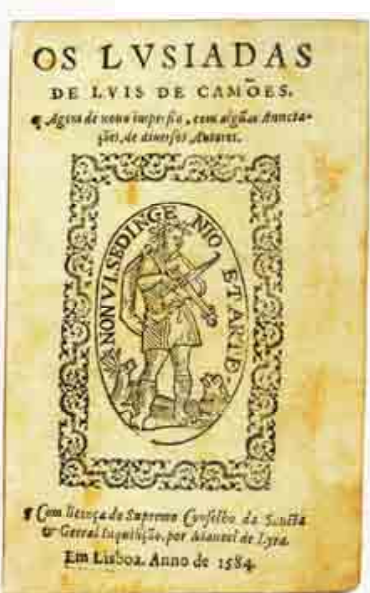
maisva DA $L I N$ N $G$ O

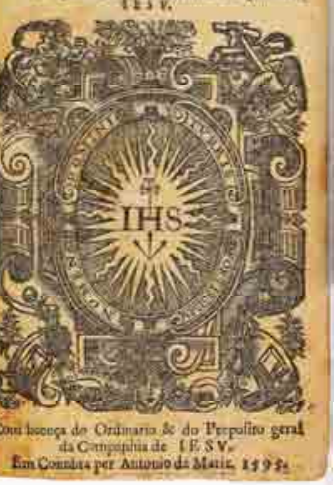




\section{(2)}

Próximo ao final do século XVIII, quando as técnicas de gravura em madeira e metal já se encontravam bastante apuradas, surge a litografia. Um novo e revolucionário processo de gravação e reprodução de imagens, simples e barato, que mudaria profundamente os meios de reprodução. Era um processo de gravura plana, executada sobre pedra calcárea.

Foi desenvolvida entre 1796 e 1798 pelo jovem compositor musical Aloys Senefelder (1771-1834), natural de Praga, quando buscava meios de reproduzir suas composições através de processos mais baratos. Encontrou a solução ao gravar aproveitando a propriedade da repulsão da tinta oleosa pela água.
Até a segunda metade do século XIX a xilogravura aperfeiçoou-se e seu uso tornou-se comum nos jornais e revistas, tanto que o uso da imagem xilogravada foi fundamental para a implantação do jornalismo de massa. Nas revistas foi fartamente utilizada pelo fato dos editores terem mais tempo que os de jornais para elaboração de gravuras, apresentando ilustrações de excelente qualidade. A qualidade melhorou principalmente por ter havido sensível progresso das impressoras, que passaram a aceitar blocos gravados cada vez maiores.

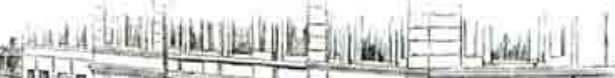

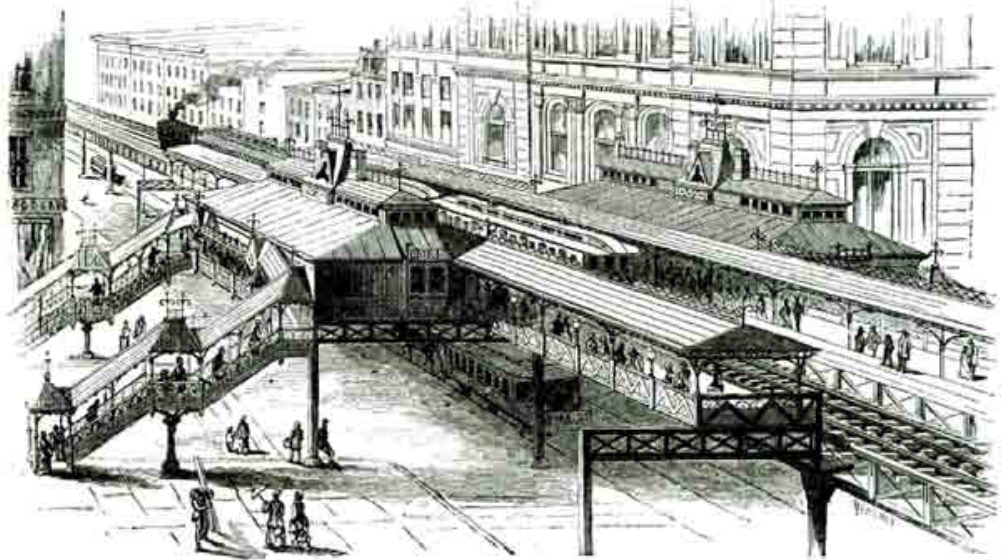

ilustração xilogravada baseada em fotografia

Ainda na década de 1860, já com a presença da fotografia, ampliou-se a utilização de gravuras mais realistas nas publicações. Nelas o artista reproduzia a fotografia por meio da gravura, pois ainda não havia meios de reproduzir diretamente o original da foto nos jornais. As gravuras eram tanto em madeira quanto em metal. Eram tempos de grande sucesso das revistas.
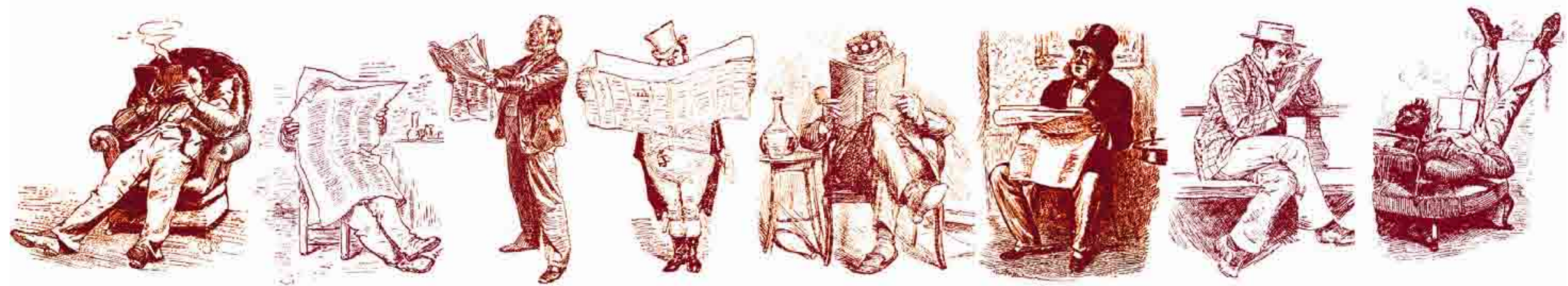

Como vimos, durante um longo período da história a imagem impressa manteve-se sem inovações tecnológicas. Com o surgimento da prensa e dos tipos móveis a escrita passou a ser reproduzida por um processo industrial, enquanto que para a imagem permaneceu artesanal. Assim se manteve até o final do século XIX, quando foi introduzida a litografia na imprensa (2). A partir desse momento a imagem começa a participar de um processo semi-industrial. 


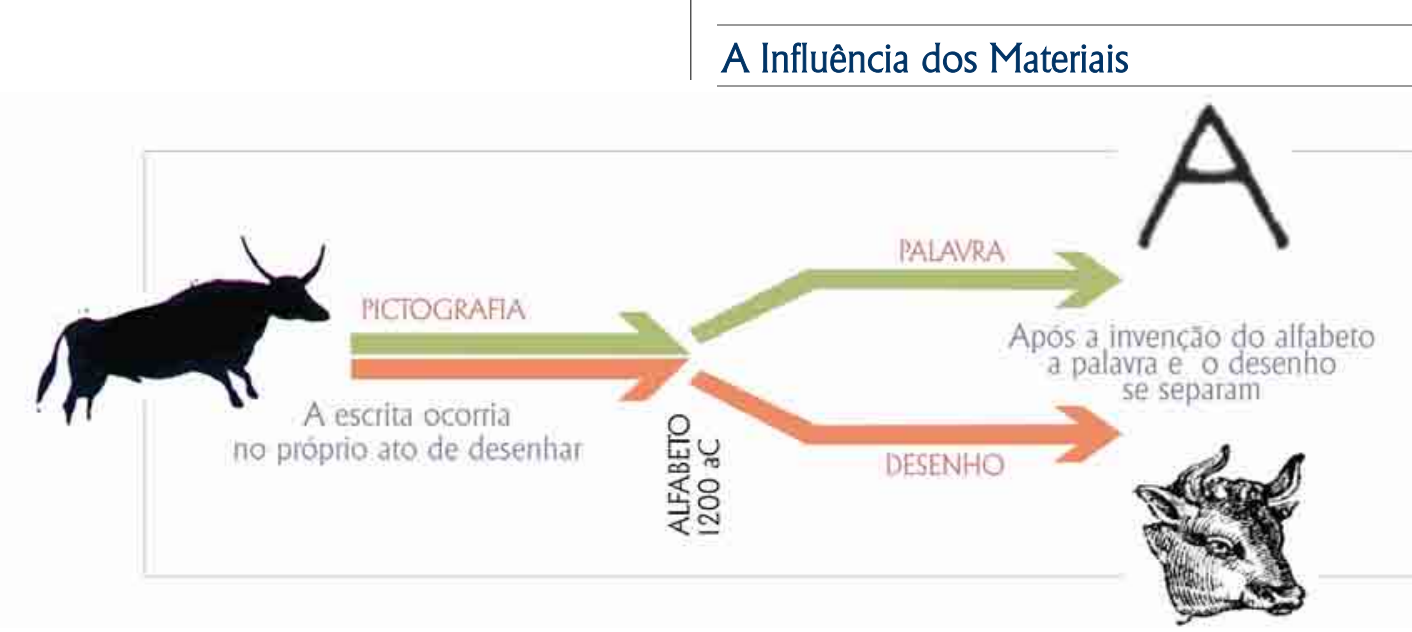

Como foi visto, a comunicação gráfica primordial teve início com a pictografia. Ali, a escrita e o desenho encontravam-se reunidos. A partir da invenção do alfabeto a escrita e o desenho se separam, porém os dois mecanismos (desenhar e escrever) mantiveram-se próximos, pois se valiam dos mesmos processos artesanais e com os mesmos materiais para confecção (papel, lápis e tinta). Esta situação perdurou até 1445, quando foi inventada a tipografia. A partir da tipografia a palavra tornou-se meio mais célere na propagação dos pensamentos e, por conseguinte, passou a ser a linguagem predominante para difusão das idéias, deixando para trás o uso de imagens como articuladora dos pensamentos.

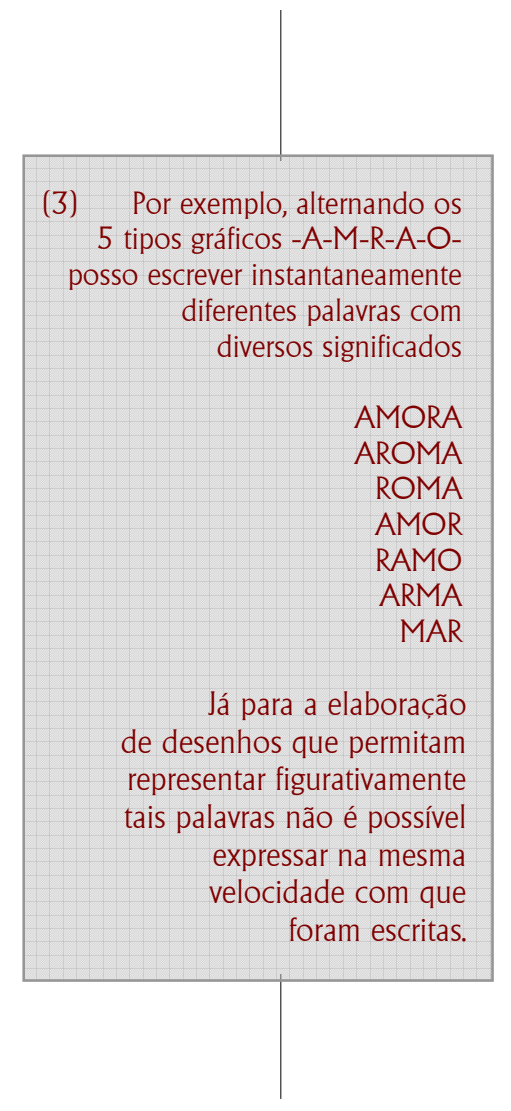

Com o advento da tipografia a palavra impressa passa a preponderar sobre as formas de comunicação gráfica, ou seja, a palavra impressa se sobrepõe à ilustração artesanal. A tipografia, assim, propiciou agilidade na construção do discurso verbal, multiplicando e popularizando sua articulação.

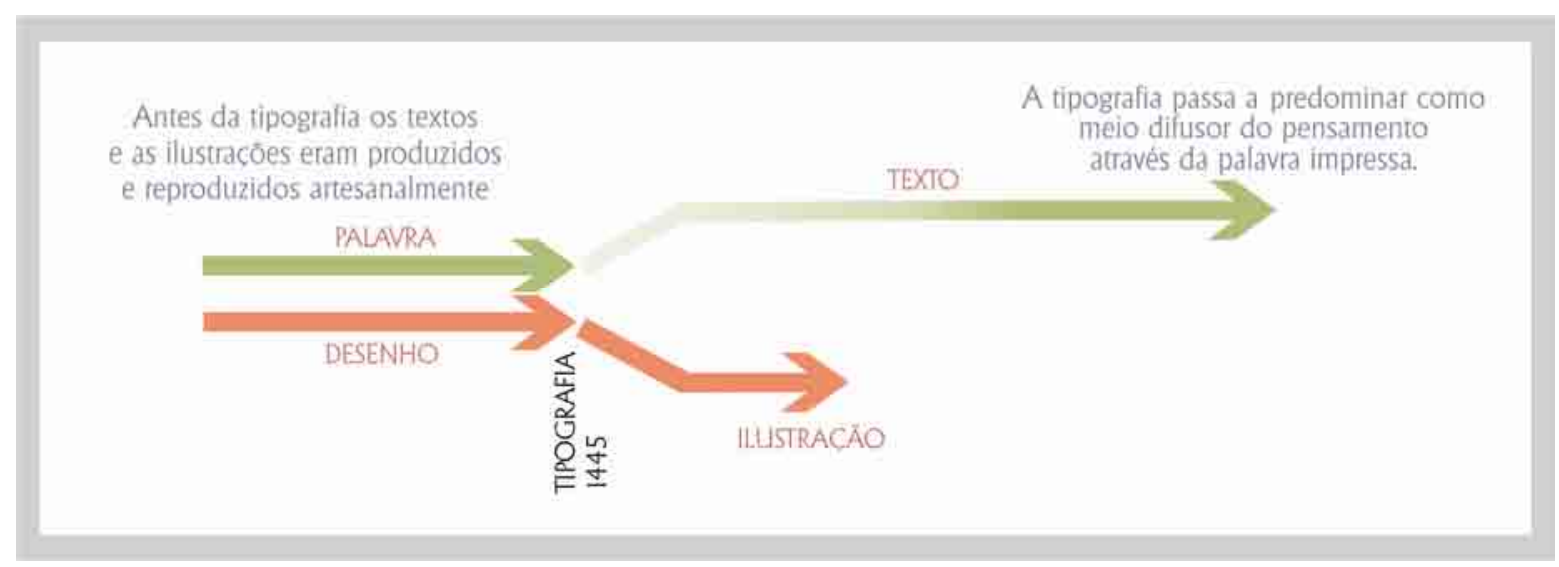

As imagens, que eram elaboradas artesanalmente nos próprios livros manuscritos, a partir da tipografia passaram a ser ilustradas nos espaços reservados com esta finalidade. Não havia condições de competir em velocidade com a palavra tipografada (3). 


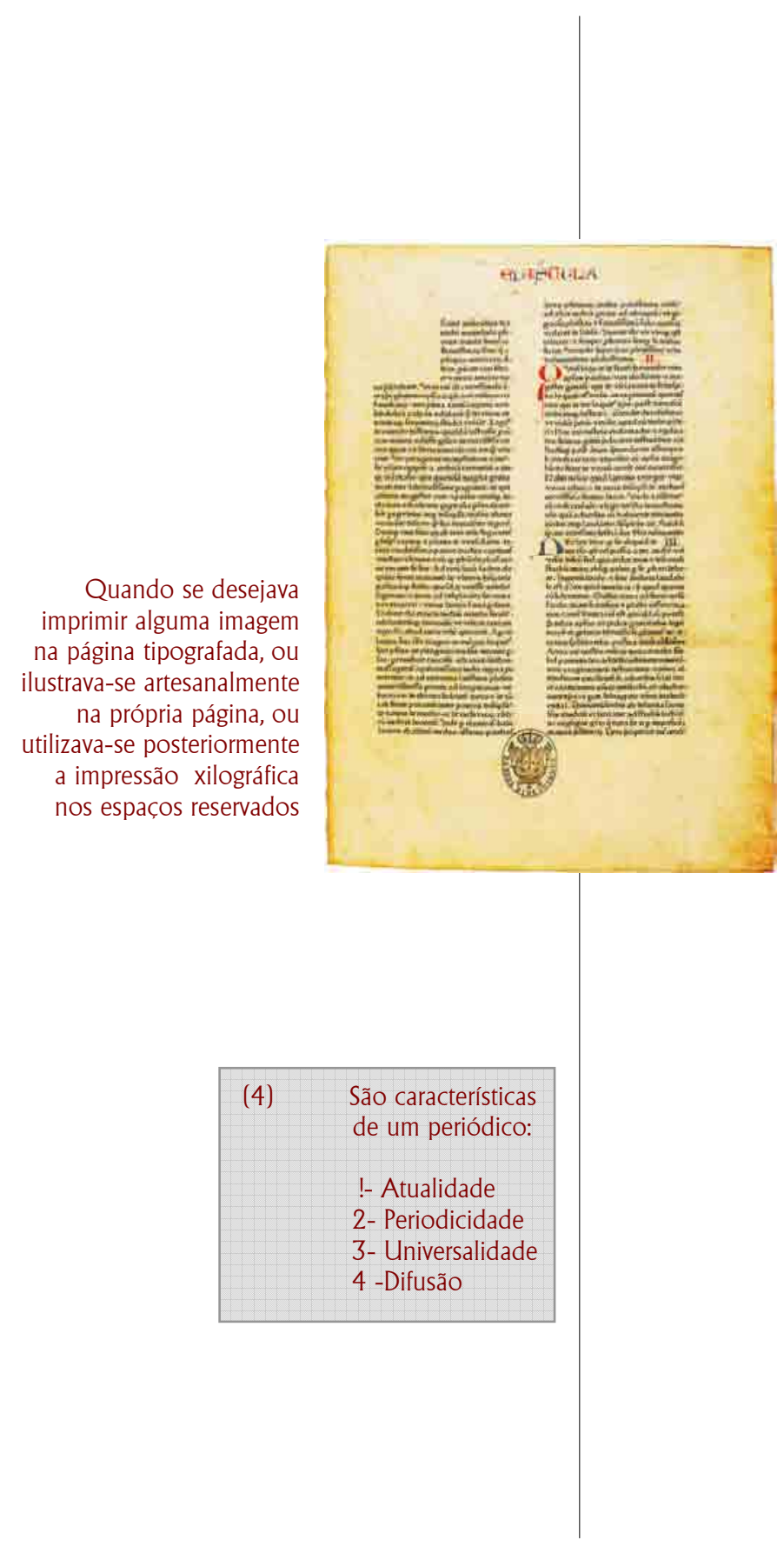

O processo evolutivo das técnicas de reprodução da palavra pela tipografia propiciou enormes avanços na linguagem verbal. Se ainda havia uma convivência entre tipografia e xilografia, esta era adaptada, ou seja, conviviam páginas verbais separadas de páginas visuais. Ou páginas tipografadas com espaços vazios para posteriores encaixes de impressão de imagens xilogravadas. Esta situação se intensificou por não existir compatibilidade mecânica para unir no mesmo processo de impressão a matriz tipográfica com a matriz xilográfica, impedindo a multiplicação das imagens em conjunto com a multiplicação dos textos.

Mesmo com a invenção da litografia, em 1798, persistiu a incompatibilidade mecânica de se reproduzir na mesma página imagens litografadas com o texto tipografado. Continuou sendo resolvida com a impressão em separado das páginas verbais das páginas visuais. Os benefícios em favor da ilustração, com a introdução da litografia, ocorreram na agilidade de produção da matriz litográfica. Esta inovação permitiu que o material-base para a criação do artista (a pedra) e o material para a sua gravação (o lápis litográfico) obtivessem maior fluidez para registro e gravação do pensamento. Anteriormente a agilidade para a criação ficava prejudicada devido aos duros e resistentes materiais de gravação e consequentemente na fluência das idéias.

E como duas das características do jornal são a atualidade e a imediata difusão (4), a reprodução da imagem deixava de existir na mesma velocidade com que era produzida a composição tipográfica. Como conseqüência, afetava a participação da ilustração no discurso jornalístico.

Antes da pedra e do lápis litográfico, as matrizes de gravação existentes eram a madeira (gravada com a goiva) e o metal (gravado com o buril). Com a pedra litográfica foi possível acelerar a expressão da gravura, aproximando-a do relato da atualidade, permitindo sua maior participação nos jornais.

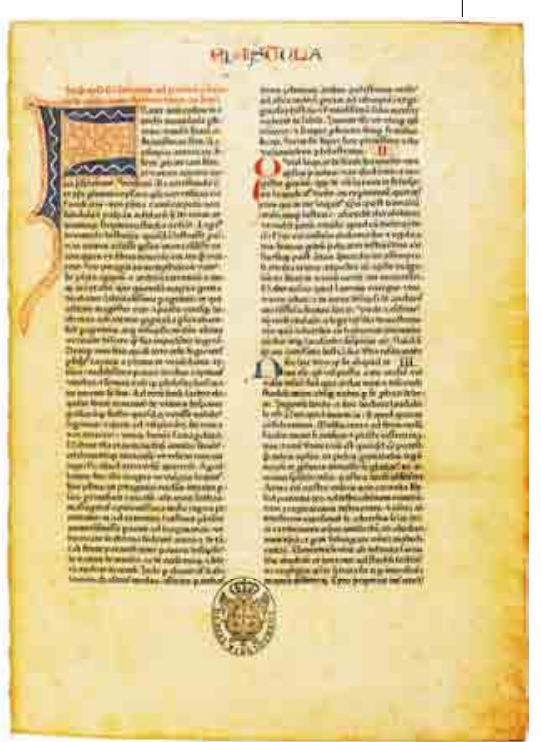


Hoje, com os recursos eletrônicos há um favorecimento na velocidade de junção das duas linguagens (verbal e não verbal). Pois, ao acelerar a velocidade na produção criativa, aumentam-se as possibilidades de expressão do desenho. Assim, cada vez mais a produção de imagens se desprende da dependência mecânica e se aproxima da velocidade do pensamento.

É interessante notar aqui esta correlação entre imaginação e técnica. Quanto mais agilidade uma tecnologia adquire para ser meio de expressão, mais ela se aproxima da velocidade da imaginação, e consequentemente passa a ser incorporada como meio preponderante de comunicação.

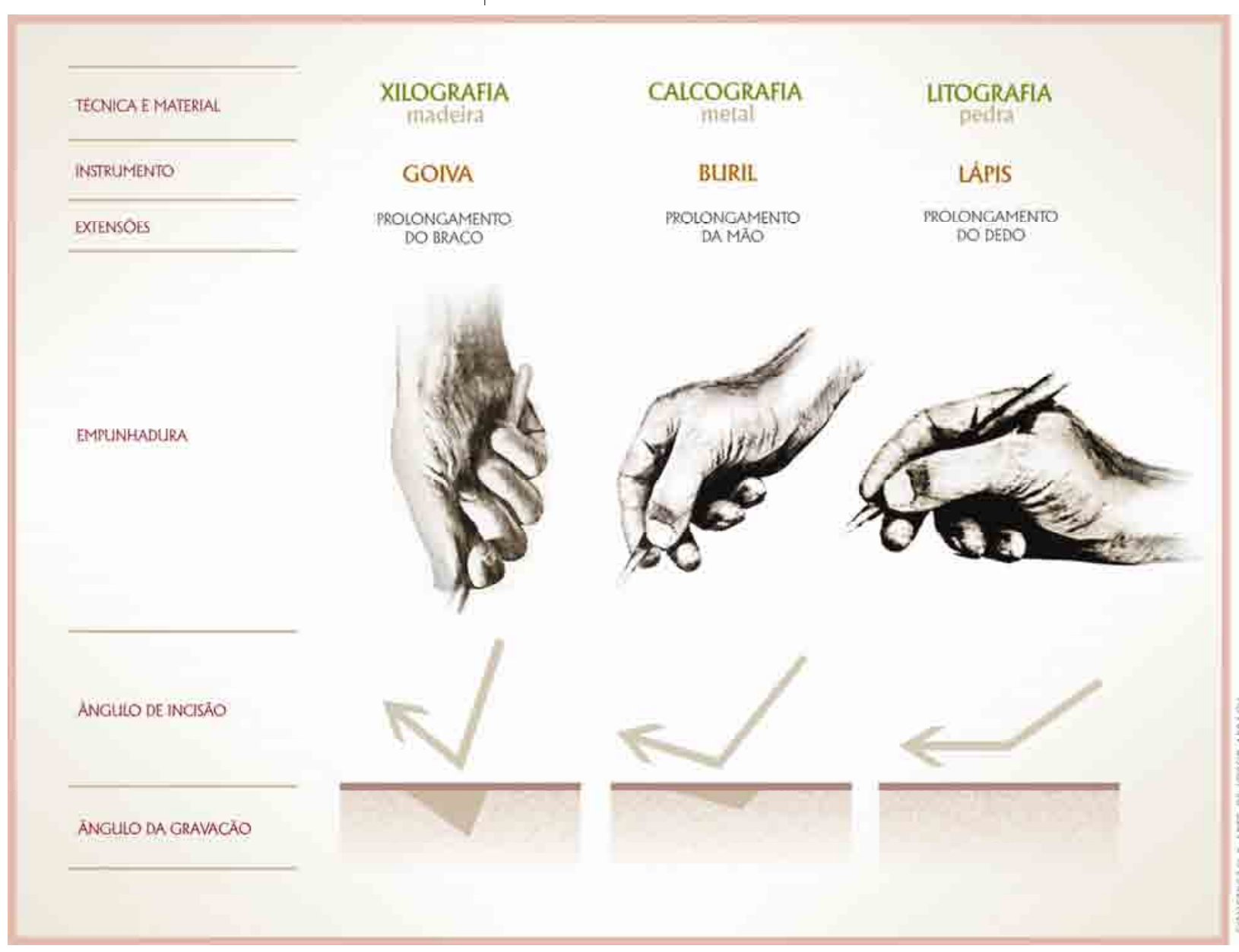

Na ilustração que apresento ao lado, sobre as técnicas de gravura, podemos identificar que há uma relação de fluência do pensamento com o ângulo de incisão necessário para romper e gravar os materiais comumente utilizados para gravar artesanalmente as imagens (madeira/metal/pedra).

Percebemos que quanto mais duro é o material, mais perpendicular é a incisão e consequentemente mais lenta será a produção de matrizes para reprodução, interferindo, assim, na fluidez das idéias.

Dessa forma, o instrumento de corte passa a agir como uma extensão física do homem. Como a resistência dos materiais atua diretamente na fluência do discurso, então, quanto mais fluência há na expressão da gravação, mais fluente será a manifestação do pensamento. Com a litografia, por conseguinte, foi possível aproximar-se de uma das características que define o jornal: a atualidade do relato.

Imagem e palavra puderam novamente se articular. A imagem pela via litográfica e a palavra pela via tipográfica. Ambas, ao longo do século XIX, retomaram uma antiga parceria, quando as duas eram confeccionadas artesanalmente nos manuscritos medievais. 


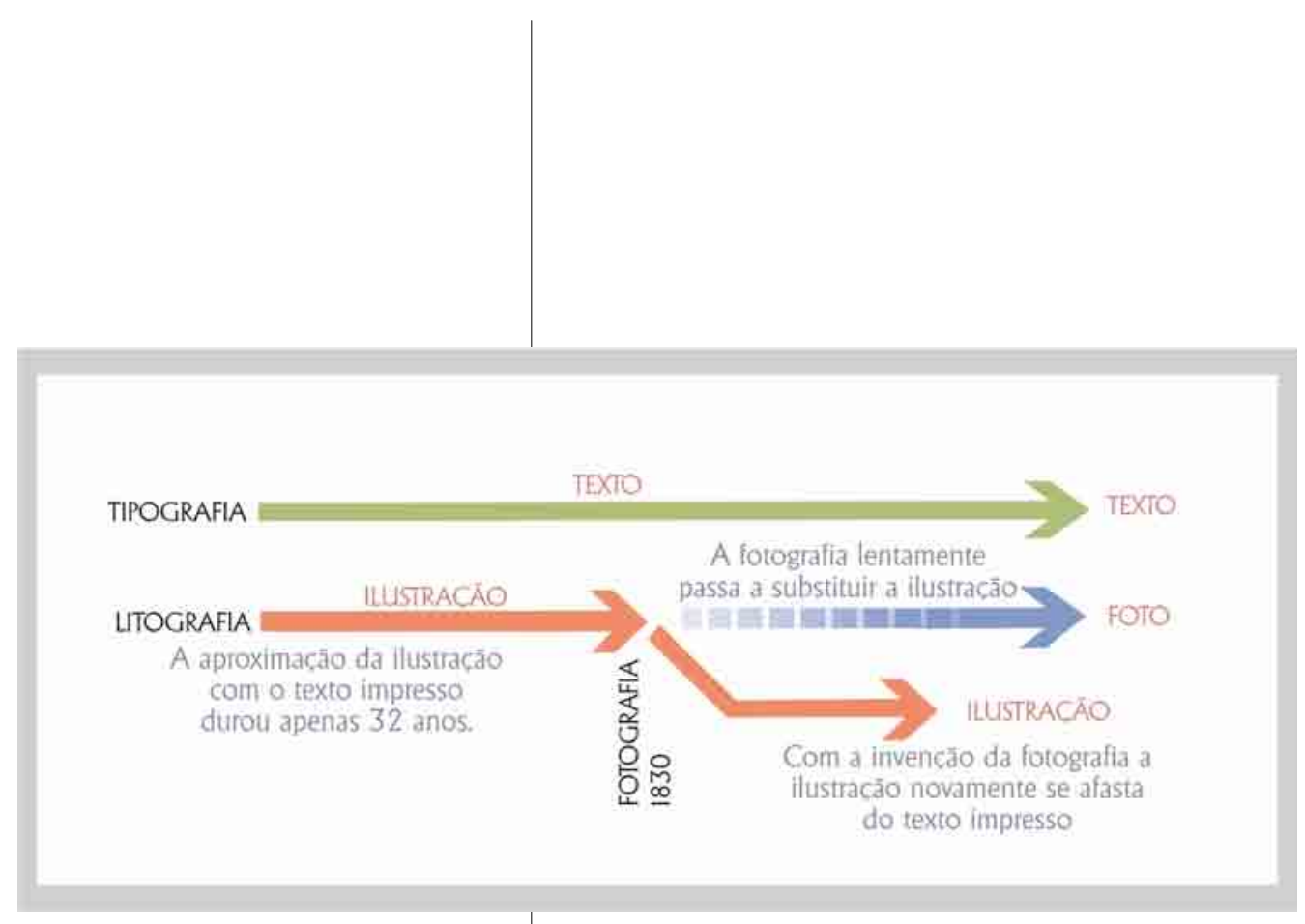

Portanto, o florescimento e o desenvolvimento da técnica litográfica no século XIX possibilitaram a difusão tanto de imagens informativas dos acontecimentos, bem como imagens opinativas através das caricaturas e dos desenhos de humor.

Nesse período o jornal empresarial se expandia e conquistava mercado, alcançando contingentes de semi-alfabetizados através das ilustrações impressas. Porém, a aproximação da ilustração com a palavra foi por um breve período, apenas 32 anos. Isto é, desde o advento da litografia, em 1798, até a invenção da fotografia, em 1830. A fotografia, ao retratar o real, retirou da imagem desenhada seu caráter informativo. Deslocou para a foto seu aspecto documental, enquanto que para o desenho permaneceu apenas seu caráter opinativo. Aos poucos foi sendo retirado da ilustração seu aspecto de atualidade e mais uma vez perdeu força participativa junto aos periódicos.

Dessa maneira, com a fotografia, a valorização da imagem como meio de difusão sofre mais uma retração, passando a foto a registrar o acontecimento com mais veracidade, servindo de testemunha ocular do fato. Isto ocorre justo no momento em que o jornalismo iniciava sua expansão, ampliando sua vertente empresarial, ao considerar a informação como matéria prima comercial. Assim, a imagem desenhada cai no descrédito como informação jornalística, agravada pela descrença da imagem como informação, ao ser considerada pelos intelectuais como informação dos não-letrados Fatos que reverberam até os dias atuais. 


\section{2 - A PRESENÇA DA FOTOGRAFIA}

DAGUERREÓTIPO Aparelho fotográfico
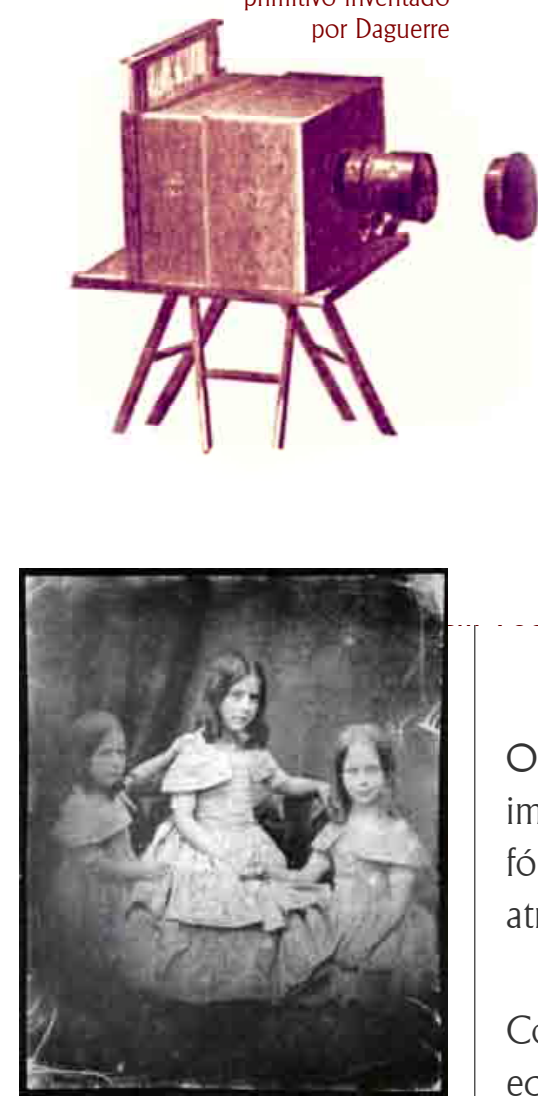

Foto experimental de William Talbot c. 1838
A descoberta da gravação através da luz por Nicéphore Niepce, foi inicialmente denominada de heliografia e posteriormente como fotografia Essa descoberta, aperfeiçoada mais tarde por Daguerre e outros seguidores - daria grande impulso para a gravação de imagens para impressão.

(..) a fotografia somente se tornou realidade quando, (...) (em 1835), os franceses Joseph Nicephore Niepce e Luis Mandé Daguerre baseados no princípio de que a prata dissolvida em matérias orgânicas enegrecia-se pela ação dos ácidos, aplicaram estes conhecimentos à câmara escura, inventando um sistema de gravar imagens em uma placa preparada com iodo e prata mercurial, que recebeu o nome de "daguerreótipo".

Em 1838, William Talbot substituiu as placas metálicas por transparentes, a fim de obter cópias em papel sensibilizado. (BELTRÃO, 1969, p. 401)

A fotografia marca praticamente o nascimento do jornal moderno: o jornalista como pessoa da informacão nasce com o fotógrafo (...). Coube ao telégrafo intensificar as informacões sintéticas: com ele, o jornal se vê povoado de informações rápidas que se organizam sem elos causais, sem pontos de vistas fixos, sem uma ordem hierárquica, o que leva o receptor a penetrar em um continente onde as imagens díspares proporcionam-Ihe um fluxo de notícias, um mosaico de significações. Este mosaico monta um painel do mundo que flagra a descontinuidade e incongruência do cotidiano no seu próprio acontecer e, por isso mesmo, exige uma imagem corporativa, uma participaça inclusiva e simultânea, capaz de apreender e conectar os resultados dispersos. (SANTOS, 2003, p. 12-13)

Os jornais até o século XIX eram eminentemente opinativos, interessando apenas às elites. Os editores interessados em implantar um jornalismo informativo anteviram o grande mercado latente de um jornalismo popular e aplicaram as fórmulas ideais para atrair o interesse do grande público. Isto é, passaram a explorar ao máximo o uso de imagens, através da ilustração gravada ou da foto desenhada.

Com o final da Guerra Civil os Estados Unidos tiveram um amplo progresso em todas as áreas, principalmente na área econômica. A imigração acelerou o aumento da população e a alfabetização atingiu 80 por cento da população. Tudo isso implicava em maior número de leitores.

O uso da foto na imprensa representaria o testemunho documental do fato acontecido e a ilustração serviria como complemento da notícia. Era justamente o que os donos dos jornais precisavam para vencer a guerra contra o jornalismo opinativo, ou seja, a informação ilustrada para o grande público, atuando como persuasão para venda e leitura dos periódicos 


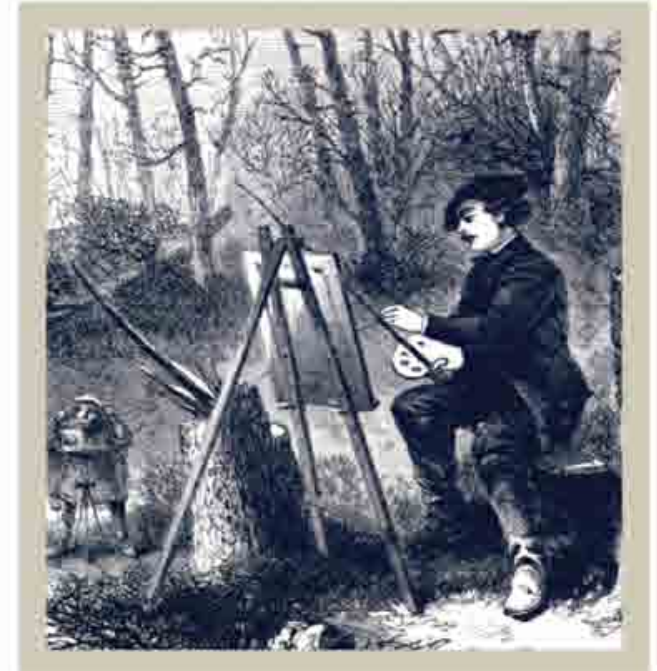

Assim, a técnica para reproduzir o real através da fotografia já estava resolvida, porém, persistia a busca para sua reprodução em jornal. Diversas tentativas foram feitas. Além desta questão, existiam as discussões sobre o estatuto ou não da fotografia como manifestação artística. $\mathrm{Na}$ época ficou definido que a imagem fotográfica libertava a arte do compromisso com a transcrição da realidade. Permaneceria adequada àquilo que é sua essência: a criação imaginária.

Com o avanço das técnicas fotográficas e de maiores possibilidades de reprodução, a fotografia afastou ainda mais a imagem artesanal para o campo da expressão artística. Passou a existir uma cisão marcante entre a foto e as artes plásticas nos campos jornalístico, social, artístico e comercial.

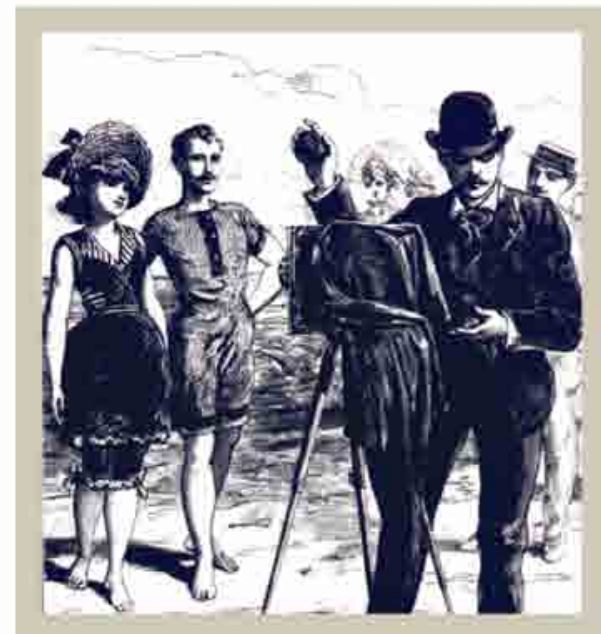

(...) durante o século XIX existirá todo tipo de discurso e declaração proclamando a "libertação da arte pela fotografia". Esses discursos de fato se baseiam exatamente na mesma concepcão de uma separacão radical entre a arte (como) criação imaginária que abriga sua própria finalidade, e a técnica fotográfica, (como) instrumento fiel de reprodução do real. A conotação dos valores mudou, mas a lógica permanece a mesma: a fotografia vê-se rapidamente designada como aquilo que deverá a partir de então se encarregar de todas as funçōes sociais e utilitárias até aqui exercidas pela arte pictural, porque é uma técnica muito mais bem adaptada do que a pintura para a reproducăo mimética do mundo. Desse modo, assistiremos à transformação dos antigos (pintores) retratistas oficiais em fotógrafos profissionais, (que passarão a ser artificices retocadores).

(...) A distribuição portanto é clara: à fotografia, a função documental, a referência, o concreto, o conteúdo; à pintura, a busca formal, a arte, o imaginário.

Essa bipartição recobre claramente uma posição entre a técnica, por um lado, e a atividade humana, por outro. Nessa perspectiva, a fotografia seria o resultado objetivo da neutralidade de um aparelho, enquanto a pintura seria o produto subjetivo da sensibilidade de um artista e de sua habilidade. Quer o pintor queira, quer não, a pintura transita inevitavelmente por meio de uma individualidade. (...) Ao contrário, a foto, naquilo que faz o próprio surgimento de sua imagem, opera na ausência do sujeito. Disso se deduziu que a foto não interpreta, não seleciona, não hierarquiza. (DUBOIS, 1998, p. 30-34)

André Bazin, em "Ontologia da imagem fotográfica", comenta: "A originalidade da fotografia com relação à pintura reside em sua objetividade essencial. Também, o grupo de lentes que constitui o olho fotográfico que substitui o olho humano chama-se precisamente "objetiva". Pela primeira vez, entre o objeto inicial e sua representação, nada se interpõe além de um outro objeto. (DUBOIS, apud BAZIN, 1998, p. 34-35) 


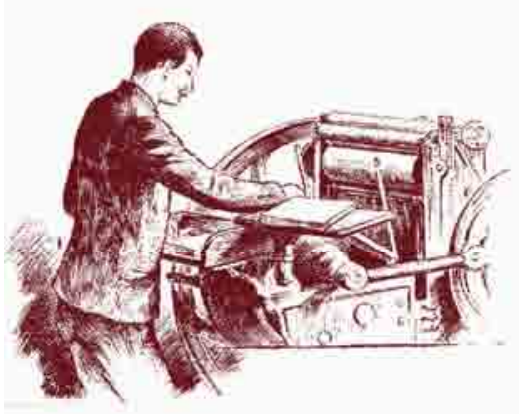

Gravuras baseadas em fotografias
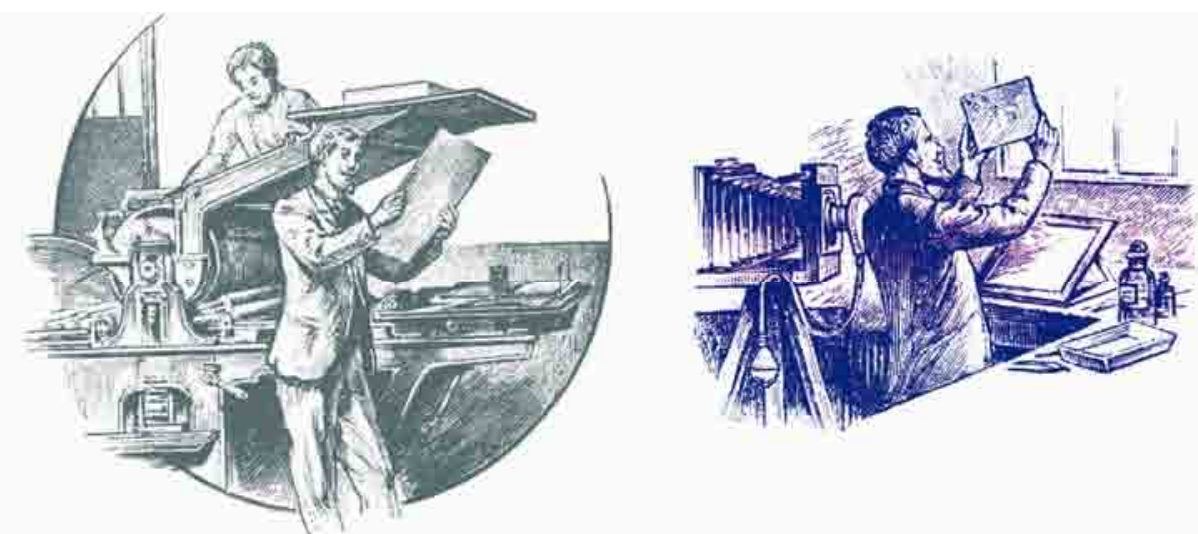

O filão do jornalismo ilustrado, europeu e norte-americano, foi bem aproveitado pelas revistas. Pois, devido à sua periodicidade (semanal ou mensal), tinham mais tempo que os jornais diários para prepararem as matrizes em chapas de madeira ou metal. De acordo com a complexidade do desenho demoravam vários dias para serem gravadas.

De acordo com a conveniência, a própria fotografia, ao ser utilizada pelo jornalismo, sofria a intervenção do profissional copiador.

Até a descoberta do negativo, que possibilitaria a confecção do clichê, a fotografia teve que esperar cerca de 40 anos para ser reproduzida fielmente num jornal. Fato que ocorreu em 1880.
Após o invento do daguerreótipo, em 1839, os artistas gravadores utilizaram a fotografia como modelo de suas gravações, ou seja, a imagem fotográfica era copiada à mão e sempre que necessário era acrescida ou subtraída de detalhes da foto original.

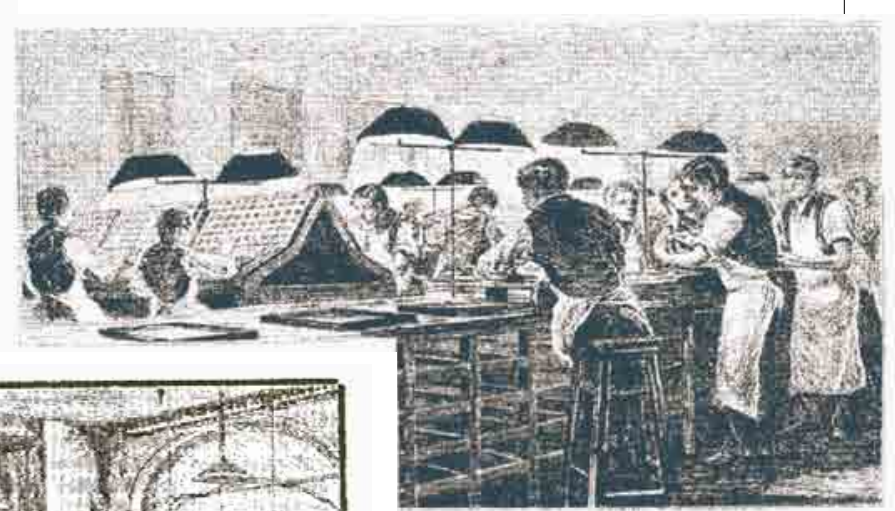

Gravuras baseadas em fotografias

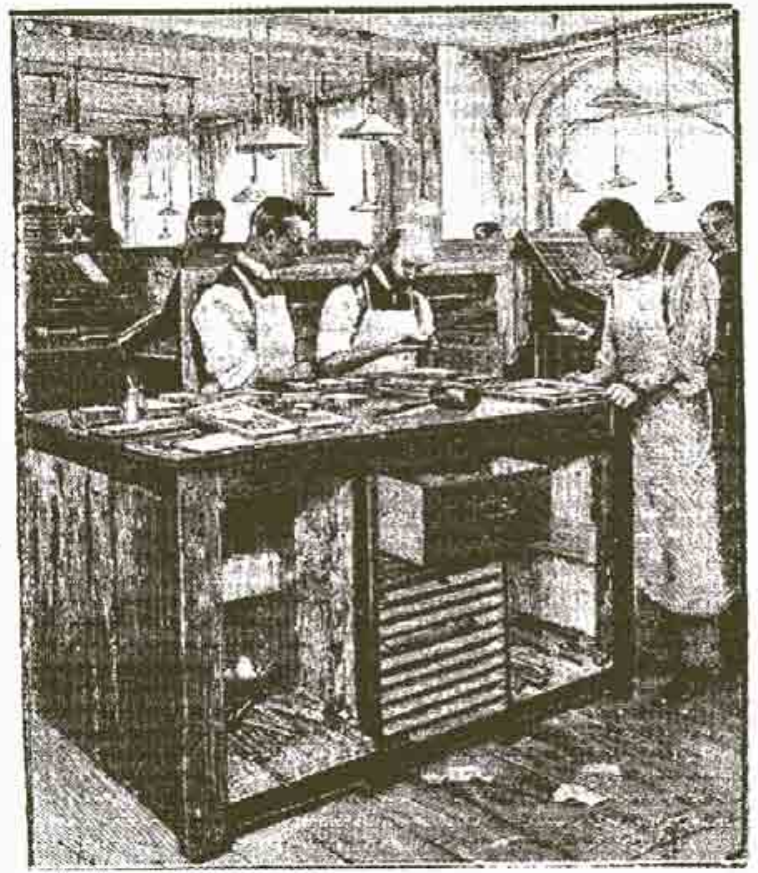




\section{Fotolitografia}

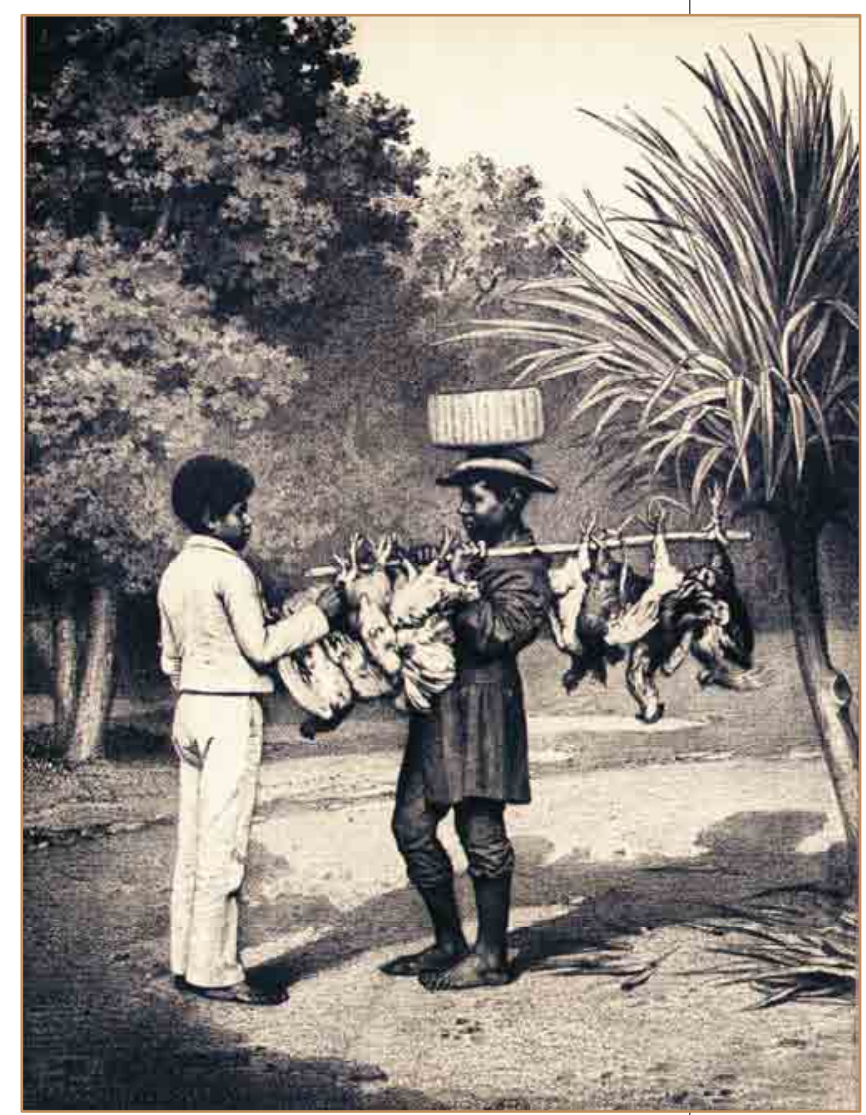

Vendedor de aves na roça

Litografias de Charpentier sobre fotografias de Victor Frond - 1859
Entre 1856 e 1857 o francês Louis-Alphonse Poitevin foi responsável pelo desenvolvimento da primeira experiência de um processo fotomecânico - a fotolitografia. Este processo marca o início de sucessivos desenvolvimentos. A técnica possibilitou a implantação dos processos de reprodução fotomecânica na imprensa periódica em maior escala. E cujos progressos não cessaram até os dias atuais.

(...) a aplicação dos princípios da fotografia à litografia, a partir das pesquisas do francês Louis-Alphonse Poitevin, resultou no desenvolvimento da fotolitografia, por ele explorada comercialmente em seu ateliê, instalado em 1855 . Incapaz de torná-lo um empreendimento rentável, vendeu sua patente em outubro de 1857 ao impressor e litógrafo Joseph-Rose Lemercier, discípulo de Alois Senefelder, que viabilizou-a em sua Imprimerie Lemercier, de Paris.

(...)

Ainda com relação à fotolitografia, vale esclarecer que este processo não conseguiu jamais, no século XIX, atender às demandas por reproducão fotomecânica de uma indústria gráfica de tiragens crescentes e prazos decrescentes, na qual a impressão era tipográfica e, portanto, a ela deveriam se subordinar os processos fotomecânicos - (...) Apenas no século XX, com o pleno desenvolvimento da denominada litografia offset, é que ocorrerá a "migração tecnológica digamos assim, da composição tipográfica para os processos de impressão litográficos - isto, graças, mais uma vez, à fotografia e, mais especificamente, à fotocomposição de textos". (ANDRADE, 2004, p. 84)

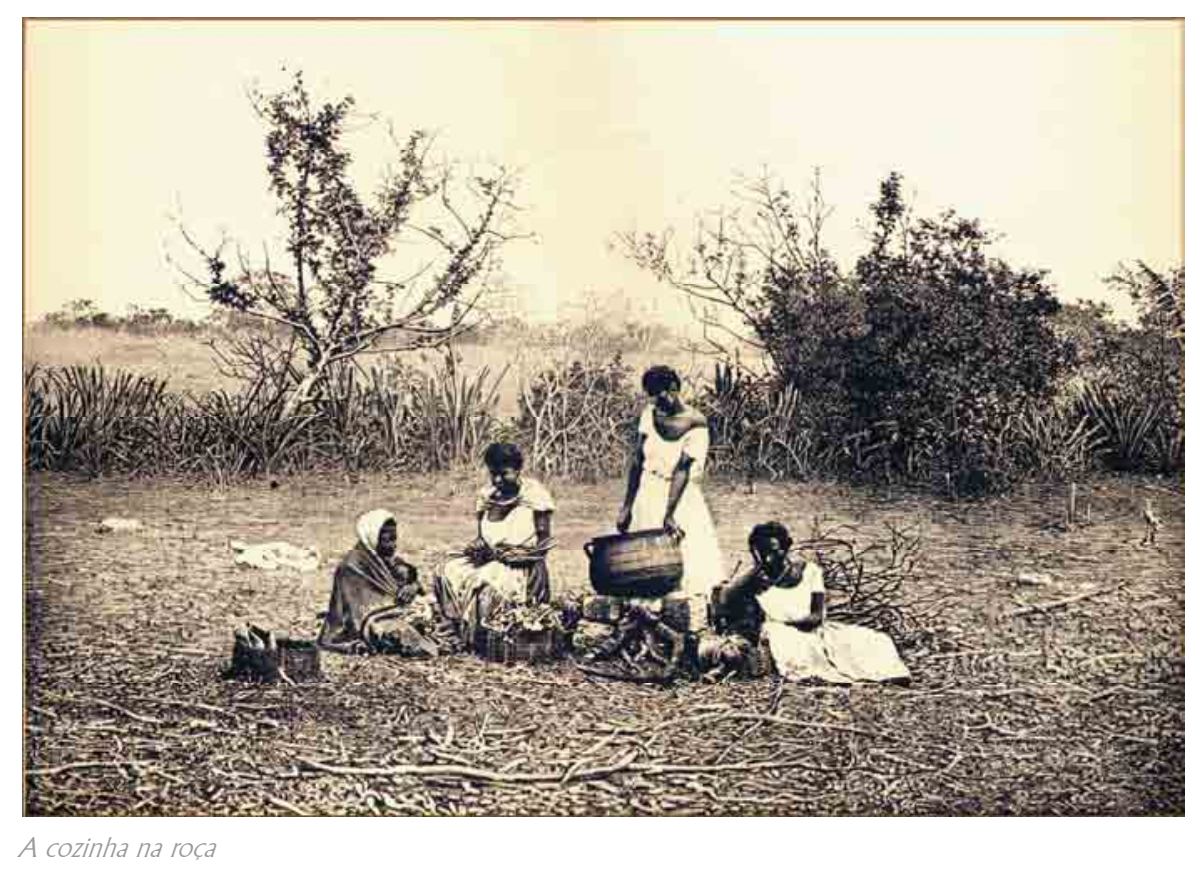




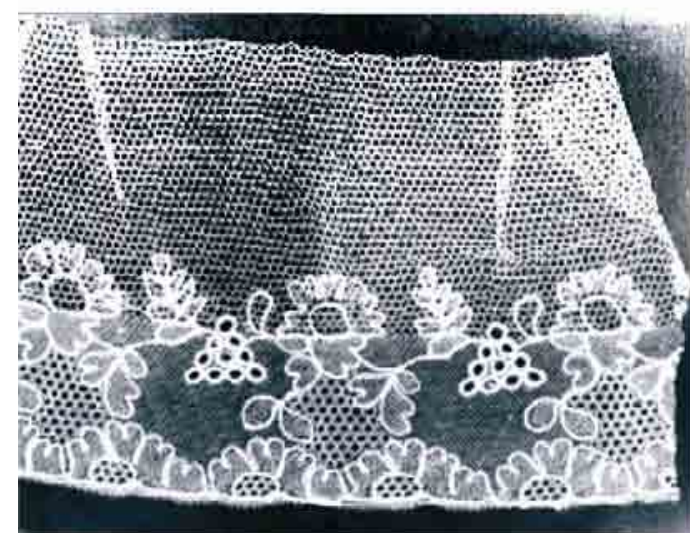

Uma das experiências de Talbot com gaze para decompor a imagem fotográfica em retículas.
Fototipia ou autotipia é o nome comumente dado aos clichês. $\bigcirc$ alemão Georg Meisenbach foi um dos muitos que pesquisaram as soluções deste importante processo que

havia sido iniciado com as experiências de William Fox Talbot com pedaços de gaze, visando à fragmentação da imagem.

Para efetivar a reprodução de fotos na imprensa, foi desenvolvida uma série de processos similares entre as décadas de 1870-1880. No processo de fototipia os tons contínuos da imagem fotográfica original são reproduzidos através de uma retícula de vidro, sendo fragmentada em milhares de pequenos pontos, distribuídos de maneira regular.
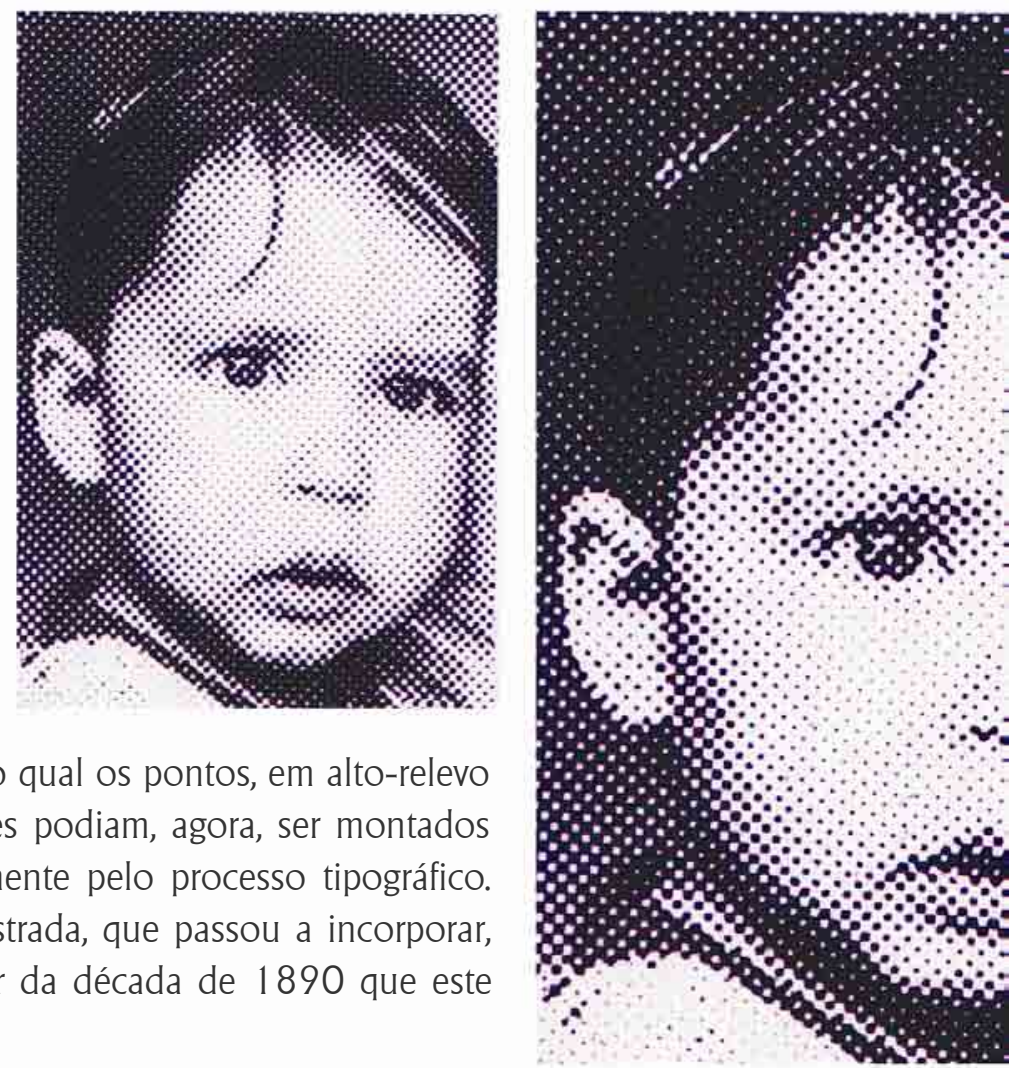

A atuação da Companhia Meisenbach, fundada em 1882 pelo inventor do processo, foi decisiva para a disseminaç̃o da autotipia. (H) esses meios-tons assinalam o início da fotografia de imprensa e portanto, ao mesmo tempo, do fotojornalismo. Mais de 40 anos depois da invenção da fotografia, tornou-se possível imprimir fotografias junto com textos através de um processo direto. No entanto, passaram-se vários anos antes que a técnica fosse utilizada em todo mundo. O nome autotipia foi dado ao processo pelo próprio Meisenbach. (ANDRADE, 2004, p. 97) 


\section{Litografia $=$ Zincografia $=$ Off-set}

Devido ao custo e às outras dificuldades impostas pelas volumosas e pesadas pedras litográficas, foram vários os experimentos - a começar pelo seu inventor Aloys Senefelder - no sentido de desenvolver alternativas para o processo litográfico. O zinco foi o material que melhor se prestou ao caso. Mais barato e de mais fácil obtenção, transporte e manuseio, suportando tiragens compatíveis com as necessidades dos periódicos, sua superfície podia ser tratada de modo a se tornar áspera ou polida, cumprindo satisfatoriamente as funções da tradicional pedra litográfica. Assim, a zincografia passou a adotar o mesmo processo da impressão litográfica.

A partir da zincografia a técnica de impressão de imagens evoluiu continuamente, aperfeiçoando-se ao final com a impressão off-set, denominada à época de fotolitografia off-set. Curioso é notar que ainda hoje, após 130 anos, os filmes revelados para gravação em chapas de impressão mantêm a denominação de fotolito (foto=luz e lito=pedra).

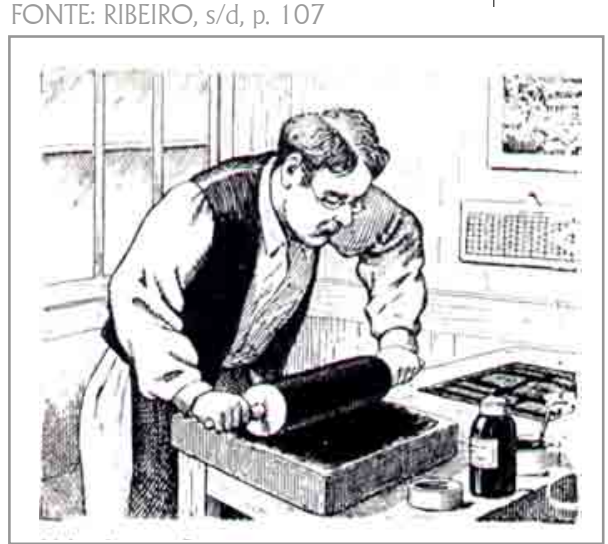

Litógrafo entintando a matriz de pedra calcárea Neste processo de impressão a pedra foi substituíd posteriormente pela chapa delgada de zinco.
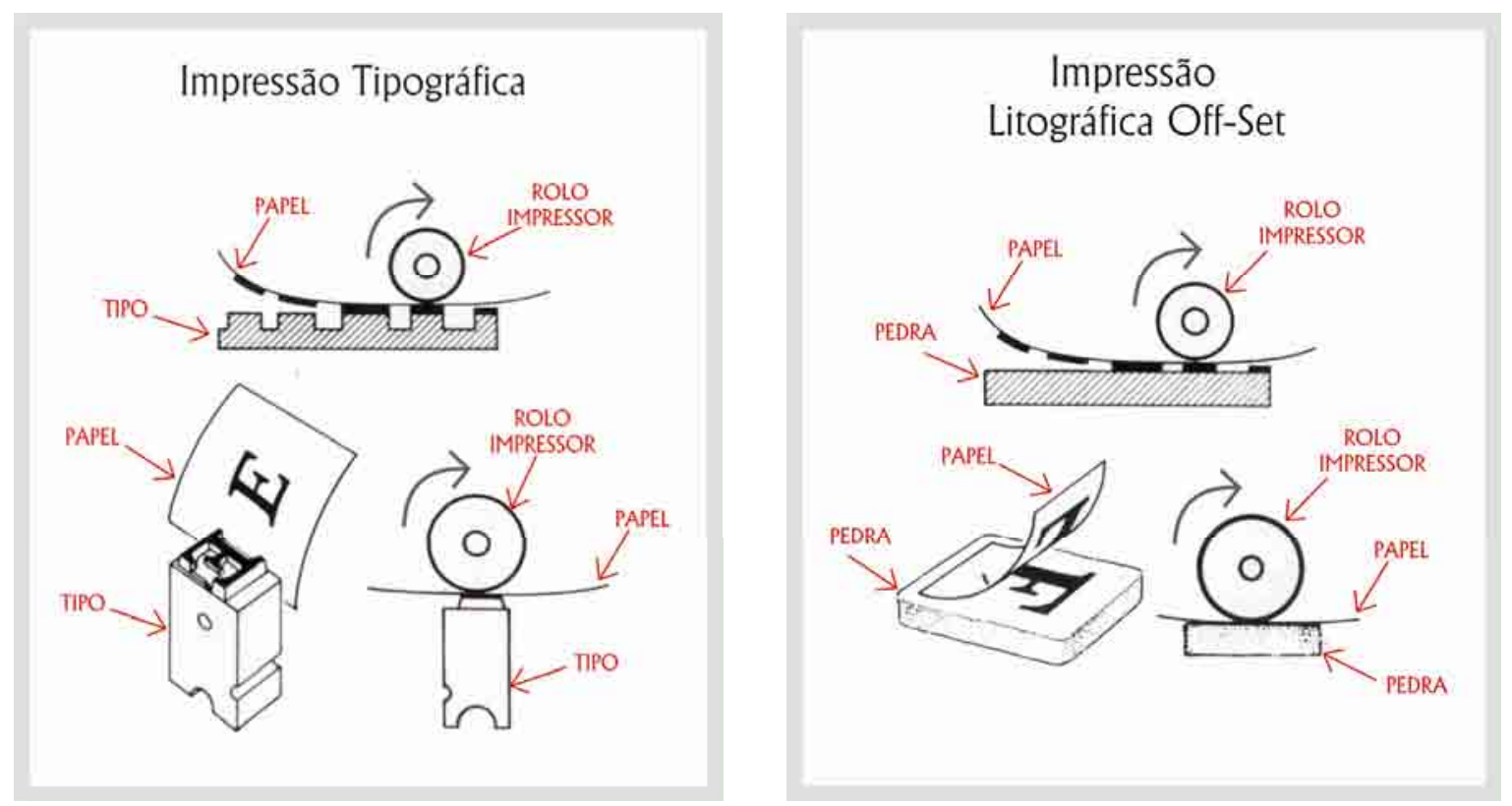


\section{A Imagem nos Jornais Brasileiros}

Como no exterior, na imprensa periódica brasileira também ocorreu uma gradual transição da ilustração gravada para a fotografia. Não fo imediata a adoção da fotografia nas publicações, por não haver condições técnicas de transferir e reproduzir mecanicamente a foto nos jornais. Só era possível copiar "fielmente" a foto à mão, realizada por artistas gravadores copistas.

Abaixo são apresentadas 3 litografias de Ângelo Agostini, demonstrando três diferentes formas de ilustrar baseadas em fotos ou em testemunhos relatados por terceiros.

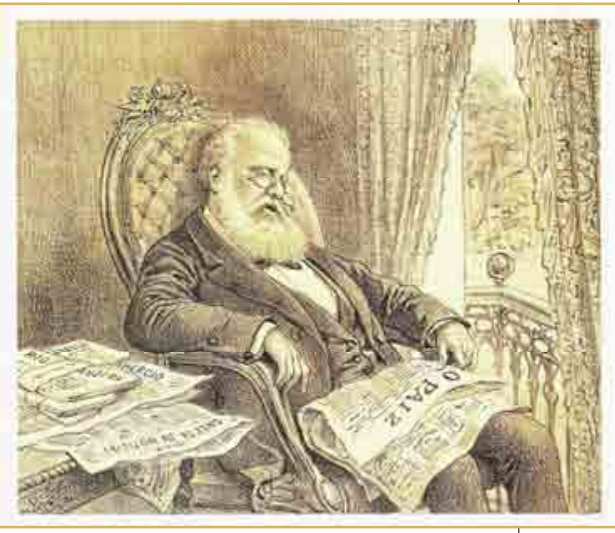

\section{$1=$}

O primeiro processo é uma composição imaginária utilizando a fotografia como referência. Esse processo ocorreu com freqüência em desenhos caricatos
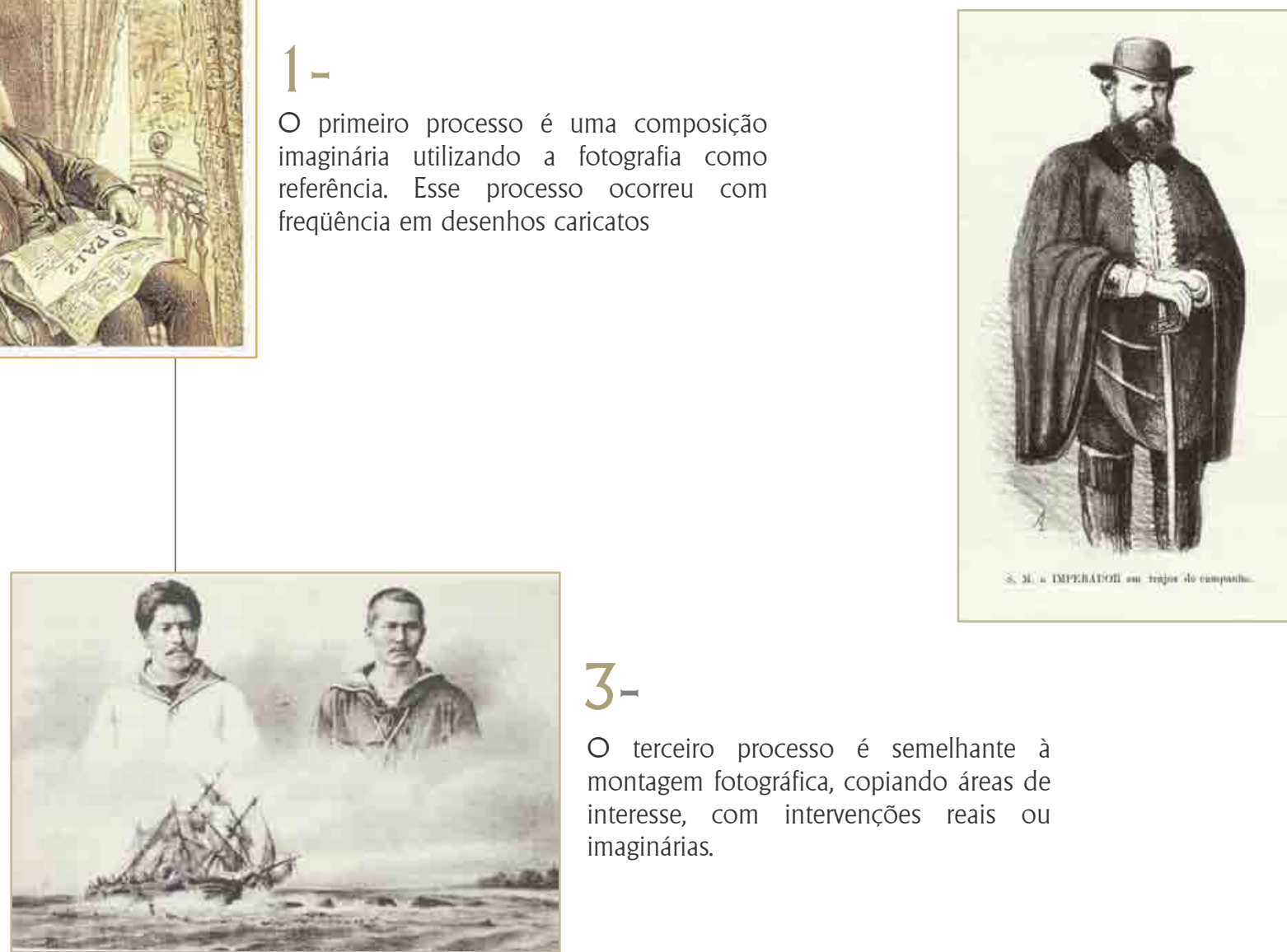

$2=$

O segundo processo é o da cópia integral, com todos os detalhes, cumprindo função documental.
3-

O terceiro processo é semelhante à montagem fotográfica, copiando áreas de interesse, com intervenções reais ou imaginárias. 
FONTE: $A$ História da fotorreportagem no Brasil. ANDRADE, 2004, p. 146-147

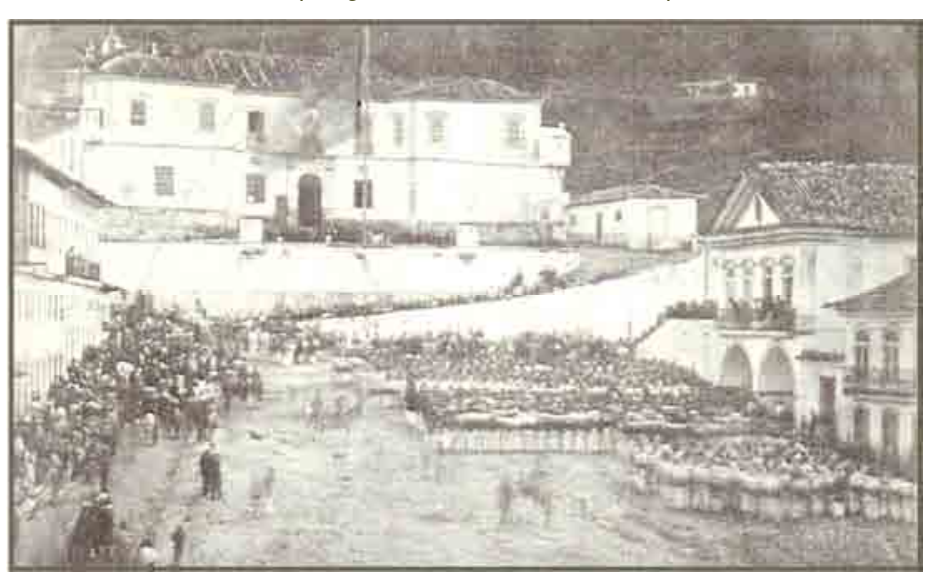

Com a gradual participação das fotografias no espaço do jornal, lentamente foi sendo retirado do desenho seu caráter de veracidade. Somente nas primeiras décadas do séc. XX o clichê reticulado permitiu reproduzir mecanicamente a fotografia original com todos os seus detalhes, ocasionando a eliminação por completo do desenho documental das páginas dos jornais.

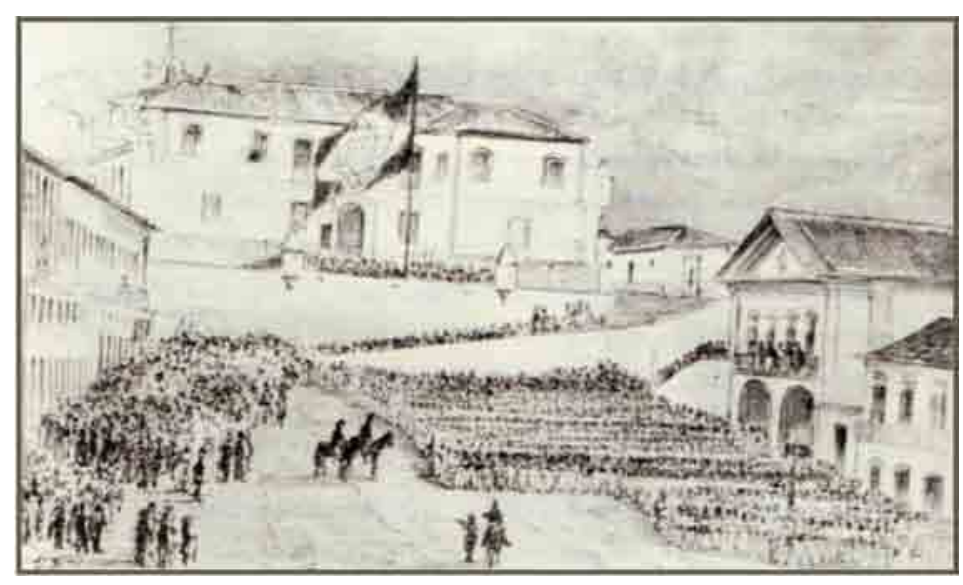

Desenho publicado na Semana Ilustrada de 09/07/1865, divulgando evento oficial ocorrido na praça de Ouro Preto.

Aqui se vê um exemplo da utilização da fotografia como base para o desenho litográfico. 


\section{3 - INFLUÊNCIAS E REPERCUSSÕES}

\section{Contextos Culturais}

Nos primeiros anos do século XX Vigotsky compôs uma obra em que expressa a existência de uma relação intrínseca entre palavra e pensamento (2).

(2) VIGOTSKY, Lev. Pensamento e Linguagem. São Paulo: Martins Fontes,

1973

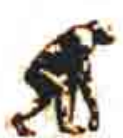

(...) e que essa relação é produto do desenvolvimento histórico da consciência humana. (...) A verdadeira comunicação humana pressupõe uma atitude generalizante, e que vai constituir um estágio avançado do desenvolvimento do significado da palavra.

(...) O significado de uma palavra representa um amálgama tão estreito do pensamento e da linguagem, que fica difícil dizer se se trata de um fenômeno da fala ou de um fenômeno do pensamento. Uma palavra sem significado é um som vazio; o significado, portanto, é um critério da palavra, seu componente indispensável. (Vigotsky,1993, p. 132)

Vigotsky (1993, p. 135) esclarece que, apesar de possuirmos as bases biológicas inerentes ao nosso ser, o que nos torna humanos é a capacidade de utilizarmos instrumentos simbólicos para complementarem nossas atividades.

Ele expressa que as formas tipicamente humanas de pensar surgem, por exemplo, na infância, quando uma criança pega um cabo de vassoura e o transforma em um cavalo. Os chimpanzés, por mais inteligentes que sejam, podem no máximo utilizar o cabo de vassoura para derrubar bananas e jamais para criar uma situação imaginária. O que nos torna humanos, segundo Vigotsky, é a nossa capacidade de imaginar.
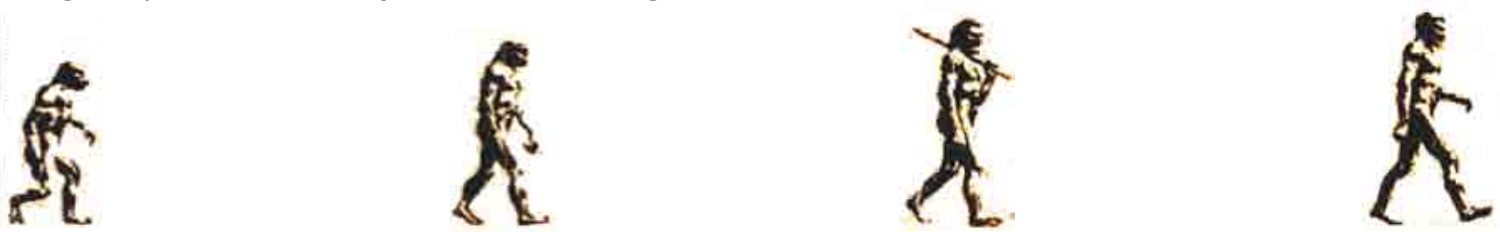

A linguagem é uma espécie de "cabo de vassoura", capaz de transformar decisivamente os rumos de nossa atividade. Assim, quando aprendemos a linguagem específica de nosso meio socio-cultural, transformamos os rumos de nosso próprio desenvolvimento. Portanto, o contexto social é de extrema importância na construção do indivíduo e de suas ações. 
Não só a ação do indivíduo é condicionada pelo meio social, como também as possíveis formas a serem criadas que vêm ao encontro de conhecimentos existentes, de possíveis técnicas ou tecnologias, respondendo a necessidades sociais e aspirações culturais. Assim, o indivíduo, ao lidar com uma matéria, ela já surge com algum nível de informação e já de certo modo configurada e impregnada de valores culturais. Todavia, o contexto cultural, como substrato individual do homem, fornece determinadas condições que permitem a manifestação e talvez a realização de certas propostas que em outras épocas seriam inconcebíveis.

O contexto do Renascimento permitiu uma visão como a de Leonardo da Vinci, assim como também permitiu o humanismo. A concepção do pensamento renascentista continha a possibilidade de observar o universo e entendê-lo pela razão, e não mais só pela fé.

As conquistas intelectuais sempre apresentaram expoentes em várias épocas, mas foi a partir da Renascença que revelou uma evolução sem precedentes, como fruto de um período de transformação, de desejo de investigação científica e de inquietação. Tudo isso abriu novas perspectivas para a humanidade e possibilitou construir e conduzir à sociedade moderna.
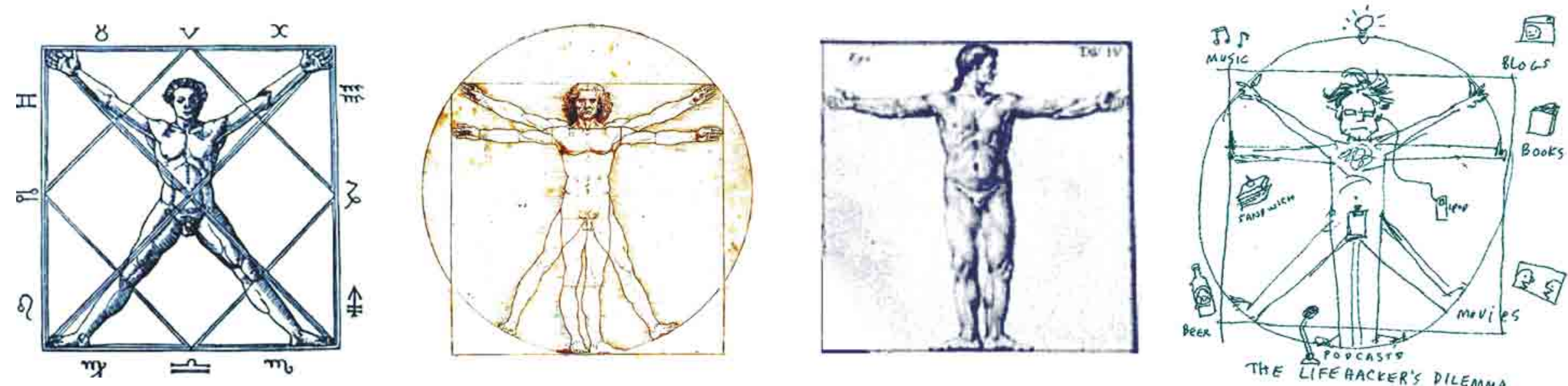
(3)

McLUHAN, Marshall. A galáxia de Gutembers São Paulo: Cia. Editora Nacional.

$$
1977 .
$$

No rol de fatores que também contribuíram para a ascensão humana e conduzir à sociedade moderna, deve-se priorizar a descoberta dos tipos móveis e a descoberta da prensa em substituição ao manuscrito.

Na obra A Galáxia de Gutemberg (3), de Marshall McLuhan (1977, p. 91), o autor frisa que a conseqüente expansão da sociedade mecanizada aconteceu a partir de meados do século XV, deflagrada com o processo de impressão com os tipos móveis. $\bigcirc$ autor argumenta que, com o impacto do advento do processo tipográfico, criaram-se meios de armazenamento da informação e possibilidades de criar recursos de recuperação instantânea do conhecimento, exigindo da humanidade uma nova dinâmica na reconstrução do diálogo.

Interessante, e inusitada ainda, é a reflexão oferecida por McLuhan (1977, p. 122) ao apontar que o planejamento industrial e militar do ocidente obedeceu a uma organização sistemática e linear que tem sua origem na existência e na popularização do alfabeto. Argumenta que, semelhante ao desenvolvimento linear da escrita alfabética, o mesmo ocorre com as transformações psicológicas e sociais nas sociedades letradas, que possuem seus controles centrados na uniformização e na continuidade.
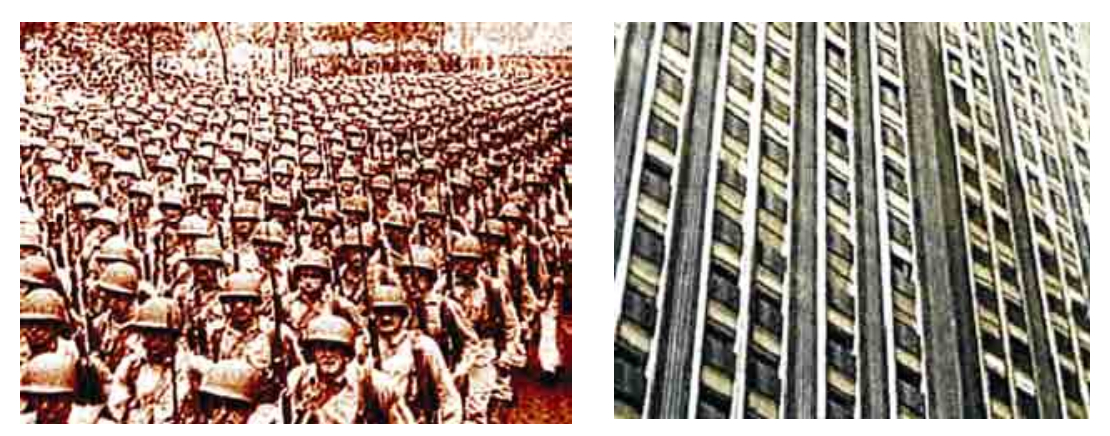

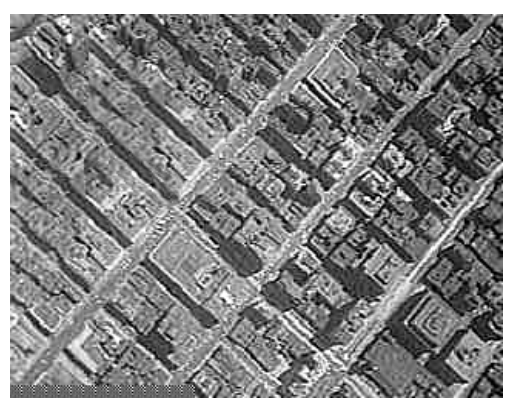


Ao alterar a dinâmica na articulação do pensamento, a palavra impressa, consequentemente, permitiu que o discurso mental e verbal sofresse impulso sem precedentes na história da humanidade.

A partir do século XX a rapidez tornou-se imperativa e a velocidade passou a ser presença constante, não se admitindo exceder em tempo a compreensão de um texto escrito. Pensar já não é, e nem pode ser predominante, pois pensar requer tempo.
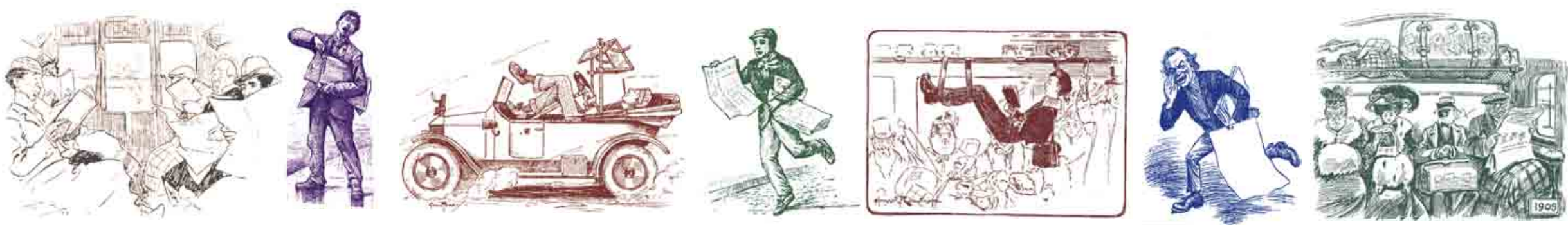

No dinamismo exigido atualmente na comunicação, é a imagem quem predomina. Falar em imagem equivale agora falar em reflexo, não mais em reflexão. Reflexo da imagem como tradução do mundo, não mais como reflexão mental sobre o mundo. 


\section{CAPÍTULO 6 \\ A INFORMACĀO}

6.1 - A CIRCULAÇÃO DA INFORMAÇĀO

6.2 - A VERSÃO DOS FATOS

6.3 - A VERSÃO DAS FOTOS 


\section{1 - A CIRCULAÇÃO DA INFORMAÇÃO}

\section{As Cartas Romanas}

Os mais antigos escritos aparentados com o jornal se constituem nas Efemérides, dos gregos, que não passavam de anuários astronômicos, anunciando a posição do Sol e as fases da Lua.

Posteriormente, em Roma, os acontecimentos importantes eram publicados numa tábua branca, o Álbum, que permanecia pendurado o ano todo no muro do palácio público. Daí resultaram os Anais (Annales Maximi), ponto de partida da história romana. Por possuírem periodicidade e atualidade, características próprias de um jornal, cedo atraíram a variedade e por conseguinte a popularidade.

Na linguagem romana, publicar alguma coisa não queria dizer levá-la a público e sim deixá-la ao conhecimento do público, afixando-a em lugar onde pudesse ser facilmente lida. Comunicava-se por simples exposição. $\bigcirc$ aumento e a freqüência dos textos implicaram no desdobramento dos álbuns e como nem toda gente pudesse lê-las no Fórum, começaram a mover-se dentro e fora da metrópole por meio de cópias particulares.

Apesar de já haver a difusão popular da leitura e da escrita, a circulação das cópias era trôpega e restrita, em vista da inexistência de correios públicos e devido aos altos custos do papiro e do pergaminho. Excetuando a técnica da tipografia, os romanos chegaram a conhecer todo o processo de evolução do jornalismo.

É através das Cartas Romanas ou Atas Romanas, que os letrados se valiam entre si. Passavam de mão em mão quando continham novidade de interesse. Liam-se, comentavam-se e transcreviam-se aquelas que os personagens públicos expunham seus pontos de vista. Era por meio delas que se procurava formar uma espécie de opinião geral. Certas cartas eram afixadas nas praças ou suas cópias corriam distribuídas pelos destinatários, tornando-as públicas.

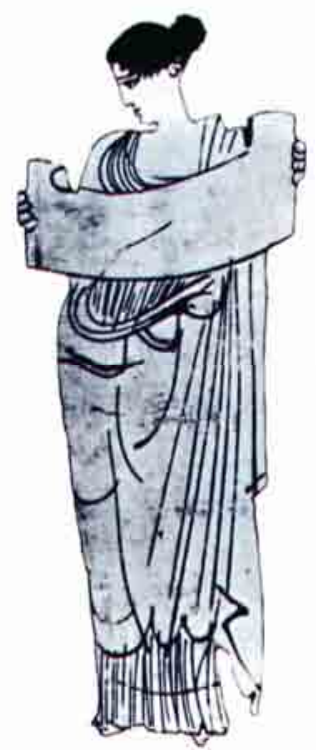




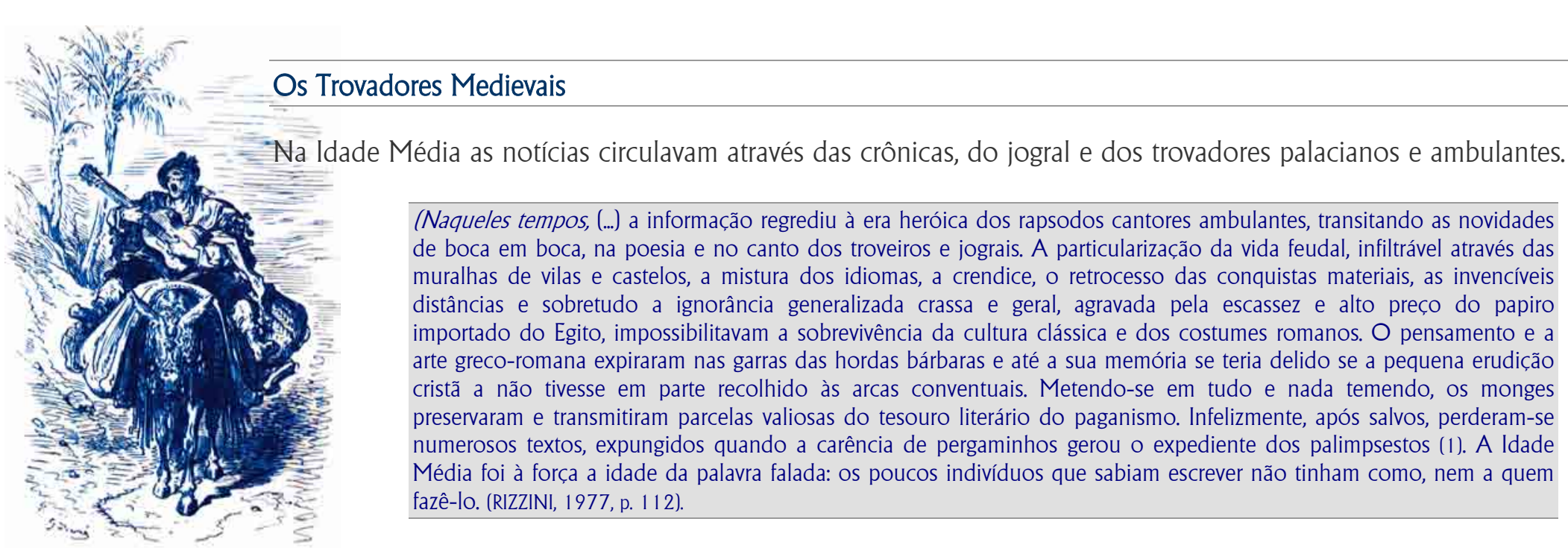

(1)

PALIMPSESTO

Pergaminho utilizado duas ou três vezes, mediante raspagem do texto anterior devido à sua escassez e alto preço.

RAPSODO = Cantor ambulante de rapsódias; RAPSÓDIA = Fragmento de poesia épica;

TROVADOR ou TROVEIRO = Poeta ambulante que cantava seus poemas ao som de instrumentos; TROVA = Composição ligeira e popular;

JOGRAL= Intérprete de poemas e cançōes de caráter épico, romântico ou dramático;

SÁTIRA = Composição poética que visa ridicularizar. GESTA = Canção que celebra grandes acontecimento CANTILENA = Estrofes breves, meio líricas,

meio narrativas;

MENESTREL = Cantor medieval de origem plebéia

a servico de um nobre;

CRONISTA = Narrador histórico que organiza

os fatos em ordem cronológica;

NOVELA = Narração ordenada de fatos humanos verossímeis
Os romances, as canções e as sátiras medievais eram como o prenúncio do periodismo, uma forma embrionária da informação em movimento. Até o século $\mathrm{Xl}$, as notícias difundiam-se pelas cantilenas cujo fundo seria largamente aproveitado na composição das canções.

Errantes por natureza, os trovadores e jograis na primavera retornavam com novas músicas e novelas, trazendo as aventuras da sociedade. As canções eram narrativas rimadas, ou enternecedoras ou cáusticas. "Após declamarem contos engraçados e fragmentos de epopéias, narravam o que tinham visto ou ouvido. Mostravam, através das sátiras e críticas, o reverso das almas e davam curso à malevolência e ao descontentamento do seu tempo". (RIZZINI, 1977, p. 121)

Chegados de cidades importantes, onde os fatos acontecem ou ressoam, eram os jograis recitadores mais estimados pelo que conheciam e podiam narrar, do que pelo repertório de músicas e canções inéditas. (...) Assim, não lhe transmitiam os fatos originais, mas a sua versão segundo o enredo palaciano e a mordacidade das ruas. Era o eco, o efeito dos acontecimentos, que os jograis levavam e expandiam; numa palavra: a opinião. (...) Isto é, eram mercadores de novidades políticas.

Um momento chegou (...) em que os jograis, esposando idéias, partidos e paixões, intervieram ativamente nas questões públicas, atacando os poderes estabelecidos. Gazeta viva e ouvida todos os dias, eles assoalhavam as notícias, comentavam-nas febrilmente e agitavam os povos. Nem essas, nem outras proibições evitaram que o jornalismo oral progredisse (...). (RIZZINI, 1977, p. 118). 


\section{Os Escritos da Renascença}

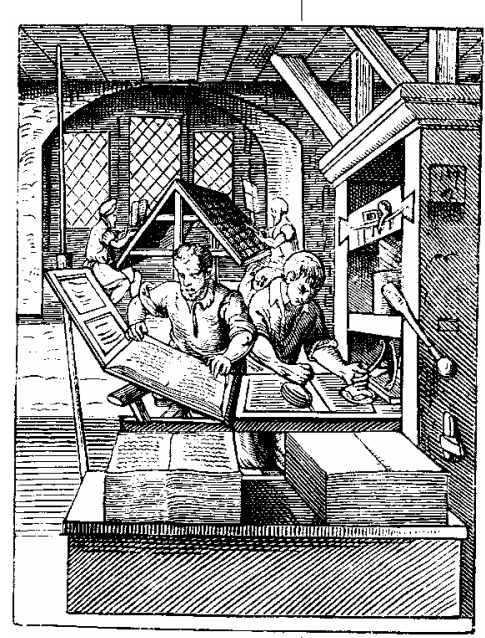

Irrompendo das trevas medievais para o Renascimento, a informação oral cedia espaço para a informação escrita. Tudo o que então se escrevia em prosa e verso, anotando os acontecimentos, reproduziam-se e expandiamse, atendendo à curiosidade e à sede crescente de conhecimento.

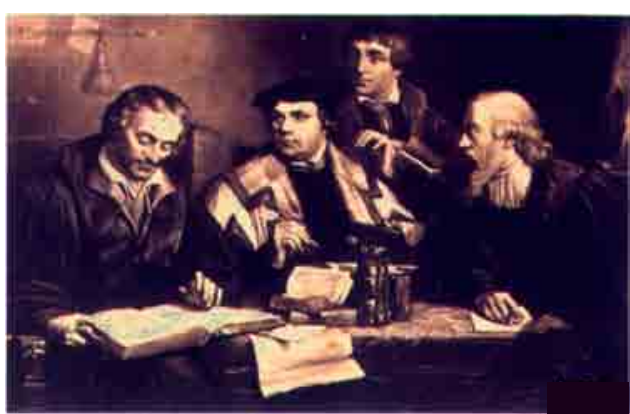

Até o amadurecimento da imprensa confundiam-se história e jornalismo. A informação não possuía meios adequados de projetar os fatos presentes, limitava-se aos novos fatos, embora antigos mas que ainda se mantinham relevantes. Os redatores de escritos, trabalhando com estes fatos, não podiam e não pretendiam fazer história. Hoje é nítida a diferença entre jornalismo e história. O jornalismo recolhe e espalha os acontecimentos vivos e quentes enquanto que a história os organiza e os interpreta.

As cidades italianas quase todas tiveram os seus cronistas. Um deles, de Florenca, (cerca de 1500) Pietro Villola, ofereceu a particularidade de versejar em tercetos só sucessos dia a dia, pondo-os à vista dos curiosos na sua papelaria mediante certa retribuição. Villola figurava-se informado por um peregrino, (estado embrionário de repórter, de apanhador de notícias), o qual, vindo de muitas partes, trazia-lhe o ano, o mês, o dia, o como e o quando dos acontecimentos. (...). (RIZZINI, 1977, p. 123).

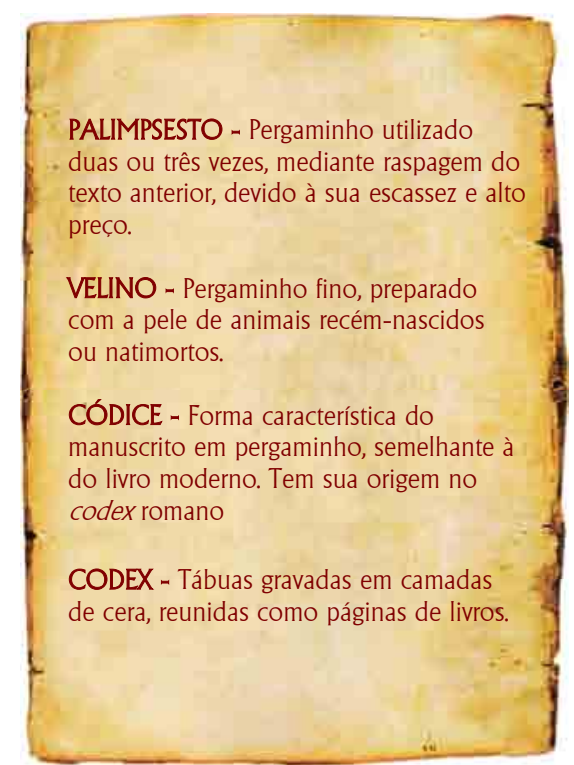

Nos registros genealógicos havia a preocupação também com as anotações marcantes das famílias. "Nos livros portugueses de Genealogia e Linhagens, dos séculos XIII e XIV, a par do cadastro das famílias, aparecem entremeadas as tradições das origens dos solares, prepotências senhoriais, incêndios de castelos, raptos e violentações, infidelidades de casados e desregramento de solteiras; ódios e malquerenças pessoais, apelidos de fidalgos, e casos mais ou menos célebres, ocorrências e assuntos próprios de jornal”. (RIZZINI, 1977, p. 132).

\section{O Papel}

A carestia do pergaminho na Idade Média responde pela perda de preciosidades literárias. Não tendo onde grafar salmos e antífonas ou simples notas e lembretes, os frades aproveitavam antigos manuscritos raspando-os ou lavandoos com uma solução alcalina (denominados palimpsestos). Os beneditinos de Monte Cassino, segundo testemunho de Boccaccio, expungiam os velinos e neles escreviam oraçōes que vendiam às crianças, ou cortavam-lhes as margens para fazer amuletos que vendiam às mulheres. (RIZZINI, 1977, p. 95).

No século XIV, com o maior aproveitamento do algodão e do linho, implantam-se as oficinas de papel, se instalando na Itália, França, Inglaterra e Alemanha. O papel de algodão e o de trapos de linho não substituíram logo o pergaminho no trabalho dos copistas. Até o século XVII os documentos de importância e os códices valiosos continuaram a ser escritos em peles, embora o papel já se apresentasse consistente e encorpado. O seu primitivo processo de fabricação, com a massa de trapos triturada em pilões movidos a água e modelada em fôrma perdurou até 1803 quando surgiu em Hertford, na Inglaterra, o papel-contínuo. 


\section{Os Correios}

O primeiro correio a aparecer confiável e ágil foi o pombo. Os antigos já haviam aproveitado a intuição com que ele e a andorinha se norteiam no espaço e voltam aos ninhos.

O papel e o correio exerceram decisiva influência na evolução do jornal. A evolução do jornalismo teria paralisado na carta particular, entregue por mensageiros casuais, se o advento do correio não a transformasse em jornal manuscrito, entregue regularmente. "O correio foi mais essencial (ao jornal) do que a tipografia. Importa mais ao leitor receber informações regularmente e em tempo, do que as receber escritas nesta ou naquela maneira” (RIZZINI, 1977, p. 112).

Em 1464 Luís XI instalou nas principais estradas da França, de quatro em quatro léguas, estações de muda para os correios a cavalo, iniciando-se assim a organização de um serviço regular. No século seguinte foi aperfeiçoado e tornado público.

\section{Primitivos Repórteres}

O legendário soldado de Maratona simboliza o correio na sua simplicidade. O encadeamento de vários mensageiros, a pé ou a cavalo, cobriu remotamente as mais longas e acidentadas distâncias. Durante anos sem conta esse foi o meio normal de comunicar a informação. A tantas jornadas de um lugar a outro - explica Heródoto - correspondiam tantos postos em que homens a cavalo, prontos a disparar, venciam celeremente os trajetos, afrontando a neve, a chuva, o calor e a noite. O primeiro correio transmitia as ordens ao segundo, o segundo ao terceiro, e assim passavam de mão em mão, como, entre os gregos o archote, nas festas de Vulcano. A essa carreira a cavalo denominavam os persas angareion, literalmente estafeta. Avisos convencionais transmitiam-se também e ainda hoje se transmitem através de sinais sonoros e luminosos. A esses sinais substituíram os telégrafos ou postígrafos, semáforos, ou "ianelinhas", como o povo chamava, situados nas pontas elevadas e nos morros (...). (RIZZINI, 1977, p. 124).

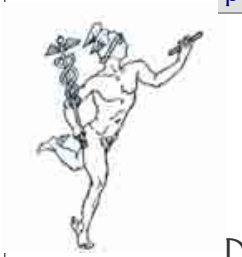

Do início da Idade Média até o século XIII, não houve outro meio de comunicação além da penosamente feita por emissários e transportadores e eventualmente por trovadores, que recitavam recados aos reis, príncipes e damas, quando não eram somente portadores silenciosos. 


\section{As Cartas de Notícias}

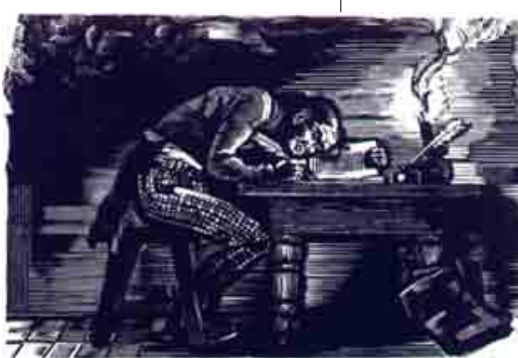

As cartas particulares dos séculos XVI, XVII, XVIII possuíam maior conteúdo jornalístico do que a maioria dos jornais avulsos impressos ou escritos à mão. Eram mais interessantes que as primeiras gazetas sob a égide dos governos, voltadas para o noticiário tendencioso. A organização do correio no século XVII implicou uma regularidade nas correspondências que mais se assemelhou às cartas do que aos jornais. Naturalmente as cartas passaram a constituir crônicas semanais. Mal seguiam os correios regulares, cuidava-se logo do próximo. Anotava-se isto ou aquilo, retinha-se de memória tal ou qual fato ou incidente, exatamente como faz hoje um secretário de jornal, que recebe e classifica a matéria da edição do dia seguinte.

Antes do periódico manuscrito, sustentado por quem pagasse, as cartas particulares atravessaram um estágio que marcou o ponto de germinação do profissionalismo: a periodicidade.

Como as cartas eram comumente trocadas entre pessoas do mesmo nível social, elas eram normalmente citadas nas conversas. E ao serem lidas em comum, ganhavam difusão própria. Alguns mandavam cartas aos amigos na esperança de que as copiassem e as distribuíssem entre si.

A carta-de-notícias era mandada a estabelecimentos comerciais e personagens de relevo pelos seus agentes no estrangeiro para que o conhecimento das informações pudesse preservar seus empreendimentos. Havia necessidade de se conhecer o que se passava em territórios distantes, inclusive além-mar.

Os negociantes, de um lado, e de outro os notáveis (...) assentaram redes de informações epistolares tão tensas e entretecidas, que sabiam em suas cidades, com relativa presteza, o que ocorria no mundo civilizado.

A pesada censura, a espionagem do Santo Ofício, a vigilância policial do poder e a força da própria fé, intolerante e grosseira, semeadora de sustos e suspeitas, faziam inviável o curso das notícias. Inúmeras pessoas padeceram os efeitos de inocentes indiscrições.

ão das bibliotecas onde se arquivam jornais e revistas.

Desde a reportagem dos crimes, até as informações da corte e da cúria patriarcal (...) desde os anúncios e comunicados, até às notícias da sociedade e às indiscrições mundanas, de tudo se encontra nesses arquiavós setecentistas da hemeroteca moderna.

Determinadas coleções de cartas são tidas como o melhor repositório de fatos e de opiniões do seu tempo, tão preciosas, quanto as posteriores colecões de jornais. A circunstância de serem as cartas de certas pessoas, mostradas, copiadas e colecionadas, criou aos poucos uma consciência profissional nos escritores de notícias.

(...) O jornalismo epistolar, quase periódico, de acordo com os (portadores, dispunha) de um público (...) ávido e crescente. Não necessitou senão atravessar do diletantismo ao profissionalismo para encarreirar-se no seu próprio (...) destino de informar mais. Mais depressa e a mais gente

A epístola, (...) (era então manuscrita), não por cortesia, mas por obrigação; não sobre assuntos escolhidos mas sobre todos; não a um destinatário-amigo, mas a quantos destinatários-assinantes se dispusessem a pagá-la - (...) (Aqui) surge a gazeta manuscrita. (RIZZINI, 1977, p. 132-138) 
(2) A palavra propaganda foi formada dentro da Igreja Católica, tendo origem semântica no termo latino propagare (propagar).

No início do século XVII o Papa Urbano VIII criou o Congretio de Propaganda Fide (Congresso de Propaganda da Fé) para organizar a maior difusão das idéias católicas em resistência ao avanço da doutrina originária da Reforma Luterana. (CARVALHO, 1998, p. 2)

(3)

NIHIL OBSTAT

Do latim: 'nada obsta'.

Termo com que a censura eclesiástica autoriza a publicação dos livros que the são submetidos

e contra os quais não existe objeção doutrinal.

Surpreendente é saber que o jornal manuscrito nasceu depois da tipografia. Isto ocorreu devido aos altos custos dos trabalhos tipográficos e à intolerância dos governos à divulgação de notícias, impedindo o uso freqüente da tipografia para difusão de notícias. Os redatores de gazetas manuscritas mantinham-se na clandestinidade e sob constante ameaça de encarceramento. Não cogitavam levar seus escritos a impressores. Compreende-se também que assim, isentos de censura, apresentavam noticiário desenvolto e ousado, apto a despertar e satisfazer a curiosidade pública. Enquanto que as gazetas impressas sofriam vigilância regular.

\section{Propagação e Controle}

Na Idade Média o poder absoluto da Igreja dominava a produção literária. Eram suas as maiores bibliotecas de manuscritos e o maior contingente de escribas. A Igreja era a grande detentora da informação. Em conseqüência influenciava quase que totalmente na produção literária, direcionando-as, em sua maior parte, para os temas religiosos (2).

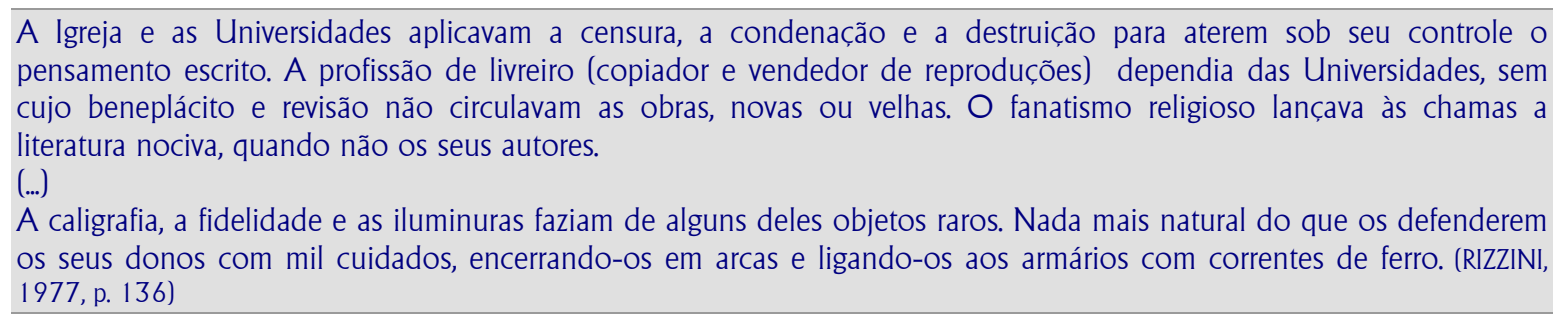

A Igreja e as Universidades aplicavam a censura, a condenação e a destruição para aterem sob seu controle o pensamento escrito. A profissão de livreiro (copiador e vendedor de reproduções) dependia das Universidades, sem cujo beneplácito e revisão não circulavam as obras, novas ou velhas. O fanatismo religioso lançava às chamas a literatura nociva, quando não os seus autores.

(1)

A caligrafia, a fidelidade e as iluminuras faziam de alguns deles objetos raros. Nada mais natural do que os defenderem os seus donos com mil cuidados, encerrando-os em arcas e ligando-os aos armários com correntes de ferro. (RIZZINI, 1977, p. 136)

A raridade dos livros extremava-se na exigência de transcrições exatas e límpidas. A princípio os escribas monásticos esmeravam-se na sua árdua tarefa, levando-a às alturas de uma devoção. Consideravam-na serviço de Deus e por isso privilegiado.

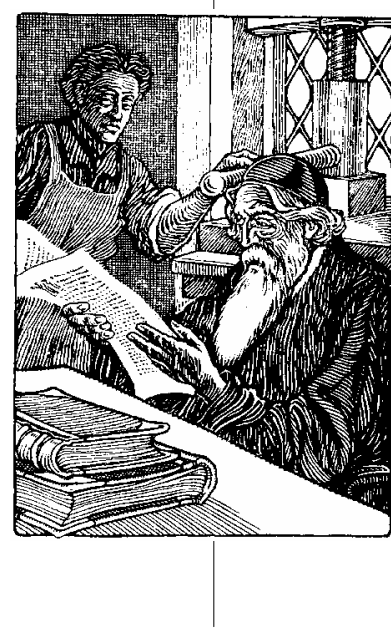

Os avulsos impressos (denominados folhas volantes) foram os precursores do jornal impresso. Estes eram à época eminentemente opinativos. Circularam, após a invenção da tipografia por Gutenberg em 1445, e fizeram a propaganda da Reforma na Alemanha e em outros países, que se desligavam da ortodoxia da Igreja de Roma. Contudo, como faziam os papas e os reis católicos, a impressão dessas folhas opinativas iria ser controlada e monopolizada pela autoridade leiga e pela lgreja. As "folhas volantes" sofreram dupla censura: governamental e eclesiástica, que, até então se confundiam em um só instrumento de poder. Tudo estava sujeito ao duplo nihil obstat(3).

Foram os movimentos sociais e a efervescência política provocados na Europa pela Revolução Francesa, em 1798, que restauraram o prestígio dos impressos de opinião. O público reclamava uma orientação e os impressos se converteram em agentes de luta, defendendo e propagando ideologias e combatendo opositores. 


\section{Circulação de Notícias no Brasil}

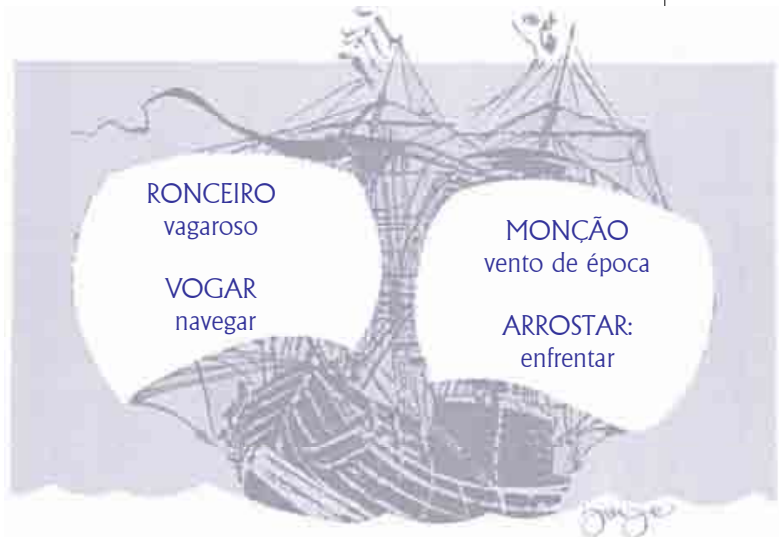

Repercutindo o que ocorria na Europa, as transformações chegavam tardiamente ao Brasil. E por aqui se processavam em ritmo lento.

(...) (No Brasil Colônia) as notícias do mundo chegavam (...) envelhecidas de meses, de semestres e até de anos. Os navios eram poucos e ronceiros, vogavam nas moncões e arrostavam riscos sem conta. Uma ou outra carta de família ou negócio, recomendaçōes e ordens oficiais, e o relato infiel dos marinheiros - eis o que vinha do além-mar. Vinha e estagnava nas soleiras litorâneas da Bahia e do Recife. Daí, para atingir escassos núcleos de vida tinha de baldear para as embarcacōes da costa e dos rios e para o lombo dos animais. Notícias - o que menos importava - sempre vinham, fosse nas naus reais ou nos barcos dos reis amigos, fosse nos navios portugueses avulsos que excepcionalmente licenciados traziam mantimentos. (RIZZINI, 1977, p. 99).

Por muitos anos o correio do mar entre Portugal e Brasil ficou limitado a viajantes e marinheiros. Por mais de três séculos o navio de vela foi a única ligação entre os pontos do litoral. $O$ traço de união entre esses pontos e os povoados ribeirinhos, os engenhos, as fazendas foram a canoa e os animais de carga.
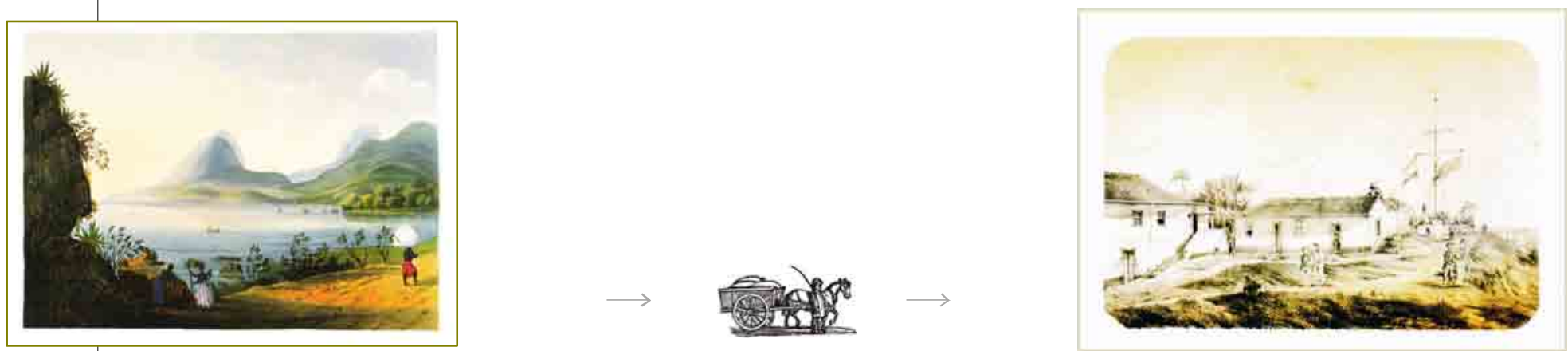

Enquanto permaneceu Colônia, o pouco papel consumido no Brasil vinha de Lisboa. Aqui não havia tipografia e o povo imerso em completo analfabetismo. $O$ papel que chegava era destinado apenas a embrulhos, para raras cartas ou escasso expediente oficial. Contudo, em 1809, já com a Família Real por aqui, conseguiu-se no Rio de Janeiro o fabrico de folhas de papel à base de embira, uma espécie de planta fibrosa. 
Com a chegada da Família Real ao Brasil, em 1808, nasce a imprensa, mas não o jornalismo brasileiro. Nessa primeira fase o governo dá condições técnicas, mas censura a expressão dos cidadãos. É uma imprensa defasada, autoritária e arcaica.

Os jornais se configuravam como "Boletins Oficiais" e, algumas vezes, eram utilizados como elementos de instauração da prática da contra-informação, cuja afirmação se deu no Império através do surgimento dos pasquins, quando a "imprensa oficial" se sentia no dever de combater aqueles ousados pasquineiros, (...) insufladores de rebeliōes contra os poderosos.

A maioria dos jornais desse século se caracteriza pela proximidade que eles encerram com o poder, além de uma existência-periódica ligada à autorização da Corte. Portanto, nessa fase da nossa história não existia o jornalismo enquanto prática de produção da informação e codificação de eventos sociais para transformá-los em notícias. (BELTRÃO, 1980, p. 50)

O jornalismo surge oficioso e subordinado à dupla censura: leiga e eclesiástica, se fazendo antes como informativo e literário. A opinião só vai tomar fôlego na imprensa brasileira após a Independência, em 1822 e eclodir, incontrolável e apaixonada em 1827, quando um decreto ministerial declara abolida formalmente a censura. Essa liberdade chegou a inqualificáveis excessos com os panfletos e pasquins, em "ataques pessoais e insinuações maldosas".

A imprensa no Brasil da segunda metade do século XIX não pode ser considerada como um exercício puramente jornalístico. $\mathrm{O}$ caráter doutrinário embutido nos impressos perfazia uma imagem de jornal que, em sua maioria, não sobreviviam longe da sombra do poder. Praticamente, não havia o exercício de construção da "opinião pública", mas uma imposição de idéias como instrumento de reforço ético e social para as medidas dos governantes.

No Brasil, a fase do predomínio da opinião sobre o objetivismo frio da informação, se estende desde a Regência até por volta de 1880 (...) quando o jornal toma características de empreendimento mercantil. A imprensa adquire expressão no campo das atividades industriais.

(...)

Desde logo a tipografia perde o seu conteúdo artesanal para conquistar a posição de indústria gráfica de definida capacidade econômica. Os pasquins, os papeluchos, os jornalecos efêmeros, de duas ou quatro folhas de reduzido formato e limitada penetração, desaparecem não como por encanto, porém como resultante das novas condições sociais (...).

Uma imprensa participante é chamada a ocupar lugar de fundamental influência no quadro da vida pública do País. (SODRÉ, 1966, p. 43)

A imprensa e o jornalismo existem, mas os jornais só se firmarão como empresa no final do século XIX. 


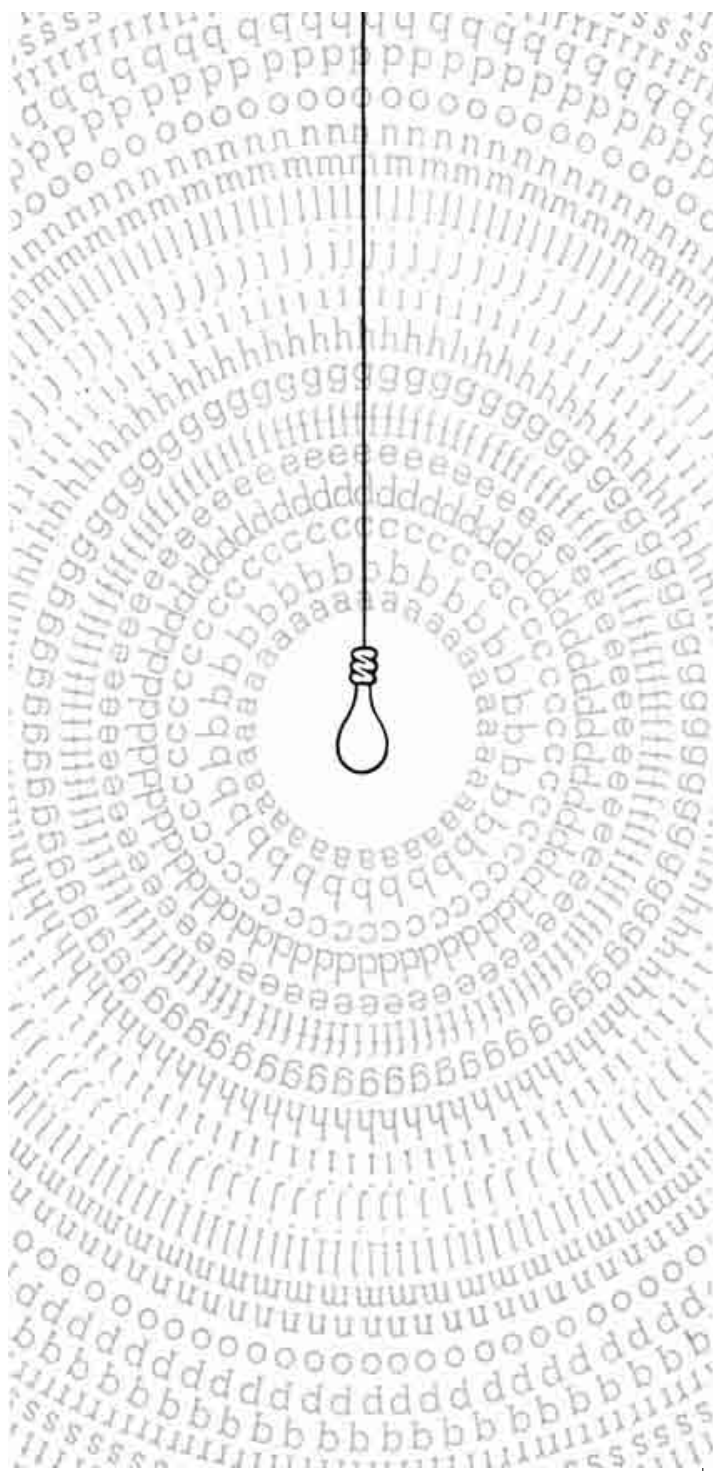

\section{2 - A VERSÃO DOS FATOS}

\section{A Imagem Informativa}

A partir da invenção do processo tipográfico ampliou-se a difusão da informação através das palavras, predominando o conceito de que as figuras impressas deveriam ser apenas ilustrativas. Deveriam somente harmonizar visualmente o texto, evitando que atraíssem para si a atenção do leitor em detrimento da palavra ou da apresentação dos caracteres tipográficos.

Por séculos a palavra prevaleceu como articuladora do pensamento e das idéias. Outros fatores contribuíram ainda mais para relegar a ilustração a um segundo plano.

1 Ainda no século XVII, na Europa, havia grande contingente de pessoas que não sabiam ler, cujo interesse se voltava para as imagens, principalmente nos nascentes periódicos populares ilustrados. Mesmo sendo os livros bem mais baratos, devido à produção tipográfica em série, ainda eram caros para o homem comum.

2ำ A história da imprensa registra a difusão do conhecimento como privilégio das elites. Pois, livros com bom conteúdo literário e informativo eram mais caros e destinados à aristocracia, enquanto ao povo comum eram direcionados os impressos mais baratos com figuras em folhas soltas.

3을 Os periódicos ilustrados nunca foram vistos com bons olhos pelos intelectuais do séc. XVIII. Os jornais, mesmo sem figuras, eram considerados na categoria "livros periódicos". Ali nascia o conceito, que permanece, de que a publicação com maior quantidade de texto verbal possui melhor conteúdo literário e informativo em comparação com as publicações que apresentam farto conteúdo de imagens.

4ํㅜㄹevalece até hoje também um conceito inexorável que a própria imagem transporta consigo, no que diz respeito à sua facilidade de assimilação. A compreensão pela imagem é imediata, enquanto que a compreensão pela palavra é mediada. Ou seja, por ser a palavra uma linguagem simbólica, necessita de um código para seu entendimento, exigindo maior esforço para sua compreensão. Assim, consequentemente, o leitor considera ter havido um esforço intelectual maior do autor para elaboração do texto do que do artista para a produção da imagem. 


\section{A Empresa Informativa}

Se o conhecimento sempre foi considerado um privilégio e uma riqueza da humanidade, na mesma proporção suas formas de difusão também sempre foram valorizadas. Daí a importância para com o surgimento da imprensa que permitiu a produção de impressos em série, como livros e periódicos.

A tipografia foi decisiva pela mudança da forma de transmitir conhecimento, não apenas no aspecto prático, ao dispensar a cópia manual de textos, adotando a técnica mais rápida e simples de duplicação, mas também no econômico. O que era impresso em série passou a custar bem mais barato que a cópia manuscrita, um estímulo precioso para a cultura e a educação, para o aprendizado da leitura e da escrita. A grande maioria da população que não podia pagar por cópias manuscritas, passou a ter acesso aos impressos multiplicados pela prensa tipográfica a custos menores. (CARVALHO, 1998, p. 46)

As décadas seguintes à invenção da tipografia significaram tempos de ruptura ao bloqueio do conhecimento e da informação, que até àquela época era privilégio das classes abastadas. Antes, os caros livros manuscritos eram reservados às bibliotecas particulares sem acesso ao público em geral.

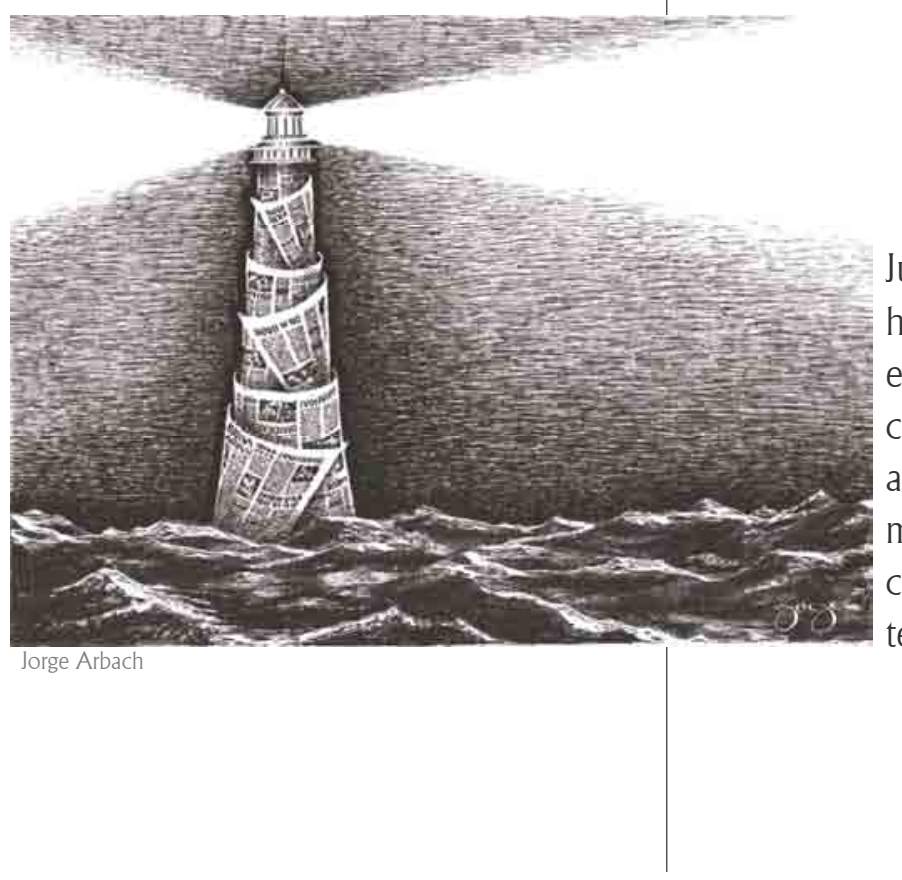

Junto com a tipografia, o jornalismo é outra forma de difusão do conhecimento valorizada pela humanidade. Teve início nas cartas de notícias manuscritas que traziam, para comerciantes e empreendedores, informações de interesse de regiões distantes. O jornalismo como nós o conhecemos caracterizou-se desde seus primórdios por selecionar e hierarquizar os acontecimentos, construindo a realidade, interpretando as notícias, o conhecimento, a cultura e o mundo. Buscou métodos e aperfeiçoou formas de narrativas para melhor atrair e se comunicar com o leitor. Utilizando a linguagem adequada para o grande público, valeu-se dos processos técnicos e editoriais específicos de cada período histórico. 


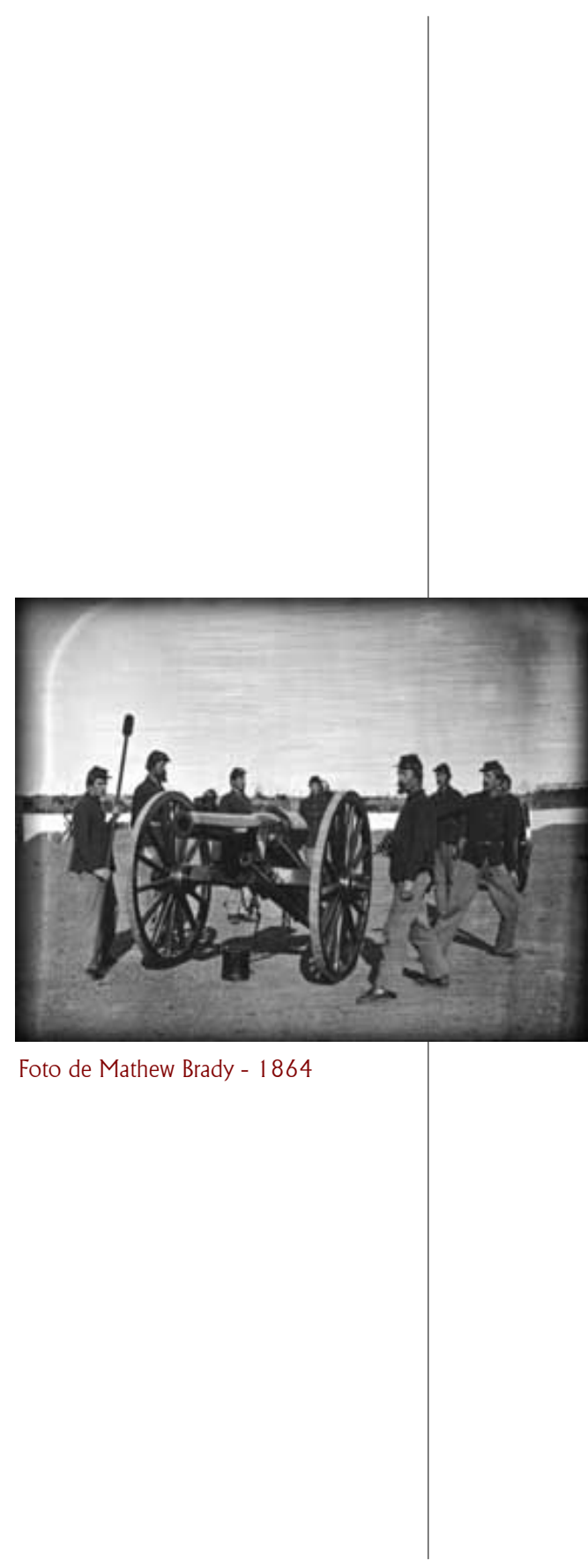

Em meados do século XIX as nascentes empresas jornalísticas norte-americanas se depararam com o desafio de diariamente apresentar um jornal com conteúdo editorial que atraísse e agradasse o leitor comum. A saída foi criar uma imprensa popular privilegiando mais a notícia que o artigo opinativo. Uma imprensa que utilizasse mais a imagem do que o texto.

O novo modelo do jornalismo informativo enfrentou oposição dos modelos tradicionais do jornalismo opinativo em função de ideais político-partidários. Porém, na luta travada entre os dois gêneros o uso da imagem foi fundamental para que o jornalismo informativo se firmasse como meio de comunicação de massa, em contraposição ao jornalismo opinativo que, apesar de ser o único praticado até então, possuía perfil elitista.

O entrelacamento definitivo da tríade jornalismo, capitalismo e progresso técnico solidificaram-se no advento da revolução industrial. Alguns anos após sua invenção, a máquina a vapor foi utilizada para mover as prensas tipográficas, permitindo a produção em massa dos meios impressos a preços reduzidos, o que possibilitou grande circulação. Nascia a comunicação de massa, através de jornais e revistas.

Era o nascimento do jornalismo informativo, legitimado pelo uso da imagem, opondo-se ao jornalismo opinativo. (BELTRÃO, 1980, p. 61)

Essa imprensa informativa de massa atingiu seu ápice de tiragem com a Guerra da Secessão na década de 1860. O público, ávido por informações do confronto, consumia cada vez mais jornais e revistas. E estimulava que utilizassem um dispositivo decisivo para a consolidação do jornalismo noticioso: a imagem fotográfica.

O jornalismo informativo surgia para atender as necessidades dos primeiros veículos populares de comunicação. Surgiram em função do desenvolvimento capitalista da época, ficando caracterizada como grande empresa comercial e industrial. Um negócio como qualquer outro que precisava vender seu produto: a notícia. Vender para o grande público, e vender barato! Graças às grandes tiragens foi possível alcançar tal meta. "Quanto mais, melhor!"

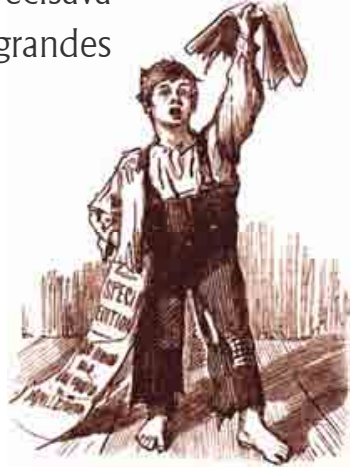




\section{A Versão dos Fatos}

O jornalismo veicula três categorias específicas de opinião: a do editor, a do jornalista e a do leitor, que, juntas, irão oferecer à comunidade a manifestação (...) da opinião pública.

A opinião do editor é expressa pelos editoriais e pela linha do jornal, identificáveis pelo critério de seleção das informações, pelo relevo dado a determinadas matérias, pelos títulos, fotografias e outras características.

A opinião do jornalista reflete (...) uma parte expressiva do público, contribuindo de modo decisivo para a formação do pensamento coletivo (...).

(...) (e as cartas) constituem mesmo o único e mais efetivo recurso de que dispõe o editor para receber o retorno do imenso e disperso público receptor de suas mensagens. (BELTRÃO, 1980, p. 76)

Mesmo mantendo acesos os ideais jornalísticos, não há como o jornalista passar as informações imunes aos seus próprios conceitos. Mesmo que a editora para qual ele trabalha não lhe exija comprometimento às suas diretrizes, comercial e ideológica, ao dar um cunho interpretativo à

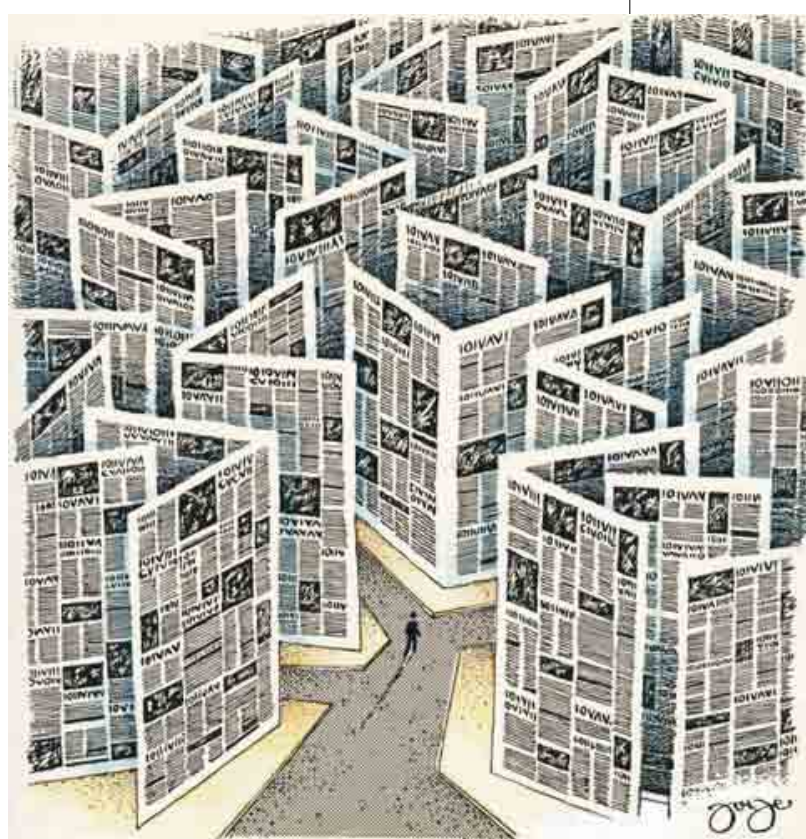

Jorge Arbach narrativa, ele sempre apresentará a interpretação do fato de acordo com a sua formação sóciohistórica.

\section{A interpretação jornalística consiste em saber que (...)}

(...) a cada momento o jornalista tem em mãos um enorme volume de fatos e situações que se poderão transformar em matéria de difusão; contudo, o veículo de que se utiliza, seja por limitação de tempo ou de espacco, reclama uma seleção, efetuada à base do primordial interesse do público, o que exige "o desenvolvimento de um critério especial, de um juízo jornalístico, que se resume em submeter o interesse particular e transitório para obter a universalidade e considerar, nos fatos, o seu valor permanente". (BELTRĀO, 1980, p. 37).

O relato jornalístico, mesmo situando-se mais próximo possível da verdade, será o produto de uma interpretação pessoal ou de determinado grupo, já que, qualquer instituição, ao se referir a um assunto, apresentará suas observaçōes sob uma visão particular, inerente aos seus princípios. Daí, podemos admitir que a objetividade não existe. Não há como admitir a existência de uma história "pura e verdadeira" sem a interpretação histórica do jornalismo sobre o fato narrado. (CARVALHO, 1998, p. 52).

Não é de hoje que se diz que a simples escolha de uma pauta contraria o conceito de objetividade e de imparcialidade. O mesmo ocorre quando se escolhe uma notícia, um lead, uma legenda, um título ou uma imagem. 


\begin{tabular}{|cr|}
\hline (5) & $\begin{array}{r}\text { DENOTATIVO } \\
\text { A imagem é revelada } \\
\text { por sinais objetivos }\end{array}$ \\
& \\
(6) & CONOTATIVO \\
& A imagem é revelada por \\
associações subjetivas
\end{tabular}

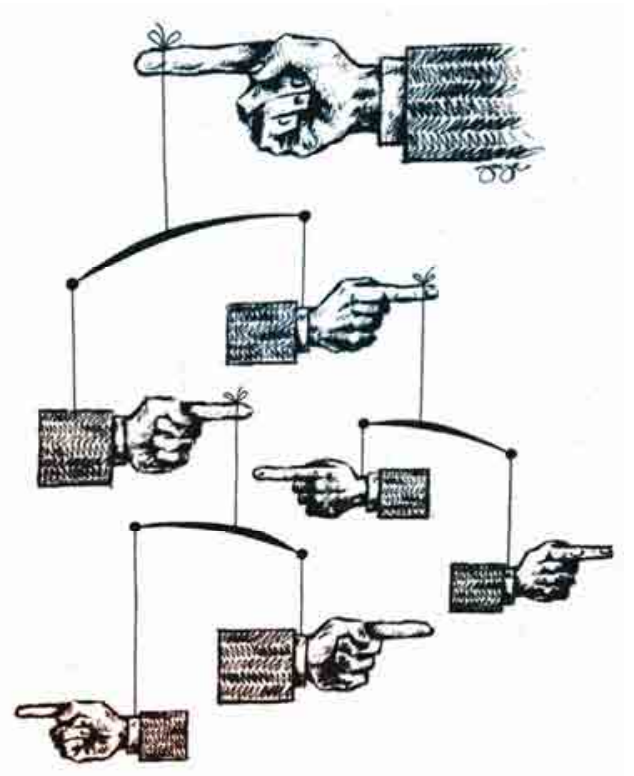

Ao ser empregada inicialmente pelo jornalismo, a própria fotografia já sofria a intervenção do profissional copiador da placa de madeira xilogravada ou da chapa de metal riscada a buril. Ou seja, a imagem fotográfica era copiada à mão e, sempre que necessário, era acrescida ou subtraída de detalhes da foto original. Após seu invento (até a descoberta do negativo para confecção do clichê) a fotografia teve que esperar por cerca de 40 anos para ser reproduzida integralmente num jornal. Fato que ocorreu em 1880.

A fotografia, especialmente a jornalística, por sofrer os processos de edição é muito mais polissêmica que o texto verbal. A subjetividade do leitor é incentivada, não só pelas fotos, mais ainda pelo desempenho das invenções ilustrativas.

(....) a fotografia, embora sendo também imagem, não possui a capacidade opinativa do desempenho caricatural. Antonio Luis Cagnin explica essa diferença entre desenho e fotografia: "se, por um lado, a fotografia pode escolher o seu assunto, o seu enquadramento e seu ângulo, por outro lado, não pode interferir no interior de um objeto (salvo trucagens), isto é, a denotação (5) do desenho é menos pura que a denotação fotográfica, pois jamais houve desenho sem estilo. Na fotografia, a cena é captada mecanicamente mas não humanamente (o mecânico, no caso, é a garantia de objetividade); as intervenções do homem sobre a fotografia (enquadramento, distância, luz, filtro, granulações etc.) pertencem todos, com efeito, ao plano da conotação (6), tudo se passa como se houvesse, no ponto de partida (mesmo utópico), uma fotografia (frontal e nítida) sobre a qual o homem colocaria, graças a certas técnicas, os signos extraídos do código cultural". (BRIL; MELO, 1987, p. 114)

O jornalismo atual enfrenta ainda o desafio da linguagem rápida e objetiva das imagens que outros meios utilizam, principalmente a TV. Isso faz com que o jornal impresso se molde ainda mais aos esquemas do texto curto, diminuindo os espaços para a palavra e aumentando para a imagem. Para enfrentar a concorrência com a televisão o jornal procurou ser também imagético por meio de uma interatividade entre linguagem escrita e linguagem visual.

Hoje o jornal impresso, que em sua história primou em buscar o texto mais analítico, procura também ser cada vez mais uma reprodução dos processos televisivos, marcados pela fragmentação de relatos.

Diante da certeza da subjetividade no jornalismo, devemos trabalhá-la na consideração de seus dois aspectos: um que proporciona a interpretação mais coerente, esclarecedora e precisa do fato; outra que procura desviar o sentido da notícia em relação ao acontecimento real, apresentando versões não condizentes com a realidade, com o propósito de provocar interpretações de interesse particular. (CARVALHO, 1998, p. 97). 


\section{3 - A VERSÃO DAS FOTOS}

O jornal é um catalisador de opiniões, um agente da consciência pública. Não é o que cada um pensa e exprime, mas somatório do que pensa uma expressiva parcela da opinião pública. Daí que a linha editorial do jornal deve imprimir o mesmo caráter incisivo e convincente com que se exprimiria em um artigo no qual expressasse seu ponto de vista pessoal. $O$ jornal é como um porta-voz, que amplia o tom das palavras e o sentimento das idéias para que atinja a comunidade, levando-a a se manifestar e agir.

Os meios impressos procuram atender às necessidades de informação de seu leitor, como agente social de extrema importância. Nesse sentido temos a narrativa integrada à sociedade, atendendo às suas aspirações, interpretando seus acontecimentos, orientando suas concepções, privilegiando e destacando determinados fatos... ou escondendo outros.

Porém as notícias jornalísticas correm o risco de não passarem de versões. Podemos buscar o exemplo das pesquisas históricas que para comprovar determinado acontecimento do passado utiliza a reprodução da página de jornal da época. Tal procedimento reforça a condição da imprensa como "documento histórico" e "fonte de verdade". Mas quando se confrontam páginas de publicações diferentes de mesma data, enfocando os mesmos fatos, é possível verificar que cada jornal narra a história apresentando versões muitas vezes divergentes.

O mesmo tipo de orientação pode ser feita pelo editor de fotografia, através da escolha de fotos, de cortes e pela justaposição de imagens que, isoladamente, contariam uma história diferente.

Já nos primórdios da fotografia, os primeiros correspondentes de guerra se tornaram exemplos de como o mesmo fato
(...) pode ser "interpretado" como múltiplas verdades Em 1855, o fotógrafo inglês Roger Fenton capta, na Criméia, em
360 placas de vidro, as imagens de uma guerra suave, guerra piquenique, quase que sorridente. A reportagem era
dirigida de modo a não chocar as famílias dos combatentes. Uma guerra pousada, "subjetiva", autocensurada. (...). (Já)
Em 1861 , o fotógrafo norte-americano Matthew B. Brady, caçador da verdade, traz milhares de daguerreótipos da
guerra civil americana. O foco da guerra aqui é bem diferente. (BRIL; MELO, 1987, p. 14)

Encarada como registro visual da verdade, a fotografia foi incorporada, no início do século XX, à atividade jornalística na condição de "evidência material" do acontecimento relatado pelo texto. A fotografia passava a ser um recurso adicional destinado a reforçar a "verdade dos fatos". Exigência básica feita ao texto jornalístico. 
O semiótico Charles Peirce classifica a fotografia como índice, isto é, um signo indicativo como um traço deixado por seu objeto, a exemplo da pegada que um pé descalço deixa na areia molhada.

Uma vez associados, a fotografia e o jornalismo passaram a reforçar mutuamente o ideal de objetividade, uma vez que a foto era oferecida como um certificado visual do texto, incorporando nela a existência da "prova", na condição de registro fidedigno da verdade.

\section{Controle Visual da Opinião}

Depois da II Guerra Mundial e em face da crescente popularização dos novos veículos audiovisuais de informação, observamos que passou a ocorrer na política editorial dos jornais a tendência para o jornalismo interpretativo, que não se limita somente aos aspectos descritivos do fato, mas explora suas causas e repercussões na sociedade.

A edição da notícia é essencialmente objetiva: relata aquilo que sucedeu, está sucedendo ou vai suceder. Para o editor é necessário apresentar uma outra dimensão, além das do tempo e do espaço que limitam o fato, é necessário apresentar a dimensão da profundidade. Assim, o enfoque dado pelo editor tanto pode nascer da notícia, como dela transcender, ou adiantar-se sobre ela, valendo-se de dados subjetivos ou retirando de um fato inferências e conclusões que apresenta como um roteiro à comunidade.

O texto de um editorial moderno não é apenas opinião. Inclui análise e esclarecimento mesmo que não opine. Expõe e interpreta o que é obscuro do aparente caos da mistura dos acontecimentos.

Para a fotografia jornalística atribui-se poder documental que advém da percepção de que a imagem fotográfica é uma espécie de testemunho do objeto fotografado. Até o advento da fotografia as páginas dos jornais eram maciçamente ilustradas artesanalmente com gravuras de madeira ou metal. A ilustração perdeu gradualmente espaço como mecanismo de informação ao ser introduzida a veracidade do fato, garantida pelo testemunho da foto.

Num veículo de comunicação em que o aproveitamento do tempo é fator preponderante para o resultado final do produto, a possibilidade técnica que tem a fotografia de gerar original mais rápido, concorreu para reduzir as ilustrações artesanais das páginas dos jornais. 

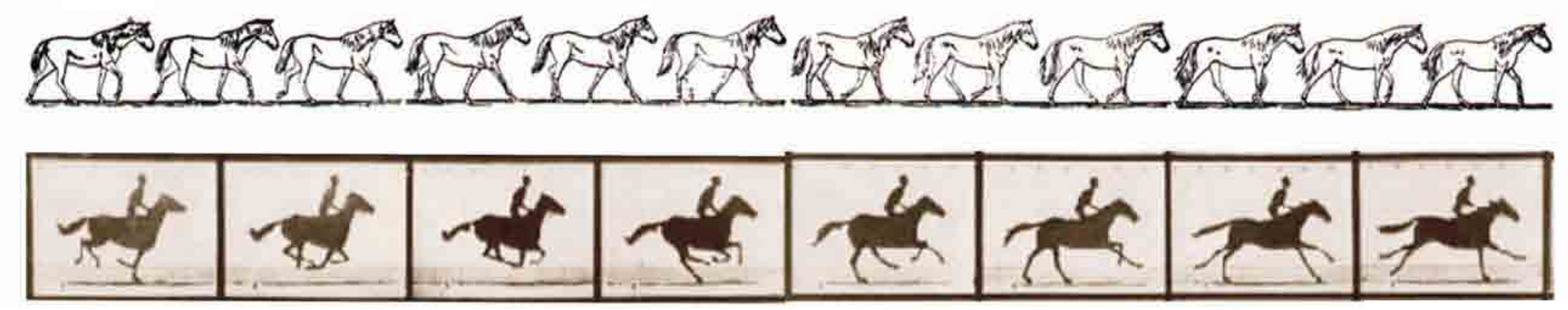

Eadweard Muybridge - 1872
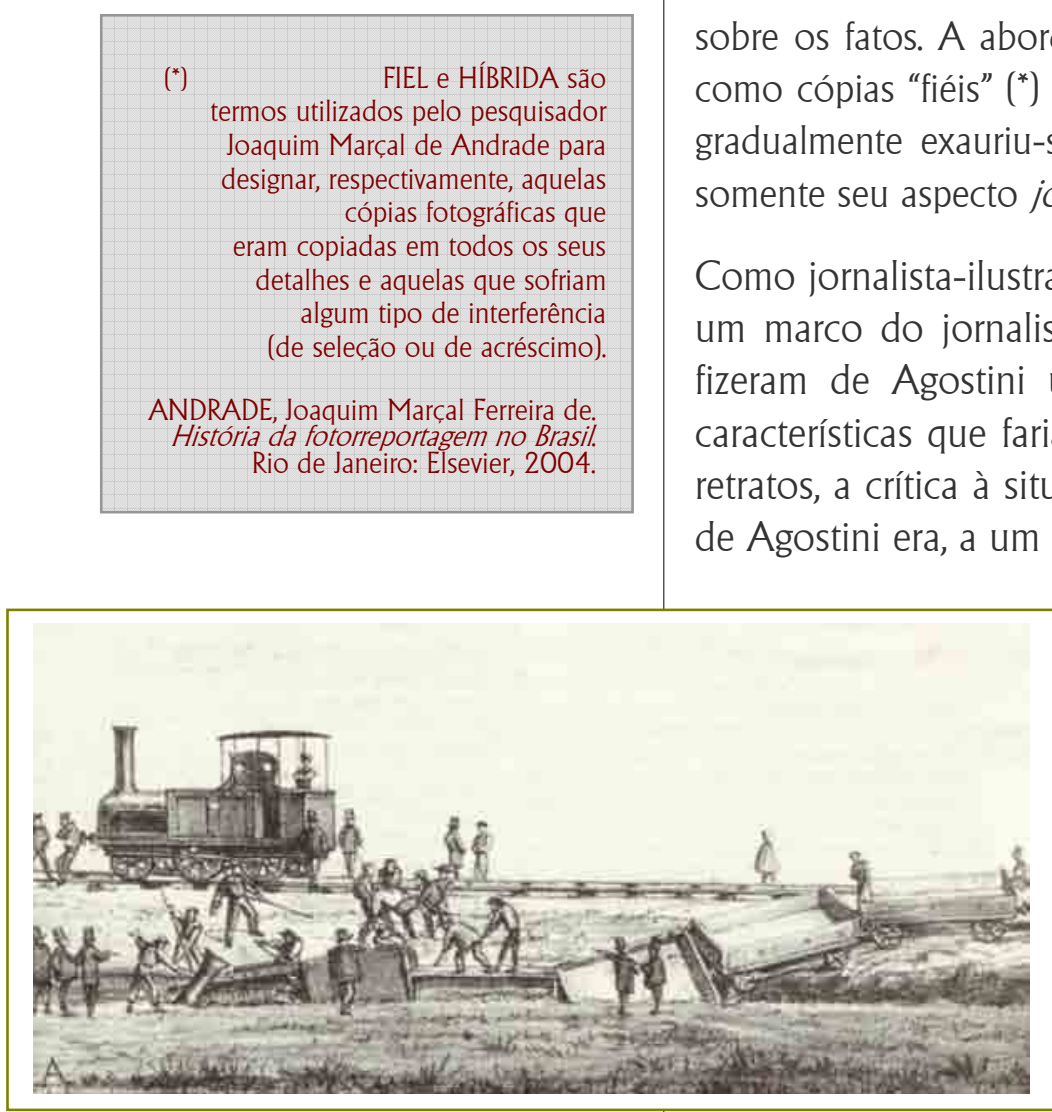

Este novo cenário contribuiu para desmembrar efetivamente das ilustraç̃es as possibilidades informativas das opinativas sos fatos. A abordagem ilustrada dos acontecimentos precisou aproximar-se das características descritivas da foto gradualmente exauriu-se do seu caráter jornalístico/informativo (como relato do fato), para assumir, aos poucos, tão somente seu aspecto jornalístico/opinativo (como comentário do fato). características que fariam do artista um dos grandes intérpretes do Império brasileiro: o traço forte, o realismo dos retratos, a crítica à situação social, a ironia contra tudo e todos. Numa época em que faltavam imagens, o desenho de Agostini era, a um só tempo, documento e criação; fato e ficção”. (SCHWARCZ, 2005, p. 2).
Desenho/Relato

de Ângelo Agostini

ESTRADA DE FERRO

"Posição do trem

depois do desastre (...)" (1865)

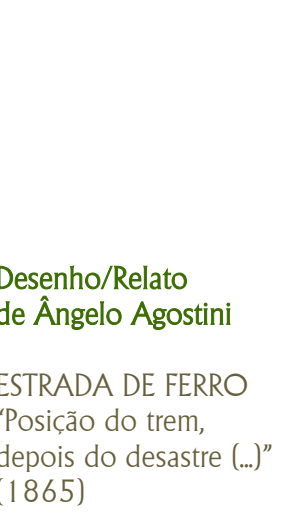

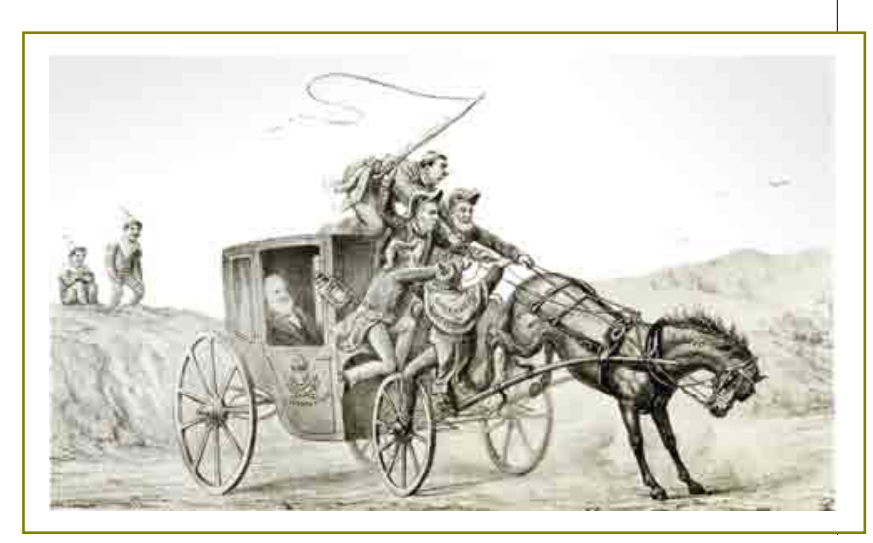




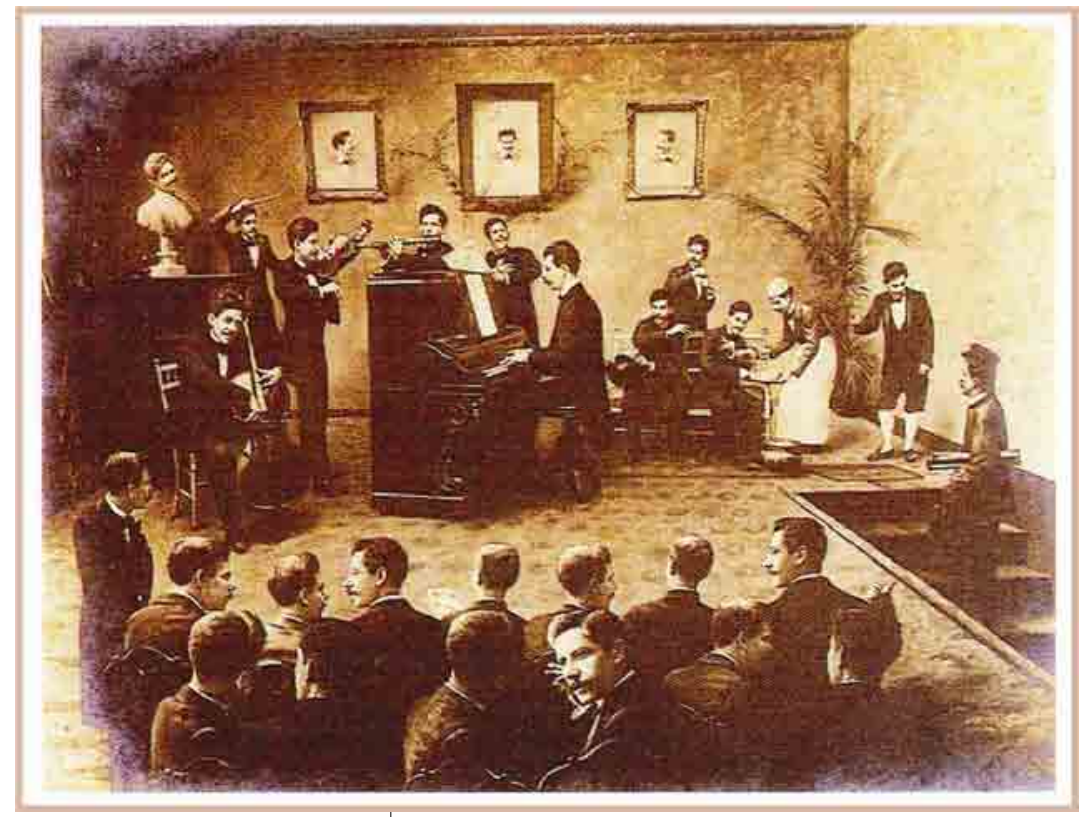

A fotografia nunca foi imparcial e a manipulação sempre existiu, embora não fosse tão eficiente.

Em 1901, o genial Valério Vieira celebrizou-se com Os Trinta Valérios, em que o rosto do fotógrafo repete-se na audiência, nos músicos, no maître, no garçom, nos retratos pendurados na parede e no busto que enfeita um móvel. Esse marco da fotografia brasileira evidencia as possibilidades da fotomontagem e faz o público suspeitar da realidade fixada pela prata no papel.

Mas o que ocorre é que a manipulação começa muito antes do processamento. A ideologia do fotógrafo transparece na seleção do assunto e passa pela escolha de lentes, abertura, enquadramento e exposição. Toda foto é um recorte de uma realidade mais complexa, uma representação bidimensional de um mundo em três dimensões. Nesse ponto a fotografia não é diferente de um texto jornalístico. Pode lançar esclarecimento sobre os fatos, ou pode mentir sobre eles. $O$ poder que o texto tem de revelar a verdade é o mesmo poder que tem de esconder a verdade.

Hoje, com os recursos digitais, não há meio de assegurar que uma determinada foto foi manipulada ou não. O leitor só pode contar com a reputação de seu autor e do veículo que a publica para decidir. Exatamente como se faz com qualquer texto jornalístico.

Os delegados do 2 . . Congresso da Internacional Comunista de 1920, em Moscou, foram retocados da foto original.

Para os registros oficiais só restaram Lênin e Gork

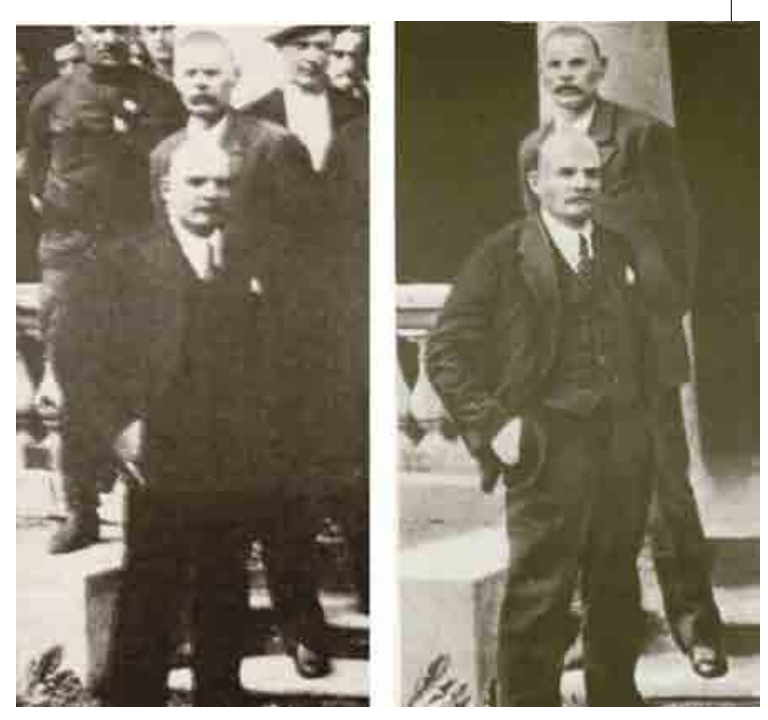




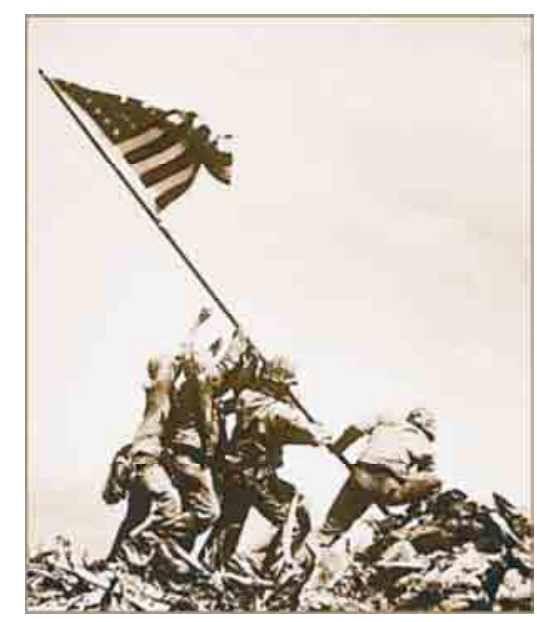

\section{O Instantâneo Encenado}

Em 1945 o prêmio Pulitzer de fotografia foi concedido a Joe Rosenthal, por sua fotografia que não passou de uma encenação de um flagrante jornalístico. Tratava-se de uma cena da Segunda Guerra Mundial mostrando o hasteamento da bandeira dos Estados Unidos na ilha de Iwo Jima, no Pacífico, por tropas norte-americanas que minutos antes haviam conquistado o território. Anos depois se descobriu que Rosenthal chegara atrasado ao momento em que os soldados realmente hasteavam sua bandeira. Mas pediu que os soldados repetissem $\mathrm{o}$ ato, registrando-o por meio da fotografia e que conquistaria o prêmio de foto-jornalismo daquele ano. (CARVALHO, 1998, p.108)

"Hasteamento da Bandeira Vermelha sobre o Reichstag", de 2 de maio de 1945, considerada uma das fotografias mais importantes do século, por ser o símbolo da derrota do nazismo e ascensão do comunismo. Até os anos 80 corria o mundo sem se saber quem era seu autor. $O$ fotojornalismo na ex-União Soviética era considerado uma atividade sem importância. No início dos anos 90 finalmente foi revelado o nome do autor que registrou o instantâneo do hasteamento da bandeira da União Soviética no alto do parlamento alemão em Berlim, tendo ao fundo uma vista parcial do centro da cidade destruído. (CARVALHO, 1998, p. 108)

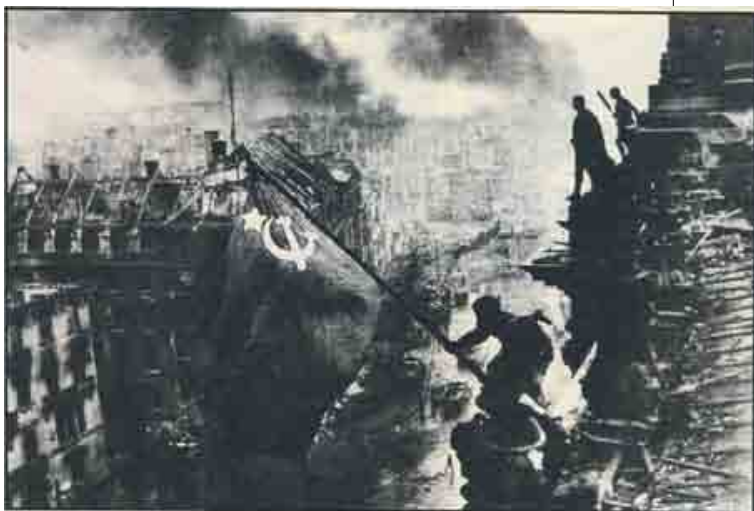

Ivgeni Kaldei, fotógrafo oficial do exército soviético, que, bastante franco, não titubeou em revelar como montou o cenário para sua famosíssima foto. Inspirado na foto de Joe Rosenthal, do hasteamento da bandeira norte-americana em Iwo Jima, feita três meses antes, Kaldei planejou sua foto com cuidado. Pediu a um tio alfaiate que confeccionasse a bandeira soviética, aplicando a foice, o martelo e a estrela sobre uma toalha de mesa vermelha, que ele levou para a frente de batalha. Com a vitória das tropas soviéticas, levou um grupo de soldados até o parlamento alemão para que eles hasteassem a bandeira enquanto ele batia uma série de fotos. As imagens selecionadas para divulgação pelo governo soviético ainda recebeu dois retoques no laboratório. A fumaça ao fundo teve sua direção alterada para dar maior impacto dramático e o soldado que está embaixo, no primeiro plano teve um de seus dois relógios apagados (...) Ele trazia um em cada pulso. Esse segundo retoque foi uma ordem direta de Stalin, já que dava a idéia de saque das tropas soviéticas, coisa não tolerada de um combatente do Exército Vermelho, embora comum na prática. (CARVALHO, 1998, p. 109) 


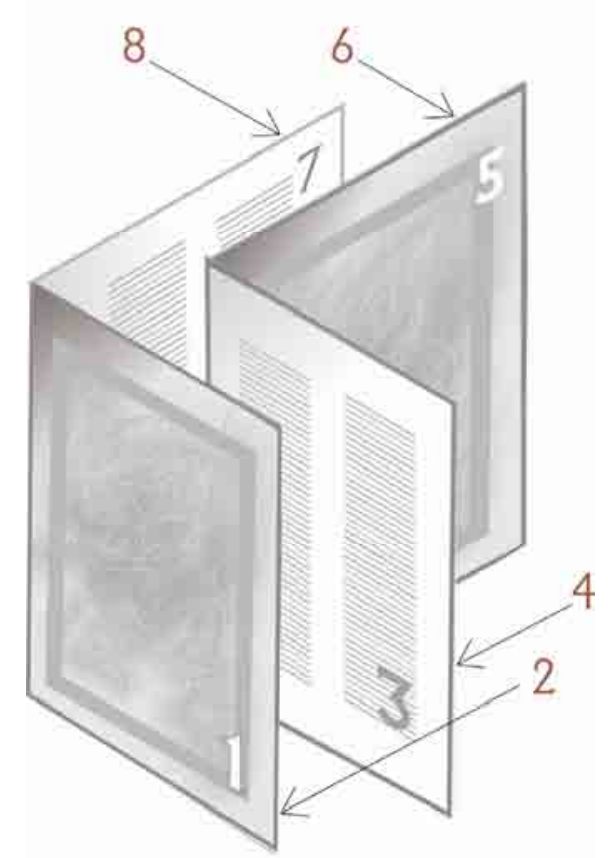

Como os demais periódicos da época, o Diabo Coxo trazia uma convivência sem conflitos entre páginas visuais $(1,4,5$ e 8$)$ com as páginas verbais $(2,3,6$ e 7$)$. Isto equivale a dizer que a impressão litográfica ocorria

na frente e a impressão tipográfica no verso.

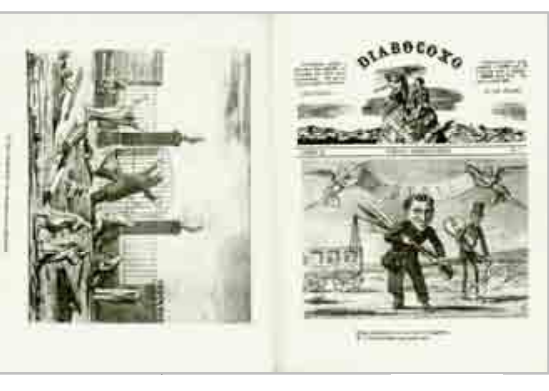

pg. 8 pg. 1

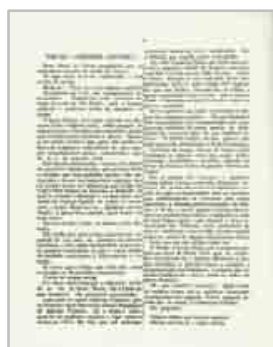

pg. 2

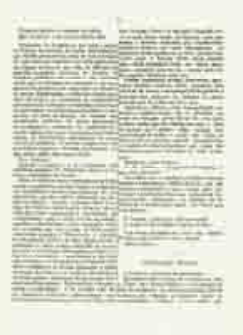

pg. 7

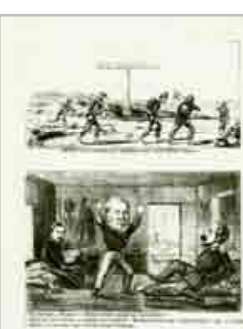

pg. 4

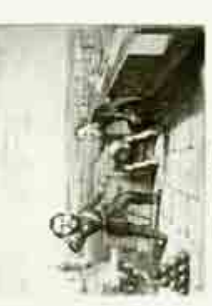

pg. 5

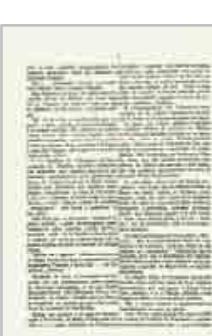

pg. 6
DIABO COXO - 23/07/1865

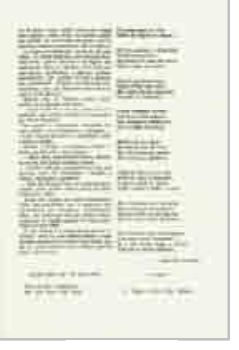

pg. 3 
Estúdio de xilogravadores da revista francesa L'Illustration, entre 1843 e 1848 Fonte. ANDRADE, 2004, p. 79
"No Brasil, no entanto, a inexistência de uma mão-de-obra local qualificada para transpor imagens fotográficas para a matriz xilográfica (na madeira) impediria o florescimento imediato de jornais, nos quais o texto e a imagem pudessem dividir a mesma página, pela impressão simultânea. Assim, alguns periódicos optaram por apresentar imagens encartadas, gravadas geralmente em talho-doce (no metal) ou então litográficas (na pedra)”. (ANDRADE, 2004, p. 37)

\section{A Fotografia Gravada}

Logo após o advento da fotografia surgem as primeiras obras impressas como cópias declaradamente "fiéis" de fotografia, proporcionando maior informação. A fotografia passa a ser agora portadora de evidência e de um poder de comunicação sem precedentes na história da humanidade.

Abaixo transcrevemos um depoimento lamentoso de Olavo Bilac, escrito originalmente em 1901, sobre a presença de ilustrações que vão se avolumando nas páginas dos periódicos. Apesar de não haver nele qualquer menção específica à fotografia, o texto nos dá boa medida da força que a imagem havia adquirido àquela época. Até mesmo em jornais puramente textuais já começavam a ser inseridas lentamente as fotografias e ilustrações em suas páginas. A omissão da palavra fotografia nesse depoimento serve de testemunho e evidência de que a reprodução da imagem original fotográfica não tinha presença marcante na imprensa até a virada do século.

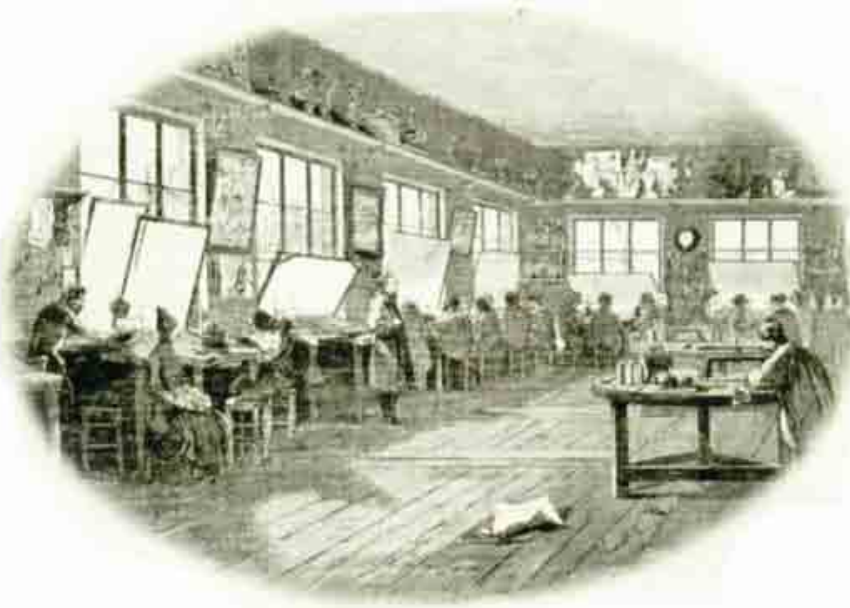

“(...) Vem perto o dia em que soará para os escritores a hora do irreparável desastre e da derradeira desgraça. Nós, os rabiscadores de artigos e notícias, já sentimos que nos falta o solo debaixo dos pés. Um exército rival vem solapando os alicerces em que até agora assentava a nossa supremacia: é o exército dos desenhistas, dos caricaturistas e dos ilustradores. (...) Já ninguém mais lê os artigos. Todos os jornais abrem espaço a ilustrações copiosas, que [entram] pelos olhos da gente com uma insistência assombrosa. As legendas são curtas e incisivas: toda a explicação vem da gravura (...). Olavo Bilac, 1901" (Olavo Bilac apud ANDRADE, 2004, p. 203)

Vale esclarecer que durante o longo período em que as fotografias foram reproduzidas através de xilografia (fora do Brasil), o processo aperfeiçoou-se, buscando maximizar a fidelidade aos originais e minimizar a interferência do estilo individual dos xilogravadores: neste sentido, as chapas de madeira eram emulsionadas e, em seguida, recebiam a projeção dos negativos. Após a revelação, a imagem obtida sobre a madeira servia de guia para o gravador, que "abria" a matriz com seus instrumentos de corte, buscando ser o mais fiel possível ao original fotográfico (...) (ANDRADE, 2004, p. 208). 
O surgimento dos primeiros periódicos ilustrados, na década de 1830, deu novo impulso a esse mercado em formação. Novas publicações ilustradas iam sendo sucessivamente lançadas. Eram muitos os desafios a serem enfrentados em face das dificuldades de uma constante atualização tecnológica dos equipamentos e para a obtenção de mão-de-obra especializada. A dificuldade a ser superada era a integração entre os discursos verbal e visual, uma vez que os processos de impressão de textos e imagens não eram compatíveis. Este aspecto se tornava mais grave ao se tentar reproduzir fotografias. Era um processo extremamente trabalhoso e especializado.

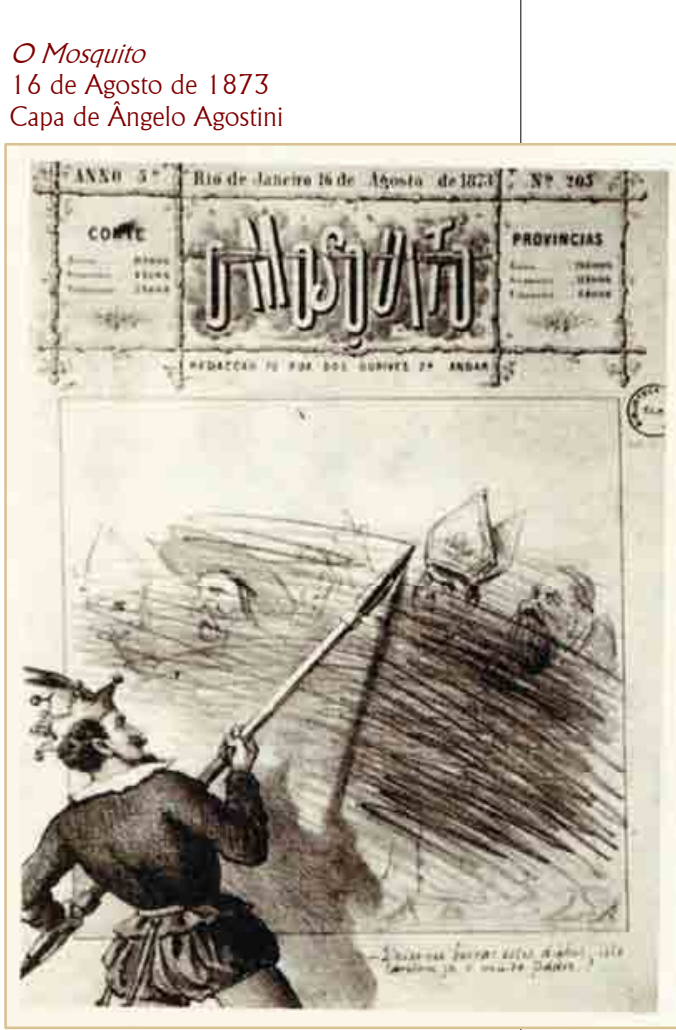

16 de Agosto de 1873

Capa de Ângelo Agostin

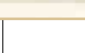

Na Europa e nos Estados Unidos, os periódicos ilustrados litográficos ficaram confinados a um gênero específico da imprensa, o caricatural, enquanto os periódicos ilustrados noticiosos adotavam a xilografia - compatível com a impressão tipográfica (de textos) e onde acontece uma ampla utilização da fotografia - aqui, (no Brasil, a partir das décadas de 1850 e 1860) arriscaríamos afirmar(que), os periódicos ilustrados litográficos, quase todos dando espaço às caricaturas se tornaram um sinônimo de imprensa ilustrada no geral.

(...) O principal motivo, parece-nos, foi a inexistência de mão-de-obra local para realizar as matrizes xilográficas com rigor e a rapidez necessárias, características da imprensa. Diante desse quadro, houve ampla disseminação, na imprensa local, da litografia como principal processo para a produção de imagens, enquanto os textos tipográficos demandavam um outro sistema de impressão. Afora este motivo, certamente haverá outros de ordem histórica e sociológica, para que nossa imprensa ilustrada noticiosa e nossa imprensa ilustrada caricatural - na melhor tradição do caricaturista francês Daumier - tenham sido, na essência, uma só e tenham tido tanto sucesso e boa aceitação por tão longo período. Dentre esses motivos, um está relacionado ao fato de que os principais caricaturistas eram quase todos imigrados do exterior, tendo aqui encontrado uma sociedade distinta daquela onde nasceram e obtiveram sua formação, o que certamente já aguçava e facilitava o exercício de seu censo crítico. (ANDRADE, 2004, p. 52)

Rio de Janeiro 8 de Ferereiro de 1873

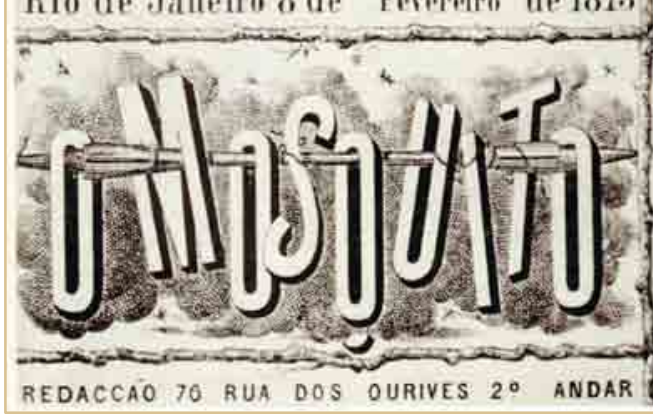

Assim, a litografia continuou a ser realizada pela mão do artista, com o lápis ou crayon litográfico - como era denominado imperando em nossa imprensa ilustrada até a virada do século

A presença do lápis litográfico como técnica predominante na vida do artista e no cotidiano dos periódicos ilustrados, aparecerá muitas vezes como citação visual nas ilustrações ou até mesmo como marca nos frontispícios dos jornais, como no título da revista O Mosquito, onde as letras estão penduradas num porta-crayon. 


\section{Cópia Fiel e Imagens Híbridas}

De Henrique Fleiuss, o célebre artista, designer e editor da Semana Ilustrada, escolhemos um perfeito exemplo daquilo que denominamos imagem híbrida: numa reportagem sobre a visita do imperador D. Pedro II às tropas envolvidas na Guerra do Paraguai, no sul do país, Fleiuss estampou uma litografia do imperador ao lado do duque de Saxe, posando à frente de um acampamento militar em plena guerra. Na legenda, lê-se "S.M. o Imperador e S.A. o Sr. Duque de Saxe em traja de campanha. Copiados das fotografias enviadas de Porto Alegre." Embora o leitor desavisado creia estar frente a uma imagem verdadeira do imperador num acampamento de guerra, o leitor atento deverá observar o plural, "copiados das fotografias"... Pois bem, localizamos não apenas alguns estudos anônimos a grafite das fotografias dos dois personagens, como também os originais - realizados no conforto e na segurança do estúdio do fotógrafo Terragno. (ANDRADE, 2004, p. 69)
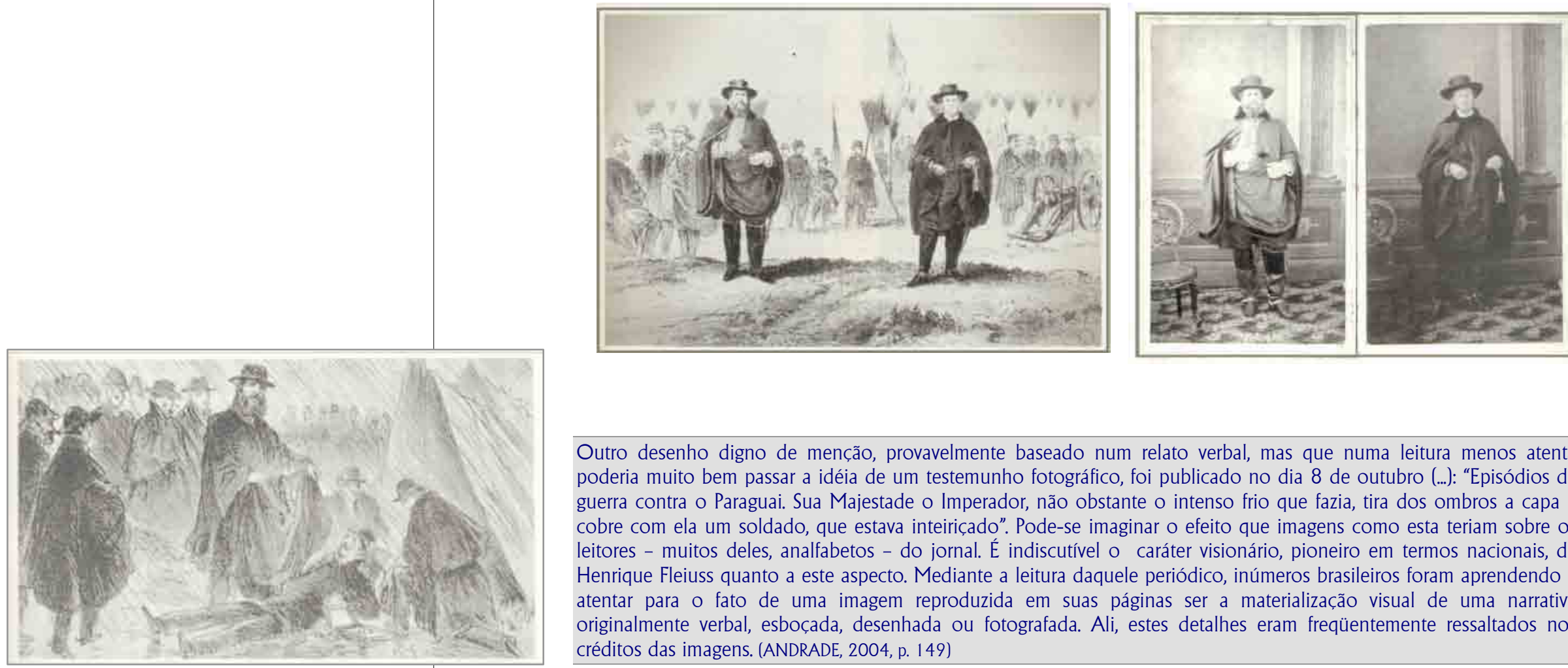

Outro desenho digno de mencão, provavelmente baseado num relato verbal, mas que numa leitura menos atenta poderia muito bem passar a idéia de um testemunho fotográfico, foi publicado no dia 8 de outubro (...): "Episódios da guerra contra o Paraguai. Sua Majestade o Imperador, não obstante o intenso frio que fazia, tira dos ombros a capa e cobre com ela um soldado, que estava inteiriçado". Pode-se imaginar o efeito que imagens como esta teriam sobre os leitores - muitos deles, analfabetos - do jornal. É indiscutível o caráter visionário, pioneiro em termos nacionais, de Henrique Fleiuss quanto a este aspecto. Mediante a leitura daquele periódico, inúmeros brasileiros foram aprendendo a atentar para o fato de uma imagem reproduzida em suas páginas ser a materialização visual de uma narrativa originalmente verbal, esboçada, desenhada ou fotografada. Ali, estes detalhes eram freqüentemente ressaltados nos créditos das imagens. (ANDRADE, 2004, p. 149) 
A llustração do Brasil 29 de Julho de 1876

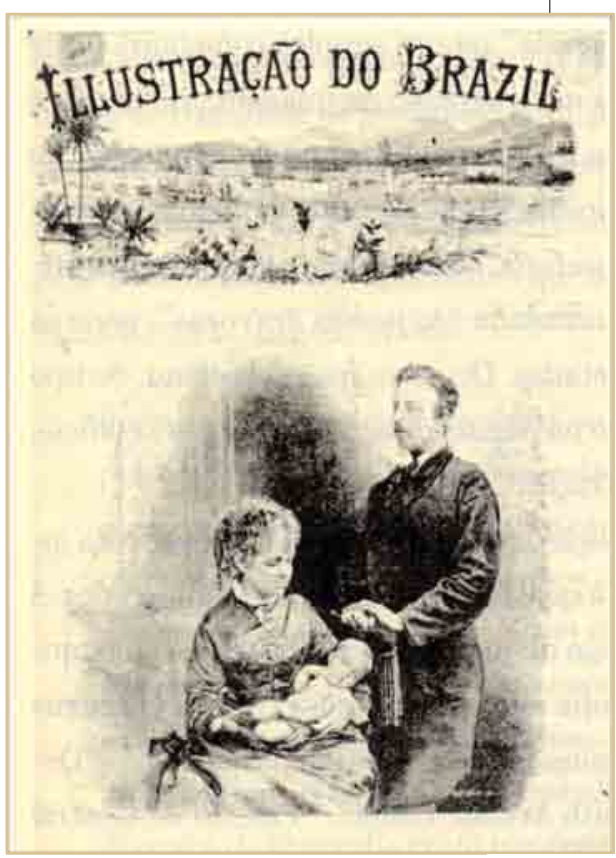

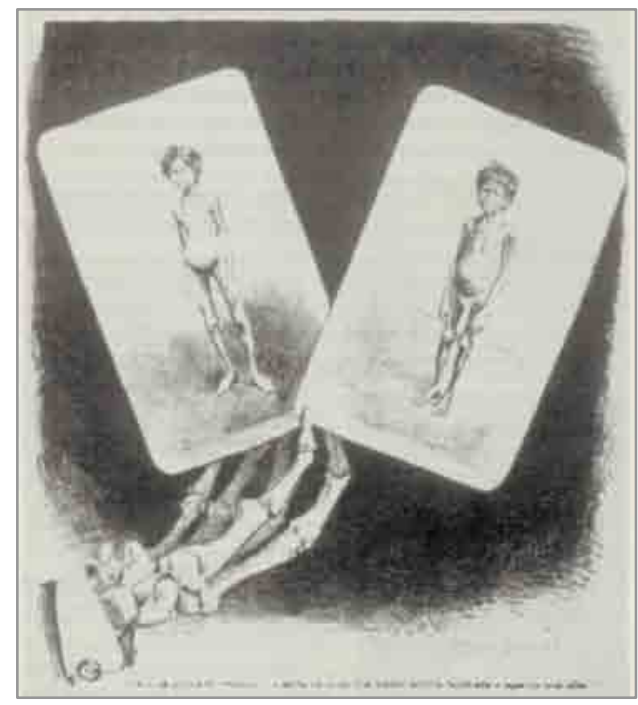
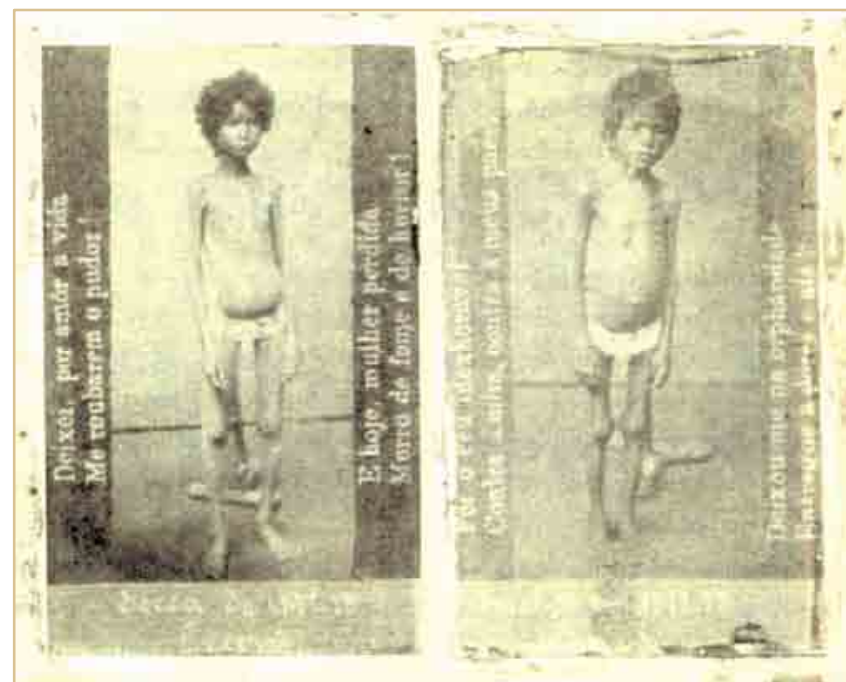

Duas fotografias foram reproduzidas na primeira página do número de 20 de julho de 1878 de $O$ Besouro. A ilustração litográfica, de autoria de Bordalo, mostra a mão de um esqueleto humano, trajando camisa social com abotoadura e paletó, segurando duas carte-de visite que retratam criancas vítimas da seca, contra fundo negro, e é encimada pelo título "Páginas tristes - Scenas e aspectos do Ceará (para S. Majestade, o Sr. Governo e os Senhores Fornecedores verem)". Logo abaixo, uma observação entre parênteses: "cópias fidelíssimas das fotografias que nos foram remetidas pelo nosso amigo e colega José do Patrocínio". (ANDRADE, 2004 p. 192)

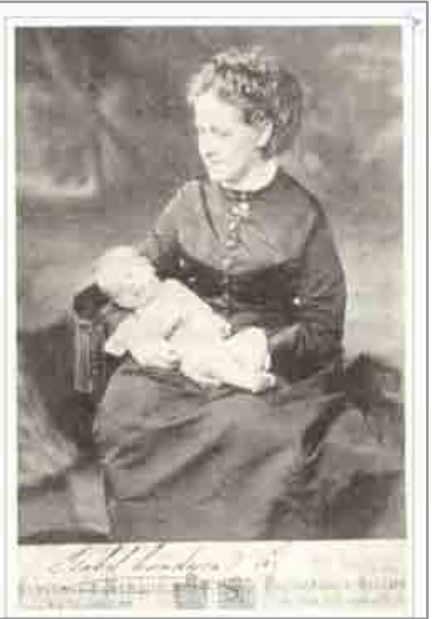

Ao mostrar as cópias fidelíssimas à sua maneira, Bordalo Pinheiro representava com as cartas a informação jornalística, com a sua "objetividade positivista, enquanto que a caveira representava a sua opinião pessoal (...), dando um toque de subjetividade à notícia”. As fotos deste relato foram desenhadas invertidas, provavelmente pelo efeito de decalque da foto e o espelhamento na impressão litográfica.

Efeito semelhante encontra-se na imagem da Princesa Izabel, com o filho recémnascido, na capa da revista I/ustração do Brazil. Nela é feita uma junção de duas fotos. Uma da Princesa Izabel e seu filho e outra com a foto do Conde D’Eu, seu esposo. No desenho litográfico aparece a montagem, junto com o espelhamento da impressão. 
Não ser pode deixar de ressaltar que sempre se buscou conjugar os processos de impressão de imagens com os processos de impressão de textos. Em qualquer época ou por qualquer técnica isto sempre foi um objetivo para as artes gráficas. Sempre que isso não foi possível as imagens eram impressas em separado e depois inseridas na encadernação. Ou então as imagens e os textos eram impressos por processos distintos, e em momentos distintos, na mesma folha de papel, isto é, na frente o processo litográfico e no verso o processo tipográfico.

\section{Fotolitografia}

Na França, entre 1856 e 1857, Louis-Alphonse Poitevin marca o início de sucessivos desenvolvimentos com a fotolitografia. Essa técnica possibilitou o início da implantação da reprodução fotomecânica na imprensa periódica, que a partir da década de 1880 passa a ocorrer em maior escala.

\section{(...) com relação à fotolitografia (...) vale esclarecer que este processo não conseguiu jamais, no século XIX, atender às demandas por reprodução fotomecânica de uma indústria gráfica de tiragens crescentes e prazos decrescentes, na qual a impressão era tipográfica e, portanto, a ela deveriam se subordinar os processos fotomecânicos (para reprodução de imagens)- o que não era o caso da litografia (....). Apenas no século XX, com o pleno desenvolvimento da denominada litografia offset, é que ocorrerá a "migraç̃o tecnológica digamos assim, da composição tipográfica para os processos de impressão litográficos - isto, graças, mais uma vez, à fotografia (...)”. (ANDRADE, 2004, p. 186)}

Pelas observações de Andrade (2004, p. 186) é interessante notar que quando do surgimento da fotografia, no final do século XIX, e com a chegada da fototipia (clichê), houve um forte motivo para reduzir o espaço de participação das ilustrações das páginas dos jornais. Porém foi também com a fotografia que se permitiu o retorno dos ilustradores para as páginas dos periódicos com os processos de fotogravura. Assim, pela fotografia, os textos antes tipografados, "migraram" para os processos da fotolitografia off-set, fazendo com que a tipografia se adaptasse à fotolitografia. É também interessante notar que ainda hoje o filme utilizado para transportar em conjunto texto e imagem para a chapa metálica de gravação chama-se fotolito (junção de foto=luz e lito=pedra)

Já mais próximo do final do século XIX, quando foram introduzidos os processos de fotogravura, tornaram viáveis a reprodução na imprensa periódica das fotografias e dos desenhos, passando aos poucos a ser introduzida a fototipia (clichê).

Com o surgimento dos processos fotoquímicos, desenvolvidos pelo alemão Meisenbach foi possível se chegar à técnica da fototipia (clichês). A partir dessa técnica de reprodução de fotos através de retículas, os clichês podiam agora ser montados juntamente com os blocos de texto e impressos simultaneamente pelo processo tipográfico, então adotado na indústria gráfica. Esta nova técnica possibilitou uma verdadeira "revolução" na imprensa periódica ilustrada. Agora não haveria mais obstáculos para a reprodução de desenhos e fotos. 


\section{CAPÍTULO 7 \\ O JORNAL}

7.1 - ASPECTOS HISTÓRICOS

7.2 - O JORNAL NO BRASIL

7.3 - EMPREENDIMENTOS E TECNOLOGIAS 


\section{1 - ASPECTOS HISTÓRICOS}

\section{Os Primeiros Jornais}

O termo gazeta sempre foi equivalente à palavra jornal em diversos idiomas e países. Nasceu relacionado à atividade de difusão de notícias em público, pela fala de algum emissário proveniente das fontes dos fatos.

O vocábulo Gazetta, de origem italiana, traduzida literalmente era (...) o nome da moeda veneziana do século XV, quando Veneza era o mais rico estado independente do Mediterrâneo e travava uma guerra com os turcos em 1566. Nesse período, os comerciantes venezianos, bastante preocupados com sua rota comercial no Mediterrâneo, (...) ávidos por notícias de guerra, pagavam para ouvir os mais recentes relatos das batalhas. Quando o portador das últimas informações chegava na cidade, imediatamente se dirigia a um local fechado onde transmitia oralmente o que havia acontecido recentemente nos campos de batalha, as condições e necessidades das tropas venezianas, expectativas dos seus comandantes etc. Para ouvir os relatos, tendo acesso ao local onde eram transmitidos diretamente pelo emissário (caracterização de um "jornal noticioso falado"), cada pessoa pagava o valor correspondente a unidade monetária: uma gazeta. (CARVALHO, 1998, p. 34).

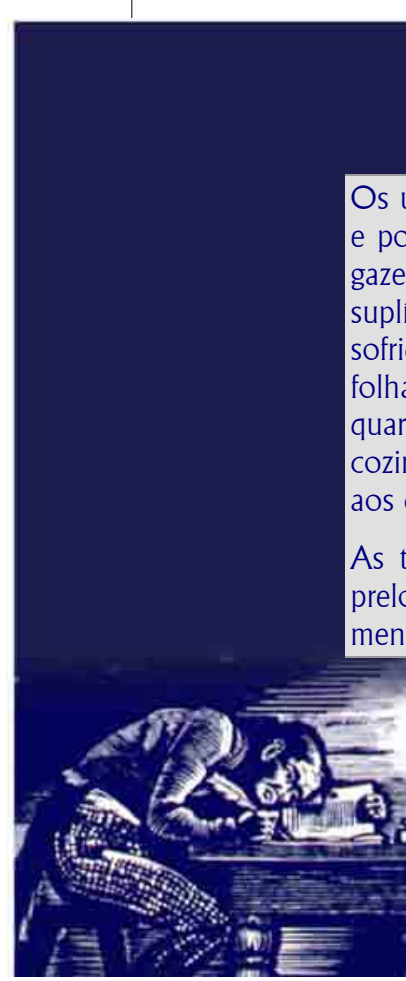

A difusão de notícias à coletividade nasceu desse costume de se transmitir acontecimentos através de relatos orais, enquanto que o relato impresso permaneceria privilégio de poucos.

Os utensílios de um redator de gazeta limitavam-se a uma pena, um tinteiro e uma folha de papel; copiado o panfleto posto em mãos seguras nada Ihe trairá o segredo. (...) Essa consideração (...) resume e explica a vida de agruras dos gazetistas em geral; vida sarjada de perseguições, fingimentos e fugas, angústias e retratações, prisões, castigos e suplícios. Na história das lutas pela liberdade da palavra escrita, terá o jornalismo páginas mais eloqüentes, mas não tão sofridas quanto as do prólogo, alinhavadas sem glória e sem paga pelos noticiaristas anônimos ou esquecidos das olhas manuscritas. Com os quadrilheiros nos calcanhares, sem casa nem parada, dobrando esquinas, acoitando-se em quartos amigos e alcovas suspeitas, rabiscando nos fundos de tavernas e estalagens, em cima dos joelhos, das mesas de ozinha e das tábuas de passar roupa, os noticiaristas entregavam, eles mesmos, às escondidas, as folhas aos clientes e os correios. (...)

As tipografias (ao contrário) instalavam-se com licença e funcionavam sob inspeção dos governos. Nada saía dos relos sem exames, beneplácitos e privilégios; nem livros, nem opúsculos, nem papéis volantes - nada. Nada e ainda enos notícias, absolutamente proibidas. (CARVALHO, 1998, p. 66).

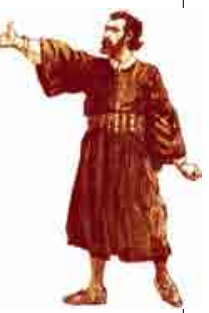


(1) Os exemplares mais antigos e mais conservados de um jornal primitivo foram publicados na Alemanha em 1609, mas não indicam nem a cidade, nem o impressor ou o editor. Tomando por base a análise do papel, tipo, técnica impressora, conteúdo político e o colorido religioso, os peritos admitiram que o berço desse conhecido jornal primitivíssimo deveria estar no norte da Alemanha. (.) Bremen é o berço mais provável do primeiro jornal.

(EMERY apud CARVALHO, 1998, p. 13)
Não há precisão entre os historiadores sobre o surgimento do jornal. A periodicidade seria a condição imposta para o reconhecimento do primeiro título, já que desde o final do século XV, na Europa, eram comuns os avulsos manuscritos. Esses precursores dos jornais circulavam nas cidades, sem título, data, previsão de publicação ou periodicidade. Eram chamadas de folhas volantes, gazetas, libelos ou pasquins. Estes podem ser considerados a germinação do jornal. No entanto, o consenso mais comum entre a maior parte dos historiadores indica que o primeiro jornal surgiu na Alemanha, nos primeiros anos do século XVII (1).

Um retrospecto da história do jornal revela que, como veículo de comunicação, resistiu como resistiu o livro, a todos os embates da tecnologia e das mudanças sociais.

movimento de aperfeiçoamento e acomodação dos mecanismos de comunicação demonstram o quanto esta dinâmica é um processo imperecível. A voz não substituiu o gesto, nem o livro foi destruído pela TV, nem o jornal pelo rádio, nem o cinema pelo vídeo. A própria comunicação, faculdade inerente ao homem, se eterniza e faz subsistir seus instrumentos. A introdução de novas tecnologias acarreta tanto sua aceitação quanto resistência à sua assimilação.

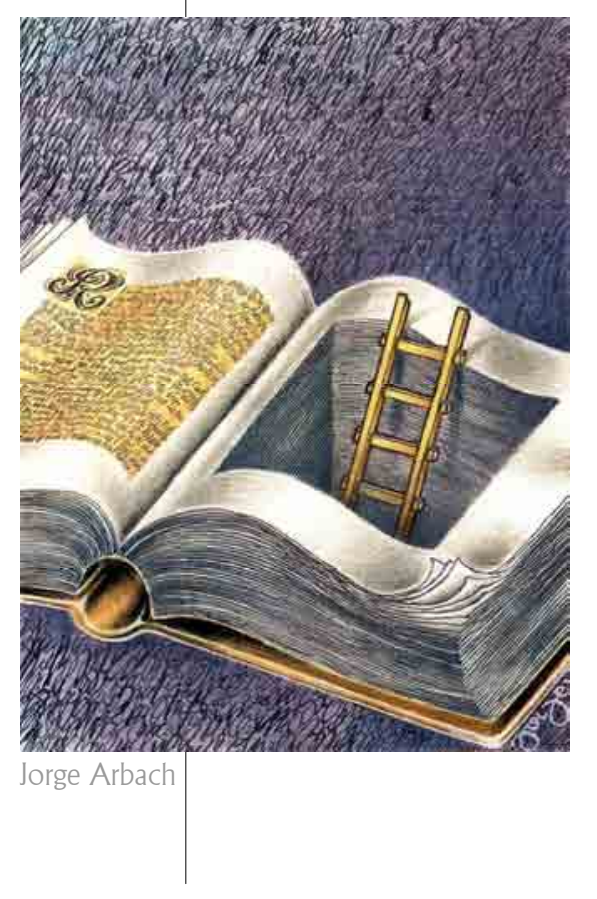

A primeira grande revolução no processo de comunicação, ocorrida na Grécia, com a adoção e a popularização do alfabeto, criou um embate entre os filósofos da época, que consideravam a introdução da escrita um golpe mortal na capacidade de memorizar. A memória era, então, o único recurso para vencer o tempo. Sócrates disse em Phaedrus. "A descoberta do alfabeto criará o esquecimento nas almas dos alunos porque eles não usarão suas memórias; confiarão em caracteres escritos externamente e não lembrarão por si mesmos. Daremos aos nossos discípulos não a verdade, mas a impressão da verdade (...)" (DINES, 1996, p. 64). Certamente vimos que o que ocorreu foi uma acomodação e uma adaptação à nova tecnologia da escrita. E se hoje a capacidade de memorização das palavras perdeu parte da sua importância no processo intelectual, em compensação estas mesmas palavras escritas passaram a estimular a imaginação e a representar importante papel de evocação de imagens e conceitos. A retenção do pensamento com a palavra escrita criou condições de ir além com a mente: de imaginar, de sonhar, planejar, filosofar, conceituar e conjeturar. 


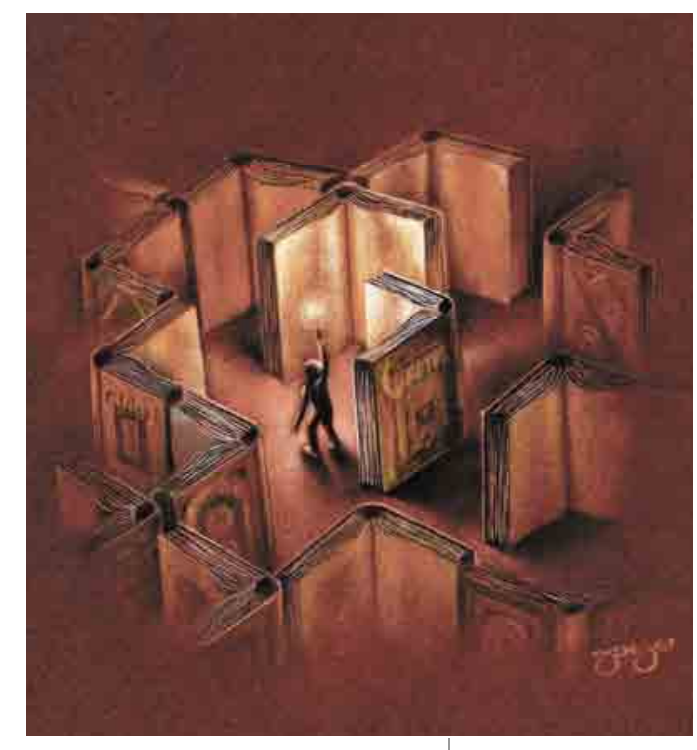

“(...) onde entra a imaginação para recompor a realidade, a retenção é muito maior. Um filme sobre (...) guerra será uma sucessão de cenas fortes sobre (...) guerra. Mas o depoimento de um jornalista que viveu essa guerra aciona a imaginação do leitor, que compõe com as suas próprias imagens (fornecidas pelas palavras do repórter) uma descrição forte e indelével do acontecimento". (DINES, 1996, p. 93). As palavras possuem a capacidade de estimular a imaginação mais que as imagens reais.

E é com as imagens que o leitor irá compor seu imaginário mental, acionado com as sugestões contidas nas palavras. Ele estará, assim, compondo seu repertório de imagens, sua imaginação. A transposição de uma cena fotográfica para a mente poderá ser bem fixada pela memória com os seus detalhes, mas a composição mental de uma imagem através das palavras será realizada com os elementos próprios da imaginação. E esta será duradoura.

Jorge Arbach

\section{Aspectos Formais}

Até recentemente o jornal era uma massa de composição, subdividida em textos e títulos e mais um pequeno percentual dedicado à ilustração. Os ingleses e franceses iniciaram a utilização de elementos ornamentais, mas não foi apenas nos formatos dos tipos, na aparência e nas dimensões. Isto também ocorreu na composição visual da mensagem impressa.
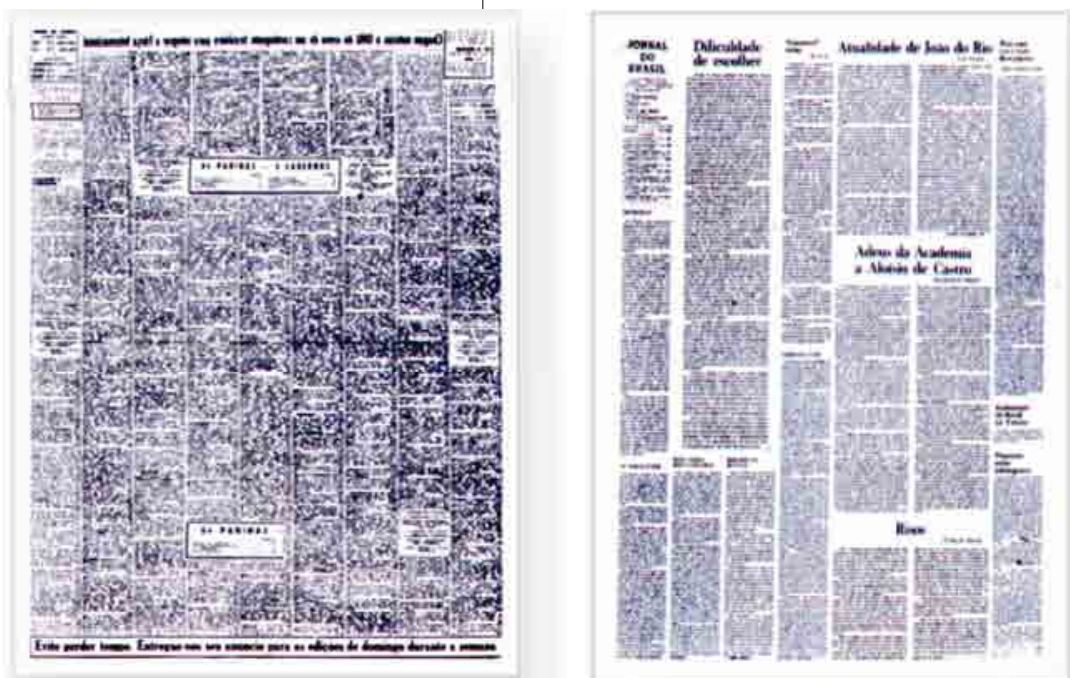

Excluindo esses recursos gráficos, antes não havia mais nada para se preocupar esteticamente, e a própria distribuição da massa de textos era irregular. As únicas páginas de jornal com lay-out eram as da extremidade da edição (primeira e última). Atualmente o leitor habituou-se ao jornal bonito, logicamente apresentado e racionalmente disposto. A revolução do desenho industrial tornou a funcionalidade uma questão estética e o jornal beneficiou-se diretamente com estes novos valores.

Amilcar de Castro, escultor e artista gráfico, trouxe para a imprensa brasileira, em 1957, através do Jornal do Brasil, o jogo de espaços e volumes. Harmonizou o confronto da horizontal com a vertical, equilibrou simetria com a assimetria. 


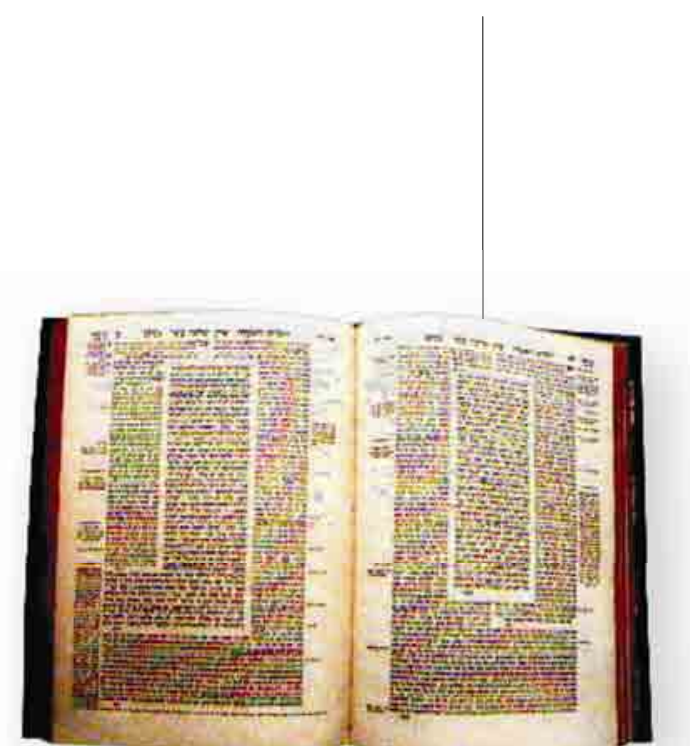

Os antigos ornamentos foram substituídos por novos elementos para estimular e melhor atrair o leitor. Foram trabalhados subtítulos, entretítulos, boxes, textos complementares, que, além de movimentar e embelezar uma página tornaram ainda mais atraente sua leitura. Estes recursos editoriais e formais foram adotados pelos jornais destinados a propiciar a dupla-leitura.

\begin{abstract}
A dupla-leitura origina-se no estilo tipográfico dos velhos tratados religiosos, notadamente israelitas, onde o texto principal mais curto era composto em corpo maior e os comentários, mais extensos, dispostos à sua volta em corpo menor. O sistema foi revivido pela revista Planète e, hoje, é adotado, com variações, em grande número de publicacões e livros, especialmente os didáticos. Consiste em oferecer, com a ajuda de corpos maiores e textos sintéticos, uma primeira idéia do conteúdo daquela matéria, de modo que o leitor, através de duas ou três frases, tenha o seu interesse despertado para uma segunda leitura, mais demorada e profunda. (DINES, 1996, p. 102).
\end{abstract}

Diagramacão de um livro sagrado israelita

(2) O Jornalismo antes da tipografi.

Além da técnica da dupla-leitura ampliaram nos últimos anos outros tipos de informação visual, como mapas, gráficos e tabelas. Seu emprego passou a ter função e objetivos estéticos. Com a crescente utilização de equipamentos para impressão off-set e meios eletrônicos de edição, alcançou-se melhor qualidade nas impressões de textos, fotos e ilustrações.

\title{
Jornalismo e Correio
}

O registro dos acontecimentos através das páginas de um manuscrito poderia no futuro servir de elemento de prova da verdade histórica mas nenhuma relação teria com o jornalismo. Uma coisa é recolher sucessos e aprisioná-los para eventual consulta da posteridade, e outra é recolhê-los com o fim de transmiti-los incontinenti ao público. A comunicação subentende um meio material superador das distâncias, capaz de efetuar a entrega da notícia ao seu destinatário, onde ele estiver. Em quase toda a Antiguidade e em toda a Idade Média, os mensageiros particulares e os mercadores andarilhos constituíram os únicos, acidentais e precaríssimos tracos de união entre os homens (RIZZINI, 1977, p. 98).

Carlos Rizzini, em seu livro O Jornalismo antes da tipografia (2), assinala que, mesmo existindo a tipografia, desde 1445, nem se cogitava ainda na produção de periódicos manuscritos ou impressos. Do primeiro livro impresso ao primeiro jornal impresso transcorreram 160 anos. "De onde se conclui que a relação entre a tipografia e o jornal é semelhante à do tear mecânico e o pano: uma relação de aperfeiçoamento” (DINES, 1996, p. 66). $\bigcirc$ extraordinário é que o jornal nasceu quando já funcionavam as tipografias por toda parte. $\bigcirc$ jornal nasceu manuscrito, e por muito tempo permaneceu manuscrito. Superou as oficiosas folhas impressas que surgiam e mesmo antes de o correio ser instituído, os jornais manuscritos seguiam ou pelas mãos de seus redatores ou através de estafetas, burlando a vigilância dos poderes constituídos. 
Esclarecendo com datas:

o primeiro livro impresso é de 1445 ;

o primeiro jornal manuscrito é de 1530 ;

o primeiro jornal impresso é de 1605 ;

Essa defasagem entre o advento da tipografia e o $1 \cong$ jornal impresso é explicável pela clandestinidade a que a perseguição dos governos condenou os primórdios do jornalismo e pelo elevado preço dos trabalhos tipográficos. Da comparação das datas verifica-se terem sido os correios, e não a tipografia, a determinante do periodismo. Compreendese, pois, que para atingir o seu fim, a informação não precisava ser escrita desta ou daquela maneira, mas ser regularmente transmitida do redator ao leitor.

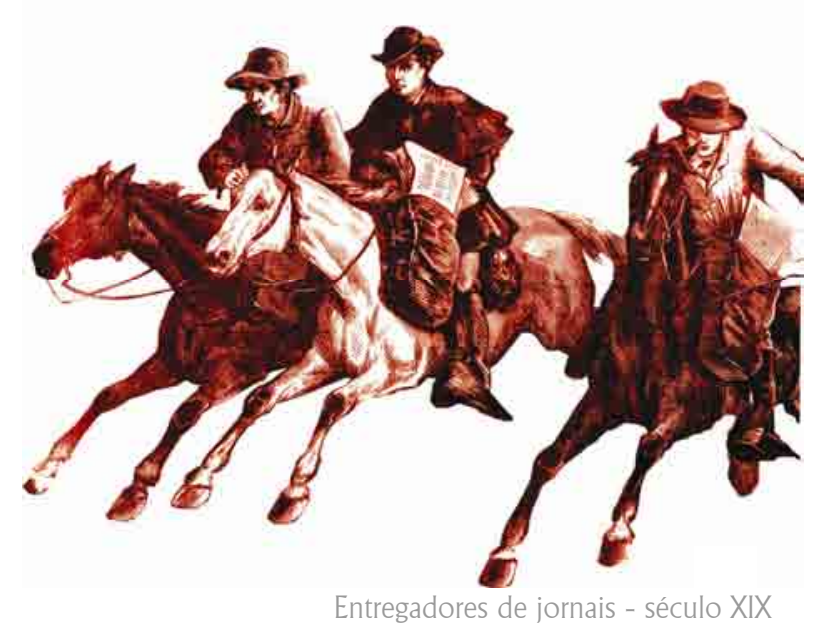




\section{2 - O JORNAL NO BRASIL}

A invenção da imprensa em meados do séc. XV não garantiu de imediato a ampla circulação de textos, pois o domínio da Igreja e dos nobres senhores feudais rechaçavam tentativas de se estabelecer uma comunicação mais livre. Foi somente com o fortalecimento da classe burguesa, por volta do século XVIII, representada por mercadores, artesãos e mais tarde por industriais, que a imprensa passou a fazer parte do cotidiano social.

Interessava aos burgueses a criação de espaços comunicativos livres, para a troca de informações econômicas sem o controle da Corte. A intenção era transformar a informação em um espaço público capaz de dar visibilidade aos assuntos econômicos. Assim, as primeiras informações jornalísticas eram narrativas de emissários enviados às regiões de conflitos trazendo notícias mais recentes dos acontecimentos. Posteriormente, com a liberação monárquica, a circulação de informação passou a ser impressa. No início eram informações econômicas, veiculando cotações de preços e análises que pudessem ajudar a nova classe social que surgia.

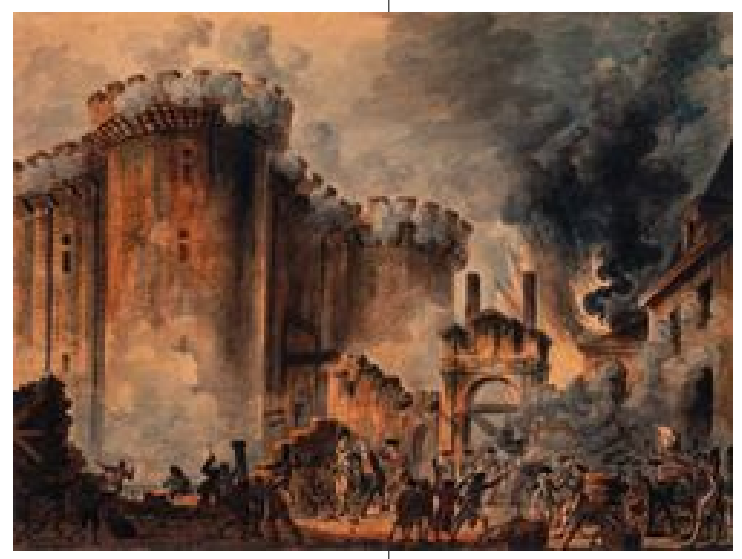

A Tomada da Bastilha - 1798

Logo após a Revolução Francesa em 1798, as constituições liberais reservariam um artigo em defesa da liberdade de expressão, tamanha a importância que a publicação impressa havia alcançado. Era preciso garantir o espaço livre da opinião para dar continuidade ao projeto político da democracia. Era a superação da fase artesanal da imprensa através da necessidade de comercialização de informações úteis a determinados grupos econômicos.

Os jornais são criados para reforçar as negociações, o que coincide com a primeira fase de instauração da burguesia. Nesse momento a informação ainda não tem um tratamento metodológico, não há técnicas para a elaboração dos jornais. $\bigcirc$ que prevalece é a capacidade de gerar lucros através das ofertas de informações que poderiam melhor orientar o plantio ou a colheita.

Esse modelo de imprensa imposto pela organização do capital não tem reflexo nos jornais que começam a aparecer na mesma época no Brasil. Nesse período histórico os jornais não estão ainda organizados e estruturados, continuam sendo artesanais. 
(...) os europeus, que ocuparam as (áreas espanholas) na América, nelas encontraram culturas avançadas que, inclusive, conheciam a mineração e aproveitavam os metais preciosos. (...) Não se tratava de comunidades primitivas na idade da pedra lascada, como no Brasil, mas de culturas já em nível adiantado de complexidade. Essas culturas precisavam ser destruídas e substituídas, sob pena de graves riscos para a ocupação, (...) e à retirada do ouro e da prata que o mercantilismo colocava em destaque. Assim, onde o invasor encontrou uma cultura avançada, teve de implantar os instrumentos de sua própria cultura, (...) a dualidade de culturas representava sérios riscos ao domínio. $\bigcirc$ aparecimento precoce da Universidade e da Imprensa (na zona espanhola) esteve longe de caracterizar uma posicão de tolerância. Foi, ao contrário, sintoma de intransigência cultural, de esmagamento, de destruição. Necessidade de (...) implantar a cultura externa, justificatória do domínio, da ocupação e da exploração.

(...)

Essa necessidade não ocorreu no Brasil, que não conheceu por isso, nem a Universidade nem a Imprensa, no período colonial. Aqui, não tinha a necessidade da existência prática, pois não representava risco algum.. (SODRÉ, 1966, p. 12-13)

O movimento de implantação da imprensa no Brasil foi vivido com atraso, pois a coroa portuguesa também proibia a vinda de máquinas de impressão para a Colônia. Somente com a chegada da Corte de D. João é que se instala a imprensa oficial e, daí em diante são produzidos jornais, panfletos, folhas avulsas, etc. A imprensa surgia finalmente no Brasil, mas por iniciativa oficial. Aqui, com a chegada da Família Real criavamse condições para um surto de progresso que mudaria o país. Foi implantada a oficina da Impressa Régia, de onde, a 10 de setembro de 1808, saiu o primeiro número da Gazeta do Rio de Janeiro. Jornal oficial onde nada nele constituía atrativo para o público. Nem essa era a preocupação dos que o faziam, preocupados quase e tão somente com o que se passava na Europa. Este foi o primeiro jornal impresso no Brasil.

Nesse período a imprensa é marcada pela censura, pelo controle das publicações e pela prisão daqueles que ousassem criticar a Coroa Portuguesa. A crítica quando conseguia alcançar algum jornal vinha de forma indireta, velada. Contudo, aqui e ali os textos contra a monarquia e o sistema escravocrata começavam a aparecer através dos pasquins. Estes pequenos jornais eram financiados por pequenos grupos para divulgarem suas idéias, expressando seu ponto de vista.

O jornalismo, (...) continuaria extremamente panfletário e a serviço apenas dos ideais de alguns grupos. Não havia um jornal de grande circulação e o número sempre crescente de publicações significava a diversificação de posturas ideológicas. Os jornais informavam pouco e eram extremamente opinativos (e tendenciosos). Com o preço da tipografia relativamente baixo, grupos políticos, literários e até carnavalescos possuíam um jornal.

Até quase meados do século XIX, para cada idéia, havia um jornal. O interesse não era vender os exemplares, mas distribuí-los gratuitamente ou vendê-los por um valor irrisório aos simpatizantes das causas. (FERNANDES, 2000, p. 63). 


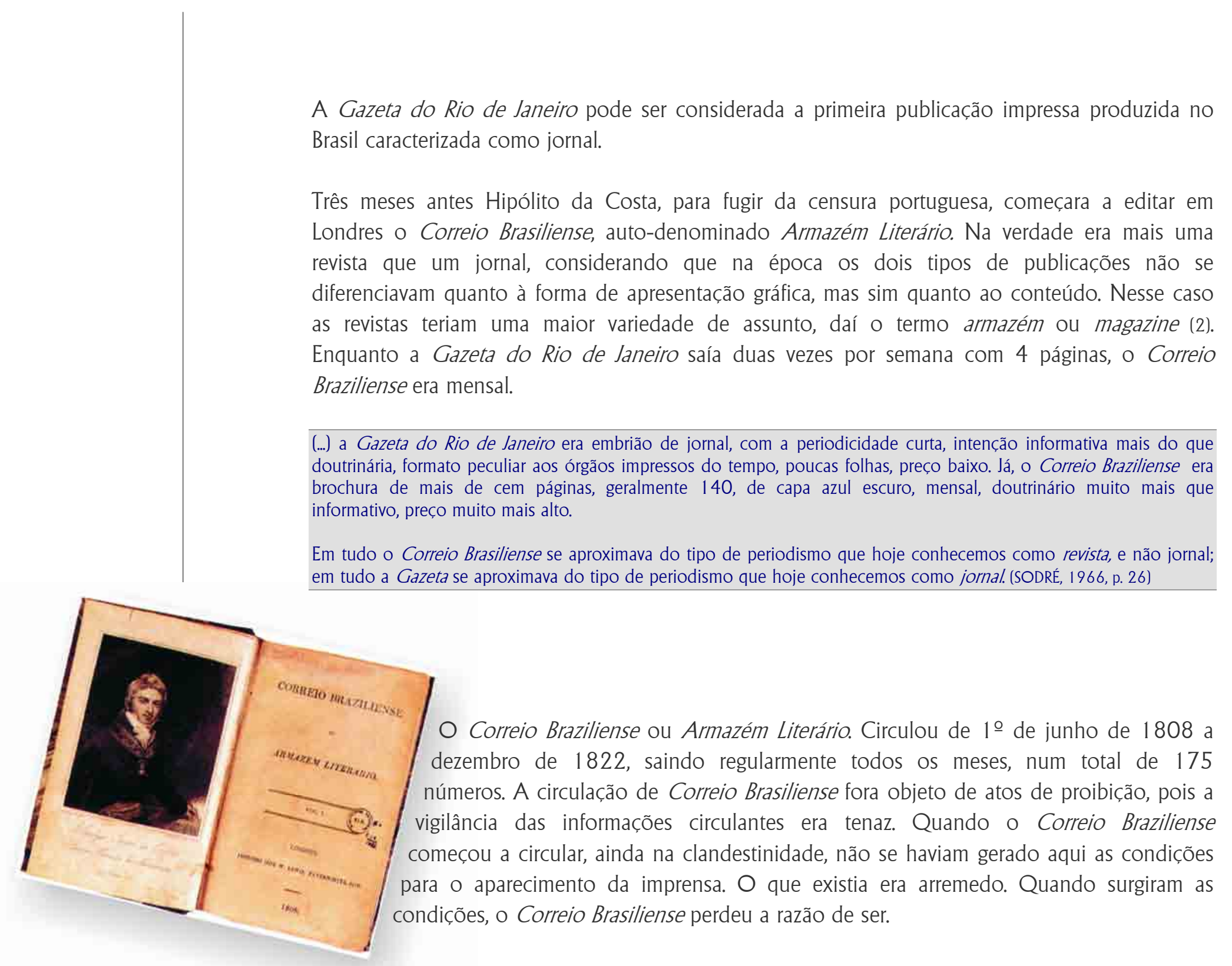




\section{A Imprensa da Época}

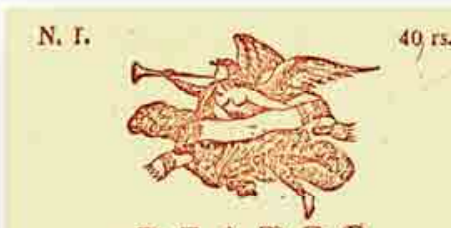

DI $\triangle \mathbb{B} I$ (1)

DO RIO DE JANETRO.

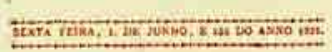

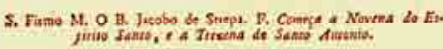

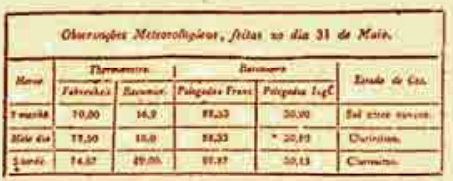

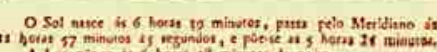

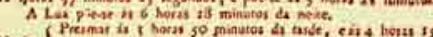

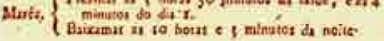
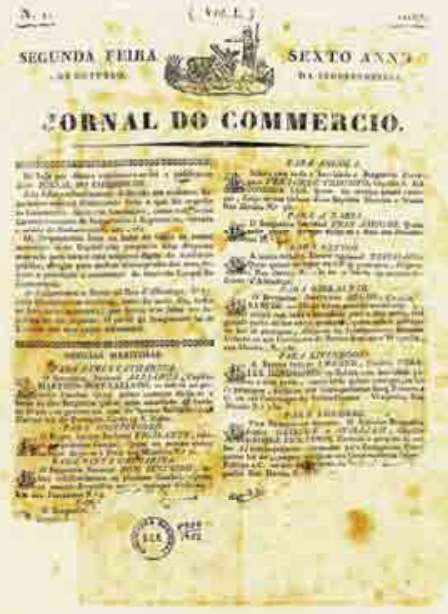

processo da Independência do Brasil foi longo, tortuoso, com avanços e recuos, influenciados por diversos fatores. Tudo isso repercutiu na imprensa da época. Nesse período a imprensa tem, então, sua primeira fase autêntica, quando os episódios políticos marcaram a evolução dos acontecimentos.

\section{Em junho de 1821 aparecia na Corte o Diário do Rio de Janeiro.}

(O Diário do Rio de Janeiro) foi realmente o primeiro jornal informativo a circular no Brasil. Ocupava-se quase tão somente das questões locais, procurando fornecer aos leitores o máximo de informações particulares e anúncios: (...) (os assuntos) tratavam de furtos, assassínios, demandas, reclamações, divertimentos, espetáculos, observacõos meteorológicas, marés, correios; tratavam de escravos fugidos, leilões, compras, vendas, achados, aluguéis e preços de gêneros alimentícios. (SODRÉ, 1966, p. 58)

Passou a ser conhecido como o Diário do Vintém, pelo preço que era comercializado, e como Diário da Manteiga porque trazia os preços, entre outros gêneros, da manteiga que chegava à Corte para consumo da população. Seu distanciamento das questões políticas era de tal modo que não noticiou a proclamação da Independência, inserindo apenas, a partir de 24 de setembro, editais decorrentes do acontecimento.

O ano da Independência assinalou o aparecimento de numerosos periódicos na Corte e nas províncias, caracterizando a tensão política e assinalando as tendências. Marcante também eram as iniciativas pessoais:

(...) vindo de seu país por motivos políticos, Pierre Plancher, trouxe o seu meio de vida, uma oficina tipográfica completa, que logo pôs em funcionamento, imprimindo folhinhas, leis e papeis avulsos, vendendo na loja também livros e calendários, Plancher tinha, entretanto, a coceira jornalística e logo começou o Spectador, que ele mesmo redigia sob o aparente pseudônimo de Hum Francês Brasileiro. Foi na oficina, instalada à rua da Alfândega 47, que Pierre Plancher iniciou, a 1 을 de outubro de 1827, o Jornal do Comércio. Assim, a folha não se destinava apenas a dar melhor e maior divulgaç̃o às noticias comerciais - preços, movimento de paquetes, informaç̃es sobre importacão e exportaç̃o, noticiário do país e do exterior, particularmente do quadro político, participando, assim dos episódios principais daquela fase. (SODRÉ, 1966, p.126).

Mesmo em ritmo lento, as técnicas de impressão no Brasil começaram a evoluir e os estrangeiros tiveram papel pioneiro nessa evolução. Foram relativamente numerosos os franceses que chegaram ao Brasil na fase da Independência, sendo que a maioria se radicou no Rio de Janeiro, que desfrutava as honras de Capital Federal. Boa parte deles era constituída por livreiros, tipógrafos e jornalistas. Criadas as condições políticas, as matérias começaram a surgir e quase sempre proporcionadas por estrangeiros. E junto com ela a introdução da arte da gravura. 
(3) De 1831 a 1850 foram 19 anos de sucessivas revoltas provinciais, todas de caráter liberal, contra o poder central:

- a guerra rural dos Cabanos, chamada Cabanada, em Pernambuco e Alagoas, de 1832 a 1853 - a Cabanagem, no Pará, de 1835 a 1840; - a Farroupilha, no Rio Grande do Sul, a mais longa, de 1836 a 1845 ;

- a Sabinada, na Bahia, de 1837 a 1838;

- a Balaiada, no Maranhão, de 1838 a 1840 e

- a Praieira, em Pernambuco, de 1848 a 1850

- além de algumas revoltas menores, em Minas Gerais e no Rio de Janeiro.
A imprensa vinha se desenvolvendo na medida em que o problema político se tornava mais agudo. As lutas políticas refletiram profundamente no desenvolvimento da imprensa. Foi um desenvolvimento de conteúdo político, não um desenvolvimento técnico. Sob os aspectos formais - impressão e circulação - os jornais não apresentavam mudanças sensíveis. Nos aspectos de conteúdo, porém, as mudanças foram grandes. A vigilância do poder central era constante.

Os jornais livres encontravam-se nas áreas rebeladas, como em Pernambuco, em 1824. “(...) jornalisticamente, em 1831 com o Carcundão, surgido no Recife, nasce a caricatura em nosso país. A respeito deste periódico, escreve Alfredo de Carvalho: (...) era redigido com extrema mordacidade (...) trazia grosseiras vinhetas caricatas abertas a canivete em entrecasca de cajazeiro, primeira tentativa de jornalismo ilustrado em Pernambuco”. (BELTRÃO, 1969, p. 396)..

Para sustentar a Independência os brasileiros aprofundaram o processo. (...) “não temeram levá-lo às últimas conseqüências. Dai o surto nativista, o ódio ao português, a crítica implacável, a oposição vigilante e virulenta. (...) $\bigcirc$ que as forças conservadoras mais temiam era justamente o aprofundamento (...) das alterações estruturais, a perda de seu domínio tradicional." (SODRÉ, 1966, p. 79).

Nessa época “(..) a imprensa era então panfletária e atrevida. Nos períodos de tolerância ou de liberdade atingiu a grandes violências de linguagem e polêmicas, refletindo o ardor apaixonado das facções em divergência, chegando a excessos, a ataques pessoais e insinuações maldosas". (SODRÉ, 1966, p. 76). A Assembléia Legislativa exigia medidas especiais contra a imprensa. Era, agora, impossível contê-la. Esse ambiente agitado deu lugar a um tipo de imprensa de características específicas: o pasquim. As razões do aparecimento e do desenvolvimento desse tipo de imprensa residiram nas condições reais de vida, não surgiram de desejos e deficiências dos jornalistas do tempo.

\section{O Pasquim}

A partir de 1831, no período da Regência, proliferaram diversas revoltas provinciais (3). Paralelamente apareceram dezenas de folhetos humorísticos de curta duração (vide subtítulo 7.4). Se juntaram novos periódicos, quase todos agressivos, injuriosos, menos preocupados com os problemas gerais e mais preocupados com as pessoas. Surgiam todos os dias novos jornais, novos pasquins. Uns duravam semanas ou meses, outros perduravam. Os que morriam ressurgiam às vezes com nome mudado, mas sempre animados do mesmo espírito de intriga, da mesma vocação para a calúnia. As paixões políticas dessa época estão retratadas mais nos pasquins do que nos jornais dotados de continuidade e estabilidade "(...) escritos na maior parte em estilo desabrido e empregando a sátira burlesca e muitas vezes desonesta, cuja virulenta linguagem era própria da época (...). Os jornais daquele tempo foram a válvula de onde partiram ofensas e calunias contra os governantes". (SODRÉ, 1966, p. 112).

Nesse período a imprensa continuou no seu papel, refletindo as contradiç̃es sociais e políticas, influindo no andamento dos acontecimentos. Em função das lutas políticas travadas o desenvolvimento da imprensa não ocorreu só na Corte. Estendeu-se a todo o país, particularmente nas províncias, em que as lutas políticas alcançaram nível mais alto. Estendeuse até à última de 1848, em Pernambuco, quando encerrou a fase da turbulência. 


\section{Características do Pasquim}

A linguagem virulenta não era de uso apenas nas folhas de oposição. Na época, influente jornalista confessaria que "a maioria dos jornais que possuímos mais insulta do que argumenta”, comprovando que as características do jornalismo da época derivavam diretamente das condições do meio, era uma oposição às normas estabelecidas.

Contra essas normas, prevenindo tais alterações, as folhas avulsas, (...) vigilantes, sentindo a ameaça, explodiam no vitupério, inventando aquilo que não podiam conhecer ou antecipando eventos que, em alguns casos, não tinham sido previstos ou preparados. O pasquim trazia para a rua uma política habitualmente preparada em gabinetes, introduzindo o elemento popular naquilo de que ele havia sido propositalmente excluída. (SODRÉ, 1966, p.180).

As inquietações geradas por três séculos de domínio colonial sob a rígida estrutura do latifúndio deflagrariam a necessidade de transformações. Traduziam-se sob as formas mais diversas, a tal ponto de apresentar o comerciante luso como responsável por todas as mazelas, propício a todos os golpes, misturando as condições nacionais às condições de classe e às condições de cor.

Eram vozes desconexas e desarmoniosas, bradando em altos termos e combatendo desatinadamente pelo poder que Ihes assegurasse condicões de existência compatíveis ou com a tradição ou com a necessidade. Não encontrando a linguagem precisa, o caminho certo, a norma política adequada aos seus anseios e a forma e a organização a isso necessárias, derivavam para a vala comum da injúria, da difamação, do insulto repetido. Não podiam fazer uso de outro processo porque não o conheciam, não estavam em condições de utilizá-lo. Num meio em que educação, (...) estava pouquissimamente difundida, em que a massa de analfabetos era esmagadora, em que os que sabiam ler não tinham atingido o nível necessário ao entendimento das questões políticas, e em que os que haviam freqüentado escolas superiores se deliciavam em estéril formalismo e no abuso da eloqüência vazia, a única linguagem que todos compreendiam era mesmo a da injúria. (SODRÉ, 1966, p. 181).

Não havia venda dos pasquins nas ruas; comprava-se nas tipografias e nas lojas de livros indicadas. Os títulos das matérias se referiam, via de regra, a pessoas, acontecimentos, coisas de interesse notório no momento. Via de regra um só artigo ocupava todo o espaço do pequeno jornal.

(O pasquim) não tinha periodicidade certa, não aparecia em dias previamente fixados, na grande parte dos casos. Houve mesmo exemplos em que se anunciava o aparecimento para quando fosse possível, enquanto houvesse verba, mediante aviso posterior. A maior parte dos pasquins não passou do primeiro número. A quase totalidade teve vida efêmera, saída irregular e até orientação flutuante.

Outro aspecto sob o qual, a rigor, também se deixaria de lado o pasquim, na história do periodísmo nacional, foi o seu traço específico de produto de uma só pessoa. Um homem, escritor, foliculário, político, servindo a interesse seus ou de outrem, adotando orientação própria ou obedecendo àquela imposta por seus mandantes, escrevia o jornal inteiro, Jornal de um só assunto, sempre, e de artigo único, quase sempre. (SODRÉ, 1966, p. 178) 
Mas nunca, certamente, a imprensa viveu tão de perto os acontecimentos políticos e essa foi a grande virtude do pasquim.

Nessas competiç̃es, aqui e ali, às vezes repetidamente (..) apregoava-se a defesa do bem comum, da causa pública. Mas os alvos eram as pessoas que encarnavam estas ou aquelas idéias, posições, doutrinas, tendências, poderes. (...) Tudo isso é perfeitamente compreensível numa época atormentada, em que se pretendia gerar as bases institucionais

do país, construir o seu aparelho de estado, consolidar uma estrutura de produção (...) Havia, assim, a tendência constante em tornar grandes as pequenas questões, em tornar públicos os problemas de ordem privada, em tornar pessoais as controvérsias políticas. (SODRÉ, 1966, p.192).

A pregação do sistema federativo e a difusão de idéias republicanas eram consideradas subversivas em seu conteúdo. A linguagem em si tinha circulação franca, por mais injuriosa que fosse. Pela parte adversária era respondida pela mesma linguagem, quando não pelo atentado pessoal.

\section{A Expansão da Imprensa}

A possibilidade do jornal diário e a introdução da caricatura são os dois dados mais importantes nesse momento.

O aparecimento da caricatura de forma sistemática traria à imprensa recursos que anunciavam mudanças a que o processo político não ficaria imune. A caricatura chegou regularmente à imprensa brasileira em 1844, com a Lanterna Mágica, numa de suas fases mais difíceis, quando a agonia da liberdade de expressão avançava depressa, embora continuassem a surgir aqui e ali, esporadicamente, uns poucos pasquins. Os problemas políticos voltavam ao primeiro plano. Era a época da Guerra do Paraguai, da luta pelo Abolicionismo e do implemento da República.

(...) na verdade, o período de 1830 a 1850 foi o grande momento da imprensa brasileira (...) (o pasquim) foi, realmente
representação extraordinariamente rica do ambiente brasileiro, em sua inequívoca autenticidade. Tomando o conjunto
de suas características - a virulência de linguagem não foi senão uma dessas características - revelando peculiaridades
nacionais e conservando conteúdo democrático que constitui o seu traço mais admirável.
(...)
Corresponde, por outro lado, ao período artesanal, em que era possível alguém fazer um jornal sozinho. Encerrada essa
fase, o jornal passará a ser empresa - pequena empresa, de início, para chegar às proporções de grande empresa, como
se apresenta em nossos dias. (SODRÉ, 1966, p. 207).

As dificuldades dos transportes e do serviço de Correio impediam que os jornais da Corte e das capitais se difundissem para o interior. Com isso, a imprensa também passou a se desenvolver no interior das províncias. 
No fim da década da década de 1860 as alterações na fisionomia do país começaram a crescer e a se manifestar em acontecimentos políticos.

A partir do início da segunda metade do século XIX o Império está com sua estrutura articulada e firme. Os germes da mudança surgirão logo após a guerra com o Paraguai. E o primeiro deles é a extinção do tráfico negreiro.

Virão em seguida inovações na técnica de impressão, principalmente com a litografia, e alterações no sistema de distribuição. As publicações retomarão o ímpeto ao aproximar-se o fim do século. Estará, então, aparelhada para enfrentar nova etapa de expansão.

Até 1874 as notícias do exterior chegavam por carta. Nesse ano a agência telegráfica de notícias Reuter-Havas instala no Rio sua primeira sucursal. Agora a imprensa nacional já se interliga ao mundo e entra em sua fase empresarial.

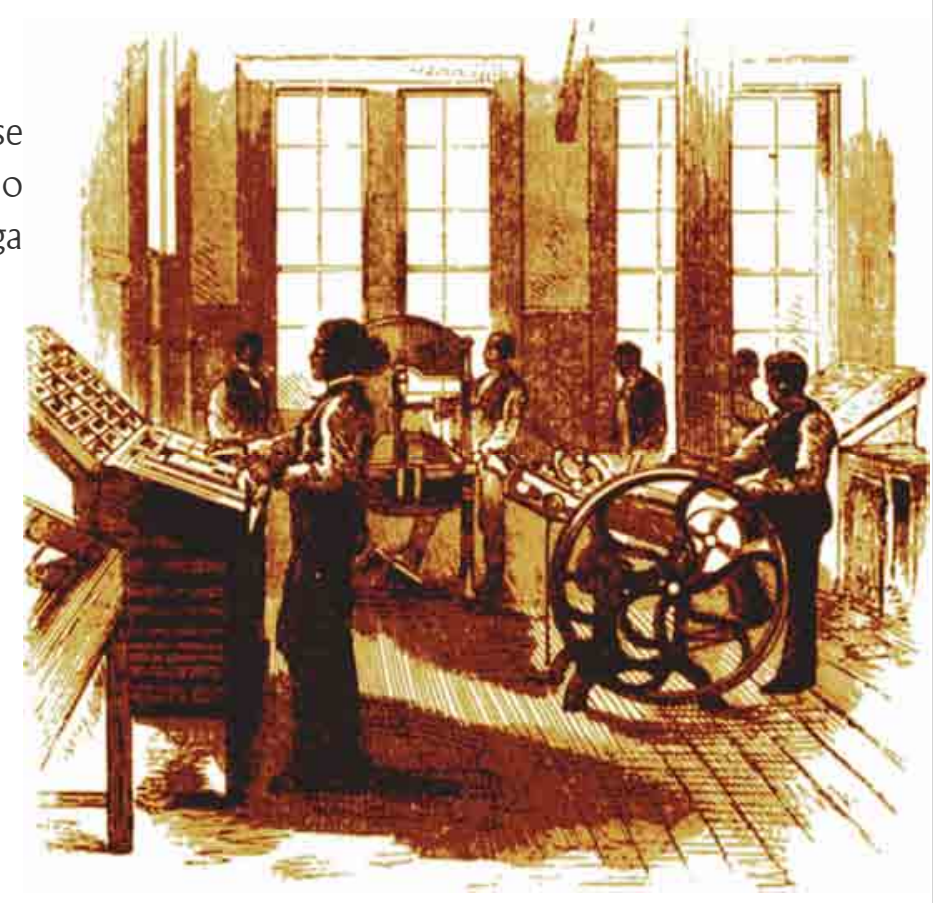




\title{
7.3 - A EMPRESA JORNALÍSTICA
}

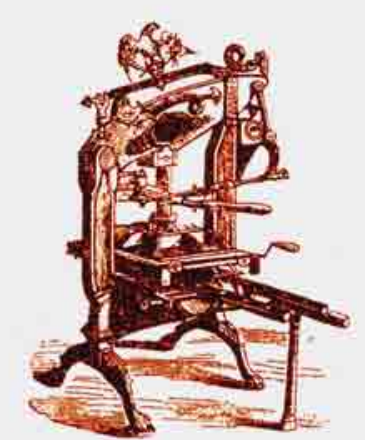

\begin{abstract}
A passagem do século assinala, no Brasil, a transição da pequena à grande imprensa. Os pequenos jornais, de estrutura simples, as folhas tipográficas, cedem lugar às empresas jornalísticas, com estrutura específica, dotadas de equipamento gráfico necessário ao exercício de sua função. Se é assim afetado o plano da produção, o da circulação também o é, alterando-se as relações do jornal com o anunciante, com a política, com os leitores. (...) A transformação na imprensa é um dos aspectos desse avanço; o jornal será, daí por diante, empresa capitalista, de maior ou menor porte. O jornal como empreendimento individual, como aventura isolada, desaparece nas grandes cidades. Será relegado ao interior, onde sobreviverá, como tal (...). Uma das conseqüências imediatas dessa transição é a redução no número de periódicos. Por outro lado, as empresas jornalísticas começam a firmar sua estrutura, de sorte que é reduzido o aparecimento de novas empresas. Acontece ainda, particularmente nas fases de inquietação política. É agora muito mais fácil comprar um jornal do que fundar um jornal; e é ainda mais prático comprar a opinião do jornal do que comprar o jornal. (SODRÉ, 1966, p. 256)
\end{abstract}

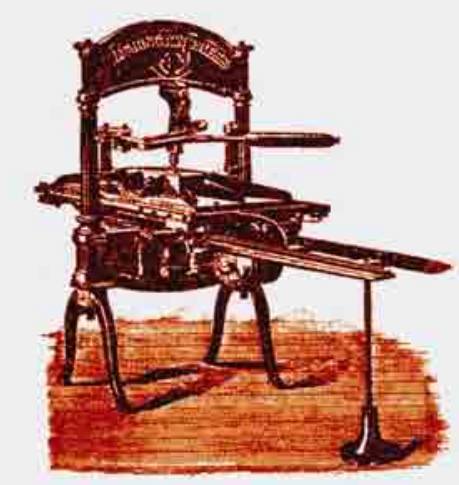

Tudo se personaliza e se individualiza. Daí a virulência da linguagem da imprensa política, ou seu servilismo, como contraponto. Não se trata de condenar a orientação ou os princípios - desta ou daquela personalidade; trata-se de destruir a pessoa, o individuo. A virulência é semelhante, na forma, à do pasquim da primeira metade do século XIX, mas diferente no conteúdo.

\section{Imprensa e literatura}

Nos jornais as colaborações literárias começam a ser separadas na paginação, constituindo matéria à parte. Aparecem seções de crítica e o esboço do que mais tarde serão os suplementos literários. Divisão de matéria, mas intimamente ligada à divisão do trabalho, que começa a impor as suas inexoráveis normas: jornalistas e escritores.

O que mais se fazia, naquela fase, era discutir, por em dúvida, analisar, combater. Combater a pretensa sacralidade das instituições: da escravidão, da monarquia, do latifúndio. A imprensa era abolicionista e republicana, e pelos seus melhores jornais e jornalistas. Não era apenas uma grande época política, era também uma grande época literária.

A primeira manifestação do esforço para ampliar a cultura impressa, subordinada à deficiência das técnicas de impressão, fez-se através dos almanaques, que constituíram os livros de uso e consulta generalizados. "Em todas as províncias, e na Côrte, surgiram almanaques repositórios de literatura, evidentemente de qualidade inferior e de informações úteis. $\bigcirc$ almanaque correspondia e se adequava a uma fase de precariedade das técnicas de impressão. Era o livro de um país que não tinha ainda público para suportar a difusão de livros." (SODRÉ, 1966, p. 223) 
Nos almanaques e nas revistas ilustradas é que irão se refugiar os homens de letras, acentuando a tendência para caracterizar-se definitivamente o jornal como imprensa. As revistas passarão por um período em que serão principalmente literárias, embora também um pouco mundanas e, algumas críticas.

Salvou-as, sem a menor dúvida, a arte da caricatura, que teve, nessa época, grandes nomes a praticá-la e a dar-lhe um sentido, um conteúdo e uma qualidade e execução, uma forma, insuperáveis. É o grande, profundo e significativo aspecto que apresentam. (Se permanecessem) limitadas à literatice, teriam sido inócuas e não teriam alcançado a penetração relativa que alcançaram.. (SODRÉ, 1966, p. 346)

\section{O Estado de São Paulo}

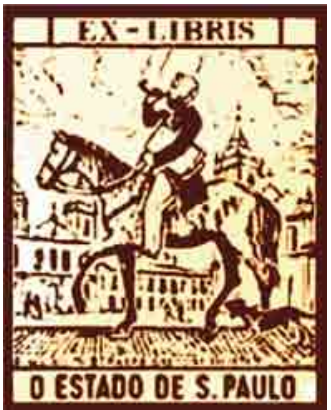

O número inicial da Província de São Paulo (atual O Estado de São Paulo) apareceu (...) a 4 de janeiro de 1875. Como os outros jornais do tempo, (...) a Província de São Paulo, vivia de anúncios e de assinaturas, estimuladas por prêmios sorteados com a loteria, o maior no valor de um conto de réis. (...) (Na época não) havia venda avulsa. Esta foi iniciada pelo novo jornal, a 23 de janeiro de 1876: o ajudante de impressor Bernard Gregoire, tocando buzina nas ruas. A população achou aquilo um dispautério, houve repulsa à iniciativa que levaria a "mercantilização da imprensa”. (...) Logo depois, entretanto, os jornais acompanharam a inovação: surgiram jornaleiros, depois as bancas e os pontos, e a disputa dos pontos. Essa divisão do trabalho assinalava também (...) a "mercantilização da imprensa”. (SODRÉ, 1966, p. 260).

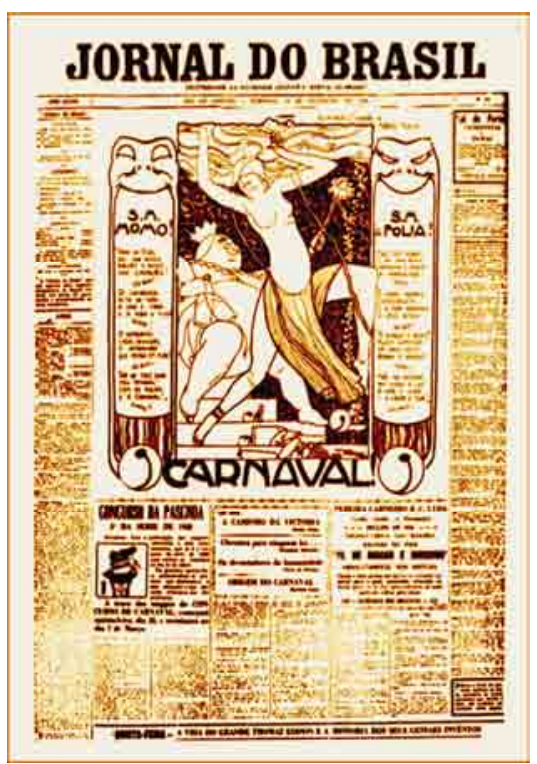

Jornal do Brasil

A mudança do regime, de Monarquia para República, não alterou o desenvolvimento da imprensa. Os grandes jornais continuaram os mesmos. Os de linha republicana com mais prestígio e os monarquistas com mais combatividade. Não surgiram de imediato grandes jornais novos. Só em 1891 apareceria o Jornal do Brasil.

O Jornal do Brasil chegava para ser um dos grandes. Fora montado como empresa, com estrutura sólida. Vinha para durar. E trazendo inovações, pelo menos na importância que deu a cada uma delas. A distribuição feita por carroças era uma. A amplitude dos correspondentes no exterior era outra. Publica os primeiros clichês em xilogravura. Aparecem no $J B$ os primeiros clichês obtidos por zincografia.

Os grandes jornais começam a construir na Av. Rio Branco seus edifícios próprios. O JB recebe as primeiras linotipos que o Rio conheceu, máquinas de impressão em cores e clicheria de sistema fotomecânico. 
O século aproximava-se do fim. O Jornal do Brasil instalara oficinas de fotografia e de gravação de matrizes metálicas. Publicava os desenhos de Julião Machado, Luiz Peixoto, Artur Lucas (Bambino), Celso Hermínio e Raul Pederneiras.

O seu parque gráfico, em 1916, é o maior da imprensa brasileira.

\section{A Empresa Moderna}

A imprensa iria, agora, atravessar a primeira de suas fases tormentosas no regime republicano. Como todas as fases de

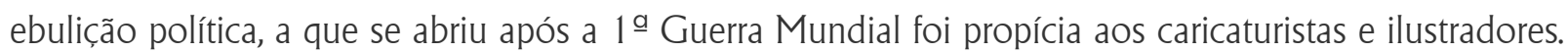

Se, com o após-guerra, profundas alterações se denunciavam na vida brasileira, tais alterações, para a imprensa, acentuam rapidamente o acabamento da sua fase industrial relegando ao esquecimento a fase artesanal: um periódico será, daí por diante, empresa nitidamente estruturada em moldes capitalistas. Continuam a aparecer revistas de vida efêmera, literárias ou humorísticas, e jornais de circunstância, principalmente para atender injunções originadas da luta política, cada vez mais acirrada, mas são fatos pouco numerosos e acidentais. Na maioria dos casos, trata-se de empresas mal estruturadas, que se esgotam depressa, que consomem rapidamente o capital, mas sempre empresas, e não empreendimentos individuais. (SODRÉ, 1966, p. 409).

Surge em São Paulo, em 1921, a Folha da Noite, jornal organizado como empresa e que vai revelar um caricaturista excepcional: Belmonte. No Rio, em 1926, surge A Manhã, matutino vibrante, versátil, bem paginado, com excelentes colaborações, contando com o talento do caricaturista Andrés Guevara.

O segredo da imprensa consistia, à medida que o capitalismo avançava, na rapidez com que chegava aos leitores e na possibilidade de contá-los aos milhões. Era necessário, por isso, que a producão atendesse à multiplicação de exemplares (...) e que os transportes atendessem à distribuição oportuna, rápida, vertiginosa, dos exemplares velozmente distribuídos. As invenções que tornaram os periódicos empresas industriais aparelhadas, eficientes, capazes de produzir, todos os dias, milhões de jornais, seguiram-se umas às outras a curtos intervalos. (...) Reproduzindo ilustracões rapidamente e a baixo custo, pela velocidade na impressão (.) as novas máquinas faziam correr rolos de papel com a velocidade de um trem expresso, saindo os jornais em cores, quando era desejado e sempre automaticamente contados e dobrados. Isso permitia enorme redução no custo da unidade fabricada, ao mesmo tempo que melhorava a sua qualidade. Tudo conduzia, finalmente, ao rebaixamento do preço pago pelo leitor, numa difusão cada vez mais numerosa, em influência cada vez mais larga (...). (SODRÉ, 1966, p. 5-6).

Depois da revolução 1930 houve grande desenvolvimento da imprensa, particularmente no sentido de consolidar a estrutura empresarial. Os jornais e revistas de vida efêmera são mais raros agora. Com o desenvolvimento dos meios gráficos e a evolução dos processos de compor e a melhoria do conteúdo editorial surgem, então, as grandes empresas jornalísticas, consolidando-se a "cadeia associada". Utilizam-se os meios mais rápidos de transporte para a distribuição das ediç̃es tanto regionais como nacionais. 


\section{7) \\ DIARIO DE PLRNAMBUCO}

JORVAL DO COMMERCIO

\section{DIARIO DOPARANÁ}

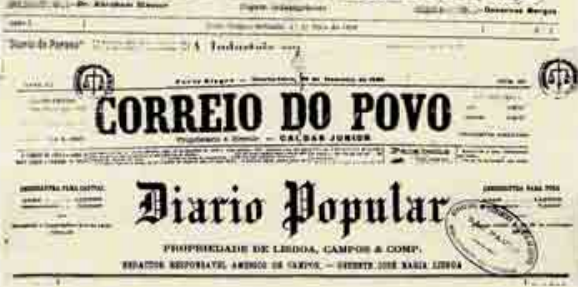

JORNAL DO BRASIL

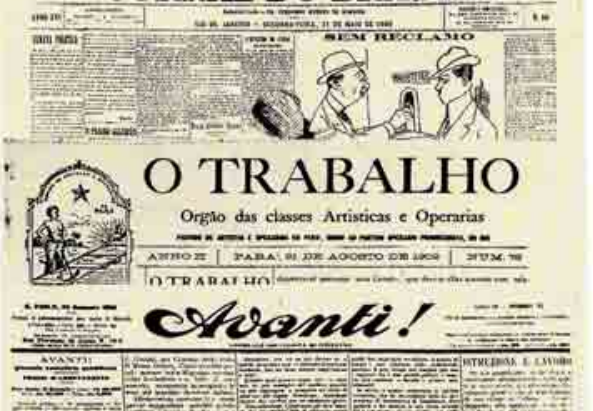

O PA I Z

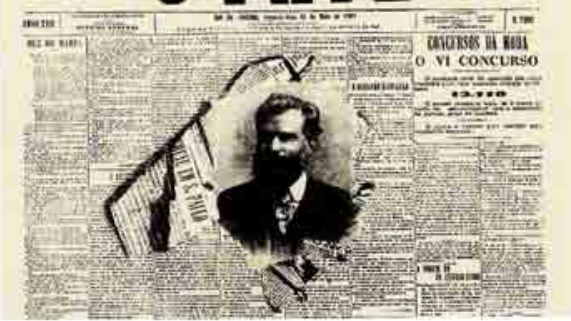

É, então, por volta da década de 40, que o jornalismo começa a mudar de rumo no Brasil, seguindo a tendência dos EUA e da Europa. A comunicação de massa passa a ser vista como um negócio, uma chance de lucro e enriquecimento. O impulso para a mudança, é claro, vem principalmente do crescimento da indústria, que deseja alcançar o potencial mercado consumidor. Os pequenos jornais opinativos vão sendo engolidos por essa forma empresarial de se fazer jornal, que resulta em investimentos tecnológicos, ampliando o número de exemplares e o alcance das emissoras.

A audiência e as vendas passam a ser preocupações centrais das empresas jornalísticas. De espaço opinativo, refletindo sempre o pensamento de um grupo restrito, os meios de comunicação de massa, incluindo, agora, o rádio, pretendem ampliar sua recepção. Quanto mais leitores e ouvintes, mais vendas, mais anunciantes, mais lucro. Para transformar o jornalismo em negócio e alcançar o maior número de receptores, era preciso, também, modificar a forma de tratar os assuntos. (FERNANDES, 2000, p. 65).

A busca pela rapidez exigiu da imprensa sucessivos inventos, acompanhando o crescente fluxo de informações.

As revistas e os jornais vivem uma época de ouro. Eram tempos de sucesso do mercado dos magazines ilustrados de interesse geral, como Life, Look, Saturday Evening Post, Stern, O Cruzeiro, Manchete, etc. Para fazer frente à $\mathrm{TV}$, as revistas e jornais buscaram utilizar em profusão a linguagem fotográfica e ilustrada. Porém, entraram em declínio com o rápido desenvolvimento da televisão. Com múltiplas linguagens a TV torna-se soberana ao relacionar imagem, som, cores e movimento.

O espantoso crescimento da televisão a partir dos anos 60 provoca o fechamento de grandes revistas ilustradas e provoca sensíveis mudanças no jornal diário. Dando margens a previsões sobre o total desaparecimento dos meios impressos. 
7.4 - ANEXO - REVISTAS ILUSTRADAS E ILUSTRADORES 
O chargista e pesquisador Laílson de Holanda Cavalcanti (2005, p. 21) revela em seu livro Historia del Humor Gráfico en Brasil que a primeira manifestação de humor impresso no Brasil ocorreu n' O Carcundão, na cidade do Recife. Não há menção de autoria, certamente devido ao repressivo sistema político dominante. Não era possível assumir publicamente um desenho crítico dirigido ao poder constituído e às autoridades. A obra foi localizada pelo pesquisador Alfredo de Carvalho, em 1908, e frequentemente desconsiderada como referência nas antologias.

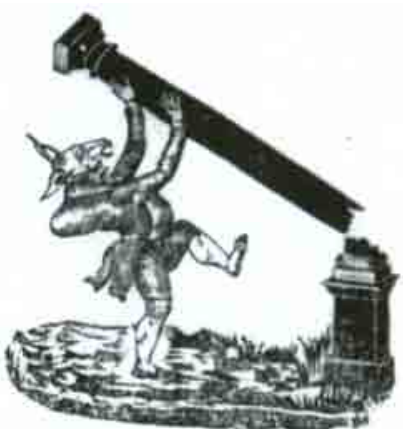

O desenho (representa) uma mistura de asno e homem que tenta sustentar uma coluna que tomba sobre ele. (...) A publicação onde apareceu essa primitiva vinhreta era $O$ Carcundão. A data da publicação é de 25 de Abril de 1831 , e tem um formato de $15 \mathrm{~cm}$ de largura por $22 \mathrm{~cm}$ de altura. $O$ desenho é uma gravura em madeira (...) Foram publicados três números de $O$ Carcundão, aparecendo o último em 16 de Maio de 1831 (_) Podemos afirmar, sem nenhuma dúvida que $O$ Carcundão publicou o primeiro desenho humorístico realizado no Brasil. (CAVALCANTI, 2005, p. 21)

O desenho pode ser compreendido como uma crítica aos membros do Partido restaurador, apelidados pelos liberais como Corcundas, que através da Sociedade Colunas do Trono buscavam devolver a coroa a D. Pedro I, que dela havia abdicado meses antes.

Em 1832, também na cidade de Recife, aparecia outra publicação que contém humor gráfico na capa: O Carapuceiro. Tem igualmente um caráter satírico e o redator era o monge beneditino Miguel do Sacramento Lopes Gama. O primeiro número de $O$ Carapuceiro, aparecido em 07 de Abril de 1832, apresenta o mesmo formato que 0 Carcundão e era impresso pela mesma Tipografia Fidedigna, embora não tenha nenhuma ilustração na capa. O primeiro desenho apareceria em 07 de Julho de 1832, embora com qualidade inferior que o desenho da capa d' $O$ Carcundão. (...). Ambas as publicações coexistiram em um mesmo segmento de tempo (...) na mesma cidade. Ambos têm, assim, uma postura crítica muito semelhante. (...) O padre Carapuceiro (como passou a ser conhecido o padre Lopes Gama) assegurava que seu periódico pretendia "falar dos vícios e nunca das pessoas (...)", assim podemos intuir que o objetivo das duas publicacões era o mesmo desde o ponto de vista moral e político (...) e que o autor de ambas as publicações foi uma só pessoa (...) o padre Lopes Gama. (CAVALCANTI, 2005, p. 22) 
Foi a Lanterna Mágica, que circulou no Rio de Janeiro entre 1844 e 1845, com o sub-ttítulo de Periódico PlásticoFilosófico, que assinalou, de forma sistemática, o início das publicações ilustradas com caricaturas impressas. Circulava aos domingos, era impresso com luxo (...). Seu diretor era o próprio Manuel de Araújo Porto-Alegre, tendo Lopes Cabral como desenhista e Rafael Mendes de Carvalho como pintor.

O aparecimento da caricatura passou a dar à imprensa recursos de enorme amplitude e anunciava uma mudanca que iria fustigar o processo político (no // Império). Era uma época de grandes mudanças marcadas pela extinção do tráfico negreiro, pela Guerra do Paraguai e pela consolidação do Império.

A revista durou até o número 23 , em 1845 , dedicava-se às letras, às artes plásticas, à crítica e à polêmica. (FONSECA 1999, p. 209)

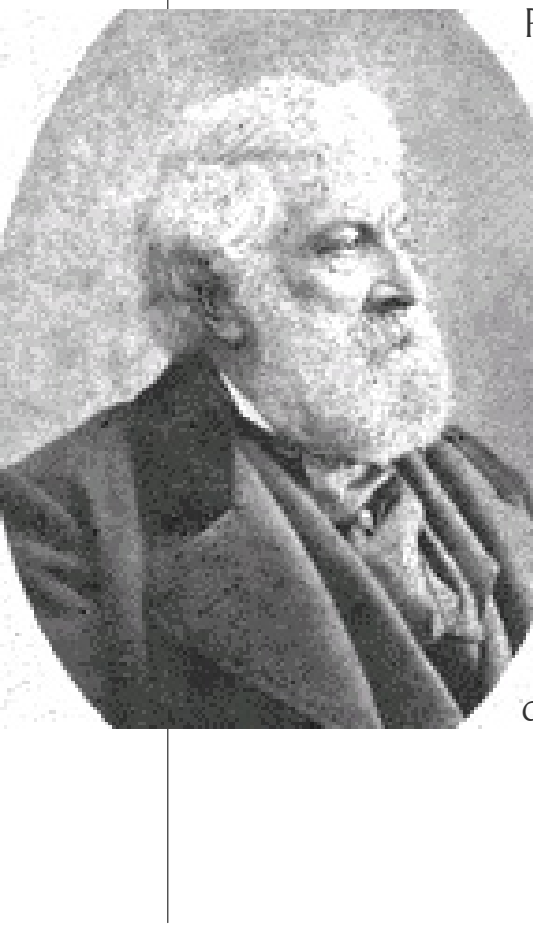

Pintor, caricaturista, arquiteto, crítico e historiador de arte, professor, escritor. Em 1816 muda-se para Porto Alegre, onde inicia seus estudos de pintura e desenho com o pintor francês François Thér (...). No ano de 1837 realiza as primeiras caricaturas feitas no país e assume a cadeira de pintura histórica na Academia de Belas Artes, que ocupa até 1848. Nesse ano pede transferência para a Escola Militar, trabalhando como professor de desenho. Funda e dirige os periódicos Minerva Brasiliense (1843), Lanterna Mágica (1844) - primeira revista ilustrada com caricaturas - e Guanabara (1849). Considerado o fundador da história e da crítica de arte brasileira (...). (Fonte: cartoonvirtual)

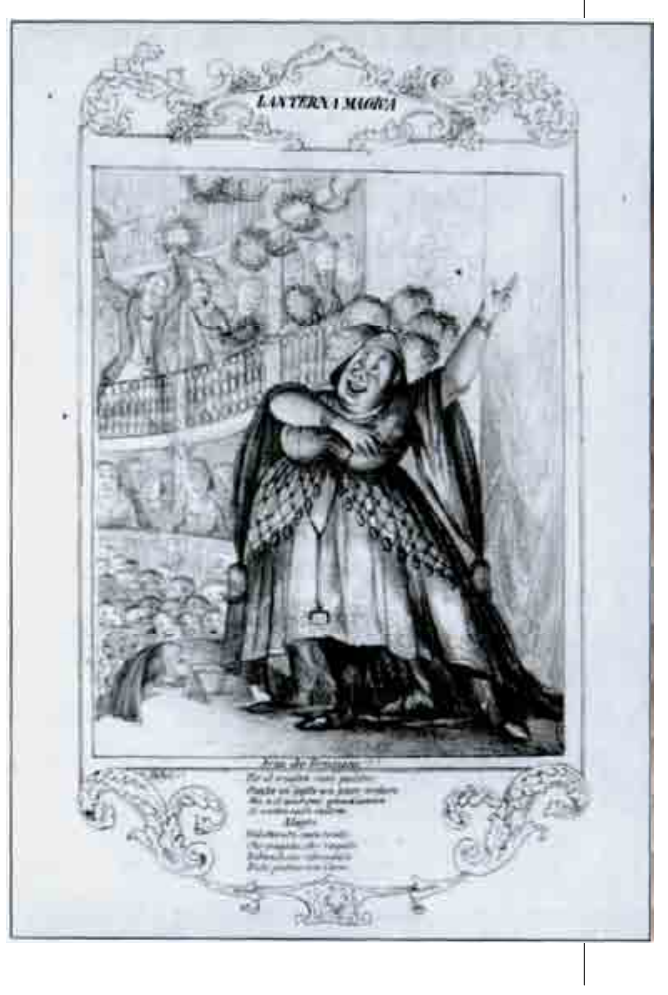




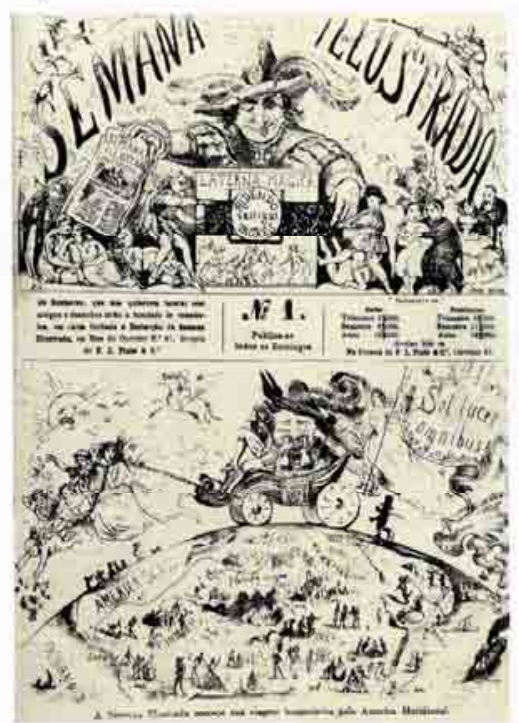

A Semana Ilustrada (circulou) desde 1860, editada pelo alemão Henrique Fleiuss, desenhista e fotógrafo de reconhecido talento, veio se sobrepor aos toscos jornais de caricaturas e estampas litográficas avulsas, como uma verdadeira revista ilustrada, de acordo com as proporçōes daqueles tempos. Seus dez primeiros números foram totalmente desenhados e litografados por Fleiuss. No início saía com um total de oito páginas, quatro de ilustrações, (detalhe ao qual é creditado o sucesso do periódico), e quatro de textos. Publicava poesias, contos e crônicas, estas sob a responsabilidade do Dr. Semana, personagem obrigatório na ilustração de capa comentando um fato da semana com seu pequeno escravo.

(...)

Pela Semana Ilustrada passaram os mais conhecidos escritores e jornalistas da época: Machado de Assis, Quintino Bocaiúva, Pedro Luis, Joaquim Manuel de Macedo, Joaquim Nabuco, Bernardo Guimarães, etc. (SODRÉ, 1966, p. 234-235).

\section{O DIABO COXO}

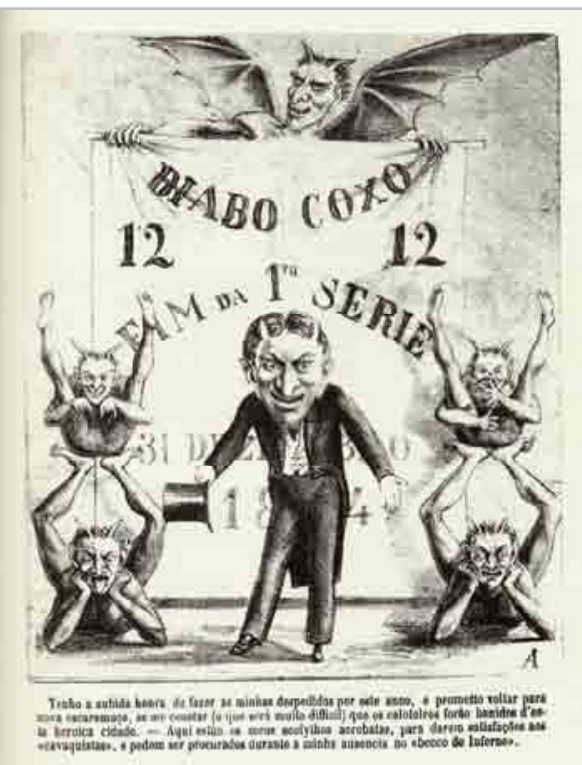

O Diabo Coxo teve o seu primeiro número circulando em São Paulo na base de assinaturas, como era costume na época. Essa pequena publicação - apenas oito páginas - alcançou popularidade notável. Era, de fato, uma novidade em nossa imprensa, toda ela marcada por certo azedume e por ironias que, muito freqüentemente, descaíam no insulto reles ou no deboche vil.

O Diabo Coxo começou a circular em 1으 de outubro de 1864 com formato pequeno, sempre ilustrado desde o início. Era impresso na Tipografia e Litografia de Henrique Schroeder. Viveu pouco mais de um ano, revelando o estilo inconfundível de Ângelo Agostini. 


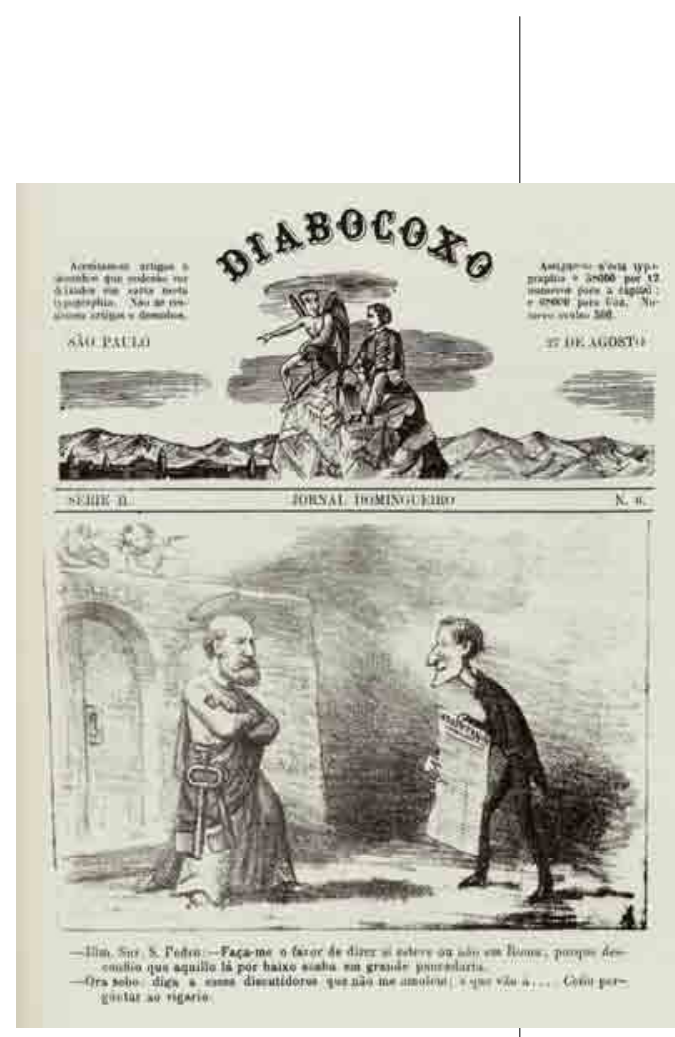

O Diabo Coxo surgiu no ambiente ainda provinciano de São Paulo. Era um jornal repleto de imagens de Ângelo Agostini.

A chegada do periódico significou um 'pandemônio', um 'atropelo', o 'diabo' - para ficarmos com os termos da época. Por apenas 500 réis, o preço de um almoço, comprava-se a edição e o acesso direto ao mundo das imagens e das crônicas. Contando com textos do abolicionista Luis Gama e de Sizenando Nabuco de Araújo, irmão de Joaquim Nabuco, além dos desenhos de Agostini, esse pequeno jornal domingueiro - (...) chegava para fazer barulho. (SCHWARCZ, 2005, p. 2).

O jornal cobriria um período importante, tendo a oportunidade de relatar os impasses da desastrada Guerra do Paraguai, as vicissitudes da Corte "que vivia nos trópicos como se estivesse em Paris", e o movimento da cidade que decididamente começava a se animar.

Mais do que isso, São Paulo seria invadida pelas imagens de Agostini, que permitiam reconhecer políticos, o Imperador D. Pedro II em trajes civis ou majestáticos, e figuras da Corte como o conde d'Eu. Afinal, tratava-se de um ambiente que mal e mal conhecia a fotografia. (...) Começava-se a 'ler imagens' e por aí havia muita novidade. (SCHWARCZ, 2005, p. 3).

O Diabo Coxo foi bem aceito pelo público paulista e logo era comparado à Semana Ilustrada, editada por Fleiuss, e principal revista da Corte. Mas, talvez pelas suas posições muito progressistas para a época, durou apenas pouco mais de um ano. Fecharia as portas em 31 de dezembro de 1865.

\section{O MOSQUITO}

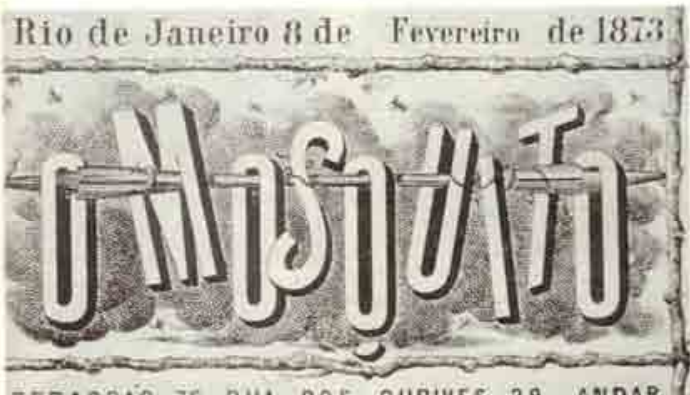

O Mosquito, revista ilustrada e satírica, lançada em 1869, com Ângelo Agostini em seu quadro de desenhistas, também publicava artistas talentosos. Experimentou significativo crescimento ao encampar outros periódicos do gênero, como $A$ Comédia Social, o Mefistófeles e Lobishomem. Em 1877 desaparecia O Mosquito, e seguindo o mesmo modelo surgia, em 1875, o Mequetrefe. 


\section{REVISTA ILUSTRADA}

Revista Ilustrada - Ângelo Agostini Io de Jane

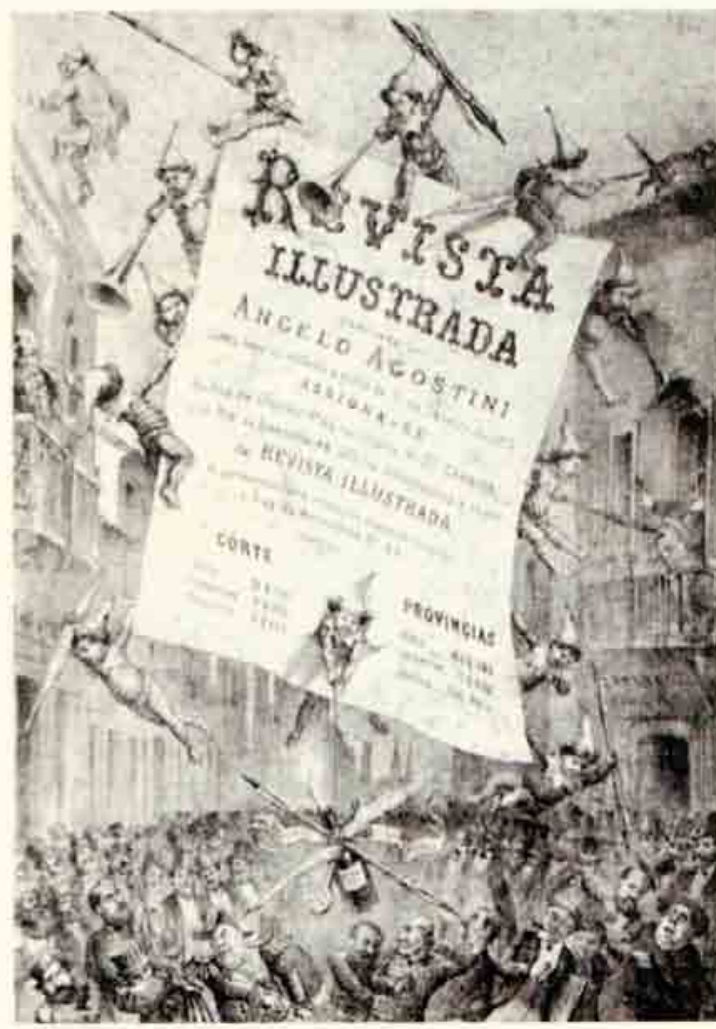

Em 1 을 de janeiro de 1876 surgia a Revista Ilustrada, a mais importante revista brasileira do final do século XIX. Era impressa por litografia a vapor e com uma tiragem de quatro mil exemplares, índice não alcançado por nenhum periódico ilustrado até então na América do Sul. Publicação que proporcionou a Ângelo Agostini oportunidades de mostrar todo seu talento.

A Revista Ilustrada era importante para as localidades longínquas que não tinham acesso a quase nenhum veículo informativo. A publicação é hoje bastante valorizada por ser o maior documento ilustrado do Brasil do final do século XIX, já que seus desenhos, produto das mãos de Agostini, não são admirados apenas pela beleza artística, mas como arte participante e crítica das mazelas sócio-políticas do Brasil daqueles tempos. A revista foi precursora dos primeiros quadrinhos do país, ao publicar As Aventuras de Zé Caipora.

Artista extraordinário, Ângelo Agostini engrandeceu as suas criações com o sentido político que lhes deu. Ninguém manejou o lápis como arma no nível e com a eficácia do ilustrador meticuloso, que apanhava com seu traço inconfundível não apenas os detalhes que a observação colhia, mas a profundidade e a significação do que se exteriorizava nesses detalhes. Seu instante épico foi o da campanha abolicionista. Mas acima de tudo isso, o que mais alto representa ainda a obra política e artística de Agostini, na Revista Ilustrada, é a campanha por ele empreendida em prol da Abolição. Por isso mesmo, em merecidíssima homenagem, Nabuco chamou a Revista Ilustrada, "bíblia da Abolição dos que não sabem ler" (...). (SODRÉ, 1966, p. 250).

A capa do primeiro número da Revista llustrada é de rara beleza e, ao mesmo tempo, de altíssimo senso jornalístico. No centro da página, aberta como um édito a ser lido por algum arauto, temos sobre fundo branco todas as informaç̃es básicas: título, nome do autor, data, endereço e preço das assinaturas. Esse cartaz está seguro e é ao mesmo tempo suspenso por um alegre e sarcástico grupo de crianças 'trajadas ao bizarro', que se parecem com gnomos ou duendes. Portam clarins e, nas mãos, as penas de escrever e desenhar. Um deles, por uma fenda no papel, sustenta um cartaz menor com as palavras célebres de Jean de Santeuil: 'Ridendo Castigat Mores' ou, em português, 'rindo castiga os costumes'. Em torno e embaixo do cartaz, aparece uma série de homens de cartola e fraque, ou de quepe e seda, tentando fugir desesperadamente, dos ataques da 'Revista'. Ao fundo e em torno, o povo se diverte e ri. (SOUZA, 1986, p. 102). 


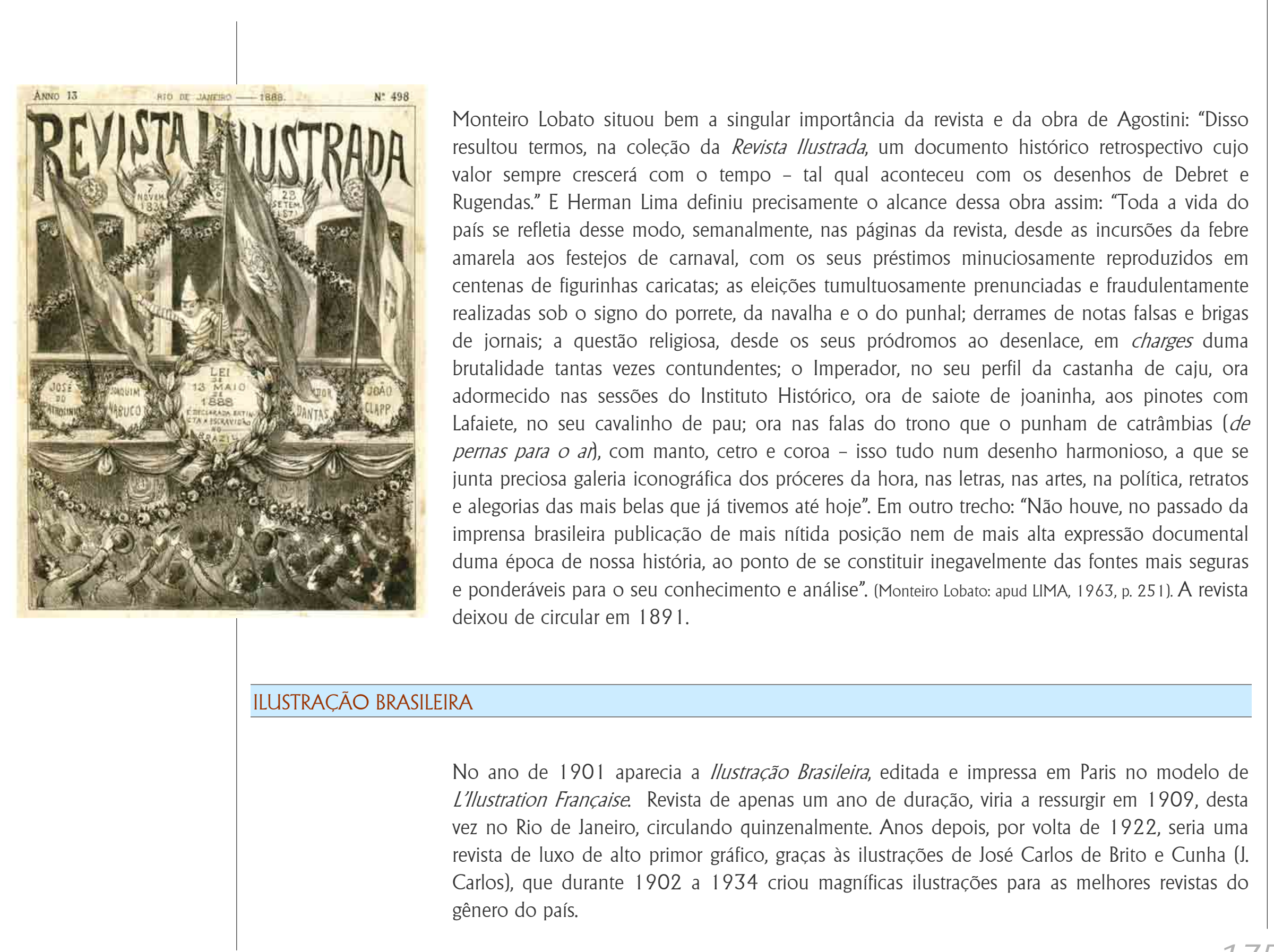




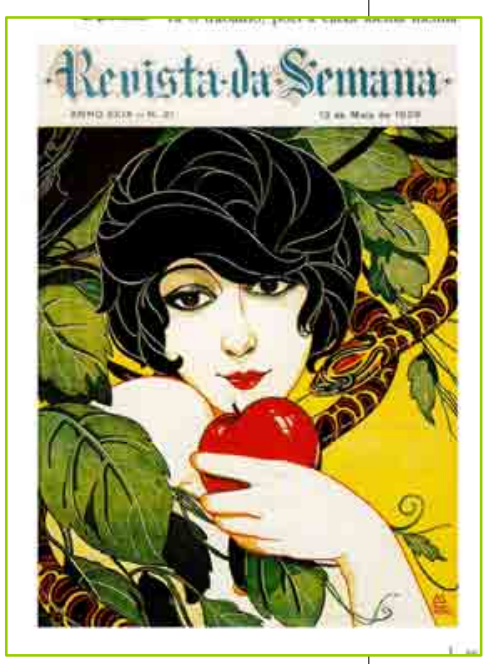

Esta revista começou a circular em 1901, como suplemento ilustrado do Jornal do Brasil. No início do século $X X$ as revistas brasileiras chegavam à era do clichê, produzidos por métodos fotoquímicos, cuja técnica, seu diretor Álvaro de Tefé, aprendera em curso realizado em Paris, de onde também trouxera material necessário para produzir os clichês na Revista da Semana.

Nessa época a tendência literária das revistas, característica predominante do gênero herdada desde o século anterior, foi deixada de lado em nome das variedades. A Revista da Semana teria papel pioneiro nesse sentido, publicando atualidades sociais, política e ocorrências policiais, num tom leve, alegre e elegante, sempre acompanhadas por ilustrações. A partir de 1915 seria mais elegante ainda, adotando uma linha editorial mais feminina.

Foi uma das mais importantes e duradouras revistas ilustradas do país na década de 40 e 50 chegando a concorrer com O Cruzeiro e Manchete.

\section{O MALHO}

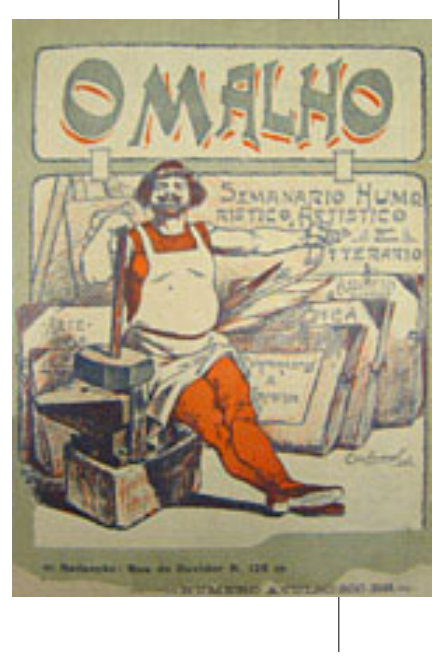

Algumas publicações ficaram para a história. Uma delas foi O Malho, criada em 1902 por Luís Bartolomeu. Politicamente foi de importância comparável à que alcançou a Revista Ilustrada, em seus dois primeiros anos de existência. O Malho dedicou-se aos desenhos de humor e a partir de 1904, porém, transformou-se em uma publicação marcadamente política, de grande força combativa. Suas famosas charges foram assinadas por todos os grandes nomes da caricatura, desde Agostini até o grupo que se revelou e se firmou em suas páginas, em 1930, sob a influência do paraguaio Andrés Guevara.

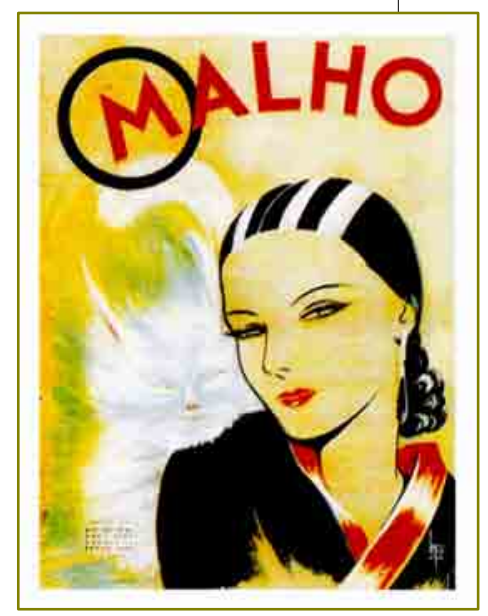

176 


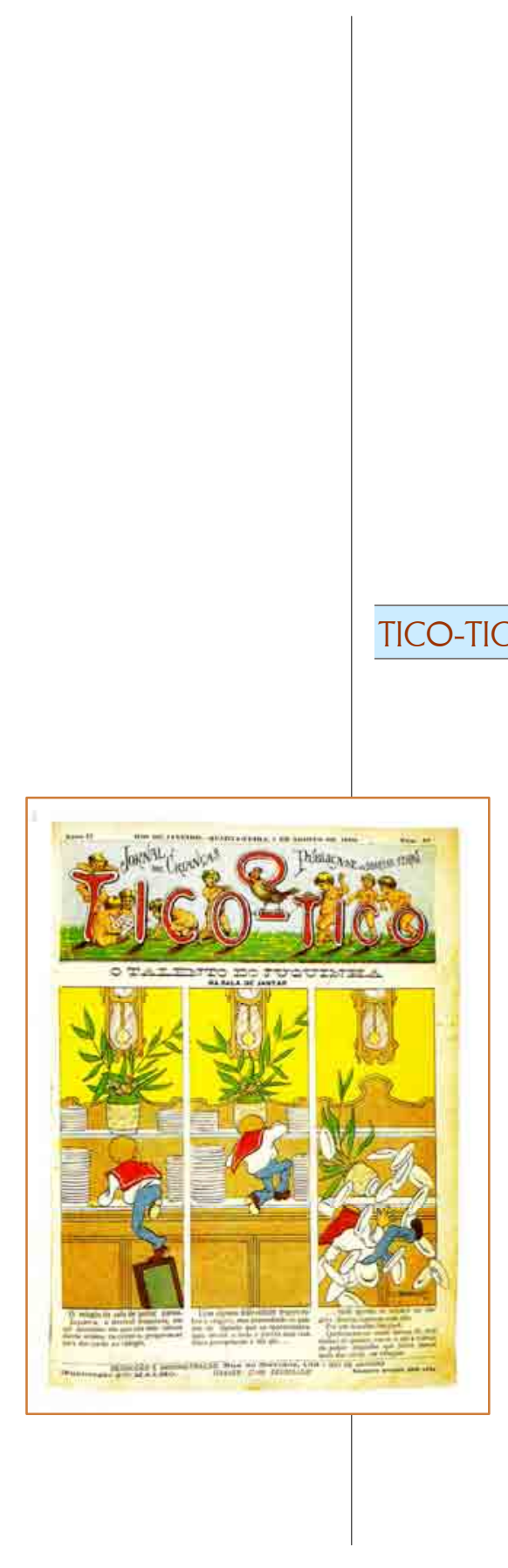

\begin{abstract}
A partir de 1918, quando passou a ser dirigido pó Álvaro Moreyra e J. Carlos, o velho O Malho passou a bater mais frouxamente. Na verdade, transformou-se em uma revista literária, a que não faltavam algumas páginas de mundanismos. Em 1925, porém, com a eleição de Artur Bernardes para a presidência da República, a revista reencontrou o seu antigo vigor. É quando cresce a figura, a personalidade e o estilo do artista paraguaio Andrés Guevara, "o admirável estilizador da máscara humana", como observou Herman Lima. Este esboco de biografia estaria lamentavelmente incompleto se não disséssemos que ele, de certa forma, venceu o passar do tempo e se eternizou na influência que exerceu sobre Theo, Nássara, Álvarus e Mendez. (SOUZA, 1986, p. 176).
\end{abstract}

Foi reconhecida como a mais importante revista de crítica do país. Bastante política, destacou-se por publicar as melhores caricaturas da época. Por ter combatido a Aliança Liberal foi incendiada. Reapareceu depois, entre 1935 a 1945, sob as condições ditatoriais do país, tornando-se apenas noticiosa e literária. Desapareceu em 1954.

O primeiro número da revista apareceu em outubro de 1905. O Tico-Tico foi uma revista alegre e didática pois desde o início pôde contar com a colaboração de todos os grandes caricaturistas brasileiros. Herman Lima assim elucidava em suas páginas as presenças de:

“(..) J. Carlos, que ali deixou outra série de criacões infantis inesquecíveis, como 'Juquinha', 'Lamparina', 'Jujuba', e 'Carrapicho'; pelo mestre Ângelo Agostini, que, além de ter desenhado o seu delicioso cabecalho, foi um dos seus maiores animadores da primeira fase, ilustrando a 'Lições do Vovô'e várias histórias em quadrinhos, muito divertidas sempre; K. Lixto, com uma série de tipos populares; (...) Storni, pai de 'Zé Macaco' e de 'Faustina'; Yantok, um mestre de histórias fantasmagóricas hilariantes, de que foram padrão as "Aventuras de Kaximbown e Pipoca"; (...) o último a merecer citação e elogio: a figura de Luís Sá, autor de uma série de aventuras e personagens inesquecíveis, que nós guardamos no lugar mais recatado e enternecido de nosso coração: 'Reco-Reco', 'Bolão' e 'Azeitona'. (SOuzA, 1986, p. 122).

Nos anos 40, quando entra na praça toda variedade de 'gibis', com heróis importados, o Tico-Tico manteve sua esplêndida capacidade de se identificar com as crianças brasileiras. É interessante notar que ao mesmo tempo em que a tradição brasileira da caricatura e da charge não se interrompeu, a das histórias em quadrinhos foi inteiramente apagada pela força de imposição e persuasão dos heróis que nos chegavam, como ainda chegam, dos Estados Unidos". (sOuzA, 1986, p.126). 


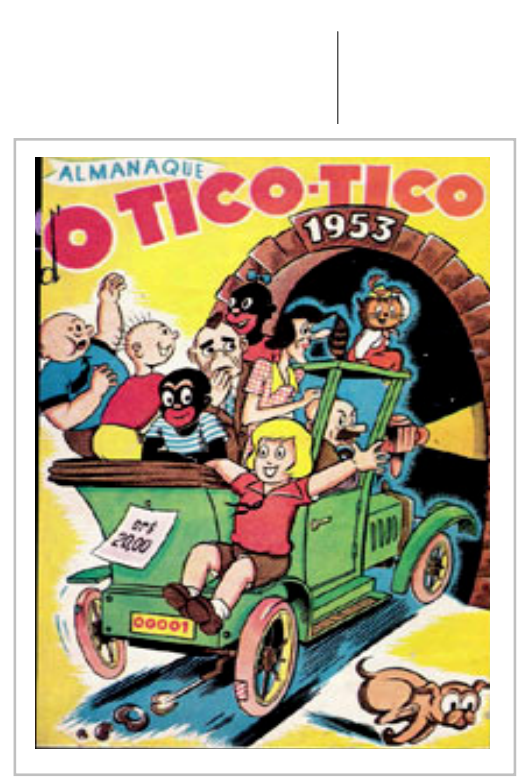

Queiram nos acompanhar, por favor, até o dia 9 de outubro de 1955, quando foi comemorado o cinqüentenário da revista. Nesse dia, o poeta Carlos Drummond de Andrade escreveu, no Correio da Manhã, um artigo muito comovido, mas com alguns momentos de bom humor e, sobretudo, de um alado lirismo:

"Uma pesquisa em regra na coleção do Tico-Tico indicaria a gênese de inúmeras vocações literárias e jornalísticas manifestadas de 1920 para cá. (...) O Tico-Tico é pai e avô de muita gente importante. Se uns alcançaram importância mas fizeram bobagens, o Tico-Tico não teve culpa. O 'Dr. Sabe-Tudo' e o Vovô' ensinavam sempre a maneira correta de viver, de sentar-se à mesa e de servir à pátria. $E$ da remota infância, esse passarinho gentil voa até nós, trazendo no bico o melhor do que fomos um dia. Obrigado, amigo!" (SOUZA, 1986, p. 206).

O Tico-Tico viveu mais de meio século, para desaparecer na fase em que, como a Revista da Semana, o Fon-Fon, O Malho, já não vigoravam as mesmas condições para a imprensa, abrindo-se nova fase editorial.

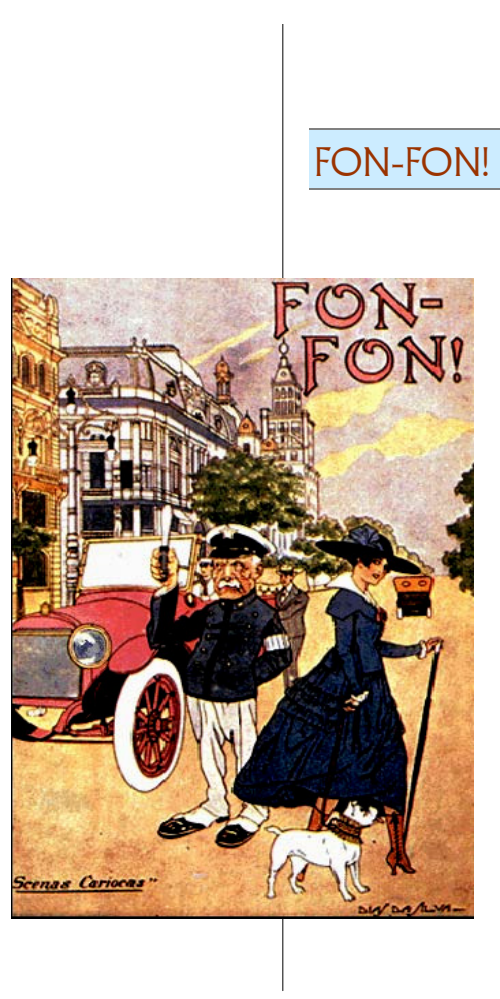

Fon-Fon! surgiu em 1907. Tinha a mesma receita - boa literatura e excelentes charges políticas - mas sem o vigor da Careta para tratar das coisas políticas e delas fazer a necessária zombaria. Teve a glória de ter apresentado, em suas páginas Nair de Teffé, que assinava Rian (Nair escrito de trás para diante). A primeira mulher a fazer charge no Brasil.

Contava com muita literatura e com os melhores ilustradores do país. "Transmitia o esnobismo carioca, fazia críticas, apresentava flagrantes e tipos do set da cidade, com muita fotografia e muita ilustração" (SODRÉ, 1966, p. 345) (...) Os ilustradores eram o que o país conhecia de melhor: Raul, K. Lixto e J. Carlos.

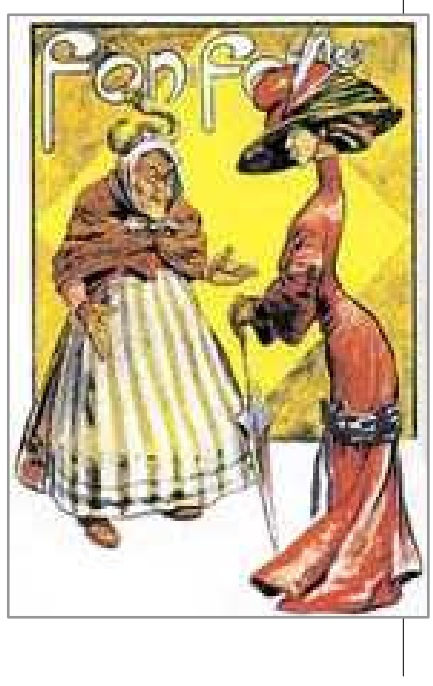



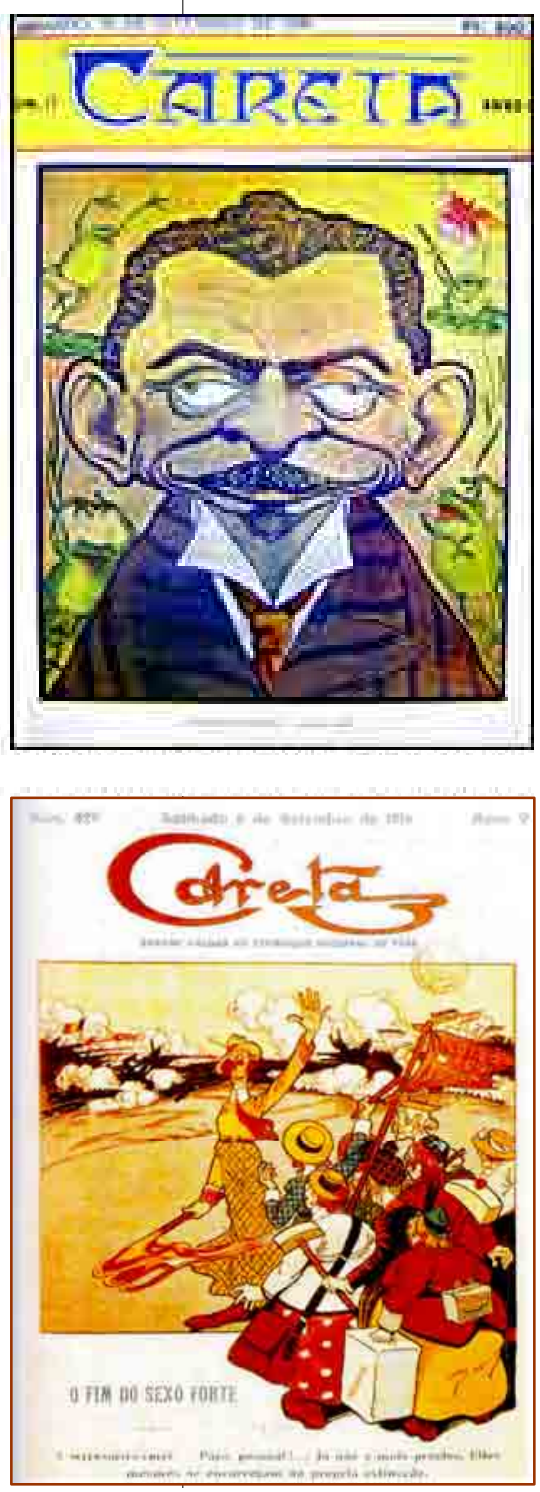

A Careta surgiu, em 1908, para alcançar um tipo de prestígio único. Ao mesmo tempo em que era consumida e debatida pela burguesia e pela classe intelectual, tornou-se a revista preferida pelo povo.

Em um artigo publicado em $A$ Noite, o pesquisador Raimundo Magalhães Júnior deu o seu depoimento sobre a Careta: "Jornal feito para o povo, podendo ser encontrado em todas as barbearias, consultórios de médicos e dentistas, de norte a sul do Brasil. A Careta sempre procurou ser, antes de tudo, desopiladamente atrevida, servindo, através do riso são. E desse atrevimento satírico, 'as inclinações e aos sentimentos do povo brasileiro (...)". Careta transcende do plano municipal e nacional ao plano internacional, dando seus tiros de atiradora solitária, de maqui (trincheira) a descoberto, contra os tubarões do fascismo, contra os pretensos salvadores do mundo, do tipo de Mussolini, de Hitler, de Franco, de Salazar, etc.

"A revista não era feita apenas de destemor e de talento - o que já seria mais do que suficiente para explicar o sucesso que alcançou. Tinha uma apresentação de gosto apurado e era toda ela impressa em papel couché, até que esse papel, em decorrência da Primeira Grande Guerra praticamente desapareceu do mercado. Tinha mais, a brava e graciosa Careta, por exemplo, o gosto pela poesia do verso bem trabalhado. Os versos eram assinados por Olavo Bilac, Martins Fontes, Olegário Mariano, Alberto de Oliveira, Emílio de Menezes, Bastos Tigre e tantos outros poderosos talentos da época. 


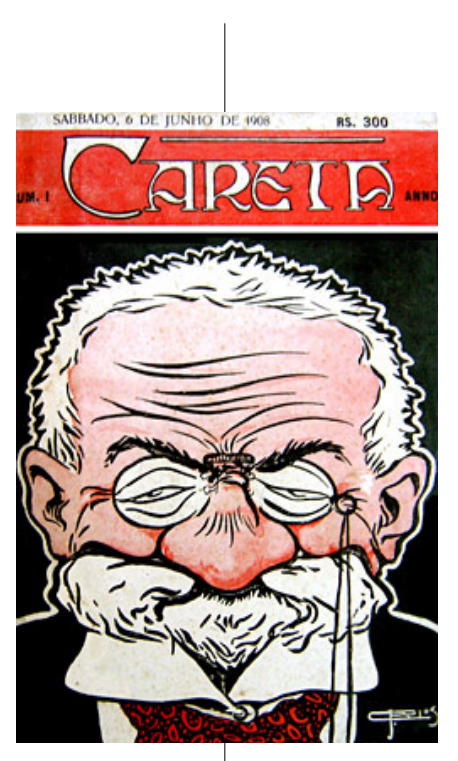

Solidificou como a mais popular revista brasileira do início do século. Desde seu início pode contar com o talento de José Carlos de Brito e Cunha (J. Carlos), cujo longo e brilhante trabalho artístico se confunde com a história dessa revista. Tornou-se popular como nenhuma outra que com seus desenhos na Careta apresentou uma profunda análise da sociedade carioca da época, como também crítica de política e de costumes." (CARVALHO, 1998, p. 133).

\section{KOSMOS}

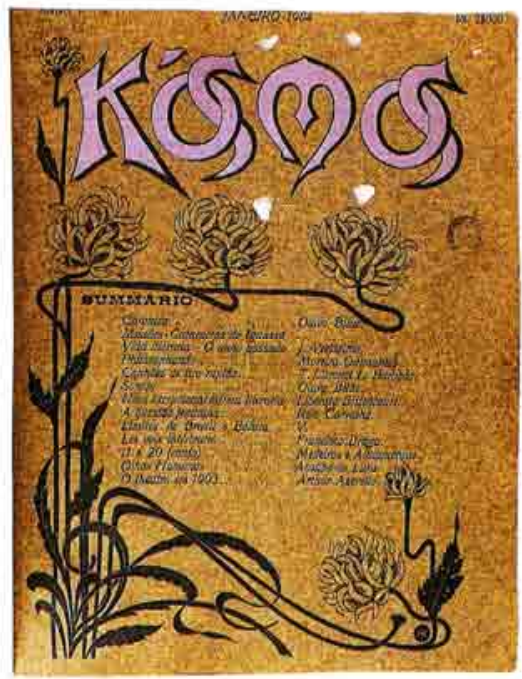

"Fundada em 1904, destacou-se pela sofisticada produção gráfica. Nos primeiros anos do século as artes gráficas no Brasil já possuía condições para permitir uma revista como a Kosmos, de excelente apresentação, com desenhos em litografia. A crônica de abertura era de Olavo Bilac, que assinava apenas com as iniciais O. B.. De teatro ocupava-se Artur Azevedo, depois substituído por Paulo Barreto. A Kosmos circulou de 1904 a 1906. Dois meses depois de desaparecer a Kosmos, aparecia a sua competidora, a Renascença." (SODRÉ, 1966, p. 233).

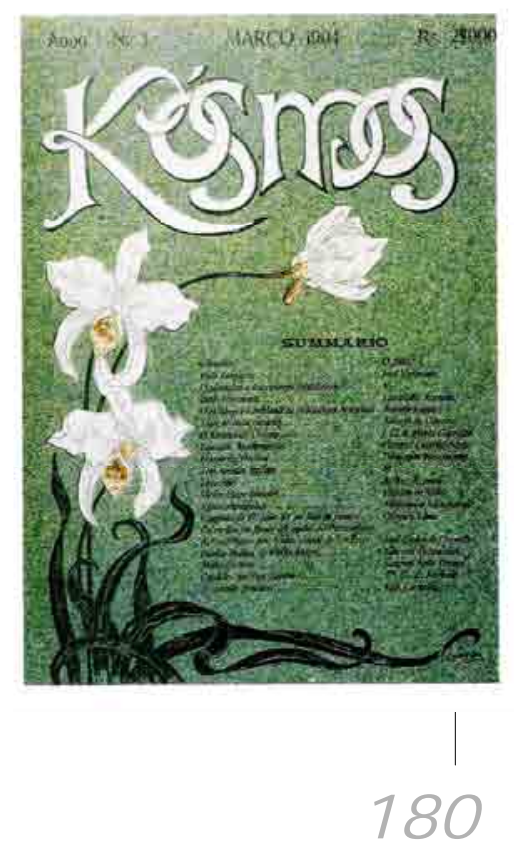




\section{O CRUZEIRO}

O Cruzeiro foi o nosso magazine ilustrado, produzido na mesma concepção que a revista americana Life. Fundada em 1928, mudou seu projeto gráfico-editorial a partir de 1943, seguindo o exemplo de sua "mãe" norte-americana, que por sua vez baseava-se em fotorreportagens originárias da imprensa alemã do final da década de 20 . Articulou sua linha editorial a partir do uso da fotografia. Foi nossa primeira revista a introduzir a reportagem ilustrada com fotos captadas no local, com o dinamismo que a matéria exigia.

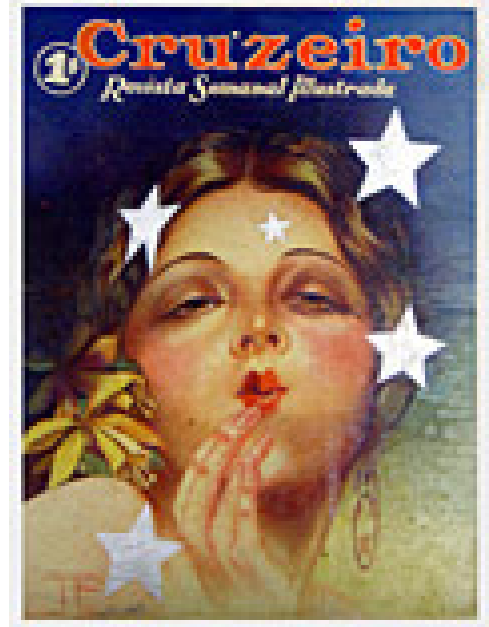

O fotógrafo acompanhava o repórter a locais longínquos para captar as imagens reais do cenário, isso quando o repórter não desempenhava também a função de fotógrafo: sertão nordestino, floresta amazônica, pampas gaúchos, Brasil Central, etc. A própria viagem, uma verdadeira aventura dos jornalistas, acompanhados de guias, sertanistas, pilotos audazes de avião, já era utilizada como uma segunda reportagem, dentro da principal.

A revista substituia a televisão, fazendo as vezes desta como o principal veículo de massa daqueles tempos, tanto que seu declínio foi provocado pela multiplicação das redes de TV que passaram a cobrir todo o território nacional.

Depois de $O$ Cruzeiro as revistas brasileiras passaram por uma grande evolução no aspecto técnico de suas imagens. Um avanço tecnológico que proporcionou aos editores infinitas possibilidades de edição para construir múltiplos discursos jornalísticos através da imagem.
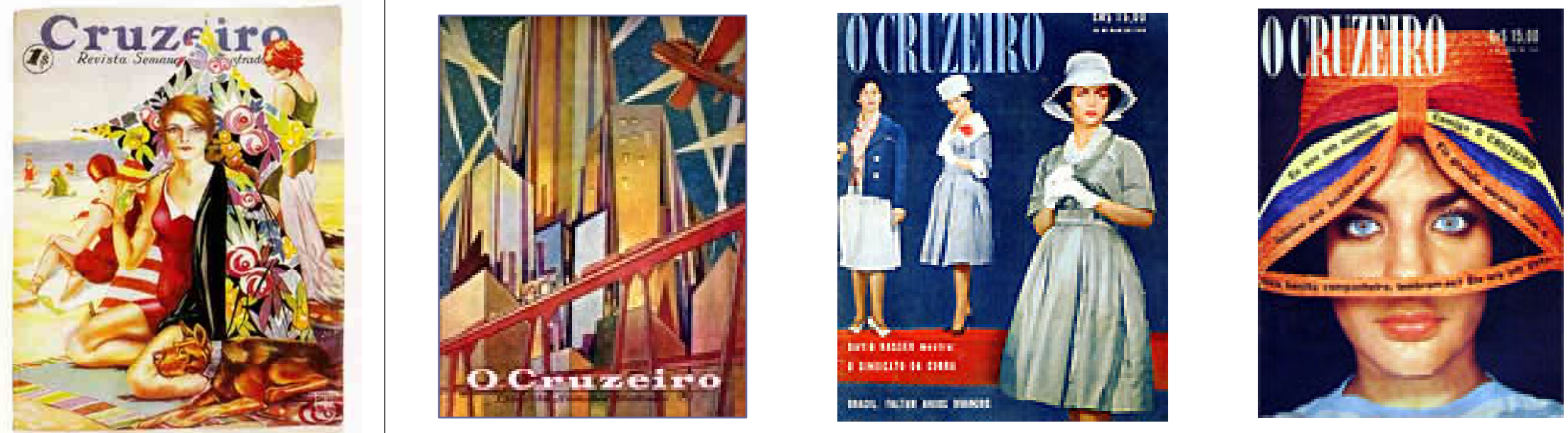
Abaixo uma relação dos impressos ilustrados entre meados do séc XIX e início do séc. XX

O Carcundão - 183

O Carapuceiro - 1832

Escorpião - 1932

O Meteoro - 1932

O Pensador - 1932

O Martelo - 1832

Segarrega - 1832

O Cabrito -1833

O Burro Magro - 1833

Esbarra - 1833

A Marmota - 1833

A Mutuca Picante - 1834

O Aristarcho - 1840

O Carapuceiro na Corte - 1840

O Belchior Político - 1844

Lanterna Mágica - 1844

A Marmota Fluminense - 1849

O Sino da Lampadosa - 1849

A Sineta da Misericórdia - 1849

O Cascalho - 1849

Sino dos Barbadinhos - 1849

O Carranca - 1849

O Fantasma - 1850

A Caricatura - 1851

O Bodoque Mágico - 1851

O Martinho - 185

O Boticário - 1852

O Azorrague - 1855

Ilustração Brasileira - 1854

L' Iride Italiana - 1854
Brasil Ilustrado - 1855

A Carapuça - 1857

Charivari - 1859

Revista Popular - 1860

Charivari Nacional - 1859

Semana Ilustrada - 1860

Nova Semana Ilustrada

Charivari - 1862

Bazar Volante - 1863

Merrimac - 1863

O Diabo Coxo - 1864

O Cabrião - 1866

A Pacotilha - 1866

O Arlequim - 1867

O Heráclito - 1867

$\mathrm{Ba} / \mathrm{Ta} / \mathrm{Clan}$ - 1867

A Vida Fluminense - 1868

O Mosquito - 1869

Para Todos - 1869

Comédia Social - 1870

A Berlinda - 1870

Paraguai Ilustrado -

Mefistófoles - 1870

Lobishomem - 187

O Guarany - 1871

A Abelha - 1873

O Diabo a Quatro - 1875

O Mequetrefe - 1875

Revista llustrada - 1876

Besouro - 1878

Ilustração do Brasil - 1876

O Ganganelli - 1876

Uustração Popular - 1876

Fígaro - 1876
Psit! - 1877

O Diabrete - 1877

Zigue-Zague - 1878

A Lanterna - 1878

O Torniquete -

Gryphus - 1882

A Vespa -

Rataplan - 1886

João Minhoca -

O Mundo da Lua -

Dom Quixote - 1895

Ilustração Brasileira - 190

O Coió - 1901

O Nu - 190

Gavroche - 1902

O Tagarela - 1902

Revista da Semana - 1901/1909

Avenida - 1903

Renascença - 1904

Leitura Para Todos - 1905

O Malho - 1902

O Pau - 1905

Século XX - 1905

Figuras e Figurões - 1905

Kosmos - 1904

Mercúrio -

Frou-Frou - 1923

Tico-Tico - 1905

O Mês - 1906

Fon-Fon - 1907

Tam-Tam - 1907

O Diabo - 1907

Careta - 1908
O Degas - 1908

O Trapo - 1909

O Rebate - 1909

O Filhote da Careta - 1910

O Pirralho - 1911

Álbum de Caricaturas - 1911

Pasquino Coloniale -

O Gato -

O Juquinha - 192

O Século - 1916

A Cigarra - 1918

A Vida Moderna - 1918

Revista Nacional - 1918

Para Todos - 1919

O Mé - 1921

Beira Mar - 1922

A Maçã - 1922

O Shimmy - 1925

O Cruzeiro - 1928

O Papagaio - 1928

O Saci -

Cinearte -

A Cigarra -

Vida Nova -

A Lanterna - 1926

Carioca -

A Manha - 1926

Vida Nova - 1926

Vamos Ler -

Excelsior - 1928

A Noite llustrada - 1928

A partir da implantação do

Estado Novo há uma retração na publicação das revistas ilustradas. 


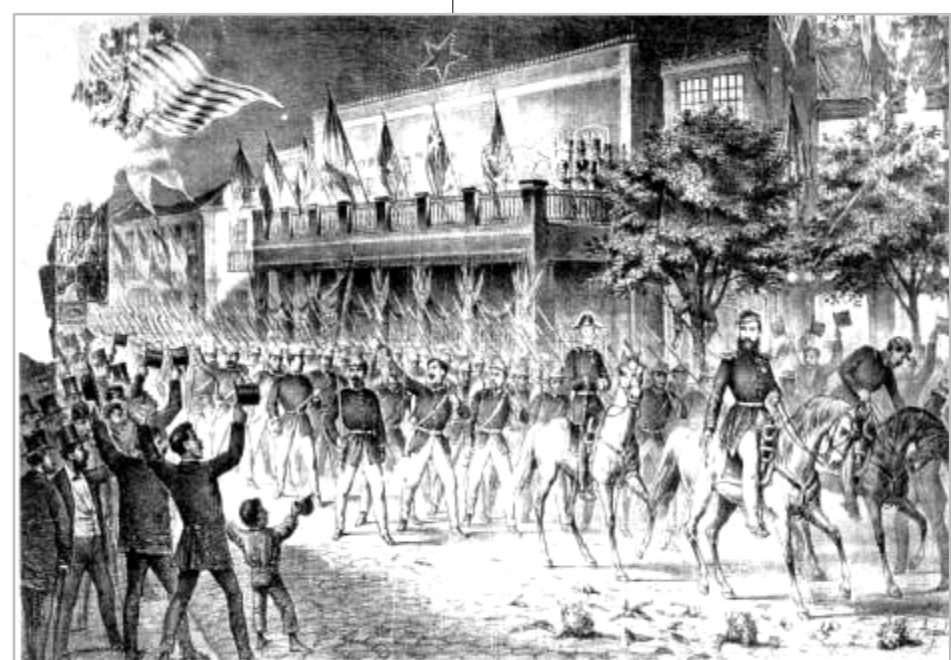

Nasceu em Colônia, Alemanha, e veio para o Brasil com 35 anos. Veio contratado como desenhista da expedição científica por Spix e Martius. Terminado seu contrato fixou-se no Rio de Janeiro, em 1859. Ao fundar seu estabelecimento tipolitográfico em 1863, deu início à primeira escola de xilogravura que existiu no país. De sua oficina, intitulada Instituto Artístico e, depois batizada de Instituto Imperial, saiu em dezembro de 1860 a Semana Ilustrada. Excelente desenhista e litógrafo, Fleiuss teve mais importância artística do que jornalística.

Quando Henrique Fleiuss lançou na Corte a Semana Ilustrada, já haviam circulado pequenos e toscos jornais de caricaturas e litografias avulsas; o que não havia até então era uma revista ilustrada. Nesse sentido. Fleiuss foi realmente pioneiro.

Desenho de Fleiuss

Em geral a Semana Ilustrada não se propunha a ser crítica, pois Fleiuss era amigo da casa imperial, que sempre prestigiou. Sempre se posicionou desta maneira junto aos governos. Fleiuss, grande desenhista e litógrafo, não era humorista nem crítico.

Em História da Caricatura no Brasil, Herman Lima dá o seguinte depoimento sobre a arte de Henrique Fleiuss: “(...) se Fleiuss era, acima de tudo, um artista, não deixou de fazer com que essa arte mantivesse uma relação quotidiana ou semanal com os acontecimentos da cidade".

Até o número dez a Semana Ilustrada foi totalmente desenhada e litografada por ele; dai por diante passou a receber a cooperação de outros desenhistas e litógrafos. Depois de suspender a publicação da Semana llustrada, Fleiuss tentou lançar a Ilustração Brasileira, com excelente apresentação gráfica, mas não obteve sucesso empresarial. Em 1880 decidiuse por revista menos dispendiosa, a Nova Semana Ilustrada, mas também não triunfou nesse novo empreendimento. A partir da iniciativa de Fleiuss começaram a se suceder várias revistas ilustradas. 


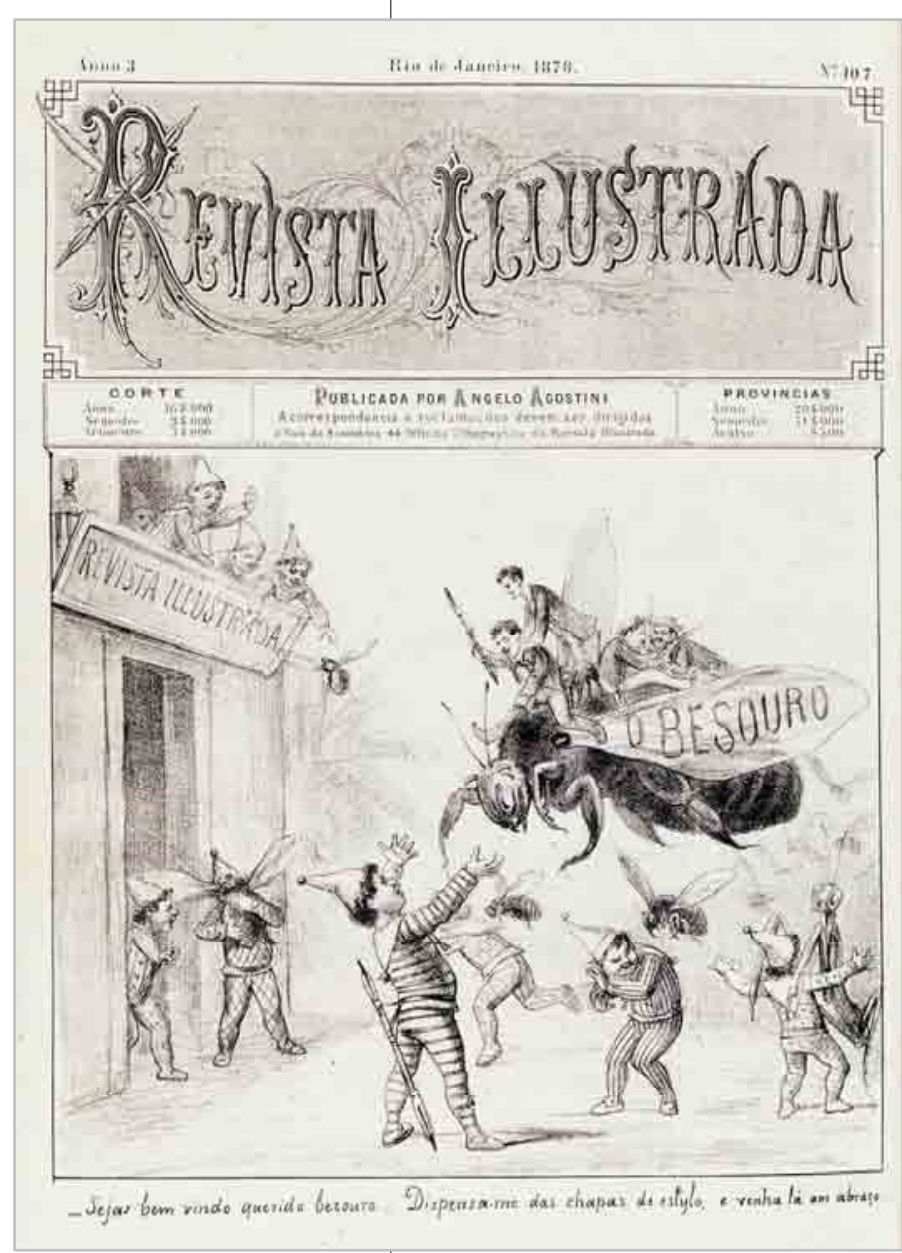

Nascido no Piemonte (Itália) em 1843, Ângelo Agostini veio para o Brasil com toda a força revolucionária do talento. Depois de ter estudado pintura em Paris, onde passou a infância e a adolescência, aqui chegou em maio de 1859. Depois de passar três meses no Rio mudou-se para São Paulo, ainda pacata e provinciana nessa época.

O jovem Agostini foi para São Paulo tendo nas mãos o lápis litográfico e, na cabeça, todos os ideais libertários. Depois de sentir-se devidamente aclimatado, Agostini lançou o Diabo Coxo juntamente com Luís Gama e Sizenando Nabuco. O Diabo Coxo apareceu, pela primeira vez, em outubro de 1864, em formato pequeno, com oito páginas, sempre ilustrado.

Agostini escapava da mediocridade reinante, com desenhos de traço requintado, de concepção grandiosa e de uma visão crítica aprofundada, não teve condições materiais de sustentar sua primeira publicação por mais de um ano. Já em 1865, o Diabo Coxo, por falta de dinheiro deixou de circular para sempre.

Em seguida Ângelo Agostini trocara S. Paulo pelo Rio e desde 1868 o jornal $O$ Arlequim passou a contar com sua colaboração. Agostini colaboraria ainda na Vida Fluminense, que durou de 1868 a 1876, quando se transformou no Figaro. Na Vida Fluminense atuou principalmente, com Luigi Borgomainério, "o mais eminente artista que veio ao Brasil”, no dizer autorizado de Agostini. 
Agostini foi dos mais expressivos exemplos de como a militância política enriquece, amplia e multiplica o efeito das criações artísticas autênticas sendo, ainda, dos mais brasileiros dos artistas que nos conheceram e nos estimaram, porque sentiu, compreendeu e expressou não apenas o que era característico em nós, daí a sua autenticidade, mas aquilo que representa o conteúdo do característico, isto é, o popular. Suas caricaturas, por vezes contundentes, puseram a nu os traços grotescos da classe dominante brasileira do tempo, suas irremediáveis mazelas, seu atraso insuportável, e o vazio triste dos ornamentos, dos artifícios, dos disfarces com que se apresentava, buscando aparentar grandeza. (SODRÉ, 1966, p. 144)

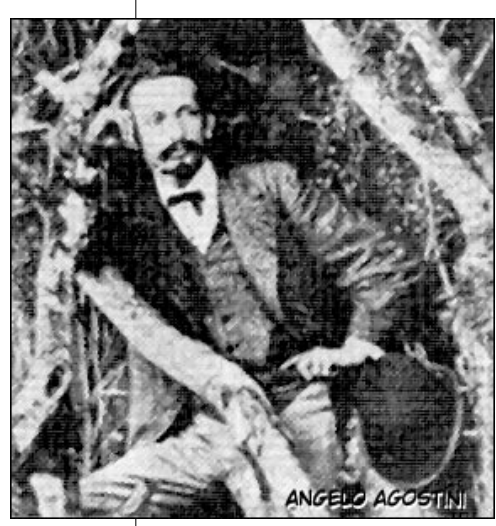

Agostini fundou o Dom Quixote, em 1898, e cooperou no lançamento de O Tico-Tico, de Luis Bartolomeu de Souza e Silva, em 1905, a primeira revista infantil publicada em nosso país. Terminou suas atividades em $\mathrm{O}$ Malho, onde trabalhou até sua morte, em 1910. Foi uma das maiores figuras da imprensa brasileira em todos os tempos. (LIMA, 1963, p. 252)

A tiragem da Revista Ilustrada alcançou o número de quatro mil exemplares, "índice até aí não alcançado por qualquer periódico ilustrado na América do Sul. Regularmente distribuída por todas as províncias e nas principais cidades do interior, com assinantes por toda parte". Foi mesmo na Revista Ilustrada que Ângelo Agostini revelou toda a força de seu talento e da sua capacidade de ironizar pessoas e acontecimentos. Agostini e sua Revista empenharam-se, sobretudo, na campanha abolicionista, a tal ponto que Joaquim Nabuco chamou-a de "a bíblia da abolição dos que não sabem ler". Herman Lima não hesita em dizer que a série de charges feitas por Agostini, em defesa da libertação dos escravos, pode ser comparada, pela qualidade do desenho e pela força da concepção, aos trabalhos do francês Honoré Daumier em sua cruzada contra a tirania. 


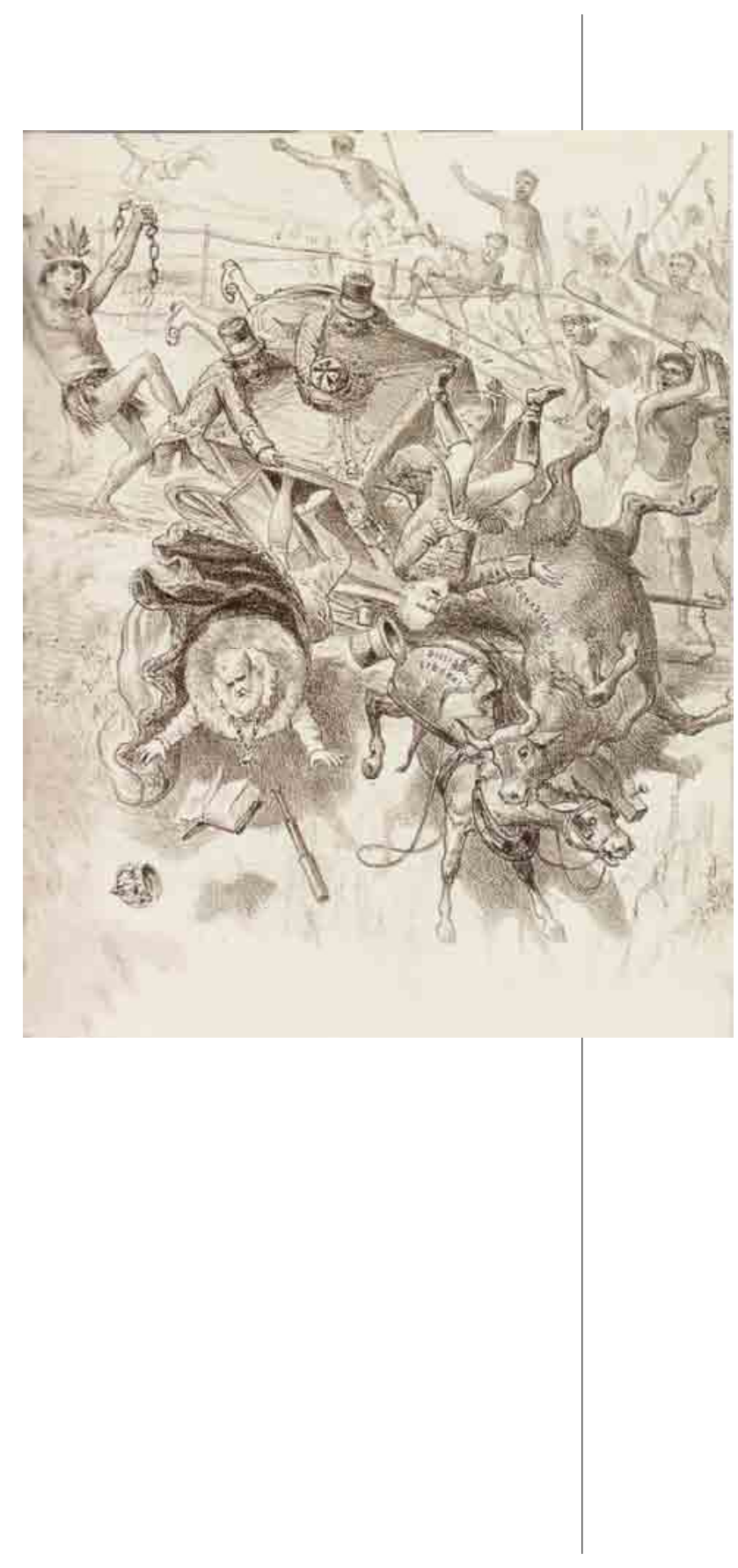

(Ângelo Agostini manteve) a Revista llustrada, de 1876 a 1891, combatendo a escravidão, como vinha fazendo naquelas em que colaborava. A Confederação Abolicionista homenageou-o, em 1888, falando Joaquim Nabuco: "Ângelo, em nome dos teus companheiros de luta, em nome da liberdade, em nome do Brasil, declaro-te brasileiro". Agostini naturalizou-se dias depois e Nabuco disse, então: "O seu título é a mais alta adoção que se possa imaginar: a de uma raça que adota um dos seus redentores, a de uma pátria que perfilha um dos seus criadores". Mestre da caricatura, jornalista exímio, Ângelo Agostini enobreceu a sua profissão e assinalou com a Revista Ilustrada principalmente, um dos grandes momentos da imprensa brasileira. A coleção dessa revista constitui um dos mais preciosos mananciais para o estudo de uma época de nossa história, insubstituível pela posição combativa do artista extraordinário que acrescentava à qualidade de suas criações, jamais exercida em seu tempo, o conteúdo de participação, a que não faltou em tempo algum.. (SODRÉ, 1966, p. 252-253).

A revista tornou-se referência, e o seu prestígio, no dizer de Monteiro Lobato tem algumas observações marcantes. Segundo ele, a Revista fazia com que o homem simples, da cidade ou do campo, penetrasse na intimidade do Imperador ou de qualquer homem público importante, para assim vê-lo de perto, com os olhos da irreverência e do sarcasmo.

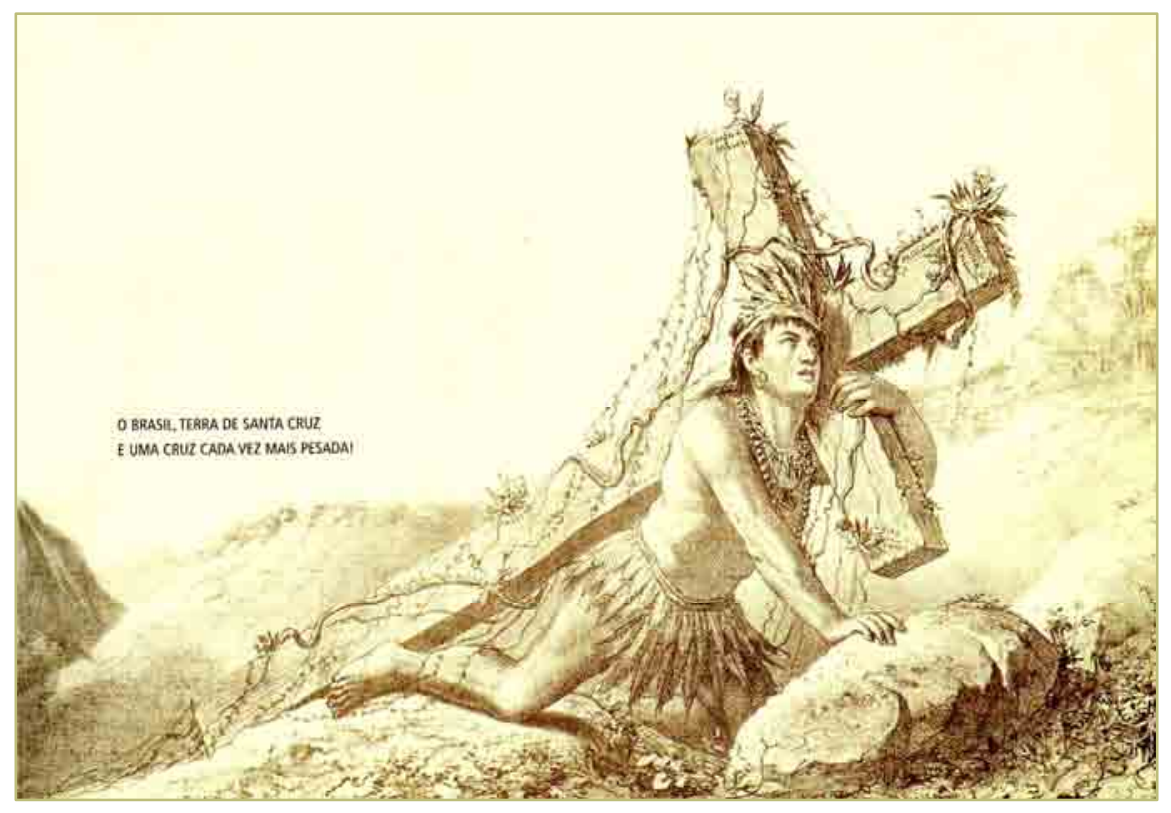




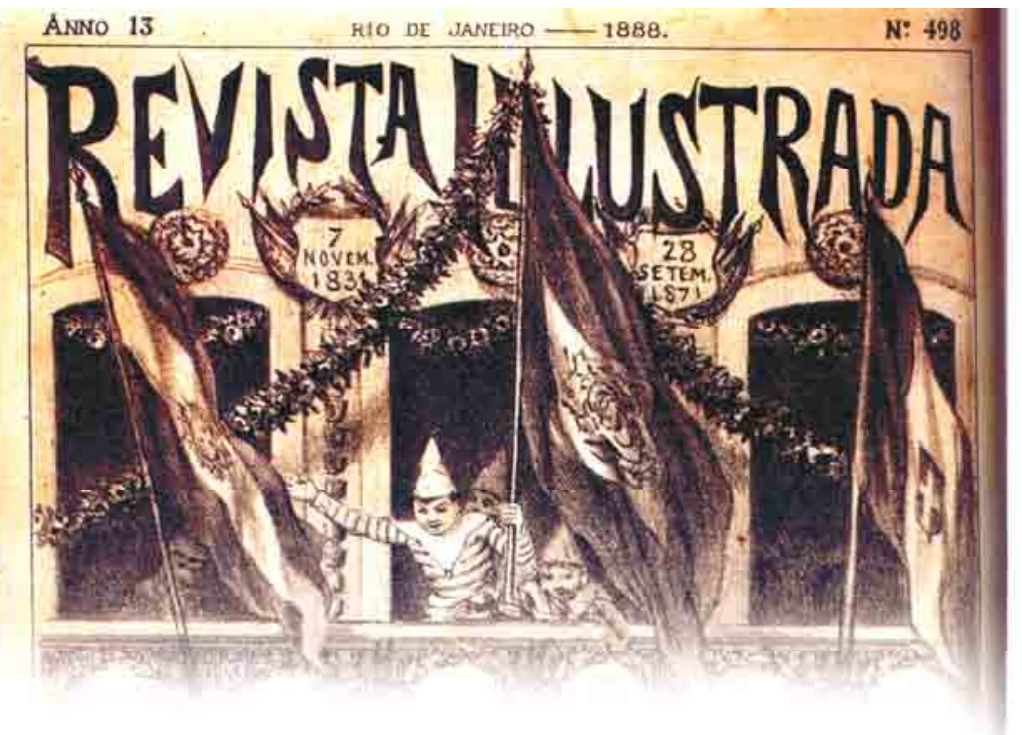

A partir de 1889, com a vitória da Abolição e da República, a Revista llustrada passou por uma série de modificações. No dia 21 de dezembro daquele ano, ela anunciava a viagem de Agostini à Europa, de onde retornaria ao Brasil, em 1895. Voltava para combater o que ele julgava ser o desvirtuamento das idéias pelas quais tanto lutara. Insurgiu-se, especialmente, contra os excessos do militarismo. Se Agostini mantinha o mesmo impulso de antes, o público já estava aborrecido de tantas lutas e ardores. Era chegado o tempo das amenidades, dos achados verbais maliciosos, do texto refinado. Que os ilustradores se preocupassem mais com o traço elegante e gracioso, em que agora era especialista Bordalo Pinheiro. Foi então que Agostini mudou de rumo. Participou de várias iniciativas importantes, mas que não foram bem-sucedidas do ponto de vista comercial. Assim ocorreu com o Dom Quixote. Sem qualquer desânimo, Agostini resolveu cooperar com o lançamento de O Tico-Tico, a primeira revista infantil de nossa imprensa, para afinal terminar suas atividades em O Malho, onde trabalhou até o dia em que morreu, no ano de 1910. (SOUZA, 1986, p. 128)

Foram 46 anos de trabalho e mais de 6 mil páginas de arte que fizeram de Agostini um 'repórter do lápis'; como gostava de ser chamado. Em seus desenhos estão presentes as características que fizeram do artista um dos grandes intérpretes do Império brasileiro: o traço forte, o realismo dos retratos, a crítica à situação social, a ironia contra tudo e todos. Numa época em que faltavam imagens, o desenho de Agostini era, a um só tempo, documento e criação; fato e ficção. 


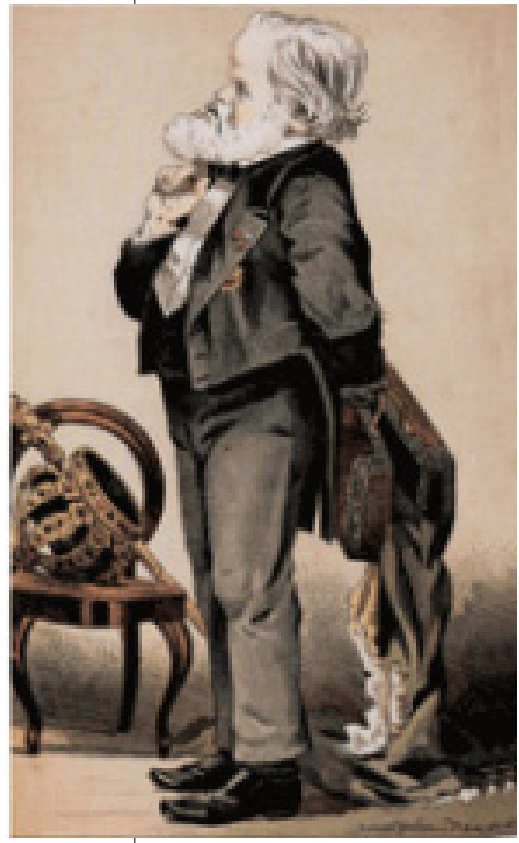

Bordalo Pinheiro nasceu em 1846 em Lisboa. Cedo ganhou o gosto pelas artes e em 1860 inscreveu-se na Academia de Belas Artes, para logo em seguida desistir. Estreou no Teatro Garrett embora não tenha feito carreira como ator. Em 1863, o pai arranja-Ihe um lugar na Câmara dos Pares, onde descobre a sua verdadeira vocação de crítico social, derivado das intrigas políticas dos bastidores.

Em 1867 começa por tentar ganhar a vida como artista plástico com composições realistas. Em 1871 recebe prémio na Exposição Internacional de Madrid. Paralelamente vai desenvolvendo sua faceta de ilustrador e decorador.

Em 1875 cria a figura do Zé Povinho, em Portugal. Nesse mesmo ano, parte para o Brasil onde colabora em alguns jornais. Aqui, de 1875 a 1879 colaborou com O Mosquito, o Psit!!!! e O Besouro. Voltando a Portugal em 1879.

Bordalo Pinheiro deixou um legado iconográfico verdadeiramente notável, tendo produzido dezenas de litografias. Compôs inúmeros desenhos para almanaques, anúncios e revistas. Dotado de um grande sentido de humor mas também de uma crítica bastante apurada. Sua figura mais popular, o Zé Povinho, conseguiu projetar a imagem do povo português de uma forma simples, atribuindo um rosto ao país. 


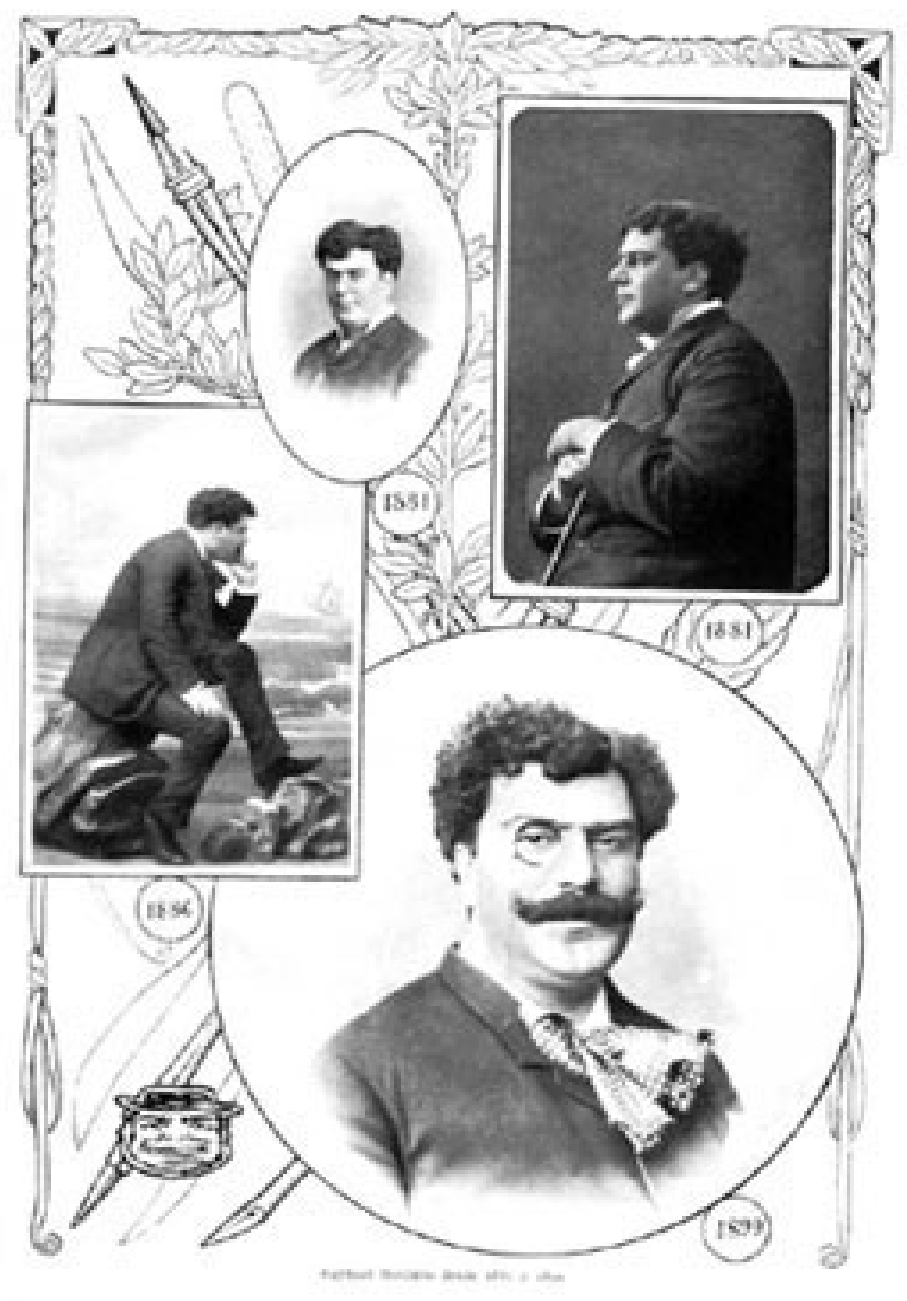

Fotografias de Bordalo, de 1881 a 1889
Rafael Bordalo Pinheiro destacou-se sobretudo como um homem de imprensa. Durante cerca de 35 anos (de 1870 a 1905) foi a alma de todos os periódicos que dirigiu, quer em Portugal, quer nos três anos que trabalhou em terras brasileiras. Aqui no Brasil influenciou muitos artistas com o seu traço refinado e sua técnica apurada. Trouxe para cá uma nova grafia para os desenhos.

Bordalo enquanto homem de imprensa soube manter uma indiscutível independência face aos poderes instituídos. 


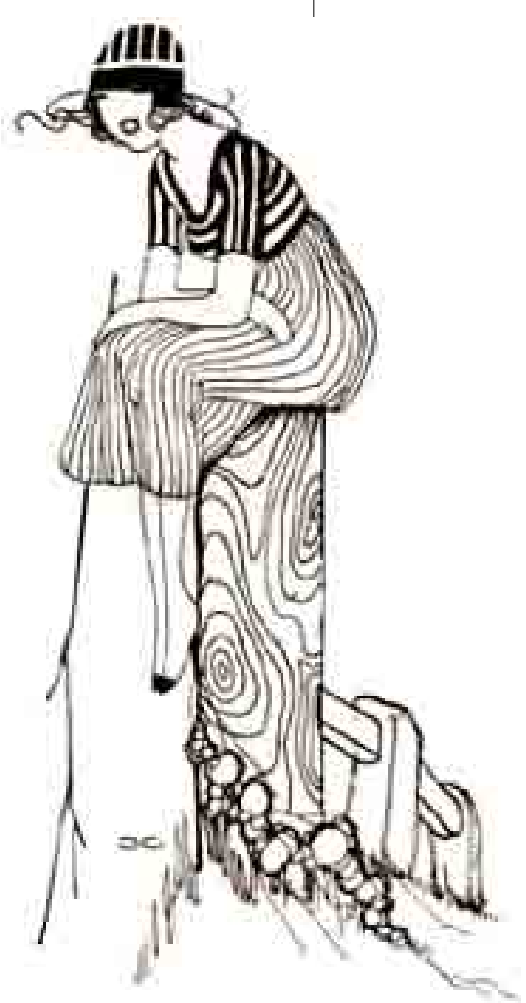

José Carlos de Brito e Cunha (1884-1950), celebrizado como J. Carlos, estreou em O Tagarela, em 1902. “(...) ninguém exerceu com maior dignidade profissional a sua arte do que esse incomparável desenhista, cujas criações, da mais bela e escorreita execução e do mais fino gosto, aliados à graça do motivo e à elegância do traço, encheram durante quase meio século as páginas das nossas melhores revistas ilustradas". O seu vulto esgalgo, (...) "estabeleceu o esguio marco assinalador do advento da zincogravura na ilustração da imprensa - libertando o periodismo da litografia a crayon ou da xilogravura a buril sobre traços de grafite". Sucessor natural de Ângelo Agostini, colaborou nas diversas publicações políticas e de humor da época. "(SODRÉ, 1966, p. 399).

Trabalhador infatigável, J. Carlos, em seus desenhos, glorifica a mulher e gera tipos, tendo, por isso, dimensão universal. Foi um pioneiro na caricatura mundana e criador de tipos como a melindrosa, como crítica ao top da época.

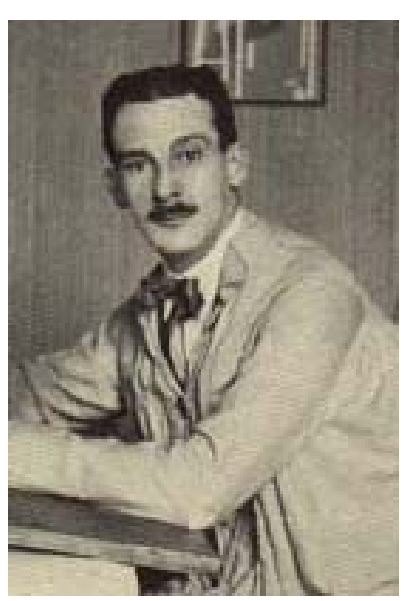
Soube como nenhum outro captar o espírito carioca. Embalou a infância e fascinou os adultos. Tendo estreado, sob a direção de Raul Pederneiras e K. Lixto no Tagarela, depois de ter abandonado em meio o curso ginasial, dedicou-se inteiramente à arte em que se imortalizaria, morrendo diante de sua prancheta de desenho, na Careta, em 1950.

Embora afastado da Careta entre os anos de 1922 a 1935, dedicou-se à direção artística das revistas da empresa O Malho (O Malho, Ilustração Brasileira e Para Todos). J. Carlos, que nela trabalhou de 1908 a 1922 e de 1935 até sua morte em 1950, realizou verdadeira análise e tipificação da sociedade carioca, além da crítica política e de costumes. 

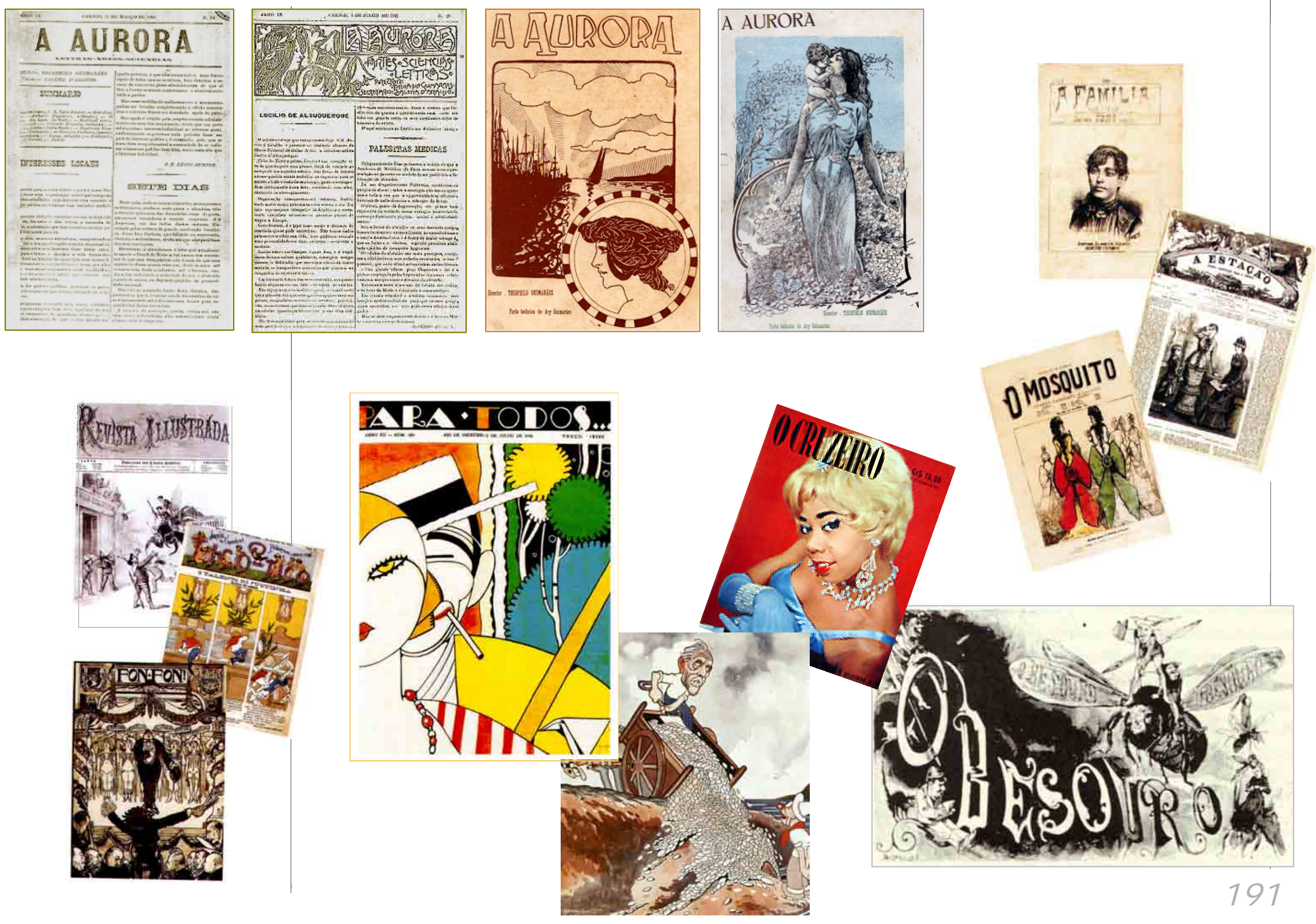


\section{CAPITULO 8}

HUMOR GRÁFICO

8.1 - OS MEIOS E OS MOVIMENTOS

8.2 - ASPECTOS CONCEITUAIS

8.3 - A OPINIĀO ILUSTRADA 


\section{1 - OS MEIOS E OS MOVIMENTOS}

Ainda que em 1500 a imprensa já existisse aqui no Brasil, a forma oral foi a modalidade utilizada para se divulgarem as idéias, as notícias e os produtos. E assim permaneceu por mais de três séculos, até a chegada da Família Real.

Entre nós, foram os pregões dos mascates, cantados ou gritados, os primeiros meios para apregoar mercadorias. Recorrer à voz, à música e ao canto para vender produtos é um recurso antigo, herança dos arautos, quando as notícias eram vendidas como mercadorias e trazidas de longe.

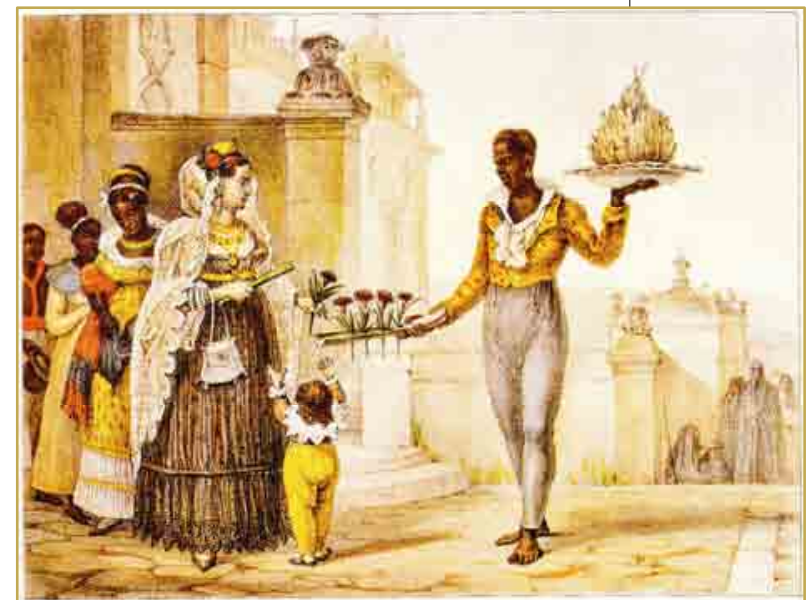

Mercadores de flores na porta de uma igreja

Jean Baptiste Debret - c. 1837

Aqui na colônia, a prática de venda realizada pelos ambulantes, era sempre sonora, por cânticos, por meio de cornetas, ou matracas. Este ainda era o mecanismo de difusão quando aqui aportou a Família Real, em 1808, e com eles a primeira impressora.

Com os embates políticos os folhetos avulsos e os periódicos não tardaram a proliferar. Nos jornais que existiam, até o fim do século XIX, predominavam os anúncios de barbeiros, escravos fugidos ou vendas de quinquilharias.

Esses personagens urbanos, os costumes de nosso povo e as paisagens da terra foram registrados nas primeiras ilustrações pelas mãos dos artistas estrangeiros que aqui aportaram. Estes possuíam conhecimento técnico e artístico apropriado para iniciar a formação de um contingente de admiradores e aprendizes. Nossos primeiros ilustradores conhecidos foram Debret e Rugendas na década de 1830, através de cuja obra é possível reconstituir as características da sociedade colonial da época.

A virada do século traz um fato marcante na imprensa brasileira. Os jornais, por estarem naquele momento se inserindo na indústria da informação, modificaram seu conteúdo, reduzindo seu perfil folhetinesco. Essa redução da participação de escritores na imprensa diária e a inacessibilidade da população aos livros, bem como a necessidade de ampliar a cultura da população, desembocou nos populares almanaques.

Para chamar atenção a propaganda passou a explorar todas as possibilidades da imagem: fotografias, montagem, associação com o texto, apelos emotivos e efeitos visuais.

No Brasil, já nas primeiras décadas do século XX, desenvolvia-se a inquietação artística paralela à inquietação política.

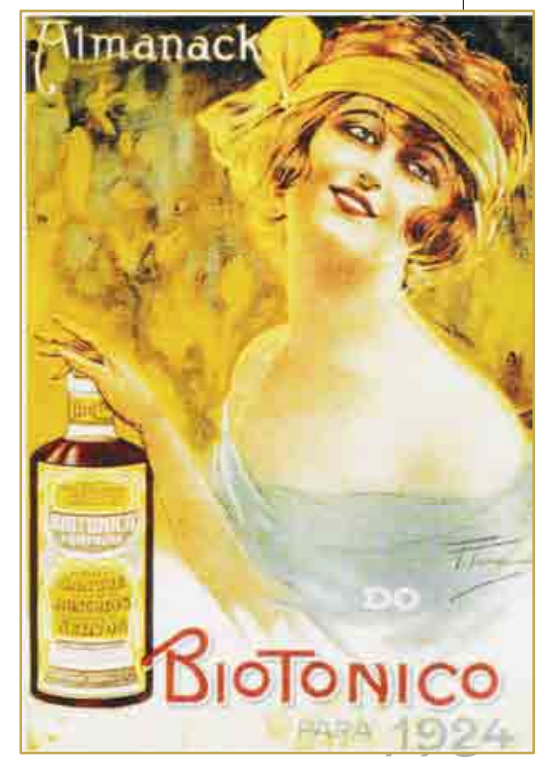



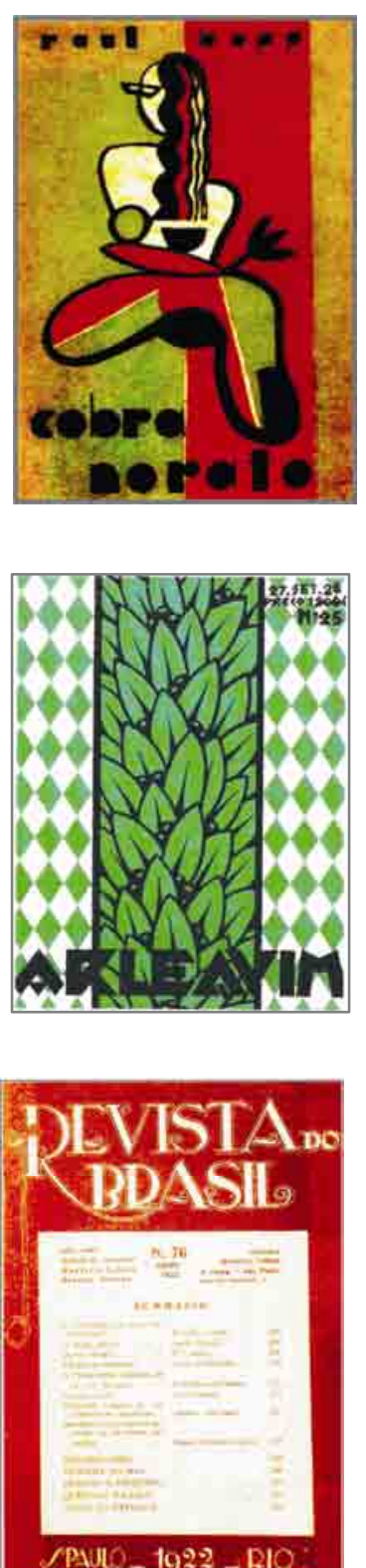

Apareceram em S.Paulo, no Rio e em vários outros centros culturais

do país, revistas modernistas, todas de vida efêmera mas que fizeram muito ruído, embora os ecos se limitassem aos meios intelectuais:

Klaxon, em S. Paulo, em 1922;

Estética, no Rio, em 1924,

Terra Roxa em S. Paulo, em 1926;

Outras Terras, em S.Paulo, em 1926

Revista de Antropofagia, em S.Paulo, em 1928;

Papel e Tinta, no Rio, em 1925

Revista do Brasil, no Rio, em 1925 a 1926

Festa, também do Rio, de 1927 a 1929, com relançamento em 1934;

Movimento, depois chamada Movimento Brasileiro, de 1928 a 1930;

A Revista, de Belo Horizonte, em 1925;

Verde, em Cataguases, em 1928;

Elétrica, em Itanhandu, em 1928 e 1929;

Novíssima, em S. Paulo, em 1926;

Arco e Flecha, na Bahia, em 1928;

Maracajá, em Fortaleza, em 1929;

Madrugada, em Porto Alegre, em 1929,

$$
\text { e outras. }
$$
manifestações como na pintura de Anita Malfatti e na escultura de Vitor Brecheret, tornando-se nítida na literatura com o pósguerra e marcada por acontecimentos como a Semana de Arte Moderna, em São Paulo. Essa inquietação estava enraizada em condições internas, que afetavam todas as formas de atividades, mas recebia, também, acentuada influência externa de um mundo abalado pelo conflito militar. O movimento artístico e literário encontrou campo largo para manifestar-se nas revistas de vanguarda que apareceram a partir de 1922.

Simultaneamente à evolução gráfico-visual das revistas no início do século XX, começaram também a repercutir artisticamente as tendências modernistas, mais leves e mais elegantemente satíricas do que as truculentas sátiras do Império. O movimento de Arte Moderna, ligado à Semana de 1922, começa a aparecer no plano das artes gráficas através da Revista Klaxon, e anos depois, com a Revista de Antropofagia. Os artistas modernistas começaram a se expressar através das capas e ilustrações, agregando novos conceitos visuais.
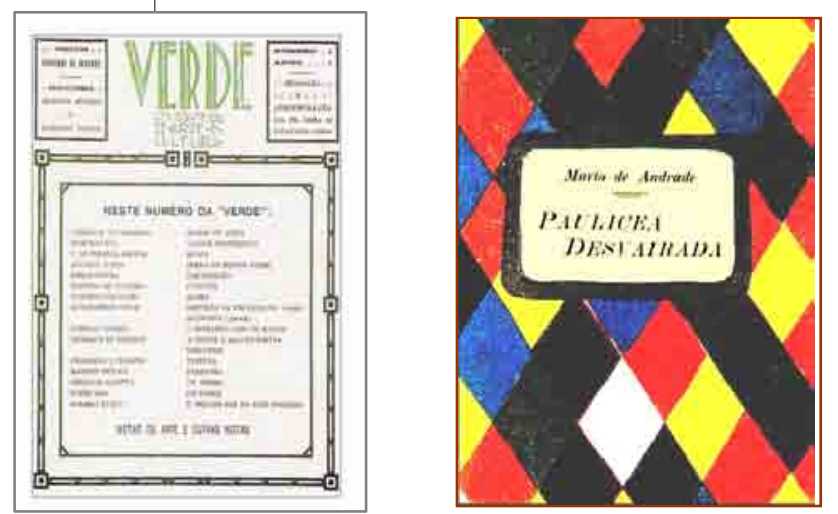

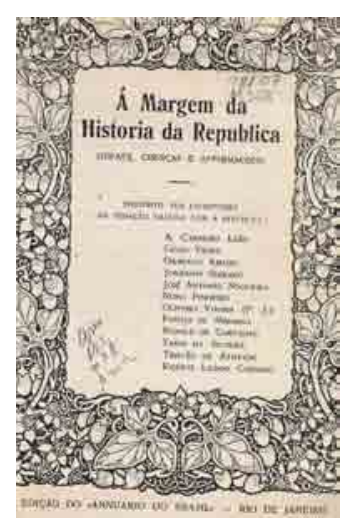

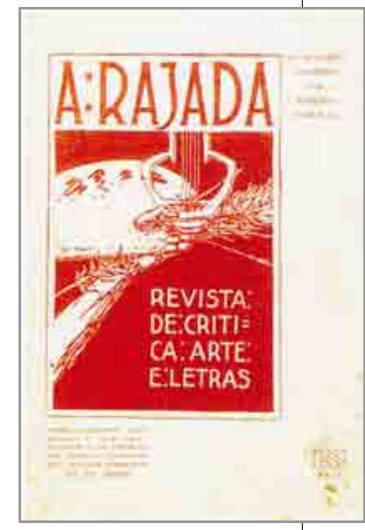
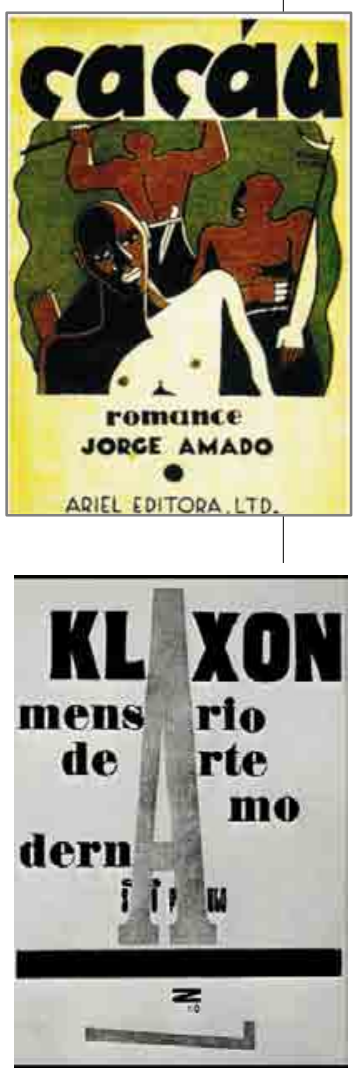
Com os avanços nas técnicas de reprodução, especialmente no campo da tipografia e da fotogravura, intensificou-se o uso de fotos e desenhos nas publicações. Por meios fotomecânicos a reprodução de qualquer imagem gráfica passou a ser utilizada com freqüência e liberdade, conjugada aos variados desenhos de alfabetos,

O repertório gráfico (...) começa a se ampliar não apenas com o surgimento e o uso de novos alfabetos, como também com a percepção da possibilidade intersemiótica de mesclar harmoniosamente o design gráfico com os mais variados desenhos. O repertório não se ampliou ainda mais pelas limitações gráficas e pela falta de percepção dos artistas por não usarem tanto o clichê fotográfico, que já era utilizado pelos jornais e revistas a partir do começo do século (1907), ou mesmo a colagem, extremamente explorada pelos europeus. (MARTINS, 1992, p. 71)
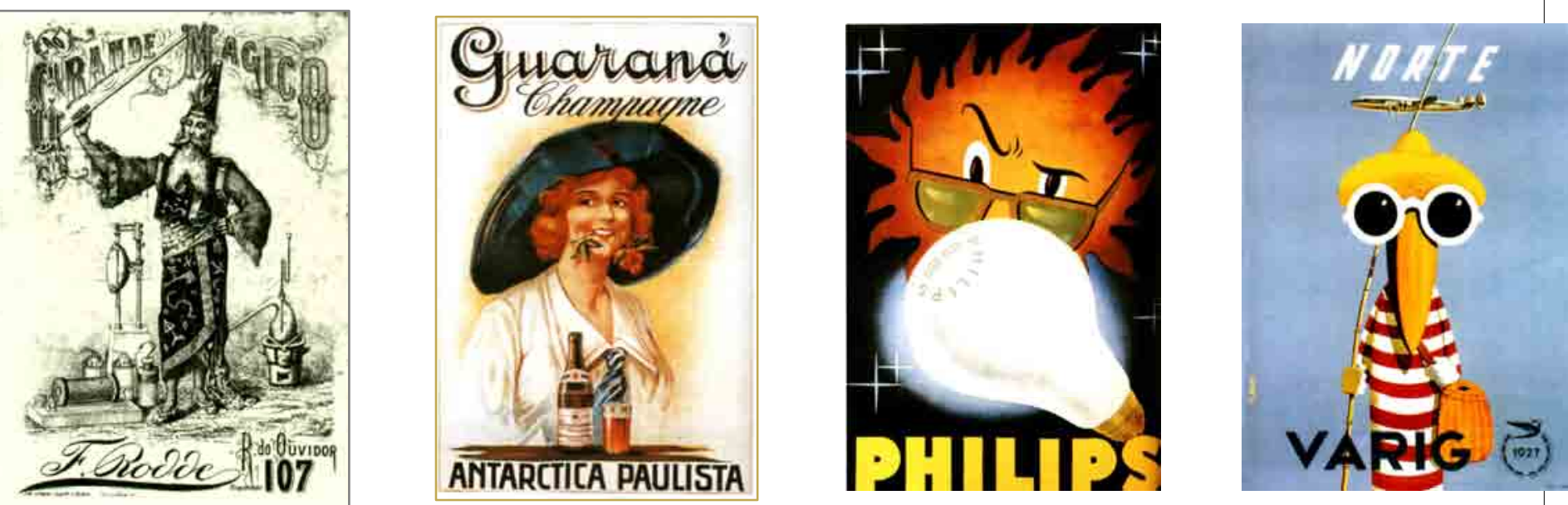

Quanto aos jornais, durante as décadas de 30 e 40, em plena vigência da ditadura do Estado Novo, os meios de difusão foram cerceados, afetando as inovações na linguagem jornalística, forçando-a a evoluir mais lentamente. $O$ ambiente político na época não propiciou significativas mudanças conceituais no âmbito do humor gráfico. Desapareceu a caricatura libertária para entrar em cena a caricatura de costumes. Os desenhos humorísticos, crítico e satírico, se retraem. Evoluirão sob vigilância, acompanhando lentamente a evolução social e política do país.

Deve-se destacar aqui o trabalho precursor e inovador de Millôr Fernandes já ao longo das décadas de 40 e 50 . Millôr, apesar de trabalhar numa revista popular, O Cruzeiro, produziu um humor de alto repertório verbal e visual. Como um Steinberg brasileiro, nas suas duas páginas, já coloridas, semanais, o artista dialogava com várias linguagens (...) Como exemplo paródico, de alto repertório às artes plásticas, é o Enterro de Mondrian. A composição é elaborada de tal maneira, que as cruzes vão se unindo e formando uma inesperada composição mondrianesca. Uma metalinguagem irônica para o grande público. (MARTINS, 1992, p. 78-79) 


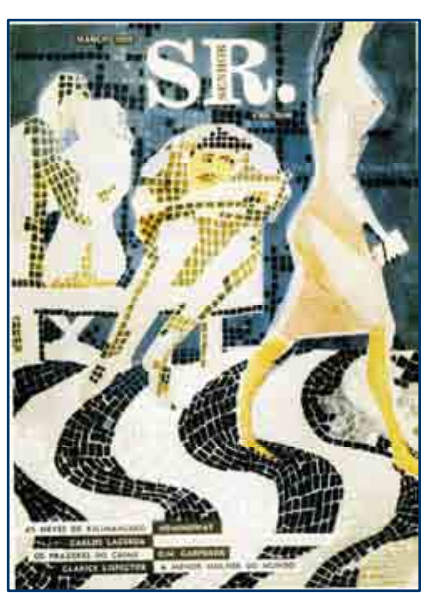

Já no final dos anos 50 surge no Rio de Janeiro a sofisticada revista Senhor, considerada um marco no design gráfico brasileiro.

Outro fator que estimulou e abriu espaço para a ilustração jornalística foi a reformulação gráfica do Jornal do Brasil, ocorrida na segunda metade dos anos 50. Reformulação que se tornou referência no contexto do jornalismo brasileiro.

Segundo Alberto Dines (1), do ponto de vista editorial, os jornais brasileiros dos anos 40 e 50 foram influenciados pelo "France Soir", jornal francês bem espaçado, mas ainda de paginação tradicional. O marco inicial do moderno design gráfico jornalístico pode ser considerado o redesenho do Jornal do Brasil feito pelo escultor e diagramador neoconcreto Amílcar de Castro ainda nos anos 50. Tornou-o, aos poucos, em um jornal leve, legível, elegante, verticalizando o texto, isto é, arrumando-o modularmente em blocos, de uma, duas ou três colunas. As fotos ficaram maiores, virando pontos focais das páginas. (MARTINS,1992, p. 78)

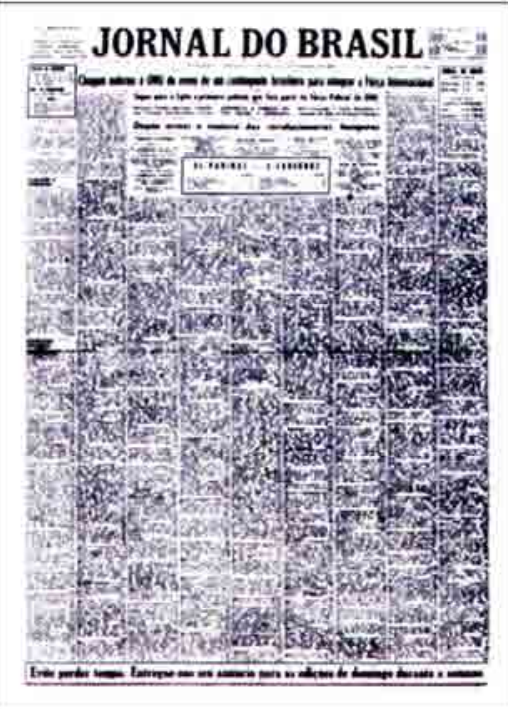

JB em 1956

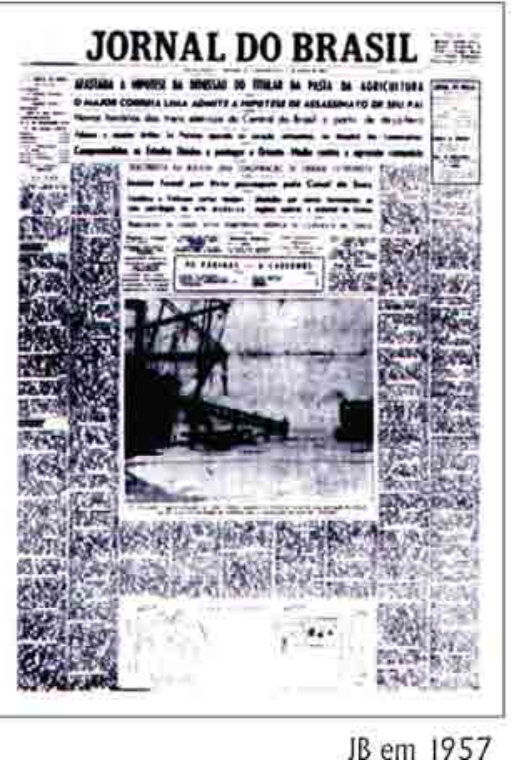

JB em 1957

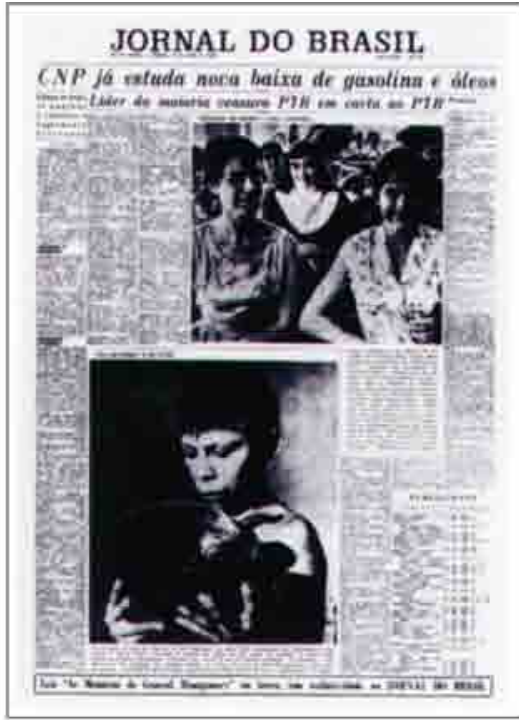

$\mathrm{JB}$ em 1959

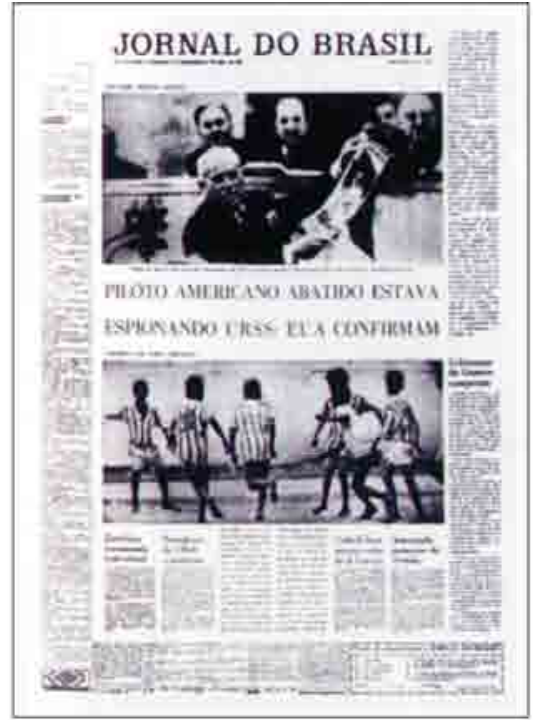

$\mathrm{JB}$ em 1960 
Nos anos 60 as informações se aceleram devido à instantaneidade das imagens fornecidas pela TV. Surgem aprimorados projetos gráficos para competir com a qualidade das imagens eletrônicas.

Influenciado pela reformulação do Jornal do Brasil, surge em São Paulo o Jornal da Tarde, com uma linguagem arrojada, além de aspectos inovadores em sua diagramação. Esse jornal apresentou soluções graficamente atraentes na utilização das ilustracões e fotos. Utilizou os recursos visuais do movimento concretista dos anos 50 de maneira criativa nos títulos, manchetes e reportagens.

O desenho de humor (no Jornal da Tarde) tem, nos casos analisados (abaixo), a função de uma ilustração, mas apresenta características particulares. O desenho de humor pode conter uma piada visual, um trocadilho visual ou pode trabalhar apenas com os aspectos sintáticos e expressivamente cômicos. Por trocadilho visual entendo um jogo de imagens semelhantes e/ou parecidas, mas de significados diferentes que dão margem a equívocos e surpresas. (MARTINS, 1992, p. 96)

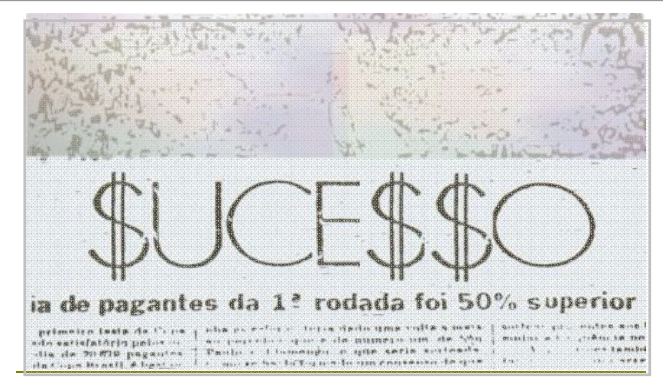

Manchete do JT: em uma reportagem comentando o aumento da média de público pagante nos estádios de futebol, o logotítulo \$uce\$\$, sintetiza o signo dinheiro com a

palavra sucesso. Ao desviar o título da palavra sucesso e caminhar para os cifrões, a solução apresenta um típico procedimento trocadilhesco. (MARTINS. 1992:p 86-87)

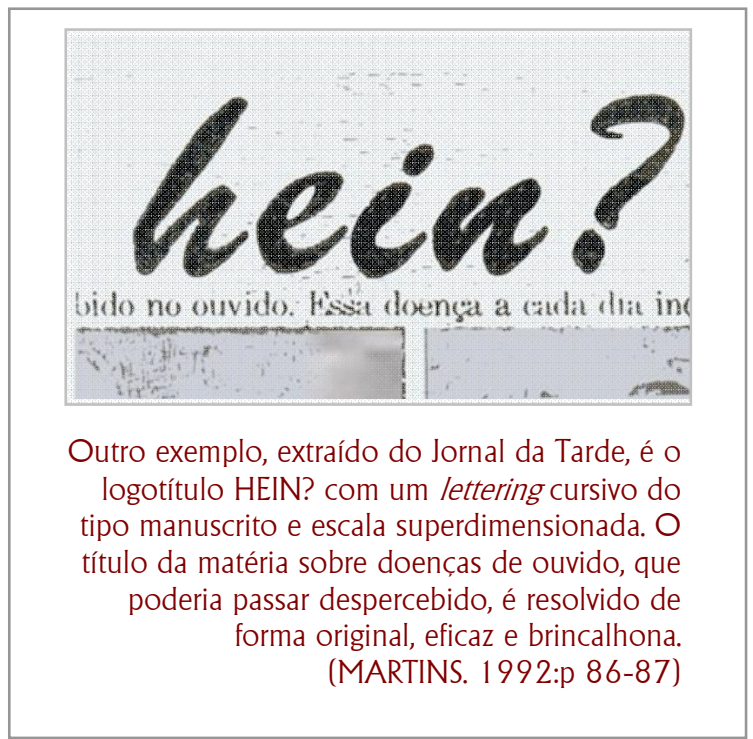

Com a criação de novos tipos gráficos um novo campo se abriu para a escrita. As letras circulam pelas páginas, distribuindo e diversificando a linguagem impressa. As possibilidades da diagramação jornalística se ampliam. A palavra começa a adquirir repentina personalidade plástica. 


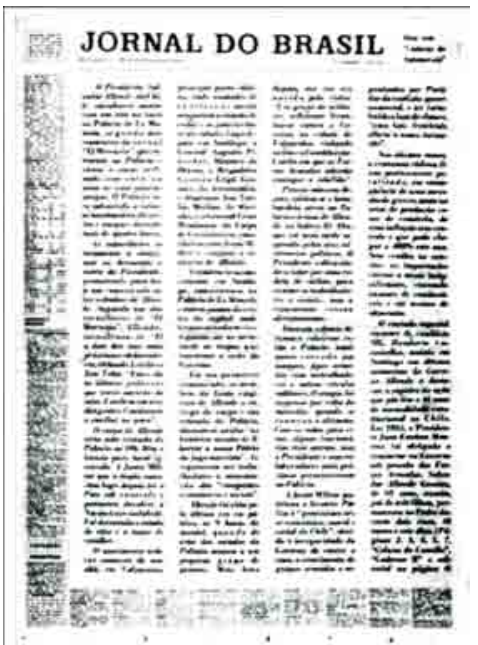

Jornal do Brasil - 12/09/73 Golpe no Chile. Editorial sem título ocupando toda $1^{\underline{a}}$. página

Com a interação desses novos elementos gráficos o jornal inicia a plena junção entre palavra e imagem. $\bigcirc$ código alfabético passa a ter presença dentro da sintaxe visual. Nos jornais, verifica-se o surgimento de uma nova linguagem reunindo forma e conteúdo. Uma linguagem organizada no cruzamento entre diferentes códigos e diferentes processos sígnicos (...)

(...) que integra simultaneamente a linguagem verbal escrita, a linguagem fotográfica, a linguagem diagramática e também a variação do tamanho e da exposição dos tipos gráficos, conseguindo, sob esse ângulo, transformar o caráter verbal da palavra escrita em arquiteturas gráfico-imagéticas.

Essa mistura do verbal-visual deve-se (.) (historicamente) no jornal, ao aparecimento da fotografia e do telégrafo. Com estes elementos, o verbal sofre transformações profundas: o jornal passa a utilizar as virtudes do espaço em branco, explorando as riquezas de uma organização sígnica que lança mão de tipos gráficos, que variam em cor, forma e tamanho; criam-se manchetes variadas que mantém com a foto um diálogo crítico complementar. (SANTOS, 2003, p. 12 e13)

A instantaneidade da imagem e da palavra, manifestados inicialmente pela fotografia e pelo telégrafo, e respectivamente, hoje, pelos recursos digitais e pela internet, influenciaram decididamente na sintaxe e na semântica da veiculação da informação. Estes dois meios ágeis na propagação da informação, verbal e não verbal, viabilizaram a maior integração entre as linguagens, ganhando fluidez nos discursos e derrubando barreiras comunicativas.

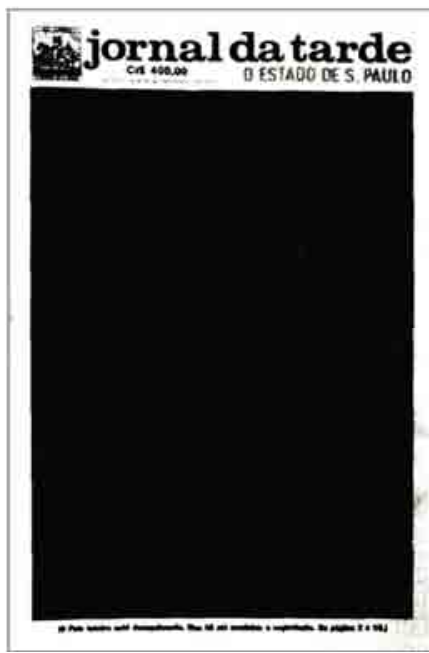

Jornal da Tarde - 26/04/84 "Eleições diretas não aprovadas no Congresso" Luto total na $1 \stackrel{\text { a }}{\text { página. }}$

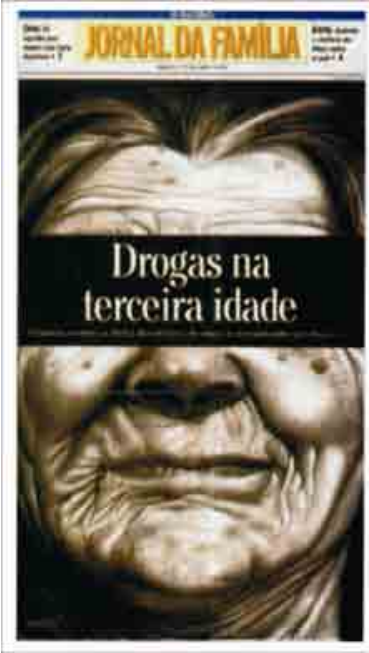

O Globo -2002 "Drogas entre os idosos" A tarja preta nos olhos remete aos problemas da delinqüência

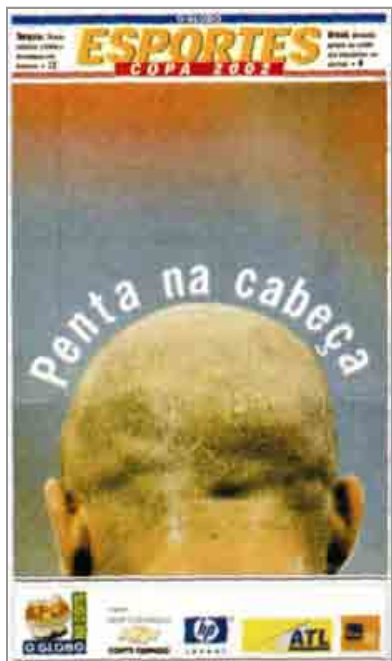

O Globo - Junho/2002 Campanha da seleção brasileira na copa

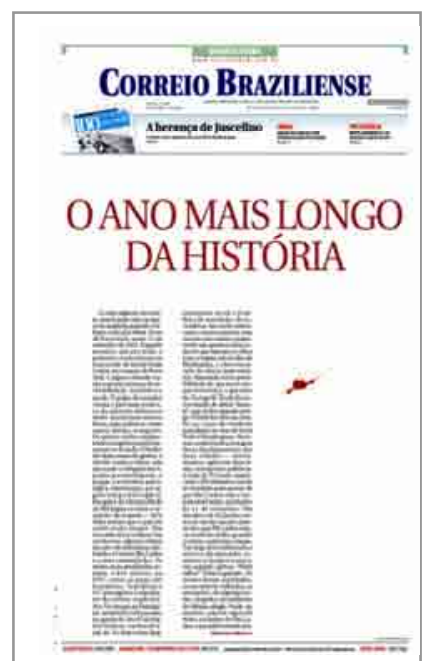

Correio Braziliense - 11/09/02 "Um ano após o atentado ao WTC" Duas colunas de textos substituem as duas torres 


\section{2 - ASPECTOS CONCEITUAIS}

O riso não é uma característica inata no ser humano, nem simplesmente uma reação fisiológica. $\bigcirc$ riso é um aprendizado conquistado pela humanidade ao longo dos tempos. Revela-se como vestígio de sua civilização. É um sintoma da evolução cultural do Homo Sapiens. Transparece como uma capacidade intelectual, ou seja, uma característica que pressupõe possibilidades de ver em torno de si e a si mesmo.

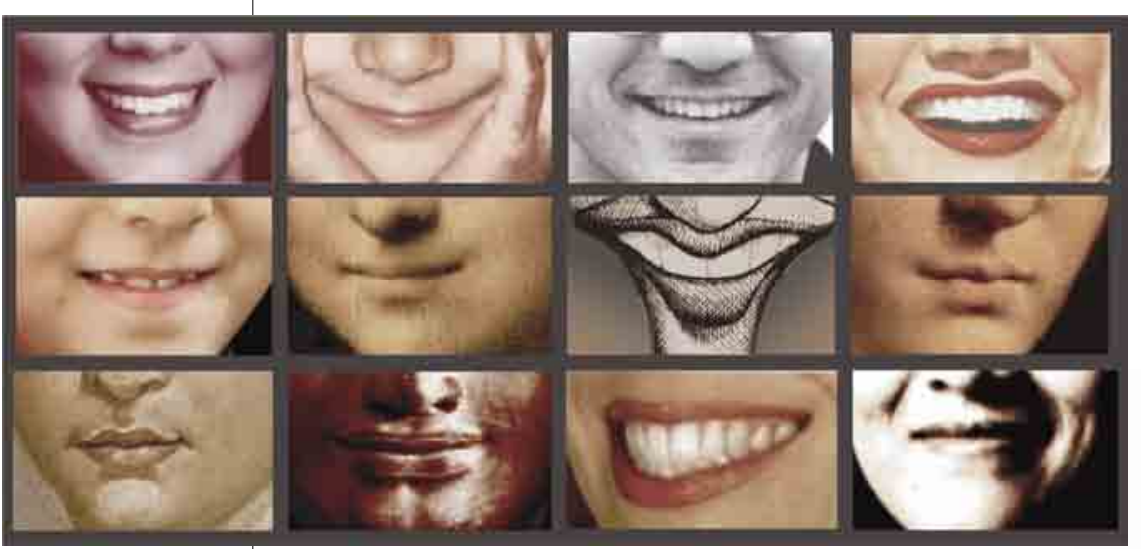

A reação fisiológica do humor transparece na face humana desde um sorriso sutil até uma espalhafatosa gargalhada. No entanto, somente essa reação fisiológica não esclarece plenamente o fenômeno da manifestação do humor.

O que se percebe de comum nas manifestações do humor é a associação fisiológica com o prazer intelectual repentino que é transmitido. Por ser prazer resultante de conquista cultural, o conceito de humor certamente acompanha as evoluções e mutações culturais que ocorrem ao longo dos séculos.

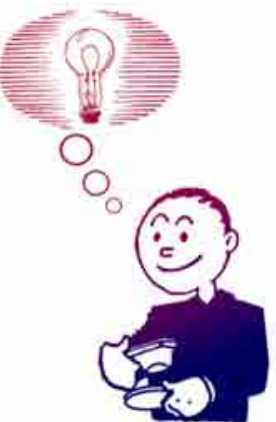

A reação de uma gargalhada ao presenciar um escorregão, como nas comédias, se traduz como perda da conquista do equilíbrio vertical, não só de si, mas como árdua conquista obtida pela humanidade ao erguer-se da condição de animal rastejante.

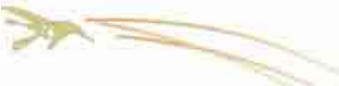

Assim, no extremo oposto temos o humor sutil, um prazer inconsciente oriundo de um lampejo advindo de qualquer esclarecimento intelectual, como se encontrássemos uma saída iluminada nos libertando de um obscuro labirinto mental.

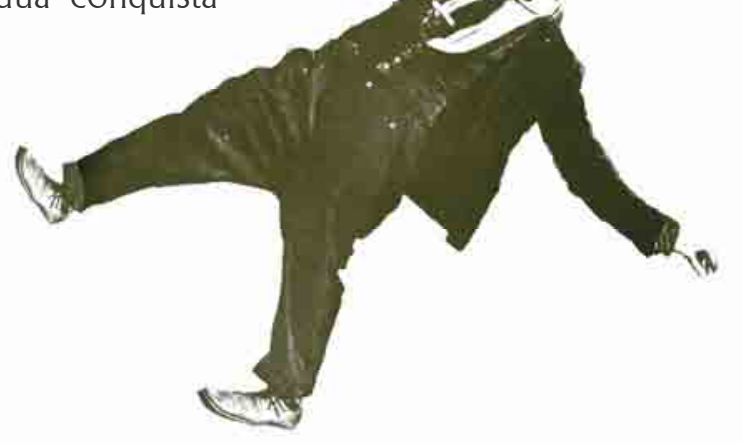

Conclui-se que em comum há prazer no humor, com o riso ou sem o riso. 
Um vínculo que frequentemente está associado ao humor é o que se refere à diversão. E aqui cabe esclarecer

as variações semânticas na interpretação que hoje são feitas com os 2 termos: humor e diversão.

\section{HUMOR}

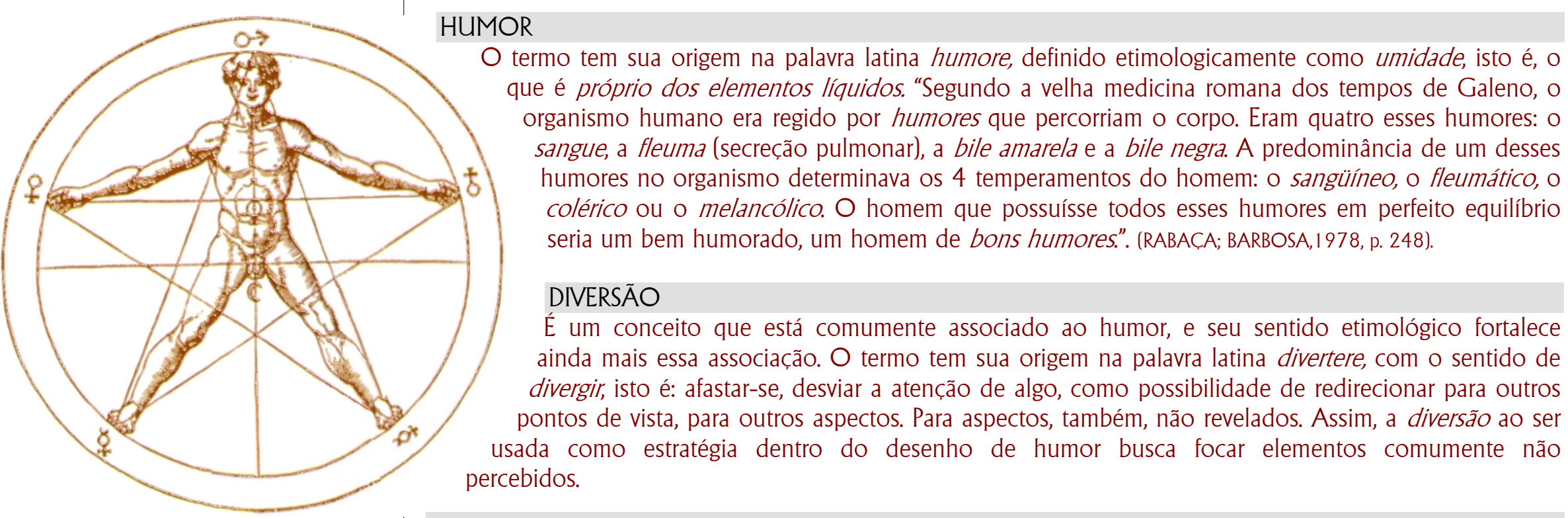

(...) uma concepção do riso, surgida em forma de rascunho na Antiguidade cristã e que atravessou incólume intacta praticamente toda a Idade Média e Renascença, é a que veio a ser descrita em 1855 por Charles Baudelaire: o riso é sinal inequívoco da condição humana, situada entre duas 'distâncias' privadas do riso: Deus e os animais. O riso do homem se dá, por um lado, em razão de sua infinita inferioridade diante de Deus, e por um outro lado, em virtude de sua infinita superioridade em relação ao restante da criação. (XAVIER, 1997, p. 10).

Somente na Renascença é que surge o conceito da razão dando significado ao riso e à sua concepção como impulso criativo e como impulso criador.

Portanto, o motivo para o humor se manifestar hoje já não é mais como o era considerado nos alfarrábios medicinais, isto é, vinculado à saúde espiritual do indivíduo. Não é mais estar submetido à fluidez dos líquidos vitais do corpo, mas submetido à uma forma de expressão que aprofunde a consciência crítica, estimulando o espírito humano. 
Caco Xavier, em seu trabalho (...) Humor e Saúde: Análise dos cartuns (...) (1997, p. 16) lembra que foi Laurent Joubert o primeiro a dizer que os recém-nascidos e os animais não riem porque lhes falta o pensamento. Pois é a partir do intelecto que temos a introdução do súbito, que atravessa o pensamento como uma flecha e fere a lógica, inserindo um tipo de lógica imprevisível, absurda, cuja intromissão leva ao riso.

“Da maior relevância é (...) destacar que o humor, além de ser uma arrojada posição do espírito criador, que requer erudição e competência na (...) arte de invenção e renovação, consegue, também, a proeza através da sua força alusiva, ressignificadora (...), de reler e repensar os próprios fatos culturais”. (MARTINS,1992, p. 179).

Para José Marques de Melo (1994, p. 22) a introdução do desenho de humor na imprensa explica-se pela conjugação de dois fatores sócio-culturais: o avanço tecnológico dos processos de reprodução gráfica e a popularização do jornal como veículo de comunicação coletiva. No primeiro caso, o desenho de humor só se desenvolveu depois que a litografia passou a constituir um recurso plenamente incorporado aos processos de produção jornalística. No segundo caso, o recurso do desenho de humor representou uma necessidade social de um jornalismo que ampliava o seu raio de ação ganhando novos contingentes de leitores.

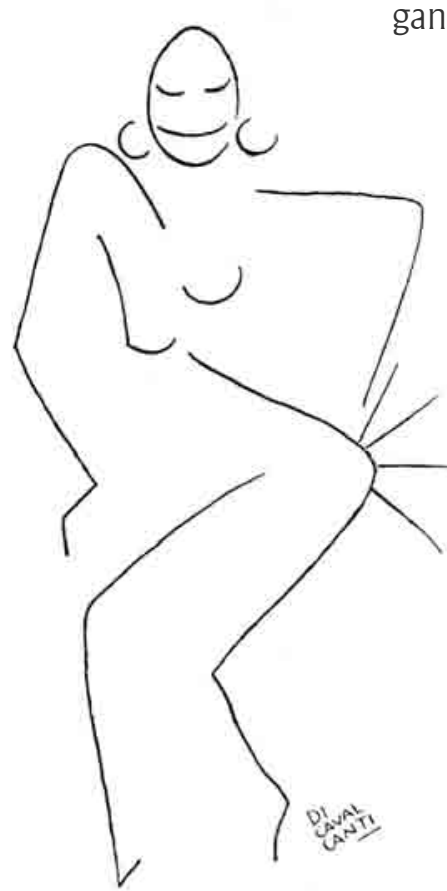

Josephine Baker por Di Cavalcanti - 1929
O desenho de humor pode ser considerado mais como forma narrativa do que um meio de expressão estética. Podemos dizer que nele o objetivo estético sempre ocupa um espaço secundário, pois é a idéia quem ocupa o ponto principal.

Conforme esclarece Caco Xavier (1997, p. 16) qualquer aspecto do humor gráfico estará enquadrado predominantemente num desses seis tópicos abaixo relacionados:

METÁFORA - Um elemento qualquer ocupando lugar de outro.

HIPÉRBOLE - Um elemento ou situação qualquer sendo apresentada de maneira exagerada PARADOXO - Conciliação de duas idéias antagônicas e inicialmente inconciliáveis.

IRONIA - Algo transmitindo idéia contrária ao que comumente significa. COMPARAÇÃO - Situações ou elementos similares ocupando o mesmo espaço. METALINGUAGEM - O desenho tem como tema o seu próprio processo de realização.

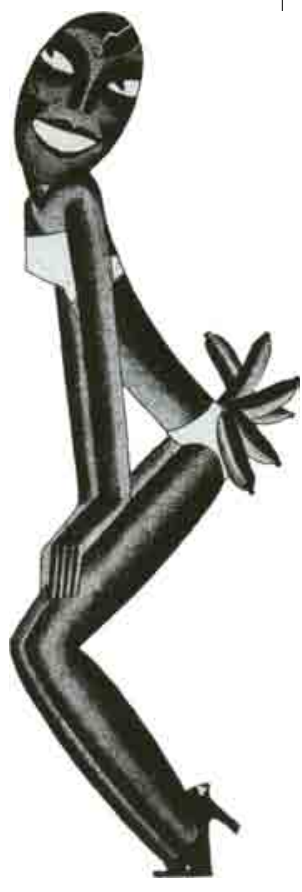

Josephine Baker por Guevara - 1929 


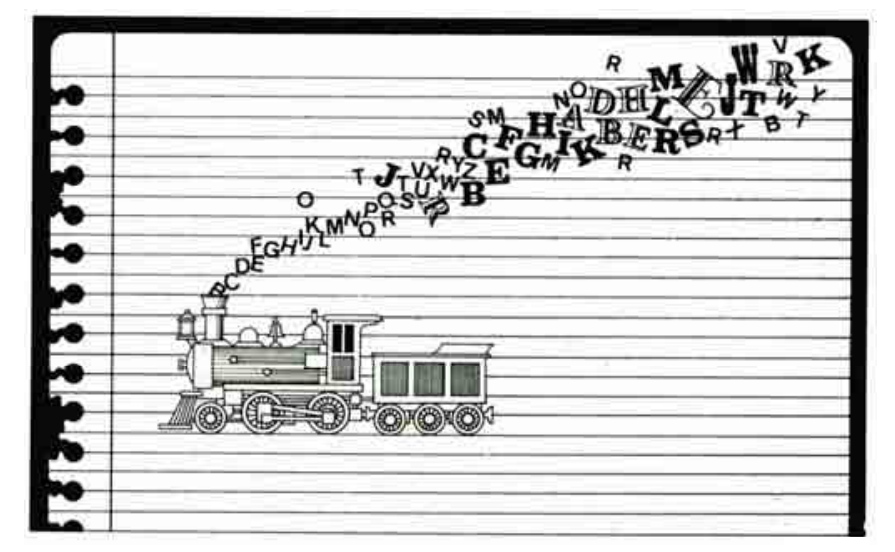

METÁFORA

\section{HIPÉRBOLE}

PARADOXO

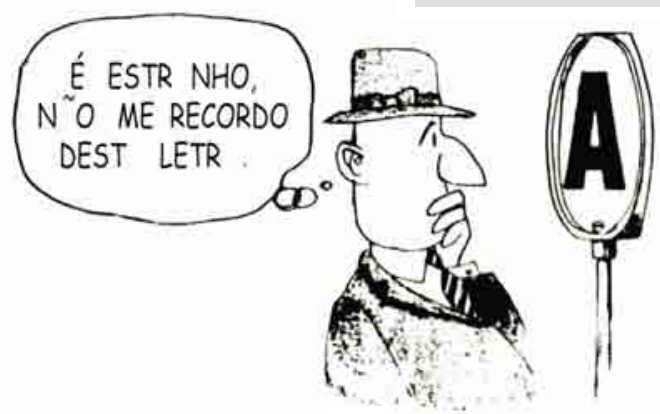

QUINO
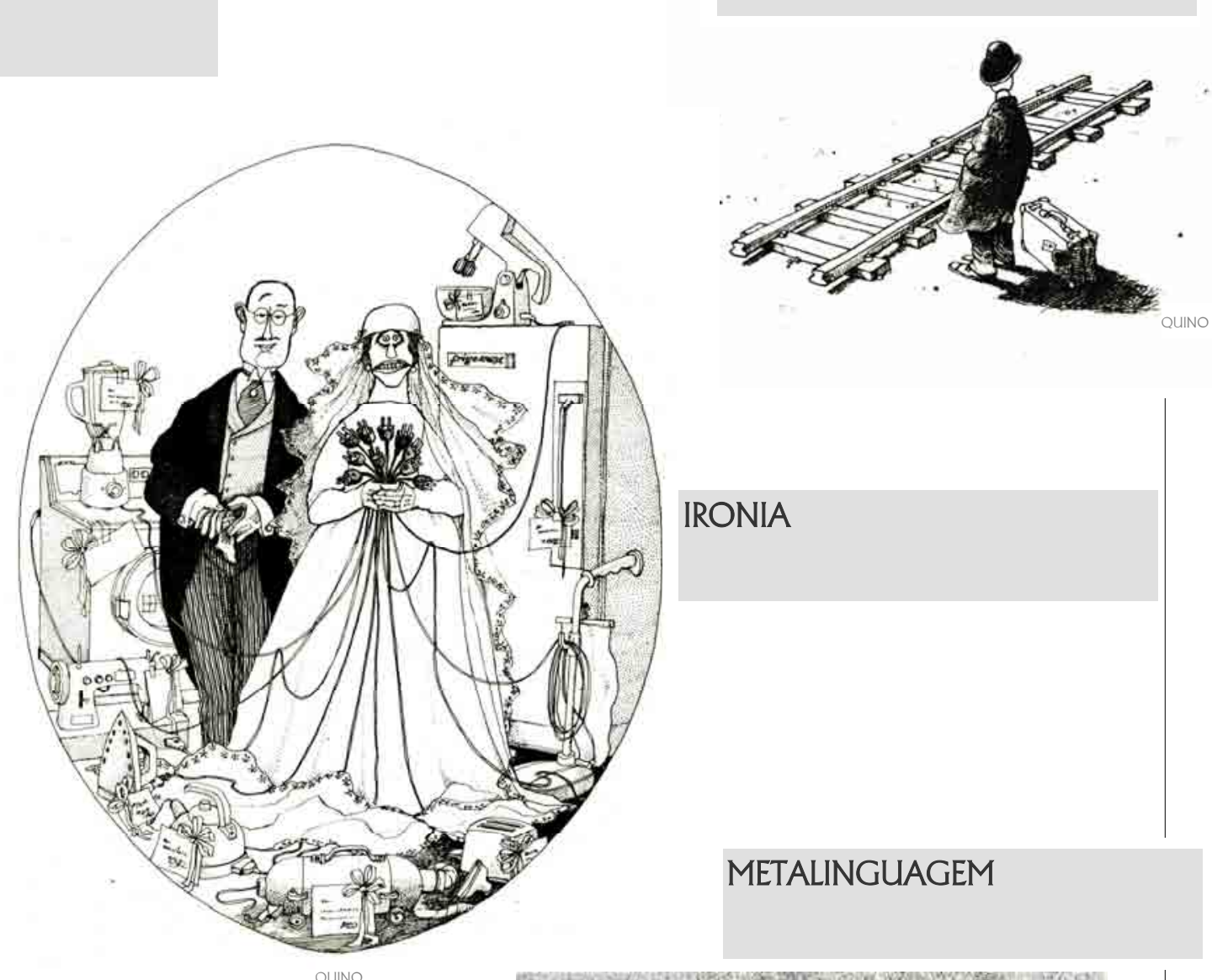

COMPARAÇÃO

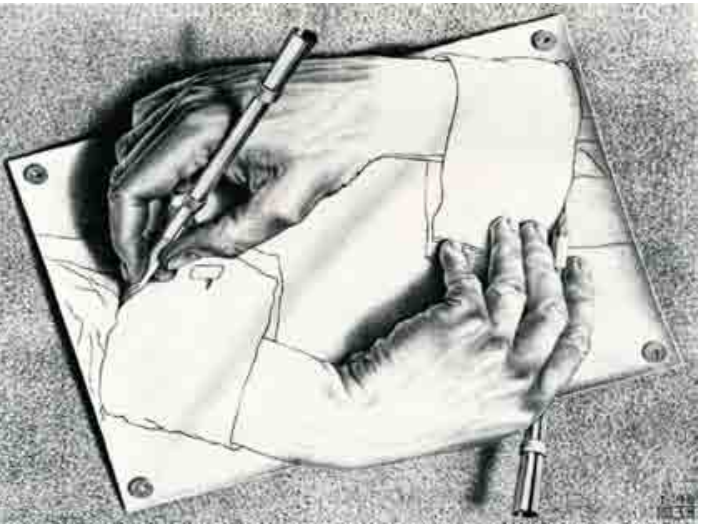

METALINGUAGEM

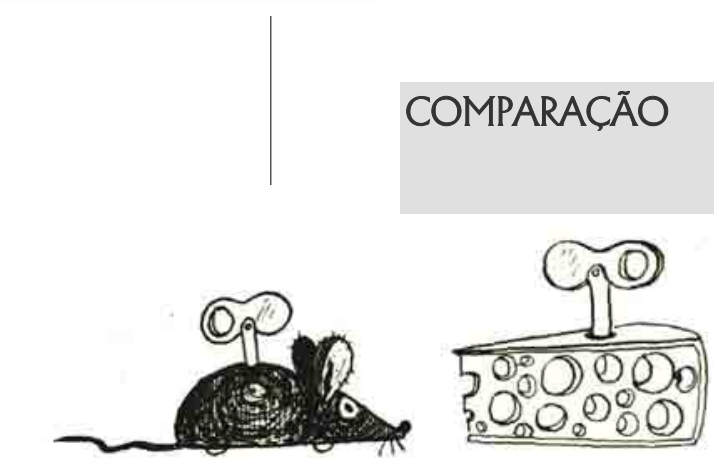


Nem sempre o objetivo do humor é fazer rir. Como no humor satírico, provocando rejeição do objeto da ridicularização, mesmo sendo um ataque fictício. Ou como no humor irônico, onde se expressa algo com o propósito de expressar o inverso, essencialmente tendo um caráter moral que se destina a fazer a sociedade refletir e se rever.

(..)

Num extremo temos as situações de comédia pastelão (...) e no outro extremo da escala, há a sátira, como uma composição sarcástica, mordaz, que apela para a inteligência, divertindo uns e golpeando outros. (SILVA, 2002, p.119)

Portanto o humor gráfico como um gênero jornalístico possui uma missão social. Ela pode se manifestar através de textos ou pelo impacto do desenho de imediata absorção pelo leitor. É um tipo de manifestação que só se desenvolve e sobrevive em regimes democráticos, devido às suas características de crítica social e política, minguando, portanto, nos regimes autoritários. 


\section{3 - A OPINIÃO ILUSTRADA}

\section{A Caricatura no Brasil}

Como representação satírica de pessoas ou acontecimentos a caricatura sempre foi veículo de opinião e instrumento de crítica social. As primeiras caricaturas impressas no Brasil apareceram em 1832, no Recife, nos periódicos $O$ Carcundão e O Carapuceiro. O autor do livro Historia del Humor Gráfico en Brasil, Laílson de Almeida Cavalcanti (1) afirma que o irreverente padre Lopes Gama foi o editor dessas primeiras caricaturas.

No Rio de Janeiro as ilustrações apareceram logo após, como peças avulsas ou encartadas em periódicos. Algumas eram importadas e tão desligadas do corpo do jornal quanto da própria realidade brasileira. Outras representavam pilhérias que, no máximo, produziam riso fácil e rápido.

Esses periódicos não dispunham de condições técnicas que lhes permitissem reproduções de gravuras em suas páginas, o que só veio a acontecer, de forma regular, na segunda metade do século XIX, com a chegada ao país de artistas imigrantes que conheciam a técnica da litografia. Foi o desenvolvimento dessa técnica que permitiu que os jornais brasileiros chegassem a uma caricatura sintonizada com as questões nacionais. A partir daí as caricaturas e as charges passaram a ser mais adotadas nos periódicos e com elas os jornais puderam ampliar sua capacidade crítica, aumentando a influência que exerciam sobre o leitor e a opinião pública.

Campainha e o cujo - 1837

Uma das primeiras caricaturas brasileiras.

É atribuída a Manuel de Araújo Porto-Alegre.

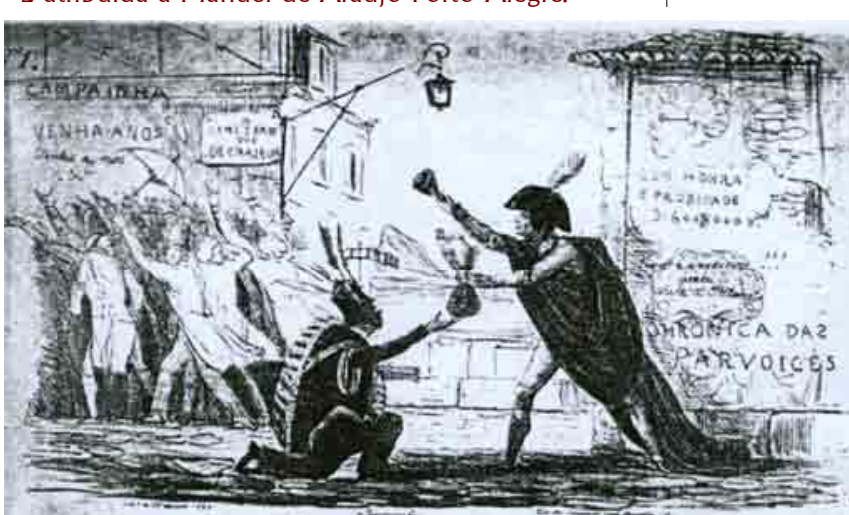

Pode-se ler em $A$ Marmota edição de 4 de janeiro de 1853 , a seguinte informação: "A imprensa apresentou, no ano de 1852, algumas inovações dignas de louvor. A litografia e a gravura começaram a ilustrar nossos jornais literários e de modas, à semelhança do que se usa na Europa. A Marmota, neste gênero, tem-se enriquecido, trilhando a modesta vereda que adotou: excelentes gravuras sobre madeira. Músicas litografadas e figurinos coloridos, do melhor gosto foram dados aos assinantes". (SOUZA, 1986, p. 31)

Até pouco tempo os historiadores consideravam como primeira caricatura no Brasil a que surgiu no dia 14 de dezembro de 1837, quando foi publicado o desenho Campainha e o Cujo, vendido como estampa avulsa. O pesquisador Álvaro de Moya comenta a este respeito: "Já corriam soltas as estampas litografadas, mas o anúncio no Jornal do Comércio consolidou a data oficial, com a ilustração atribuída a Manuel de Araújo Porto Alegre, sob o título: Campainha e o Cujo, estampa litografada de Victor Larée." (Álvaro de Moya apud ARBACH,1990, p. 5) 


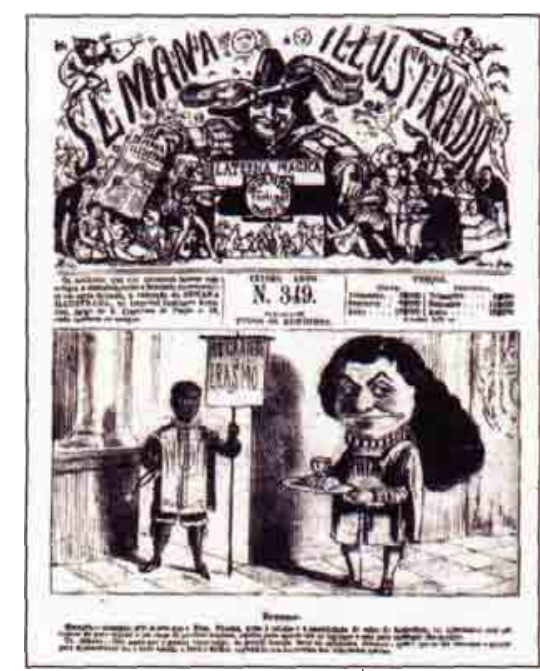

SEMANA ILUSTRADA
Capa desenhada Capa desenhada
por Henrique Fleiuss

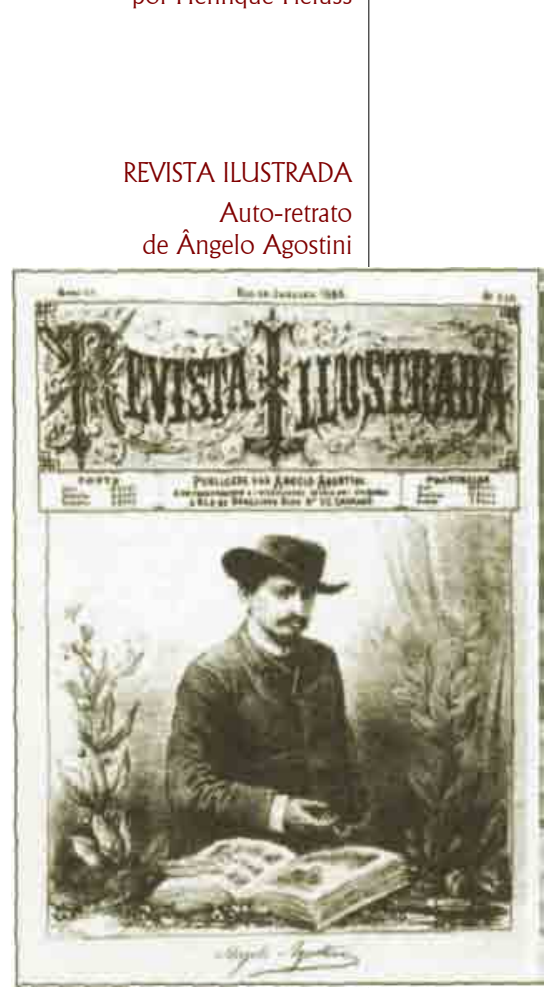

Já em 7 de Agosto de 1844 o Diário do Rio de Janeiro publicava interessante anúncio:

(...) o do aparecimento da (...) Lanterna Mágica-Jornal de Caricaturas. Sairia aos domingos, orientada por Araújo Porto Alegre e Rafael Mendes de Carvalho, que era o caricaturista. O novo jornal, que apresentava o primeiro sério avanço técnico na imprensa brasileira, (...) fazia a crítica de costumes. O aparecimento da caricatura, de forma sistemática, traria à imprensa recursos cuja amplitude o meio iria começar a sentir e anunciava a mudança a que o processo político não ficaria imune. (SODRÉ, 1966, p. 205)

Com o lançamento da Lanterna Mágica a caricatura impressa passou a ser incorporada aos periódicos, iniciando um ciclo de publicações ilustradas. Ao se autodenominar Periódico Plástico-Filosófico esse periódico assumia publicamente seu compromisso editorial. $\mathrm{O}$ aparecimento da caricatura deu à imprensa recursos de enorme amplitude anunciando uma mudança que iria fustigar o processo político. Era uma época marcada pela extinção do tráfico negreiro (1850), pela Guerra do Paraguai (1860-1870) e pela consolidação do Império.

A história da caricatura no Brasil sempre esteve associada ao combate político e à crítica dos costumes. A revista Brasil Ilustrado foi a primeira a publicar, sistematicamente retratos desenhados de pessoas e de paisagens, além de caricaturas e gravuras humorísticas, elaboradas por Sebastien Auguste Sisson. Entretanto, quem revolucionou o gênero foi o ítalo-brasileiro Ângelo Agostini. O artista voltava de Paris, onde fora estudar pintura i, em 1859, e depois de uma escala de três meses no Rio de Janeiro estabeleceu-se em São Paulo.. Vinha com o equipamento necessário para elaborar litografias, segundo o dizer de Monteiro Lobato: "Chegou com muito ânimo e uma pedra litográfica debaixo do braço”. (Monteiro Lobato apud SODRÉ, 1966, p. 234).

(...) (com a caricatura) se criticava com mordacidade os episódios políticos e sociais. Foi, inclusive, através da (revista) Ilustracão Brasileira que o seu criador o italiano Angelo Agostini, comecou a impulsionar a caricatura no Rio de Janeiro. Juntamente com Agostini, formando o trio-base da introdução da caricatura no Brasil, então Henrique Fleuiss e Luigi Borgomaniere. Fleuiss era alemão e criou a revista Semana Illustrada e Luigi Borgomaniere foi idealizador da revista Figaro (ambas as publicações criticavam a sociedade carioca da época, principalmente com referência à falta de higiene no Rio). (De CASTRO,1990, p. 22-23) 


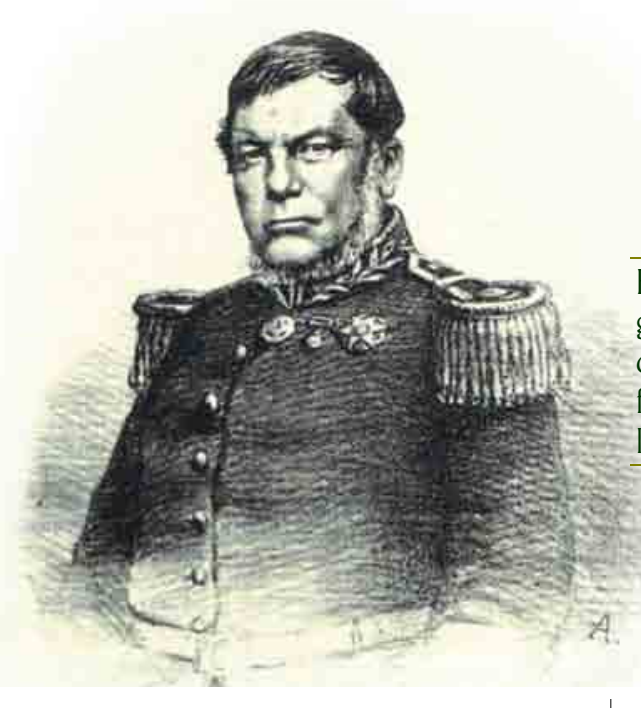

Litografia esfumada de Ângelo Agostini
Para termos idéia de como era difícil fazer ilustração para jornal nos últimos anos do século XIX, Raul Pederneiras escreveu um depoimento com o título $A$ Gravura que fala da arte dos artistas de então. Além do testemunho das dificuldades dos ilustradores, faz menção em dois momentos, das duas técnicas utilizadas na época pelos ilustradores: uma é a litogravura e a outra a zincogravura:

Todos eles, exímios no crayon litográfico, desenhavam diretamente sobre pesadas pedras, às avessas, para que, na impressão, o resultado parecesse natural. Tal destreza, tal perícia, adquiriam no manejo do lápis que, em poucas horas, davam conta de quatro grandes páginas e alentado formato, cuidadosamente estilizadas.

(...)

Com a tinta autográfica e a pena de irídio, o artista desenhava o seu trabalho sobre papel especial, obedecendo ao tamanho exato que deveria ter o clichê, fosse ele de uma polegada. Uma prensa fazia o desenho aderir ao zinco, por um modo semelhante ao das decalcomanias, fixava-se o desenho ao calor do fogo com betume, e, em seguida, a chapa de metal entrava em banhos graduados de água-forte que, roendo o metal, deixavam em relevo os traços do desenho protegidos pela tinta betuminada. (LIMA, 1963, p. 78).

É importante destacar a obra do artista Angelo Agostini, um inovador no contexto gráfico da época. Em 1876, na Revista Ilustrada. Era considerado mestre no esfumado da caricatura litográfica. Essa técnica de reprodução gráfica, predominante na época,

foi bastante utilizada por Agostini, influenciando uma geração de desenhistas. A itografia como meio de reprodução predominou até fins do século XIX.

Com uma técnica diferente da litografia, o artista Raphael Bordalo conseguiu em O Besouro um desenho inovador ao introduzir na imprensa o desenho a bico-depena. Essa mudança deveu-se às inovações nos meios de reprodução impressa deflagrada pela introdução dos mecanismos fotográficos. Aos poucos, o antigo meio litográfico de reprodução foi perdendo espaço.

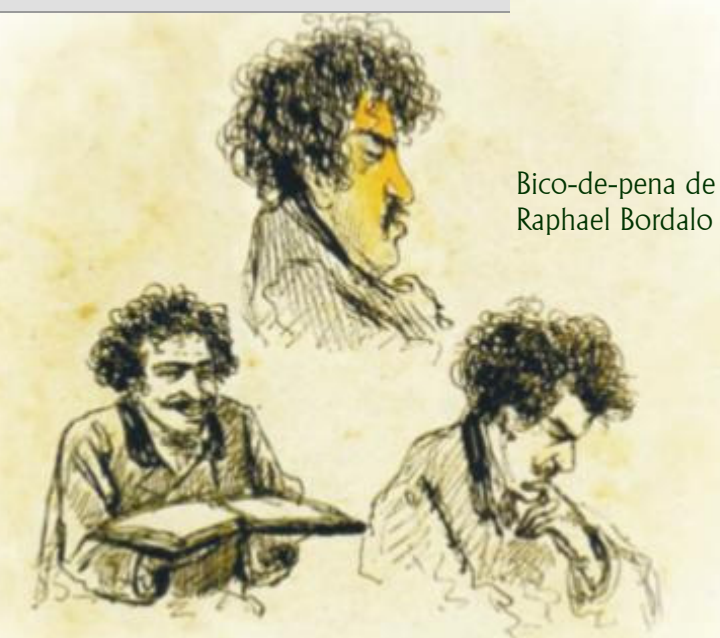

Os periódicos começavam a criar novidades para atrair o público leitor. A Gazeta de Notícias teve duas iniciativas pioneiras e renovadoras. A primeira delas teve inicio em 1896 com a publicação de uma série chamada Caricaturas Instantâneas, de Lúcio de Mendonça, com 'bonecos' de Julião Machado. A segunda foi em 7 de julho de 1907, quando passou a publicar clichês em cores, em papel acetinado, em máquinas rotativas. Isso tudo representava "uma completa inovação na imprensa diária sulamericana”.

O Brasil, por essa época, já estava pronto para consagrar plenamente a caricatura. O Rio de Janeiro, como Capital Federal acabava de passar pela revolução urbanística e de saneamento público realizado por Pereira Passos e Oswaldo Cruz. Acompanhando os ventos da renovação, a imprensa e o público assistiam ao lançamento dos grandes jornais políticos e de novas revistas ilustradas. Lá estavam o Jornal do Brasil, fundado por Rodolfo Dantas, em 1891, e o Correio da Manhã, que surgiu em 1901, para ser um dos jornais que mais contribuíram para o fim da chamada República Velha. 

no jornalismo do País, comandaram

uma autêntica revolução na caricatura, acentuando a massa das figuras e tornando-as mais plásticas e atraentes. São dessa escola Alvarus, Théo, Fritz, Belmonte, Seth e outros que surgiram com suas charges nos principais jornais e revistas.

Seguem-se-Ihes (...) Péricles, o criador do Amigo da Onça, (...) Augustinho Rodrigues, (...) Nássara, Carlos Estevão,

A Revista da Semana, fundada em 1900 por Álvaro de Teffé, foi a primeira publicação a utilizar dos métodos fotoquímicos nas ilustrações. Essa inovação, considerada notável, viria revolucionar os meios gráficos na nossa imprensa. No início do século XX surgiram talentos que atravessaram décadas colaborando para as diversas revistas. Entre eles K. Lixto, Belmonte, Raul Pederneiras, J. Carlos e Voltolino.

Por essa época, na história da caricatura e do jornalismo no Brasil, firmava-se o nome de J. Carlos. É claro que tanto K. Lixto quanto Raul Pederneiras eram espíritos requintados e tracos da maior qualidade mas J. Carlos foi quem verdadeiramente abriu os caminhos para a moderna caricatura brasileira. Não se limitou a ser apenas aquele sutil desenhista capaz e manter viva, para sempre, toda uma época, aquela belle-époque que antecedeu a Primeira Grande Guerra Mundial. Foi ainda mais: deu às suas figuras o cenário perfeito, àquilo que Herman Lima chamou de "o ambiente específico". Um dado impressionante: muitos de seus trabalhos sobre as figuras da guerra de 14-18 eram freqüentemente reproduzidos na Europa, em todas as melhores revistas do gênero. (SOUZA, 1986, p. 91)

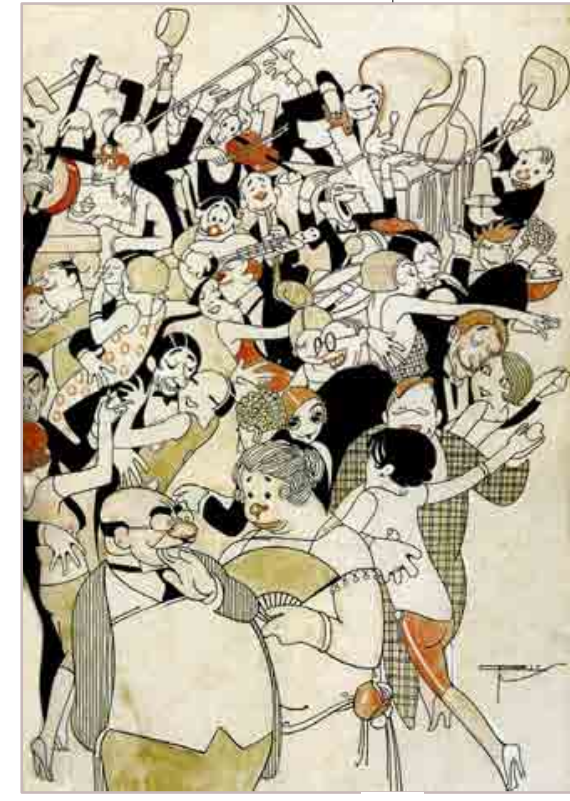

J. Carlos - c. 1922
Foi durante os anos 20 que a ilustração brasileira começou a se popularizar, onde mais tarde dois artistas estrangeiros revolucionariam a caricatura brasileira: o paraguaio Guevara e o mexicano Figueroa (2). Lançaram um estilo de caricatura mais plástica, que logo teve aceitação por parte de ilustradores da época, influenciando artistas até meados dos anos 50. A implantação da fototipografia (clichês) ofereceu aos artistas relevante importância jornalística à ilustração e à caricatura. Essa inovação ampliou as possibilidades do discurso visual do humor gráfico no jornalismo.

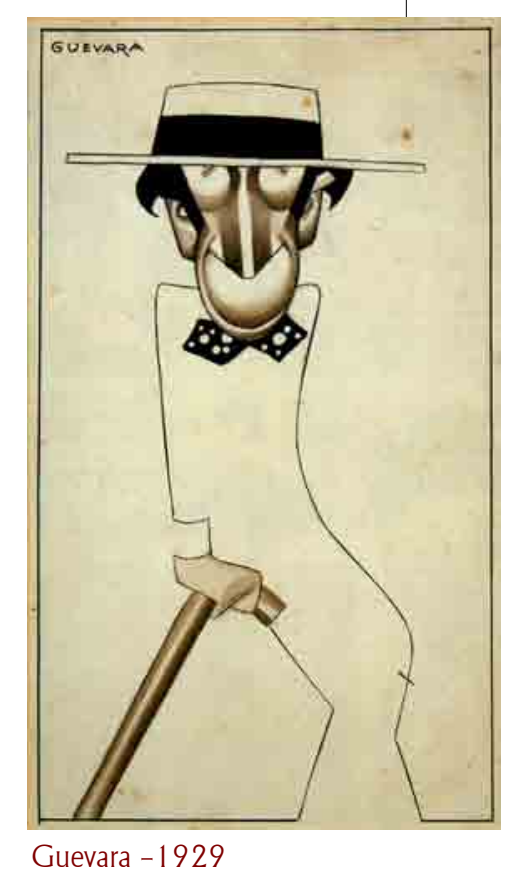




\section{Concepções de Humor Gráfico}

Diariamente os leitores dos principais jornais se deparam com grande volume de informações textuais sobre os mais variados temas. Há, no entanto, um elemento dentro dos periódicos que mostra de forma não-textual os assuntos que estão na pauta do dia. É o desenho de humor, que atua como informação, servindo de fonte documental. Ocupam lugar de destaque nos veículos dividindo a página com os editoriais e os articulistas. Embora sejam consideradas como sátiras da realidade, os desenhos veiculam opiniões e representam forma alternativa de como encarar os fatos expostos nas matérias dos jornais. Daí, o que é manifestação artística transforma-se em comentário e o discurso não-verbal assume valor opinativo.

Através de uma linguagem intersemiótica a produção gráfica do Humor Gráfico ocorre com objetivos de dirigir-se ao indivíduo dentro do social. Nessa acepção vamos classificar as cinco espécies de humor gráfico mais adotadas no jornalismo:

\begin{tabular}{ccccc}
1 & 2 & 3 & 4 & 5 \\
\hline Caricatura & Charge & Cartum & Desenho de Humor & Quadrinhos
\end{tabular}

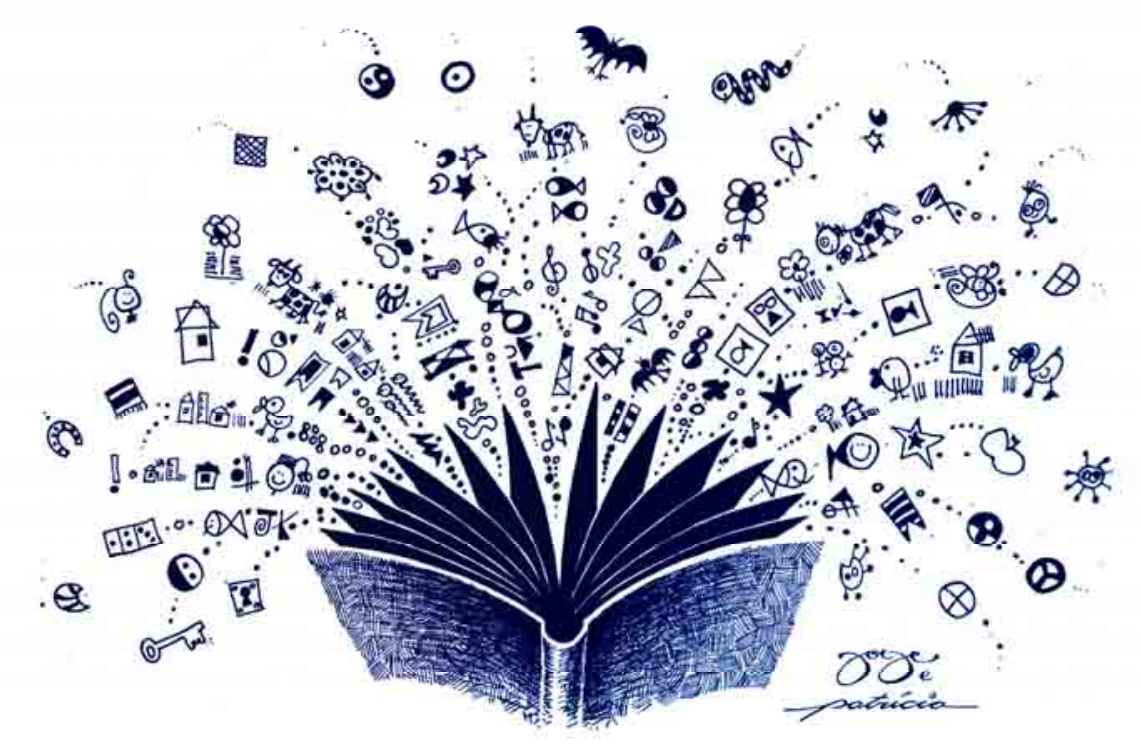




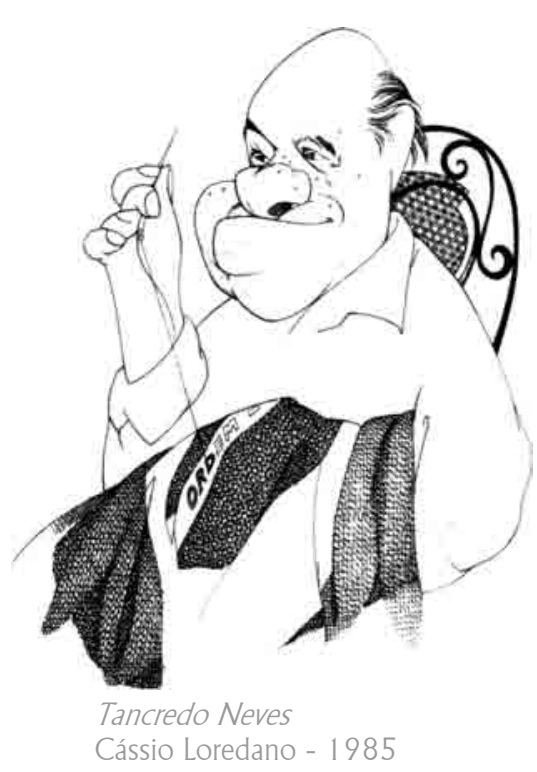

Cássio Loredano - 1985

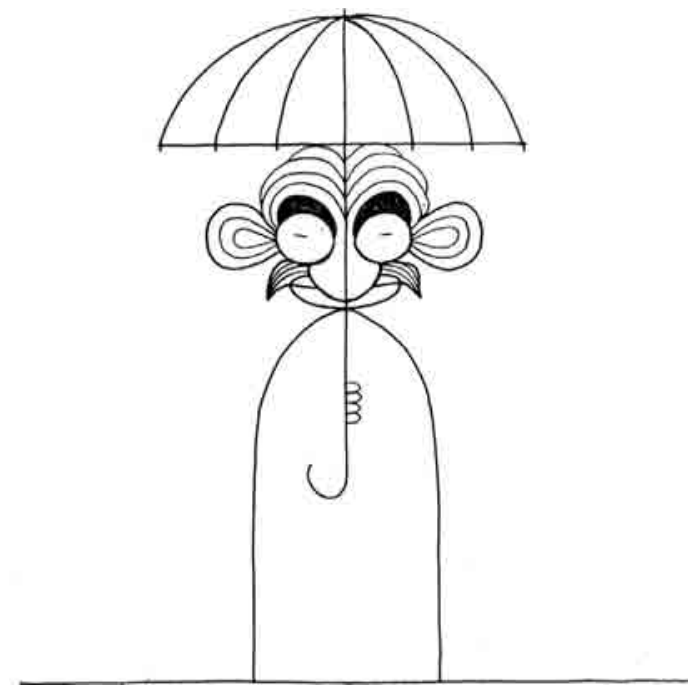

Gandhi

Vasquez de Sola - c. 1974

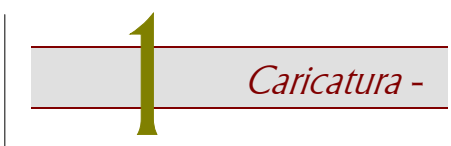

A palavra caricatura tem origem do latim caricare, significando ação de carregar, ou seja, impor uma carga sobre algo, dando entendimento de exagerar. O exagero visa revelar determinada característica da fisionomia humana, ato ou situação, salientando traços com o objetivo de identificá-los através do humor.

“O termo caricatura apareceu pela primeira vez numa série de desenhos dos irmãos Caracci, de Bolonha, Itália, nos fins do século XVI". (RABACA; BARBOSA, 1978, p. 69).

A caricatura (como sátira desenhada) tal como a conhecemos hoje, é uma arte recente: sua invencão se deveria aos irmãos Carracci que "trabalhavam em Bolonha e em Roma por volta do fim do século XVI e princípios do século XVII". Logo, os conhecedores e críticos de arte da época "sentiram um prazer especial em confirmar e definir o novo modo de representação da figura humana", os ritratti carichi (...) (literalmente "retratos carregados") como uma deliberada transformação dos traços humanos na qual as deficiências e fraquezas da vítima são exageradas". O caricaturista procura manter no seu trabalho a maior semelhança possível com a pessoa reproduzida, mas, como o salientava Baldinucci, já em 1681, "com intenção jocosa, e algumas vezes com o intuito de zombaria", acentuava-Ihe ou aumentava-lhe desproporcionadamente os traços marcantes, "de forma que o retrato resultante pareça idêntico ao modelo, por mais que os detalhes tenham sido alterados". Ora, "o reconhecimento do parecido no diferente produz um efeito cômico, uma vez que a comparação é o caminho preferido do cômico". (BELTRÃO, 1980, p. 101)

A caricatura traz em sua própria substância motivos para reflexões nem sempre superficiais, cuja finalidade é "(...) (revelar) a par com a satisfação de um prazer estético, derivado de sua beleza, graça ou elegância de concepção e de execução (...)". (LIMA, 1963, p. 101).

Como explica o prof. Cagnin, devido a uma 'flutuação' histórica imposta ao termo caricatura no Brasil, "ocorre uma generalização do significado de caricatura como 'retrato' sugerido pela semelhança entre a palavra 'caricatura' e 'cara'. "No entanto, há que se advertir que só nos países de fala portuguesa é possível supor que a palavra 'caricatura' seja derivada de 'cara' e, em conseqüência, que caricatura seja um retrato, uma representação humorística da cara, em que se ressaltam os traços característicos para provocar o riso (...). Certamente o rosto, presente em quase todos os desenhos de humor, consolidam este conceito equivocado de supor que a palavra 'cara' tenha dado origem à palavra 'caricatura'”. (CAGNIN, s/d, p. 6)

Desde o seu aparecimento a caricatura esteve relacionada intimamente com a crítica. Até o final do século XVIII o sentido cômico foi a marca inconfundível desse tipo de manifestação, encontrando na caricatura de personalidades (portrait-charge) sua consolidação definitiva na imprensa da época. 

História da caricatura no Brasil. Rio de Janeiro: José Olympio.

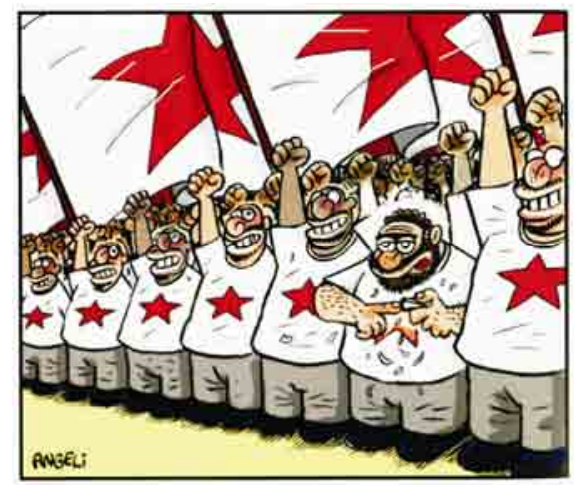

Por essa interpretação a caricatura seria então aquela imagem em que se carregam os traços mais evidentes de um fato ou pessoa, com a finalidade de levar ao riso. Contudo, a manifestação da caricatura gráfica foi antecipada pela caricatura textual. Ela começou quando muitos escritores já praticavam a sátira e o humorismo, deformando ou exagerando características de pessoas ou situações, para depois, com desenvolvimento das técnicas gráficas de reprodução, firmarem-se através do desenho personalizado.

A trajetória da caricatura brasileira foi ricamente traçada por Herman Lima (3) recuperando de forma minuciosa todas as variantes do jornalismo caricato utilizado pelos jornais brasileiros desde meados do século XIX até a metade do séc. XX.

Sendo a caricatura uma manifestação crítica, ela se torna vulnerável em regimes autoritários. Muitas vezes sua presença é interrompida pelos “donos do poder”. ○ exemplo mais recente de jornalismo caricato brasileiro por excelência foi o Pasquim que num ato de resistência, durante todo o período revolucionário pós-64, atacou das mais variadas formas caricaturais todo o processo histórico, político, social e econômico da sociedade brasileira nos anos da ditadura militar.
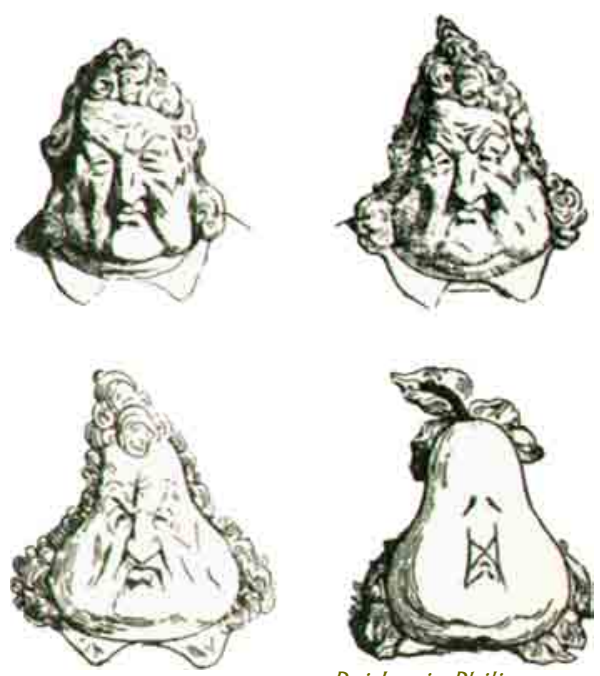

Rei Louis-Philippe

Charles Philipon

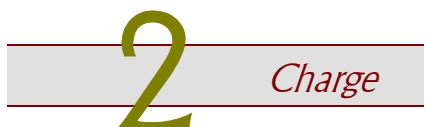

"Charge é a representação pictórica, de caráter burlesco e caricatural, em que se satiriza um fato específico, em geral de caráter político e que seja do conhecimento público". Por ser crítico de um fato isolado, a charge pode ser enquadrada dentro do campo da caricatura. Pode ser considerada como a arte de caracterizar.

Seu objetivo é uma crítica humorística ou de um fato ou acontecimento específico. É a reprodução gráfica de uma notícia já conhecida do público, segundo a ótica do chargista. Tanto se apresenta somente através de imagens quanto combinando imagem e texto. Sua ocorrência opera em cima de fatos reais e o conhecimento prévio do tema abordado na charge, por parte do leitor, é fator essencial para compreendê-la. 


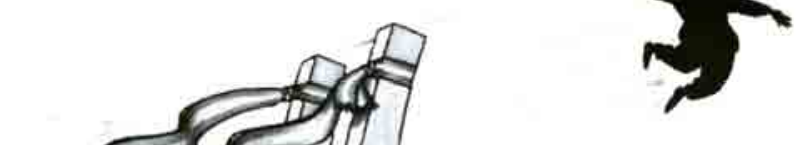

A respeito da necessária atualidade da charge e do conhecimento prévio do tema, Luiz Beltrão exemplifica que hoje não há condições de se compreender plenamente os significados das situações caricaturadas sobre o II Reinado e conseqüentemente sobre D. Pedro II. Pois, podemos apreciar a arte gráfica do desenho, mas falta a atualidade por já termos conhecimento dos resultados dos conflitos políticos. Este conhecimento posterior não nos conduz a uma opinião participativa.

O conteúdo humorístico da charge é eminentemente crítico e interpretativo. Pela possibilidade de sintetizar uma situação pode às vezes ter a importância de um editorial. "O termo charge tem origem do francês charger, com o sentido de carregar, exagerar. Embora ainda permaneça essa conceituação sobre o desenho político, o termo charge entrou em desuso, mesmo na França". (FONSECA, 1999, p 26).

Cabe à charge "expor uma idéia, dissertar sobre um tema, pois ainda que esteja ligada a um fato ou acontecimento e o represente de alguma forma, sua preocupação ou a do chargista, não é o acontecimento, mas o conceito que se faz dele, ou mais comumente a crítica, a denúncia do fato. Isso quando não procura aliciar o leitor para os seus arrazoados, princípios, programas ou ideologia". (CAGNIN, s/d, p. 4).

"Com relação à função social atribuída à charge, (esta) não pretende apenas distrair, mas, ao contrário, alertar, denunciar, coibir e levar à reflexão". (AGOSTINHO, 1993, p. 229)

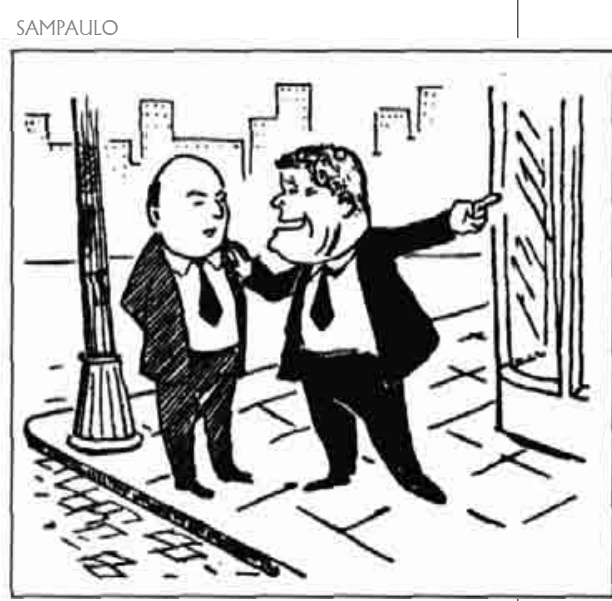

“Uma outra qualidade da charge é a de constituir-se como instrumento de persuasão (...), intervindo no processo de definições políticas e ideológicas do receptor, através da sedução pelo humor e criando um sentimento de adesão que pode culminar num processo de mobilização". (MIANI, 2000, p. 64).

A força da caricatura é incontestável. Um candidato à Prefeitura de Porto Alegre, em passado recente, perdeu suas chances de ser eleito provavelmente devido a uma charge do cartunista gaúcho Sampaulo (Paulo Sampaio). O desenho apresentava o prefeito que deixava o cargo mostrando a cidade para seu candidato oficial, correligionário proveniente de outra cidade do estado, ensinando-lhe onde ficavam os pontos principais da capital gaúcha, na insinuação óbvia de que o candidato não conhecia a cidade que pretendia governar. (FONSECA, 1999, p.12)

"Aqui é a Rua da Praia, ali a

Galeria Chaves e lá o Viaduto...” 


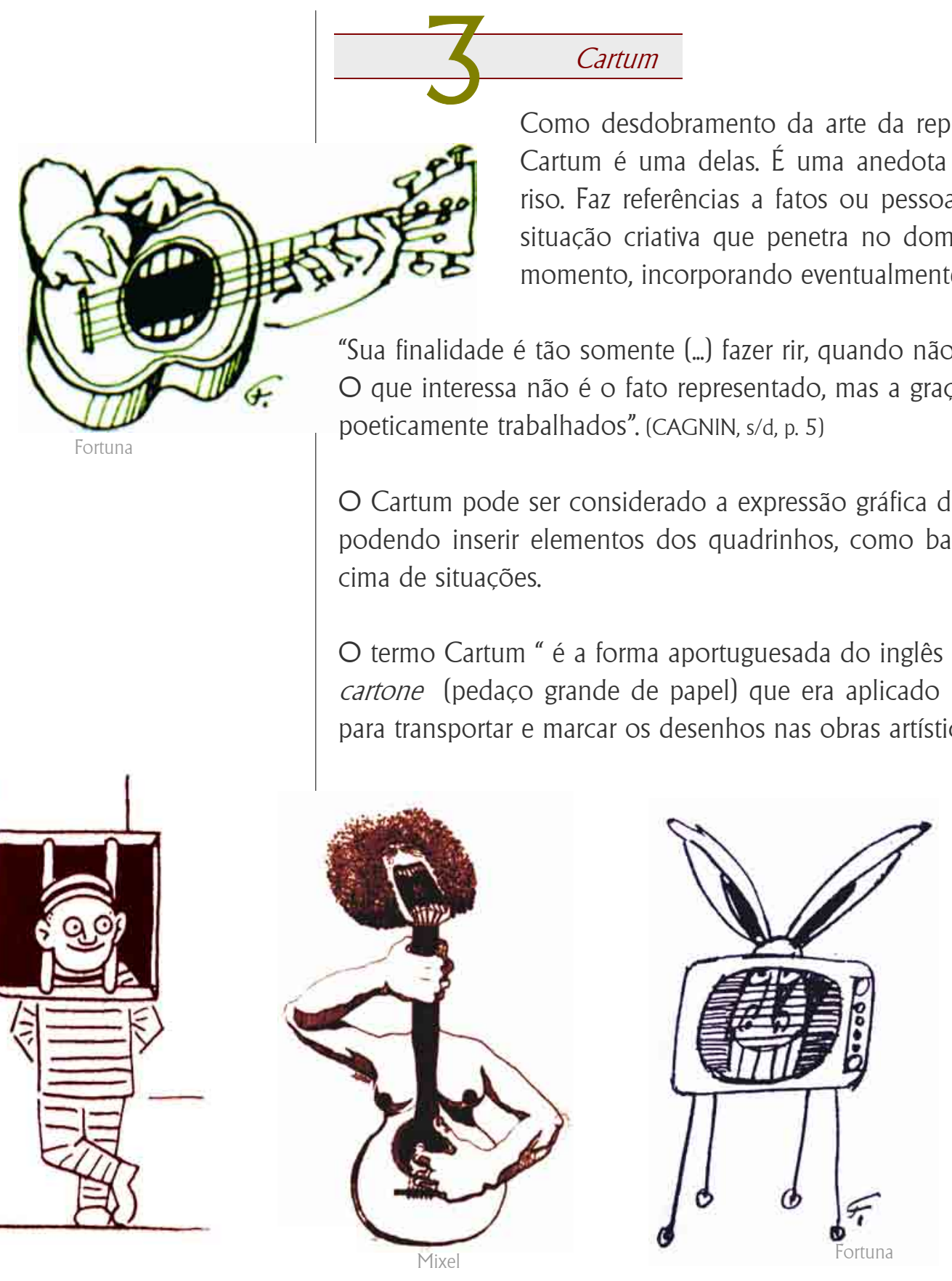

"A expressão, com o sentido que tem hoje, nasceu em 1841 nas páginas da revista inglesa Punch (...). O Príncipe Albert encomendara a seus artistas uma série de cartoons para os novos murais do Palácio de Westminster; os projetos dos artistas reais expostos foram alvo da crítica e da mordacidade do povo inglês, e a revista Punch resolveu publicar os seus próprios cartoons, parodiando a iniciativa da Corte. O nome pegou." (FONSECA, 1999, p. 26) 


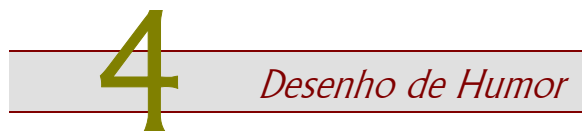

Desenho de Humor é a designação que se atribui a um Cartum que não tem como finalidade principal conseguir o riso, mas representar, com os elementos da Caricatura, um momento do ser humano que seja visto sob o prisma do Humor. Em geral, no Desenho de Humor, considera-se o desenho como obra de arte em si, sem separá-lo, contudo, do seu objeto principal que é o humor.

A designação é recente e quase se pode afirmar que ela apareceu, pela primeira vez entre nós, para definir o trabalho de Saul Steinberg, artista romeno radicado nos Estados Unidos, um dos expoentes máximos do Desenho de Humor no mundo. "As primeiras manifestações do desenho de humor registradas no Brasil remetem à exposição de Carlos Thiré, no Rio, na década de 50 e à famosa exposição de Millôr Fernandes, no Museu de Arte Moderna do Rio de Janeiro, em 1957". (RABAÇA; BARBOSA, 1978, p. 197).

A comunicação do Desenho de Humor é realizada muitas vezes através de metáforas visuais, não se ignorando a presença de manifestações argumentativas e interpretativas. Tem como objetivo estimular o espectador a refletir sobre o comportamento humano através do humor. Revelar o que ocorre em si e em redor de si. Situar-se no mundo, com o mundo.

A atribuição feita ao Desenho de Humor não pretende buscar o riso, mas, ao contrário, levar à reflexão. Possui cunho social, ocorrendo em cima de questões filosóficas e éticas.
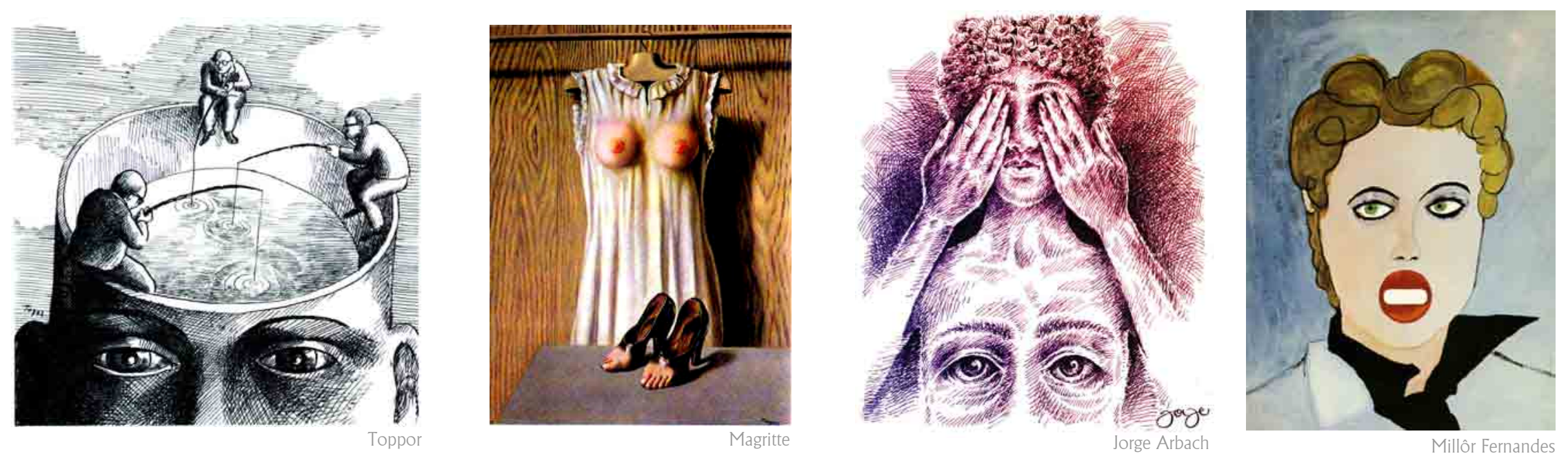

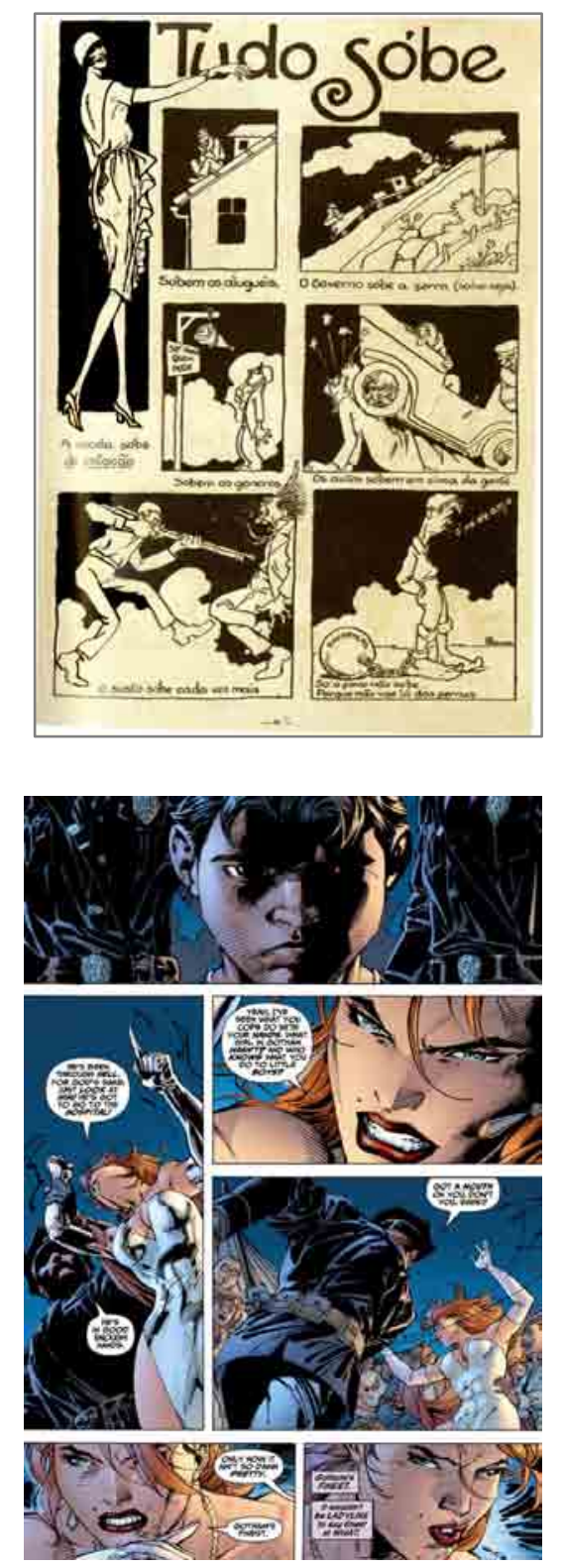

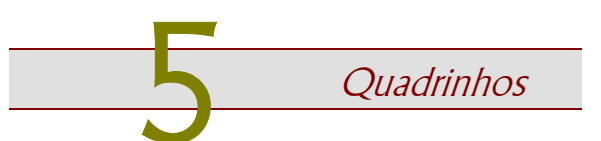

O século XIX proporcionou condicões para que, em diferentes locais, vários artistas desenvolvessem um conceito de trabalho quase simultâneo, principalmente nas áreas vinculadas à produção gráfica. Os artistas, ilustradores e cartunistas dos incontáveis jornais que proliferavam na época começavam a experimentar a associação entre imagem e texto acrescentando a estes uma dimensão seqüencial. Dessa maneira, surgiam tanto cartuns mudos construídos em três ou quatro quadros separados por uma pequena barra vertical, quanto seqüências ilustradas da mesma maneira com legendas em tipos compostos (...) Alguns perseveraram nesta rudimentar linguagem seqüencial e inauguraram um novo modo de contar histórias nos jornais. (XAVIER, 2002, p. 13)

Quadrinhos ou História em Quadrinhos é uma narrativa composta por imagens que se sucedem e que pode ser complementada por textos, balões ou legendas. No jornal aparece de forma seriada e nas revistas é publicado integralmente. São utilizados, seja por ilustradores ou caricaturistas, servindo tanto à informação quanto à opinião.

No princípio, ainda no século XIX, simultaneamente nos EUA e na Europa, ensaiava-se o mesmo processo de narrativa visual. Os desenhistas desenvolviam as ilustrações para retratar cenas ou contar histórias. Muitas vezes tudo era mostrado em um único desenho, em um único quadro. Em outro momento as ilustrações passaram a aparecer em seqüência sem legenda.

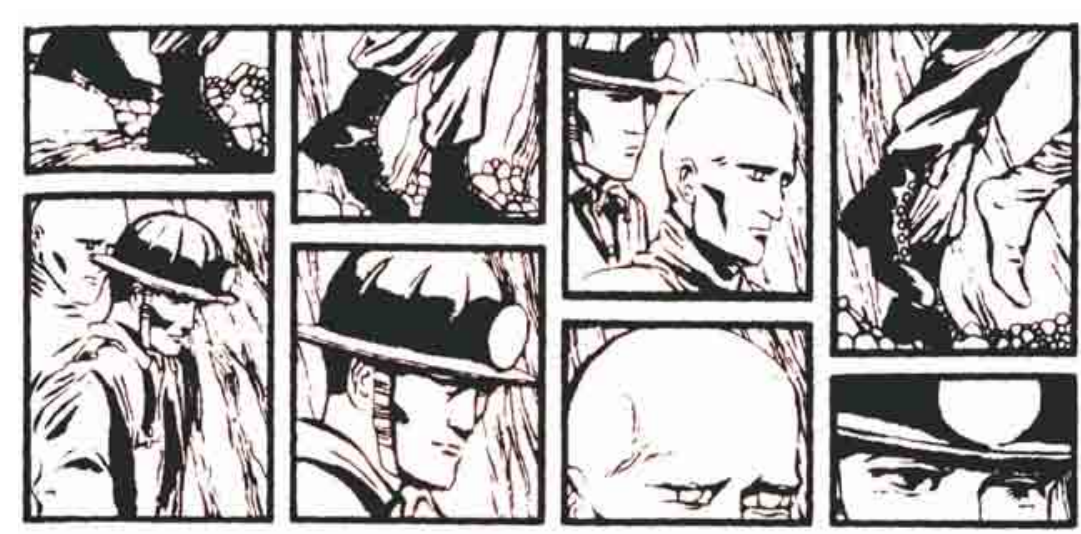

Comic é o outro nome adotado para os quadrinhos. A palavra é de origem inglesa, que quer dizer cômico ou humorístico. Pois, no início o conteúdo das histórias em quadrinhos era predominantemente humorístico. Os primeiros exemplares conhecidos conjugavam piadas ou anedotas relacionadas a dois temas principais: crianças e fantasia. Essa expressão universalizou-se e é utilizada até hoje. Inclusive para histórias que não possuem caráter cômico. 


\section{ESTUDO DE CASO}

1 - CÓDIGOS DO HUMOR GRÁFICO

2 - O PASQUIM 


\section{1 - CÓDIGOS DO HUMOR GRÁFICO}

Qualquer material impresso no período do Brasil-Colônia, era sempre encarado com muita desconfiança pelos dirigentes políticos. As bibliotecas não poderiam ser constituídas nas casas particulares, somente nos mosteiros, pois livros só eram permitidos nas mãos dos religiosos e restritos aos seus ofícios. Ler não era apenas indesculpável, era prova de crimes imperdoáveis. Qualquer delito se agravava caso fosse revelada a existência de biblioteca na casa dos acusados.

Somente após o processo de Independência do país é que foi permitida a circulação de informações e opiniões, seja através de livros ou de periódicos. Esse momento assinala o aparecimento de numerosos periódicos na Corte e nas províncias. A imprensa se desenvolvia na medida em que os problemas políticos se agravavam frente às revoltas provinciais. As tendências políticas foram retratadas nesses jornais efêmeros, mais do que nos dotados de estabilidade. Sob a ferrenha vigilância do estado imperial a imprensa foi sendo controlada até o advento da República.

A mudança de regime político não fez surgir de imediato grandes jornais, mas definiu a passagem da pequena imprensa para a grande imprensa. Os pequenos jornais foram cedendo espaço para as empresas jornalísticas mais estáveis e o jornal, daí em diante, foi se personalizando, foi se tornando empresa capitalista.

A ditadura do Estado Novo, nos anos 30, criou órgão específico, o Departamento de Imprensa e Propaganda (DIP), segundo o modelo nazista. O famigerado DIP controlava a imprensa e o rádio e baixava listas de assuntos proibidos. Com a ditadura surgiu, inevitavelmente, uma implacável censura à imprensa e mais do que isso, a proibição de novos jornais e o fechamento de outros: "A censura em São Paulo, por exemplo, foi das mais severas do país e o controle da imprensa falada e escrita foi intenso, especialmente no período da ditadura estadonovista, quando cercearam todos os veículos de divulgação existentes entre nós. (...) No negro período de 1937-1945, foi grande o número de jornais, revistas e panfletos fechados por determinação do executivo e grande também o número de jornalistas presos por delitos de imprensa". (SODRÉ, 1966, p. 438)

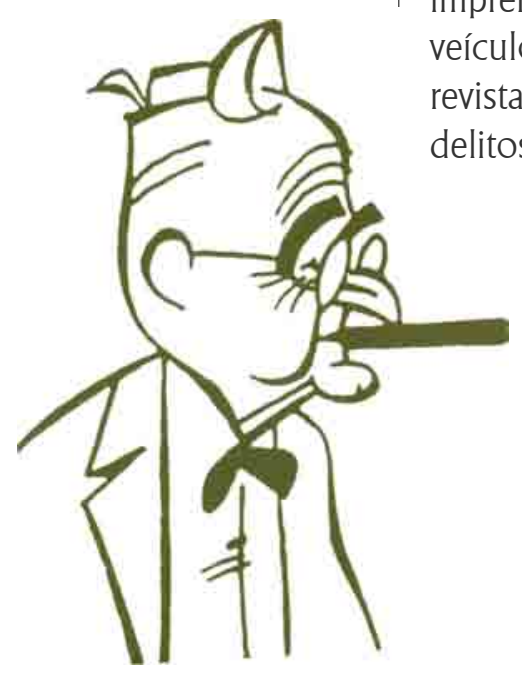

A caricatura, para só mencionar um aspecto da situacão, entrou em decadência; não poderia sobreviver em tal clima: “A partir de 1937, com a implantação do Estado Novo e a criaçao do D.IP. (Departamento de Imprensa e Propaganda), a caricatura política brasileira, que dera os mais belos frutos até então, perdeu terreno, arrefeceu o ímpeto, asfixiada por oito anos de pressão policial (...)". A falta de liberdade liquidara a caricatura, ou melhor, o que parecia, então, era caricatura da caricatura. Compreende-se assim, facilmente, que ninguém mais do que a caricatura precisa de liberdade, para a criação de suas obras tantas vezes capaz de atravessar o tempo. Era assim que em pleno Estado Novo, falando à Revista da Semana, em agosto de 1944, J. Carlos afirmava categoricamente a decadência da caricatura, por falta de ambiente propício, porque "reproduzir nos jornais, deformandoa cara das pessoas ilustres famosas ou conhecidas por qualquer motivo, não tem nenhuma significacão' - não sendo diferente a atitude de Álvarus, ao ser ouvido na mesma ocasião: "Atualmente, a caricatura política esta reduzida a dois bonecos, um virado para o outro, debaixo dos quais se escreve uma legenda qualquer . A família da caricatura esta seriamente doente: intoxicação totalitária”. (LIMA, 1963, p. 440). 


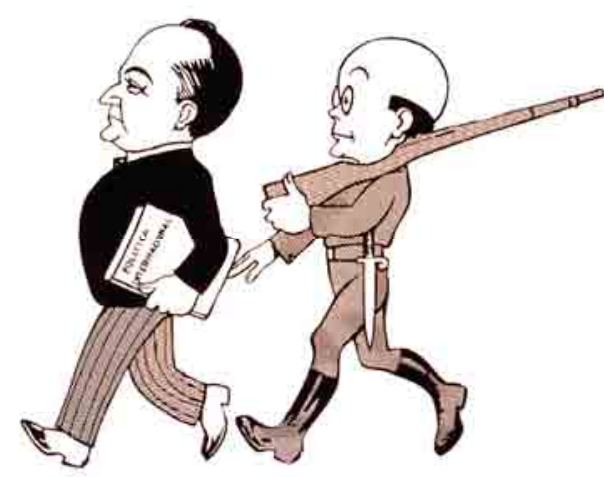

Getúlio Vargas e Juca Pato: O Brasil declara guerra à Alemanha e Itália

O irrompimento da segunda guerra Mundial teria reflexo muito profundo no Brasil na fase inicial, quando do avanço das forças nazistas, fascistas e nipônicas. Esses reflexos foram no sentido de fortalecer o regime totalitário aqui dominante. O Brasil adotou posição neutra, e só a partir da entrada dos Estados Unidos no conflito, em 1941, o país modificou seu posicionamento. A entrada do Brasil na guerra, no segundo semestre de 1942, foi realmente a consolidação dessa mudança. Nesse momento o Estado Novo começou a deteriorar-se rapidamente. No decorrer dessa evolução a imprensa teve condições para desafogar suas manifestações. A maioria dos jornais tomou o partido dos países que combatiam o nazi-fascismo. A caricatura foi lentamente liberada, recompondo aos poucos sua feição. Nisso se distinguiu particularmente Belmonte, cujo personagem Juca Pato buscava expressar o sentimento popular e cuja campanha contra o totalitarismo teve grande alcance.

No livro Prazer e Poder do Amigo da Onça (1), de Marcos Antônio da Silva (1989, p. 62), o autor comenta que: "O Estado

Novo, por sua radical identificação com os ideais brasileiros, fez com que logicamente desaparecesse a caricatura libertária, de ataque e crítica às realizações governamentais. Fez com que se enveredasse por outro caminho, de caráter mais universal e, portanto, mais humana. A caricatura política deixou de existir para ceder lugar à caricatura de costumes. E, nessa trilha, ela continuou exercendo sua função (...) concomitante à evolução social”. Porém, uma publicação, corajosamente irreverente vigorava nesse contexto: A Manha.
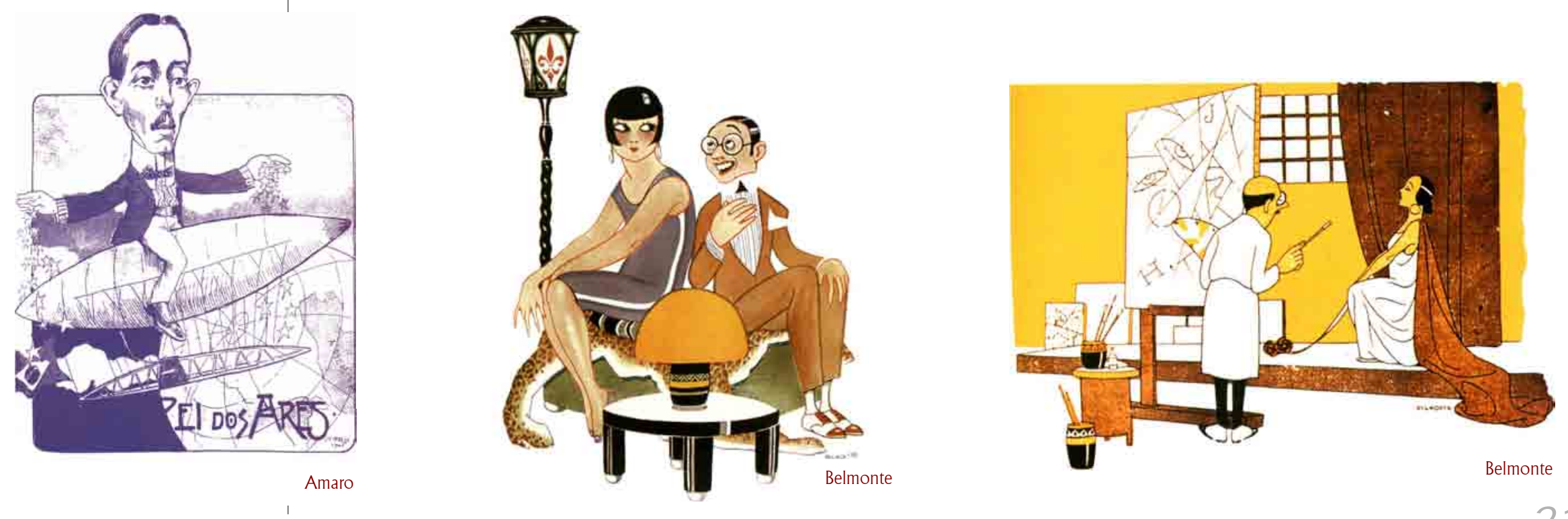


\section{A Manha}

Em 1926 começou a circular A Manha, semanário de humor que viria a se tornar o mais popular durante 26 anos. Ao lado da violência da censura o terror era empregado em doses crescentes, porém um jornalista se destacava na cidade. Era Aparício Aporelly, o popular Barão de Itararé.

Dirigido e escrito por Aparício Aporelly, ao estilo de paródias, o jornal também parodiava com o seu título o jornal $A$ Manhã, de grande circulação na época e onde o próprio Barão colaborava. Usava a mesma tipologia do jornal, diferenciando com a frase ladeando o título: "Quem não chora, não mama".

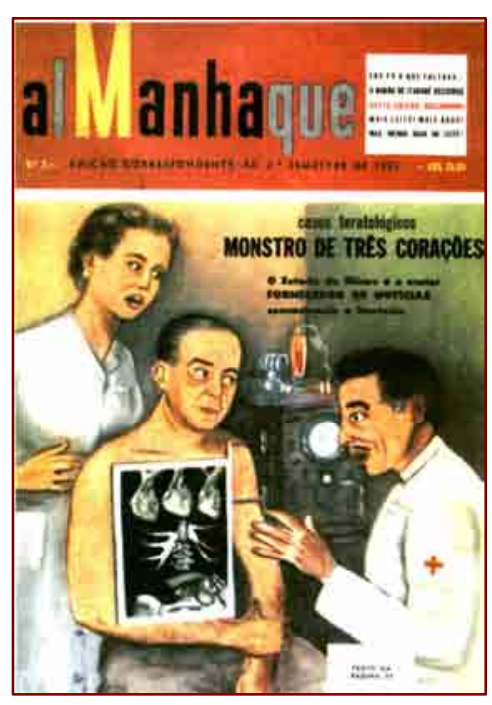

Capa do Almanhaque de 1955

O personagem Barão de Itararé nasceu em 1930, durante a iminência da batalha de Itararé, que foi amplamente propagada pela imprensa. Apporelly não ficou de fora desta tendência com o seu jornal. Previa-se o confronto entre as tropas fiéis ao presidente Washington Luís que se dirigiam para o sul para enfrentar as da Aliança Liberal sob o comando de Getúlio Vargas. Essas vinham do Rio Grande do Sul em direção ao Rio de Janeiro para tomar o poder. A cidade de Itararé, na divisa de São Paulo com o Paraná estava prevista para ocorrer a batalha "mais sangrenta da América do Sul", no dizer da época. Felizmente os dois lados fizeram acordos, em que uma junta governativa assumiria o poder no Rio de Janeiro. O Barão de Itararé comentaria esse fato mais tarde da seguinte maneira: "Fizeram acordos, (...) e eu fiquei chupando o dedo. Foi então que resolvi conceder a mim mesmo uma carta de nobreza. Se eu fosse esperar que alguém me reconhecesse o mérito, não arranjava nada. Então passei a Barão de Itararé, em homenagem à batalha que não houve." (PIMENTEL, 2004, p. 25)

A Manha trazia um tipo de humor verbal pautado em paródias e jogos de palavras. Muitas vezes utilizando-se de desenhos e fotografias para ironizar. Conseguiu exprimir hibridismo lingüístico com a utilização do culto no popular.

Durante o Estado Novo (1937-1945) foi preso diversas vezes. Em 1948, em virtude de problemas financeiros A Manha deixou de circular. Em 1949 associa-se ao caricaturista paraguaio Guevara e lança em São Paulo o primeiro Almanhaque, parodiando os populares almanaques. Em 1950 reaparece editada, agora em São Paulo, até 1952, quando o jornal deixa de circular, definitivamente.

Essa publicação e o tipo de linguagem adotada foi referência para as demais publicações humorísticas que surgiriam posteriormente. 
Nos anos 60 ocorre uma ampliação de códigos de linguagem que permite trabalhar com diversos tipos sínteses intersemióticas provocando novos discursos humorísticos. Assim, a intensidade do humor passou a ser comandada pela mensagem metalingüística, proveniente de mecanismos simbólicos. Para abordar conteúdos com sentidos políticos, os jornalistas e cartunistas desenvolveram a habilidade de escrever e desenhar nas entrelinhas, burlando a censura. Assim, modificaram o contexto tradicional da interlocução jornalística e encontraram possibilidades de dialogar com leitores perspicazes, que passaram a ser cúmplices, aptos em decifrar as intenções veladas em ironias e significados.
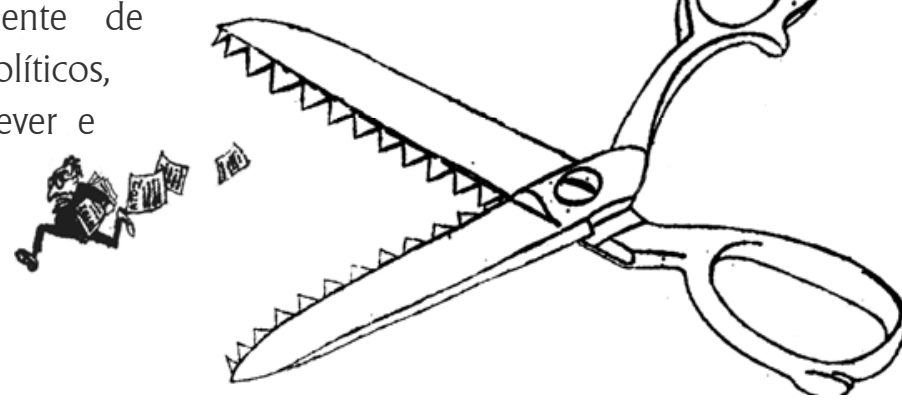

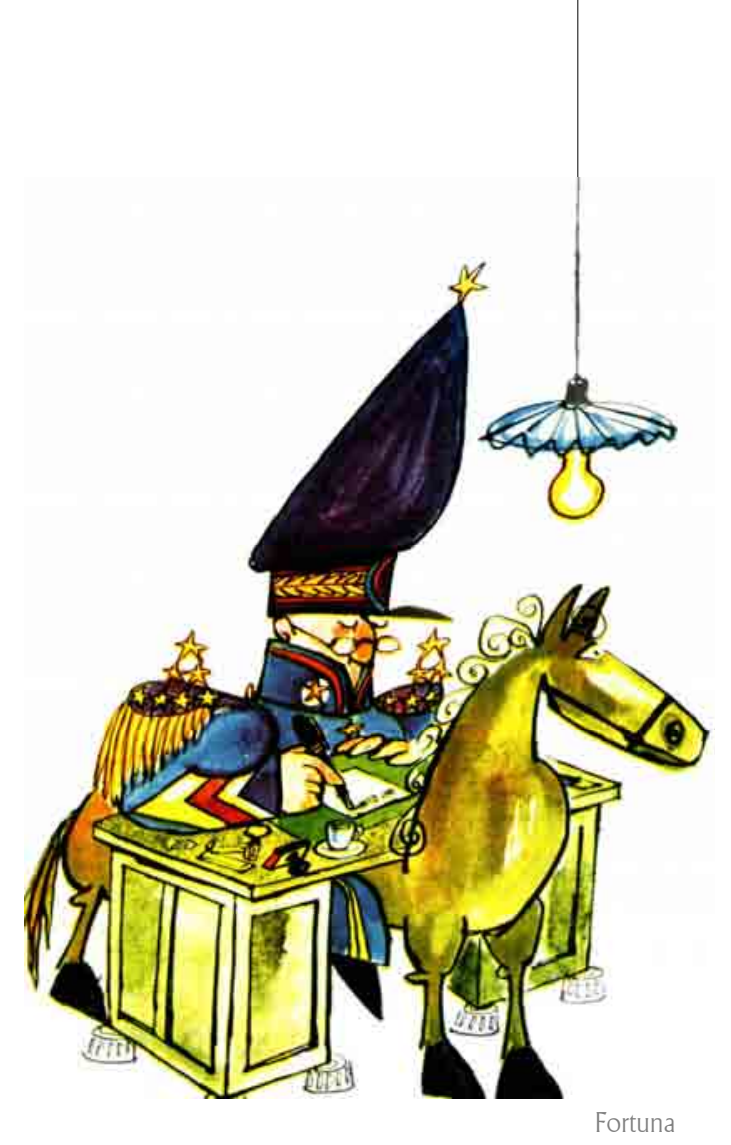

Coincidindo com esta ampliação de códigos de linguagem, aconteceu a instalação da longa fase de censura. No plano gráfico, o humor crítico começa a ter uma importância cultural cada vez maior, graças à sua capacidade irônica, satírica e paródica que sempre necessitaram da cumplicidade sagaz e inteligente do leitor. Como diz Millôr Fernandes: Todo tempo de grande opressão é tempo de grandes sutilezas'.

Numa época de forte censura verbal, o lado icônico do humor conseguiu romper a brecha da censura verbal e preencher um espaço cultural da maior importância. Graças à enorme capacidade de alusão do humor, o receptor mais esperto sempre conseguia preencher o vazio alusivo que era passado gráfica e visualmente pelos humoristas. (MARTINS, 1992, p 175).
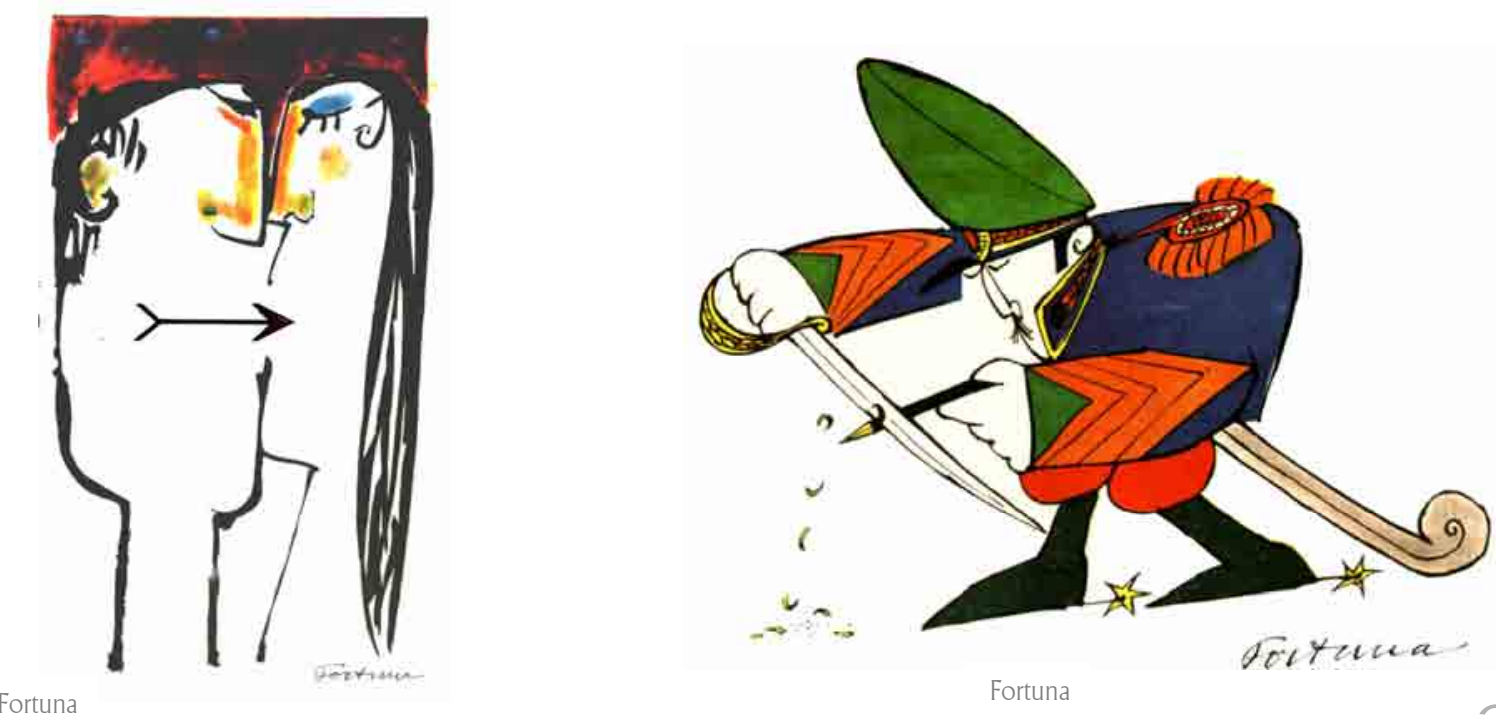


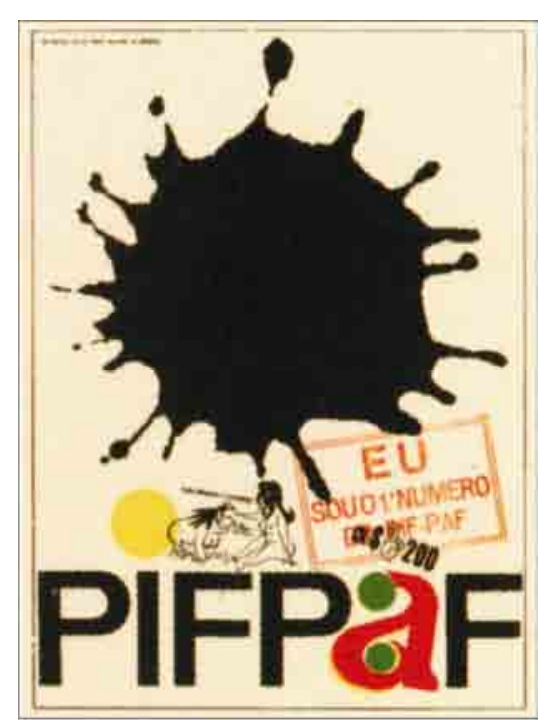

Primeira edição do Pif-Paf, maio 1964

Millôr Fernandes foi precursor da imprensa alternativa ao lançar o Pif-Paf no dia 21 de maio de 1964, como resposta ao golpe militar. Apesar de produzido precariamente, o Pif-Paf teve sucesso imediato, principalmente entre estudantes, intelectuais e políticos. Sinal disso: a primeira edição vendeu 40 mil exemplares. Quando teve a oitava edição apreendida, Millôr parou com o jornal, dando por encerrada, nas palavras de Kucinski, "uma empreitada que não conseguia mais levar sozinho". (CHAPARRO, 2000, p. 63).

De maio a agosto de 1964 foram publicadas quinzenalmente 8 edições da revista Pif-Paf. Os históricos oito números da revista Pif Paf criada e liderada por Millôr Fernandes, publicados em 4 meses, influíram no jornalismo, no humor e na inteligência do Brasil.

“(...) aliavam humor cáustico e projeto gráfico moderno, criação do austríaco Eugênio Hirsch, (...) na definição do próprio Millôr. A publicação nasceu da demissão do humorista das páginas de O Cruzeiro, principal revista da época, na qual trabalhou por 25 anos e da qual saiu por ter escrito uma irreverente Verdadeira História do Paraíso, atraindo a ira de conservadores católicos. Desempregado, mas contando com a ajuda de amigos e de um empréstimo bancário, Millôr foi à luta e transformou em revista sua coluna d' O Cruzeiro, (...)”. (CARNEIRO, 2005, p. 125).

Millôr se associou a Ziraldo e aos então pouco ou nada conhecidos Claudius, Fortuna e Jaguar para criar a revista. Dentre os colaboradores estavam Rubem Braga, Sérgio Porto, Leon Eliachar, Don Rossé Cavaca e Antônio Maria.

"Em agosto de 1964, cinco meses após o início do regime militar e com apenas oito números, um editorial de Pif Paf alertava: 'Se o governo continuar deixando que circule esta revista, com toda a sua irreverência e crítica, dentro em breve estaremos caindo numa democracia'. Foi o suficiente para que tivesse fim o primeiro tablóide do jornalismo carioca e a curta carreira do humorista Millôr Fernandes como dono de revista. O Pif Paf teve existência breve e com pequena tiragem - apenas 20.000 exemplares -, mas influenciou os jornais da imprensa alternativa que viriam em seguida, inclusive o mais bem-sucedido deles, $O$ Pasquim". 


\begin{tabular}{|r|}
\hline (2) TROCADILHO VISUAL \\
Jogo de imagens \\
aparentemente semelhantes \\
permitindo diferentes \\
significados.
\end{tabular}

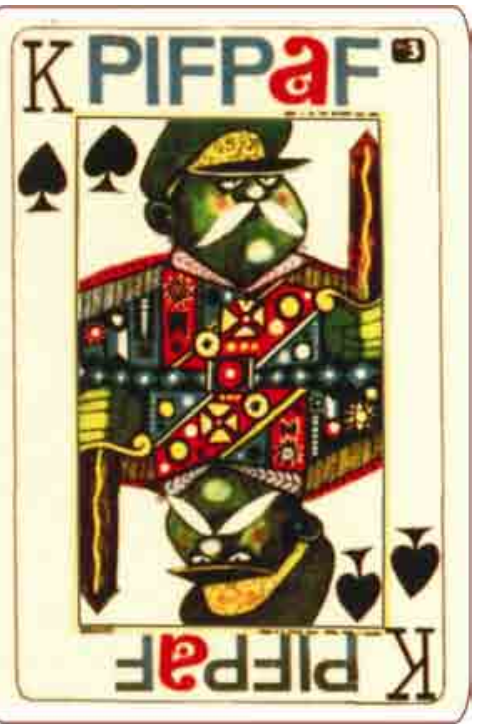

(3)

MARTINS, Sérgio A invencão do humor no espaço gráfico. Tese de Doutorado. São Paulo: FAU/USP, 1992.
A partir d'A Manha e do Pif-Paf o desenho de humor adotado pela imprensa alternativa adquire características particulares. Passa a ocorrer pela via do trocadilho visual (2) ou apenas através de aspectos sintáticos e expressivamente humorados. Utilizando os novos recursos da linguagem gráfica, o desenho de humor passa a atuar essencialmente como forma de reflexão. Ao trabalhar com alegorias cria novos conceitos visuais e, com as ambigüidades, subverte a semântica das imagens. E ao estabelecer metáforas, gera conflito entre duas realidades.

Sérgio Martins (1992, p. 100), em seu trabalho de doutoramento (3), nos orienta sobre as mudanças do humor gráfico inaugurado naquele momento. Ele afirma que na Revista Pif-Paf, por exemplo, podemos observar essa mudança de espírito nos conteúdos gráficos e críticos. Sua capa da edição 3 é emblemática dessa nova situação e dessa nova forma de linguagem.

A capa é ocupada por uma enorme carta de baralho, criada carnavalescamente por Ziraldo, é igual tanto vista normalmente como de cabeça para baixo. A letra "K" é a letra do rei de copas, só que a imagem é substituída por um general cheio de medalhas no peito. A ironia visual é obtida assim, por uma substituição inteligentemente satírica. Esta ironia da imagem da capa é complementada por um pequeno texto no canto inferior direito: "Esta é a nossa capa. Aliás, capa e espada". Temos agora o trocadilho verbal, o deslocamento do significado capa de revista para capa roupa. Este deslocamento é que vai permitir relacionar os conhecidos romances e filmes aventureiros de capa e espada com as "aventuras" políticas dos militares. (MARTINS,1992, p. 100-101).

Este caminho, que mostra o desenho de humor mesclado com a pesquisa gráfica será desenvolvido em vários momentos no Pasquim. Usando o mesmo procedimento criador, Ziraldo produziu marcas-símbolo de pessoas famosas:

A marca de Yoko Ono, além de fazer a síntese do " $Y$ " de Yoko e o " $Y$ " do sexo feminino, utiliza também outra forma que pode ser lida como "O" de Ono em forma de bunda. É bom lembrar que Yoko Ono ficou famosa mundialmente ao posar nua, de costas com John Lennon. O resultado visual apresenta uma ambivalência, por relacionar uma mulher vista tanto de frente como de costas. A caricatura transforma-se totalmente em marca-símbolo.

Já na marca para Fidel Castro, Ziraldo utiliza-se do "F" de Fidel para iconizar os elementos significativos do "comandante": a barba e o boné revolucionários e seu inseparável charuto cubano. (MARTINS, 1992, p. 103).
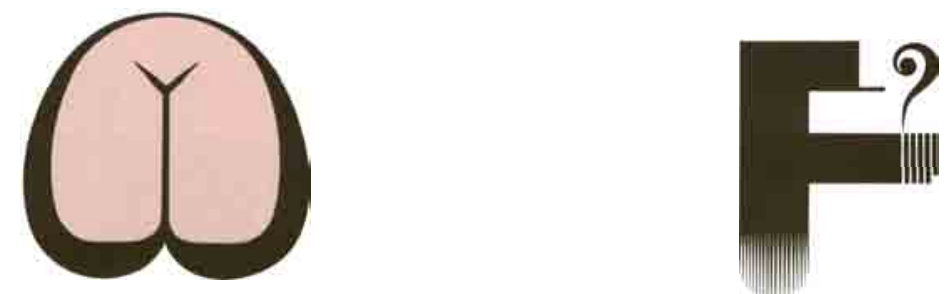
Dois aspectos devem ser destacados nessas peças gráficas:

No aspecto lingüístico, o que se observa é um processo de união do significante com o significado.

No aspecto icônico, um processo de integração do desenho gráfico ao desenho de humor.

É a forma vinculada ao conteúdo, é a sintaxe unida à semântica. Estes passam a ser os novos códigos do humor gráfico. 


\section{2 - O PASQUIM}

Durante o regime militar ocorrido no Brasil entre os anos de 1964 a 1985 apareceram no Brasil cerca de 150 periódicos regionais e nacionais, todos de oposição à ditadura. Cada um deles adotando uma linha editorial própria. Em comum possuíam os mesmos temas motivadores. Denunciavam as violações dos direitos humanos, a falta de liberdade de opinião, a tortura, o arrocho salarial dos trabalhadores e a degradação das condições de vida dos brasileiros.

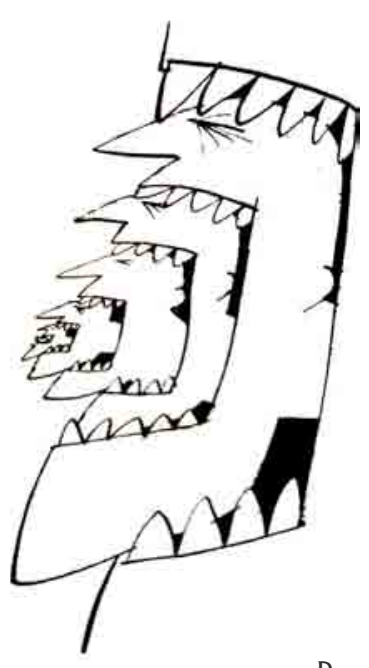

Ziraldo

KUCINSKI, Bernardo Jornalistas e Revolucionários nos tempos da imprensa alternativa. São Paulo: Scritta, 1991

(Devido às) restrições impostas aos periódicos pelos governos saídos do movimento de 1964, cuja censura estava presente nas redacões (...) a opinião se vale de semanários, que se constituem em uma "imprensa alternativa", a qual recebe também o apelido de nanica, pois em sua maioria os jornais têm o formato tablóide. A ação dessa imprensa, eminentemente política, que se mantém pelo apoio maciço dos públicos das grandes áreas metropolitanas, quase sem publicidade, é que se deve o quadro apresentado pela grande imprensa, na década de 1970, retomando gradualmente sua função vertical opinativa. (BELTRÃO, 1969, p. 86)

marco significativo que deu origem à imprensa alternativa no país ocorreu em 1969, com o surgimento do Pasquim, que chegou a circular com uma tiragem de 250 mil exemplares. No seu rastro apareceram o Bondinho (1970), Polítika (1971), Opinião (1972), Ex (1973), entre outros. A partir de 1974 a imprensa alternativa catalisa o caráter de portavoz dos movimentos da esquerda. Destacam-se nesta linha editorial os jornais Movimento (1974), Versus (1975), Brasil Mulher(1975), EmTempo (1977) e Resistência (1978).

Bernardo Kucinski em seu livro (4), listou 131 jornais alternativos que surgiram entre 1964 e 1980. Dos listados 51 deles possuíam natureza política, 34 eram voltados para a reportagem investigativa, 22 dedicados à cultura, 10 de caráter humorístico, 6 ecológicos, 3 feministas, 2 anarquistas e um voltado ao universo gay. Em sua maioria, 94, tiveram a breve existência de menos de um ano.

Parte dos fracassos dos periódicos alternativos, incluindo aí $O$ Pasquim, atribui-se à ausência da capacidade de gestão empresarial e aos conflitos internos, enfraquecendo assim, gradativamente, o projeto original.

O Pasquim transformou-se durante a década de 70 em um veículo de grande força renovadora, canal da sátira social e política. Fundado em 1969, converteu-se no mais importante dos jornais alternativos no Brasil. Com tiragens que atingiram a marca dos 250 mil exemplares chegou a ser um próspero empreendimento empresarial. Reunia em suas

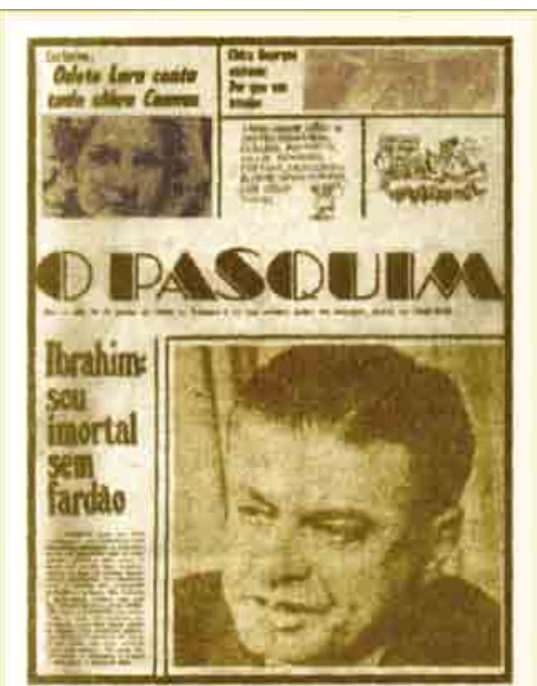

Primeira edição do Pasquim, em 25/06/69 a 
páginas alguns dos melhores jornalistas e cartunistas do país, incorporando a mais inteligente e debochada irreverência e fazendo a mais sagaz crítica do cotidiano, tudo sempre impregnado de conotações políticas. Tendo como argumento primordial o ataque ao autoritarismo, representou um jornalismo combativo e polêmico, sempre permeado de pleno humor.

Adotando uma linguagem mais coloquial, abrigou em suas páginas alguns dos melhores textos e desenhos do Brasil. Era editado por um grupo de inteligentes jornalistas, escritores, artistas e cartunistas. Um grupo que optou pelo uso da inteligência para esvaziar o Poder trazendo à tona seu ridículo.

Um periódico de crítica de costumes, onde em cada edição havia espaço para se discutir temas diversos, mesmo os mais inquietantes para a sociedade da época: droga, feminismo, sexo ou divórcio. Num período de intensa repressão intelectual, seu público principal estava entre os jovens universitários e os intelectuais que buscavam alternativas para se manterem informados.

O Pasquim cumpriu muito bem sua missão de não deixar que o espírito crítico naufragasse, se valendo em seus textos e desenhos de signos para dar seu recado, já que a censura se mantinha a postos e atuante.

Num momento da vida política brasileira em que vigorava um feroz regime autoritário, o jornal rapidamente conquistou amplo espaço na imprensa nacional manifestando anseios e expectativas da sociedade. Assim como incomodava os militares, que ocupavam os altos cargos do poder, também empolgava os segmentos inconformados da época.
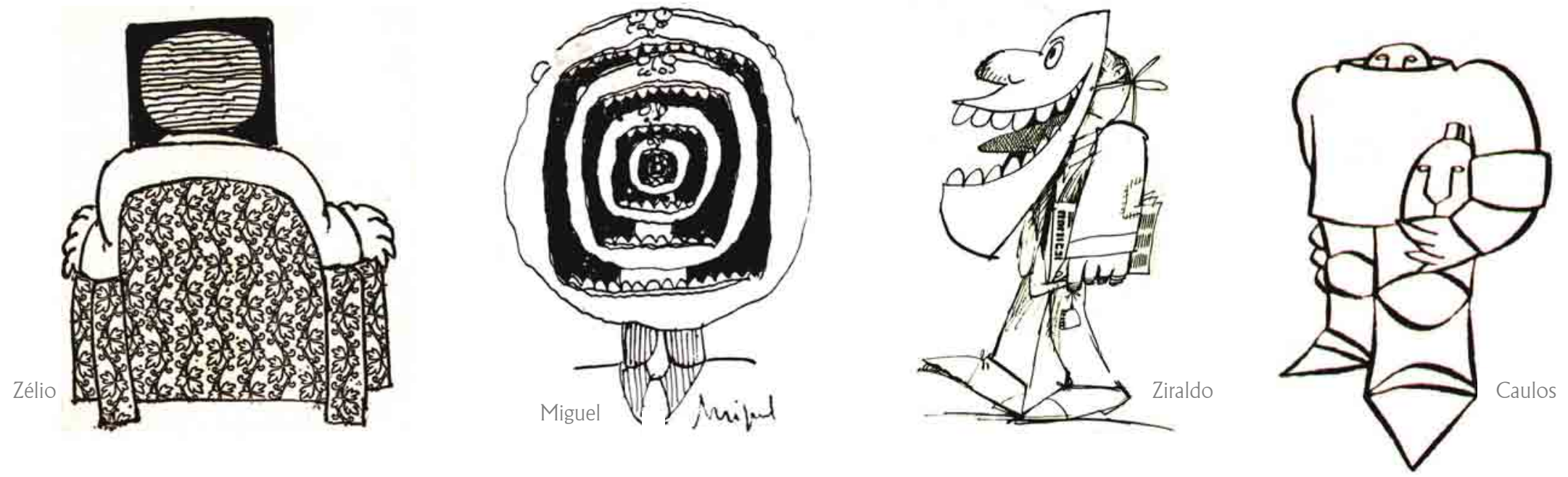


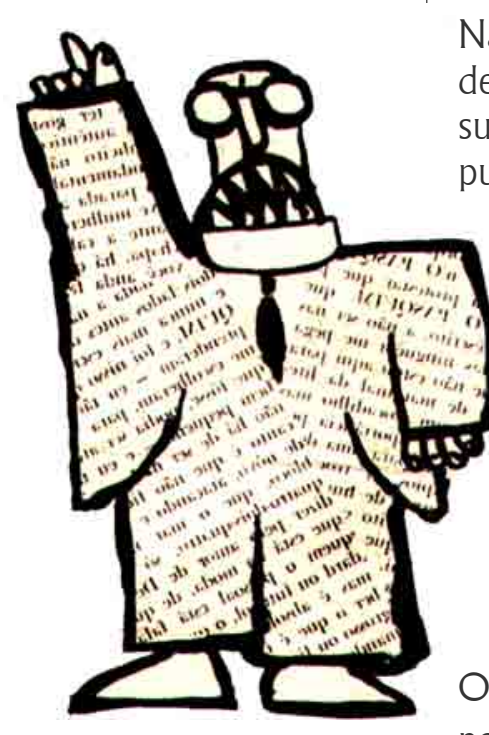

Na visão de Bernardo Kucinski (1991, p. 92) "o Pasquim era uma revolução de linguagem que preenchia os vazios deixados pelo fracasso dos movimentos populares e pelo desaparecimento da hegemonia cultural das esquerdas. E o sucesso comercial do jornal chegou a incomodar a grande imprensa, que o via como concorrente na divisão do bolo publicitário".

Jaguar

Nos seus melhores tempos, entre 1969 e 1973, o jornal chegou a vender até 250 mil exemplares. Um volume acima do razoável se lembrarmos que os jornais de tiragem nacional rodam hoje, mais de 30 anos depois, com toda a informatização, com facilidade de distribuição, com fortes campanhas de assinantes, cerca de 300 mil exemplares. A verdade é que o comportamento da chamada "Patota do Pasquim" era tão anárquico quanto o conteúdo do jornal. Os militares e a elite brasileira tentaram impedir sua circulação diversas vezes e de formas variadas, mas quando conseguiram, ele já havia disseminado uma nova forma de comportamento nos meios de comunicação.

O primeiro número chegou às bancas em 26 de junho de 1969. Era um semanário de críticas de costumes onde pouco espaço cabia ao comentário político aberto. Uma marca deixada pelo Pasquim eram suas longas entrevistas, realizadas quase como um bate-papo entre amigos, em que o entrevistado acabava falando de tudo. No começo não falavam quase nada de política, era uma publicação comportamental. Mas a ditadura foi colocando o jornal contra a parede e, aos poucos, o Pasquim tornou-se mais e mais politizado. Na medida em que a censura aumentava, o Pasquim intensificava sua postura crítica. É da tradição do humor impresso a luta contra a opressão. Herdeiros de $O$ Malho, $A$ Careta, Dom Quixote, A Manha e o Pif-Paf, jornais que em sua época não deram sossego ao governo. Os humoristas do Pasquim se sentiam na obrigação de se tornarem porta-vozes da indignação social brasileira.

Tudo era controlado, vigiado, censurado. Pouca coisa escapava do crivo dos censores. Mandavam para Brasília material suficiente para fazer quatro jornais e o que passasse seria a próxima edição do Pasquim que chegaria às bancas. A forma de se expressar era insinuar, entrelinhar, implicitar; qualquer alfinetada nos militares já era uma conquista. Como não era possível opinar nada, bastava a mais discreta das críticas, bem camuflada num desenho, para causar impacto.

O Pasquim resistiu durante um longo tempo: conseguiu ridicularizar quatro presidentes militares e dois civis. Foram 22 anos de oposição, até fechar definitivamente, em 1991. Ajudou a renovar a imprensa brasileira, tornando-a menos engravatada. E ofereceu à juventude esclarecida brasileira um jornal que, em plena ditadura militar, podia ser carregado debaixo do braço com orgulho. 

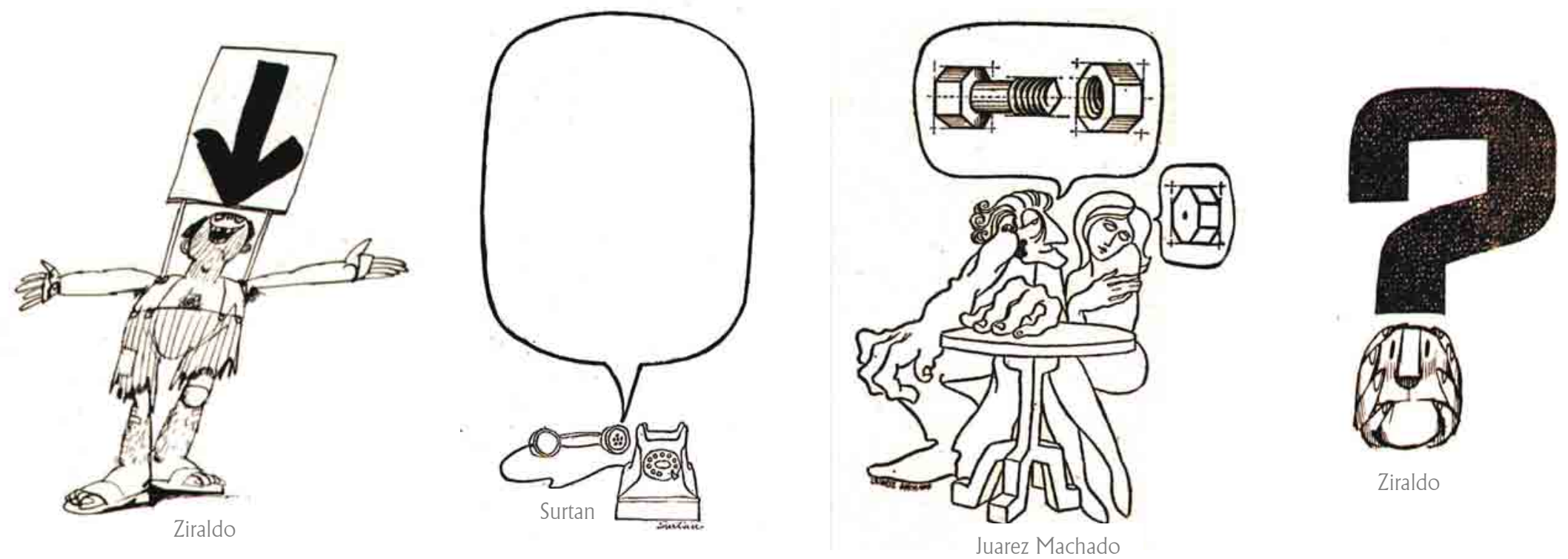

Ziraldo

(5) CAGNIN, Antonio Luiz. Caróes, caras salão de humor e de outros humores texto inédito: $s / d$.

\section{A Opinião Patrulhada}

Num sucinto panorama cronológico o pesquisador Antonio Luiz Cagnin (5) observa que a combatividade da caricatura política durante o Império era manifestada através de uma sátira ferina e escrachada. Foi se arrefecendo ao final do século XIX, com o fim da Monarquia. Voltando a crescer novamente no começo do século XX, com os primeiros anos da República, para depois calar-se pela ditadura de Vargas. E após uma breve lufada de renovação nos anos 50, volta a ser calada com a tomada do poder pelos militares, em 1964.

Porém, o cerceamento da opinião aberta durante o período ditatorial não impediu o ataque sutil, fino e inteligente. Em 1970, os principais jornais brasileiros foram submetidos a uma intensa censura prévia, que permaneceu por um período de cinco anos. Nos jornais alternativos ela ocorreu de forma feroz e sem limites. O primeiro e principal alvo da repressão foi o Pasquim. 
No dia 1 de Novembro de 1970 a situação na redação do Pasquim modificou-se de forma repentina e violenta, quando foi invadida por um comando policial-militar, prendendo os editores do jornal. Foi um grande impacto para um projeto editorial que se expandia rapidamente. Após 2 anos de seu lançamento seus editores estavam presos. $\mathrm{O}$ jornal recebeu a solidariedade de talentosos colaboradores e o apoio de alguns poucos jornais para que continuasse a circular. Uma das matérias de solidariedade foi publicado na Folha 2, de Londrina, transcrita posteriormente na edição no. 79 do próprio Pasquim. Nela é possível perceber a análise do momento político.

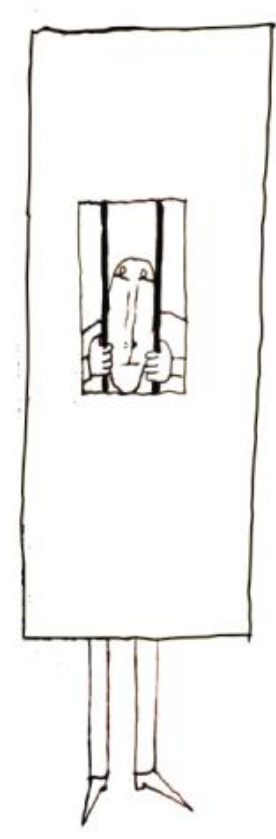

Depois de mais de um ano de vida, $O$ Pasquim entra numa pausa que ninguém sabe até quando irá ou se é, de fato, o fim do jornaleco: quase todos os seus redatores estão presos e a circulação do jornal acaba de ser proibida, "até segunda ordem", pela Polícia Federal, que não explicou a razão da proibição.

E o que é (ou era) O Pasquim? Um jornal que encontrou público (ou seu público), pois chegou além dos 200.000 exemplares de tiragem - o que quer dizer que, na sua mais áurea fase, deverá ter vendido aproximadamente até 180.000 exemplares, pois uns $20 \%$ sempre sobram nas bancas.

Respeitado porque conseguiu uma enorme massa de leitores, chegou a ser respeitado também porque demonstrou, desde o início, uma coerência editorial que não era previsto. “Esse jornalzinho vira humorismo puro já, já”, diziam..

Mas O Pasquim continuou na sua linha de avacalhação dirigida (ou orientada, ou pelo menos lúcida). Ao lado de histórias curtas sempre recheadas de críticas aos costumes, as charges e os cartuns faziam o balanço, a análise e a crítica satírica do próprio público a que se dirigia: estudantes, na maioria, e as camadas liberais da burguesia em geral. Atrás de toda a avacalhação, a lucidez. Atrás do riso, a sátira ou a crítica. Atrás das mesas, provavelmente havia muito menos garrafas vazias de uísque do que os leitores se acostumaram a pensar. Profissionais regulares e responsáveis estavam ali: Ziraldo, Fortuna, Millôr Fernandes, Henfil, Francis. Ao lado de alguns "catados" aqui e ali: os "correspondentes" estrangeiros, Vinícius de Moraes etc. E algumas figuras esporádicas que apareciam e desapareciam, pareciam escrever quando queriam e davam ao jornal um espírito amadorístico e irresponsável - o que seu próprio presidente, Tarso de Castro, sempre fez questão de frisar. Em toda essa aparente anarquia, porém, sempre apareceram bem fixadas certas diretrizes revolucionárias:

a - Liberdade de estilo ao profissional ou ao colaborador. Assim, O Pasquim trouxe à imprensa brasileira personalidades e possibilidades de confrontação estilística. $\mathrm{E}$ - o que é mais importante - deixou bem claro, para quem quis ver que o jornalismo, mesmo para os jornais noticiosos, deve ser cada vez aproximado de técnicas literárias e de artes plásticas.

b - Exposição e crítica de cartunistas internacionais, além de inovações gráficas.

c - Palavra livre ao leitor, o que não é tão raro, mas muito mal aproveitado pela imprensa brasileira em geral. Não é novidade uma página de cartas aos leitores, pois os maiores jornais do mundo as conservam; o que $O$ Pasquim fez foi uma seleção de cartas interessantes a ponto de ser uma das mais lidas no jornal.

d - Divulgação a tendências e movimentos artísticos marginalizados, do Mundo Ocidental e Oriental

e - Renovação e revigoramento da crônica política, com Paulo Francis, sem o marasmo e a estéril seriedade do "gênero". 
f - Divulgação e crítica, anarquicamente, de literatura, cinema, artes plásticas, filosofia, acontecimentos políticos, costumes, modismos etc, através das "Dicas" - uma seção intermediária entre as tradicionais"pílulas noticiosas" e o comentário curto.

g - Gozação e auto-gozação, numa coerente e contínua atitude suicida.

Agora, suicidado, O Pasquim pode merecer um balanço. Relaxado, mas graficamente revolucionário - para a imprensa brasileira, é claro.

Amadorístico, mas com os melhores profissionais do humor brasileiro. Debochante mas familiar. E, para maior paradoxo, crítico mas canalha. "Fino", mas "grosso". Enfim: o mais caracterizado produto de uma comunicacão "quente" mas de um profissionalismo irreverente porque marginalizado e de uma aparente anarquia empresarial porque justamente contrário à organização empresarial. Aliás, foi quando saiu de sua fase espontânea e ainda sem estrutura empresarial, que $O$ Pasquim começou a morrer, pois se desencadeou nos moldes do Sistema. Foi quando começou a ser distribuído pela Editora Abril. Deixou então de ser um produto quase rebelde de uma anti-cultura, para ser um exemplo semi-oficial da permissividade do Sistema: "olha aí, O Pasquim continua circulando".

Teve o mérito, porém, de caluniar e estimular intelectuais, e de romper o provincianismo moral e artístico que cava um abismo cultural entre as cidades do interior e as capitais.

Querendo colocar areia no moral imperante, acabou por vezes emperrando na mesma tecla do o-que-é-que-tem-demais-este-palavrão. Não se poderia exigir, porém, que com a reduzida equipe permanente, pudesse ser um eterno poço de criatividade.

Agora, porém, não se sabe quando se poderá ver (ou ler) o trabalho de tantos bons profissionais de imprensa reunidos. Que promoveram, enquanto $O$ Pasquim durou, o mais prolongado debate sobre a vida, os costumes, a política e as artes do Brasil. Contra ou a favor de $O$ Pasquim, é possível reconhecer tranqüilamente que nunca um jornal tão pequeno uniu tanto uma classe social, culturalmente, na terra onde Pedro Álvares Cabral aportou nas notas de mil. (O PASQUIM, 1971, no. 79)
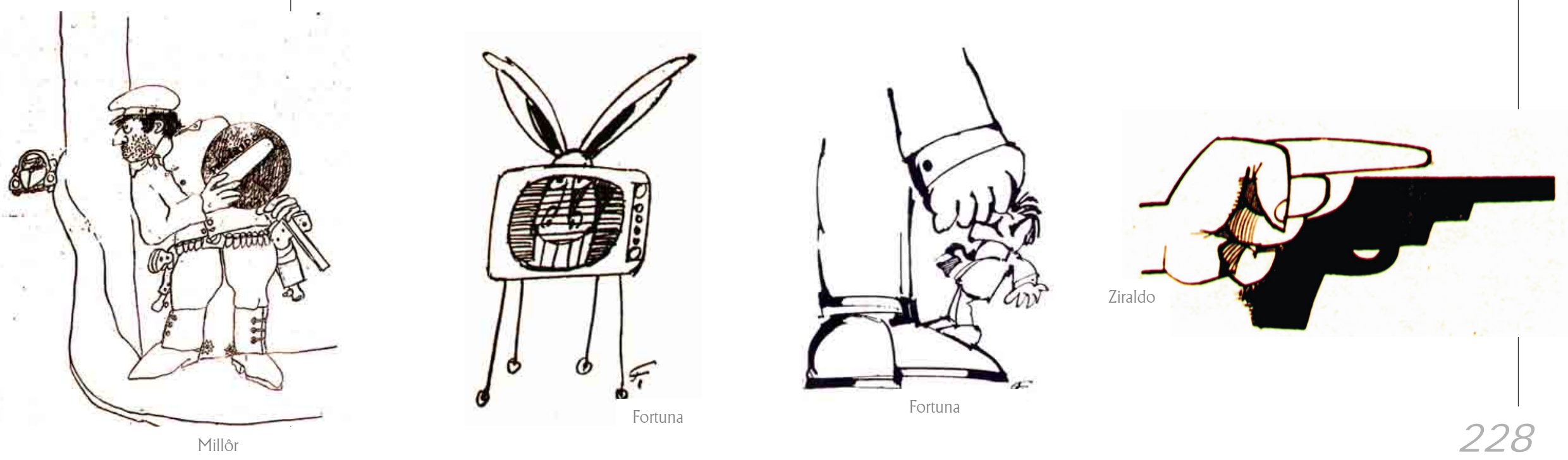

Fortuna 
Quando os editores foram liberados, após dois meses retidos, a tiragem havia caído de 180 mil exemplares para 60 mil E para agravar a situação do empreendimento a publicidade havia desaparecido. Sem nenhum critério a censura prévia a partir deste momento tornou-se ensandecida, com o nítido propósito de destruir o jornal. Mesmo sendo editado no Rio de Janeiro o jornal era obrigado previamente a enviar para Brasília todo o material da edição seguinte. Por diversas vezes o material encaminhado ficava seguro por dias, prejudicando a periodicidade da publicação. A equipe editorial permanecia em constante tensão, não só por razões de segurança pessoal como pela constante retenção do material da edição seguinte. Na medida em que a censura se acirrava, o Pasquim intensificava sua postura crítica.

No que se refere à censura prévia, aos seus métodos e efeitos, o que atingiu o Pasquim foi semelhante ao que se poderia contar a respeito de Opinião (1972-1976) e do Movimento (1975-1981), os dois mais importantes jornais alternativos de natureza política. Em alguns a censura prévia não foi tão devastadora, ou não chegou a existir, mas a repressão chegou a todos, na forma de apreensão de edições e prisão de quem os fazia. Na opinião de Bernardo de servir de advertência à grande imprensa."

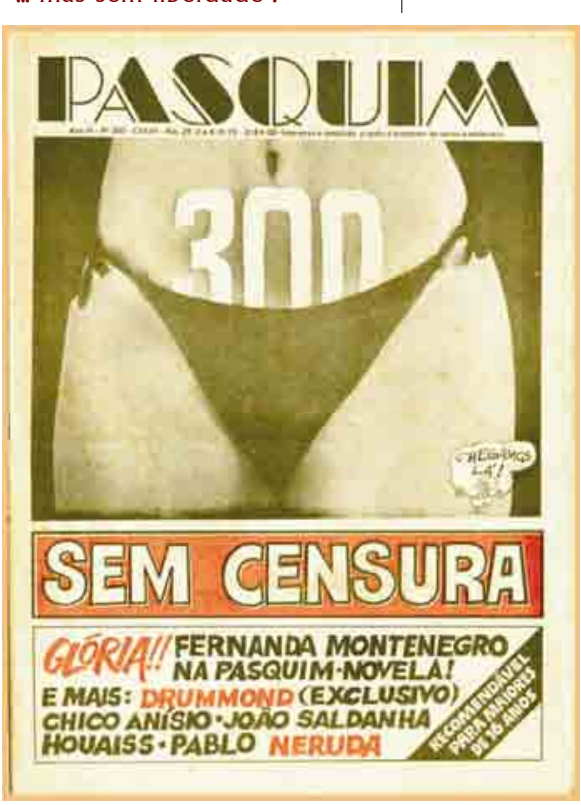

A censura prévia ao Pasquim vigorou durante cinco anos, de abril de 1970 a março de 1975. Ao final do período de cerceamento de opinião, a censura estabelecida por órgãos oficiais é banida, embora a liberdade de expressão continuasse relativizada. A liberdade editorial para o Pasquim permaneceu por pouco tempo. Um editorial de Millôr Fernandes na edição de no. 300 deu a notícia da suspensão da censura.

“Cinco anos depois, tão misteriosamente como comecou - 'ordens superiores' - a sinistra censura sobre este jornal se acabou. O dr. Romão, o último interventor de plantão dos vinte ou trinta que passaram pela tarefa nestes mil e quinhentos dias de violências, comunicou a Nelma (secretária) que 'vocês agora não precisam mandar mais nada pra censura'. Mas, vício do ofício, não conteve a ameaça: 'Agora a responsabilidade é de vocês'. A responsabilidade sempre foi nossa (...) o fato é que, mesmo sob censura prévia, a responsabilidade sempre foi nossa. (...) Agora $O$ Pasquim passa a circular sem censura. Mas sem censura não quer dizer com liberdade..." (FERNANDES, 1975, no 300)

O teor do texto levou à apreensão da edição na semana seguinte. O cerceamento editorial saiu da redação para ressurgir fora dela. 
O ambiente político e social no país modificavam-se forçosamente. Uma seqüência de acontecimentos contribuiu para deflagrar o processo de redemocratização no país:

- a constante crise econômica durante o período militar;

- cidadãos que permaneciam presos e sob tortura;

- o cerceamento da opinião, através da censura prévia, coordenada por órgãos do governo;

Com a perspectiva dos desdobramentos da gravidade dos problemas, que tenderiam a deflagrar conflitos sociais, o presidente militar Ernesto Geisel define novas atitudes políticas, iniciando um lento processo de abertura.

Enfrentando ameaças, o Pasquim sobreviveu, e cunhou um padrão de jornalismo satírico que explodiu por todo o país em pequenas publicações alternativas, editadas por cooperativas de jornalistas ou por movimentos populares.

O jornal sobreviveu até 1991, e nos últimos anos de circulação, já em outro ambiente político, O Pasquim foi vendido a um antigo colaborador. Mesmo com novo impulso empresarial o jornal vendia acanhados três mil exemplares com periodicidade irregular, acumulando dívidas e respondendo a ações trabalhistas na justiça.

O modelo do Pasquim se constituiu em síntese do verdadeiro jornalismo caricato: traço e texto lado a lado, ironizando o cotidiano, satirizando os poderosos da notícia, registrando com humor a emergência de um novo projeto de sociedade.
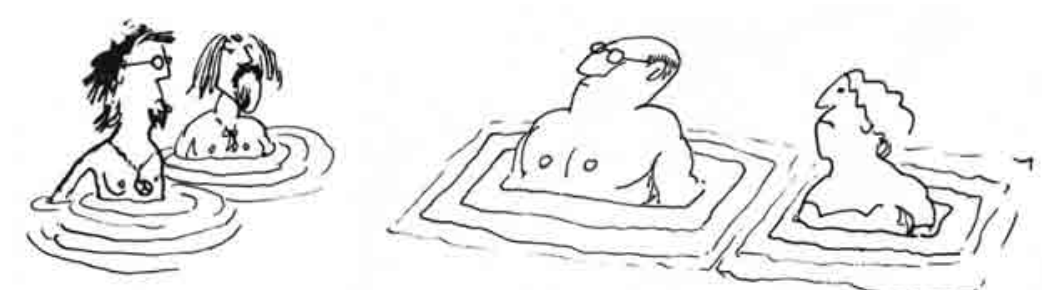


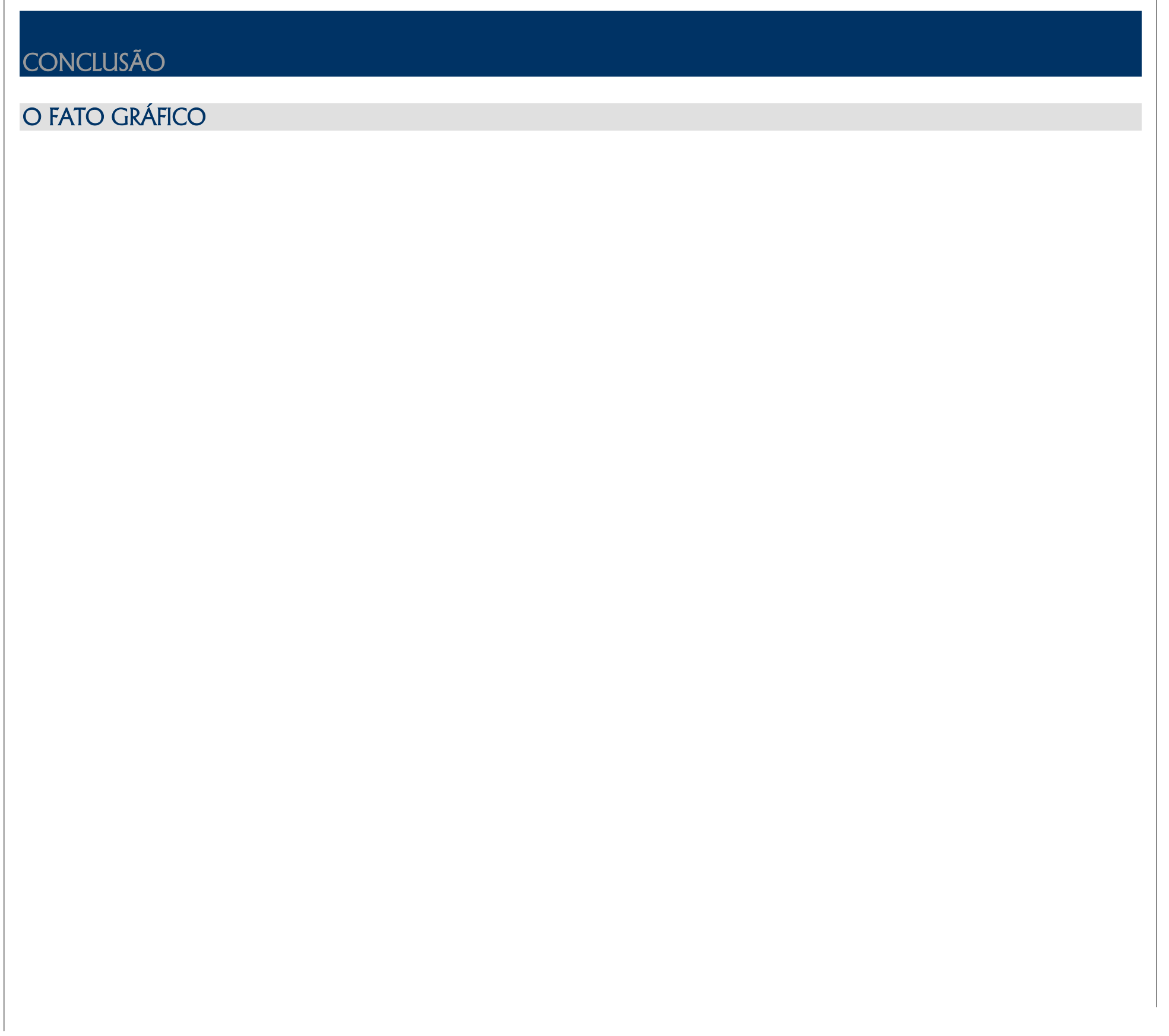




\section{O FATO GRÁFICO}

Assim como há um raciocínio mental para elaboração das idéias, há também um raciocínio gráfico para elaboração das imagens. Certamente existem outras formas de raciocínio, como o raciocínio matemático ou o raciocínio musical. Todos eles capazes de revelar conceitos apenas diferenciados em suas materialidades de manifestação.

Para o entendimento das imagens impressas o mecanismo de recepção utiliza tão somente o meio visual. Assim, torna-se tão intensamente subjetivo seu entendimento, pois necessita obrigatoriamente da presença do receptor para ver. $\mathrm{E}$ comparar é o impulso primordial que é acionado para interpretar qualquer imagem. Portanto, ver remete a comparações predominantemente analógicas.

Os olhos só podem interpretar o que é, não o que foi ou o que será. E para tal, é necessária a presença física do observador junto à imagem. Só o que não estiver presente se realizará através da imaginação. É o que comumente ocorre no campo verbal, por ser a palavra simbólica e não analógica. E sendo simbólica é altamente permeável à imaginação.

Para com as imagens o processo imaginativo só será deflagrado com a representação gráfica de uma metáfora visual. Ali estará rompida a expectativa da previsível analogia que o desenho remete. Com as metáforas a leitura da imagem passa a atuar no inconsciente, não mais no raciocínio lógico. Assim, agem diretamente no subjetivo mais do que a palavra, por estar o campo verbal condicionado a um código esclarecedor anterior. Metáforas visuais conduzem a um universo interior, tanto para o ilustrador quanto para o observador.

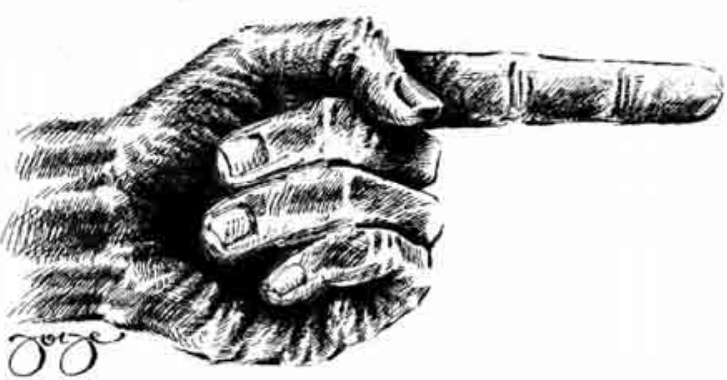

IMAGEM ANALÓGICA

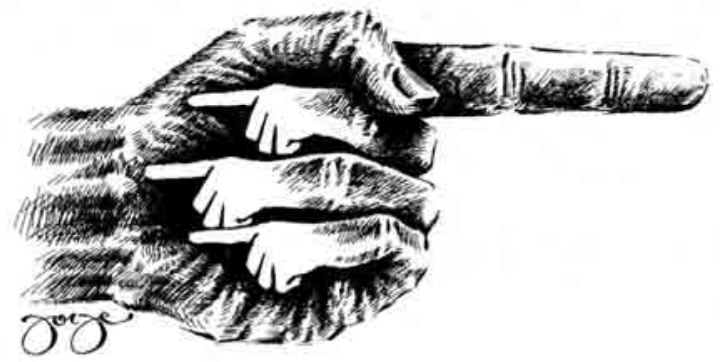

METÁFORA VISUAL 
Como relatamos ao longo da pesquisa apresentada, a escrita em sua formação teve que se desprender da linha figurativa porque esta se tornou insuficiente como sistema de troca de idéias.

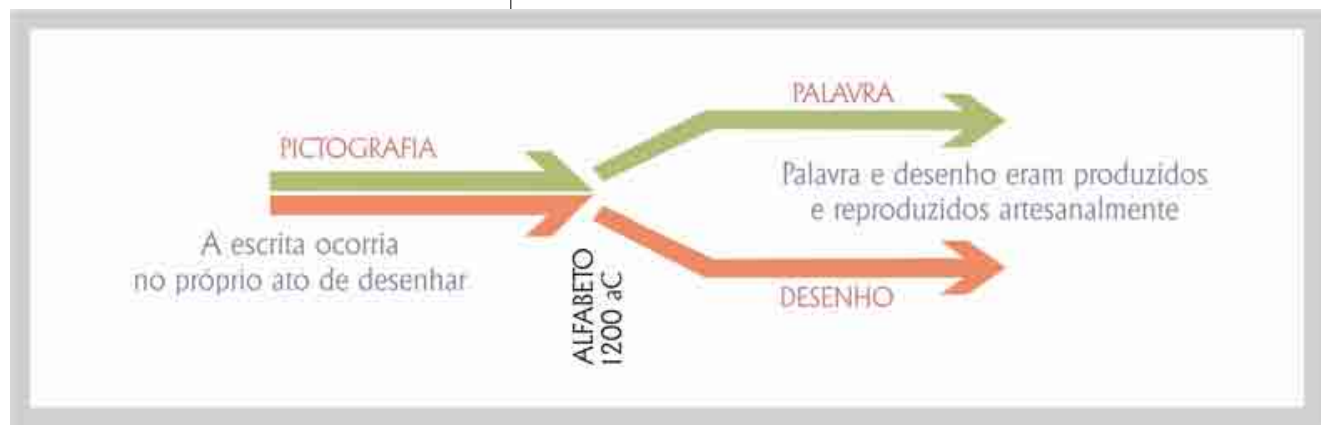

Nos primórdios da comunicação humana a confecção pictográfica representava a escrita e o desenho no mesmo ato. Com o surgimento do alfabeto se separam, e caminham por séculos sendo reproduzidos com os mesmos recursos técnicos, porém ainda artesanalmente. Segundo Walter Benjamin, "com a xilogravura, o desenho tornou-se pela primeira vez tecnicamente reprodutível, muito antes que a imprensa prestasse o mesmo serviço para a palavra escrita”. (BENJAMIN, 1975, p. 166).

As conquistas dos processos mecânicos de reprodução ao longo dos séculos culminaram com a invenção da tipografia impulsionando a palavra como articuladora das idéias e retendo o desenho como difusor do pensamento.

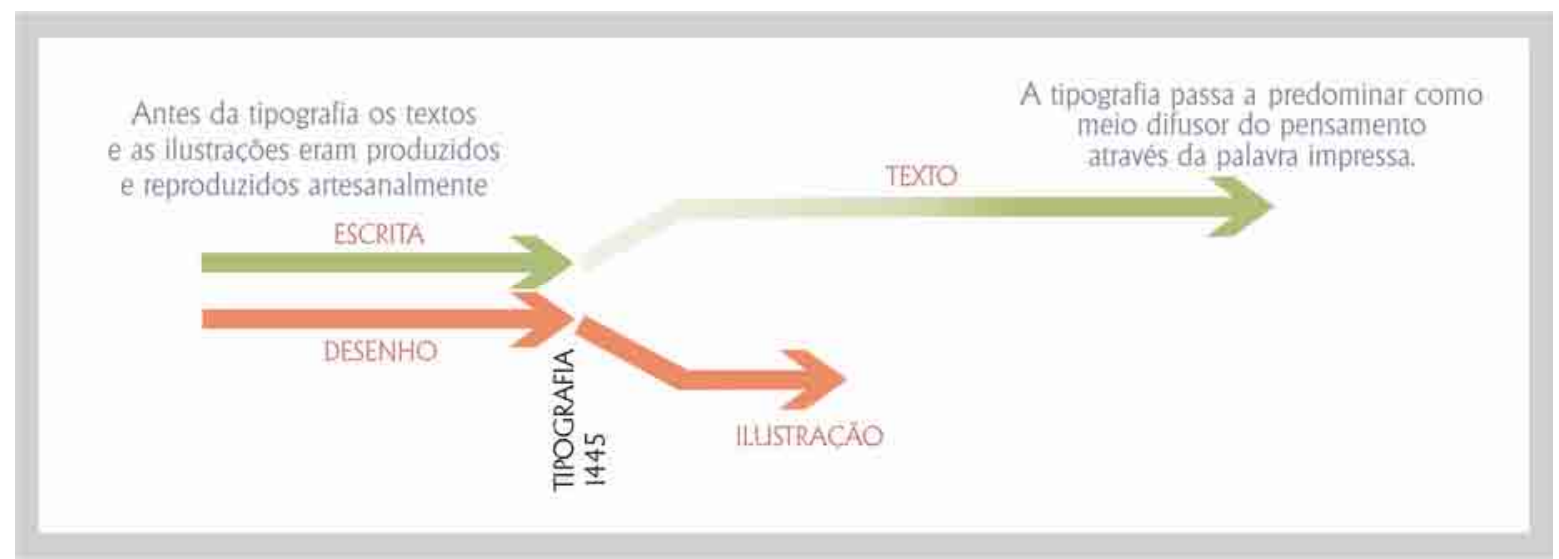

O processo de valorização da palavra impressa perdurou por cerca de 4 séculos. Nesse período a imagem não conseguiu acompanhar o mesmo processo por não existir tecnologia capaz de substituir mecanicamente a confecção da matriz artesanal e de ainda existir incompatibilidade técnica de ser impressa conjuntamente com a matriz tipográfica. 
Nesse período histórico os processos tipográficos evoluíram permitindo a difusão de livros, folhetos e jornais. Como uma das características do jornal é a atualidade, a tipografia contribuiu para que as idéias fossem rapidamente transmitidas pela palavra impressa, preponderando tão somente o discurso verbal dentro do jornalismo. $\bigcirc$ mesmo não aconteceu com a ilustração, que deixou de conviver regularmente nas páginas por um longo período.

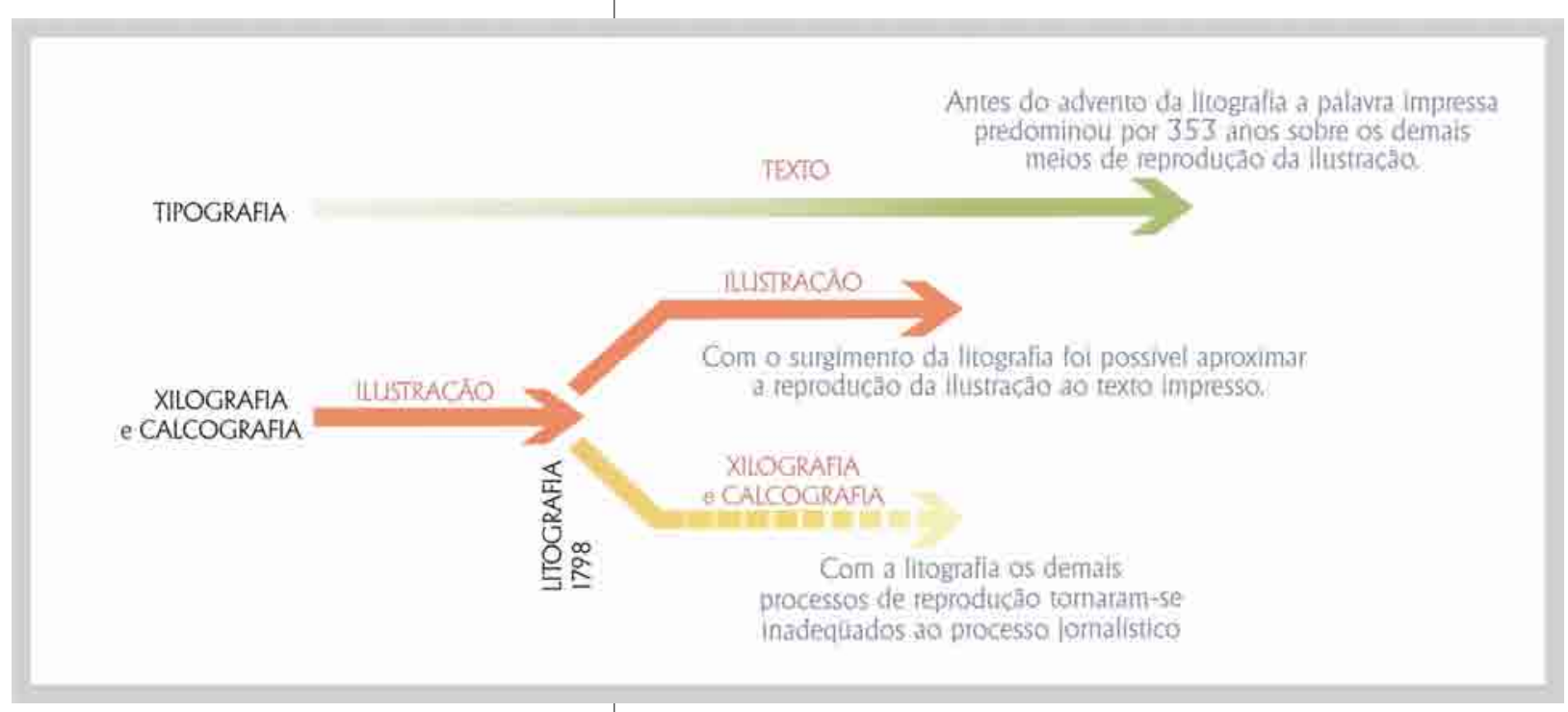

Houve um momento em que se esboçou uma reação de aproximação entre o texto e a ilustração quando do surgimento da litografia, em 1798. A técnica da litografia permitiu que nos periódicos convivessem, mesmo que separadamente, páginas verbais com páginas visuais. Porém, esse fato não foi suficiente para consolidar efetivamente a presença da ilustração dentro do agora nascente jornalismo empresarial.

Em meados do século XIX, a ilustração novamente sofre um revés. Depois de passados 32 anos da invenção da litografia (favorecendo o desenho) surge a fotografia para retirar da ilustração seu conteúdo documental.

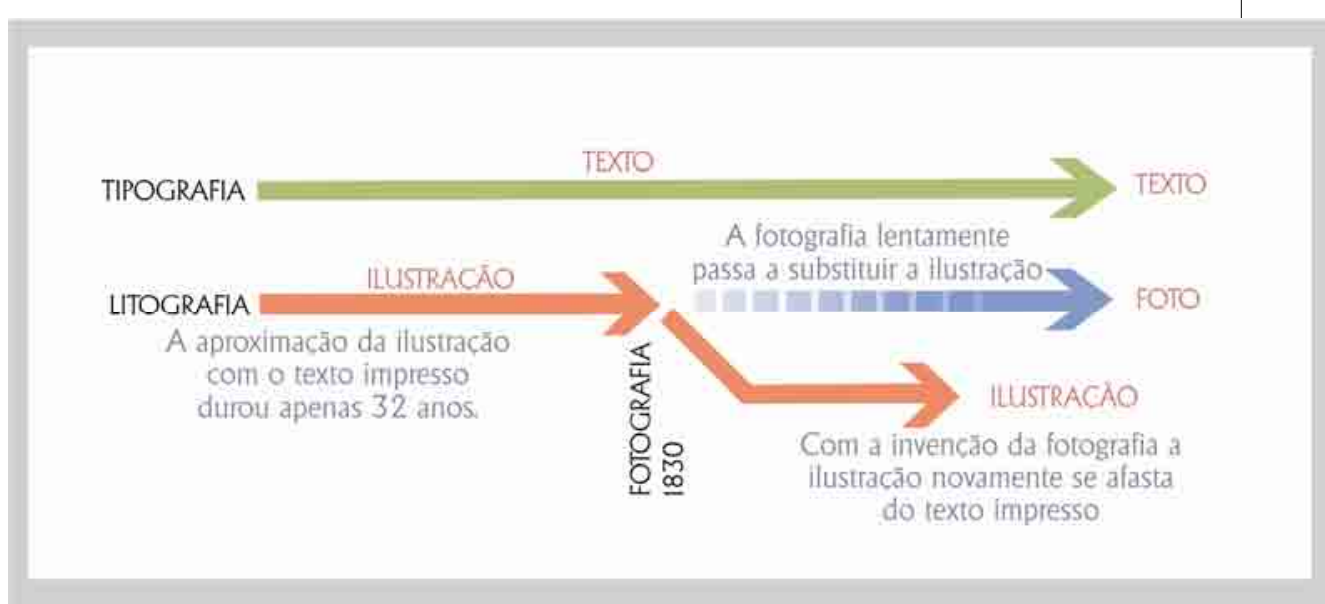




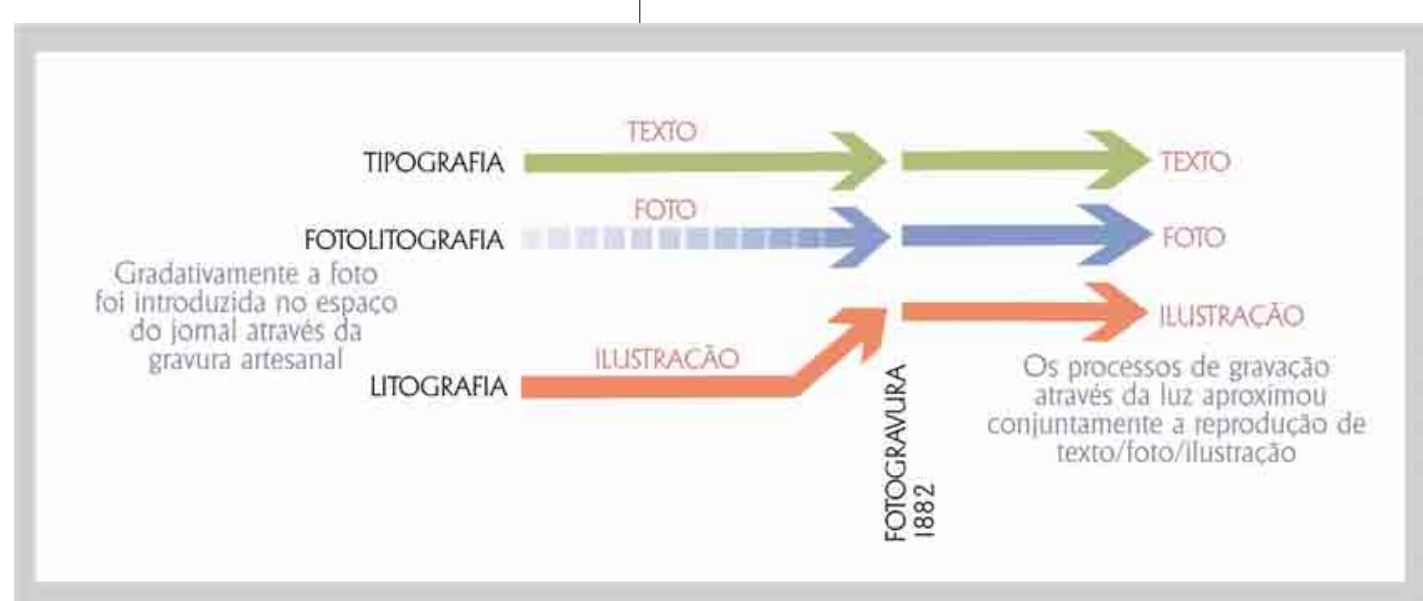

A mudança em favor da ilustracão somente passou a acontecer a partir de 1882 quando se iniciaram os experimentos com matrizes gravadas por processos luminosos, e não mais por processos artesanais. $O$ processo de gravação através da luz alterou todo o mecanismo de reprodução, não só para o desenho mas também para a foto e o texto. A partir de então a gravação da imagem deixa de sofrer a ação manual para passar a ser gravada através da fotogravura (do grego photo $=$ luz). A criação do desenho original continuou sendo artesanal (como a escrita), porém o que se alterou foi o tempo da gravação da matriz de impressão. Esse tempo foi reduzido ao tempo de uma revelação fotográfica. Assim, voltaram a se aproximar texto e imagem.

No painel abaixo se encontram demarcadas as principais técnicas de reprodução com as respectivas relações cronológicas entre si.

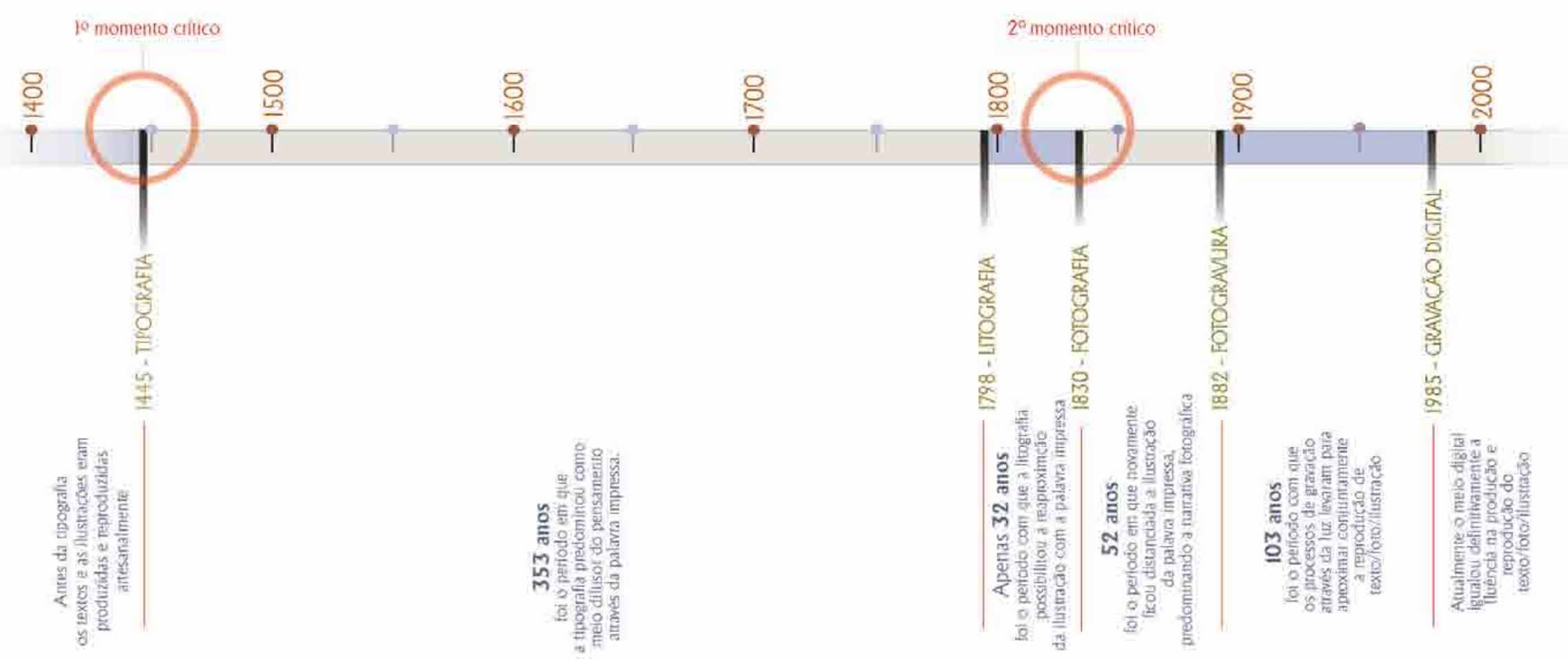




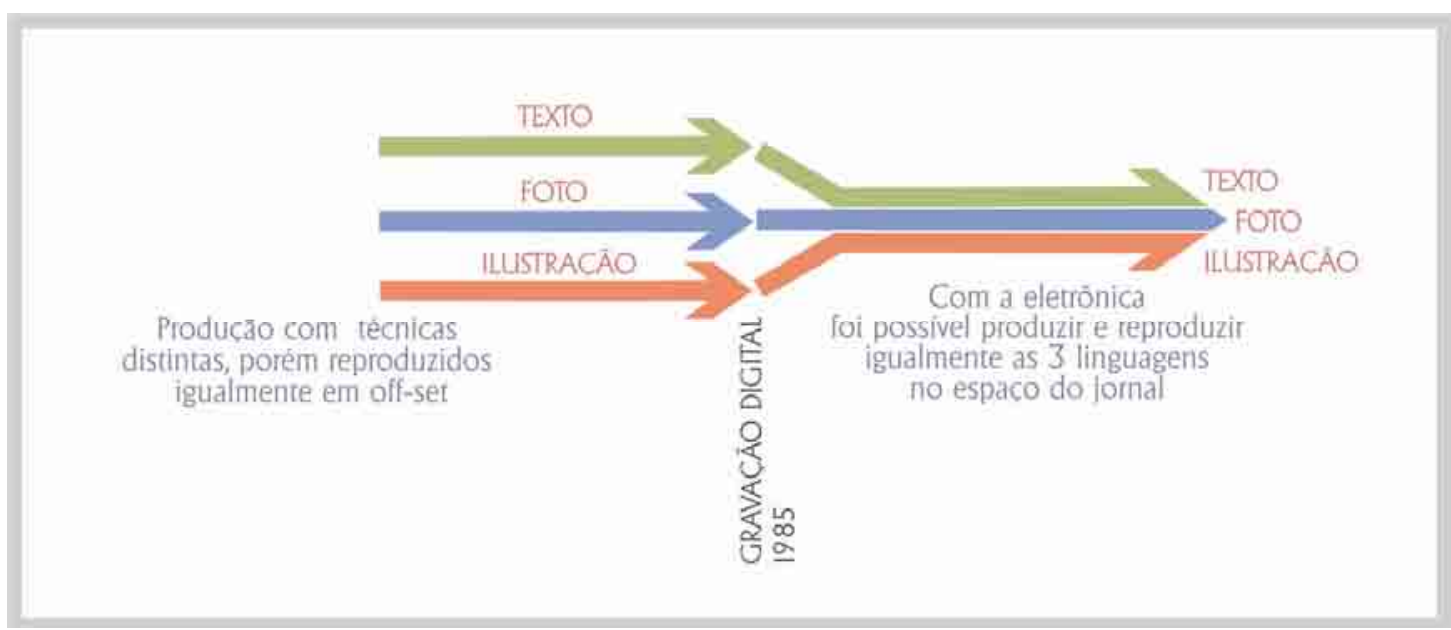

A reaproximação das linguagens, verbal e não verbal, está ocorrendo em nossos dias com o advento do processo de gravação de matrizes através da luz (fotogravura) e mais aceleradamente ainda com as novas tecnologias digitais. Com os recursos eletrônicos os processos de produção têm se aproximado dos processos do pensamento. Com a eletrônica o atual processo de gravação utilizado pelo computador tornou possível aproximar muito mais a imaginação da reprodução, fazendo com que acontecessem quase que simultaneamente. Pois, a fluência ideal de qualquer linguagem é a possibilidade de se poder pensar e imediatamente reproduzir esse pensamento.

Já não existem barreiras que impeçam a reprodução de qualquer discurso, seja verbal ou não-verbal. Como a atualidade é uma das características do jornalismo, e vital para o fluir das informações, as técnicas eletrônicas de produção com sua respectiva reprodução, viabilizou a junção das 3 linguagens (texto/foto/ilustração). Estamos, finalmente, diante de mecanismos capazes de transportar para as páginas dos jornais, com maior fluência e mais atualidade o discurso contido nas ilustrações.

Recapitulando o processo descrito, apresento abaixo um esquema evolutivo abrangendo os meios e os mecanismos utilizados na reprodução do discurso jornalístico.

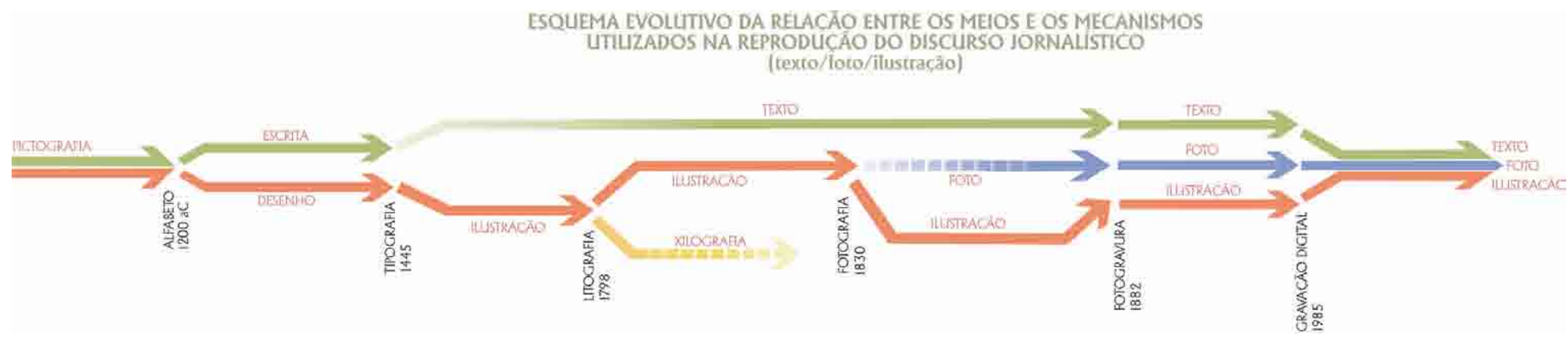




\section{Proposta Classificatória}

Para a difusão informativa no jornal os recursos não verbais vêm se tornando cada dia mais eficientes. O jornal moldouse aos esquemas do texto curto, atendendo às exigências da objetividade. Reduziram-se os espaços para a palavra e ampliaram-se os espaços para as imagens. Para fazer frente aos recursos televisivos, o jornal procurou intensificar o uso de imagens através de uma interatividade entre linguagem escrita, linguagem fotográfica e linguagem gráfica. Aprimorada com a inserção do recurso digital pelo computador, a fluência técnica viabilizou a fluência discursiva do Humor Gráfico, possibilitando incorporar o reale a atualidade, características fundamentais para a existência do jornalismo.

O Humor Gráfico é criação recente como forma jornalística. Adquiriu linguagem própria por encontrar condições tecnológicas de reproduzir o que se imagina, no tempo que o jornal necessita. Atualmente, pela linguagem do desenho, é possível expressar comentários mais amplos e analisar com mais fluência os comportamentos sociais, políticos e psicológicos do indivíduo.

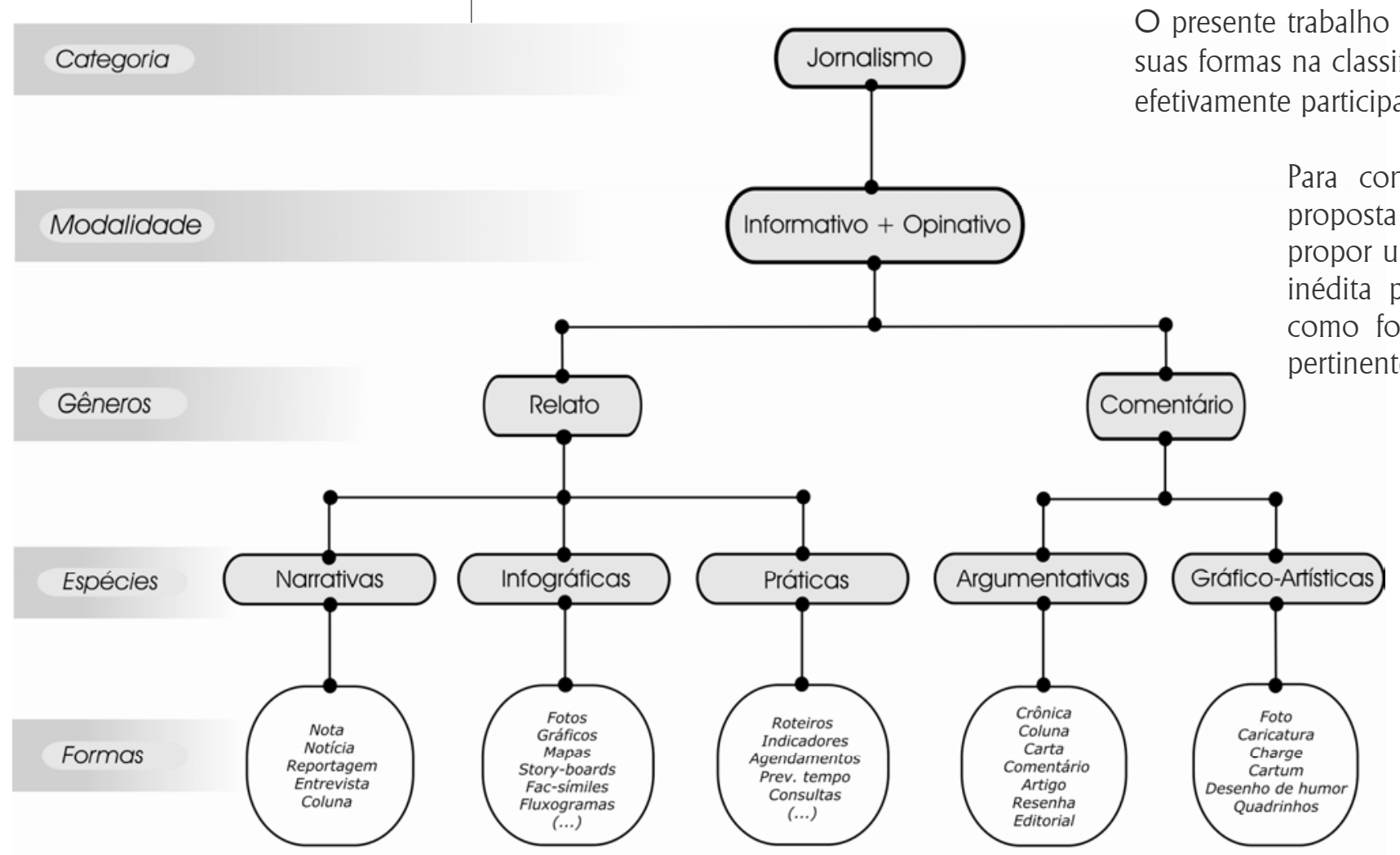
inserção nas classificacões jornalísticas dos 5 formatos com que se apresenta o Humor Gráfico (caricatura, charge, cartum, desenho de humor e quadrinhos).

Para ordenar as argumentações lançadas apresento ao lado a seguinte grade classificatória. 
Finalizamos este trabalho parafraseando o Prof. Chaparro $(1998$, p. 83) em sua obra Sotaques d'aquém e d'além mar, onde menciona que "como cada vez mais estão indefinidas as fronteiras entre os gêneros, muitas vezes aparece o que se chama de subgêneros. As alterações são decorrentes de vários fatores, como a introdução de novas tecnologias e a necessidade dos meios impressos fazerem frente aos demais meios eletrônicos de comunicação, atingindo todos os níveis sociais e culturais. Fatores diversos influenciam constantemente na dinâmica do discurso jornalístico. Para identificação das novas formas de relato da atualidade não se deveria aplicar uma classificação previamente elaborada, mas ser gestada nas próprias redações dos jornais." 


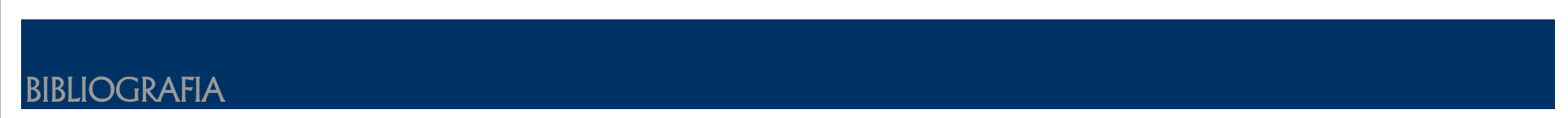




\section{BIBLIOGRAFIA}

A CRÍTICA DA CHARGE. FrontBraza. Disponível em <http://www.imagodays2.com.br> Acessado em 9 de abril de 2003.

ADES, Karin. Revista. São Paulo: FAU/USP, 1990.

AGOSTINHO, Aucione Torres. A charge. São Paulo, ECA/USP, 1993 (tese doutorado).

ALBERTOS, José Luis Martinez. Curso de Redacción Periodística. Madrid: Paraninfo, 1991.

ALCUNE, Lenise. CARNEIRO, Rosane. FERRAZ, Maria N.S. Tipos de Comunicação - Verbal e não verbal. Rio de Janeiro: Editora SENAC,1996.

ALDUNATE, Ana Francisca e LECAROS, María José. Géneros Periodisticos. Santiago: Pontíficia Universidad Católica de Chile, 1989

ANDRADE, Joaquim Marçal Ferreira de. História da fotorreportagem no Brasil. Rio de Janeiro: Elsevier, 2004.

ANDRADE, Mário de. O desenho. Disponível em <http://www.frontbraza.org.br> Acessado em 06 de junho de 2001.

ARBACH, Jorge M. I. Desenhos Falados. Juiz de Fora: Esdeva, 1990.

COOPERMAN, Priscilla. ARBACH, Jorge. A representação do imaginário: mental e gráfico. 2000. Dissertação (Mestrado em Comunicação e Ética:

Imaginário e Natureza. - Faculdade de Comunicação da Universidade Federal de Juiz de Fora/ECO, Universidade Federal do Rio de Janeiro, 2000

ARTIGAS, Vilanova. Aula inaugural na FAU/USP. São Paulo: s. e. 1967.

ASSIS, Diego. Charge e caricatura têm interpretações distintas na história. site Observatório da Imprensa. - da FolhaonLine. 06h48 - 22/08/2004 .

AUMONT, Jacques, A imagem. 2ª ed., Campinas, Papirus, 1993

BAHIA, Juarez. Jornal, história e técnica - História da Imprensa Brasileira. São Paulo: Ática, 1990.

BAKHTIN, Mikhail, Marxismo e filosofia da linguagem. 2ª ed., São Paulo, Hucitec, 1981.

BARRY, Sir Gerald. Os meios de expressão. Maia/Portugal: Europa-América, 1969.

BELTRÃO, Luiz. A imprensa informativa. São Paulo: Folco Masucci, 1969.

. Jornalismo interpretativo. $2^{a}$ ed, Porto Alegre: Sulina, 1980.

. Jornalismo Opinativo. Porto alegre: Sulina, 1980.

BELUZZO, Ana Maria de M., Voltolino e as raízes do modernismo. São Paulo, Marco Zero, 1992.

BENJAMIN, Walter. A obra de arte na época de suas técnicas de reprodução. Os Pensadores, v. XLVIII, São Paulo, Abril Cultural, 1975.

BERWANGER, Ana Regina, LEAL, João Eurípedes Franklin. Noções de Paleografia e de Diplómática. 2 ed. Santa Maria/RS: UFSM, 1995.

BETTO, Frei. Do ofício (tão difícil) de escrever - Rio de Janeiro: Record, 1996.

BRAGA, Robson Aurélio Adelino. O poder da imagem e a imagem do poder:

mito e ideologia no fotojornalismo cubano. dissertação de mestrado. São Paulo: ECA/USP, 2002

BRITO, Ronaldo C. A Imagem na Imprensa. Opinião, São Paulo: Zero Hora, 1981. 
BURGIERMAN, Denis Russo. O primeiro dia da história. Superinteressante, São Paulo, Três, jul./1999, p. 52.

CAGNIN, Antonio Luiz. Carôes, caras e caretas: salão de humor e de outros humores. texto inédito: s/d.

CAMPS, Sibila e PAZOS, Luiz. Los géneros periodísticos in Así se Hace Periodismo -

Manual prático del periodista gráfico. Barcelona: Paidós, 1994.

CARNEIRO, Marcelo. Pequena abusada. São Paulo: Ed. Abril, revista Veja, 5/04/05.

CARVALHO, André Luiz Piva de. Quadros maquiados - Gênese e producão de sentido da imagem impressa em revistas tendo como modelo a narrativa das capas da revista Veja enfocando Fernando Collor de Melo. Dissertação de mestrado. São Paulo: ECA/USP, 1998

CAVALCANTI, Laílson de Holanda. História do humor gráfico no Brasil. Espanha: Milênio, 2005.

CHAPARRO, Manuel Carlos da Conceição. Sotaques d' aquém e d'além mar:

percursos e gêneros do jornalismo português e brasileiro. Lisboa: Edições Jortejo, 2000.

. As formas não se opõem à arte de escrever. Comunique-se. Disponível em <http://www.imagodays2.com.br>. Acessado em 9 de maio de 2005.

COELHO, Aguinaldo Caiado de Castro Aquino. Transformações gráficas na primeira página - jornal O Popular. Goiânia: ECA/USP - FAV/UFG, 1998

CONSOLO, Maria Cecília. A imagem (tipo)gráfica). São Paulo: Disertação de Mestrado, ECA/USP, 2002.

De CASTRO, Roberto Luiz Carvalho. A realidade em traços: a ilustração no jornalismo contemporâneo. Projeto experimental

Orientadora: Vera Monteiro de Castro Amara. Juiz de Fora: Faculdade de Comunicação Social / UFJF, 1990.

DIAS, Paulo da Rocha e MENDEZ, Rosemary Bars. Gêneros e formatos na comunicação massiva periodística - um estudo do jornal

"Folha de São Paulo" e da revista "Veja". Coord.Prof. Dr. José Marques de Melo. São Paulo:Universidade Metodista de são Paulo, s/d.

DIAS, Sueli Maria Baliza. Do pregão à web: breve histórico da propaganda no Brasil. Aula Magna, Belo Horizonte, Número Especial, Ano 6, 2000.

DINES, Alberto. O papel do jornal: uma releitura. 6으 ed, Summus, 1996.

DONDIS, Donis A. Sintaxe da linguagem visual. São Paulo: Martins Fontes, 1991.

DOCZl, György. O poder dos limites. São Paulo: Mercuryo, 1990

DUCCINI, Mariana. Quadrinhos, coisa de "gente grande". Revista Imprensa, Número 177, Ano 16, 2002.

ECO, Umberto. Interpretação e Superinterpretação. São Paulo, Martins Fontes, 1993.

ERBOLATO, Mário. A Técnica de Codificação em jornalismo, Rio de Janeiro: Editora Vozes, 1979.

ERBOLATO, Mário. Dicionário de propaganda e jornalismo. São Paulo: Papirus, 1986.

FAUSTO, Boris. História do Brasil. São Paulo: Edusp, 1994.

FLÁVIO, Jean. Ilustração e estranhamento. Disponível na Internet no e-group FrontBraza, mensagem n. 8 de 03/03/2001. Arquivo consultado em 200 1 .

FERLAUTO, Cláudio, JAHN, Heloísa. O livro da gráfica. São Paulo: Hamburg, 1998.

FERNANDES, Adélia Barroso. (Mestre em Comunicação Social pela UFMG) O Jornalismo participa da História do Brasil.

$\mathrm{N}^{\circ}$ Especial, Ano 6, 2000. UNI-BH, Belo Horizonte. Aula Magna.

FERREIRA, Aurélio Buarque de Holanda. Novo dicionário da língua portuguesa. Rio de Janeiro: Nova Fronteira, 1975 
FONSECA, Joaquim.. Caricatura - A imagem gráfica do humor. Porto Alegre: Artes e Ofícios, 1999.

GOMES FILHO, João. Gestalt do objeto/sistema de leitura visual. São Paulo: Escrituras, 2000.

GOMES, Luiz Vidal Negreiros. Desenhando: Um panorama dos sistemas gráficos. Santa Maria, RS: EDUFSM, 1998.

GONÇALVES, Maria Helena Barreto, KRITZ, Sonia. Comunicação Verbal e não verbal. Rio de Janeiro: Senac Nacional, 1996.

Introdução à comunicação e artes. Rio de Janeiro: Senac Nacional, 1997.

GONTIJO, Silvana. O mundo em comunicação. Rio de Janeiro: Aeroplano, 2002.

HURLBURT, Allen. Layout: o design da página impressa. São Paulo: Nobel, 1986.

HERKENHOFF, Paulo. Biblioteca Naciona/Rio de Janeiro: GMT, 2002.

JÚNIOR José Colucci. Fotojornalismo-Tecnologia e hipocrisia digital. Observatório da Imprensa. Disponível em <http://www.observtoriodaimprensa.com..br>. Acessado em 9 de abril de 2003.

KOLLERT, Günter. A origem e o futuro da palavra: a teoria da linguagem segundo Goethe e Rudolf Steiner. São Paulo: Antroposófica, 1994.

LEFEBVRE, Henri. Introdução à modernidade. Rio de Janeiro: Paz e Terra, 1969.

KIPPER, Henrique A. Dois jornalismos, Dois Usos da Imagem. e-group FrontBraza, Message:13, 29/01/2001 e Message n.ㅇ 23 de $29 / 4 / 2001$. Disponível em <http://www.imagodays2.com..br>. Acessado em 2001.

Ilustrações Conceituais; Parrot e imprensa desinformante. Disponível em <http://www.imagodays2.com..br> Acessado em 28 de julho de 2001. Autor com Autoridade. Message: 14, 13/04/2002. Disponível em <http://www.imagodays2.com.br>

Feito à mão ou a computador: Qual será o mais artístico? Disponível em <http://www.webcanal.com.br/colunas/cultura/kipper.asp>

O Spacca é bom nessas coisas. e-group Front Braza. 13/08/01

Sintaxe da imagem na imprensa X arte. Disponível na Internet no e-group FrontBraza, mensagem n.ำ 1 de 04/04/2001. (online) Arquivo consultado em 2001 .

KOESTLER, Arthur. Jano. São Paulo: Melhoramentos, 1981.

KUCINSKI, Bernardo.Jornalistas e revolucionários - nos tempos da imprensa alternativa. São Paulo: Scritta, 1991.

LADEVÉZE, Luiz Núñez - Introducción al Periodismo Escrito.Barcelona: Editorial Airel, S.A, 1995.

LAGAR, Antonio López de Zuago. Dicionário Del periodismo. Madrid: Pirâmide, 1978.

LAGO, Pedro Corrêa. Caricaturistas Brasileiros (1836-1999). Rio de Janeiro: GMT, 1999.

LANYI, José Paulo. Que manchete você quer? São Paulo: Boletim eletrônico Comunique-se. Acessado em 6 de outubro de 2005.

LANNERS, Edi. Ilusões. Rio de Janeiro: Ediouro, 1982

LEMOS, Renato. (org.). Uma história do Brasil através da caricatura.(1840-2001). Rio de Janeiro: Letras e Expressões, 2001.

LÉVY, Pierre. A Ideografia Dinâmica: rumo a uma imaginação artificial? São Paulo: Loyola, 1991.

LIMA, Alceu Amoroso. O jornalismo como gênero literário. Rio de Janeiro: Agir, 1960.

LIMA, Herman. História da caricatura no Brasil:Rio de Janeiro: José Olympio, 1963. 
LOWE, Robert in The Times in BELTRÃO, Luiz. A imprensa informativa. São Paulo: Folco Masucci, 1969.

LUYTEN, Sonia B. (org.). Cultura pop japonesa. São Paulo: Hedra, 2005.

MARINGONI, Gilberto, Humor na charge política no jornal, in Revista Comunicação e Educação, no. 7, São Paulo, Moderna/USP, 1996.

MARTINS, Itajahi. Desenho: arte e técnica. São Paulo: Fundação Nestlé de Cultura e Ponte Editorial, 1992.

MARTINS, Luiz Geraldo Ferrari. A Escrita Plástica: desenho, pensamento, conhecimento e interdisciplinaridade.

Tese de doutorado. São Paulo: ECA/USP, 2004

MARTINS, Sérgio. A invenção do humor no espaço gráfico. Tese de Doutorado. São Paulo: FAU/USP, 1992.

MASSIRONI, Manfredo. Ver pelo desenho, aspectos técnicos, cognitivos, comunicativos. Lisboa: Edições 70, 1982.

MAYER, Alice M. Monteiro, ABRANCHES, Iracema; ARBACH, Jorge; KOPKE, Regina C. Moraes. Ética e Imaginário. Juiz de Fora: 2000. Monografia (Mestrado em Comunicação)-FACOM/UFJF e ECO/UFRJ.

MAYRINK, Robertson. A era da imagem na propaganda. Revista de Cultura Universitária, n 7, abr/2002, UNI-BH, Belo Horizonte. Aula Magna Mc CLOUD, Scott Desvendando os quadrinhos.. Detroit: Makron Books, 1995.

Mc LUHAN, Marshall. A galáxia de Gutemberg. São Paulo: Cia. Editora Nacional, 1977.

MELO, José Marques de. Gêneros jornalísticos na Folha de São Paulo. São Paulo: FTD, 1992.

A opinião no jornalismo brasileiro. 2aㅡ ed, Petrópolis: Vozes, 1994.

A opinião no jornalismo brasileiro. 3ํㅡ ed, Campos de Jordão: Mantiqueira, 2003.

et al. Gêneros e formatos na comunicação massiva periodística: um estudo do jornal Folha de São Paulo e da revista Veja. Universidade Metodista de São Paulo, São Paulo.

MIANI, Rosinaldo Antonio. A utilização da charge na imprensa sindical na década de 80 e sua influência política ideológica. Dissertação de mestrado. São Paulo: ECA/UISP, 2000

MOLES. Abraham A. Em busca de uma teoria ecológica da imagem. in: Imagem e Comunicação, Anne-Marie Thimbault.

São Paulo: Melhoramentos, 1976.

MOTTA, Flávio. O sorriso da Gioconda. São Paulo: Depto. História FAU/USP, 1963.

MOYA, Álvaro de. A ilustração como arte. in: ARBACH, Jorge. Desenhos Falados. Juiz de Fora: Esdeva, 1990.

NEGREIROS, Luiz Vidal Gomes. Desenhismo. Santa Maria, RS: Universidade Federal de Santa Maria, 1996.

NUNES, Benedito. Introdução à filosofia da arte. São Paulo: Ática, 1991.

OLIVEIRA, Rui de. Reflexões sobre a Imagem \& Ilustrações:Pelos Jardins Boboli. Dissertação (Doutorado em Comunicações e Artes), Universidade de São Paulo, São Paulo, 2004.

OLIVEIRA, Jô e Lućilia Garcez. Explicando a Arte: (uma iniciação para entender e apreciar as Artes Visuais) - Rio de Janeiro - EDIOURO, 1999.

O PASQUIM: A Subversão do Humor. Especial de 5 de agosto de 2004. Disponível em <http://www.camara.gov.br/internet/midias/mostramidias.asp> Acessado em 25 de setembro de 2004

O PASQUIM: o balanço de uma experiência. (Re) Publicado N’O Pasquim, no 79 6, 12 de janeiro de 1971 . O que há para ler. 
O PASQUIM E A DITADURA: Licença de Uso da Enciclopédia Digital Master On-Line, 2001.

OSTROWER, Fayga. Criatividade e Processos de Criação. 13ª ed, Petrópolis: Vozes, 1999.

. Acasos e criação artística. São Paulo: Campos, 1990.

. Universos da Arte. Rio de Janeiro: Campus, 1991.

A Sensibilidade do Intelecto. Rio de Janeiro: Campus, 1998.

PENTEADO, Jr. Whitaker. A técnica da Comunicação. São Paulo: Pioneira, 1974.

PEREIRA, Wellington. Crônica: arte do útil ou do fútil? (Ensaio sobre a crônica no jornalismo impresso). João Pessoa: Idéia, 1994

PIMENTEL, Luiz. Entre sem bater: Rio de Janeiro: Ediouro, 2004.

RABAÇA, Carlos Alberto e BARBOSA, Gustavo. Dicionário de comunicação. Rio de Janeiro: Codecri, 1978.

REVISTA IMPRENSA Breve história da imprensa no Brasil. Revista Imprensa, São Paulo, ano 14, n. 161, jun./2001.

RIBEIRO, Lavina Madeira. Contribuições no Estudo Institucional da Comunicação. Teresina: Edufpi, 1996.

RIBEIRO, Milton. Planejamento Visual Gráfico. Brasília: Linha Gráfica, s/d,

RIZZINI, Carlos. O Jornalismo antes da Tipografia. São Paulo: Nacional, 1977.

SADER, Emir. $A$ verdade, da palavra à imagem . Rio de Janeiro: Jornal do Brasil, 22/10/05.

SCHWARCZ, Lilia Moritz. Diabo Coxo - O pincel polêmico e a pena tensa. São Paulo: Observatório da Imprensa.

Disponível em <http://www.observtoriodaimprensa.com.br> Acessado em 3 de abril de 2005.

SEMERARO, Cláudia Marino. História da Tipografia. São Paulo: MASP, 1979.

SILVA, Antônio Carlos da. As teorias do signo e as significações lingüísticas.. São Paulo: Edusp, 1999.

SILVA, Marcos Antonio da. Prazer e Poder do Amigo da Onça. Rio de Janeiro: Paz e Terra, 1989.

SILVA, Josimey Costa da. O humor nada objetivo e um jornalismo muito sério. Comunicare 2, n. 2, 2‥ semestre/2002. Revista de Comunicação da Cásper Líbero.

SODRÉ, Nelson Werneck. A história da imprensa no Brasil. Rio de Janeiro: Civilização Brasileira, 1966.

SOUZA, Cláudio Mello e. Impressões do Brasil. Rio de Janeiro: Práxis, 1986.

SOUZA, Luciana C. P. Charge politica: o poder e a fenda, São Paulo, PUC (dissertação mestrado), 1986.

SOUZA. Sandra Maria Ribeiro de. Do conceito à imagem -(fundamentos do design de pictogramas). Rio de Janeiro: UFRJ, 1992.

SPACCA. Desenho x Idéia. e-group FrontBraza. 12/08/2001

SPACCA. Ilustra, charge e Cartum. Disponível na Internet no e-group FrontBraza, mensagem n.ㅇ 9

de 21/03/2001. (online) Arquivo consultado em 2001.

STRAUSS, Michaela. A linguagem gráfica da criança. trad. Sandra Beck e Simone Fáveri. Florianópolis: ed. independente, 1996

TUBAU, Ivan. De pena em punho: o humor gráfico como gênero literário. O Correio, Unesco, jun./1976, ano 4, n. 6. 
TURNBULL, Arthur e BAIRD, Russell N. The Graphics of Communication: Thypography, Layout, Design, New York, Holt, Rinehart and Winston, Inc., 2a. edição, 1968.

VALERI, Mário e GENOVESI, Giovanni. Cômico creatività educazione. Rimini: Guaraldi Edtore, 1973.

VELA, Norah Shallymar Gamboa. Notícias para ver na imprensa brasileira. Dissertação de Mestrado. São Paulo: ECA/USP, 1998.

VIANNA, Luiz Fernando. Pif-Paf de volta. São Paulo: Observatório da Imprensa. Disponível em <http://www.observtoriodaimprensa.com..br> Acessado em 5 de abril de 2005.

VIGOTSKY, Lev S. Pensamento e linguagem, São Paulo: Martins Fontes, 1993.

WOLF, Mauro. Teorias da Comunicação. 1a. ed. Lisboa, Presença, 1995

XAVIER, Caco. Aids é coisa séria - Humor e saúde: Análise dos cartuns sobre AIDS. Rio de Janeiro: Programa Radis, ENSP/Fiocruz. 1997. 


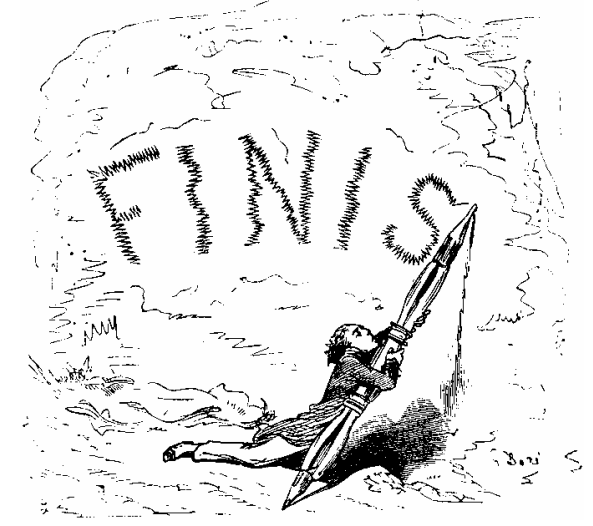

